\title{
Phase I Cultural Resources Survey AND ARCHEOLOGICAL INVENTORY OF THE PROPOSED 19.3 KM (12 MI) LONG STRETCH OF BAYOU TECHE, IbERIA PARISh, LOUISIANA
}

FINAL REPORT

AUGUST 2000

\section{DISTRIBUTION STATEMENT A \\ Approved for Public Release \\ - Distribution Unlimited}

\author{
PREPARED FOR: \\ U.S. Army Corps of Engineers \\ New Orleans District \\ P.O. Box 60267 \\ New Orleans, Louisiana 70160-0267 \\ UNCLASSIFIED: DISTRIBUTION IS UNLIMITED

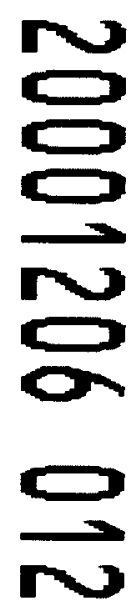

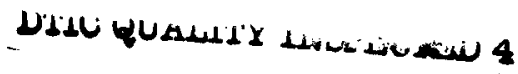

R: CHRISTOPHER GOODWIN \& AsSOCIATES, INC. 5824 Plauche STREET - NEW ORLEANS, LA 70123 . 
Public reporting burden for this collection of information is estimated to average 1 hour per response, including the time for reviewing instructions, searching existing data sources, gathening and maintaining the data needed, and completing and reviewing the collection of information. Send comments regarding this burden estimate or any other aspect of this collection of information, induding suggestions for reducing this burden, to Washington Headquarters Services. Directorate for informatidn Operations and Reports, 1215 Jefferson Davis Highway. Suite 1204 Avlington. VA 22202-4302, and to the Office of Management and Budget, Paperwork Reduction Project (0704-0188), Washington. DC 20503.

\begin{tabular}{|l|l|l|}
\hline 1. AGENCY USE ONLY (Leave blank) & $\begin{array}{l}\text { 2. REPORT DATE } \\
\text { August } 2000\end{array}$ & $\begin{array}{l}\text { 3. REPORT TYPE AND DATES COVERED } \\
\text { Final Report December } 1999-J a n u a r y-2000\end{array}$
\end{tabular}

4. TITLE AND SUBTITLE

5. FUNDING NUMBERS

Phase I Culturai Resources and Archeological Inventory of the Proposed $19.3 \mathrm{~km}$ (12 mi) Long Stretch of Bayou Teche, Iberia Parish, Louisiana

6. AUTHORS

David George, J.B. Pelletier, Dr. Roger Saucier, Katy Coyle, Sarah Milstead, Larkin Post, Dr. Richard Vidutus, Jeremy Pincoske, and William P. Athens

7. PERFORMING ORGANIZATION NAME(S) AND ADDRESS(ES)

R. Christopher Goodwin \& Associates, Inc.

5824 Plauche Street

New Orleans, LA 70123
9. SPONSORINGMONITORING AGENCY NAME(S) AND ADDRESS(ES)

U.S. Army Corps of Engineers, New Orleans District

P.O. Box 60267

New Orleans, LA 70160-0267
8. PERFORMING ORGANIZATION REPORT NUMBER

10. SPONSORINGMONITORING AGENCY REPORT NUMBER

\section{SUPPLEMENTARY NOTES}

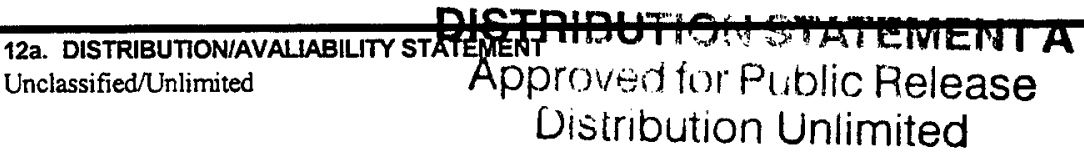

12b. DISTRIBUTION CODE

\section{ABSTRACT (Maximum 200 words)}

This document presents the results of Phase I cultural resources survey and archeological inventory of the proposed Bayou Teche project area in Iberia Parish, Louisiana. This investigation included the excavation of a $19.3 \mathrm{~km}(12 \mathrm{mi})$ long stretch of the Bayou Teche channel, as well as six terrestrial project items and two proposed access roads. The six terrestrial project items consisted of three proposed staging areas (Staging Areas 1 - 3) from which dredging operations will be coordinated and three proposed disposal areas (Disposal Areas I - 3) that will receive spoil dredged from the river bottom. The terrestrial project items surveyed comprised a total of 41.32 ha (102.1 ac). Fieldwork for this project was completed during January of 2000 on behalf of the U.S. Army Corps of Engineers, New Orleans District, by R. Christopher Goodwin \& Associates, Inc.. pursuant to Contract DACW29-97-D-0018, Delivery Order 24. This effort included underwater remote sensing throughout the bayou channel and pedestrian survey, auger testing, and systematic backhoe trenching throughout the terrestrial portions of the Areas of Potential Effect.

The underwater investigation of the $19.3 \mathrm{~km}(12 \mathrm{mi})$ long stretch of Bayou Teche included the use of a DGPS, a proton precession marine magnetometer, a side scan sonar, and a digital fathometer. As part of this investigation, data were collected and subsequently correlated via a laptop computer using $H y p a k$ hydrographic survey software. The underwater portion of this examination resulted in the identification and recordation of 614 magnetic anomalies and 48 acoustical anomalies. A total of 445 of the $6 / 4$ magnetic anomalies were classified as scatters of ferrous debris mixed with natural debris. The remaining 169 magnetic anomalies were clustered into 84 target groups that were analyzed further. Careful analysis revealed the 84 target groups to be the structural elements of modem bridges, or underwater cables, pipelines crossings, bulkheads. docks andior bank debris scattered throughout the Area of Potential Effect. None of these underwater targets possessed the qualities of significance as defined by the National Register of Historic Places criteria for evaluation (36 CFR 60.4 [a-d]). No additional testing of these targets is recommended.

The terrestrial portion of this investigation included a combination of pedestrian survey, auger testing, and backhoe trenching. Fieldwork resulted in the identification of two non-site cultural resources loci (SA2-01 and DA2-01). Locus SA2-01 was recorded within the proposed Staging Area 2 project item This locus produced only three historic period artifacts. These artifacts included a single brick fragment, 1 hard-paste porcelain sherd with gold gilt, and 1 complete colorless machine-made bottle. The remainder of the cultural material recovered from Locus SA2-01 was modem in origin and it consisted of plastic soda bottles, styrofoam, metal strips, plastic utensils, rubber fragments, piece of cement, and clothing items. Stratigraphic profiles recorded at this non-site locus indicated that the Staging Area 2 project item had been bulldozed heavily and then covered with fill.

No evidence of intact cultural deposits or research potential was identified at Locus SA2-01. This non-site locus does not possess the qualities of significance as defined by the National Register of Historic Places ( 36 CFR 60.4 [a-d]). No additional testing of Locus SA2-01 is recommended.

The second non-site cultural resources locus identified during survey of the terrestrial portions of the proposed project items, DA2-01, was identified within Disposal Area 2 . Locus DA2-01 consisted of the remains of a cow burial; in addition, a single colorless glass shard was recovered. The glass shard was not associated with the identified faunal remains. Locus DA2-01, like Locus SA2-01, retained, little if any, research potential. This non-site cultural resources locus does not possess the qualities of significance as defined by the National Register of Places criteria for evaluation (36 CFR 60.4 [a-d]). No additional testing of this non-site locus is recommended.

\begin{tabular}{|c|c|c|c|}
\hline $\begin{array}{l}\text { 14. SUBJECT TERMS } \\
\text { Bayou Teche } \\
\text { Underwater Survey }\end{array}$ & $\begin{array}{l}\text { Iberia Parish } \\
\text { Terrestrial Survey }\end{array}$ & & $\begin{array}{l}\text { 15. NUMBER OF PAGES } \\
240\end{array}$ \\
\hline St. Martin Parish & & & PRICE CODE \\
\hline $\begin{array}{l}\text { 16. SECURITY CLASSIFICATION } \\
\text { OF REPORT } \\
\text { Unclassified }\end{array}$ & $\begin{array}{l}\text { 17. SECURITY CLASSIFICATION } \\
\text { OE DUISPAGE } \\
\text { Unclassified }\end{array}$ & $\begin{array}{l}\text { 18. SECURITY } \\
\text { CLASSIFICATION OF } \\
\text { ABSTRACT } \\
\text { Unclassified }\end{array}$ & $\begin{array}{l}\text { 19. LIMITATION OF ABSTRACT } \\
\text { SAR }\end{array}$ \\
\hline
\end{tabular}




\section{DEPARTMENT OF THE ARMY \\ NEW ORLEANS DISTRICT. CORPS OF ENGINEERS \\ P.O. BOX 60267 \\ NEW ORLEANS, LOUISIANA 70160-0267}

REPLY TO

ATIENTION OF:

May 23, 2000

Planning, Programs, and

Project Management Division

Environmental planning and

Compliance Branch

To The Reader:

The U.S. Army, Corps of Engineers, New Orleans District (NOD) will dredge approximately 12 miles of Bayou Teche in and around the community of New Iberia. Four disposal areas and three staging areas will be established to facilitate the removal and disposal of the dredge material. In order to avoid impacts to significant underwater and terrestrial cultural resource sites, NOD conducted a cultural resource survey and testing investigation within the project right-of-way. As a result, no sisnnificant cultural resources were identified within the area of potential effects. Thus, the proposed project will not effect. cultural resources. NOD and the Louisiana State Historic Preservation officer concur with the authors: conclusions ard ruccinmendations.

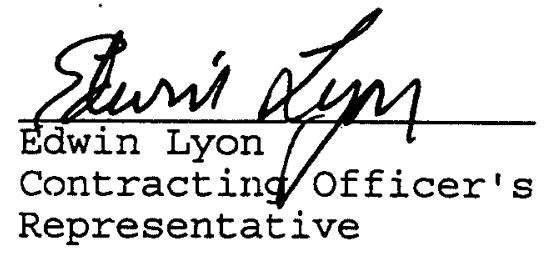

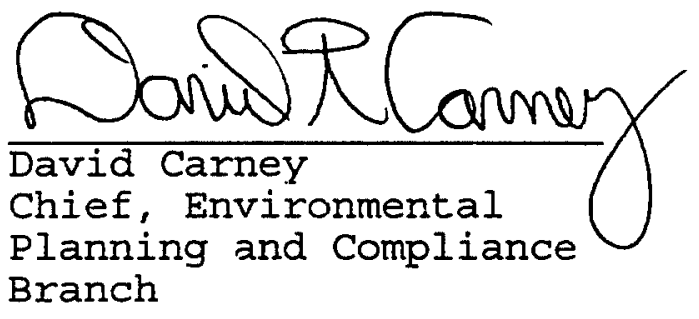


Phase I Cultural Resources AND ARChEological

INVENTORY OF THE PROPOSED 19.3 KM (12 MI) LONG

STRETCH OF BAYOU TEChE, IBERIA PARISH, LOUISIANA

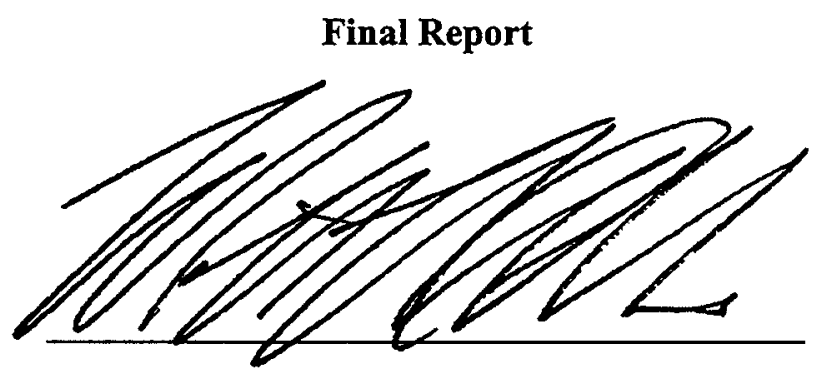

William P. Athens, M.A., A.B.D.

Principal Investigator

By

David George, J.B. Pelletier, Dr. Roger Saucier, Katy Coyle, Sarah Milstead, Larkin Post, Dr. Richard Vidutus, Jeremy Pincoske, and William P. Athens

R. Christopher Goodwin \& Associates, Inc.

5824 Plauche Street

New Orleans, LA 70123

August 2000

For

U.S. Army Corps of Engineers

New Orleans District

P.O. Box 60267

New Orleans, LA 70160-0267 
Report Documentation Page

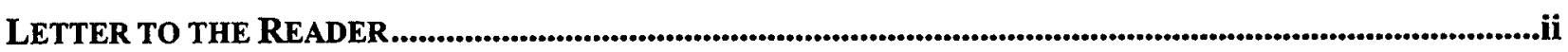

TITLE PAGE

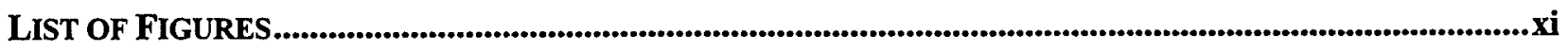

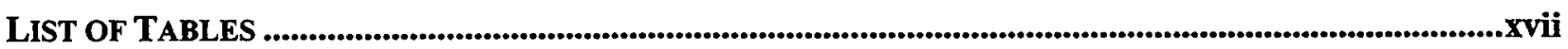

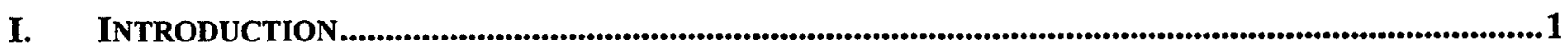

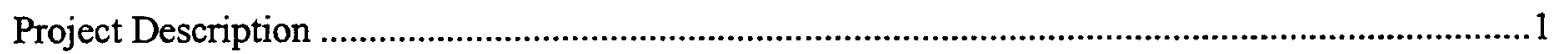

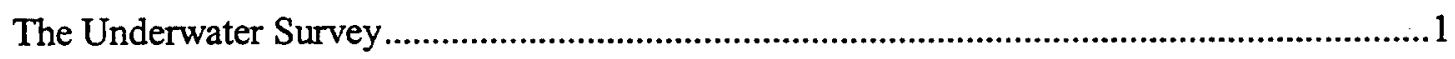

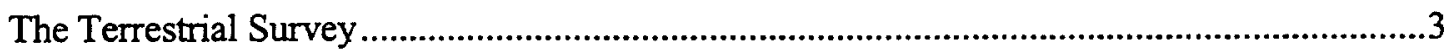

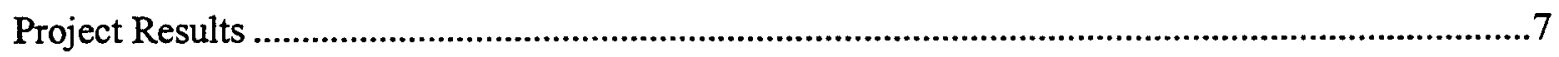

Results of the Underwater Survey ........................................................................................

Results of the Terrestrial Survey .........................................................................................

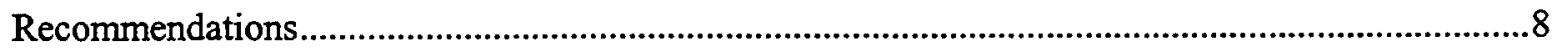

Recommendations for Identified Underwater Cultural Resources ....................................... 8

Recommendations for Identified Terrestrial Cultural Resources ........................................... 8

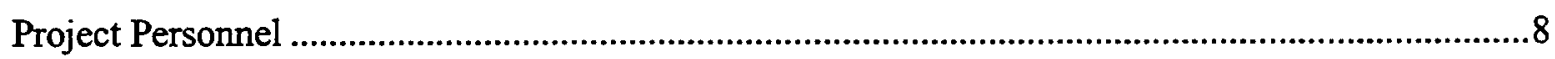

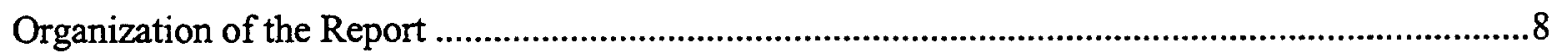

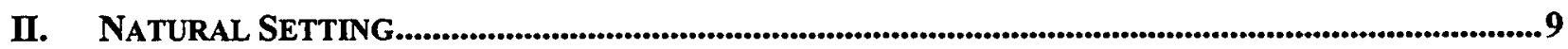

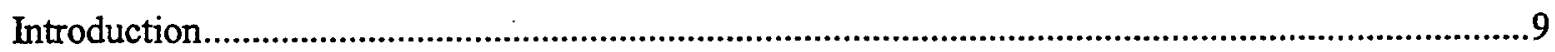

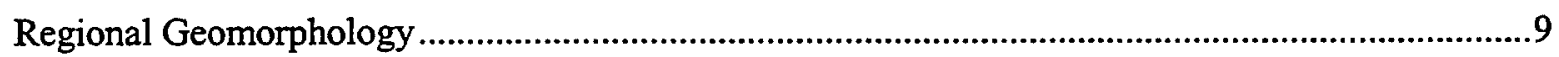

Undifferentiated Fluvial Deposits of the Prairie Complex (Ppu 1) .....................................10

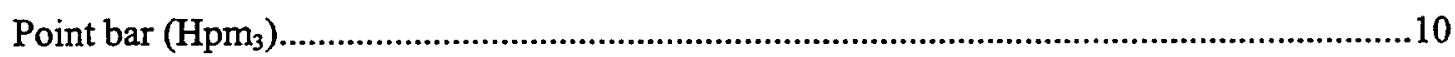

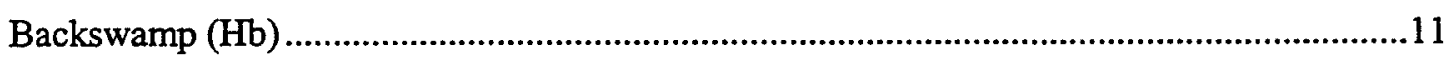

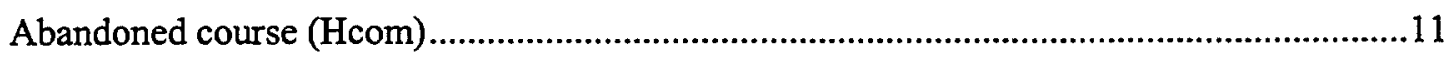

Abandoned channel (Hchm) ...............................................................................................12

The Proposed Project Area in the Context of the Atchafalaya Basin .....................................12

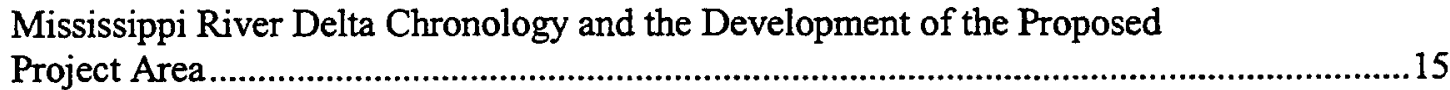

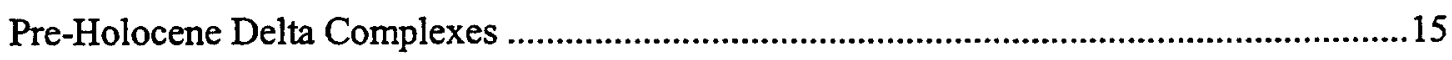

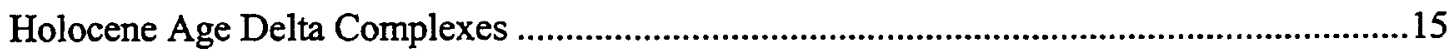

Outer Shoal Delta Complex ..................................................................................15

Maringouin Delta Complex ..................................................................................19

Teche Delta Complex ..................................................................................19

St. Bernard (Metairie-La Loutre) Delta Complex........................................................19 
Soils within the Vicinity of the Proposed Project Area ................................................................20

Historic Period Impacts to the Proposed Project Area...................................................................20

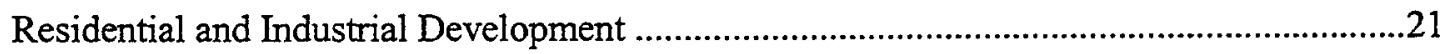

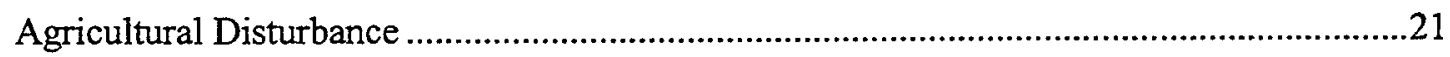

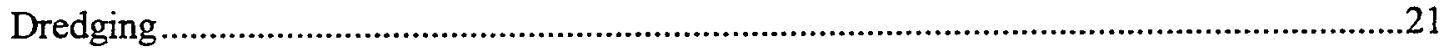

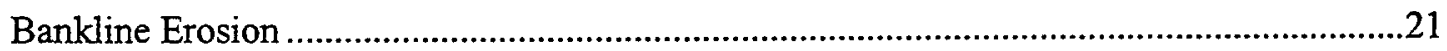

Flora and Fauna Located within the Vicinity of the Proposed Project Area ..................................21

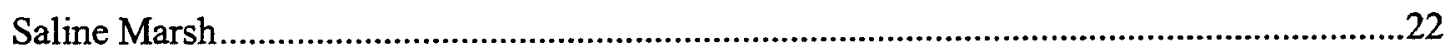

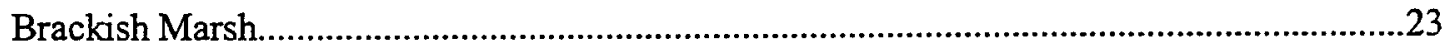

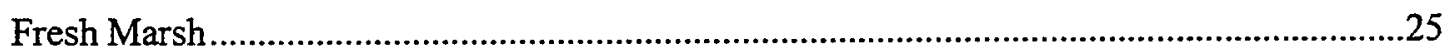

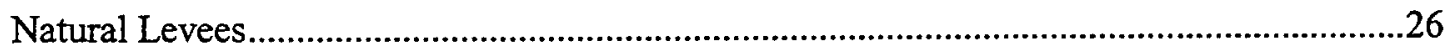

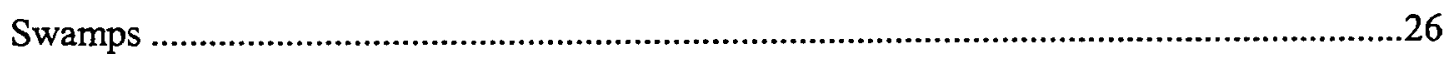

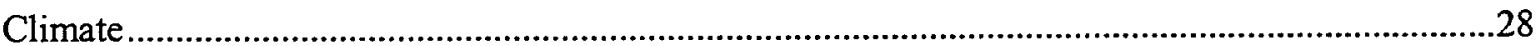

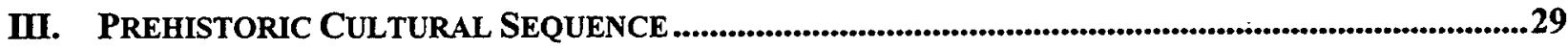

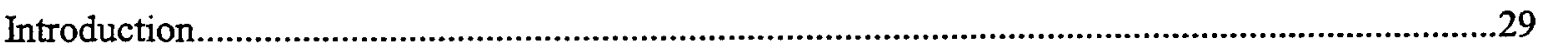

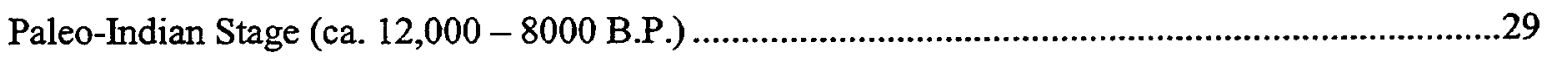

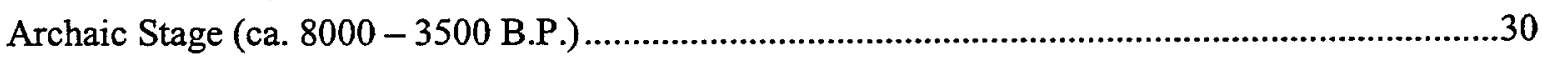

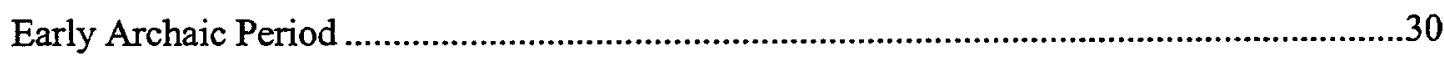

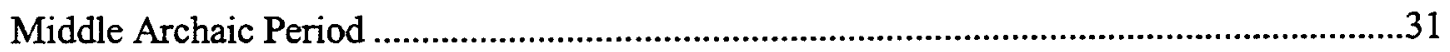

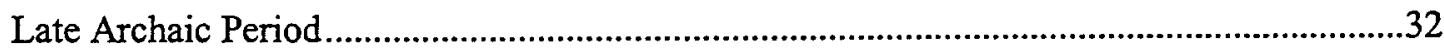

Poverty Point Culture (ca. 4000 - 2500 B.P.).................................................................................3

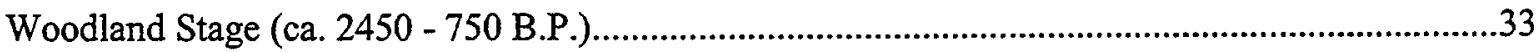

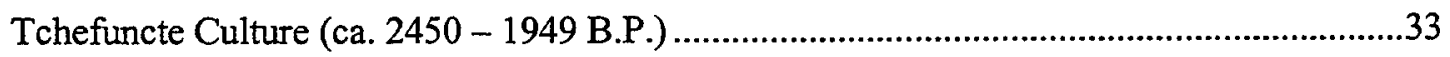

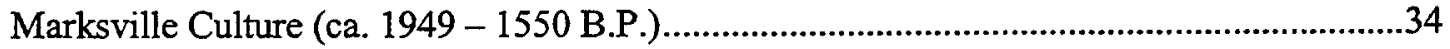

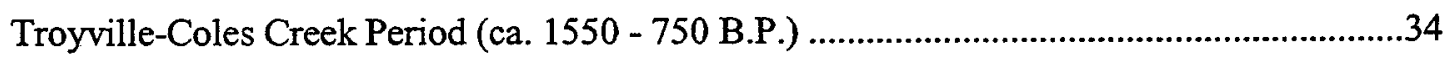

Mississippian Stage (ca. 750 - 300 B.P.) ......................................................................................35

Emergent Mississippian Period (ca. 750 - 500 B.P.).............................................................35

Late Mississippian Period (ca. 500 - 250 B.P.) ...........................................................................

Protohistoric and Early Historic Period (ca. 411 - 220 B.P.) ..........................................................37

IV. HISTORIC OVERVIEW ....................................................................................................................39

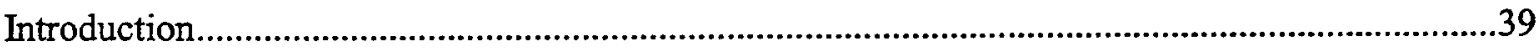

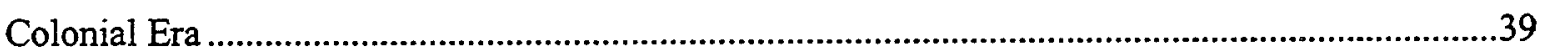

French Colonial Period, 1699-1769 ......................................................................................39

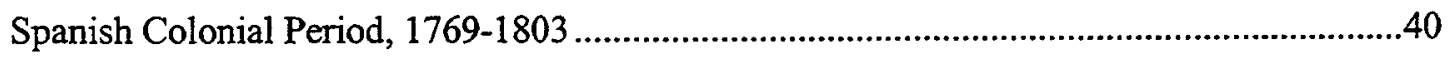

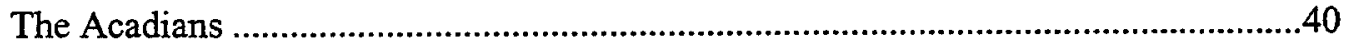

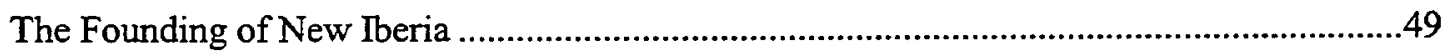

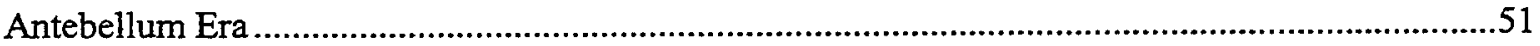

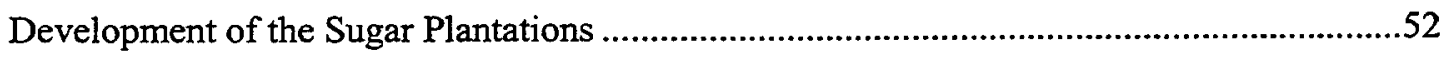

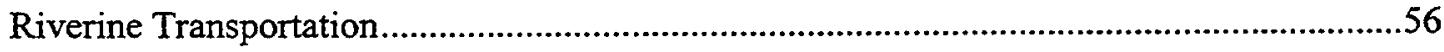




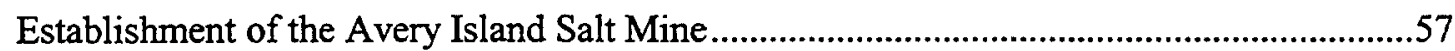

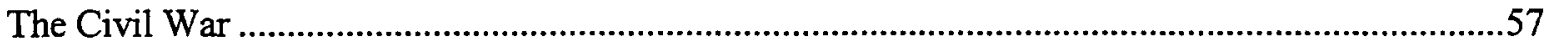

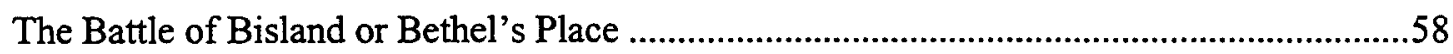

Military Engagements Along the Bayou Teche During the Civil War .................................58

The Teche Campaign and the Federal Destruction of the Avery Salt Works ........................59

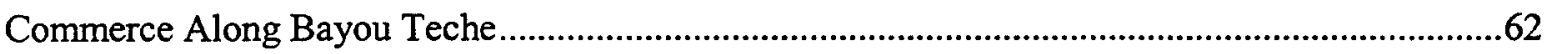

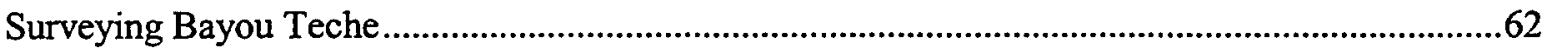

Wrecked Vessels Removed from Bayou Teche, 1870-1871 ....................................................72

Wrecks Recorded Within Proposed Project Area of Division I (St. Martinsville

to New Iberia) of Duke's Survey Maps .........................................................................................73

Wrecks Recorded Within Proposed Project Area of Division II (New Iberia to

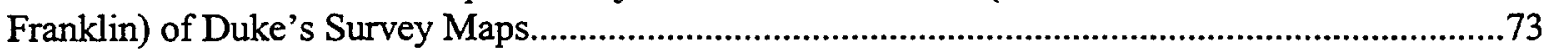

Duke Map Division I: St. Martinsville to New Iberia .................................................................75

Duke Map Division II: New Iberia to Franklin ......................................................................75

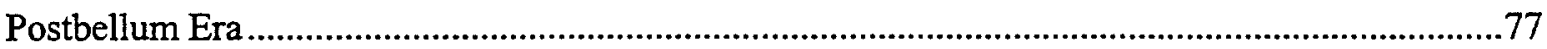

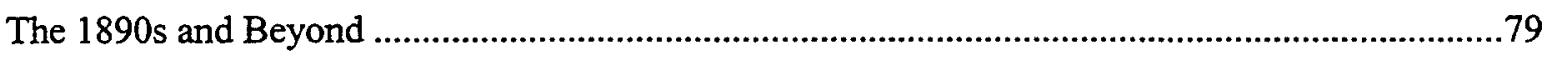

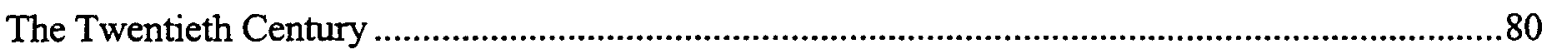

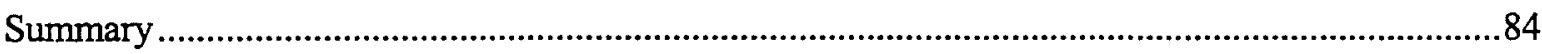

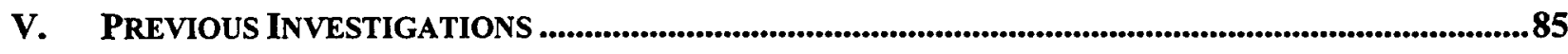

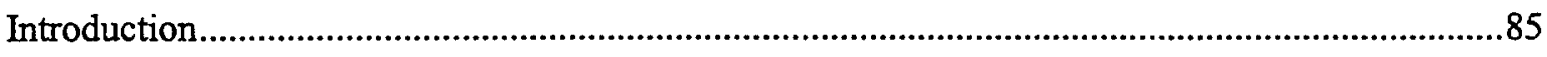

Previously Conducted Cultural Resources Surveys Situated within $8 \mathrm{~km}(5 \mathrm{mi})$

of the Currently Proposed Bayou Teche Project Items ......................................................................85

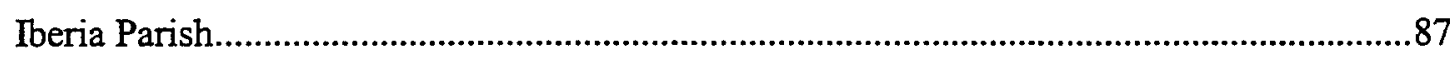

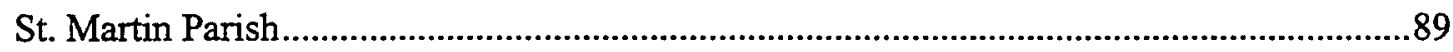

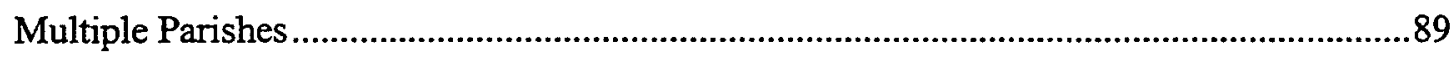

Previously Recorded Archeological Sites Located within $1.6 \mathrm{~km}$ (1 mi) of the Currently Proposed Bayou Teche Project Items ...........................................................................91

National Register of Historic Places Listed Properties Located within

$1.6 \mathrm{~km}(1 \mathrm{mi})$ of the Currently Proposed Bayou Teche Project Items ............................................92

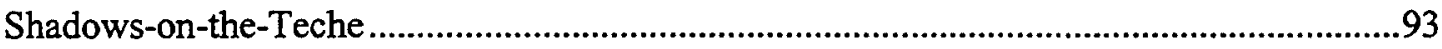

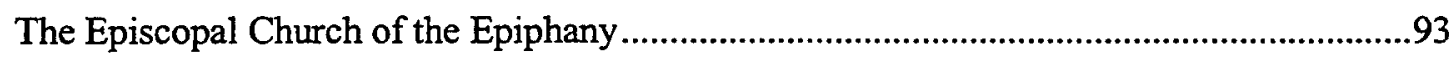

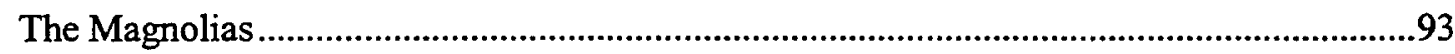

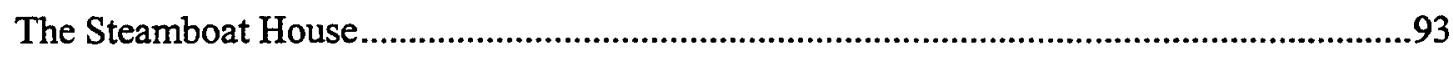

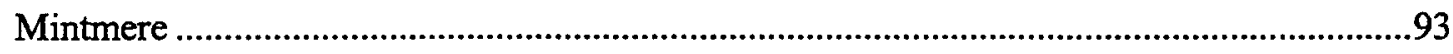

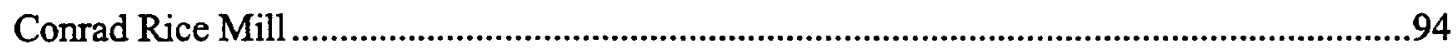

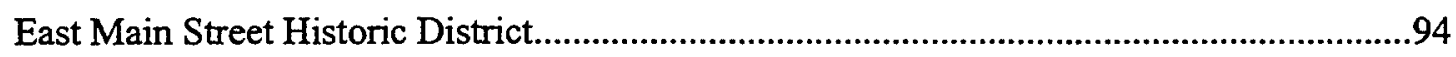

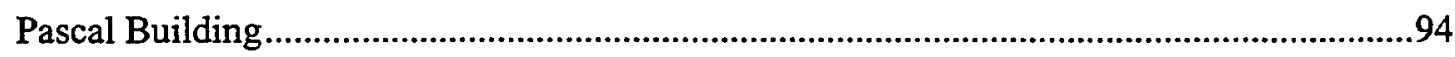

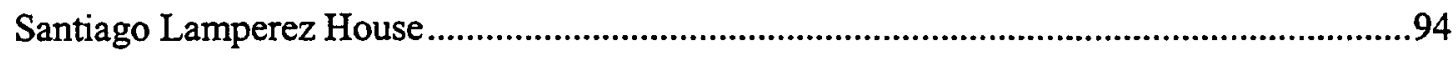

Southern Pacific Railroad Depot ..........................................................................................95

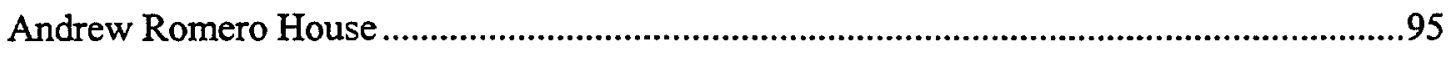

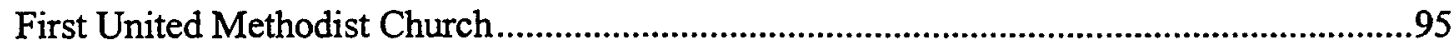




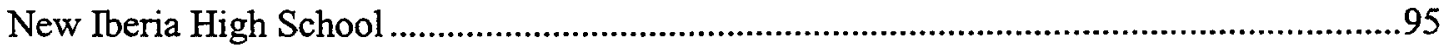

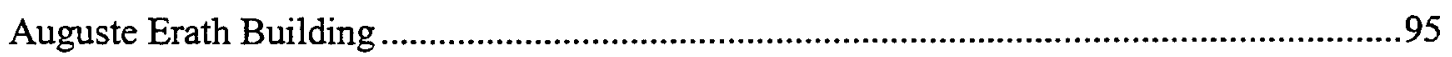

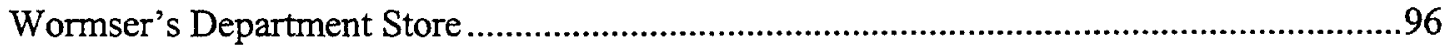

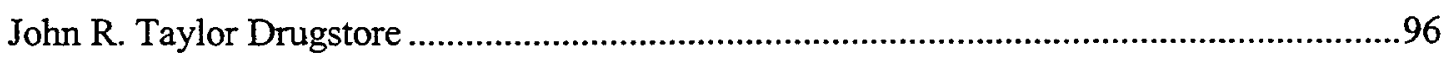

Lutzenberger Foundry and Pattern Shop ...............................................................................96

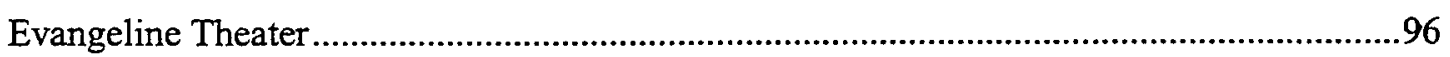

Previously Recorded Standing Structures Located within $1.6 \mathrm{~km}$ (1 mi) of the Currently Proposed Bayou Teche Project Items .........................................................................96

Previously Recorded Shipwrecks Located within $1.6 \mathrm{~km}(1 \mathrm{mi})$ of the Currently

Proposed Bayou Teche Project Items .........................................................................................98

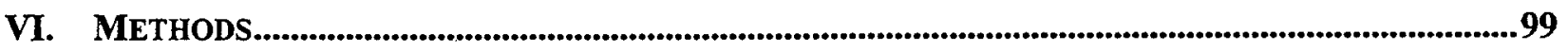

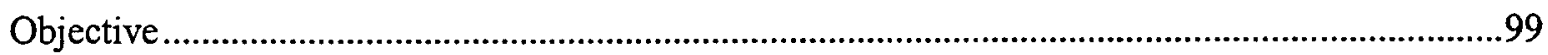

Research Methods Utilized during the Underwater Portion of the Survey ....................................99

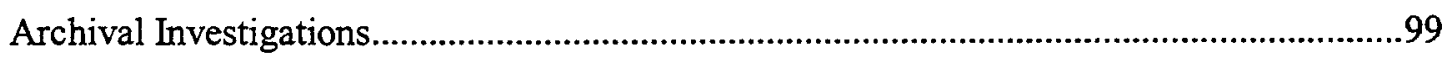

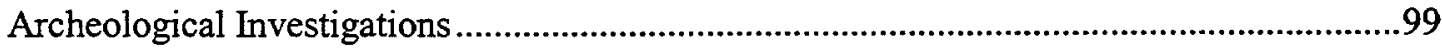

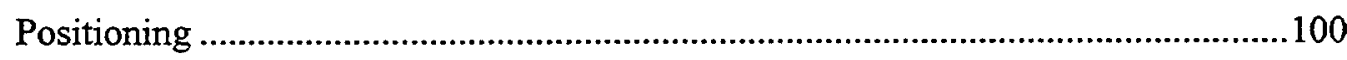

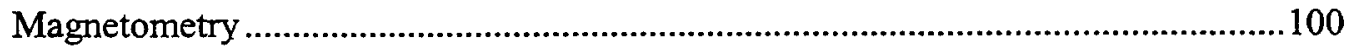

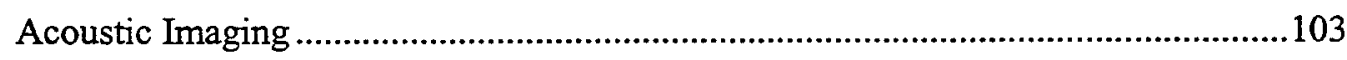

Survey Control and Correlation of Data Sets........................................................103

Remote Sensing Data Analysis .........................................................................105

Stratification of the Proposed Terrestrial Project Items into Areas of Low,

Moderate, and High Archeological Potential.........................................................................105

Field Methods Utilized during the Terrestrial Survey .......................................................106

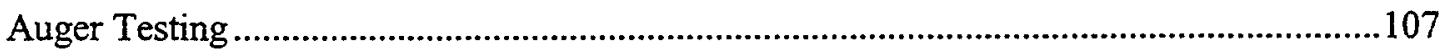

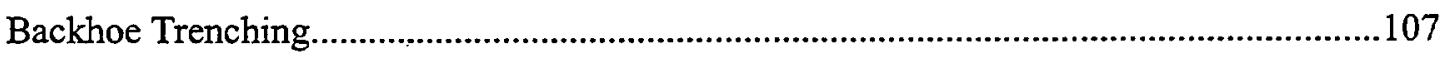

Application of the Criteria for Evaluation (36 CFR 60.4 [a-d]) ................................................108

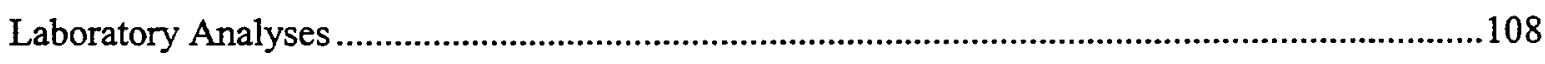

Historic/Modern Period Material Analysis ......................................................................109

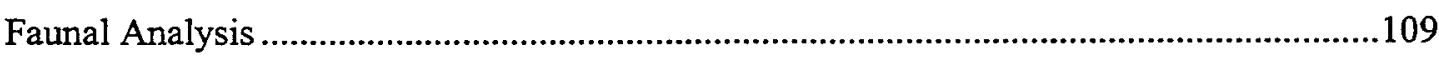

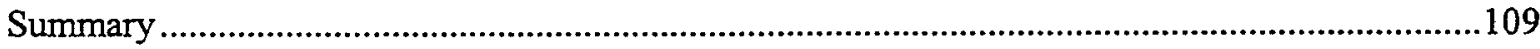

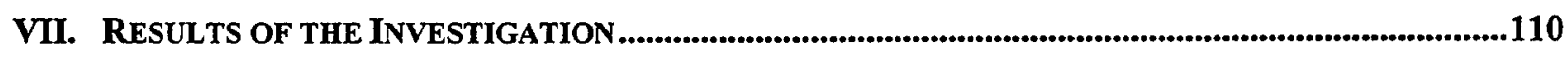

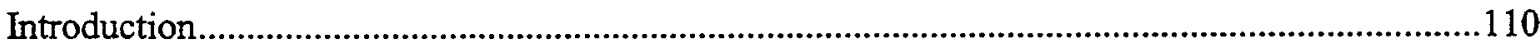

Results of Survey of the Underwater Project Item .................................................................110

General Overview of the Survey Results.....................................................................................124

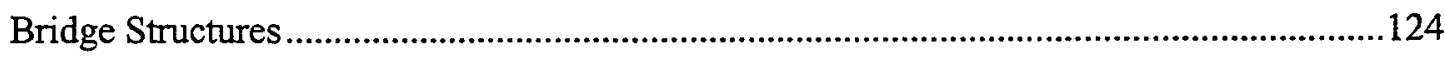

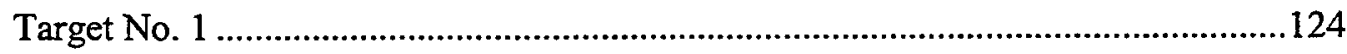

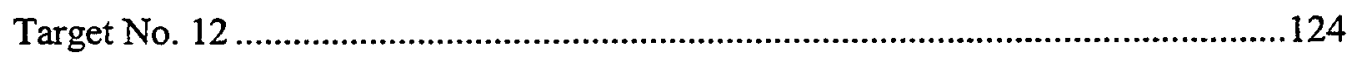

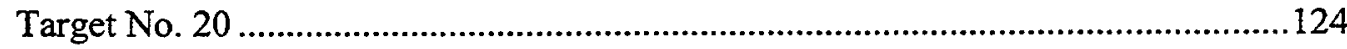

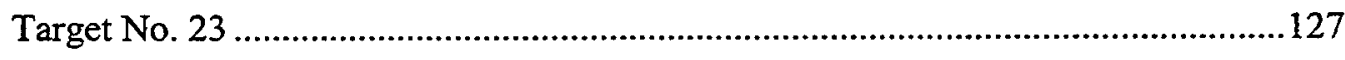

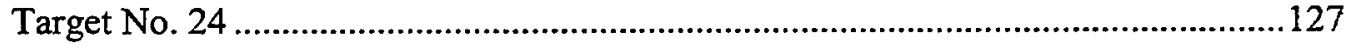




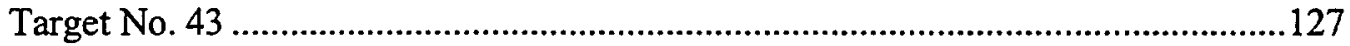

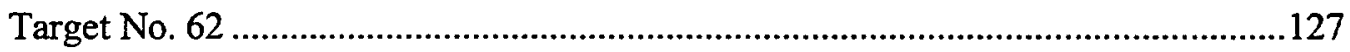

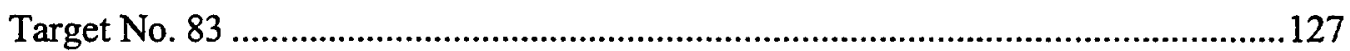

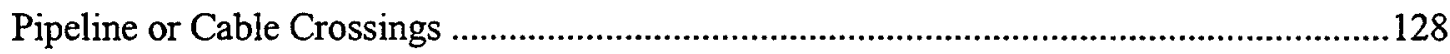

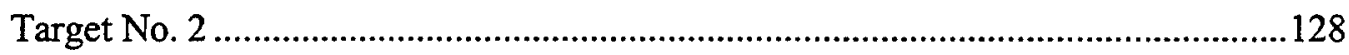

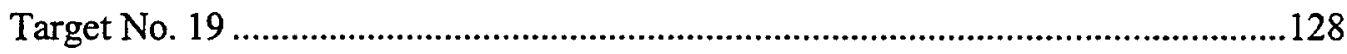

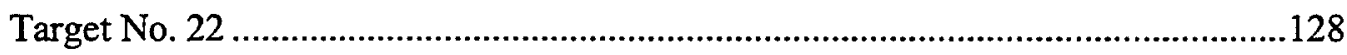

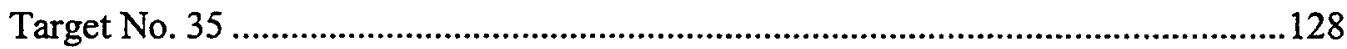

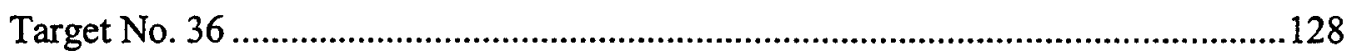

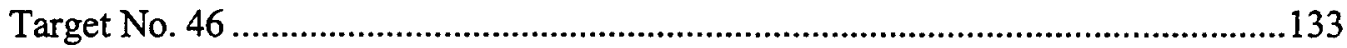

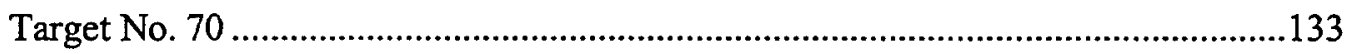

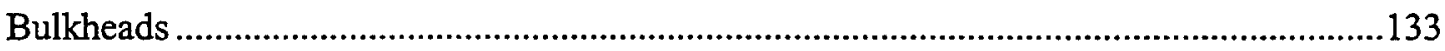

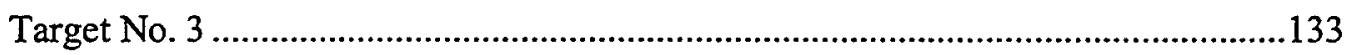

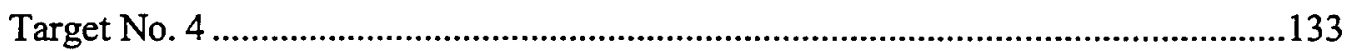

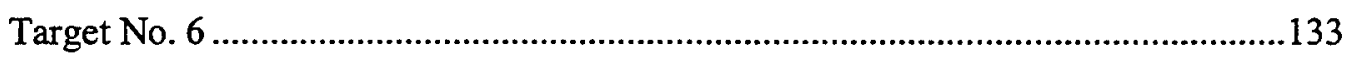

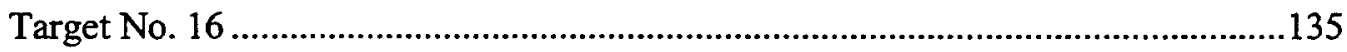

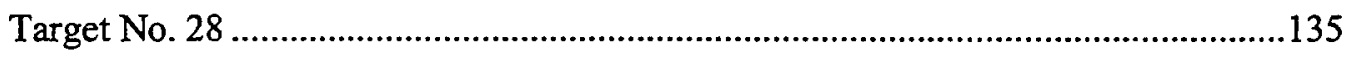

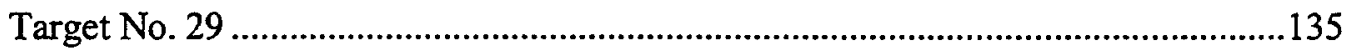

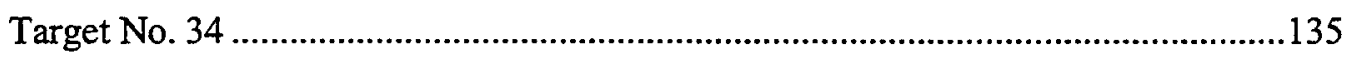

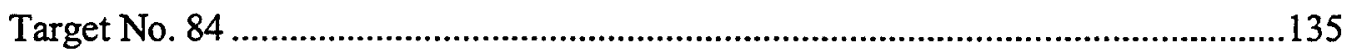

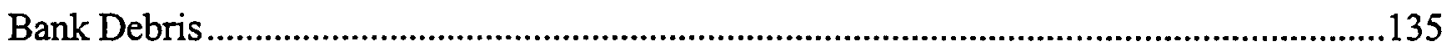

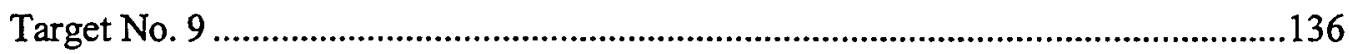

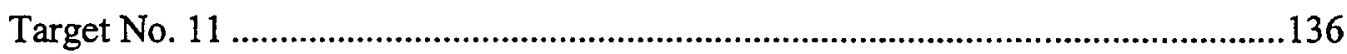

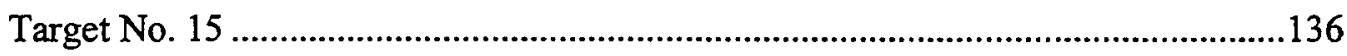

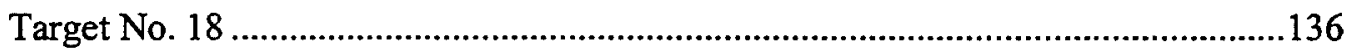

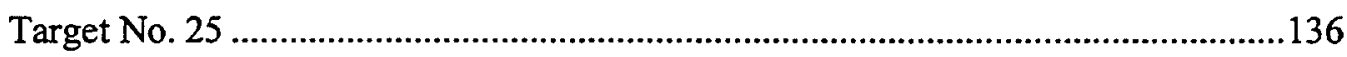

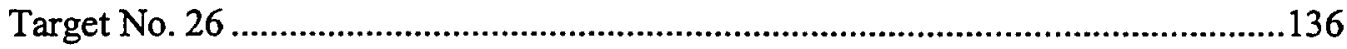

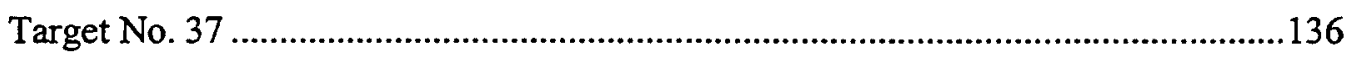

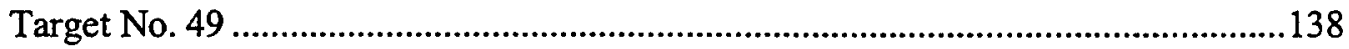

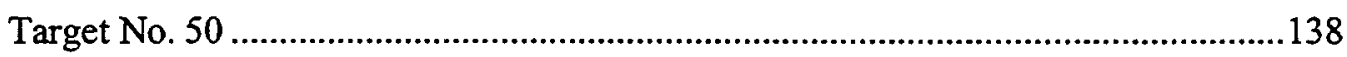

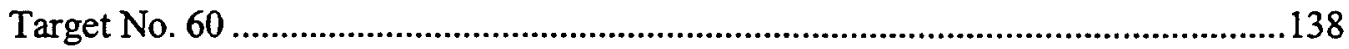

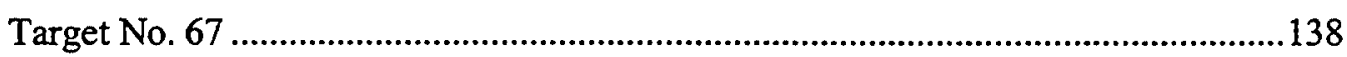

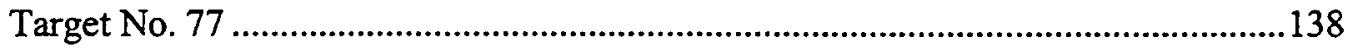

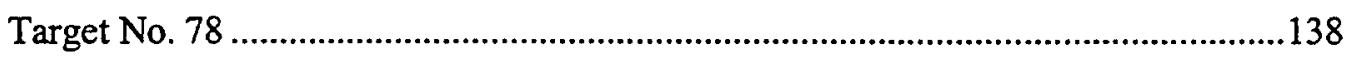

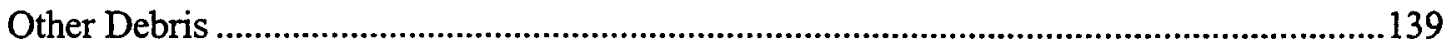

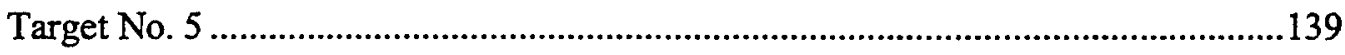

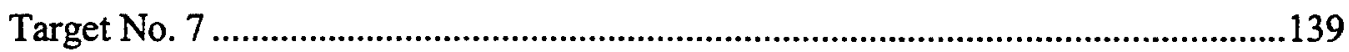

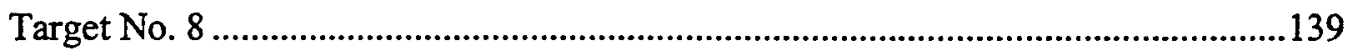

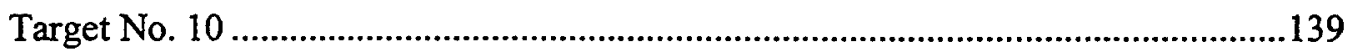

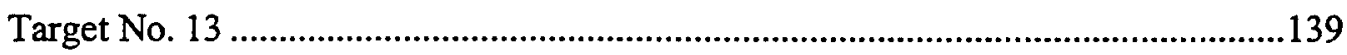

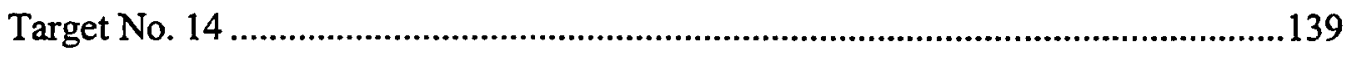




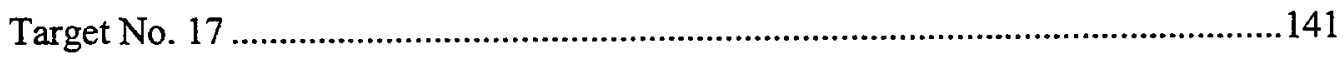

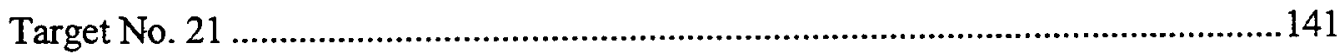

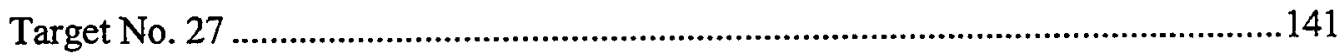

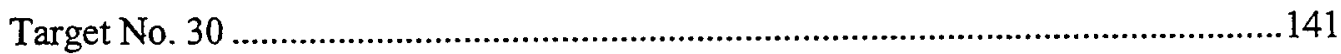

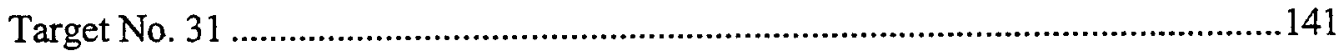

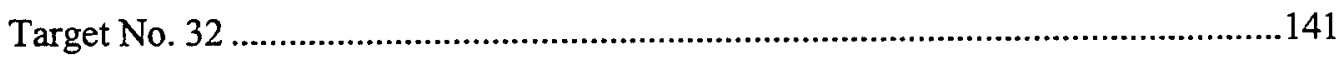

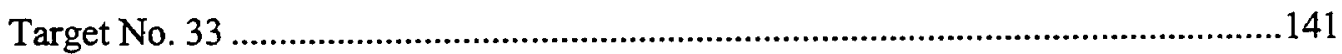

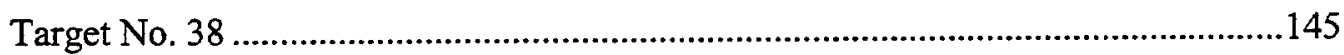

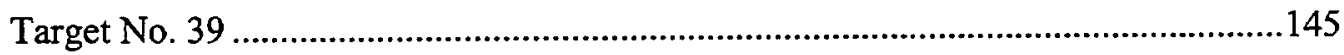

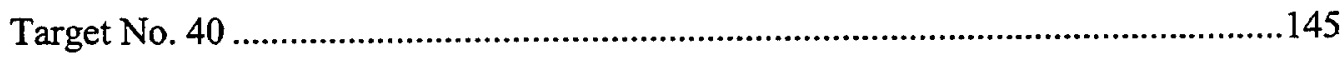

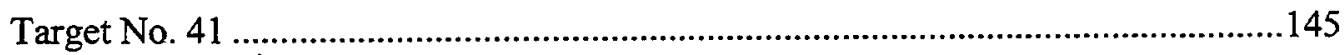

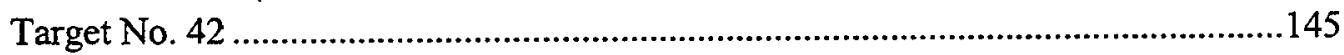

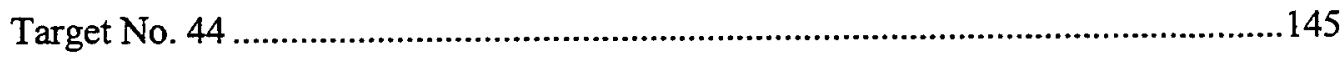

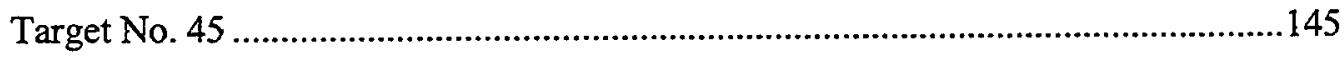

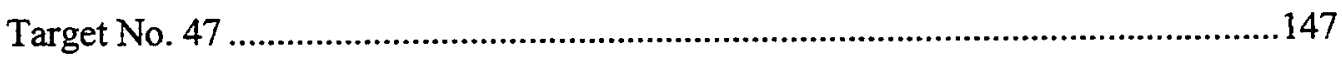

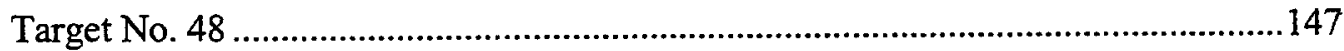

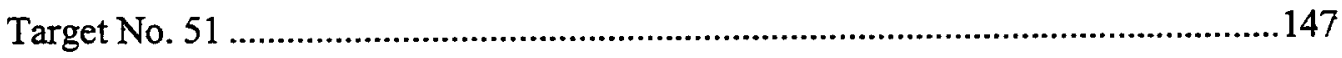

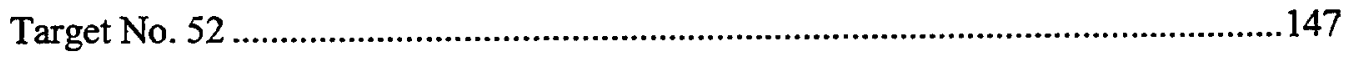

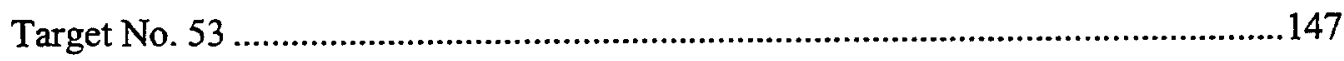

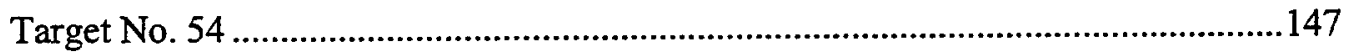

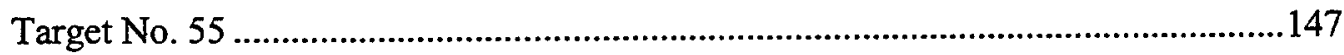

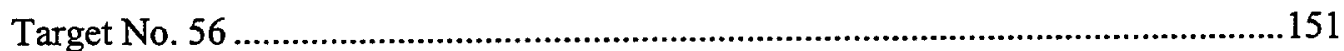

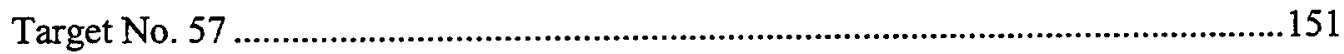

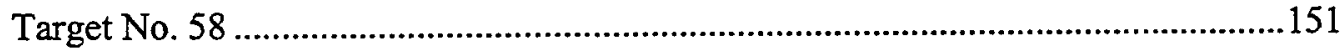

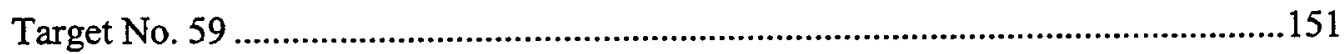

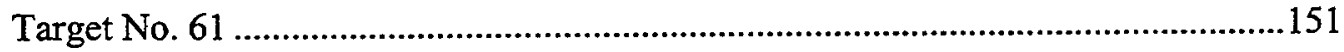

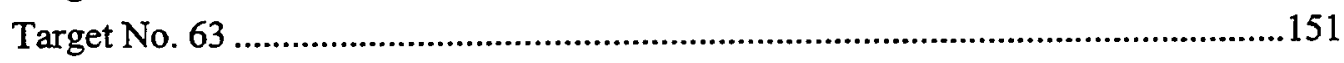

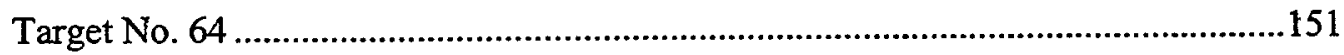

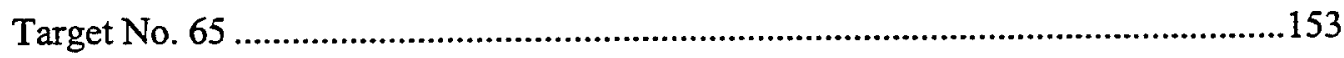

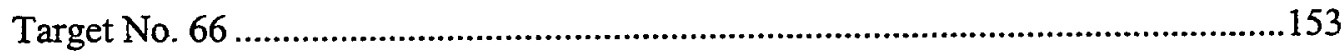

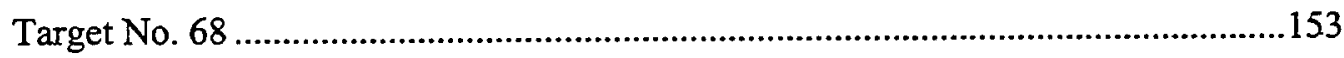

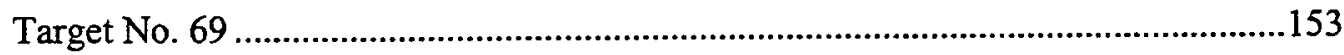

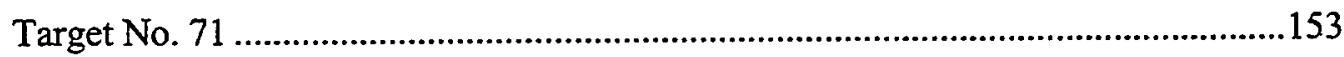

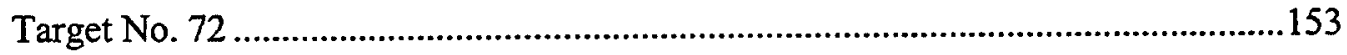

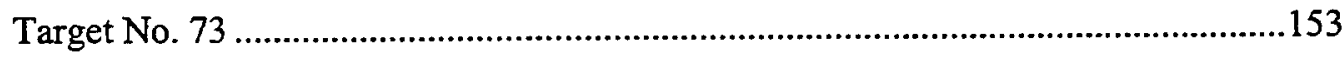

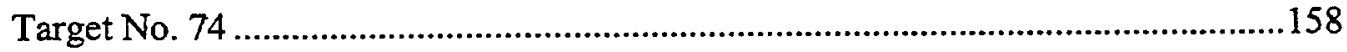

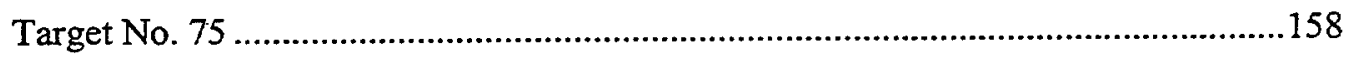

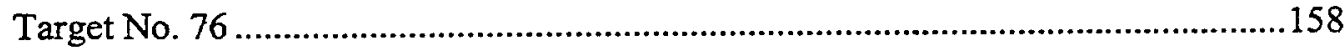

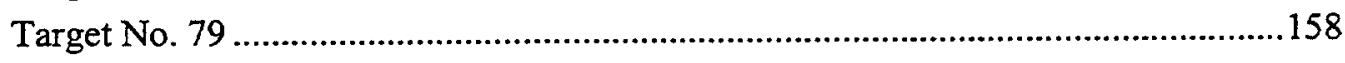

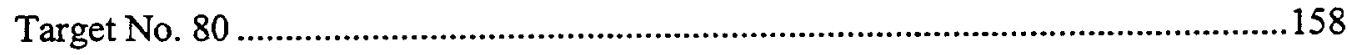

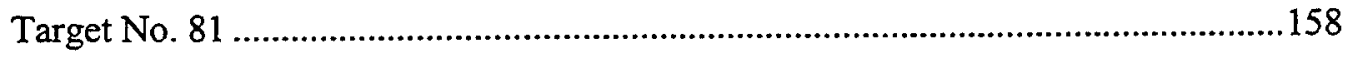




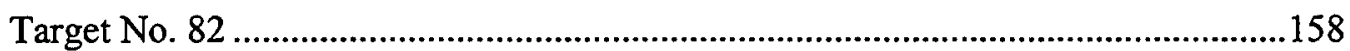

Results of Survey of the Terrestrial Project Items ..........................................................................162

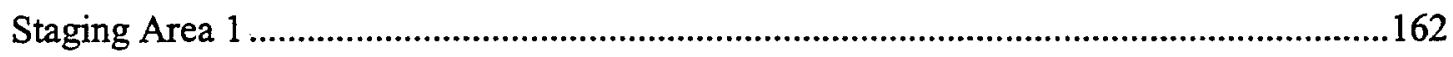

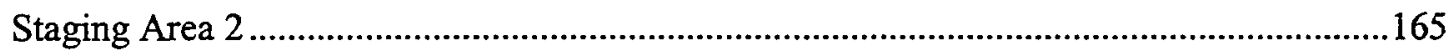

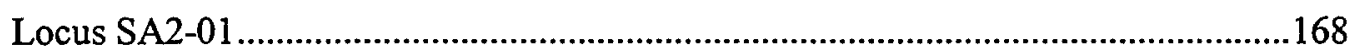

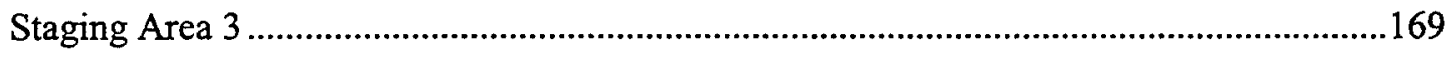

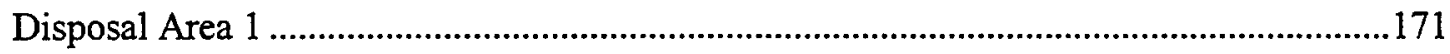

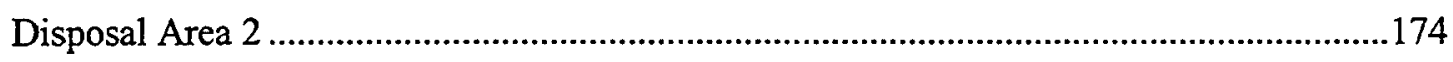

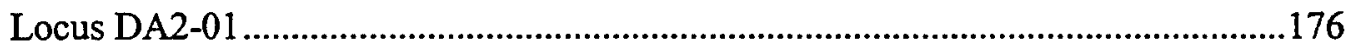

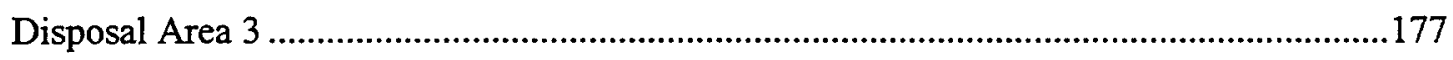

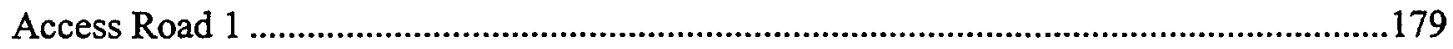

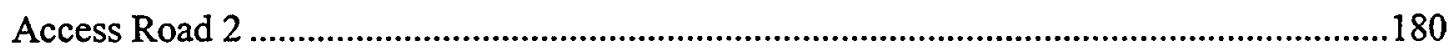

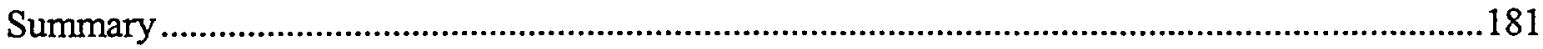

VIII. SUMMARY AND RECOMMENDATIONS ..................................................................................................182

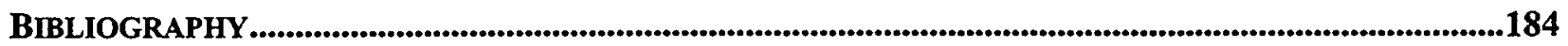

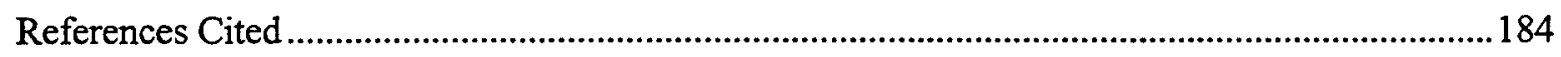

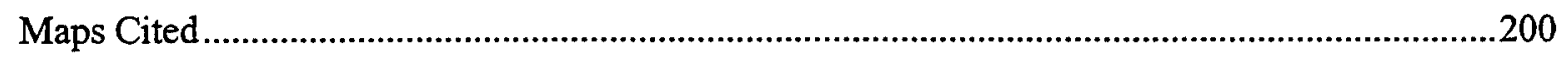

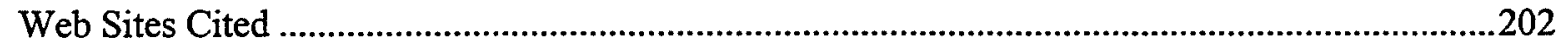

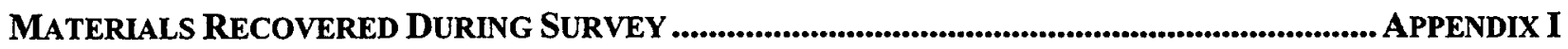

OVERSIZEd MAP Of THE PROJECT AREA 


\section{LIST OF FIGURES}

Figure 1. Map of Louisiana depicting the location of the proposed

study reach within Iberia Parish, Louisiana

Figure 2. Map of Bayou Teche depicting the location of the

underwater survey blocks.

Figure 3. Excerpt from the 1996 digital 7.5' series topographic quadrangle, New

Sheet 1 Iberia North, Louisiana, depicting the locations of Staging Area 1,

Staging Area 2, Disposal Area 1, Disposal Area 2, and Access Road 2 .5

Figure 3. Excerpt from the 1996 digital 7.5' series topographic quadrangle,

Sheet 2 New Iberia South, Louisiana, depicting the locations of Staging

Area 3, Disposal Area 3, and Access Road 1

Figure 4. Base map depicting the geomorphology within the vicinity of the proposed project area.

Figure 5. Major geomorphic subdivisions in southeastern Louisiana (modified from O'Neil 1949)

Figure 6. Palegeography of the Mississippi River Delta

Figure 7. Estimates of the ages of meander belts of the Mississippi

River and delta complexes (ages in years B.P.)

Figure 8. Chronology of delta complexes and relative sea level

(modified from Penland et al. 1988)

Figure 9. Adaptation of 1760 French map, from Brasseaux, The Founding

of New Acadia

Figure 10. [1760] Excerpt from an untitled map of Louisiana, in reference to the project vicinity. Excerpt depicts the Atacapas [Attakapas]

region and the Vacherie de Masse [Masse's cattle ranch].

Figure 11. Acadian settlements in New Brunswick and Nova Scotia, from

Brasseaux, The Founding of New Acadia.

Figure 12. Adaptation of Spanish land grant maps, along Bayou Teche, ca. 1849. From the Louisiana Surveyor General's Map, 1849.

Figure 13. This depiction of a seventeenth-century Indigotiere in the French

West Indies depicts the process used in Louisiana. From Hall, Africans in Colonial Louisiana 
Figure 14. The major Spanish land grants in the New Iberia/Fausse Pointe area of Bayou Teche, ca.1849. From G. Taylor, 1980

Figure 15. The Darby Plantation area, 1849. From G. Taylor, 1980

Figure 16. Adrian Persec's famed depiction of the Francois St. Marc

Darby Plantation on the eve of the Civil War. Adapted

from Bergerie, They All Tasted Bayou Water.

Figure 17. Divisions of the original Attakapas country. Adapted

from Bergerie, They All Tasted Bayou Water.

Figure 18. [1863] Adaptation from Abbot's Department of the Gulf, Map No.8, Atchafalaya Basin, prepared by order of Maj. Gen. N.P. Banks. Excerpt depicts Plantation owners downstream of New Iberia, as well as Petite Anse Island and Camp Bisland.

Figure 19. Excerpt from Irwin's 1893 map Irish Bend, in Raphael's The Battle in the Bayou Country.

Figure 20. Modern picture of the Episcopal Church of the Epiphany, which Union troops used as a prison during the Federal occupation of New Iberia.

From the Louisiana National Register of Historic Places, www.crt.state.la.us.

Figure 21. Adaptation from Abbot's Department of the Gulf, Map No.8, Atchafalaya Basin, prepared by order of Maj. Gen. N.P. Banks. Excerpt Depicts Location of Petite Anse Island and Camp Bisland

Figure 22. Map of Bayou Teche and surrounding localities, From Davis's The Rivers and Bayous of Louisiana.

Figure 23. Excerpt from Duke's 1870 field maps Survey of the Bayou Teche, May

Sheet 1 1870, depicting the project area.

Figure 23. Excerpt from Duke's 1870 field maps Survey of the Bayou Teche, May

Sheet 21870 , depicting the project area.

Figure 23. Excerpt from Duke's 1870 field maps Survey of the Bayou Teche, May

Sheet 3 1870 , depicting the project area.

Figure 23. Excerpt from Duke's 1870 field maps Survey of the Bayou Teche, May

Sheet 4 1870, depicting the project area.

Figure 23. Excerpt from Duke's 1870 field maps Survey of the Bayou Teche, May

Sheet 51870 , depicting the project area.

Figure 23. Excerpt from Duke's 1870 field maps Survey of the Bayou Teche, May

Sheet $6 \quad 1870$, depicting the project area. 70 
Figure 24. Excerpts from Duke's 1870 presentation maps Survey of the Bayou Teche, May 1870, Plate 1, depicting a cross section of Bayou Teche with the wreck Iberia

Figure 25. Excerpt from Trinidad's 1868 map Rough Sketch of Bayou Teche from St.

Martinsville to the Atchafalaya River showing the project area

Figure 26. Excerpts from Duke's 1870 presentation map Survey of the Bayou Teche,

May 1870, Plate 1, depicting the wrecks in the project area

Figure 27. Harper's Weekly sketch of sugar houses along the Teche, ca. 1866, from

Bergerie, They All Tasted Bayou Water

Figure 28. Main Street, New Iberia, 1910 and 1961, adapted from Bergerie, They All

Tasted Bayou Water

Figure 29. Drawing depicting array of remote sensing and positioning equipment utilized during the Bayou Teche survey

Figure 30. Hypack "Edit" screen images illustrating magnetic anomalies with positive monopolar, negative monopolar, dipolar, and multi-component signatures

Figure 31. Side Scan Sonar Image of a sunken vessel

Figure 32. Map of Bayou Teche survey area with magnetic and acoustic anomalies

Sheet 1 clustered into targets for survey Block 1

Figure 32. Map of Bayou Teche survey area with magnetic and acoustic anomalies

Sheet 2 clustered into targets for survey Block 1

Figure 32. Map of Bayou Teche survey area with magnetic and acoustic anomalies

Sheet 3 clustered into targets for survey Blocks 1 and 2 .

Figure 32. Map of Bayou Teche survey area with magnetic and acoustic anomalies

Sheet $4 \quad$ clustered into targets for survey Block 2 .

Figure 32. Map of Bayou Teche survey area with magnetic and acoustic anomalies

Sheet 5 clustered into targets for survey Blocks 2 and 3.

Figure 32. Map of Bayou Teche survey area with magnetic and acoustic anomalies

Sheet 6 clustered into targets for survey Block 3 .

Figure 32. Map of Bayou Teche survey area with magnetic and acoustic anomalies

Sheet 7 clustered into targets for survey Blocks 3 and 4 .

Figure 32. Map of Bayou Teche survey area with magnetic and acoustic anomalies

Sheet $8 \quad$ clustered into targets for survey Block 4 .

Figure 32. Map of Bayou Teche survey area with magnetic and acoustic anomalies

Sheet 9

clustered into targets for survey Blocks 4 and 5 
Figure 32. Map of Bayou Teche survey area with magnetic and acoustic anomalies

Sheet 10 clustered into targets for survey Blocks 4 and 5

Figure 32. Map of Bayou Teche survey area with magnetic and acoustic anomalies

Sheet 11 clustered into targets for survey Blocks 5 and 6 .

Figure 32. Map of Bayou Teche survey area with magnetic and acoustic anomalies

Sheet 12 clustered into targets for survey Block 6

Figure 32. Map of Bayou Teche survey area with magnetic and acoustic anomalies

Sheet 13 clustered into targets for survey Block 6

Figure 33. Magnetic contouring of Target \#62 - Parish Rd. Bridge

Figure 34. Acoustic Image of Target \#62 - Parish Rd. Bridge 126

Figure 35. Magnetic contouring of Target \#22 - Possible cable or Pipeline

Figure 36. Acoustic Image of Target \#22 - Possible cable or Pipeline

Figure 37. Acoustic Image of Target \#36-Possible cable or Pipeline

Figure 38. Acoustic Image of Target \#46-Possible cable or Pipeline

Figure 39. Magnetic contouring of Target \#84 - Bulkhead.

Figure 40. Magnetic contouring of Target \#9 - Bank debris

Figure 41. Magnetic contouring of Target \#10 - Debris 140

Figure 42. Magnetic contouring of Target \#27 - Possible Dock

Figure 43. Acoustic Image of Target \#27 - Possible Dock

Figure 44. Magnetic contouring of Target \#31 - Debris

Figure 45. Magnetic contouring of Target \#38 - Debris

Figure 46. Magnetic contouring of Target \#45 - Debris

Figure 47. Magnetic contouring of Target \#47-Debris

Figure 48. Magnetic contouring of Target \#55 - Debris

Figure 49. Magnetic contouring of Target \#59-Debris

Figure 50. Magnetic contouring of Target \#69-Debris

Figure 51. Magnetic contouring of Target \#71 - Debris 155

Figure 52. Magnetic contouring of Target \#72-Debris 156

R. Christopher Goodwin \& Associates, Inc. 
Figure 53. Acoustic Image of Target \#72 - Debris ..................................................................... 157

Figure 54. Magnetic contouring of Target \#74 - Debris ............................................................... 159

Figure 55. Magnetic contouring of Target \#80 - Debris ................................................................ 160

Figure 56. Magnetic contouring of Target \#81 - Debris ..................................................................161

Figure 57. Overview photo of Staging Area 1 facing west.............................................................. 162

Figure 58. Plan view of Staging Area 1 depicting the locations of auger tests an63

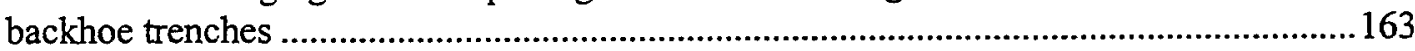

Figure 59. Profile of a typical backhoe trench excavated within Staging Area 1 ............................. 164

Figure 60. Overview photo of the profile of a typical backhoe trench excavated within Staging Area 1 ....................................................................................................... 164

Figure 61. Profile of a typical auger test excavated within Staging Area 1..................................165

Figure 62. Overview photo of Staging Area 2 facing south ............................................................166

Figure 63. Plan view of Staging Area 2 depicting the locations of auger tests and backhoe trenches 166

Figure 64. Profile of a typical backhoe trench excavated within Staging Area 2 .............................167

Figure 65. Overview photo of the profile of a typical backhoe trench excavated within Staging Area 2 .

Figure 66. Profile of a typical auger test excavated within Staging Area 2 ......................................167

Figure 67. Overview photo of Locus SA2-01 facing south ............................................................... 168

Figure 68. Selected historic period artifacts recovered from Locus SA2-01: (a) hard paste porcelain tea cup sherd with iridescent luster body, gold gilded lip and intricate handle (FS \#3); (b) colorless machine made square form bottle with a continuous thread lip (FS \#4) embossed with a "M" seal on each shoulder, "25.4 FL.OZ" on front and back heels, "750 ML" on both side heels, and "3935 A/ 5 (Brockway Glass Co.mark)/ 11" on base; and (c) a complete brick (FS \#5) embossed with "MEX-R-CO/ VIKING (Mexico Refractories Co., Missouri) 168

Figure 69. Overview photo of Staging Area 3 facing west............................................................... 169

Figure 70. Plan view of Staging Area 3 depicting the locations of auger tests and backhoe trenches

Figure 71. Profile of a typical auger test excavated within Staging Area 3....................................171

Figure 72. Overview photo of Disposal Area 1 facing east ............................................................171 
Figure 73. Plan view of Disposal Area 1 depicting the locations of auger tests and backhoe trenches

Figure 74. Profile of a typical backhoe trench excavated within Disposal Area 1

Figure 75. Overview photo of the profile of a typical backhoe trench excavated within Disposal Area 1

Figure 76. Profile of a typical auger test excavated within Disposal Area 1

Figure 77. Overview photo of Disposal Area 2 facing east

Figure 78. Plan view of Disposal Area 2 depicting the locations of auger tests and backhoe trenches.

Figure 79. Profile of a typical backhoe trench excavated within Disposal Area 2

Figure 80. Overview photo of the profile of a typical backhoe trench excavated within

Disposal Area 2

Figure 81. Profile of a typical auger test excavated within Disposal Area 2 ....................................176

Figure 82. Overview photo of Locus DA2-01 facing west............................................................176

Figure 83. Photo of cow burial identified within Locus DA2-01 ..................................................177

Figure 84. Overview photo of Disposal Area 3 facing south...........................................................177

Figure 85. Plan view of Disposal Area 3 depicting the locations of auger tests and backhoe trenches

Figure 86. Profile of a typical auger test excavated within Disposal Area 3 ....................................179

Figure 87. Overview photo of Access Road 1 facing south............................................................ 180

Figure 88. Profile of a typical auger test excavated within Access Road 1 ...................................180

Figure 89. Overview photo of Access Road 2 facing south............................................................181

Figure 90. Profile of a typical auger test excavated within Access Road 2 .................................181 


\section{LIST OF TABLES}

Table 1. Plant Taxa Characteristic of Marshes within the Vicinity of the Proposed Project Area

Table 2. Crustaceans and Shellfish Present within the Vicinity of the Proposed Project Area

Table 3. Fishes Present within the Vicinity of the Proposed Project Area... 23

Table 4. Mammals Present within the Vicinity of the Proposed Project Area 24

Table 5. Birds Present within the Vicinity of the Proposed Project Area. 25

Table 6. Reptiles and Amphibians Present within the Vicinity of the Proposed

Project Area 26

Table 7. Plant Taxa of Swamps and Natural Levees Present within the Vicinity of the Proposed Project Area

Table 8. Birds Present in the Vicinity of the Proposed Project Area. 28

Table 9. Summary of Shipwrecks and Other Cultural Obstructions along Bayou Teche, from St. Martinsville to the Atchafalaya River, Louisiana 1868-1887

Table 10. Previously Completed Cultural Resources Surveys Conducted within $8 \mathrm{~km}$ (5 mi) of the Currently Proposed Project Area of Potential Effect

Table 11. Previously Recorded Sites Located within $1.6 \mathrm{~km}$ (1 mi) of the Currently Proposed Project Area

Table 12. Historic Standing Structures Located within $1.6 \mathrm{~km}(1 \mathrm{mi})$ of the Currently Proposed Bayou Teche Study Area that Appear in the National Register of Historic Places

Table 13. Previously Recorded Standing Structures Located within $1.6 \mathrm{~km}$ (1 mi) of the Currently Proposed Project Area

Table 14. Breakdown of the Terrestrial Areas of Potential Effect by Testable Area, Testing Intervals, and Number of Auger Tests and Backhoe Trenches Excavated

Table 15. Historic period artifacts recovered from Locus SA2-01 169

Table 16. Artifacts and faunal specimens recovered from Locus DA2-01 176 


\section{CHAPTER I}

\section{INTRODUCTION}

$\mathrm{T}$ his document presents the results of Phase I underwater and terrestrial cultural resources survey and archeological inventory of a $19.3 \mathrm{~km}(12 \mathrm{mi})$ stretch of Bayou Teche situated between River Mile 48.7 and River Mile 61.0, as well as six proposed terrestrial project items and two proposed access roads located near the banks of Bayou Teche (Figure 1). Plans call for this portion of the bayou to be subjected to maintenance dredging by the U.S. Army Corps of Engineers, New Orleans District. The six terrestrial project items consist of three staging areas from which the dredging operations will be coordinated and three disposal areas that will receive the spoil removed from the bayou. In addition, the Corps plans to utilize two access roads to provide access to the disposal areas.

This investigation was completed by $\mathrm{R}$. Christopher Goodwin \& Associates, Inc., on behalf of the U.S. Army Corps of Engineers, New Orleans District, pursuant to Contract DACW29-97-D-0018, Delivery Order 24. All fieldwork was conducted in accordance with the National Historic Preservation Act of 1966, as amended; Louisiana's Comprehensive Archaeological Plan (Smith et al. 1983); the Scope of Work as drafted by the U.S. Army Corps of Engineers, New Orleans District; with 36 CFR 800, "Protection of Historic Properties;" with the Abandoned Shipwreck Act of 1987 (43 U.S. C. 2101 - 2106); with Abandoned Shipwreck Guidelines, National Park Service; with National Register Bulletins 14, 16, and 20; with 36CFR 66; and with the Secretary of the Interior's Standards and Guidelines for Archeology and His- toric Preservation (Federal Register 48, No 190, 1983).

\section{Project Description}

This section provides a brief overview of the federal undertaking as outlined in the Scope of Work prepared by the U.S. Army Corps of Engineers, New Orleans District. The U.S. Army Corps of Engineers, New Orleans District proposes to dredge an approximately $19.3 \mathrm{~km}$ (12 mi) long stretch of Bayou Teche in and around the community of New Iberia, within Iberia Parish, Louisiana (Figure 1). During the dredging process, the U.S. Army Corps of Engineers will utilize three proposed staging areas from which dredging operations will be supervised and three disposal areas onto which spoil from the bayou bottom will be deposited. In addition, two proposed access roads linking the staging areas with the disposal areas will be used during dredging operations. In order to mitigate the effects upon cultural resources located within the proposed project area, both underwater and terrestrial cultural resources surveys were undertaken. A brief overview of each survey is described below.

\section{The Underwater Survey}

In keeping with the New Orleans District's mission to preserve, document, and protect significant cultural resources, a magnetic and acoustic remote sensing survey was undertaken to locate potential underwater cultural resources. The underwater portion of the proposed project area was divided into six continuous survey blocks. Each block measured approximately 3.2 


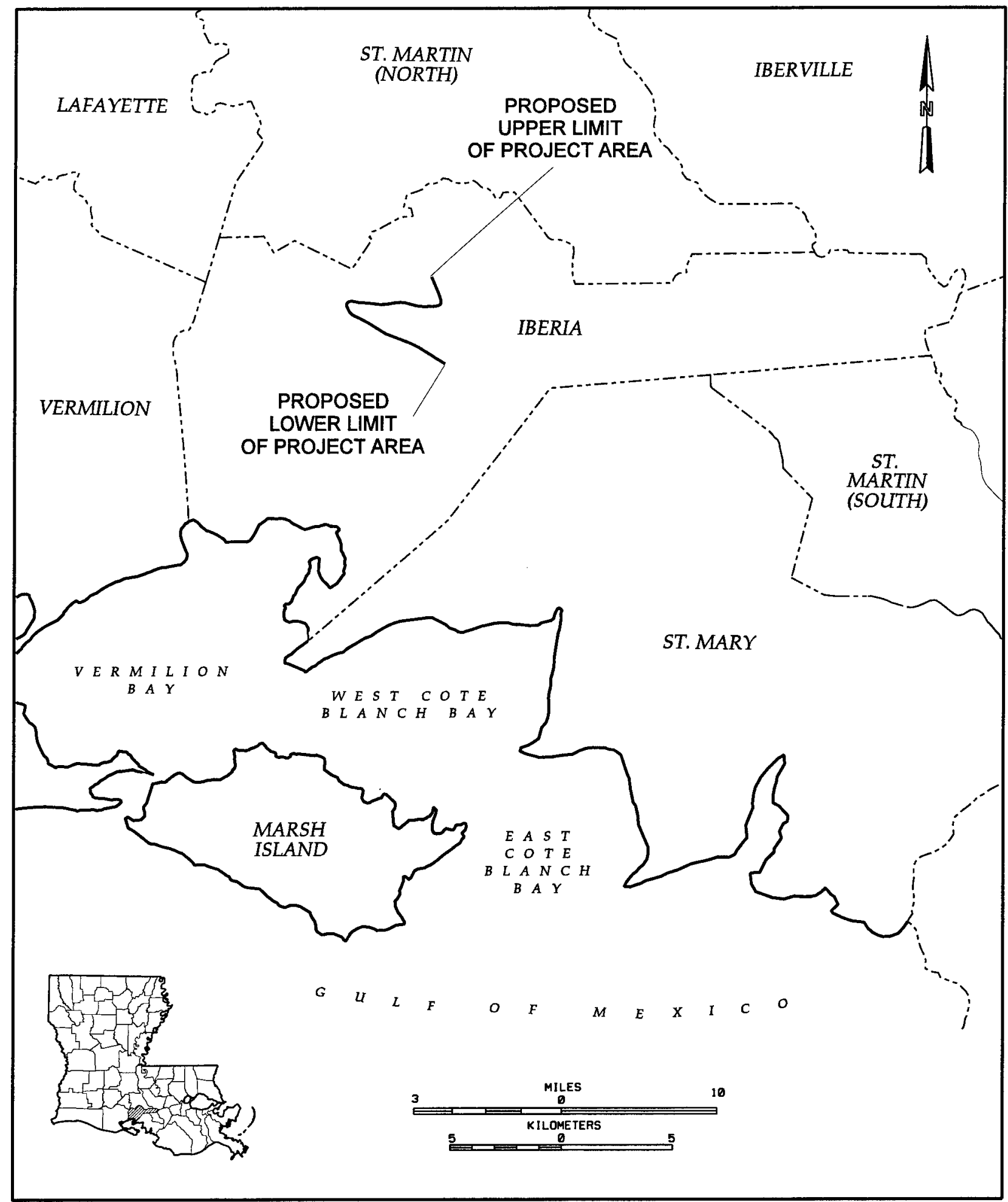

Figure 1. Map of Louisiana depicting the location of the proposed study reach within Iberia Parish, Louisiana. 
$\mathrm{km}(2 \mathrm{mi})$ in length, and examination of each block was completed utilizing two survey transects (Figure 2). A total of approximately 38.6 linear $\mathrm{km}$ (24 linear miles) of river bottom were surveyed; the survey area encompassed approximately $19,312 \times 22.9 \mathrm{~m}(63,360 \mathrm{ft} . \times 75 \mathrm{ft})$ of bayou bottom. The following coordinates delineate the limits of the survey area:

$\begin{array}{ll}\text { Olivier St. Bridge } & 29^{\circ} 58.74^{\prime} \mathrm{N} \\ & 091^{\circ} 45.23^{\prime} \mathrm{W} \\ \text { SR94 Bridge } & 30^{\circ} 01.97^{\prime} \mathrm{N} \\ & 091^{\circ} 44.20^{\prime} \mathrm{W}\end{array}$

The objectives of the underwater portion of this investigation were to identify all submerged and visible watercraft, as well as other maritime related cultural resources located within the Area of Potential Effect; whenever possible, to assess the National Register of Historic Places eligibility of identified cultural resources applying the criteria for evaluation (36 CFR 60.4 [ad]); and to provide the U.S. Army Corps of Engineers, New Orleans District with management recommendations for all identified underwater cultural resources. These objectives were met through a combination of archival research and field survey. The background study and maritime history of the proposed project area were completed using data on file with the Department of Culture, Recreation, and Tourism, Division of Archaeology, local historical files, previous cultural resources investigations conducted within the vicinity of the proposed project reach, historic period maps of the region, relevant primary map and microfilm records, and secondary literature sources.

\section{The Terrestrial Survey}

The terrestrial portions of the proposed project area included six individual project items and two access roads (Figure 3, Sheets 1 - 2). The proposed project items included three staging areas and three dredge spoil disposal areas. Each of the proposed project items, as well as the two access roads, is described briefly below.

The first proposed terrestrial staging area was located within the vicinity of River Mile 57.3 in the southeast portion of Section 9 of Township 12S, Range 7E (Figure 3, Sheet 1 and
Attachment 1). Staging Area 1 measured approximately 0.5 ha $(1.2 \mathrm{ac})$ and it was rectangular in shape. This staging area fronted on the western shore of Bayou Teche.

The second staging area measured approximately 3.8 ha $(9.4 \mathrm{ac})$ and it was irregular in shape (Figure 3, Sheet 1 and Attachment 1). Staging Area 2 was located within the vicinity of River Mile 54.5, and within the southeastern portion of Section 10 and the southwestern portion of Section 13 of Township 12S, Range 6E. This southern boundary of this proposed staging area was positioned approximately $100 \mathrm{~m} \mathrm{(328}$ $\mathrm{ft}$ ) from the western shore of Bayou Teche.

The third proposed staging area was located at River Mile 50.4 and within Section 38 of Township 12S, Range 7E (Figure 3, Sheet 2 and Attachment 1). Staging Area 3 was roughly square and it encompassed approximately 1.67 ha $(4.2 \mathrm{ac})$ of land. It too was situated on the western bank of Bayou Teche, and it fronts on the bayou.

The first disposal area was situated within the northeastern portion of Section 9 and the northwest portion of Section 77 of Township 12S, Range 7E (Figure 3, Sheet 1 and Attachment 1). Disposal Area 1 was located approximately $800 \mathrm{~m}(2,624 \mathrm{ft})$ from the western bank of Bayou Teche and within the vicinity of River Mile 57.7. This proposed project item measured approximately 10.6 ha $(26.1 \mathrm{ac})$ and it was irregular in shape. This area was bounded on the north and west by several existing sewage disposal ponds, on the east by an agricultural field, and on the south by a drainage ditch that surrounds a small housing development.

The second disposal area was located within the vicinity of River Mile 57.4. It was situated within the southeastern portion of Section 9 of Township 12S, Range 7E and it measured approximately 0.75 ha $(1.86 \mathrm{ac}$ ) (Figure 3, Sheet 1 and Attachment 1). Disposal Area 2 was rectangular in shape and it fronted along the western bankline of Bayou Teche. Proposed Staging Area 1 was located adjacent to and east of this proposed disposal area.

The final disposal area was located within the northeastern portion of Section 39 of Town ship 12S, Range 7E and it encompassed approximately 24 ha $(59.2 \mathrm{ac})$ of land (Figure 3, Sheet 2 and Attachment 1). Disposal Area 3 was 


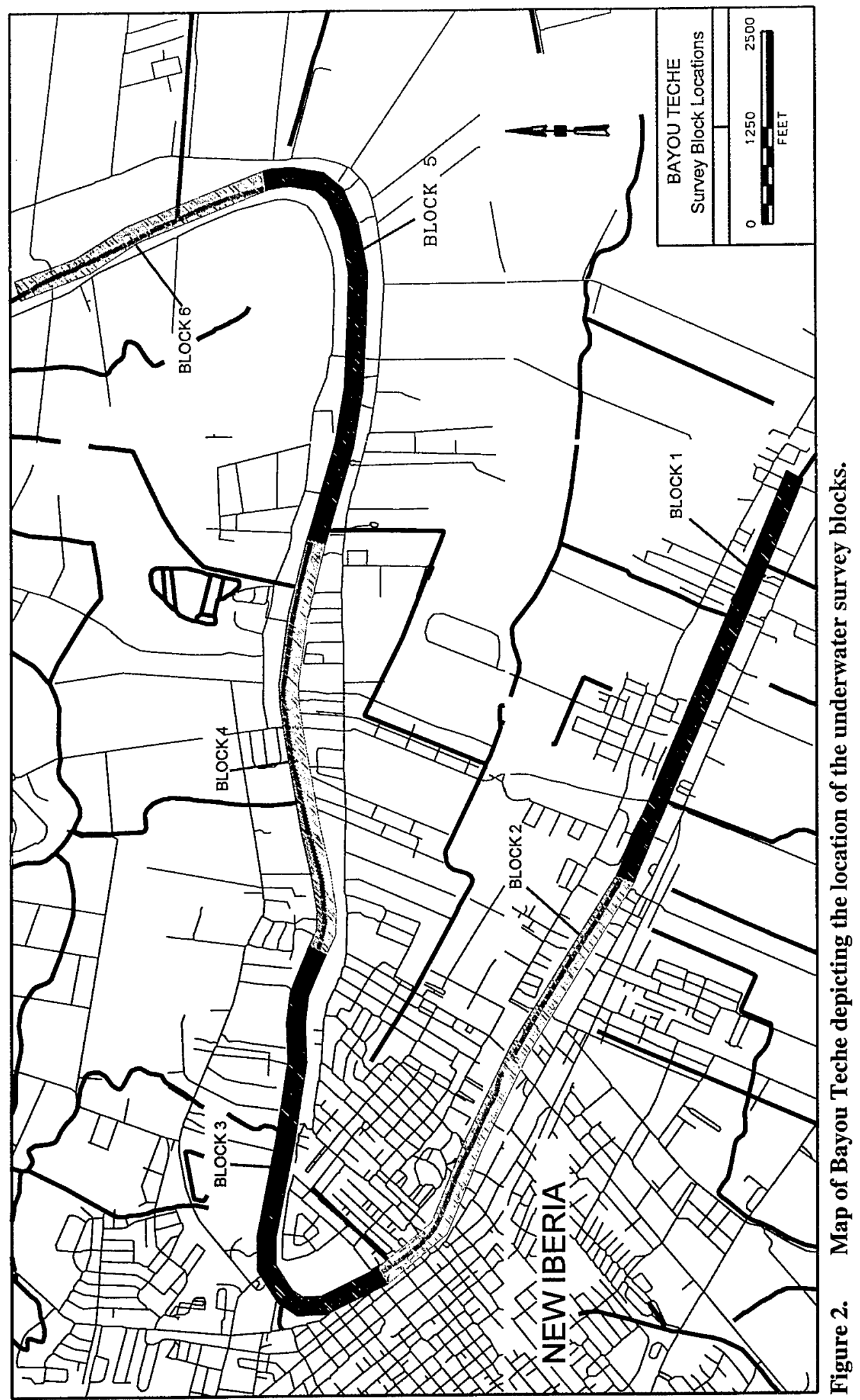




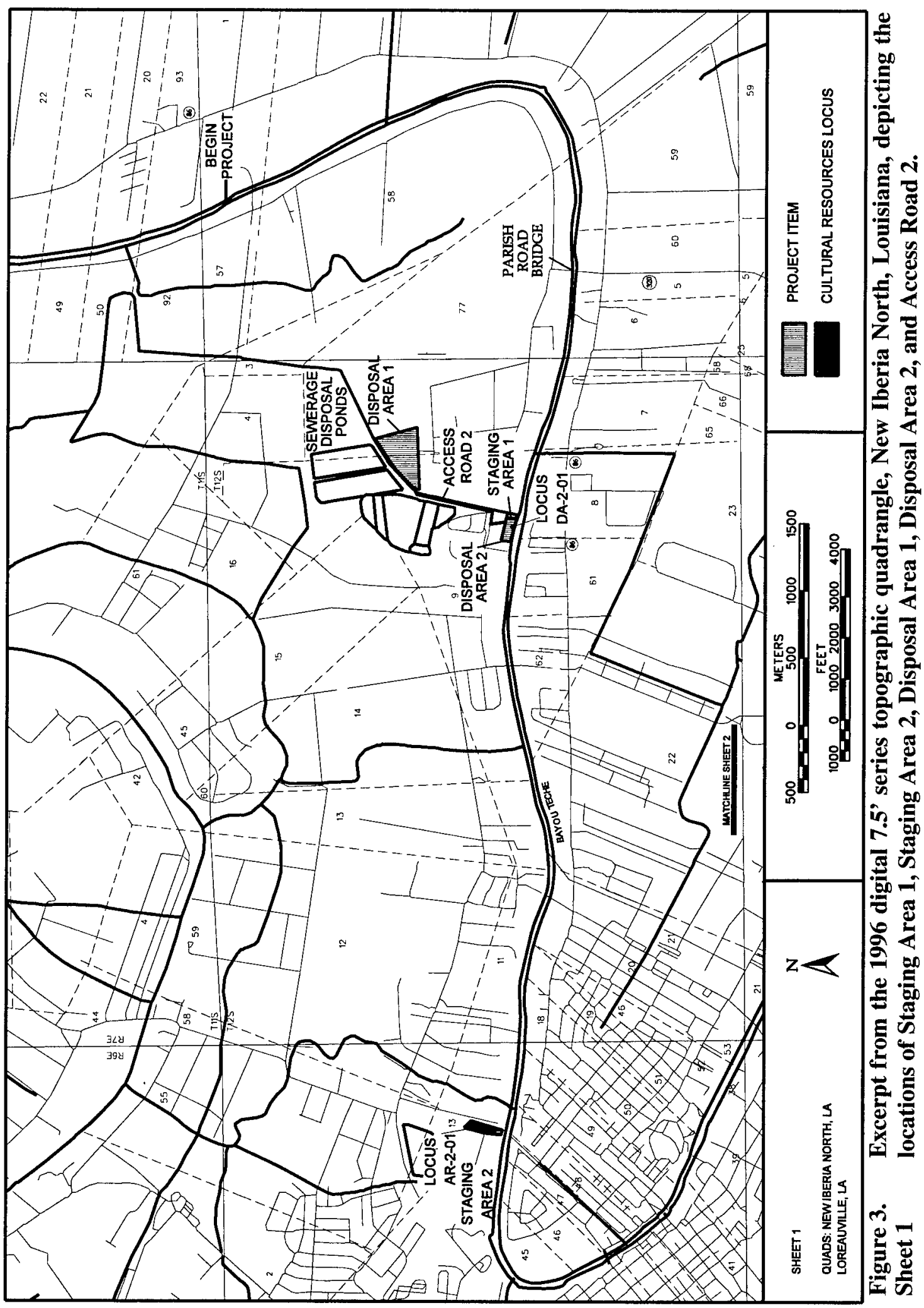


Chapter I: Introduction

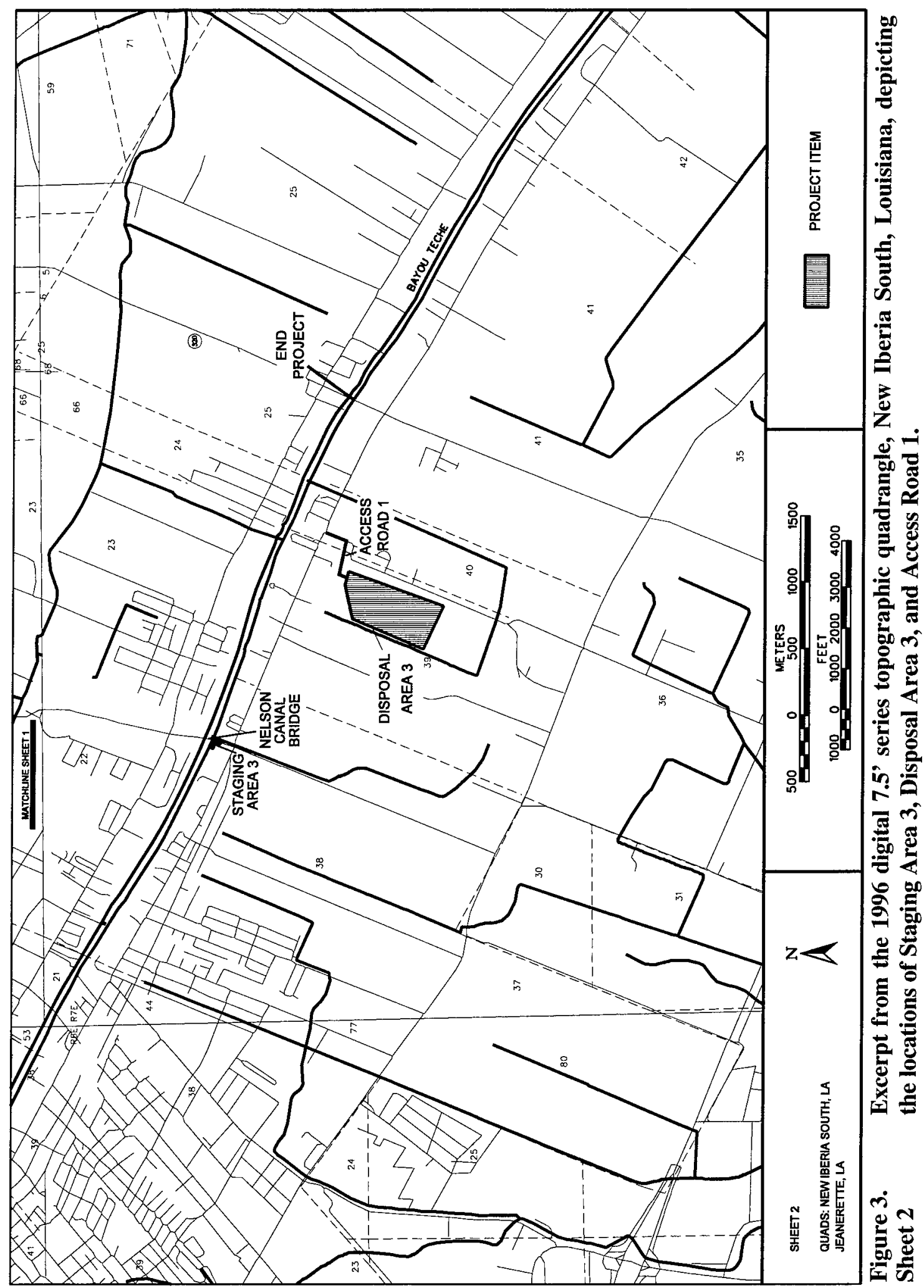


roughly rectangular in shape and it was positioned approximately $600 \mathrm{~m}(1,968 \mathrm{ft})$ south of the western bank of Bayou Teche and opposite River Mile 49.6. This disposal area currently contains three large sewage treatment ponds.

In addition, two proposed access roads were examined during fieldwork. Access Road 1 measured approximately $437 \mathrm{~m}(1,433 \mathrm{ft})$ in length and approximately $5.0 \mathrm{~m}(16.4 \mathrm{ft})$ in width and it extended from the northeastern corner of Disposal Area 3 to Central Road, an existing paved road. This access road consisted of a partly paved surface and a packed dirt twotrack road (Figure 3, Sheet 1). Access Road 2 measured approximately $790 \mathrm{~m}(2,591 \mathrm{ft})$ in length (Figure 3, Sheet 2). This road extended across a grassy area positioned adjacent to the northern portion of Disposal Area 2, parallel to an existing parish road, across a large paved parking lot owned and maintained by the Cajun Sugar Corporation, and finally along a graveled two-track road to its terminus at the southwestern corner of Disposal Area 1.

\section{Project Results}

The following sections briefly present the results of Phase I cultural resources survey of the Bayou Teche channel, the six terrestrial project items, and the proposed access roads. This discussion, like the field methodologies, is divided into two sections.

\section{Results of the Underwater Survey}

During the analysis of magnetic data derived from the underwater survey, particular attention was paid to those high density magnetic anomalies, clusters of anomalies, and single anomalies of unusually high amplitude, duration, or that exhibited complex magnetic signatures. A total of 614 individual magnetic anomalies were identified during survey. Of the 614 magnetic anomalies, 445 were determined to represent scattered modern ferrous debris. The remaining 169 magnetic anomalies were clustered into 84 target groups for additional study. These target groups then were contoured for further analysis.

In addition, 48 individual acoustic anomalies were detected during the survey of Bayou Teche. At least 20 of these acoustic anomalies are correlated with one or more of the magnetic anomalies grouped within the 84 targets. All of the acoustic anomalies appear to represent modern disturbances, such as bridge pilings, pipelines or cables, bulkheads, bank debris, or scatters of modern ferrous debris. No significant cultural resources were identified as a result of this investigation.

Of the 84 magnetic/acoustic target groups studied, none represented the remains of structures such as shipwrecks or other significant cultural resources. In fact, eight of the targets represented bridge pilings from the many bridge crossings located throughout the proposed area (Targets 1, 12, 20, 23, 24, 43, 62, and 83). Another 10 targets possibly represented pipeline or cable crossings (Targets 2, 12, 19, 20, 22, 24, $35,36,46$, and 70 ); while some of these anomalies correlate with the identified bridge structures (Targets 12, 20, and 24). A total of eight of the identified targets consisted of bulkheads that were situated along the banks of the bayou (Targets $3,4,6,16,28,29,34$, and 84). Bank debris accounted for 13 of the identified targets (Targets $9,11,15,18,25,26,37,49,50,60,67,77$, and 78 ), while the remaining 45 targets probably represent modern ferrous debris or structures that do not constitute significant cultural resources.

\section{Results of the Terrestrial Survey}

This Phase I cultural resources survey and archeological inventory of the terrestrial project items resulted in the identification and recordation of two non-site cultural resources loci (DA2-01 and SA2-01). Both of the cultural resources loci were classified as historic period/modern disposal areas. Locus DA2-01 produced evidence of a buried cow and a single glass shard, while Locus SA2-01 consisted of a scatter of late historic period/modern trash, including metal fragments, pieces of styrofoam, plastic soda bottles, modern clothing fragments, and a minor amount of twentieth century ceramic sherds. Locus SA2-01 also exhibited evidence of having been bulldozed and graded. Neither of these cultural resources loci were identified within the vicinity of previously recorded National Register of Historic Places properties. Loci DA2-01 and SA2-01 do not possess the qualities of significance as defined by the National Register of Historic Places crite- 
ria for evaluation (36 CFR 60.4 [a-d]). No additional testing of these loci is recommended.

\section{Recommendations}

This section presents the management recommendations for cultural resources identified during survey. It is divided into two sections and recommendations for the management of cultural resources identified during both the underwater and terrestrial surveys are included.

\section{Recommendations for Identified Underwater Cultural Resources}

None of the remote sensing targets identified during survey appear to possess the qualities of significance as defined by the National Register of Historic Places criteria of evaluation (36 CFR 60.4 [a-d]). As a result, no additional survey of the Bayou Teche channel is recommended; however, avoidance of the cable or pipeline crossing areas may be warranted.

\section{Recommendations for Identified Terrestrial \\ Cultural Resources}

The terrestrial portion of the current investigation failed to identify any cultural resources that possess the qualities of significance as defined by the National Register of Historic Places criteria for evaluation (36 CFR 60.4 [a-d]). No additional testing of the six proposed project items or the two proposed access roads is recommended.

\section{Project Personnel}

Dr. R. Christopher Goodwin, Ph.D., served as Principal Investigator for the underwater portion of this project. Mr. Jean B. Pelletier, M.A., acted as Project Manager and he directed all aspects of data collection and analysis. He was assisted by Mr. Larkin A. Post, B.A., Mr. David W. Trubey, B.A., and Ms. Sarah A. Milstead, B.A.
Mr. William P. Athens, M.A., served as Principal Investigator for the terrestrial portion of this undertaking. Mr. David R. George, M.A., A.B.D., acted as Project Manager. Ms. Katy Coyle, M.A., supervised the historical research. Ms. Charlene Keck, M.A., directed the laboratory analysis; she was assisted by Ms. Rebecca Johnson, B.A., and Mr. James Allen Green. Ms. Kari Krause, M.S., directed the field effort; she was assisted by Mr. James Clark, B.A., Mr. David Crowell, B.A., and Ms. Carrie Humphrey, B.A.

\section{Organization of the Report}

The natural setting within the vicinity of the proposed project area is presented in Chapter II. It includes a brief overview of the geomorphology, soils, flora, fauna, and climate of the region. The prehistory of the project area is outlined in Chapter III. The history of the proposed project area is chronicled in Chapter IV; it presents both a maritime and terrestrial history of the proposed project area. A review of all previously recorded archeological sites, historic period standing structures, National Register of Historic Places properties, and cultural resources surveys previously completed in the immediate vicinity of the proposed project area is contained in Chapter V. The field methods used to complete this investigation are discussed in Chapter VI. That chapter also includes a discussion of the laboratory methods and procedures used to process and analyze the cultural material recovered during survey. The results of this investigation, including a description of each identified cultural resource, are described in Chapter VII. A summary and management recommendations are presented in Chapter VIII. A list of artifacts recovered as a result of this investigation is included in Appendix I. 


\section{ChAPTER II}

\section{NATURAL SETTING}

工 ntroduction

The distribution of human habitation across landscape is influenced in large part by the environment and by the usable resources found within it. The portion of Louisiana encompassed by the proposed project area contains a number of exploitable ecosystems. This chapter identifies those processes that characterized the development of the area and it documents how they influenced the settlement and subsistence strategies characteristic of the prehistoric and historic period populations of the region. An overview of the natural setting of the proposed project area, therefore, serves as a useful aid in identifying those areas likely to contain archeological sites, as well as data on the possible types, chronologies, and associations of the archeological deposits contained within them.

Southern Louisiana has one of the most dynamic and active coastlines in the United States. The surface water of more than half of the North American continent drains through the Mississippi River. The silts and clays suspended in the river eventually reach and are deposited either in the Gulf of Mexico or along the Louisiana coastline. Over time, the Mississippi River has abandoned repeatedly its channel to create new meander belts. Between meander belts, the vertical accretion of lacustrine, swamp, and crevasse sediments has created a thick sequence of finegrained, often organically rich sediments (Fisk 1944; Saucier 1974).

The currently proposed Bayou Teche project area is located within Iberia Parish, Louisiana and approximately $32 \mathrm{~km}(20 \mathrm{mi})$ north of that portion of the Gulf of Mexico that contains West Cote Blanche Bay and Vermilion Bay. Elevations throughout the Areas of Potential Effect range from only 3 to $6 \mathrm{~m}$ (10 to $20 \mathrm{ft}$ ) above sea level. Topography in this region can be characterized as flat.

The proposed project corridor falls within the Teche Delta Complex. The Teche Delta Complex served as the major distributary of the Mississippi River between approximately 5,800 to 3,900 years ago. The Red River subsequently occupied this course, keeping the Teche Delta Complex active until 1,800 to 1,900 years ago. With the abandonment of this delta, the region began to subside.

The clearing of large log jams within the nearby Atchafalaya River around the turn of the century made that river, with its steeper gradient and shorter distance to the Gulf of Mexico, a more attractive alternative to the current Mississippi River channel. The construction of the Old River Control Structure in 1963, located approximately $442 \mathrm{~km}$ (275 mi) north of the proposed project area, helps to maintain the present course of the Mississippi River and restrict the waterflow of the Atchafalaya River and surrounding drainages (including Bayou Teche) to approximately 30 percent of the Mississippi River's volume. The result has been renewed sedimentation throughout the Atchafalaya Basin, including areas contained within the vicinity of the proposed project area.

\section{Regional Geomorphology}

The sedimentology and geomorphology of the Mississippi Delta in particular and southern Louisiana in general has been studied and described in detail by a large number of investigators. Coleman and Gagliano (1964), Fisk (1955, 
1960), Gould (1960), Penland (1990), and Penland et al. (1985) describe the sedimentology and geomorphology of the shoal-water deltas that comprise almost all of the Mississippi delta complexes. In addition, Kosters (1989) and Tye and Kosters (1986) describe the active processes, as well as the sediments that characterize the interdistributary bays of the delta plains. Finally, Coleman (1982), Frazier (1967), and Kolb and Van Lopik (1966) all summarize important aspects of the ecology, geomorphology, and sedimentology of the Mississippi River Delta.

A delta plain is the constructional surface of a delta complex, while a delta complex includes the principle distributaries that are fed from a common river course and the delta lobe that these distributaries have constructed. A delta lobe consists of a set of subdeltas and minor distributaries that develop from a principal distributary. The Mississippi Delta Plain represents a composite geomorphic surface that consists of a series of overlapping relict delta plains. The surface morphology of each delta plain is dominated by an extensive network of distributaries that radiate out either from an abandoned or active Mississippi River course into its delta plain. Each of these distributary networks is separated by a series of connecting interdistributary lakes and ponds. The lakes and ponds increase in size and coalesce towards the coast, forming larger, interdistributary bays that open to the Gulf of Mexico (Coleman 1982; Fisk 1960; Frazier 1967; Kolb and Van Lopik 1958). These formational processes chronicle the development of the proposed project area as it appears today.

The following sections describe the subcomponents of the geomorphology contained within the vicinity of the proposed project. These consist of undifferentiated fluvial deposits of the Prairie Complex, point bar deposits, backswamp deposits, abandoned river courses, and abandoned channels.

\section{Undifferentiated Fluvial Deposits of the Prairie} Complex (Ppu 1)

The late Pleistocene coastal plain formation known as the Prairie complex represents several distinctive overlapping sedimentary cycles initiated by upstream diversions of river flow, each cycle being the correlative of a discrete delta complex. Each cycle involves sediments laid down in multiple environments of deposition ranging from fresh water to saline in the dynamic zone of interaction where the river emptied into the Gulf. Geomorphologically, these undifferentiated fluvial deposits of the Prairie Complex developed natural levees and backswamps from the sedimentation of the Mississippi and Red Rivers.

Natural levees include the broad, low ridges which flank both sides of streams that periodically overflow their banks. The coarsest and greatest quantities of sediment, mostly silts and silty clays, are deposited closest to the stream channels; consequently, the natural levees are highest and thickest in these areas and gradually thin away from the channels. In general, the greater the distance from the stream, the greater the percentage of clays. Natural levee sediments are deposited mostly by sheetflow; however, occasionally the flow will be concentrated and crevasse channels will form. In a small number of cases, a small crevasse channel will persist through multiple flood cycles and become an alluvial valley distributary.

Backswamp environments typically have very low relief and a distinctive, anastomosing, and inefficient drainage system in which channels alternately serve as tributaries and distributaries at different times of the annual flood cycle. These broad, shallow basins beyond distal natural levees are the sites of the slow, incremental deposition (vertical accretion) of finegrained sediments (mostly clays) during times of widespread overbank flooding. Sedimentcarrying floodwater may be ponded between the natural levee ridges on separate meander belts, or between natural levee ridges and the uplands forming the valley walls.

\section{Point bar $\left(\mathrm{Hpm}_{3}\right)$}

Being by far the predominant environment in a meander belt in terms of both area and volume, the point bar environment includes materials laid down as lateral accretion on the insides of river bends as a result of meandering of a stream with a large sediment load. The deposits extend to a depth equal to the deepest portion or "thalweg" of the parent stream. Two types of deposits occur within the point bar topstratum: well-oxidized, brown and gray, silty and sandy sediments in elongate point bars or "ridges" that 
are laid down during high stages on the stream; and mostly gray, slightly oxidized, silty and clayey deposits in arcuate depressions or "swales" that are laid down during falling river stages. The ridges and swales characteristically form an alternating series (point bar accretion topography), the configuration of which conforms to the curvature of the migrating river channel and indicates the direction and extent of meandering.

Zones of point bar accretion are most widespread and most evident because of their morphology and sediments in the alluvial valley area. Nearly continuous point bar tracts, sometimes largely uninterrupted for tens of kilometers, exhibit complex patterns of cross-cutting relationships due to the meandering of multiple river bends. The accretion topography often is subdued or even completely masked by natural levees near the active and abandoned river channels. Because the changing nature of the river's sediment load and bed and bank materials in a downstream direction, cause much slower rates of meandering, zones of point bar accretion flanking the river in the deltaic plain area are much narrower and more heavily veneered with natural levee deposits than in the alluvial valley.

\section{Backswamp (Hb)}

Broad, shallow basins beyond distal natural levees are the sites of the slow, incremental deposition (vertical accretion) of fine-grained sediments (mostly clays) during times of widespread overbank flooding. Sediment-carrying floodwater may be ponded between the natural levee ridges on separate meander belts, or between natural levee ridges and the uplands forming the valley walls. Backswamp areas typically have very low relief and a distinctive, anastomosing, and inefficient drainage system in which channels alternately serve as tributaries and distributaries at different times of the annual flood cycle.

During the early and mid Holocene, backswamp tracts were much more widespread than at present, having been truncated and eroded by the progressive development of meander belts. The surviving tracts increase progressively in extent and thickness in a downstream direction, in inverse relationship to the extent of point bar areas. By far the largest contiguous tract in the
Lower Mississippi Valley occurs in the Atchafalaya Basin of Louisiana in the northern part of the deltaic plain.

Backswamp deposits consist of mostly massive sequences of soft, gray to dark gray, poorly oxidized, organic rich, and very poorly drained clays and silty clays. They average well over $30 \mathrm{~m}(100 \mathrm{ft})$ in the southern part of the Atchafalaya Basin in Louisiana. In all cases, backswamp deposits overlie glacial outwash deposits (the substratum) or may be separated from them by backswamp-like deposits laid down by streams flowing in an anastomosing environment.

\section{Abandoned course (Hcom)}

Abandoned courses are lengthy segments of rivers abandoned when streams divert to new courses across the floodplain. They generally occupy medial positions within meander belts and they vary in length from a few kilometers (but always more than one meander loop) up to hundreds of kilometers in length.

During the process of abandonment of a river course, which may take a few centuries, flow declines and the remaining channel becomes progressively more underfit. In some cases, the area between the original banklines and the surviving channel becomes filled with silty and sandy point bar-like deposits with a typical ridge and swale topography. When this occurs, the original banklines of the parent river channel may be difficult to identify. In other cases, the surviving channel continues to actively meander and it may migrate beyond the limits of the parent channel, thereby destroying segments of the abandoned course and its banklines. When a course is completely abandoned and all flow ceases, the surviving underfit stream typically functions only to accommodate local drainage and may only be a slackwater slough or bayou. Hence, the deposits of an abandoned channel may be highly analogous to point bar deposits in some reaches, but in others, they may more closely resemble those of an abandoned channel.

Five abandoned courses of the Mississippi River have been recognized and mapped in the Lower Mississippi Valley, and identifiable segments occur south of the latitude of Dyersburg, Tennessee. Two of these abandoned courses 
(Nos. 3 and 4) extend into the deltaic plain of central coastal Louisiana and constitute what is referred to as the Teche system.

\section{Abandoned channel (Hchm)}

Abandoned channels are partially or wholly filled segments of meandering streams formed by cutoffs when the stream shortens its course. Soon after formation, they are usually characterized by open water or "oxbow lakes." Later, they may become essentially filled and occasionally completely obscured by various meander belt deposits. The abandoned segment may represent an entire meander loop formed by a neck cutoff, or may represent only a portion of a loop formed by a chute cutoff when a stream diverts through a point bar swale during high water.

The upper portions of the arms of the loops of neck cutoffs normally are filled with a wedge of fine sand and silty sand that is deposited soon after cutoff. Later, soft, gray, high-water-content clays form a characteristic "clay plug" around the loop of the abandoned channel between the sand wedges as the oxbow lake fills with sediment. From time of cutoff to complete filling, an abandoned channel experiences a characteristic and predictable life cycle, the various stages of which produce different environmental conditions that were very important to humans in prehistoric times. Also, however, the life cycle of a cutoff is strongly influenced by the pattern of channel migration in the meander belt after cutoff takes place. If the active channel remains close to the cutoff, it may be rapidly filled and completely veneered and obscured by natural levee deposits. If the active channel rapidly moves away, the cutoff may remain indefinitely as an oxbow lake.

The frequency of cutoffs along meandering rivers is directly related to the rates and magnitudes of meandering. The frequency is also a function of the age (duration) of the meander belt--ones that have been occupied the longest generally have the greatest number of abandoned channels. Cutoff frequencies along the Mississippi River and its tributaries vary greatly from reach to reach because of various factors, and they decline significantly in a downstream direction.
The crests of natural levee ridges immediately flanking abandoned channels in an incompletely filled state were a highly favored setting for prehistoric settlement. In addition to the well-drained and arable soils of the levees, the lacustrine and wetland environments of the abandoned channel provided immediate access to potable water and abundant wildlife and fisheries resources.

The Proposed Project Area in the Context of the Atchafalaya Basin

The Atchafalaya Basin is a very large flood/interdistributary basin that opens eventually to the Gulf of Mexico (Figure 4); the proposed project area is located within the western portion of this basin. The Atchafalaya Basin is bounded by the natural levees of the Mississippi River, Bayou Teche, and Bayou Lafourche (Figure 5). The Basin measures approximately $110 \mathrm{~km}(68$ mi) in length and it ranges from 20 to $60 \mathrm{~km}$ (12 to $37 \mathrm{mi}$ ) in width. This basin encompasses approximately $2,830 \mathrm{~km}^{2}\left(1,093 \mathrm{mi}^{2}\right)$ of natural levees, backswamps, and lakes.

Much of the basin consists of a complex network dividing, subdividing, and rejoining distributaries of the Grand and Atchafalaya Rivers, as well as smaller drainages such as Bayou Teche; however, the natural levees associated with these distributaries and the large distributary crevasses of the Mississippi River and Bayou Teche subdivide the Atchafalaya Basin into numerous sub-basins (Figure 4). Inflow from the distributaries of these rivers, bayous, and formerly active crevasses empty into large lakes, e.g., Lake Fausse Point, Grand Lake, and Lake Verret. Prior to the modern construction of the Wax Lake Outlet, the surface waters of the basin collected in these lakes and drained into the Atchafalaya Bay through the relatively short, deep, lower Atchafalaya River and associated Berwick Bay (Tye and Kosters 1986). Underlying the lake bottoms and backswamps of the Atchafalaya Basin is approximately 25 to $35 \mathrm{~m}$ (82 to $115 \mathrm{ft}$ ) of fine-grained flood basin deposits; these deposits overlie fluvial sands and gravel. The fluvial sands and gravels consist of Late Pleistocene braided stream deposits and, possibly, Early Holocene point bar sediments. 


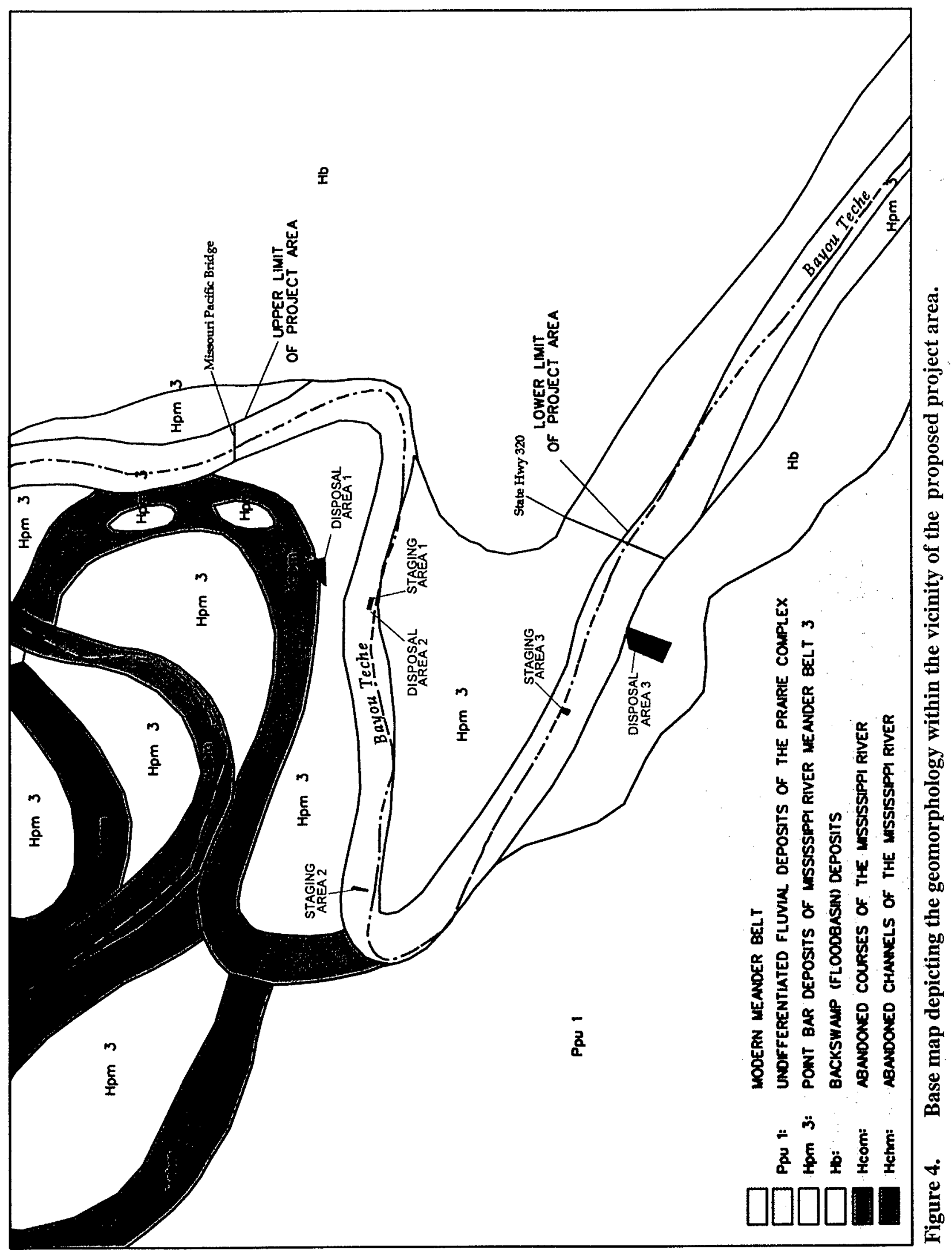




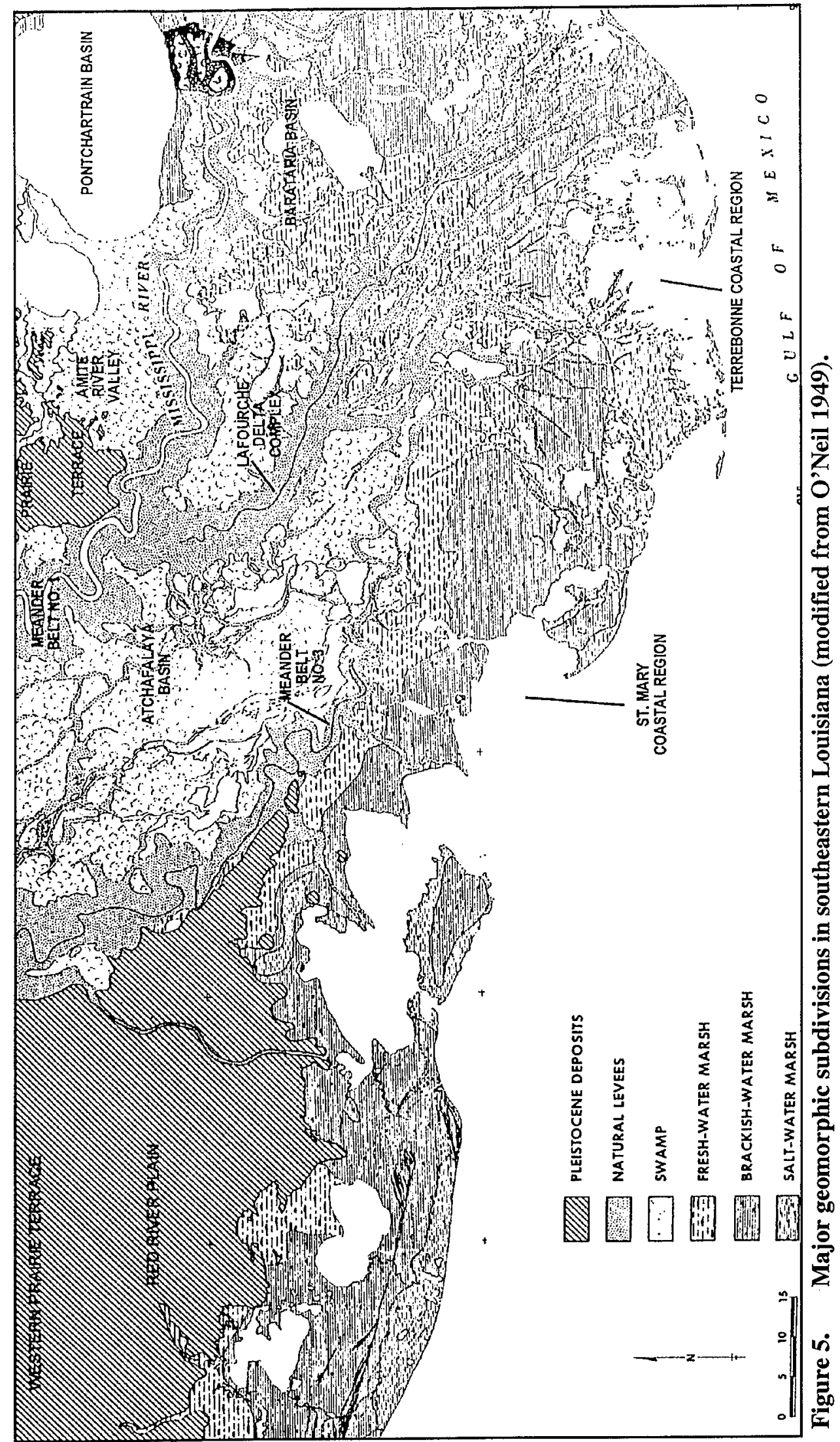


Mississippi River Delta Chronology and the Development of the Proposed Project Area

The Mississippi River Delta is one of the most intensively studied delta systems in the world. A voluminous quantity of data pertaining to its stratigraphy, sedimentology, and history have been published in innumerable publications of various types. The synthesis of these data, most notably by Frazier $(1967,1974)$, with revisions by Autin et al. (1991) and Weinstein and Gagliano (1985), has resulted in the development of three widely accepted chronologies for mid- to late-Holocene age delta lobe deposition throughout the region (Figures 6 and 7). All three chronologies subdivide the Mississippi River Delta into six major delta complexes: the Maringouin, Teche, St. Bernard (or Metairie and La Loutre), Lafourche, Plaquemines (or Modern), and Atchafalaya delta complexes; however; some delta chronologies do not illustrate the Atchafalaya Delta Complex since it is difficult to portray graphically the boundaries of this short-lived delta complex.

Each of the delta complexes is discussed below. Since the proposed project area is situated within the boundaries of the Teche Delta Complex, this complex is discussed in greater detail.

\section{Pre-Holocene Delta Complexes}

A cross-section presented by Boyd et al. (1988) shows additional delta complexes underlying the Outer Shoal Delta Complex. Unfortunately, all that presently is known about these pre-Holocene complexes is that they underlie the Outer Shoal Delta Complex and that they overlie the presumably Sangamonian surface and sediments of the Prairie Complex. Contrary to the interpretations of Boyd et al. (1988), correlation of their cross-sections with data presented by Coleman and Roberts (1988) indicates that these complexes probably are Middle Wisconsinan in age. Therefore, these delta complexes predate the human occupation of the area.

\section{Holocene Age Delta Complexes}

The Pleistocene Epoch, which began approximately 1.2 to 2 mya (million years ago), encompasses a number of stages defined by their correlation with glacial events. During a glacial retreat, huge amounts of unconsolidated sedi- ments were subject to erosion, and a great deal of the sediments in North America generated as a result of these glacial events were transported through the Mississippi River drainage system, and deposited in Louisiana and in the Gulf of Mexico. The oldest sedimentary depositions occur during the Sangamonian stage, approximately 130,000 - 125,000 B.P., with further deposition occurring during the glacial retreat of the Middle Wisconsin stage, approximately 65,000 - 30,000 B.P. The Holocene Epoch (ca. 18,000 years ago present) also experienced periods of sediment deposition (Saucier 1994).

\section{Outer Shoal Delta Complex}

Penland et al. (1985) noted that the deposition of deltaic sediments by the Mississippi River began approximately 12,000 years ago. Due to the rapidly rising sea level during the early Holocene, only thin shoal-water deltas could have accumulated, except during a sea level stillstand at approximately 15,000 - 12,000 years ago (Frazier 1967). In addition, the transgressing shoreface associated with rising sea level probably eroded these thin shoal-water deltas, and subsequent marine processes redistributed them into broad sand sheets and marine shoals such as the Sabine Bank on the western Continental Shelf (Suter et al. 1987). As a result, it is highly unlikely that the deposition of the Maringouin Delta Complex encompassed the entire period stated by Weinstein and Gagliano $(1985: 122)$ or by Frazier (1967:269) (Figures 7 and 8).

Penland et al. (1987) and Boyd et al. (1988) document another Late Pleistocene delta complex lying underneath the Maringouin Delta Complex as defined by Frazier $(1967: 269,300)$. Boyd et al. (1988) call this delta complex the "Outer Shoal Delta Complex." It forms the "Earlier Holocene Delta Plain" discussed by Penland et al. (1987), on which the Maringouin Delta Complex lies. The occurrence of this delta plain at depths of 15 to $25 \mathrm{~m}$ ( 49 to $82 \mathrm{ft}$ ) below surface suggests that it may represent the results of deltaic deposition from approximately 9,200 - 8,200 years ago. (Frazier 1974). Because very little has been determined or published regarding this delta complex, its actual age and its relationship to sea level fluctuations are unclear. 


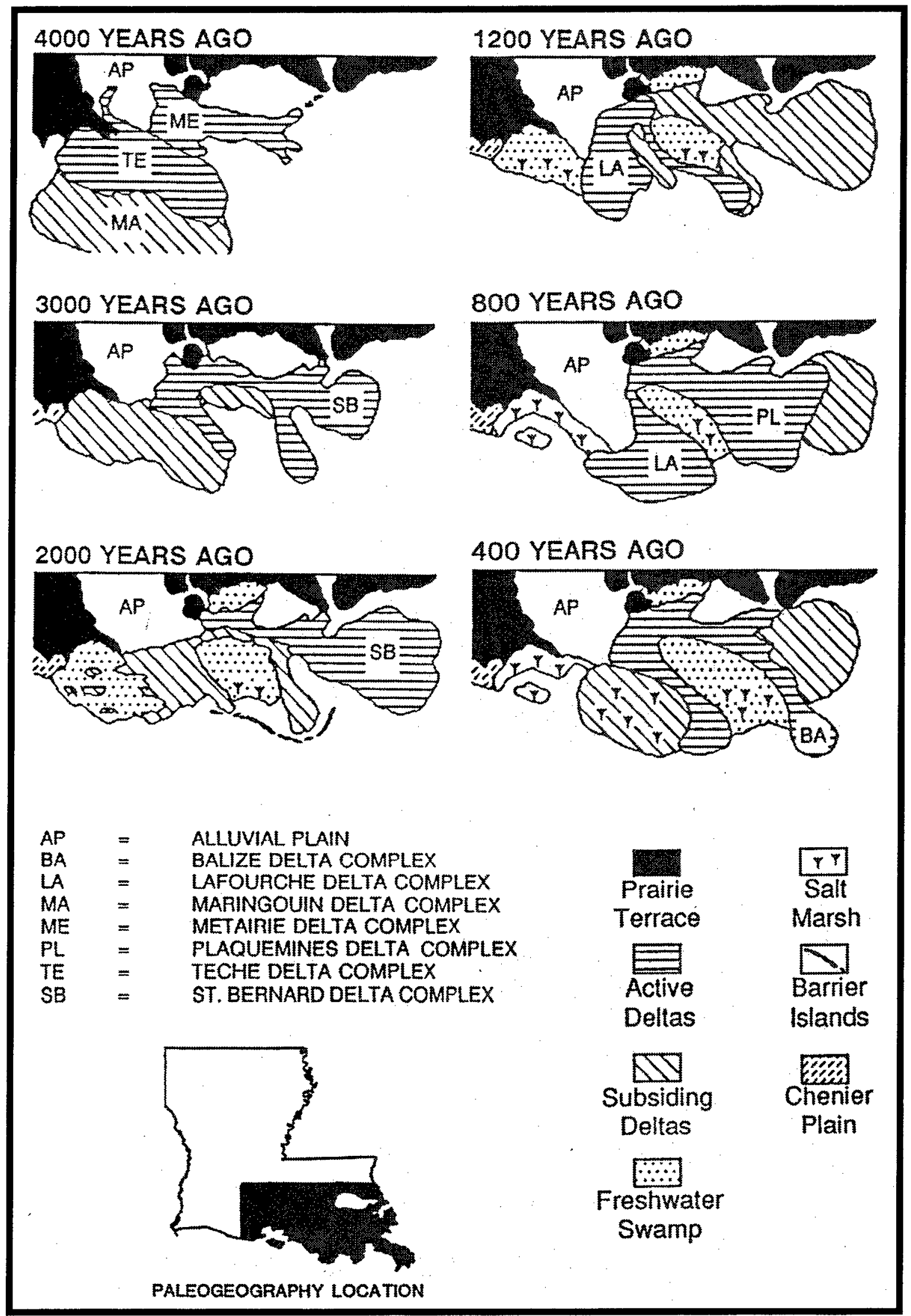

Figure 6. Palegeography of the Mississippi River Delta. 


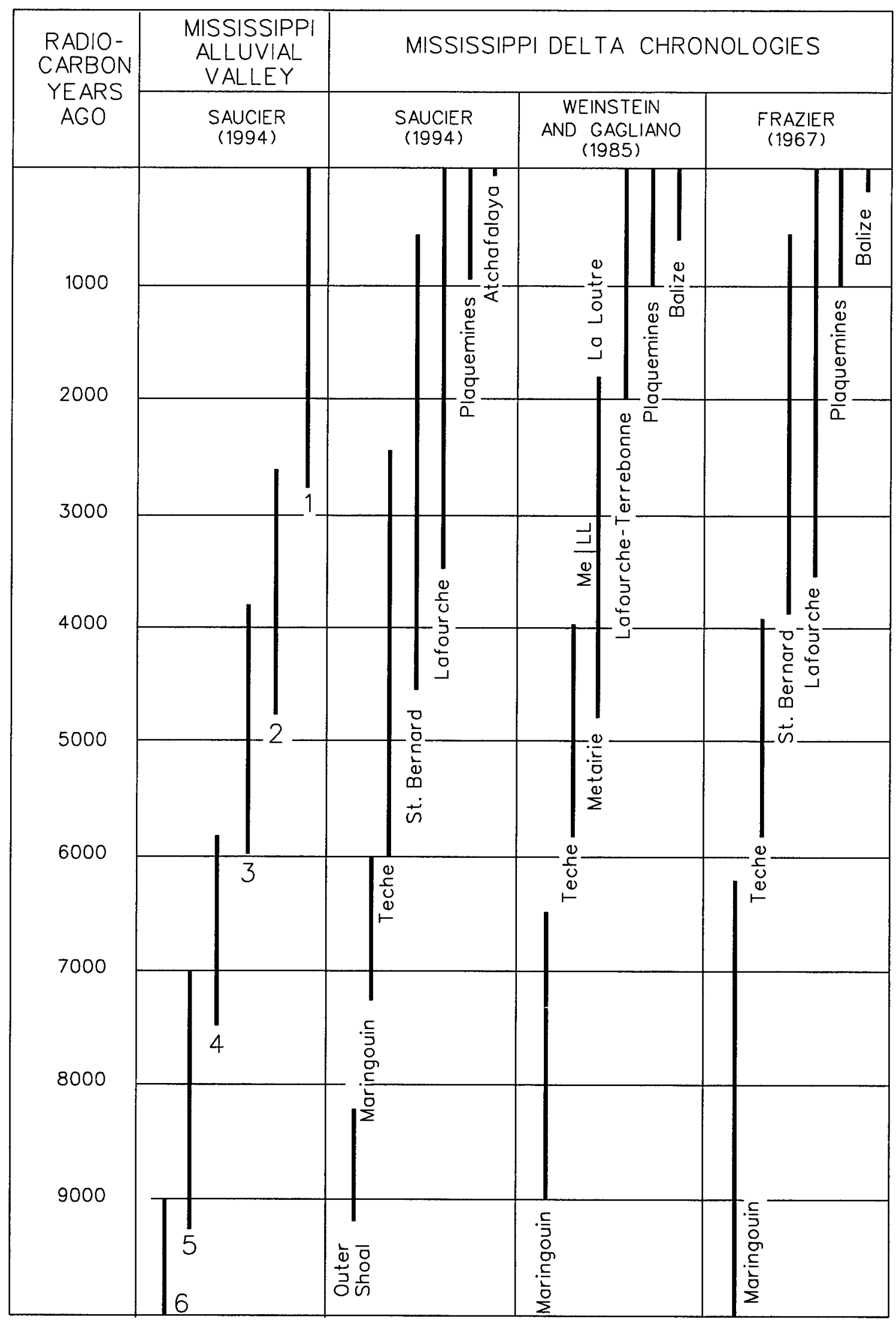

Figure 7. Estimates of the ages of meander belts of the Mississippi River and delta complexes (ages in years B.P.). 


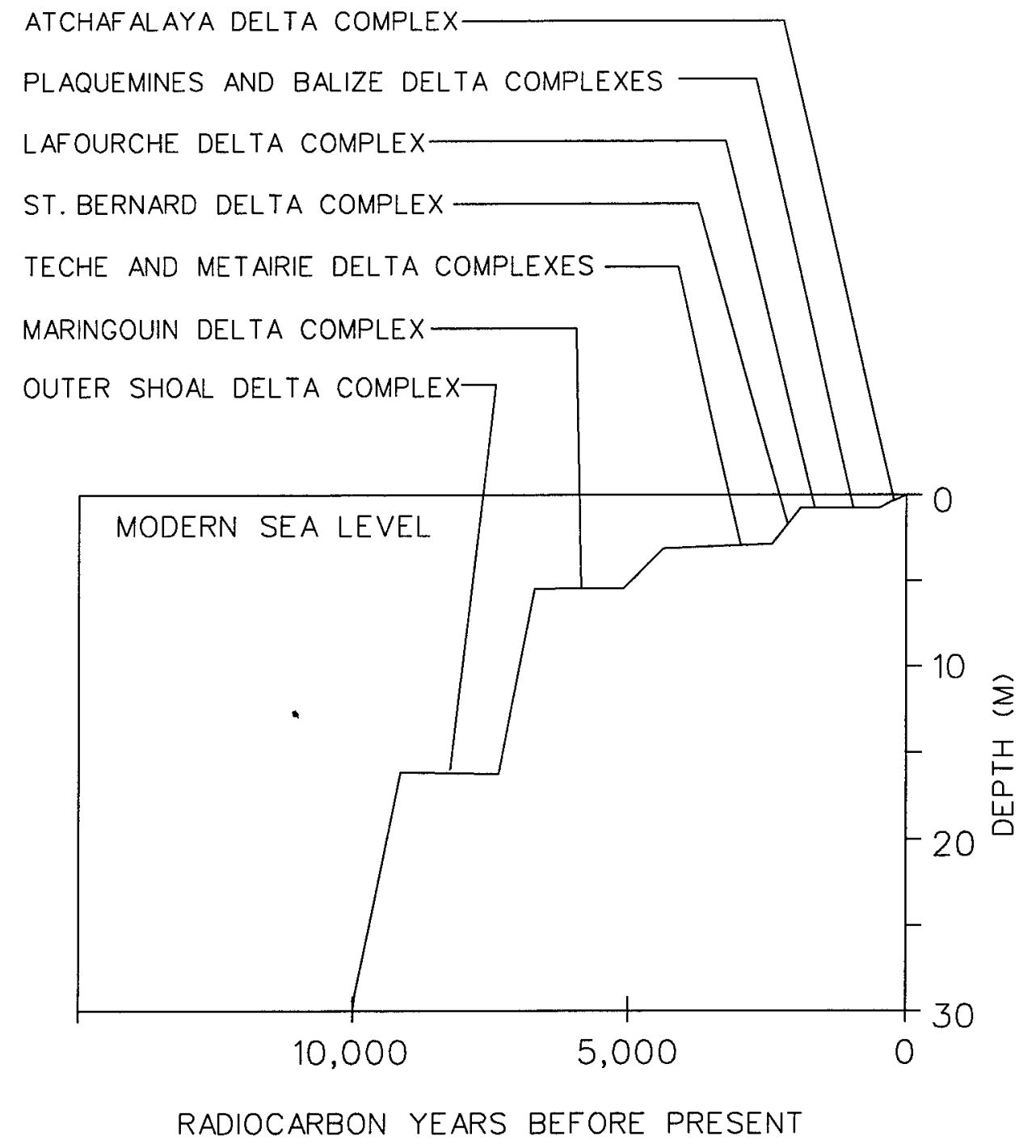

Figure 8. Chronology of delta complexes and relative sea level (modified from Penland et al. 1988). 


\section{Maringouin Delta Complex}

From about 7,500 - 5,500 years ago, a second stillstand occurred during the otherwise rapid rise in sea level, at a depth of 5 to $6 \mathrm{~m}$ (16 to 20 $\mathrm{ft}$ ) below surface (Figure 8). During this time, i.e., approximately 7,300 - 6,200 years ago, the Mississippi River built the Maringouin Delta Complex (Figures 7 and 8) (Autin et al. 1991). Frazier (1967:269) noted the presence of two stacked, depositional sequences within this delta complex.

By 5,000 years ago, the continued rise of sea level had submerged most of the surface of the Maringouin Delta Complex, i.e., the "Late Holocene Delta Plain" (Penland et al. 1987). The transgression of the shoreface across this delta plain formed a well-defined ravinement surface that later was buried by the Teche Delta Complex. Marine processes reworked the exposed portion of this delta complex into the Tiger, Ship, and Trinity shoals (Autin et al. 1991; Frazier 1967; Smith et al. 1986:68).

At the same time, rising sea level flooded the eastern portion of the Mississippi River Alluvial Valley. This resulted in the movement of the shoreline up the Mississippi River Alluvial Valley to the latitude of Baton Rouge. As a result, a brackish water embayment occupied this part of the Mississippi River Valley approximately 6,000 - 5,000 years ago (Saucier 1963:44-46).

\section{Teche Delta Complex}

Approximately 5,800 years ago, the development of the Teche Delta Complex began; this occurred after the rising sea level had submerged most of the Maringouin Delta Complex. Between 5,800 - 3,900 years ago, the Mississippi River formed the Teche Delta Complex by building over the Maringouin Delta Complex (Figures 7 and 8 ). The Teche Delta Complex buried the intact delta plain of the Maringouin Delta Complex within the vicinity of the proposed project area, while east of the Penchant Shoreline in Terrebonne Parish, the Teche Delta Complex prograded into open water over what had formerly been the Maringouin Delta Complex. The specific sequence in which the delta lobes developed, however, remains controversial (Smith et al. 1986:61-64; Weinstein and Gagliano 1985:123; Weinstein and Kelley 1989:33-34).

The eastern limit of progradation for the Teche Delta Complex also is subject to debate.
Smith et al. (1986:61-62) placed the easternmost limit of this delta complex near the city of Houma. In contrast, Weinstein and Gagliano (1985:123) argue that the eastern margin of the Teche Delta Complex lies $48.3 \mathrm{~km}$ (30 mi) east of Houma. They claim that southwest trending distributaries in the Terrebonne Delta Plain, such as Bayou Du Large and Mauvais Bois, represent Teche distributaries that were reoccupied by the Lafourche Delta Complex (Weinstein and Kelley 1989:33).

During its existence, drastic changes occurred within the river courses that fed the Teche Delta Complex. First, the Mississippi River switched from Meander Belt No. 4 to Meander Belt No. 3 as defined by Saucier (1981:16). For the first thousand years or so, Meander Belt No. 4 supplied sediment to the Teche Delta, until it was abandoned for Meander Belt No. 3 (Autin et al. 1991). Second, an abrupt aggradation of Meander Belt No. 3 caused it to abandon and bury an older meander belt, and to form the relict river course currently occupied by Bayous Teche and Black. Finally, the Red River occupied this river course as the flow of the Mississippi River shifted gradually to the east into Meander Belt No. 2 approximately 3,900 years ago. As a result, the Teche Delta Complex remained active as the Red River discharged partially its flow directly into the Gulf of Mexico (Figure 8) (Goodwin et al. 1990).

The time at which the Red River abandoned both its Bayou Teche course and the Teche Delta Complex has yet to be determined satisfactorily. Autin et al. (1991) suggest that it occurred by approximately 2,500 years ago. Pearson (1986) and Weinstein and Kelley (1989:33-34) both argue, however, on the basis of archeological data, that it occurred approximately $1,800-1,900$ years ago.

\section{St. Bernard (Metairie-La Loutre) Delta Complex}

By approximately 4,800 years ago, the Mississippi River began to shift its course from Meander Belt No. 3 to Meander Belt No. 2 at Marksville, Louisiana, which diverted much of its flow down the eastern and central part of the Mississippi Alluvial Valley (Saucier 1981:16). As a result, a new delta complex called the "early St. Bernard Delta Complex" by Frazier (1967) and the "Metairie Delta Complex" by Weinstein and 
Gagliano (1985:122-123) prograded into and through the New Orleans area, leaving much of the region containing the proposed project area to be claimed by backswamps and natural levees that were created by the development of smaller drainages such as Bayou Teche (Figures 7 and 8). The main delta of this complex prograded about $70 \mathrm{~km}(43.5 \mathrm{mi})$ southeast of New Orleans into the Gulf of Mexico. Another small delta of this complex prograded northeast to connect with a chain of southwest-trending barrier islands, the New Orleans Barrier Island Trend. When this delta joined with the New Orleans Barrier Island Trend, which is attached to the mouth of the Pearl River, it created a brackish water bay ancestral to Lake Pontchartrain (Otvos 1973; Saucier 1963:56-59).

From approximately $3,400-1,600$ years ago, the Metairie Delta Complex developed into the La Loutre Delta Complex described by Weinstein and Gagliano (1985:123) or the St. Bernard Delta Complex characterized by Frazier (1967). This delta complex formed two major delta lobes that prograded from the New Orleans area. The larger delta, La Loutre Delta, prograded eastward to form most of St. Bernard Parish. By 3,000 years ago, this delta lobe buried the New Orleans Barrier Island Trend, creating Lake Pontchartrain. A smaller delta, the Des Familles Delta, prograded southward from the New Orleans region.

Between 1,800 - 600 years ago, only the Bayou Sauvage delta of the St. Bernard Delta Complex remained active (Frazier 1967: 12). Weinstein and Gagliano (1985) considered this activity to be insufficient to characterize the La Loutre (St. Bernard) Delta Complex an active delta complex for their chronology; therefore, they classified this delta complex as inactive after 1,800 years ago. In contrast, Autin et al. (1991) interpret the activity of the Bayou Sauvage delta to be that associated with the waning phase of an active delta complex. As a result, they considered the St. Bernard Delta (La Loutre) Complex active until 600 years ago. Autin et al. (1991), however, agree with Weinstein and Gagliano (1985:123) concerning the observations of Frazier (1967) (Figure 7). This difference, as with many differences among the delta chronologies illustrated in Figure 7 , results from differences in variation of what actually constitutes an active delta complex, rather than from true differences in observed delta activity.

\section{Soils within the Vicinity of the Proposed Pro- ject Area}

A majority of the proposed project area can be described as alluvial plain (Clark and White 1978). In general, the alluvial plain represents a level and moderately to poorly drained area located north of the many coastal marshes that fringe the Gulf of Mexico; elevations in this area range from approximately 3 to $6 \mathrm{~m} \mathrm{(10} \mathrm{to} 20 \mathrm{ft}$ ) NGVD (Clark and White 1978). The following is a review of the general soil areas and associated soil series groups that occur throughout the proposed project area.

Soils found within the portion of the alluvial plain that contains Bayou Teche and the proposed project area belong to the Gallion - Galvez Baldwin soil association. Clark and White (1978) describe the Gallion soil series as dark brown to dark reddish brown silty loams and silty clay loams that range in depth from 0 to $167 \mathrm{cmbs}$ ( 0 to 66 inbs) in depth. Soils of the Galvez series are characterized as grayish brown silty loams and silty clay loams that extend from the surface to a depth of $152 \mathrm{cmbs}$ (60 inbs) (Clark and White 1978). Finally, soils of the Baldwin series vary from very dark grayish brown to gray in color and they range in depth from 0 to $182 \mathrm{cmbs}(0$ to 72 inbs) (Clark and White 1978). These soil series typically are located on level to nearly level slopes and they range from well-drained to very poorly drained. These soil series are suited to cultivation, and both rice and sugarcane are grown regularly on them. In general, however, surface drainage and commercial fertilization are needed to produce crops on a large scale.

\section{Historic Period Impacts to the Proposed Pro- ject Area}

Within southern Louisiana, historic period utilization of the Mississippi River meander belts, which contain numerous smaller drainages such as Bayou Teche, have impacted severely the archeological deposits that lie within them. Agricultural, urban, and industrial development has disturbed extensive portions of the natural levees and point bars found throughout the region. Each of these disturbance agents is discussed briefly below. 
Residential and Industrial Development

Because the natural levees of the modern and ancient courses of the numerous drainages within the vicinity of the proposed project area, including Bayou Teche, are still the only dry land within an otherwise flooded or poorly-drained alluvial plain, they have been the focus of urban and industrial development. Obviously, the construction of housing, commercial buildings, and industrial plants has impacted directly the surface and subsurface of large portions of both modern and relict natural levees in the region. In addition, the excavation of numerous sewage disposal ponds within the immediate vicinity of the proposed project area to support continued commercial and residential development has had negative impacts on the preservation of prehistoric and historic period archeological sites in the area.

\section{Agricultural Disturbance}

The natural levees of both active and abandoned river and bayou courses within the vicinity of the proposed project corridor are sufficiently fertile and well drained for agricultural use. As a result, they have been extensively developed for the production of both sugar cane and rice. In fact, several large sugarcane refinery operations and fields are located within the vicinity of the proposed project area, e.g., the Iberia Sugar Company and the Cajun Sugar Company. Both rice and sugar farming have disturbed significant portions of the natural levees through plowing and inundation (Goodwin et al. 1990).

\section{Dredging}

During canal and pipeline construction, dredging operations often affect archeological deposits. Dredging impacts the integrity and visibility of the archeological deposits and the dumping of spoil buries and conceals archeological deposits once exposed along the banks of the rivers and bayous of the area. The partial burial of sites by spoil often makes it difficult to determine the original characteristics of sites, especially their integrity, size, and artifact content.

\section{Bankline Erosion}

The abandoned course and the present course of Bayou Teche have carried and the present course continues to carry substantial recreational and/or commercial boat traffic. The fre- quent use of the waterway creates substantial wave action from riverborne traffic. The wave action generated from river traffic, as well as wind and current action, can cause extensive bankline erosion and slumping. A brief examination of the Louisiana Division of Archaeology files demonstrates that bank erosion is an extremely serious threat to archeological deposits situated along the banks of many of the waterways scattered throughout the area.

\section{Flora and Fauna Located within the Vicinity of the Proposed Project Area}

While the proposed project corridor consists entirely of natural levee and riverine habitats, the larger region encompasses a variety of ecozones, including salt marshes, freshwater marshes, backswamps, and alluvial plains. These habitats support very rich floral and faunal communities. Tables $1-8$ contain the common and scientific names of the species common to the proposed project area (Beavers et al. 1984; Brown 1965, 1972; Chabreck and Condrey 1979; Gosselink 1984; Harrar and Harrar 1946; Lowery 1974; McClane 1974; Reese 1992).

The marshlands and swamps located within the vicinity of the proposed project area are highly productive natural environments and they represent important stopping and overwintering points for migratory birds from the Mississippi Flyway. The semi-aquatic areas are used by over five million birds every winter (Chabreck and Condrey 1979:4). Permanent residents of this habitat include muskrats, raccoons, otters, mink, alligators, rabbits, and a wide array of water birds, turtles, frogs, and fishes.

The composition of the habitats found within the general vicinity of the proposed project area has been influenced strongly by both natural and man-made forces. Through time, the changing course of the Mississippi River has controlled the amount of fresh water flowing down the Atchafalaya River and its related tributaries (e.g., Bayou Teche). Currently, almost one-third of the Mississippi River discharge flows through the Atchafalaya River and into the Atchafalaya Bay. This enormous discharge of fresh water into the Atchafalaya Bay causes the salinity of the bay to be lower than the surrounding waters of the Gulf of Mexico. In turn, the extent of brackish marsh on the shores of the Atchafalaya Bay is limited by 
the low salinity. Therefore, the extent of brackish and saline marshes may have been greater in this area when the discharge of the Mississippi River was directed elsewhere.

In addition, historic period and modern modifications in the larger region have greatly modified the habitats currently found there. Brackish and saline marsh has replaced some of the original freshwater marsh. Much of the recent loss of freshwater marsh is due to the dredging and straightening of canals; these methods allow for saltwater intrusion from the Gulf of Mexico, which kills the sensitive vegetation of the freshwater marshes. If saltwater-tolerant species do not colonize the area, the marsh reverts to open water (Chabreck and Condrey 1979).

\section{$\underline{\text { Saline Marsh }}$}

Small areas of saline marsh are found directly south of the proposed project area and adjacent to the Gulf of Mexico. These marshes are inundated regularly with saltwater. The dominant plants in this habitat include salt grass, rushes, sea blite, and gulf croton (Table 1). The growth of plants within the saline marsh is influenced by a long growing season, high rainfall, rich soils, low tide differential, and the width of the marsh (Chabreck and Condrey 1979:4).

Table 1. Plant Taxa Characteristic of Marshes within the Vicinity of the Proposed Project Area.

\begin{tabular}{|c|c|c|c|c|}
\hline COMMON NAME & LATIN NAME & SALINE & BRACKISH & FRESH \\
\hline Coast milkweed & Asclepias lanceolata & & $\mathrm{x}$ & \\
\hline Aster & Aster spp. & & & $\mathrm{x}$ \\
\hline Backbrush & Baccharis halimifolia & & $\mathrm{x}$ & \\
\hline Water hyssop & Bacopa monnieri & & $x$ & $x$ \\
\hline Carex & Carex sp. & & $\mathrm{x}$ & \\
\hline Centella & Centella asiatica & & $\mathrm{x}$ & \\
\hline Coontail & Ceratophyllum demersum & & & $\mathrm{x}$ \\
\hline Saw-grass & Cladium jamaicense & & & $\bar{x}$ \\
\hline Gulf croton & Croton punctatus & $\mathrm{x}$ & & \\
\hline Umbrella-sedges & Cypenis spp. & & $\mathrm{x}$ & $x$ \\
\hline Salt grass & Distichlis spicata & $\mathrm{x}$ & $\mathrm{x}$ & \\
\hline Walter's millet & Echinochloa walteri & & $\mathrm{x}$ & $\mathrm{x}$ \\
\hline Spikerush & Eleocharis spp. & & $\mathrm{x}$ & $x$ \\
\hline Sand rush & Fimbristylis castanea & & $x$ & \\
\hline Marsh mallow & Hibiscus moscheutos & & $\mathrm{x}$ & \\
\hline Whorled pennywort & Hydrocotyle verticillata & & & $x$ \\
\hline Spider lily & Hymenocallis caroliniana & & $\mathrm{x}$ & $\mathrm{x}$ \\
\hline Morning glories & Ipomoea spp. & & $\mathrm{x}$ & $\mathrm{x}$ \\
\hline Marsh elder & Iva frutescens & & $\mathrm{x}$ & $\mathrm{x}$ \\
\hline Rushes & Juncus spp. & $x$ & $x$ & $x$ \\
\hline Virginia saltmarsh mallow & Kosteletzkya virginica & & $x$ & $\mathrm{x}$ \\
\hline Cutgrass & Leersia sp. & & $\mathrm{x}$ & \\
\hline Sprangle top & Leptochloa fascicularis & & $x$ & $\mathrm{x}$ \\
\hline False loosestrife & Ludwigia leptocarpa & & & $x$ \\
\hline Loosestrife & Lythrum lineare & & $\mathrm{x}$ & \\
\hline Wax myrtle & Myrica cerifera & & & $x$ \\
\hline White waterlily & Nymphea odorata & & & $\mathrm{x}$ \\
\hline Maidencane & Panicum hemitomon & & & $\mathrm{x}$ \\
\hline Panicoid grasses & Panicum spp. & & $x$ & $\mathrm{x}$ \\
\hline Paspalum & Paspalum spp & & & $\bar{x}$ \\
\hline Canary grass & Phalaris sp. & & $\mathrm{x}$ & \\
\hline Common reed & Phragmites commmunis & & $x$ & $\mathrm{x}$ \\
\hline Camphorweed & Pluchea camphorata & & $\mathrm{x}$ & $\mathrm{x}$ \\
\hline Smartweed & Polygonum spp. & & & $x$ \\
\hline Sago pondweed & Potamogeton pectinatus & & $\mathrm{x}$ & \\
\hline Arrowhead & Sagittaria spp. & & & $\mathrm{x}$ \\
\hline Creeping glasswort & Salicemia virginica & $\mathrm{x}$ & & \\
\hline Black willow & Salix nigra & & & $\mathrm{x}$ \\
\hline
\end{tabular}


Table 1 , continued

\begin{tabular}{|c|c|c|c|c|}
\hline COMMON NAME & LATIN NAME & SALINE & BRACKISH & FRESH \\
\hline Common elderberry & Sambucus canadensis & & $x$ & $x$ \\
\hline Bulrush & Scirpus spp. & $x$ & $x$ & $x$ \\
\hline Rattlebox & Sesbania spp. & & & $x$ \\
\hline Yellow foxtail & Setaria glauca & & $x$ & $x$ \\
\hline Marsh-grass & Spartina spp. & $\mathrm{x}$ & $\mathrm{x}$ & $x$ \\
\hline Coast dropseed & Sporobalus virginicus & & $\mathrm{x}$ & \\
\hline Sea blite & Sueda tineans & $x$ & & \\
\hline Gramagrass & Tripsacum dactyloides & & $x$ & \\
\hline Cattail & Typha spp. & & & $x$ \\
\hline Deerpea & Vigna luteola & & $x$ & $x$ \\
\hline Giant cutgrass & Zizaniopsis miliacea & & & $\mathrm{x}$ \\
\hline
\end{tabular}

A variety of crustaceans, shellfish, and fishes are residents of the saline marsh (Tables 2 and 3). Small fishes such as silversides, minnows, killifish, and mullet are important sources of food for predatory marine and estuary fish such as flounders, stingrays, tarpon, and drums. Many other predatory fish feed on the small and immature crustaceans and shellfish in, or from, the saline marsh. Muskrats, otters, raccoons, and geese also exploit the floral and faunal resources of the area (Table 4).

\section{Brackish Marsh}

Brackish marsh habitats, with their slightly saline waters, can be found just south of the proposed project area. The salinity level in the brackish marshes range from four to eight millimhos per centimeter (Craft 1984:39). A wider
Table 2. Crustaceans and Shellfish Present within the Vicinity of the Proposed Project Area.

\begin{tabular}{||l|l|c|c||}
\hline COMMON NAME & \multicolumn{1}{|c|}{ LATIN NAME } & FRESH & ESTUARY \\
\hline \hline Freshwater clam & Anodonta sp. & $\mathrm{x}$ & \\
\hline Hooked mussel & Brachidontes recurvus & & $\mathrm{x}$ \\
\hline Blue crab & Callinectes sapidus & & $\mathrm{x}$ \\
\hline Oyster & Crassostrea virginica & & $\mathrm{x}$ \\
\hline Freshwater clam & Elliptio sp. & $\mathrm{x}$ & \\
\hline Marsh periwinkle & Littorinia irrorata & & $\mathrm{x}$ \\
\hline River shrimp & Macrobrachium ohiome & $\mathrm{x}$ & \\
\hline Ribbed mussel & Modiolus demissus & & $\mathrm{x}$ \\
\hline Freshwater mussel & Mytilopsis leucopucteta & $\mathrm{x}$ & \\
\hline Eastern nassa & Nassarius vibex & & $\mathrm{x}$ \\
\hline Grass shrimp & Palaemonetes paludosus & & $\mathrm{x}$ \\
\hline Brown shrimp & Penaeus aztecus & & $\mathrm{x}$ \\
\hline White shrimp & Penaeus setiferus & & $\mathrm{x}$ \\
\hline Freshwater snail & Plysa sp. & $\mathrm{x}$ & \\
\hline River crawfish & Procambarus blandingii & $\mathrm{x}$ & \\
\hline Red swamp crawfish & Procambarts clarkii & $\mathrm{x}$ & \\
\hline Brackish water clam & Rangia cuneata & & $\mathrm{x}$ \\
\hline Mud crab & Rithropenopeus harrisii & & $\mathrm{x}$ \\
\hline \hline
\end{tabular}

Table 3. Fishes Present within the Vicinity of the Proposed Project Area.

\begin{tabular}{|c|c|c|c|c|}
\hline COMMON NAME & LATIN NAME & FRESH & ESTUARY & SEASONAL ESTUARY \\
\hline Bowfin & Amia calva & $x$ & & \\
\hline Bay anchovy & Anchoa mitchilli & & & $\mathrm{x}$ \\
\hline American eel & Anguilla rostrata & $\mathrm{x}$ & & \\
\hline Pirate perch & Aphredoderus sayanus & $\mathrm{x}$ & & \\
\hline Freshwater drum & Aplodinotus grumniens & $\mathrm{x}$ & & \\
\hline Sheephead & Archosargus probatocephalus & & & $\mathrm{x}$ \\
\hline Sea catfish & Arius felis & & & $\mathrm{x}$ \\
\hline Silversides & Atherinidae family & $\mathrm{x}$ & $\mathrm{x}$ & \\
\hline Gafftop catfish & Bagre marinus & & & $\mathrm{x}$ \\
\hline Atlantic threadfin & Bolydactylus octonemus & & & $\mathrm{x}$ \\
\hline Gulf menhaden & Brevoortia patronus & & & $\bar{x}$ \\
\hline River carpsuckers & Carpoides carpio & $\mathrm{x}$ & & \\
\hline Atlantic spadefish & Chaetodipterus faber & & & $\mathrm{x}$ \\
\hline Seatrout & Cynoscion sp. & & & $\mathrm{x}$ \\
\hline Sheepshead minnow & Cyprinodon variegatus & & $\mathrm{x}$ & \\
\hline Killifish & Cyprinodontidae famlily & & $\mathrm{x}$ & \\
\hline Carp & Cyprimus carpio & $\mathrm{x}$ & & \\
\hline Southern stingray & Dasyatis americana & & & $\mathrm{x}$ \\
\hline Bluntnose stingray & Dasyatis sayi & & & $\mathrm{x}$ \\
\hline
\end{tabular}


Table 3, continued

\begin{tabular}{|c|c|c|c|c|}
\hline COMMON NAME & LATIN NAME & FRESH & ESTUARY & SEASONAL ESTUARY \\
\hline Shad & Dorosoma spp. & $\mathrm{x}$ & & \\
\hline Banded pygmy sunfish & Elassoma zonatum & $\mathrm{x}$ & & \\
\hline Ladyfish & Elops sanmus & & & $\mathrm{x}$ \\
\hline Fringed flounder & Etropus crossotus & & & $x$ \\
\hline Lyre goby & Evorthodus syricus & & $\mathrm{x}$ & \\
\hline Gulf killifish & Fundulus grandis & & $\mathrm{x}$ & \\
\hline Topminnows & Fundulus spp. & $x$ & & \\
\hline Mosquitofish & Gambusia affinis & $\mathrm{x}$ & & \\
\hline Goby & Gobiidae family & & & $x$ \\
\hline Naked goby & Gobiosoma bosci & & $\mathrm{x}$ & \\
\hline Least killfish & Heterandria formosa & $x$ & & \\
\hline Freshwater catfish & Ictaluridae family & $\mathrm{x}$ & & \\
\hline Brook silverside & Labidesthes sicculus & $\mathrm{x}$ & & \\
\hline Pinfish & Lagodon rhomboides & & $x$ & \\
\hline Gars & Lepisosteus spp. & $x$ & & \\
\hline Sunfishes & Lepomis spp. & $\mathrm{x}$ & & \\
\hline Atlantic croaker & Mecropogon undulatus & & & $\mathrm{x}$ \\
\hline Tarpon & Megalops atlantica & & & $x$ \\
\hline Tidewater silverside & Menidia beryllina & & & $\mathrm{x}$ \\
\hline Southern kingfish & Menticirrhus americanus & & & $x$ \\
\hline Atlantic croaker & Micropogonais undulatus & & & $x$ \\
\hline Largemouth bass & Micropterus salmoides & $x$ & & \\
\hline Basses & Morone spp. & $\mathrm{x}$ & & \\
\hline Striped mullet & \begin{tabular}{|l} 
Mugil cephalus \\
\end{tabular} & & & $\mathrm{x}$ \\
\hline Golden shiner & Notemigonus crysoleucas & $x$ & & \\
\hline Shiners & Notropis spp. & $\mathrm{x}$ & & \\
\hline Southern flounder & Paralichthys lethnostigma & & & $\mathrm{x}$ \\
\hline Bullhead shiner & Pimephales vigilax & $x$ & & \\
\hline Sailfin molly & Poecilia latipinna & $\mathrm{x}$ & & \\
\hline Black drum & Pogonias cromius & & & $x$ \\
\hline Paddle fish & Polydon spathula & $\mathrm{x}$ & & \\
\hline Crappie & Promoxis sp. & $\mathrm{x}$ & & \\
\hline Red drum & \begin{tabular}{|l|} 
Sciaenops ocellata \\
\end{tabular} & & & $\mathrm{x}$ \\
\hline Hogchoker & Trinectes maculatus & & & $\mathrm{x}$ \\
\hline
\end{tabular}

Table 4. Mammals Present within the Vicinity of the Proposed Project Area.

\begin{tabular}{||l|l||}
\hline \multicolumn{1}{|c|}{ COMMON NAME } & \multicolumn{1}{c|}{ LATIN NAME } \\
\hline \hline Fin whale family & Balaenopteridae family \\
\hline Red wolf & Canis rufus \\
\hline Least shrew & Cyptotis parva \\
\hline Porpoise and dolphin family & Delphinidae family \\
\hline Southern flying squirrel & Glaucomys volans \\
\hline Red bat & Lasiurus borealis \\
\hline Northern yellow bat & Lasiurus intermedius \\
\hline Seminole bat & Lasiurus seminolus \\
\hline River otter & Lutra canadensis \\
\hline Bobcat & Lynx rufus \\
\hline Long-tailed weasel & Mustela frenata \\
\hline North American mink & Mustela vison \\
\hline Southeastern myotis & Myotis austroriparius \\
\hline Eastern wood rat & Neotoma floridana \\
\hline Evening bat & Nycticeius humeralis \\
\hline White-tailed deer & Odocoileus virginianus \\
\hline Common muskrat & Ondatra zibethicus \\
\hline
\end{tabular}

Table 4, continued

\begin{tabular}{|l|l||}
\hline \multicolumn{1}{|c|}{ COMMON NAME } & \multicolumn{1}{c|}{ LATIN NAME } \\
\hline \hline Marsh rice rat & Oryzomys palustris \\
\hline Cotton mouse & Peromyscus gossypinus \\
\hline White-footed mouse & Peromyscus leucopus \\
\hline Sperm whale family & Physeteridae family \\
\hline Rafinesque's big-eared bat & Plecotus rafinesquii \\
\hline Northern raccoon & Procyon lotor \\
\hline Fulvous harvest mouse & Reithrodontomys fulvescens \\
\hline Gray squirrel & Sciurus carolinensis \\
\hline Fox squirrel & Sciurus niger \\
\hline Hispid cotton rat & Sigmodon hispidus \\
\hline Swamp rabbit & Sylvilagus aquaticus \\
\hline Eastern cottontail rabbit & Sylvilagus floridanus \\
\hline Brazilian free-tailed bat & Tadarida brasiliensis \\
\hline Gray fox & Urocyon cinereoargenteus \\
\hline Black bear & Ursus americanus \\
\hline Beaked whale family & Ziphiidae family \\
\hline Note: Nutria (Myocaster coypus) is an introduced species \\
\hline
\end{tabular}


Table 5. Birds Present within the Vicinity of the Proposed Project Area.

\begin{tabular}{|c|c|}
\hline COMMON NAME & LATIN NAME \\
\hline Spotted sandpiper & Actitis macularia \\
\hline Red-winged blackbird & Agelaius phoeniceus \\
\hline Seaside sparrow & Ammodramus maritimus \\
\hline Pond ducks & Anas spp. \\
\hline Greater white-fronted goose & Anser albifrons \\
\hline Great blue heron & Ardea herodias \\
\hline Short-eared owl & Asio flammeus \\
\hline Diving ducks & Aythya spp. \\
\hline Solidary sandpiper & Bartramia longicauda \\
\hline American bittern & Botaurus lentiginosus \\
\hline Green-backed heron & Butorides striatus \\
\hline Sandpiper & Calidris spp. \\
\hline Snipe & Capilla gallinago \\
\hline Great egret & Casmerodius albus \\
\hline Boat-tailed grackle & Cassidix major \\
\hline Belted kingfisher & Cervle alcyon \\
\hline Killdeer & Charadrius vocifertus \\
\hline Snow goose & Chen caserulescens \\
\hline Black tern & Childonias niger \\
\hline Common nighthawk & Chordeiles minor \\
\hline Northern harrier & Circus cyaneus \\
\hline Wrens & Cistothorus spp. \\
\hline Fish crow & Convus ossifiagus \\
\hline Yellow rail & Cotumicops noveboracensis \\
\hline Heron/egret & Egretta spp. \\
\hline White ibis & Eudocimus albus \\
\hline Merlin & Falco columbarius \\
\hline Artic peregrine falcon & Falco peregrinsus tundrius \\
\hline American kestrel & Falco sparverius \\
\hline Magnificent frigate bird & Fregata magnificens \\
\hline Common snipe & Gallinago gallinago \\
\hline Common moorehen & Gallinula chloropus \\
\hline Common yellowthroat & Geothlypis trichas \\
\hline Bald eagle & Haliaeetus leucocephalus \\
\hline Black-necked stilt & Himantopus mexicanus \\
\hline Swallows & Hirundinidae family \\
\hline Louisiana heron & Hydranassa tricolor \\
\hline Least bittern & Ixobrychus exilis \\
\hline Gulls & Larus sp. \\
\hline Black rail & Laterallus jamaicensis \\
\hline Hooded merganser & Lophodytes cucullatus \\
\hline Belted sandpiper & Meacenle alcyon \\
\hline Swamp sparrow & Melospiza georgiana \\
\hline Red-breasted merganser & Mergas serrator \\
\hline Barn swallow & Mirundo rustica \\
\hline Wood stork & Mycteria americana \\
\hline Night-heron & Nycticorax spp. \\
\hline Savannah sparrow & Passerculus sanwichensis \\
\hline American white pelican & Pelecanus erythorhynchus \\
\hline Brown pelican & Pelecanus occidentalis \\
\hline Double crested cormorant & Pharacrocorax auritus \\
\hline Glossy ibis & Plegadis falcinellus \\
\hline Black-bellied plover & Pluvialis squatarola \\
\hline Eared grebe & Podiceps nigricollis \\
\hline Purple gallinule & Porphycula martinica \\
\hline Boat-tailed grackle & Quiscalus major \\
\hline Rails & Rallus spp. \\
\hline
\end{tabular}

Table 5, continued

\begin{tabular}{||l|l||}
\hline \multicolumn{1}{|c|}{ COMMON NAME } & \multicolumn{1}{c|}{ LATIN NAME } \\
\hline Bank swallow & Riparia riparia \\
\hline Terns & Sterna sp. \\
\hline Tree swallow & Tachycineta bicolor \\
\hline Royal tern & Thalasseus maximus \\
\hline Sandpiper/yellow-legs & Tringa spp. \\
\hline
\end{tabular}

Note: Some of these species are only seasonal residents.

variety of plant species can tolerate the slightly saline conditions of the brackish marsh when compared to species common in the saline marsh environment. The majority of the local plants are marsh-grasses (e.g., Spartina patens), bulrushes, panicoid grasses (e.g., Panicum virgatum), arrowheads, and other monocotyledonous genera that are well-adapted to this (semi-) aquatic habitat (Table 1). The lack of arboreal plants results in a very open and ecologically productive environment.

The brackish marsh is inhabited by semiaquatic mammals, birds, reptiles, and amphibians (Tables $4-6$ ). Geese often winter in the brackish marshes where the sedges and grasses provide an important source of forage. Muskrats, mink, otter, raccoons, rabbits, nutria, and alligators also populate the brackish marshes, while white-tailed deer sometimes venture into the brackish marshes to graze.

The brackish marsh also is part of the estuary system that provides a nursery for saltwater fishes, shrimp, and crabs (Tables 2 and 3). The seasonal abundance of these species is important for the faunal as well as the human populations of the area. The prehistoric Rangia shell middens attest to the importance of brackish water shellfish to the ancient residents of southern Louisiana.

\section{Fresh Marsh}

Fresh water marshes also are located in close proximity to the proposed project corridor. These marshes are characterized by a very low salinity level of zero to four millimhos per centimeter (Craft 1984:40). Common reed, panicoid grasses (e.g., Panicum hermitomar), cattail, bulrush, and giant cutgrass are the dominant native plants (Table 1). Although monocotyledonous species still dominate this habitat, there are a few arboreal species such as black willow and wax myrtle. 
Table 6. Reptiles and Amphibians Present within the Vicinity of the Proposed Project Area.

\begin{tabular}{|l|l|}
\hline \multicolumn{1}{|c|}{ COMMON NAME } & \multicolumn{1}{c|}{ LATIN NAME } \\
\hline Northern cricket frog & Acris crepitans \\
\hline Copperhead & Agkistrodon contrortix \\
\hline Cottonmouth & Agkistrodon piscivorus \\
\hline American alligator & Alligator mississippiensis \\
\hline Three-toed amphiuma & Anphiuma tridactvlum \\
\hline Green anole & Anolis caroliniensis \\
\hline True toads & Bufonidae family \\
\hline Snapping turtle & Chelvdra serpentina \\
\hline River cooter & Chrysemys concinna \\
\hline Painted turtle & Chrysemvs picta \\
\hline Pond slider & Chrysemys scripta \\
\hline Racer & Coluber constrictor \\
\hline Newts & Diemictylus spp. \\
\hline Chicken turtle & Dierochelys reticularia \\
\hline Ratsnakes and cornsnakes & Elaphe spp. \\
\hline Mud snake & Farancia abacura \\
\hline Eastem narrowmouth toad & Gastrophryne carolinensis \\
\hline Mississippi mud turtle & Graptemys komni \\
\hline Treefrogs & Hylidae family \\
\hline Mud turtle & Kinosternon subrubrum \\
\hline Speckled king snake & Lampropeltis getulus \\
\hline Green water snake & Natrix cyclopion \\
\hline Plain-bellied water snake & Natrix ervthrogaster \\
\hline Banded water snake & Natrix fasciata \\
\hline Diamond-backed water snake & Natrix rhombifera \\
\hline Water snakes & Nerodia spp. \\
\hline True frogs & Ranidae family \\
\hline Crayfish snake & Regina spp. \\
\hline Lesser siren & Siren intermedia \\
\hline Stinkpot & Sternotherus odoratus \\
\hline Brown snake & Storeria dekavi \\
\hline Box turtles & Terrapene spp. \\
\hline Garter snakes & Thamnophis spp. \\
\hline Spiny softshell & Trionyx spiniferus \\
\hline
\end{tabular}

A wider and more permanent variety of mammals, reptiles, and fishes inhabit the freshwater marsh rather than the more saline marshes (Tables 3, 4, and 6). The freshwater marshes share many of the same inhabitants as those found in the brackish marshes (e.g., raccoons, rabbits, otters, and alligators). Crawfish and greater concentrations of white-tailed deer also can be found in the freshwater swamps. Lesser numbers of geese and ducks, however, can be found in the freshwater marsh (Table 5). A very different array of fish live in the freshwater marshes, ponds, and lakes. Fish species common to the marsh include bowfins, freshwater drum, freshwater catfish, shad, sunfishes, gars, and basses.

\section{Natural Levees}

The natural levees along Bayou Teche and its numerous tributaries comprise the majority of the habitat types found within the proposed proj- ect reach (Figure 4). Prehistoric and historic period human habitation of the proposed project area probably focused on these levees. The natural levees afford ready access to the rich aquatic environments while protecting the residents from frequent flooding. Natural levee soils also were the most productive for modern and possibly prehistoric agriculture.

The natural levees support an array of arboreal and understory species (Table 7). Fruit (e.g., sugarberry, persimmon, hawthorn, and red mulberry) and nut (e.g., oak, hickory, and pecan) trees, for example, can be found concentrated on the levees. The understory contains a variety of important subsistence plants (wild onion, pigweed, hog peanut, maypops, knotweed, palmetto, cat/green briar, brambles, elderberry, and grapes) and medicinal (horseweed, marshmallow, yaupon, touch-me-not, mayapple, Spanish moss, and stinging nettle).

Terrestrial mammals such as red wolves, bobcats, white-tailed deer, squirrels, cottontail rabbits, and black bears that may forage in the marshes once were concentrated on the levees (Table 4). Most of the non-aquatic reptiles and amphibians such as snakes, toads, green anole, treefrogs, and box turtles needed the dry levees to survive in an otherwise semi-aquatic region (Table 6). The wading and aquatic birds of the marshes and swamps were common visitors to the levees, but there was an additional group of terrestrial birds limited to the levees (Table 8). Among the more significant birds were the raptors, including owls and hawks, woodpeckers, turkeys, and mourning doves.

\section{Swamps}

Backwater swamps occupy the area between the freshwater marsh and the natural levee. These swamps are dominated by woody plants (Table 7) and they generally remain flooded throughout the growing season. Typical swamp trees include bald cypress, Drummond red maple, swamp bay, sugarberry, and gum species. Many of the swamp trees, however, have developed physiological adaptations (e.g., buttressed trunks of bald the seasonal flooding common to the backwater swamps. 
Table 7. Plant Taxa of Swamps and Natural Levees Present within the Vicinity of the Proposed Project Area.

\begin{tabular}{|c|c|c|c|}
\hline COMMON NAME & LATIN NAME & SWAMPS & LEVEES \\
\hline Drummond red maple & Acer drummondii & $\mathrm{x}$ & $\mathrm{x}$ \\
\hline Box elder & Acer negundo & $\mathrm{x}$ & $\mathrm{x}$ \\
\hline Wild onion & Allium canadense & & $\mathrm{x}$ \\
\hline Pigweed & Antaranthus spp. & & $\mathrm{x}$ \\
\hline Common ragweed & Ambrosia artemisiifolia & & $\mathrm{x}$ \\
\hline Peppervine & Ampeopsis arborea & $\mathrm{x}$ & $\mathrm{x}$ \\
\hline Hog peanut & Apios americana & $\mathrm{x}$ & $\mathrm{x}$ \\
\hline Green dragon & Arisciema dracontium & $\mathrm{x}$ & \\
\hline Jack-in-the-pulpit & Arisaema triphyllum & $\mathrm{x}$ & \\
\hline Cane & Arundinaria spp. & $\mathrm{x}$ & $\mathrm{x}$ \\
\hline Rattan vine & Berchemia scandens & & $\mathrm{x}$ \\
\hline False nettle & Boehmeria cylindrica & & $\mathrm{x}$ \\
\hline Trumpet creeper & Campsis radicans & $\mathrm{x}$ & $\mathrm{x}$ \\
\hline Sedges & Carex spp. & & $\mathrm{x}$ \\
\hline Water hickory & Cama aquatica & $\mathrm{x}$ & $\mathrm{x}$ \\
\hline Bitternut hickory & Canva cordifonthis & $\mathrm{x}$ & $\mathrm{x}$ \\
\hline Pecan & Carya Illinoensis & & $\mathrm{x}$ \\
\hline Sugarberry & Celtis laevigata & $\mathrm{x}$ & $\mathrm{x}$ \\
\hline Buttonbush & Cephalanthus occidentalis & $x$ & \\
\hline Spiny thistle & Cirsium horridulum & & $x$ \\
\hline Virginia dayflower & Commelina virginiana & & $\mathrm{x}$ \\
\hline Dogwood & Cornus spp. & & $\mathrm{x}$ \\
\hline Swamp dogwood & Comus stricta & $x$ & \\
\hline Hawthorn & Crataegus spp. & $\mathrm{x}$ & $\mathrm{x}$ \\
\hline Swamp lily & Crinum americanum & $\mathrm{x}$ & \\
\hline Titi & Cyrilla racemiflora & $\mathrm{x}$ & \\
\hline Rattlebox & Daubentonia texana & & $\mathbf{x}$ \\
\hline Persimmon & Diospuros virginiana & & $\mathrm{x}$ \\
\hline Horseweed & Erigeron canaddensis & & $\mathrm{x}$ \\
\hline Mistflower & Eupatorium coelestinum & & $x$ \\
\hline Swamp privet & Forestiera acuminata & $\mathrm{x}$ & $x$ \\
\hline Pumpkin ash & Fraxinus profinda & $\mathrm{x}$ & \\
\hline Ashes & Fraxinus spp. & & $\mathrm{x}$ \\
\hline Bedstraw & Galium aparine & & $\mathrm{x}$ \\
\hline Water locust & Gleditsia aquatica & $\mathrm{x}$ & $\mathrm{x}$ \\
\hline Honey locust & Gleditsia triacanthos & & $\mathrm{x}$ \\
\hline Marshmallow & Hibiscus spp. & & $\mathrm{x}$ \\
\hline Pennywort & Hydrocotyle spp. & & $\mathrm{x}$ \\
\hline Possum haw & Ilex decidua & $\mathrm{x}$ & $x$ \\
\hline Yaupon & Ilex vomitoria & & $\mathrm{x}$ \\
\hline Touch-me-not & Impatiens capensis & & $\mathrm{x}$ \\
\hline Marsh elder & Iva frutescens & $\mathrm{x}$ & \\
\hline Wild lettuce & Lactuca canadensis & & $\mathrm{x}$ \\
\hline Sweetgum & Liquidambar styraciflua & $\mathrm{x}$ & $\mathrm{x}$ \\
\hline Magnolias & Magnolia spp. & $\mathrm{x}$ & $\mathrm{x}$ \\
\hline Sensitive plant & Mimosa strigillosa & & $\mathrm{x}$ \\
\hline Red mulberry & Morus nibra & & $x$ \\
\hline Wax myrtle & Myrica cerifera & & $\mathrm{x}$ \\
\hline Tupelogum & Nyssa aquatica & $\mathrm{x}$ & \\
\hline Black gum & Nyssa biflora & $\mathrm{x}$ & $\mathrm{x}$ \\
\hline Virginia creeper & Parthenocissus quiquefolia & $\mathrm{x}$ & \\
\hline Maypops & Passiflora spp. & $\mathrm{x}$ & $\mathrm{x}$ \\
\hline Swamp bay & Persea palustris & $\mathrm{x}$ & $\mathrm{x}$ \\
\hline Water elm & Planera aquatica & $\mathrm{x}$ & $\mathrm{x}$ \\
\hline Sycamore & Platanus occidentalis & $\mathrm{x}$ & $\mathrm{x}$ \\
\hline Mayapple & Podophyllum peltatum & & $\mathrm{x}$ \\
\hline Knotweeds & Polygontum spp. & & $\mathrm{x}$ \\
\hline Ressurection fern & Polypodium polypodioides & $x$ & $\mathrm{x}$ \\
\hline Water oak & Quercus nigra & $\mathrm{x}$ & \\
\hline Willow oak & Quercus phellos & $\mathrm{x}$ & \\
\hline Oaks & Quercus spp. & & $\mathrm{x}$ \\
\hline
\end{tabular}


Table 7, continued

\begin{tabular}{||l|l|c|c|}
\hline \multicolumn{1}{|c|}{ COMMON NAME } & \multicolumn{1}{c|}{ LATIN NAME } & SWAMPS & LEVEES \\
\hline \hline Swamp honeysuckle & Rhododendron viscosa & $\mathrm{x}$ & $\mathrm{x}$ \\
\hline Poison ivy & Rhus radican s & $\mathrm{x}$ & $\mathrm{x}$ \\
\hline Snout bean & Rhynchosia minima & & $\mathrm{x}$ \\
\hline Brambles & Rubus spp. & $\mathrm{x}$ & $\mathrm{x}$ \\
\hline Palmetto & Sabal minor & $\mathrm{x}$ & \\
\hline Black willow & Salix nigra & $\mathrm{x}$ & \\
\hline Elderberry & Sambucus canadensis & $\mathrm{x}$ & \\
\hline Sassafras & Sassafras albidum & & $\mathrm{x}$ \\
\hline Skullcap & Scutellaria ovata & $\mathrm{x}$ & $\mathrm{x}$ \\
\hline Cat/green briar & Smilax spp. & $\mathrm{x}$ & $\mathrm{x}$ \\
\hline Wild bean & Strophostyles helvola & $\mathrm{x}$ \\
\hline Baldcypress & Taxodium distichum & $\mathrm{x}$ \\
\hline Shield fern & Thelypteris normalis & $\mathrm{x}$ \\
\hline Spanish moss & Tillandsia usneoides & & $\mathrm{x}$ \\
\hline American elm & Ulmus americana & $\mathrm{x}$ \\
\hline Stinging nettle & Urtica chamaedryoides & $\mathrm{x}$ & $\mathrm{x}$ \\
\hline Ironweed & Veronia altissima & & \\
\hline Grapes & Vitis spp. & & $\mathrm{x}$ \\
\hline
\end{tabular}

Table 8. Birds Present in the Vicinity of the Proposed Project Area.

\begin{tabular}{||l|l||}
\hline \multicolumn{1}{|c|}{ COMMON NAME } & \multicolumn{1}{c|}{ LATIN NAME } \\
\hline \hline Red-winged blackbird & Agelaius phoeniceus \\
\hline Cedar waxwing & Bombycilla cedrorum \\
\hline Great horned owl & Bubo virginianus \\
\hline Red-tailed hawk & Buteo jamaicensis \\
\hline Red-shouldered hawk & Buteo lineatus \\
\hline Broad-winged hawk & Buteo platypterns \\
\hline Willet & Catoptrophonus semipalmatus \\
\hline Common nighthawk & Chordeiles minor \\
\hline Yellow-billed cuckoo & Coccyzus americanus \\
\hline Common flicker & Colaptes auratus \\
\hline Black vulture & Coragyps atratus \\
\hline Common crow & Corvis brachyrhynchos \\
\hline Yellow rail & Cotumicops noveboracensis \\
\hline Downy woodpecker & Dendrocapos pubescens \\
\hline Acadian flycatcher & Empidonax varescens \\
\hline American kestrel & Falco sparverius \\
\hline Wood thrush & Hylocichla mustelina \\
\hline Wild turkey & Meleagris gallopavo \\
\hline Mockingbird & Mimus polyglottos \\
\hline Common screech owl & Otus asio \\
\hline American woodcock & Philohela minor \\
\hline Barred owl & Strix varia \\
\hline Brown thrasher & Toxostoma rufum \\
\hline Robin & Turdus migratorius \\
\hline Mouming doves & Zenaida macroura \\
\hline \hline & \\
\hline
\end{tabular}

The swamps represent an important refuge for populations of mink, raccoon, duck, alligator, and otter (Table 4). In addition, ducks, wading birds, and various song birds use the swamps during certain seasons. White-tailed deer, rabbits, and turkeys use the swamps during the dry seasons. Fishes such as freshwater catfish, gars, and drums, that can tolerate the low oxygen conditions often encountered in the swamps, are common residents (Table 3). The swamps also are populated with an array of semiaquatic turtles, snakes, and amphibians (Table 6).

\section{Climate}

The proposed project area lies in a region characterized by a humid subtropical climate; long, hot, rainy summers and short, mild winters are common. The average growing season for the Iberia Parish vicinity is 278 days. The average daily maximum summer temperature for the area is $32.2^{\circ}$ $\mathrm{C}\left(90^{\circ} \mathrm{F}\right)$, but temperatures can reach as high as $38.3^{\circ} \mathrm{C}\left(101^{\circ} \mathrm{F}\right)$. The oppressive summers, however, are sometimes relieved by cool sea breezes along the coast. The winter months are relatively mild; average daily temperatures throughout the area can drop to approximately $18.3^{\circ} \mathrm{C}\left(65^{\circ} \mathrm{F}\right)$ during December, January, and February (Clark and White 1978).

On average, precipitation measures $141.5 \mathrm{~cm}$ (55.7 in) annually. July ranks as the wettest month and it receives an average of $19.05 \mathrm{~cm}$ (7.5 in) of rainfall. November, the driest month, averages only $7.62 \mathrm{~cm}$ (3.0 in) of precipitation. Thunderstorms are common during the summer months, while snowfall occurs only rarely during the winter. Hurricanes and tropical storms represent the most dangerous weather threat to the area; they occur every few years during both the summer and fall months. 


\section{ChaPTer III}

\section{Prehistoric Cultural Sequence}

\section{I} ntroduction

The proposed project area lies entirely within the Coastal Plain and within a portion of Iberia Parish, Louisiana. Iberia Parish is one of the 13 southwest Louisiana parishes that make up Management Unit III as defined by Louisiana's Comprehensive Archaeological Plan (Smith et al. 1983). Bordered to the west by the Sabine River and to the east by the Atchafalaya River, this management unit includes the sparsely settled prairies and coastal marshes of southern and southwestern Louisiana. The proposed project corridor also lies within the Southeastern Cultural Area of the United States (Muller 1983). As a result, cultural characteristics found within the vicinity of the proposed project corridor resemble those manifested in the Lower Mississippi valley and along the northern coast of the Gulf of Mexico, as well as other parts of the surrounding region.

The prehistory of Management Unit III extends from ca. 12,000 - 250 B.P. and it can be divided into four general stages. These four stages (Paleo-Indian, Archaic, Woodland, and Mississippian) represent developmental segments characterized by dominant patterns of subsistence and technology (Willey and Phillips 1958). Each archeological stage consists of a sequence of chronologically defined periods that can be subdivided into phases based on sets of artifacts and other cultural traits characteristic of a particular geographic region (e.g., Jenkins 1979; Walthall 1980). This chapter presents a brief discussion of each of the cultural units and it provides an overview of the prehistoric sequence associated with the Areas of Potential Effect.
Paleo-Indian Stage (ca. 12,000 - 8000 B.P.)

Initial human occupation of the southeastern United States generally occurred sometime between $12,000-10,000$ B.P. Sites dating from this period tend to be represented by small clusters of artifacts that include a distinctive assemblage of lithic tools. Common Paleo-Indian tool types include fluted and unfluted lanceolate projectile points/knives, unifacial end- and side-scrapers, gravers, and spokeshaves.

The earliest Paleo-Indian cultures identified in North America has been termed "Clovis," named after the type-site identified in Clovis, New Mexico in the 1920s. In the western United States, Clovis sites date from a relatively narrow time range (ca. 11,500 - 10,900 B.P.) (Haynes 1991; Story et al. 1990:178). The smaller, related fluted Folsom and unfluted Midland projectile points knives once were thought to postdate Clovis culture. Radiocarbon dating of numerous Folsom components in Texas, however, has produced dates ranging from ca. $11,000-10,000$ B.P. (Largent et al. 1991:323-332; Story et al. 1990:189). This suggests that Folsom culture may be partially contemporaneous with Clovis culture and it may simply represent a variation in tool morphology required by different subsistence adaptations.

Paleo-Indian peoples were highly mobile hunter-gatherers, organized into small bands or extended family groups. The formerly prevalent notion that these populations specialized in big game hunting seems less tenable as additional information becomes available from a more inclusive set of Paleo-Indian sites. A possible exception to a generalized subsistence system could 
be the Folsom culture. Folsom artifacts have been associated consistently with bison kill sites on the Great Plains. This culture may represent an adaptation to a specialized hunting strategy associated with the cyclical migration of large herds of bison (Story et al. 1990:189).

Very few archeological sites with good associations of megafauna and Paleo-Indian cultural material have been recorded in the eastern woodlands. One such site is the Kimmswick Site (23JE334) in southeastern Missouri. Excavations at the Kimmswick Site produced Clovis projectile points in direct association with disarticulated mastodon bones (Graham et al. 1981). Paleo-Indian tools also have been recovered in direct association with mastodon bones near Nashville, Tennessee. At the Coats-Hines Site (40WM31), 34 chert artifacts were recovered within the thoracic cavity of a mastodon (Breitburg et al. 1996). These artifacts consisted of 10 formal tools and tool fragments (one bifacial knife, two gravers, one prismatic blade, two unifacial side scrapers, and two scrapers/cores) and 24 resharpening flakes. The presence of artifacts such as these in association with Pleistocene megafauna indicates that large animals did comprise at least a portion of the Paleo-Indian subsistence regime (Graham et al. 1981). In contrast, two locations in south central Louisiana, Avery Island (Salt Mine Valley; Site 16IB23) and the Trappey Mastodon Site (16LY63) in Lafayette yielded the remains of Pleistocene fauna; however, however neither site yielded a clear Paleo-Indian/Megafauna relationship (Gagliano 1964; Gibson and Miller 1973; Neuman 1984).

Louisiana's Comprehensive Archaeological Plan (Smith et al. 1983) documents only four Paleo-Indian sites within Management Unit III (Smith et al. 1983) and three of these sites are located a substantial distance away from the proposed project corridor. The fourth site, on Avery Island (Site 16IB3), documents the presence of Late Paleo-Indian period sites within the Coastal Zone. It is likely that Paleo-Indian Stage sites occur across the other salt domes located near the proposed project reach. It also is possible that many other Paleo-Indian sites were located in the Coastal Zone, but they either have been destroyed or buried by the continued introduction of large amounts of sediment throughout the Holocene.

\section{Archaic Stage (ca. 8000 - 3500 B.P.)}

The term "Archaic" first was used during the second quarter of the twentieth century as a descriptor for the pre-ceramic cultures that followed the Paleo-Indian stage. The Archaic stage can be divided into three subdivisions or periods: Early Archaic, Middle Archaic, and Late Archaic. A warming trend and a drier climate at the end of the Pleistocene, accompanied by a rise in sea level, may have spurred a combination of technological and social developments that now are associated with the initiation of the Archaic stage (Willey and Phillips 1958). Archaic populations exploited a greater variety of terrestrial and marine species when compared to their Paleo-Indian predecessors.

\section{Early Archaic Period}

In the Southeastern United States, the Early Archaic period extended from ca. 10,000 to 8000 B.P. Because of the regional variation and the temporal overlapping of stages, however, the assignment of Late Paleo-Indian and Early Archaic period artifacts to correct temporal stages can be complex. Like the preceding Paleo-Indian stage, Early Archaic period sites are scarce in Louisiana; nevertheless, some broad patterns in settlement location and subsistence patterning are apparent.

Throughout the Early Archaic, the subsistence pattern probably resembled that of the preceding Paleo-Indian stage. Early Archaic peoples most likely traveled seasonally in small groups between a series of base camps and extractive sites, hunting and collecting edible plants and exploiting the available natural resources (Chapman and Shea 1981; Lentz 1986; Parmalee 1962; Parmalee et al. 1976). The majority of the recorded sites have been identified throughout the uplands and Gulf Coastal Plain, but the extent to which the many microenvironments of the broad Coastal Zone were utilized remains unknown.

It is during the Early Archaic period that pecked and groundstone tools associated with food processing, including manos, milling stones, and nutting stones, are recovered. Commonly utilized plant foods, such as walnuts and hickory nuts, could have been hulled and eaten without cooking or additional processing (Larson 1980). Much of our knowledge regarding 
Paleo-Indian and Early Archaic lifeways, however, is limited by problems associated with preservation. Lithic tools often are the only artifacts to survive, but they provide only limited information concerning a narrow range of activities (i.e., tool manufacture and maintenance, meat and hide processing, and wood and bone working).

\section{Middle Archaic Period}

During the Middle Archaic period, three interrelated events occurred that helped shape subsequent prehistoric cultural traditions. First, the effects of continental glaciation subsided, resulting in a warmer and drier climate in which modern climatic and environmental conditions prevailed. Second, technological improvements were made, particularly with respect to groundstone, bone, and antler tool production. Finally, sociopolitical organization changed in some areas; an increased number of ranked societies and related social developments appeared.

The Middle Archaic period throughout the southeastern United States is marked by several technological advances and by changes in subsistence patterns. Middle Archaic projectile points tend to be stemmed rather than notched types, e.g., Eva, Morrow Mountain, Sykes, Benton, and Newnan types. In addition, the Middle Archaic is represented by projectile points/knives that include Evans, Morrow Mountain, Johnson, Edgewood, and possibly Calcasieu types (Campbell et al. 1990:96; Green 1991; Perino 1985:195). Excavations at Site 16VN791, located in Vernon Parish, Louisiana (i.e., Management Unit I) produced evidence of a long tradition of corner notched projectile points/knives dating from the late Middle Archaic. It has been suggested that these points, and others in the region, were derived from types incipient to central Louisiana (Campbell et al. 1990).

Other technological innovations include the appearance of ground, pecked, and polished stone tools and the use of celts and grooved axes for heavy woodworking, possibly including the manufacture of dugout canoes. The atl atl, or spear thrower, first appeared during the Middle Archaic, as indicated by bone atl atl hooks and the appearance of ground stone bannerstones that apparently were attached to the spear thrower and may have served as atl atl counterweights or as fetishes.
The widespread occurrence of plant processing tools such as milling slabs, manos, and nutting stones suggests an increase in the utilization of plant foods. However, comparisons of floral and faunal assemblages from the Early Archaic show little change in the diversity or relative importance of plant species utilized. The Middle Archaic rough milling tools used in plant processing all have Early Archaic antecedents (Smith 1986:21).

Acorns and hickory nuts continued to be the most heavily utilized plant foods. Remains of squash (Curcurbita pepo) and bottle gourds (Lagenaria siceraria) appear for the first time during the Middle Archaic. The earliest occurrence of the bottle gourd dates from $5340 \pm 120$ radiocarbon years B.C. at the Windover Site (8BR246) in Florida (Doran et al. 1990). "Squash" rind dating from 5050 B.C. from the Napoleon Hollow (11PK500) and Koster (11GE4) sites in west-central Illinois initially identified as the cultivar C. pepo, now is thought to be representative of the Texas wild gourd $(C$. texana), rather than cultivated squash. Although the seeds of these plants are edible, it appears that their rinds were thin, woody, and inedible. These gourds probably were collected primarily for use as containers rather than as sources of food. Stronger evidence for the domestication of squash gourds occurs after 2350 B.C., i.e., during the Late Archaic (Smith 1987).

In many areas, a major exception to this apparent continuity in earlier subsistence practices was a significant increase in the utilization of fish and shellfish. The rising importance of aquatic resources can be seen in the development of the extensive shell middens found along many of the southeastern rivers. Shell middens first appear between 4550 and 4050 B.C. during the Hypsithermal (Altithermal) climatic episode, when rivers entered a phase of aggradation and low flow. These climatic changes promoted the development of oxbow lakes and shallow water shoal habitats favorable for mollusk growth and shellfish collection (Stein 1982). Although the food value of mollusks is low, these shellfish can be collected efficiently in bulk and appear to represent the economic focus for semi-sedentary Archaic Stage occupations for many parts of the southeastern United States (Russo et al. 1992). 
Extensive, deep shell midden sites presumably represent seasonal reoccupation of favored locations by small social groups with band-type socio-political organization. Large cemeteries at some Middle Archaic sites, such as Carleston-Annis (15BT5) in Kentucky and Little Salt Spring (8SO18) in Florida, represent interments made over long periods of time by groups who seasonally returned to these specific locations (Clausen et al. 1979). Increasing population during the Middle Archaic also may have led to more circumscribed territories, which is evidenced by the repeated occupation of favored locations and increased emphasis on locally available raw materials utilized in stone tool manufacture.

Recent research has demonstrated that earthwork and mound construction occurred at least in isolated instances during the Middle Archaic period (Saunders 1994, 1996, 1997; Saunders et al. 1992, 1997). At present, a total of four possible Middle Archaic mound sites are known in northeast Louisiana, and these include Hedgepeth Mounds (Site 16LI7), Watson Brake Mounds (Site 16OU175), Frenchman's Bend Mounds (Site 16OU259), and Hillman's Mound (Site 16MA201). Of the four, the Watson Brake mound group (Site 16OU175) is the largest and the most securely dated at 5400 B.P. (Saunders et. al. 1997:1797). The site consists of 11 mounds and connecting ridges constructed on a terrace above the Ouachita River flood plain. The civic structures at Watson Brake (Site 16OU175), and several other Middle Archaic sites, suggest that huntergatherer groups were capable of tasks that required relatively complex social organization and semisedentary living. For example, Griffin wrote:

From our knowledge of the general cultural stage of these early Archaic people we may assume that they lived in groups or bands of closely related people who probably reckoned descent through the father and were probably patrilocal... They probably lived in bands of twenty or thirty or perhaps a few more, ranging over a fairly specific hunting territory (1952:354).

Southern Louisiana reflects a paucity of permanent habitation floodplain sites dating from the Middle Archaic period. Only one Middle Archaic period cultural phase is currently recognized in coastal Louisiana. The Banana
Bayou phase, identified in the Petit Anse region along the central part of the Gulf coast, is represented by the artifact assemblage observed by Gagliano (1964) at Avery Island, near Banana Bayou (Neuman 1984).

\section{Late Archaic Period}

The Late Archaic period represents a time of population growth, as demonstrated by an increasing number of archeological sites identified throughout the United States. Stone vessels made from steatite, the occasional recovery of fibertempered pottery, and a variety of groundstone artifacts characterize the Late Archaic tool assemblage. Late Archaic projectile point/knife types found throughout Louisiana include a variety of corner-notched and stemmed varieties such as the Benton, Gary, and Ponchatoula types.

In the eastern United States, the Late Archaic period riverine economy was focused on a number of different wild resources, including deer, mussels, fish, and nuts. During the spring, macrobands coalesced to exploit forested riverine areas, while during late fall and winter, these Late Archaic groups fissioned into microbands that subsisted on harvested and stored nut foods, as well as on the faunal species commonly found throughout the upland areas. This pattern of microband/macroband settlement patterning and subsistence likely began to appear during the Middle Archaic period and perhaps even as early as the end of the Early Archaic period.

Archaic period sites typically are located along the boundary of Quaternary and Tertiary areas with relatively flat or undulating bluff tops that overlook the floodplains. Gibson (1976a:11) notes that most of the Archaic stage sites in south-central Louisiana were situated on the old, elevated landforms of the Lafayette-Mississippi River system and near the lowlands. The Banana Bayou Site (16IB104), for example, produced a radiocarbon date calibrated to ca. 5850 - 4805 B.P. (Gibson and Shenkel 1988). This suggests that the land forms associated with the Teche delta complex may be old enough to contain Archaic period deposits. According to the Louisiana Comprehensive Archaeological Plan, 40 Archaic sites had been documented in Management Unit III (Smith et al. 1983); four of these are located within Iberia Parish, the location of the proposed project area. 


\section{Poverty Point Culture (ca. 4000 - 2500 B.P.)}

The Poverty Point culture represents a transitional culture that originated ca. 4000 B.P., but it did not realize its apex until much later. As a result, the Poverty Point sphere of influence may not have arrived in the coastal region of southcentral Louisiana until ca. 3450 B.P. (Gibson 1979, 1994; Neuman 1984). This culture is best represented by the Poverty Point type site (16WC5) in northeast Louisiana. The Poverty Point Site is best known for exhibiting several fundamental and distinguishing characteristics of a complex society, e.g., the presence of massive public architecture and extensive long-distance trade networks, while maintaining only a hunting and foraging based economy (Jackson 1991).

The material culture of Poverty Point society is distinctive. Artifacts associated with this culture include atl atl weights, plummets, beads and pendants, thin micro flint blades, clay cooking balls, clay figurines, fetishes, and food storage and preparation containers. Container types include steatite vessels, basketry, and untempered ceramic materials. Most ceramic vessels are sandtempered, although a minority of grit-tempered, clay-tempered, fiber-tempered ceramics, and untempered ceramic sherds and vessels have been recovered from Poverty Point sites. In addition, Webb (1982) reports the recovery of seed processing implements, stone hoe blades, nutting stones, and milling stones; earthen ovens also have been identified.

Possible Poverty Point sites identified within the Coastal Zone of south-central Louisiana consist of camp locations on Avery Island and Belle Isle (Gagliano 1967:98; Gibson et al. 1978:33-34). Both of these islands are located to the south of the proposed project area. While the presence of Poverty Point shell midden sites in southeastern Louisiana suggest seasonal and specialized adaptations to marsh environments, the dearth of similar sites in south-central Louisiana may represent a period in prehistory when the LaFourche deltaic complex was subsiding (Gibson et al. 1978).

Louisiana's Comprehensive Archaeological Plan lists only 15 Poverty Point sites in Management Unit III (Smith et al. 1983). Nearly half of these sites $(n=7)$ are located within Iberia Parish, i.e., the location of the variously proposed project items.

\section{Woodland Stage (ca. 2450 - 750 B.P.)}

The Woodland stage often is characterized by the introduction of horticulture, the bow and arrow, and the widespread use of ceramic containers. This cultural stage can be subdivided further into three periods: Early, Middle, and Late. In south-central Louisiana, the Early Woodland period (ca. 2450 - 1949 B.P.) is represented by Tchefuncte culture, the Middle Woodland period (ca. 1949 - 1550 B.P.) is associated with Marksville culture and to a lesser extent Troyville culture. Finally, the Late Woodland period (ca. 1550 - 750 B.P.) originated with Troyville culture, but it later was dominated by Coles Creek culture.

\section{Tchefuncte Culture (ca. 2450 - 1949 B.P.)}

The Tchefuncte culture is characterized by the first widespread use of pottery, although within the context of a Late Archaic-like hunting and gathering tradition that maintained a Late Archaic-like tool inventory (Byrd 1994; Neuman 1984; Shenkel 1981:23). Tchefuncte ceramics usually are characterized by a soft, chalky paste, and a laminated cross-section (Phillips 1970). Vessel forms consist of bowls, cylindrical and shouldered jars, and globular pots that sometimes contain podal supports. Many vessels are plain; however, some are decorated with punctations, incisions, simple stamping, drag and jab, and rocker stamping. During the later portion of the Tchefuncte period, red filming also appears on some vessels (Perrault and Weinstein 1994:4647; Phillips 1970; Speaker et al. 1986:38).

For the most part, the stone and bone tool subassemblages remained nearly unchanged from the preceding Poverty Point culture. Stone tools typical of the culture include boat stones, grooved plummets, chipped celts, and sandstone saws; bone tools included awls, fish hooks, socketed antler points, and ornaments. In addition, some tools such as chisels, containers, punches, and ornamental artifacts were manufactured from shell. Bone and antler artifacts, such as points, hooks, awls, and handles, also became increasingly common during this period.

Tchefuncte sites generally are classified either as coastal middens, or as inland villages or hamlets. Settlements usually occurred along the slack water environments of the slow, secondary streams that drained the bottomlands, floodplain 
lakes, and littoral zones of the region (Neuman 1984; Toth 1988:21-23). Shell midden sites also are common and they document the exploitation of a wide variety of food resources during this period. Tchefuncte burials and artifacts recovered from southwest and south-central Louisiana suggest an egalitarian type of social organization. The population probably remained focused within macrobands, and hunting, gathering, and fishing remained integral to the Tchefuncte lifestyle.

According to Louisiana's Comprehensive Archaeological Plan (Smith et al. 1983), 37 Tchefuncte period sites or components had been documented within Management Unit III; however, only four these sites were identified within Iberia Parish, the location of the proposed project area.

\section{Marksville Culture (ca. 1949 - 1550 B.P.)}

Marksville culture often is viewed as a localized version of the elaborate Midwestern Hopewell culture that filtered down the Mississippi River from Illinois (Toth 1988:29-73). A more complexly organized social structure than their Tchefuncte predecessors is implied by the elaborate geometric earthworks, conical burial mounds constructed for the elite, and the unique mortuary ritual systems that characterize Marksville culture. Some items, such as elaborately decorated ceramics, were manufactured primarily for inclusion in burials. Other burial items include pearl beads, carved stone effigy pipes, copper earspools, copper tubes, galena beads, and carved coal objects. Toward the end of the Marksville period, Hopewellian influences declined, and mortuary practices became less complex (Smith et al. 1983; Speaker et al. 1986).

The presence of ceramic decorative motifs such as cross-hatching, U-shaped incised lines, zoned dentate rocker stamping, cord-wrapped stick impressions, stylized birds, and bisected circles suggest interaction between the Marksville and Hopewell cultures (Toth 1988:45-50). Additional Marksville culture traits include a chipped stone assemblage that includes knives, scrapers, celts, drills, ground stone atl atl weights and plummets; bone awls and fishhooks; and baked clay balls. Projectile points recovered from Marksville culture sites are dominated by the Gary type.
In addition, a variety of artifacts made from exotic materials are commonly found at Marksville sites and their presence suggests the existence of and participation in a variety of extensive trade networks, as well as the emergence of a possibly ranked, non-egalitarian society whereby elites received goods of a higher quality. Some exotic items commonly recovered from Marksville culture sites include imported copper earspools, panpipes, platform pipes, figurines, and beads (Neuman 1984; Toth 1988:50-73). Despite the infusion of exotic materials into the Marksville economy, the utilitarian material culture remained essentially unchanged. This seems to reflect an overall continuity in subsistence systems (Toth 1988:211). Marksville peoples probably employed a hunting, fishing, and gathering subsistence strategy much like those associated with earlier periods. Gagliano (1979) suggests that food procurement activities were a cyclical, seasonal (transhumance) activity that revolved around the utilization of two or more shifting camps.

Recent investigations in nearby Terrebonne and St. Mary parishes have identified additional Marksville period sites, including mound sites, hamlets, and shell middens (Weinstein and Kelly 1989). The authors, after a review of a number of Marksville period ceramics recovered from sites identified throughout the region, concluded that the entire sequence of early through late Marksville period sites can be found within the region. According to Louisiana's Comprehensive Archaeological Plan (Smith et al. 1983), 38 Marksville sites have been documented within Management Unit III (Smith et al. 1983); only six of these sites were situated within Iberia Parish, the location of the proposed project area.

Troyville-Coles Creek Period (ca. 1550 - 750 B.P.) Troyville culture, also referred to as Baytown elsewhere in the region, represents a transition from the Middle to Late Woodland period that culminated in the emergence of Coles Creek culture (Gibson 1984). Though distinct, these two cultures are sufficiently similar that many researchers combine them into a single prehistoric cultural unit. The continuing developments of agriculture and the refinement of the bow and arrow during this time radically altered subsequent prehistoric lifeways. During the 
Troyville cultural period, bean and squash agriculture may have become widespread based on the appearance of large ceramic vessels. This shift in subsistence practices probably fostered the development of more complex settlement patterns and social organizations.

The Late Woodland Coles Creek culture emerged from the Troyville culture by approximately 1200 B.P. and it represented an era of considerable economic and social change throughout the Lower Mississippi Valley. By the end of the Coles Creek period, communities had become larger and more socially and politically complex. In addition, there is a great deal of evidence that large-scale mound construction occurred, and that long-distance trade resumed on a scale not seen since Poverty Point times (Muller 1983). These changes probably initiated the transformation of Coles Creek cultural traits into what is now recognized as the Plaquemine culture sometime before 750 years ago (A.D. 1200) (Jeter et al. 1989; Williams and Brain 1983).

Ceramics of this period are distinguished by their grog or grog and sand tempers, as opposed to the chalky, sand-tempered paste associated with the previous ceramic series. Sites dating from the Coles Creek cultural period primarily were situated along stream systems where soil composition and fertility were favorable for agricultural production. Natural levees, particularly those situated along old cutoffs and inactive channels, appear to have been desirable settlement locations (Neuman 1984). Most large Coles Creek period sites, usually are located inland, and they often contain one or more mounds.

Within the Louisiana Coastal Zone, agriculture probably represented only a minor portion of the subsistence pattern in operation during Troyville-Coles Creek times. Gibson et al. (1978:41) note that the tidal fluctuations, saline conditions, and the restricted amount of elevated ground on which to grow crops precluded large scale cultivation within the Coastal Zone. Louisiana's Comprehensive Archaeological Plan documents 196 sites with Troyville-Coles Creek components within Management Unit III (Smith et al. 1983). Of the 196 sites recorded, 27 were located within Iberia Parish.

\section{Mississippian Stage (ca. 750 - 300 B.P.)}

The Mississippian stage represents a cultural climax in population growth and social and political organization for those cultures that occupied the southeastern United States (Phillips 1970; Williams and Brain 1983). Formalized site plans consisting of large sub-structure "temple mounds" and plazas have been noted throughout the Southeast (Hudson 1978; Knight 1984; Walthall 1980;Williams and Brain 1983). In the Lower Mississippi Valley, the Mississippian stage is characterized by the Plaquemines or Emergent Mississippian period (750 - 500 B.P.) and by the Late Mississippian period (500 - 250 B.P.). Evidence of late historic period Mississippian culture is found only in limited parts of the coastal zone of south-central Louisiana and it may never have reached the southwest portions of the state (Jeter et al. 1989; Brown 1981; Brown and Brown 1978). Within the vicinity of the proposed project corridor, the Plaquemine culture may have flourished until after the period of European contact (200 B.P.) (Jeter et al. 1989; Gibson 1976a, 1976b).

\section{Emergent Mississippian Period (ca. $750-500$}

\section{B.P.)}

The Emergent Mississippian period Plaquemine culture represents a transitional phase representing evolution of the Coles Creek culture into a pure Mississippian culture (Kidder 1988). Plaquemine peoples continued the settlement patterns, economic organization, and religious practices established during the Coles Creek period; however, sociopolitical structure, and religious ceremonialism intensified, suggesting a more complex social hierarchy. Large sites often are characterized as ceremonial sites, and these sites typically contain multiple mounds constructed around a central plaza. Smaller dispersed villages and hamlets also formed part of the settlement hierarchy (Neuman 1984).

Although it is clear that Plaquemine ceramics are derived from the Coles Creek tradition, they display distinctive features that mark the emergence of a new cultural tradition. In addition to incising and punctating pottery, Plaquemine artisans also decorated their vessels with brushed and engraved designs (Phillips 1970). By ca. 500 B.P., Plaquemine culture throughout much of the 
Lower Mississippi Valley apparently had evolved into a true Mississippian culture (Kidder 1988:75).

Plaquemine sites have been recorded only rarely in south-central Louisiana. Those identified along Bayou Teche, the Vermilion River, and the Lower Atchafalaya Basin do not exhibit the cultural traits found in the nearby Lower Mississippi and Lower Red River Valleys (Gibson 1976a:20; Gibson et al. 1978:44). Most of the emergent Mississippian period sites recorded within the vicinity of the proposed project area consist of shell middens or small villages that are less elaborate than their more inland counterparts. Rectangular mound sites with centralized plazas are not altogether unknown in the region, but they occur much less frequently than in other areas of the state (Gibson 1976a:20). In addition to these shell middens and villages, other more specialized sites have been identified within the vicinity of the proposed project area. The Salt Mine Valley Site (16IB23) situated on Avery Island in Iberia Parish is one such specialized site. Prehistoric salt production in the United States gained importance primarily during the Mississippian period, post ca. A.D. 900 (Brown 1981:1) and it continued into the historic period.

In 1997, R. Christopher Goodwin \& Associates, Inc., completed data recovery excavations at Site 16LF66, a Plaquemine period site, in Lafourche Parish, Louisiana. Excavations at the site produced evidence of intact, stratified prehistoric period cultural deposits that produced ceramic sherds, bone tools, faunal remains, and human burials. These data suggest that Site 16LF66 represented the remains of a perennial occupation by Plaquemine culture peoples dating primarily to the fifteenth century A.D. (Miller et al. 1999).

The substantial midden identified at Site 16LF66 produced a variety of important information about Plaquemine subsistence in the marshes of southeastern Louisiana. Faunal remains were numerous and indicated a focus on the use of aquatic species, especially fish. While macrobotanical remains generally were sparse, the site did yield evidence of maize agriculture in the form of maize kernels. Further, cultural features, including hearths, pits, postmolds, and wall trenches, also provided information about the range and spatial distribution of activities conducted at the site, including the construction of dwellings and data on subsistence-related facilities. Finally, both primary and secondary burials identified within the midden yielded important information regarding prehistoric demography and burial patterns throughout the region (Miller et al. 1999).

The presence of a large number of burials and the thickness of the midden both suggest that the site was occupied continuously or discontinuously over a number of years. Site 16LF66 seems to be a clear example of a long-term village whose occupants focused on the procurement of aquatic resources; however, the consumption of maize at the site also suggests that agriculture may have played some role in the daily life of the prehistoric residents of the site.

According to ethnographic accounts, Coastal Plaquemine culture in south-central Louisiana, unlike groups located further inland and to the east, possibly remained unchanged until as late as ca. A.D. 1750. Louisiana's Comprehensive Archaeological Plan identified 83 Plaquemine period sites in Management Unit III (Smith et al. 1983). Of the 83 Plaquemine sites recorded, 17 were located within Iberia Parish.

\section{Late Mississippian Period (ca. 500 - 250 B.P.)}

During this time, several traits distinctive of the Mississippian period spread across most of the southeastern United States. Diagnostic cultural traits dating from this period include welldesigned mound groups, a wide distribution of sites and trade networks, shell-tempered ceramics, and a revival in the ceremonial burial of the dead (Griffin 1990:7-9). Late Mississippian period subsistence was based on the cultivation of maize, beans, squash, and pumpkins; despite this focus on maize agriculture, the collection of local plants, nuts, and seeds, as well as and fishing and hunting continued to supplement the subsistence base. A typical Mississippian settlement consisted of an orderly arrangement of village houses, surrounding a truncated pyramidal mound. These mounds served as platforms for temples or as houses constructed for the elite.

Late Mississippian ceramic types frequently are characterized by shell-tempering, an innovation that enabled potters to create larger vessels with thinner walls (Steponaitis 1983). Shelltempered ceramic vessels included such forms as 
globular jars, plates, bottles, pots, and salt pans; in addition, loop handles are found on many Late Mississippian vessels. Although utilitarian plainware was common, decorative techniques included engraving, negative painting, and incising; modeled animal heads and anthropomorphic images also adorned ceramic vessels dating from this time period. Other types of late Mississippian period artifacts included chipped and groundstone tools; shell items such as hairpins, beads, and gorgets; and mica and copper artifacts. Projectile point styles such as Alba and Bassett also were common at this time.

In south-central Louisiana, the Late Mississippian period is less clearly defined than in other areas of the state. As previously stated, some continuity may have existed between earlier Plaquemine occupation and later occupations found throughout the region. Recent investigations tend to support the position that the Plaquemine culture continued to dominate the region throughout the Mississippian period. Evidence for this argument derives from research conducted in the Terrebonne Marsh in southcentral Louisiana. This research revealed that shell-tempered "Mississippian" ceramics were in the minority, while Plaquemine ceramics were heavily represented at most sites in the area (Weinstein and Kelley 1992:378).

Although probably underreported, Louisiana's Comprehensive Archaeological Plan documented only 17 Mississippian cultural period sites components within Management Unit III (Smith et al. 1983); seven of these sites were located within Iberia Parish. While not reported, hybrid Mississippian-like artifacts may be found in association with Plaquemine, Attakapan, or Chitimacha sites that date from either the protohistoric or early historic cultural periods.

\section{Protohistoric and Early Historic Period (ca. 411 - 220 B.P.)}

An understanding of protohistoric and historic period Native American cultures of the southeastern United States is limited severely by our frequent inability to recognize the ancestral cultures from which these historic groups were derived. This is due in part to the waning influence of the Mississippian culture and, to a lesser degree, the Plaquemine culture, but primarily it is a result of the social disruption initiated by the legacy of the Hernando de Soto entrada of 1539 1543. In addition, the subsequent French and Spanish exploration and colonization of the Southeast has effected the clarity to which the Protohistoric period can be brought into focus. During this period, Native American population upheavals and depletions were related to warfare, disruptive migrations, and epidemics introduced by European contact (Davis 1984; Smith 1987).

Villages apparently were similar to those reported for the preceding Plaquemine and Mississippian periods. The larger villages generally featured one or more truncated pyramidal mounds surmounted by chiefs' houses and temples; the remaining villagers lived in the area surrounding the mounds and in satellite hamlets. The houses were rectangular in shape and they were constructed of poles placed in the ground, that supported wattle and daub walls, and thatched roofs (Swanton 1946). The French learned cultivation techniques for corn, squash, potatoes, tobacco, and other indigenous crops from the Chitimacha and they apparently lived in the nearby Native American communities during times of famine.

Gibson (1976a:21) states that early colonists arriving in the region "found the Plaquemine culture still flourishing" during the $1700 \mathrm{~s}$. These inhabitants reportedly belonged to the Vermilion band of the Attakapa tribe and to the Chitimacha tribe. According to contemporary accounts, the Chitimacha occupied the lower Bayou Teche region, the Grand Lake area, and the lower stretch of the Atchafalaya River.

The Attakapa originated in southeast Texas, but, following varying degrees of interaction, began migrating to southwest Louisiana during the Late Prehistoric period. Swanton (1953:197-199) recounts that the easternmost Attakapa resided on the Mermentau River and in the vicinity of Vermilion Bay. In 1760, the Attakapa sold the land located between Bayou Teche and the Vermilion River, where their village was located, to a French settler, Fusilier de la Clair (Swanton 1946). The village, however, continued to be occupied by the band until the early nineteenth century.

According to Kniffen et al. (1987:53) and Swanton (1946:119, 1953:202-204), the Chitimacha originally were located on Bayou Lafourche, Grand Lake, and the lower portion of Bayou Teche. In 1702, however, Louis Antoine 
Juchereau de St. Denis took several members of the Chitimacha tribe as slaves. He was ordered immediately by Jean Baptiste le Moyne, Sieur de Bienville to return the captured Chitimacha to their people. In 1706, the alliance between the French and the Chitimacha was broken when the Chitimacha attacked and killed four Frenchmen in retaliation for an attack carried out by the Teansas earlier that same year. For the next 12 years, the Chitimacha fought the French and their Native American allies.
In 1718, peace terms were agreed upon between the French and the Chitimacha. According to those terms, the Chitimacha were to relocate to the Mississippi River near the present-day town of Plaquemine. Within a short period, however, the Chitimacha, once the strongest and most "cultured" of the south Louisiana tribes, was reduced greatly in numbers and they were forced to merge with other tribes in the area. Only a few Chitimacha remained by 1881 and they were living on a reservation situated near the town of Charenton, Louisiana (Kniffen et al. 1987:75). 


\section{Chapter IV}

\section{Historic OVERVIEW}

I ntroduction

The currently proposed project area is located within Iberia Parish, Louisiana. The project reach consists of that stretch of Bayou Teche extending from the railway bridge at Vida, through New Iberia, and downstream to the highway bridge at Olivier. In addition, six other project items are associated with the project; they consist of three staging areas and three dredge spoil disposal areas. Historically, the region containing the project area has been associated with the development of the city of New Iberia, and with cane cultivation and sugar manufacture along Bayou Teche. This chapter serves as a general overview, and it provides data on the history of the region from the colonial era to the present.

\section{Colonial Era}

During the French and Spanish colonial periods, the project reach included that part of the Louisiana colony known as the Attakapas region, or district, so-named for one of the Native American tribes indigenous to the area. French trappers and concessionaires were joined in the Attakapas region by Acadians, many of which migrated from the Chignecto Isthmus of Nova Scotia as a result of being exiled during the French and Indian War; by Spanish settlers, mostly Málagans, emigrants from the Costa del Sol in southern Spain; and by African slaves, many of whom came from the Senegambian region.

\section{French Colonial Period, 1699-1769}

Nearly 140 years following the last of the unsuccessful sixteenth century Spanish expeditions through the Louisiana region, the French began exploration of the lower Mississippi River
Valley area. On April 9, 1682, Réné Robert Cavelier, Sieur de la Salle, claimed all lands drained by the Mississippi River for Louis XIV, King of France. Approximately 16 years later, i.e., in 1698 - 1699, Pierre le Moyne, Sieur d'Iberville, led an expedition to explore the lower "Colbert or Mississippi River, from its mouth to the Natchez Nation," and to "establish a colony in Louisiana" (French 1875:29, 31).

Shortly after the founding of the Louisiana colony in 1699, the French established permanent settlements along the Mississippi River and the Gulf Coast; however, colonization of southwestern Louisiana was not encouraged by the French government. In addition, settlers were reluctant to leave the security of the Mississippi River posts for "the west," as the territory then was called by the French colonists. This area was uncharted and populated widely by Native Americans. Despite these trepidations, Spanish missionaries reported secluded groups of colonists in the Attakapas as early as 1713. The Native Americans of the Attakapas-Opelousas region initiated trade with the colonial government, offering pelts, tallow, and horses in exchange for French goods. By the 1740 s, a profitable deerskin and fur trade had been established with the "Attakapas Country," which name had replaced "the west" as the common designation for southwestern Louisiana (Figure 9) (Bergerie 1962:3; De Ville 1973:2431, 1986:4; Fontenot and Freeland 1976:1; Iberia Parish Development Board ca. 1948:12).

By the mid-eighteenth century, the French had discovered that the southwestern Louisiana prairies were well-suited for cattle ranging, and they thought that tobacco cultivation might succeed throughout this rich marshland (De Ville 
1973:31-33, 1986:4). Edouard Masse, one of the earliest documented colonial settlers in the area of present-day St. Martinville (situated approximately $13 \mathrm{~km}$ [ $8 \mathrm{mi}$ ] northwest of the project item), probably arrived during the 1740 s. Masse owned 20 slaves, many of whom he freed in his will, as well as a partnership in a cattle ranch. Masse lived in crude frontier conditions:

[He] lived in an open shack, slept on bearskin stretched on boards, and dressed in deer skins. His only utensils were a knife and horn, both of which he carried with him. He lived this way for nearly twenty years, extending hospitality to anyone asking for it; but there were few comforts to induce any travelers to linger there (Bergerie 1962:4).

In 1760, Masse and his partner, retired military officer Antoine Bernard Dauterive, were granted an Attakapas concession upon which they established a cattle ranch, or vacherie (Figure 10). This grant was situated on the east side of Bayou Teche near the present-day site of Loreauville (less than $3 \mathrm{~km}$ [2 mi] upstream from the proposed project corridor). The DauteriveMasse concession later became the site of the first Acadian settlement in the region, Fausse Pointe (Brasseaux 1987:75, 91-92).

Shortly thereafter, the French government proposed a military post in the Attakapas country as part of its plan to protect and secure the boundaries of the developing Louisiana colony from both Native Americans and other colonial powers. The Poste des Opelousas was established under the command of Louis Pellerin in 1763, after France officially transferred western Louisiana to Spain. The Opelousas Post, situated in the vicinity of modern-day Port Barre (St. Landry Parish), also became known as Attakapas, after the region it served; however, that name was discontinued with the establishment of the Poste des Attakapas at present-day St. Martinville (Brasseaux 1987:94; De Ville 1973:32-34; Fontenot and Freeland 1976:19; Pittman 1973:36).

\section{Spanish Colonial Period, 1769-1803}

On November 3, 1762, under terms of the Treaty of Fontainebleau, France secretly ceded the Isle of Orleans and all of the Louisiana colony west of the Mississippi River to Spain. Not only would France be ridding itself of the heavy financial burden of administering and supporting the colony, but the transfer also prevented a sizeable portion of the territory from falling under British control as a result of the impending English victory in the French and Indian War. Although the transfer was announced publicly in 1764, it was not until 1769 that the French colonial government finally was abolished and Spanish control was established under the governorship of Alejandro O'Reilly (Chambers 1898:48; Davis 1971:69-70, 97-105).

\section{The Acadians}

Throughout the eighteenth century, European powers struggled for colonial dominance in the New World of the Americas. France and Great Britain, in particular, fought over New France (Canada) and control of the Mississippi River. In 1713, France ceded "Acadie"-Nova Scotia and New Brunswick-to Britain in the

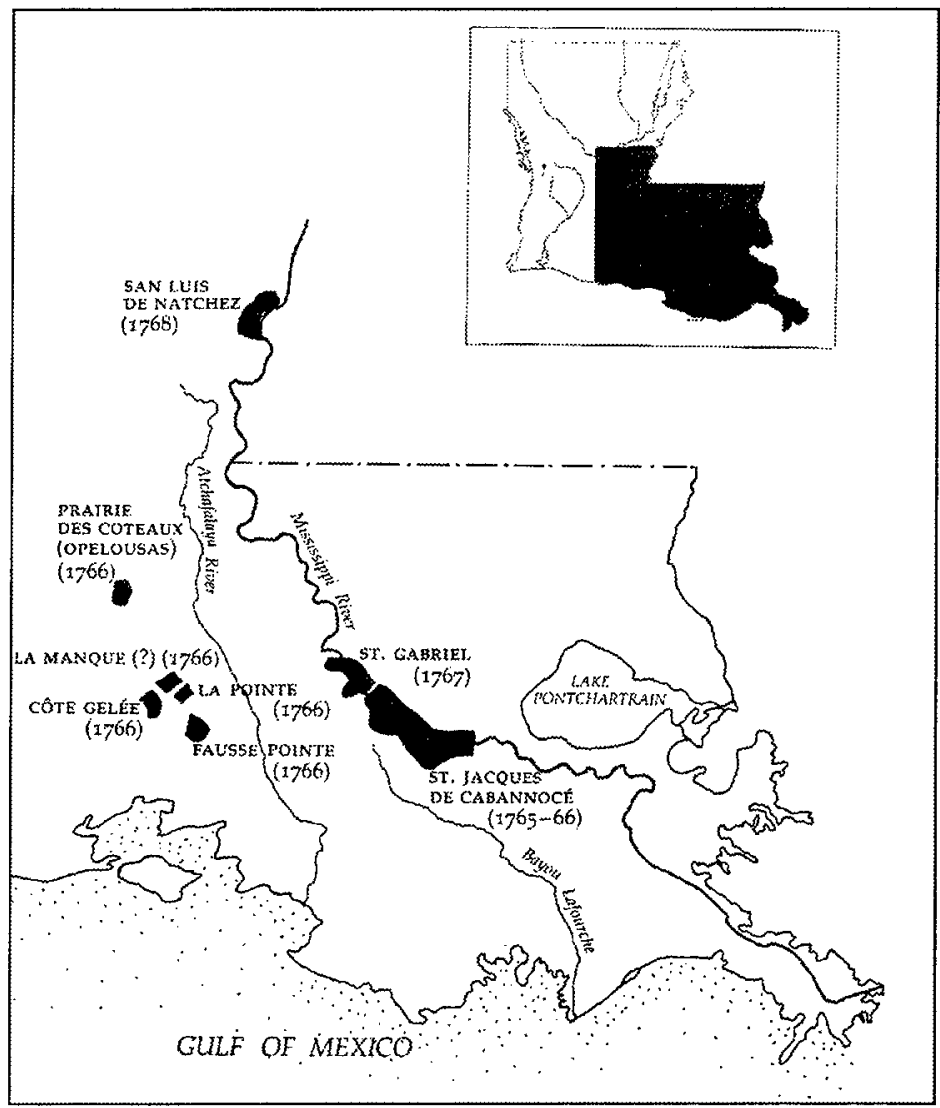

Figure 9. Adaptation of 1760 French map, from Brasseaux, The Founding of New Acadia. 


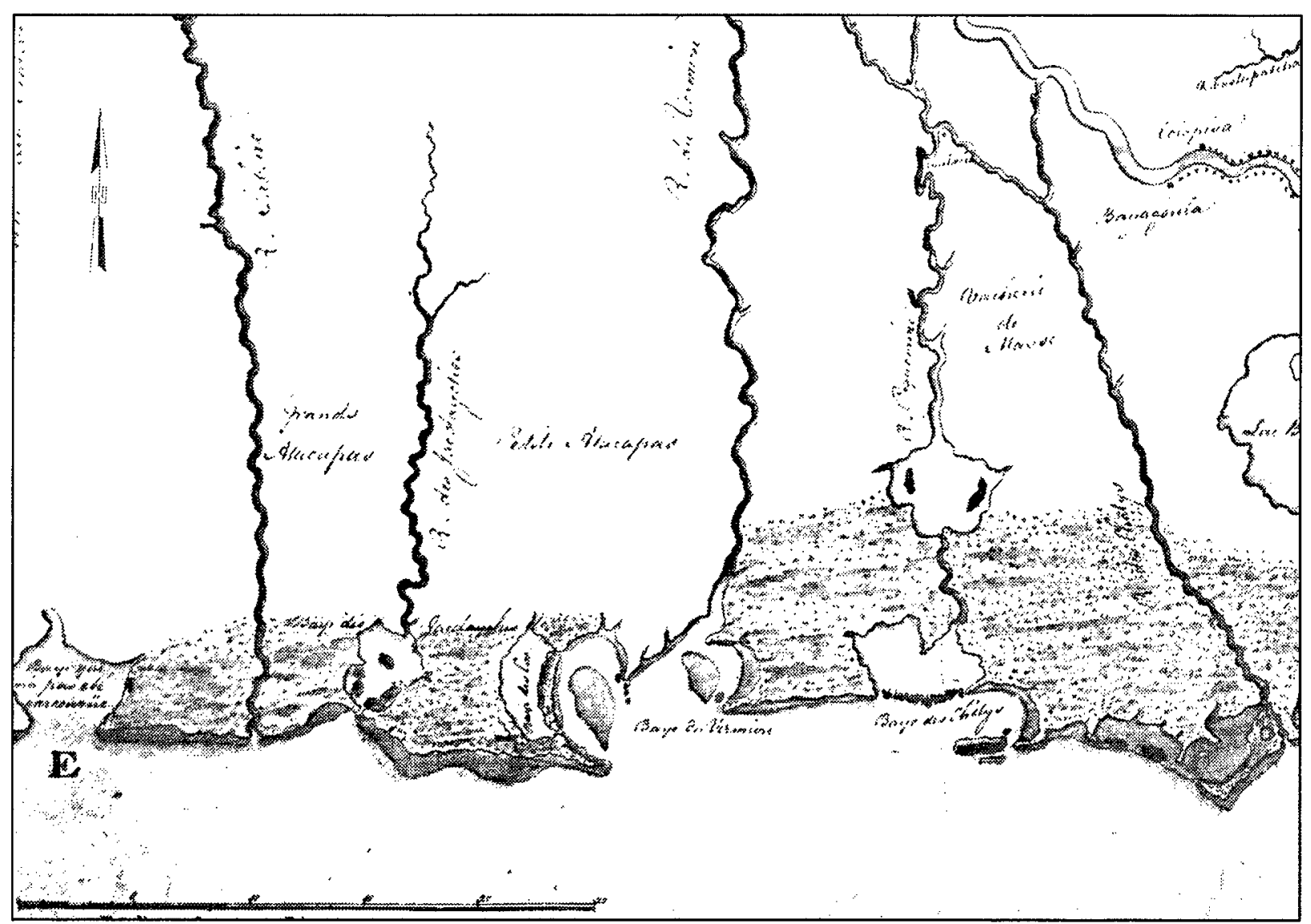

Figure 10.

[1760] Excerpt from an untitled map of Louisiana, in reference to the project vicinity. Excerpt depicts the Atacapas [Attakapas] region and the Vacherie de Masse [Masse's cattle ranch].

Treaty of Utrecht. These lands, populated by the French colonists known as Acadians, were important strategically, located half-way between Boston and the mouth of the St. Lawrence River. Britain required the Acadians to swear an oath of allegiance to the royal crown. Independent, largely Catholic, and convinced of their right to participate in the political process, the Acadians refused, and they struggled with British authorities for decades. On September 5, 1755, approximately 6,000 - 7,000 Acadians, half the total Acadian population, were imprisoned, and shortly thereafter deported to dozens of different colonial settlements. This mass deportation became known as Le Grand Dérangement, The Great Deportation (Figure 11) (Brasseaux 1987:25-27; Encyclopedia of Cajun Culture 2000:1).

Two small groups of exiled Acadians arrived in Louisiana, by way of "Santo Domingo" (Haiti). The French government in New Orleans sent the emigres to the Attakapas and Opelousas regions. The Spanish Attakapas District extended "along the sea coast between the Delta of the Mississippi and the Western boundary" (the Sabine River), while the Opelousas District adjoined Attakapas to the north (Sibley 1806:97). Several Acadian settlements were established ca. 17651766 within these southwestern districts. First and southernmost was Fausse Pointe, originally called "le dernier camp d'en bas" (roughly, "the last camp of the lower side"). The Fausse Pointe community originally extended along both sides of Bayou Teche and it was situated roughly between the present-day communities of Loreauville and Morbihan, in the vicinity of the upper portion of the proposed project area (Disposal Areas 1 and 2, Staging Area 1). To the northwest, along Bayou Teche between present-day Parks and the original site of the Opelousas Post, were La Pointe de Repos, La Manque, and Prairie des 


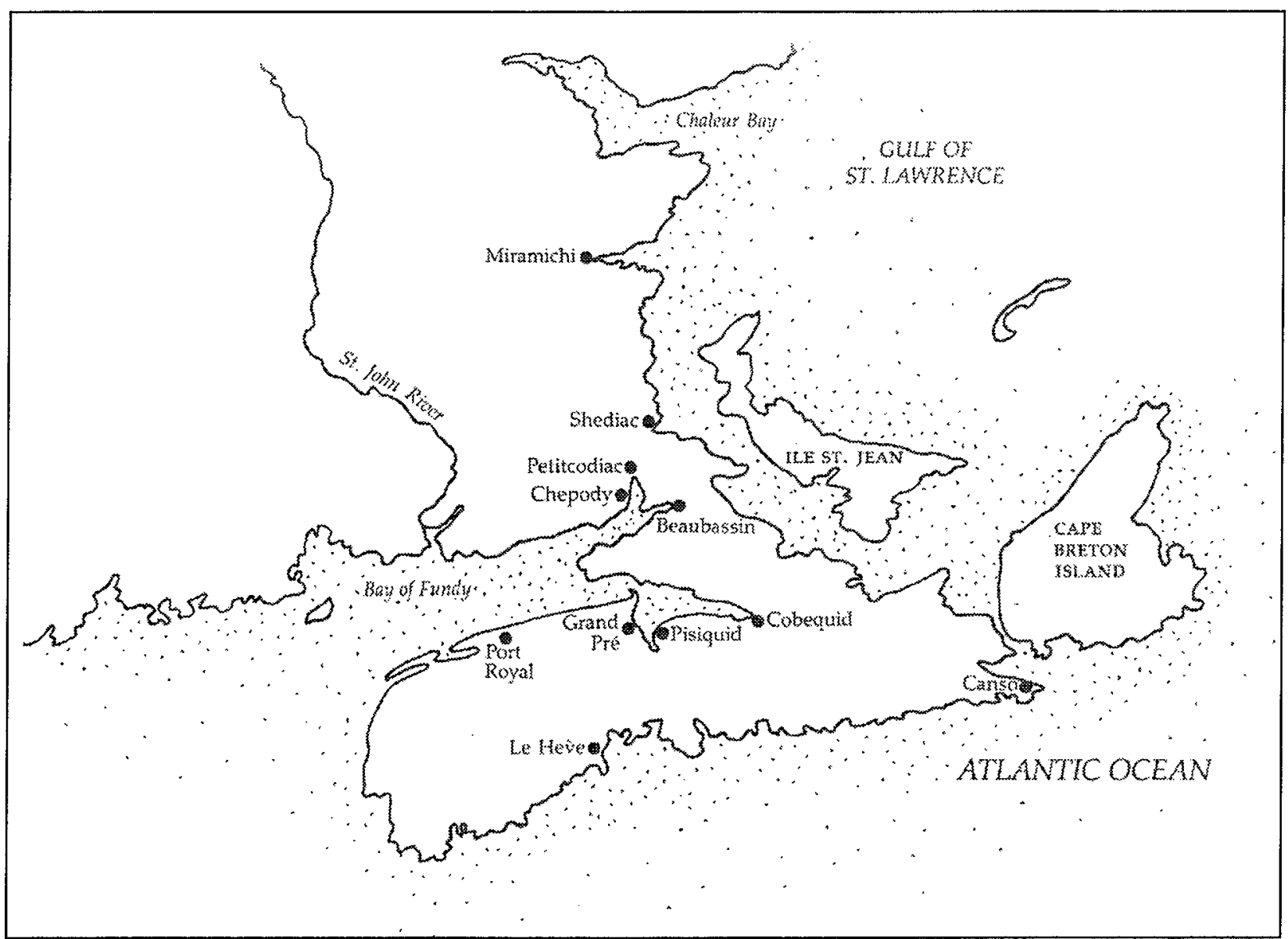

Figure 11. Acadian Settlements in New Brunswick and Nova Scotia, from Brasseaux, The Founding of New Acadia.

Coteaux (Opelousas). Côte Gelée was established on the west bank of Bayou Tortue, to the west of Fausse Pointe and La Pointe settlements (Brasseaux 1987:92-95).

On April 4, 1765, eight Acadian "Chieftains" (or family leaders) agreed to settle in the Attakapas region on lands owned by Antoine Bernard Dauterive and Edouard Masse at Fausse Pointe, i.e., along the east bank of Bayou Teche. In return for tending the cattle of the DauteriveMasse vacherie for a period of six years, Dauterive promised to supply each family with "five cows and their calves, one bull, and one halfinterest in the produce grown and cultivated on his lands in the Attakapas Country" (Rees 1965:25). In addition, the Acadians would receive the concession granted to Dauterive and Masse five years earlier. They further agreed that the livestock would be delivered when the Acadians arrived at the Attakapas. The French colonial government also supplied the Acadians with seed rice, seed corn, tools, and "sufficient flour, hardtack, hulled rice, and salt pork and beef to support them for six months" (Brasseaux 1987:75). The eight Acadian "Chieftains" included Joseph Broussard (who was called "Beausoleil"), Alexandre Broussard, Joseph Guilbeau, Jean Dugas, Olivier Tibaudau, Jean-Baptiste Broussard, Pierre Arceneau, and Victor Broussard (Bergerie 1962:5-6; Brasseaux 1987:74-76; Rees 1965:25).

Despite the attractive offer, the eight families soon abandoned their arrangement with Dauterive:

... within days of their arrival at the [Attakapas] post, the Acadians were denounced as trespassers by Dauterive's neighbors. Moreover, in 1771 Dauterive, who had recently become sole proprietor of the ranch, donated a 
large portion of the designated settlement site to St. Martin de Tours Catholic Church. Finally, rather than raise cattle on shares for Dauterive, the exiles purchased an undetermined number of cattle from Jean-Baptiste Grevemberg shortly after their arrival at Fausse Pointe. These settlers immediately sought patents to the land, thereby invoking the wrath of their neighbor, Jean-Baptiste Grevemberg, who claimed the area between Fausse Pointe and the Vermilion River as his personal fiefdom. In mid-July, Grevemberg addressed a memorial to Governor [CharlesPhilippe] Aubry and Commissaireordonnateur [Denis-Nicolas] Foucault, asserting his right to the land and requesting a patent to his fourteen-year-old vacherie. Despite the cattle baron's tenuous legal claim to the campsite ...., Aubry and Foucault permitted the Acadians to remain on their new farmsteads; Grevemberg could console himself with a concession of 7.5 square leagues (18.75 square miles [30 sq km]) (Brasseaux 1987:92).

Both Grevemberg and Broussard had a significant impact on the development of the overall project area. "Beausoleil" Broussard, who had been the militia captain of a "highly effective guerrilla unit" in Nova Scotia, obtained a Spanish land patent just above the proposed project area in 1772 (Figure 12) (Taylor 1980). Grevemberg held the patent immediately west of Broussard's. The Acadians who colonized this region, especially around Fausse Pointe, settled in widely separate communities, rather than establishing a central town. This pattern was in keeping with their tradition, and it aided them in establishing livestock areas, as well as developing farm acreage. Most of these Acadian families settled on lands positioned adjacent to one another, so that extended family structures remained intact, and grew through intermarriage (Brasseaux 1987).

The Attakapas Acadians anticipated a reunion with other exiled Acadian immigrants and they believed that a "New Acadia" would emerge at the Attakapas post. Insufficient support from the French colonial government, though, prevented other Acadians from settling in the Attakapas region. In order to protect the area against Native American raids, a group that arrived in May of 1765 was forced to settle along the lower Mississippi coast, rather than in the Attakapas region (Brasseaux 1987:76-77). Moreover, during the early Spanish period, colonial government officers prevented new Acadian exiles from settling with family members in the Opelousas and Attakapas regions, in an effort to enforce new settlement areas (Brasseaux 1987).

By April of 1766, the Attakapas Acadians had dispersed into three or four settlements. The census of April 25, 1766 listed an estimated 150 inhabitants in the district: 16 households at the "District of the Pointe" (Fausse Pointe), 17 households on Bayou Tortue (Côte Gelée), 14 households at La Manque (probably located between present-day Breaux Bridge and Parks), and 2 households under the category "Allibamont Established at the Attakapas" (the "Allibamont," or Alabamons, were French nationals who left Fort Mobile in 1763 to escape British rule). This last "Allibamont" entry included Edouard Masse's 20 slaves, who were the only slaves recorded in the Attakapas District; the remaining 130 inhabitants consisted entirely of white settlers (Brasseaux 1987:94; Taylor 1980:16 fn.14; Voorhies 1973:124-125).

- Nearly four years later, in early 1770 , Don Eduardo Nugent and Don Juan Kelly journeyed through western Louisiana. Their report to the Spanish governor recorded a white population of 166 inhabitants in the Attakapas District. The account also listed 33 slaves, of whom 26 were at least 12 years of age and, therefore, "able to work." The livestock included 1,323 oxen and bulls, 18 calves, 14 "carts with oxen", 266 horses and mares, and 565 pigs (Martin 1976:187, 191192). The conclusion of the district survey noted:

This district is quite similar to the district of Opelousas with regard to pastures and food production [corn, rice, and sweet potatoes].

Considered as a whole, it stretches over twenty leagues of longitude by six of latitude with population scattered throughout the district.

The Attakapas are favored with a better situation. More lands are cleared [there] than in the Opelousas District. The Acadians have settled there and raised cattle. They are extremely industrious and eager to work. Their women weave cotton which they turn into excellent cloth. They use it to make clothes for everyone. They also make stockings and cloth which they use as linen, but they were discouraged from cultivating cotton and manufacturing it, not knowing if the government would permit them to do so (Martin 1976:192). 


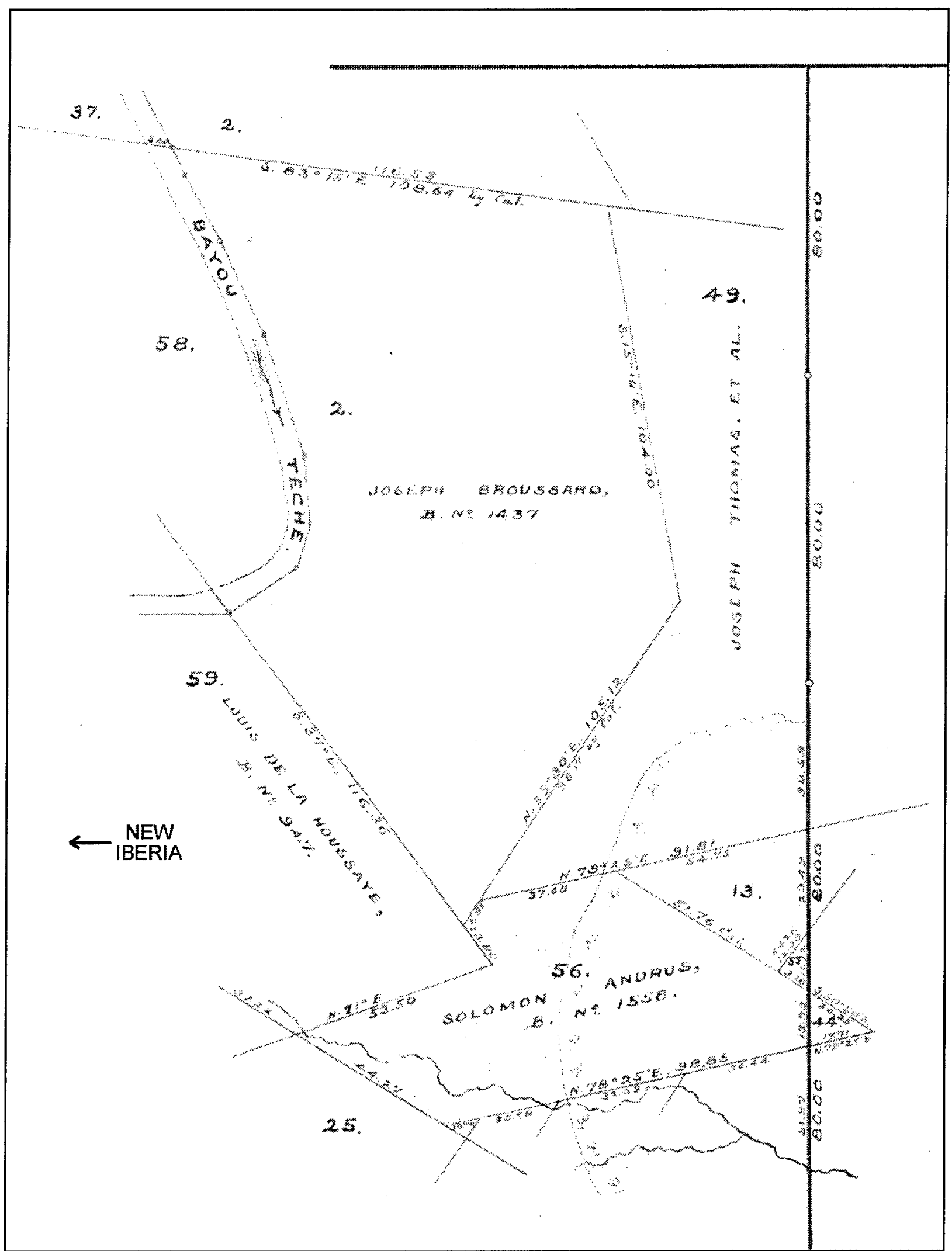

Figure 12. Adaptation of Spanish land grant maps, along Bayou Teche, ca. 1849, from the Louisiana Surveyor General's map, 1849. 
In these early settlement years, both the French and Spanish provisional governments refused to honor the French-Canadian paper currency held by the Acadians. As a result, few of these settlers could afford to purchase slaves. This, in turn, prevented most first-generation farmers from cultivating cash crops such as cotton, tobacco and sugar, all of which were laborintensive forms of agriculture. Within a generation, however, Acadians began to purchase bondsmen to work their lands; however, throughout the late eighteenth century, most settlers only held between two and four slaves. Consequently, most practiced subsistence farming and cattle ranching (Brasseaux 1987:192-93).

By 1774, the general census of the Attakapas region (October 30, 1774) documented significant growth: 323 white settlers, 129 adults, and 194 children. In addition, a small settlement of gens de couleur libre, free people of color, had been established along the Teche; it was comprised of 12 adults and 6 children. These families had been enslaved, but they were set free by the original concessionaires Masse and Fuselier. In just four years, the slave population also had grown dramatically. A total of 155 slaves now worked the plantations in the region. Despite this increase, three planter families, the DelaHoussayes, the deVaugines, and the Fuseliers, owned most of these bondsmen. In fact, only 19 of the 73 white households owned any slaves at all. Even before the turn of the nineteenth century, then, wealth was becoming concentrated along the Teche, foreshadowing the plantocracy that would soon evolve.

Regardless of these early successes, colonial settlers struggled to find a staple crop to sustain the colony. The first cash crop that planters developed was indigo, which became important during the Spanish colonial period. Indigo was a particularly labor-efficient crop; a single slave could plant and tend 0.8 ha $(2.0 \mathrm{ac})$ of the crop and still have time to attend to his own provisions (Holmes 1967:340). Each plantation or farm usually had its own indigo processing facility, since the manufacture of dye from indigo required little expensive machinery. The cut plant was placed in a vat called a "steeper," and the indigo then was covered with water until fermentation occurred. The liquid byproduct then was drawn off into another vat, called a "beater," where it was agitated much like the churning of butter (Figure 13). A precipitate was formed in the solution by adding lime water. The water was drawn off, and the indigo solids were placed in cloth bags to dry (Holmes 1967:344). Because indigo was fairly easy to cultivate, it could be produced with equal efficiency on large plantations and small farms.

While the cultivation of the crop was easier than that of cotton or sugar, the processing was not. Indigo as a staple thrived in the young colony largely because many slaves from the Senegambia region of Africa brought with them the knowledge of how to build vats, beat the leaves, and gauge the timing of the process. No other ethnic group in the area -- French, Spanish or Native American -- had any experience in indigo manufacturing. Unlike failed tobacco crops, which were unsuited to the soil, planters knew indigo would grow in the marshy Louisiana land, since it grew wild throughout the colony. While the indigo produced locally was inferior to that produced in the West Indian colonies, it became one of the few export staples of eighteenth century Louisiana (Hall 1992).

During this period, the majority of the land along the Teche was dispersed under Spanish patents. Most of the claimants owned land along both banks of the Teche, providing access to agricultural lands on the west bank and to pasturage on the east bank. The size of the landholdings varied greatly. There were several small landholdings of 243 ha $(600 \mathrm{ac})$ or less, but most of the claims were in excess of 405 ha $(1,000 \mathrm{ac})$. The largest landholdings in the proposed project area were those of François Cézar Boutté, François Prevost, John Baptiste St. Marc Darby, Augustin Grevemberg, Paul DelaHoussaye and Etienne deVaugine. They owned 853 ha $(2,108 \mathrm{ac}), 904$ ha $(2,233 \mathrm{ac}), 597$ ha $(1,475$ ac), 854 ha $(2,111 \mathrm{ac}), 737$ ha $(1,820 \mathrm{ac})$, and 822 ha $(2,031 \mathrm{ac})$, respectively (Figure 14$)$. It also should be noted that the Chitimacha held land positioned along both banks of Bayou Teche in the area of their present reservation, i.e., downstream of the proposed project corridor. The tribe had held an additional upriver 20 arpents front on both banks of the bayou, but they sold this parcel, in 1804, to Hyacinth Bernard (Original Conveyance A-2, \#455, St. Mary Parish). 


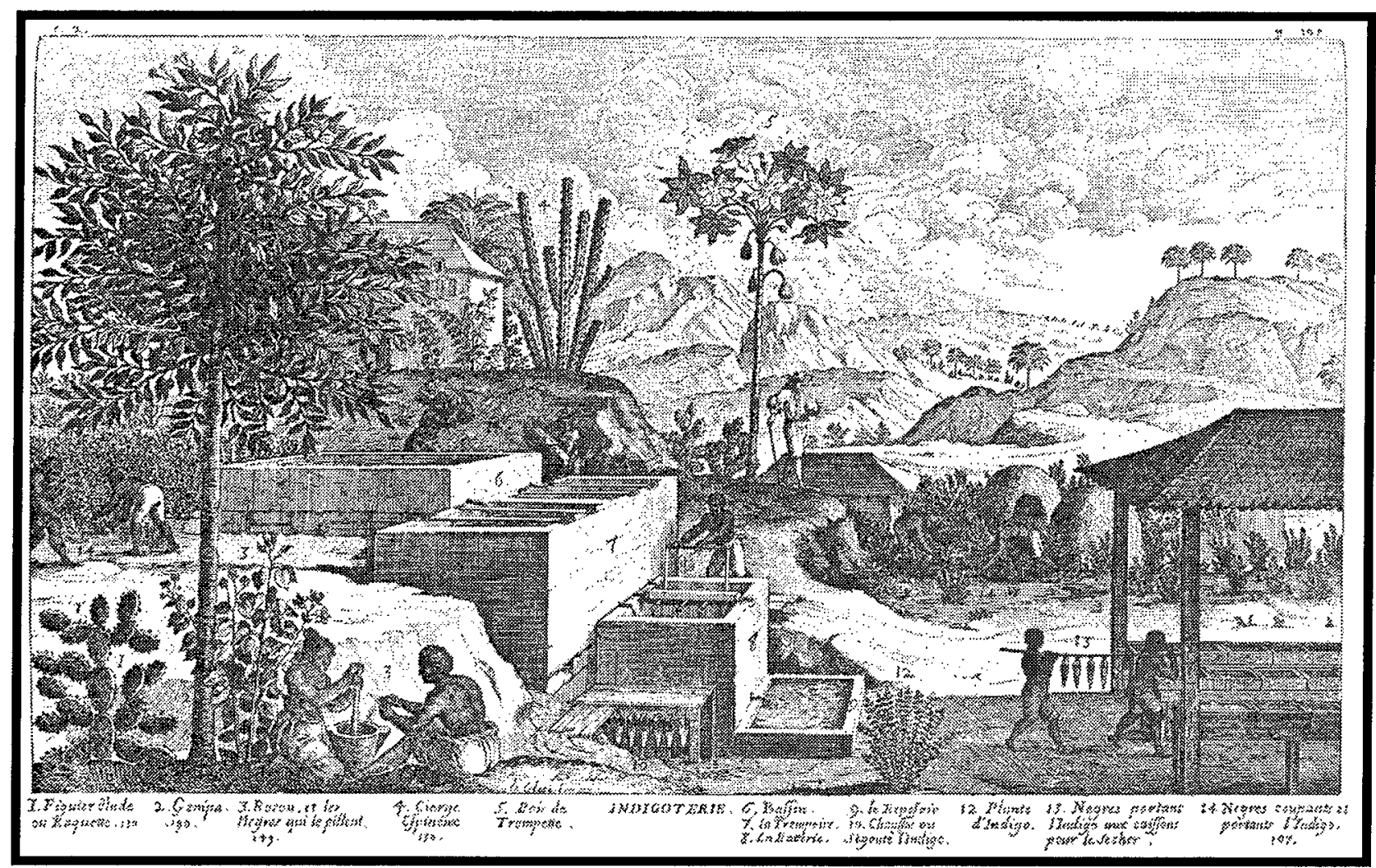

Figure 13. This depiction of a seventeenth-century Indigotiere in the French West Indies depicts the process used in Louisiana, from Hall, Africans in Colonial Louisiana.

Etienne deVaugine's considerable land spanned both sides of the Teche at Fausse Pointe, i.e., the area positioned approximately $0.8 \mathrm{~km}(0.5 \mathrm{mi})$ from Disposal Area 1 . A 1773 inventory of his indigo estate, performed by neighbor, Claude Boutté, and witnessed by other nearby concessionaires, Paul DelaHoussaye and Louis Grevenberg, showed his holding to be a good forerunner of the plantation system that evolved along the Teche during the nineteenth century. Self-contained and self-sufficient, the deVaugine land housed himself and his wife (Mrs. Pelagie Petit de Livilliers, recently deceased), as well as 33 slaves. These slaves, valued in toto at 4,210 piastres (a silver coin roughly equal to an American dollar), were worth significantly more than the land, houses, indigo processing material, furniture and all other items included in the inventory combined, which together totaled only 2,534 piastres. As these numbers suggest, planters with either liquid capital or connections to willing creditors had a significant advantage over the subsistence farmers of the region (Dart 1926:571-577).

The value of a slave to a concessioner, both in cash investment and in labor potential, must have made runaways a primary concern for men such as deVaugine. In addition to the slaves listed on the plantation, the inventory notes that two slaves named Jasmin and Guillaume were "fugitives for fifteen months at New Orleans and without any news of them" (Dart 1926). It seems likely that Jasmin and Guillaume joined one of the many "maroon" communities (groups of runaway slaves, African and Native American) in the New Orleans area, such as St. Malo's community by the mouth of the river, close to present-day Venice (Hall 1992:97-99, 214). Such communities made it all the more remarkable that deVaugine trusted another of his slaves, "Big Louis," so much that he sent Louis to New Orleans to collect several debts for him.

The deVaugines' house was not remarkable by plantation standards, but it was quite elabo- 


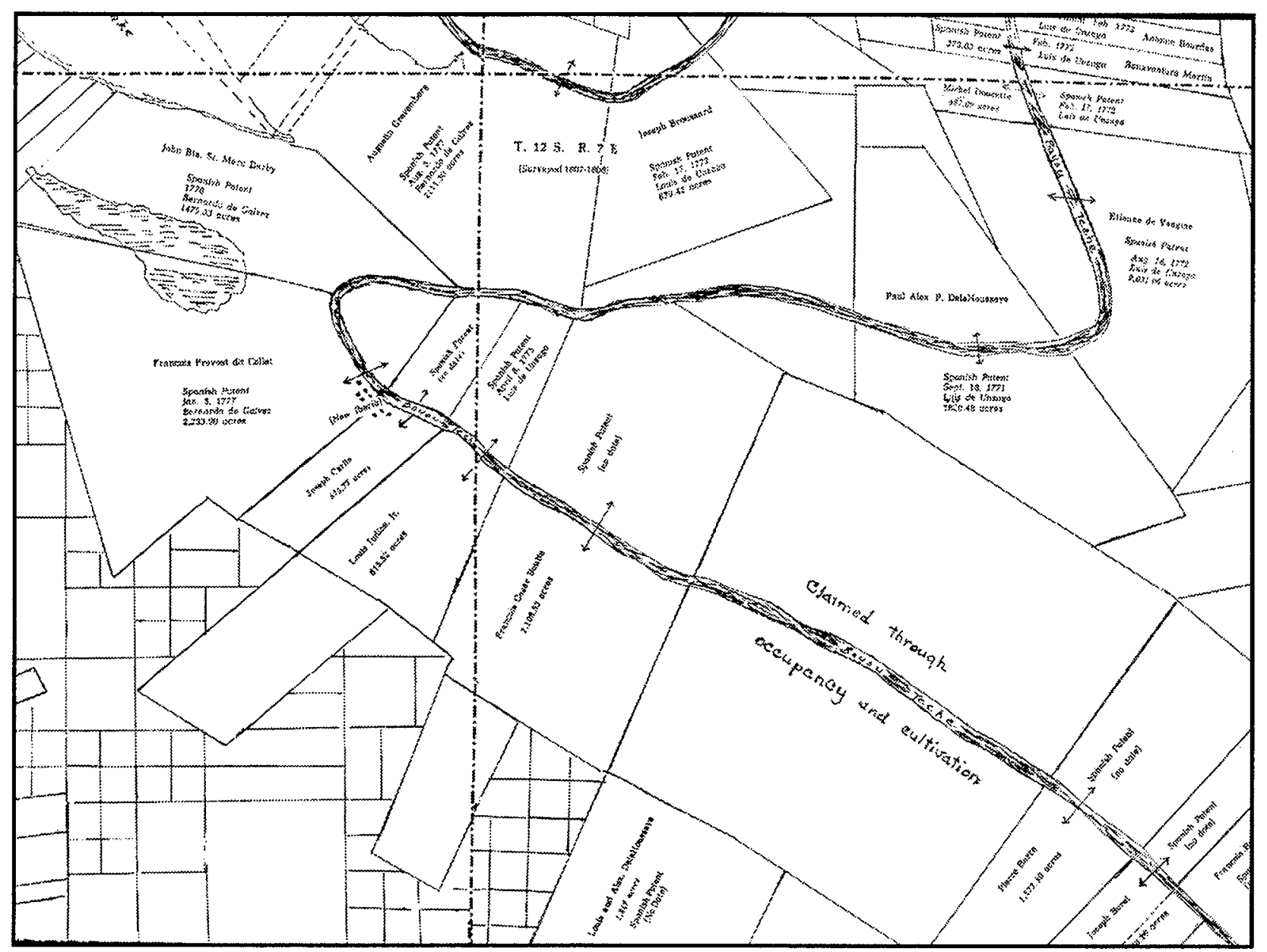

Figure 14. The major Spanish land grants in the New Iberia/Fausse Pointe area of Bayou Teche, ca. 1849, from G. Taylor, 1980.

rate for an early Teche settlement. The principal house consisted of a raised cottage on sleepers (piers); it contained three rooms. Galleries enclosed the house on two sides, allowing ventilation through the long, hot summers. The only other buildings mentioned were the two indigo warehouses. This is notable, in that no housing for bondsmen existed. Moreover, while the planter and his wife apparently shared a "walnut bedstead on roe-buck (stag) feet," as well as a feather bed and linen sheets, no provisions for slave bedding existed (Dart 1926).

A few other clues about slave life can be gleaned from the inventory. A total of two married slave couples were listed, including "Sauvier...and his lawful wife Izabelle" (Dart 1926:572). The other couple, l'Eveille "The Lively," and his wife Minerva, apparently were not married legitimately. It is interesting to note that while an able-bodied man was estimated to be worth 240 piastres, and an able-bodied woman at 160 piastres, the legitimate couple, Sauvier and Izabelle, together were estimated at only 300 piastres. Evidently, a married couple, appraised together, was "worth" less, perhaps because of the limited resale possibilities of a legitimate slave couple. In addition to keeping married couples together, four bondswomen were listed with their children, suggesting perhaps that the separation of young slave children from mothers had not yet come to the Teche.

Except for the few large planters like deVaugine, most white inhabitants engaged mainly in livestock farming. They owned collectively 5,208 head of cattle, 701 horses and mules, 1,126 pigs, and 96 sheep. The small free people of color community also raised livestock, owning 87 head of cattle, 33 horses and mules, 
and 45 pigs (Voorhies 1973:280-283). The preponderance of cattle reflects the economic importance of animal husbandry within the Attakapas region. Most of the Attakapas Acadians immigrated from the Chignecto region of Nova Scotia, "a sparsely wooded sea marsh and prairie that for half a century before the Grand Dérangement had supported small cattle ranches" (Brasseaux 1987:122). A description of the Chigneto beef economy concludes: "In view of their background, it is hardly surprising that the 1765 Acadian immigrants, whose leaders were drawn exclusively from the Chignecto Isthmus, selected homesites in South Louisiana's prime grasslands and immediately engaged in ranching" (Brasseaux 1987:122). The Acadians were successful, and the size of their herds increased rapidly. In addition to raising cattle, the Attakapas Acadians also farmed enough corn, cotton, and vegetables to be self-sufficient (Brasseaux 1987:122-125).

The size of the parcels claimed suggests that by the early nineteenth century farming and livestock raising had increased in scale. Indeed, major economic changes occurred during the 1790 s and into the early 1800 s throughout Louisiana. These changes were spurred partly by the economic failure of indigo production, the major cash crop during the colonial period. In terms of quality, indigo grown in Louisiana could not compete in the world market with indigo produced in the West Indies. Indigo also was susceptible to insect blights and it was sensitive to weather. Consequently, crop losses could be severe. Furthermore, the crop exhausted the soil. An increase in the price of slaves in Louisiana made it difficult to obtain the labor necessary for large scale indigo production on the plantations. Finally, the terrible smell of indigo production attracted disease-carrying insects, and the production of indigo polluted streams (Holmes 1967:346-348). This toxicity also may have contributed to the high death rates seen among young male slaves, traditionally the age group who worked the indigo (Hall 1992:301).

Technological advances also contributed to the decline of indigo, and the subsequent rise of cotton and sugar. During the 1790s, Eli Whitney invented the cotton gin, significantly reducing the time and labor involved in processing cotton. During this same decade, Etienne de Bore de- veloped a process that enabled the commercially successful extraction of sugar from cane. In 1795, the Haitian sugar maker Morin introduced refining processes and equipment that helped to make the sugar industry profitable. As a result of these inventions, cotton and sugar rapidly became major money making crops throughout the area. Berguin-Duvallon, in his 1802 narrative on the status of agriculture in Louisiana, states that "sugar and cotton are the staple commodities of the colony" (Davis 1806:131).

In addition to the Attakapas Acadians, the proposed project area, both above and below New Iberia, was settled by native French and Spanish settlers, as well as "Creoles," i.e., settlers born in the colony to immigrant parents. Among these colonial settlers, Paul Alex DelaHoussaye, François Prevost, François Cézar Boutté and John Baptiste St. Marc Darby all held large land grants along the Teche. Boutté, a Creole son of French concessionaires André Claude Boutté and his wife Françoise, and Prevost, a large land owner all around the state, probably did not settle on their land grants. The Darbys, however, did build a home on this concession, in 1813. John Baptiste had died by 1805 , but his widow, Françoise, continued to own the large land grant, including Disposal Area 1, as late as 1849 , though the boundaries of the plantation had changed (Figure 15) (Surveyor General's Map, October 1849). The huge house, once called Coteau, but eventually known as Darby, faced Spanish Lake on the North end of the plantation. Noted artist Adrien Persac painted the home, cistern house, garçonnieres, and slave quarters on the eve of the Civil War (Figure 16). The structure was built with bricks and made by slaves on site, using large cypress timbers to construct the structure (NRHP, Darby Plantation 2000:1)

Darby, like most other Attakapas concessions in the early years of settlement, was first a cattle ranch; however, it had converted to sugar production by 1810 . This shift to staple crop agriculture required a significant increase in labor. Conveyance records from New Orleans show that M. Francois St. Marc Darby, son of John Baptiste and Françoise, purchased 20 slaves from a slavetrader in May, 1828, to meet that growing need for plantation labor (Tolle 1973:89). In 1828, Darby produced 101 hogsheads of sugar, by far the most in the nascent New Iberia area. That same year, 


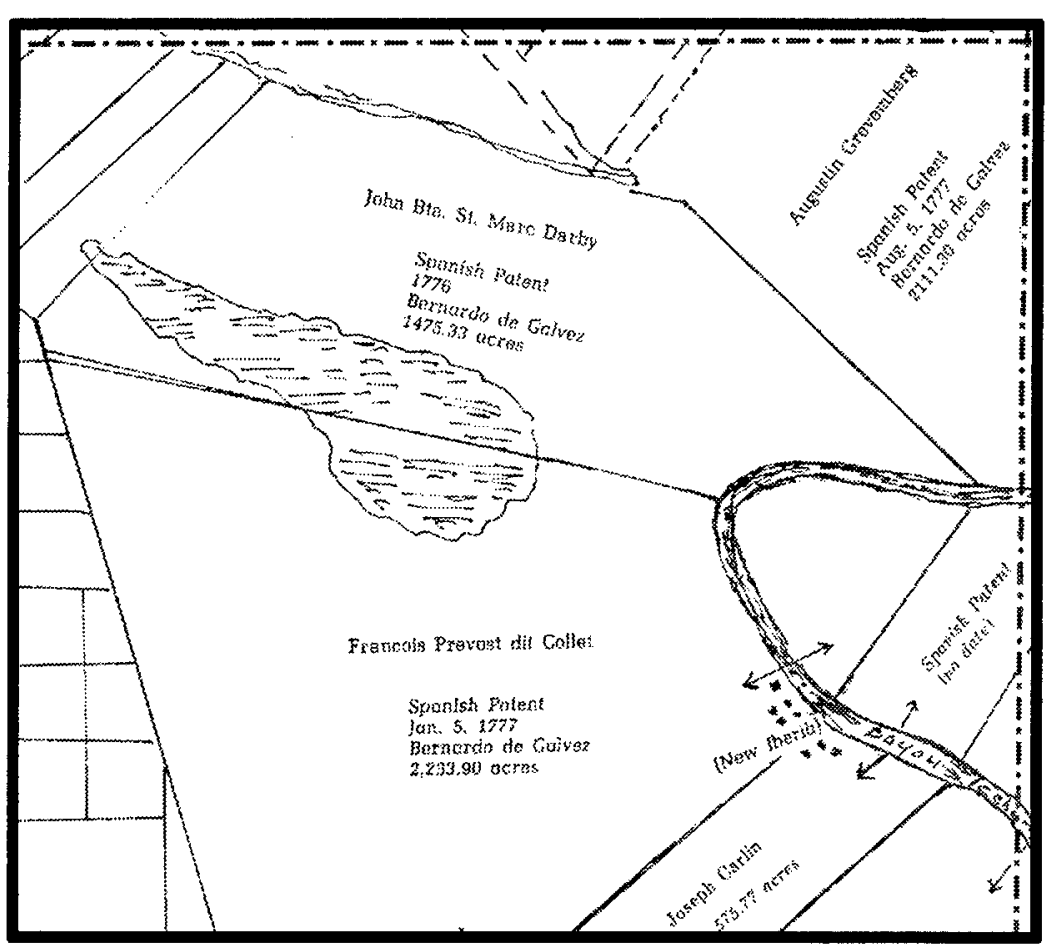

Figure 15. The Darby Plantation area, 1849, from G. Taylor, 1980. bringing Irish, German, and French immigrants to the region. Surnames associated with these early settlers include Romero, Villatoro, de Aponte, Ortiz, Balderas, Lagos, Segura, and Porras (Allain 1979a:80; Bergerie 1962:9; St. Martin Parish Development Board 1950:9).

Bouligny arranged for an elaborate array of supplies for the settlers of Nueva Iberia. These provisions included: salt, rum, powder, bullets, shot, flints, cutter's knives, beads, cloth, work clothes, chisels, posts, shingles, two-handled knives, nails, pliers, pincers, scythes, hammers, clamps, pots, saws, drills, hatchets, cranes, axes, mortars and pestles, fishing equipment, hinges, locks, hooks, trowels, iron hoops, iron (for making hatchets, hoes, and ploughshares), chains, ropes, soap, pitch, thread, needles, chalk, files, compasses, pencils, paper, shovels, weights, manacles, pulleys, tar, shoes, sharpening stones, and a variety of specialized tools for coopers, woodworkers, and blacksmiths. The government also procured slaves for the colonists, to undertake the heavy labor of clearing the ground and for construction (Allain 1979a:8182).

Bouligny chose a site for the settlement several miles downstream of the current town in February of 1779 . The two families of gens de couleur libre already lived at this location; however, they were removed. Bouligny wrote of his plans for settling the Málagan families:

\section{I intend to assign each settler six arpents of land fronting the Teche on the right bank going up for cultivation. I will also grant them six on the left bank where I will found the town and where I will leave the land in common for grazing, allowing each settler to build a fence around the land which belongs to him on that side should he wish to cultivate it (Allain 1979a:83).}

By March 1779, modest huts and warehouses had been built. In addition, fields were cleared, and hemp, flax, wheat and barley were 


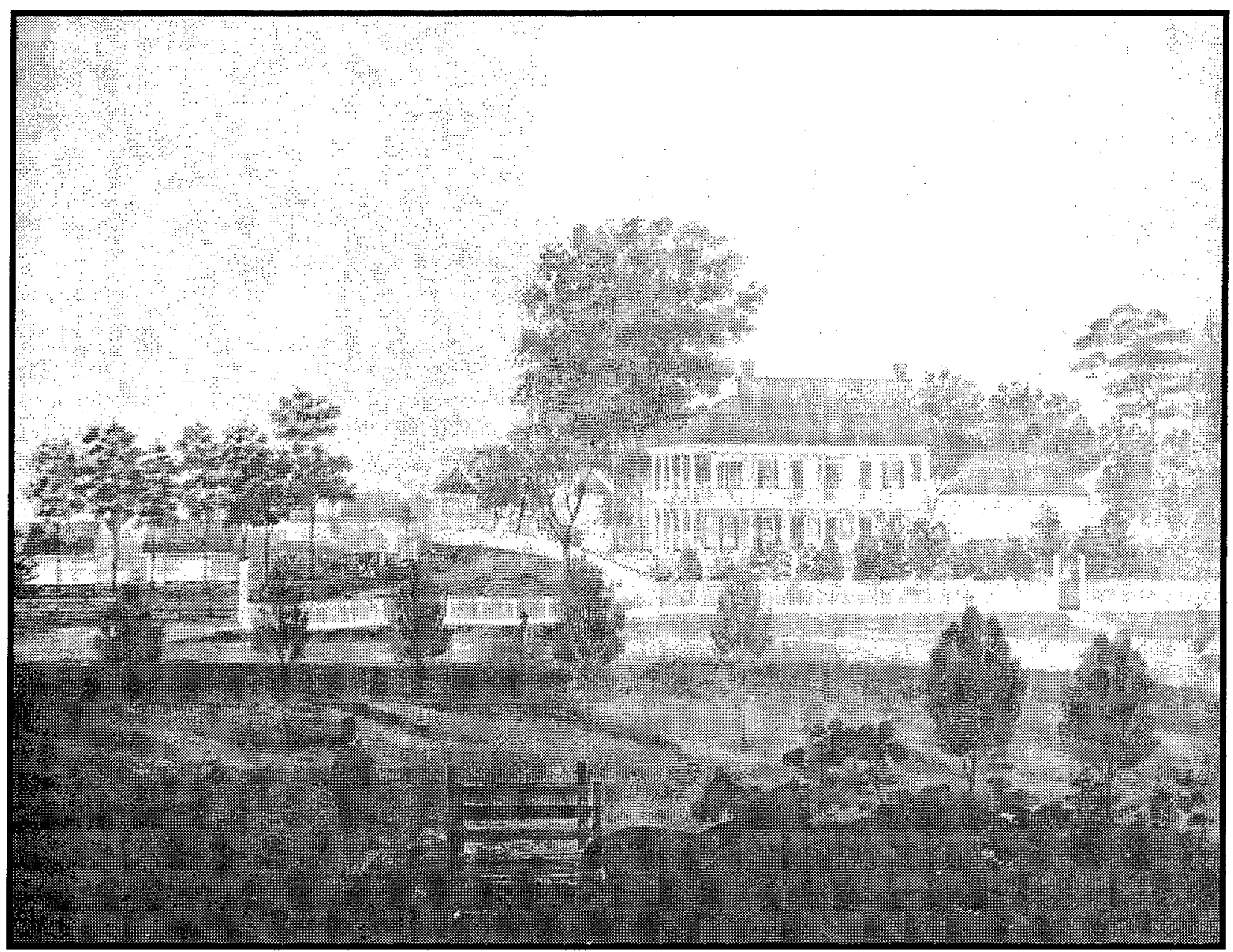

Figure 16.

Adrian Persec's famed depiction of the Francois St. Marc Darby Plantation on the eve of the Civil War. Adapted from Bergerie, They All Tasted Bayou Water.

planted. By April, though, a disastrous flood forced Bouligny to abandon the site and to search for higher ground. Bouligny bought land at the current site of New Iberia from Joseph Prevost (who was called "Colet") and he settled the Málagan families there:

. . I purchased from him a piece of land, thirty arpents frontage by eight arpents of depth, seven or eight leagues above my first establishment on the west bank of the Teche, out of the concession he established. I paid him 400 pesos and promised to grant him, subject to your lordship's good pleasure, two islands near the same place that he will be able to settle as he pleases, a piece of land near the same place for an orchard, and in a remote area that his cattle could reach ... (Allain 1979b:127).
The new location apparently suited the settlers. They planted corn, rice, potatoes, and tobacco, and felled trees for use in construction (Trammell 1987:246). Royal surveyor Thomas Berviquet [Berwick] was assigned the task of planning the town site. Besides constructing the town roads, Berwick was responsible for building the structures for the settlement:

... houses for the blacksmith, the families of the Artache, Prados, Migas y Vida, and Ybañez; two houses for the Germans and two for the soldiers; and houses for Mr. Flammand and Mr. Henderson, who also had a warehouse built. They constructed a royal warehouse, a great shed in which to make bricks and lime, and a large enclosure for the oxen (Trammell 1987:246). 

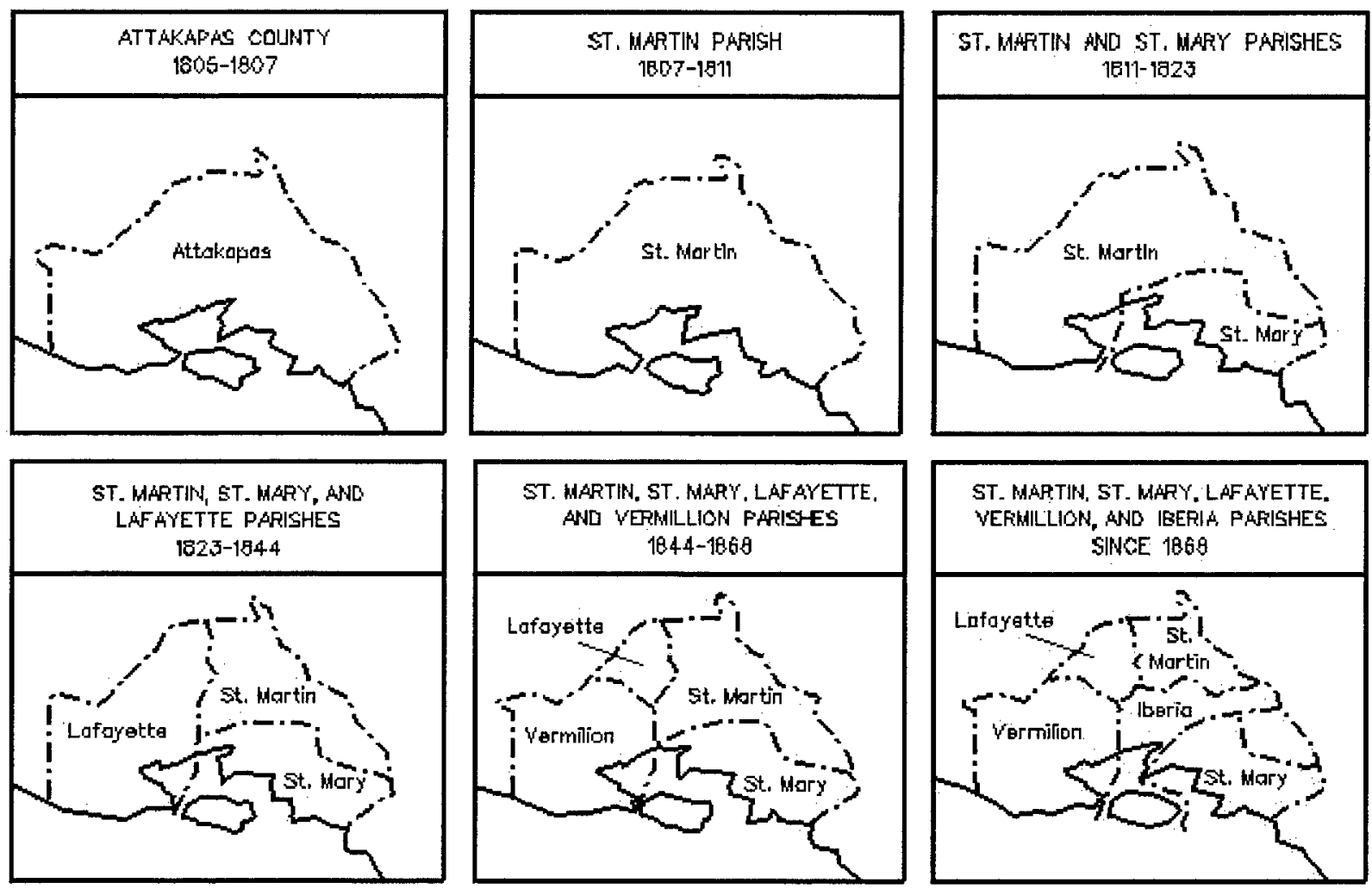

Figure 17.

Divisions of the original Attakapas country. Adapted from Bergerie, They All Tasted Bayou Water.

By 1785 , there were 125 inhabitants settled along the west bank of Bayou Teche (the east bank usually was reserved for pasture). Approximately three years later, the census recorded a population increase to 190 colonists at Nueva Iberia (Bergerie 1962:10-13, 27, 48).

\section{Antebellum Era}

As part of the negotiations leading to the 1803 Louisiana Purchase, Spain restored western Louisiana to France, which shortly thereafter conveyed the Louisiana Territory to the United States. On March 26, 1804, that portion of the Louisiana Purchase located below the thirty-third parallel was designated the Territory of Orleans. The following year, Orleans was partitioned into 12 counties, including the county of Attakapas, which encompassed the present-day parishes of Iberia, St. Mary, and Vermilion, most of Lafayette and St. Martin Parishes, and portions of Cameron and Iberville Parishes. In 1807, the territorial legislature reorganized the county system, further dividing the Territory of Orleans into 19 parishes. Attakapas County was superseded by the parish of St. Martin, which encompassed roughly the same territory as its predecessor. In 1811, southeastern St. Martin Parish was re-designated St. Mary Parish, which included Marsh Island and part of what later would become southern Iberia Parish. The following year, on April 30, 1812, the State of Louisiana was admitted to the Union (Figure 17) (Bergerie 1962:14-15; Davis 1971:157-164, 167169, 176; Goins and Caldwell 1995:41-42).

The Federal Government wasted no time in surveying their new territory. They sent James Leander Cathcart and John Landreth to the Attakapas region to conduct a survey of timber resources. From their journal entries recorded during $1818-19$, it may be concluded that the western coastal environs of the Attakapas country probably were uninhabited. On the higher grounds of the "salt islands" (i.e., south of the proposed project area) and the chenieres, settlers hunted and trapped, grazed cattle, and burned 
the marshes to clear ground for small subsistence farms. Away from the marshlands, larger plantations developed along the higher ground fronting the major waterways, especially along Bayou Teche (Glass 1898:18; Prichard et al. 1945; Vermilion Historical Society 1983:6).

Stock raising continued to be a profitable industry, though cotton production became more widespread in the Attakapas region during the late eighteenth and early nineteenth centuries. Planters had experimented with cotton in the Attakapas District early during the colonial period; therefore, it is not surprising that its cultivation increased following the introduction of the cotton gin. Nevertheless, cotton, like indigo, did not surpass animal husbandry in economic importance.

During the early nineteenth century, the average yield of a superficial arpent of land (roughly 0.4 ha [1.0 ac]) was approximately 400 pounds of cotton, worth approximately $\$ 100.00$. A skilled slave could cultivate three arpents of cotton (Robertson 1911:155), as compared to two arpents of indigo. Estimates of daily cotton yields picked by an adult slave ranged from 60 pounds of cotton per day, which, when cleaned, would yield about 20 pounds (Robertson 1911:156), to 150 pounds picked per day (Taylor 1976:67). The yearly cycle of cotton production began with the plowing of fields in late winter or early spring. Corn planting was followed by cotton, and the fields were hoed to destroy weeds. Around the Fourth of July, the crop was strong enough to be "laid by." Slaves then turned their attention to gathering firewood and harvesting corn. The cotton bolls began to open in August, and the cotton picking season followed. Ginning began with the accumulation of 1,400 pounds of cotton. The cotton then was pressed into bales weighing 400 pounds each, and then they were transferred to the New Orleans market (Taylor 1976:66-67).

\section{Development of the Sugar Plantations}

Despite the continued profitability of the cattle industry and the addition of a profitable cotton industry, the tremendous success of sugar growing in southeastern Louisiana during the early nineteenth century eventually attracted the interest of the Attakapas planters. Although sugar was grown in the district during the late eighteenth and early nineteenth centuries, sugar agriculture has not dominated the Teche region. In 1810, St. Marc Darby was the only sugar planter situated within the present project area. The transfer of the Louisiana Territory to the United States, however, and the opportunities afforded by the nascent sugar industry clearly stimulated American immigration into the area. Some incoming Americans brought large amounts of capital with them for the purpose of financing sugar plantations, which required substantial capital outlays for mills, levees, and slaves. The majority of American immigrants, however, were ambitious men who saw an opportunity to advance themselves through the newly developing sugar industry. Land along the Teche was inexpensive; undeveloped land could be bought for as little as $\$ 4.00$ to $\$ 10.00$ per arpent (Sitterson 1953:24).

The influx of Americans largely was responsible for the shift to sugar staple crop cultivation along the Teche. Because both stuck raising and cotton cultivation were profitable, there was no economic imperative that forced the Creole and Acadia planters on Bayou Teche to shift to sugar cultivation. Moreover, the capital outlays to outfit a sugar plantation far exceeded those required for a cotton plantation. According to Schmitz (1977:108), by 1860 the average investment in sugar producing machinery on a Louisiana plantation was $\$ 9,900.00$. This contrasted sharply with the $\$ 830.00$ average investment for equipment on a cotton plantation. Even in the early antebellum years, when sugar manufacturers used horse-drawn sugar houses, rather than steam-powered houses, the investment in converting cane to crystal was high. Because of the relatively low expense of cotton production, it could be cultivated both by owners of large plantations and by yeoman farmers who worked their own land (Taylor 1976:65). However, the total investment in a sugar plantation could exceed $\$ 200,000.00$ (Taylor 1976:65), making sugar cultivation beyond the reach of small farmers. The attractiveness of cane cultivation derived from around a nine percent return on the planters' investment, while the return on a cotton plantation of 1500 acres was about seven percent (Taylor 1976:67).

Incoming Americans encouraged the shift to cane cultivation both by buying lands along the 
Teche, which they then converted to sugar estates, and by demonstrating to the wealthier resident Creoles and Acadians the advantages of sugar agriculture. Additional encouragement was found in the protection of domestic sugar under the tariffs of 1816 and 1828. Finally, between 1818 and 1830 cotton prices fell sharply, which further induced planters to consider sugar cultivation. Because sugar agriculture was most efficient on a large scale, it only was a question of time before livestock pasture lands were converted to cane fields. Similarly, small farms along the Teche were purchased and consolidated into sugar estates. By 1828, there were 99 sugar plantations in St. Mary, St. Martin, and Lafayette Parishes (which included present day Iberia and Vermilion Parishes). The following year, that number increased to 162 (Sitterson 1953:25). By 1835 , the vast majority of plantations along Bayou Teche were engaged in sugar production, although small amounts of indigo still were produced as late as the early 1830s (De Grummond 1949:21).

Settlement within the Attakapas region proceeded rapidly. The soil was rich, and inland waterways such as Bayou Teche provided a convenient means of transportation. Describing the region to Americans unfamiliar with Louisiana, William Darby wrote:

\begin{abstract}
Nature has been more than usually beneficient to the Attacapas, the fertility of the land is excessive, and the facility of navigation is seldom exceeded. It demands comparatively but little from the hand of art, to complete the benefits of this favored spot (Darby 1816:73).
\end{abstract}

Since lands were not difficult to clear, farms could be transformed easily into plantations, and cotton farming soon gave way to sugar cane cultivation. In addition, the region abounded with valuable timber and other natural resources.

Before 1850 , the majority of sugar planters were busy expanding and developing their holdings. Using borrowed capital, they purchased new lands and they acquired plantations, slaves, and equipment (Sitterson 1953:70). By the 1850s, the developmental phase had ended. The sugar plantation regime had become firmly established, dominating the economy of both St. Mary and St. Martin Parishes.
To make a sugar crop, the seed cane was planted in furrows, end to end, and lightly covered with soil:

as soon as the cane comes up generally they begin to work it with the Hows [hoes] until it gets about a foot in height they commence plowing it and generally plow it about twice and how it afterwards until it gets to about two feet in height then they let it stand until it is fit to cut if the land is good and the Season favorable it will often bear a second cutting and will produce a Saving crop the second time one hand on an average is allowed twenty three arpents or acres of Sugar cane to tend it (Gibson 1979:106; sic throughout).

In October, when the cane grew tall enough for harvest, fieldhands cut the stalks:

\begin{abstract}
The slaves who did the cutting used special cane knives, basically machetes with a hook on the end. Cane cutters are a rare sight today, but men and women skilled at this work developed a rhythm and economy of motion that might aptly be compared with a ballet. Seemingly never halting the movement of the knife, they lopped off the tip of the cane, stripped the blades away, and cut the stalk down as close to the ground as possible, knowing well that the last joint held the most sugar. Other workers, practically all of them slaves, gathered the cane and loaded it on the ubiquitous two-wheeled carts; they then hauled it to the sugarhouse (Wall et al. 1984:157).
\end{abstract}

During the antebellum era, sugar planters did not utilize centrally located mills or refineries. Every sugar cane plantation had to be both farm and factory, necessitating a sugar house for each plantation, regardless of its size (Roland 1957:3). Sugar cane cultivation and sugar production favored larger planters who could afford to maintain a sugarhouse. At the sugar house, the cane was processed into brown sugar, and the molasses was drawn off. Hogsheads then were filled with wet sugar. To market a sugar crop, a planter had several options. He could ship it down the Teche for sale in New Orleans; "he could sell it from his plantation wharf to the various sugar merchants assigned to buy for northern markets;" or, he could sell it to a speculator (Broussard and Broussard 1955:11; Wall et al. 1984:157-58). 
Bayou Teche was the most significant waterway in the lower Attakapas in terms of sugar cultivation. Before the Civil War, the average price of land along Bayou Teche had risen to $\$ 16.00$ per arpent of improved land, while some parcels sold for as much as $\$ 30.00$ to $\$ 40.00$ per arpent. Unimproved first quality lands often sold for $\$ 10.00$ per arpent. Land of lesser quality, as well as government lands, could be acquired for prices ranging from $\$ 2.00$ to $\$ 10.00$ per arpent inland (Gibson 1979:107).

The wealth of the local planters increased rapidly as a result of sugar agriculture. With improved transportation, both necessity and luxury goods became more readily available. The acquisition of imported goods helped to transform Bayou Teche from the frontier region described by Landreth and Cathcart in 1819, into a comfortable, visibly prosperous area. Planters abandoned their former adobe dwellings, and built larger plantation houses. Even these newer houses, though, were generally less than pretentious. Many of the plantation great houses were simple, raised cottages.

Other structures usually found on residential plantations included a kitchen, offices, garconnieres, pigeonniers, and carriage houses. The overseer had his own house, and the slaves lived in spartan one or two-room cabins set in rows. Often there was a separate kitchen for the slaves' use (Sitterson 1953:92). Barns, stables, storage sheds, and privies also were found on most sugar plantations. The major industrial structure and the major investment on a sugar plantation was the sugar house. During the early nineteenth century, these structures generally were made of wood. By 1850, however, many of the sugar houses were constructed of brick. Some of the former gin houses situated along the Teche had been converted into sugar mills (Richardson 1886). Sugar houses generally measured $30.5-45.7 \mathrm{~m}(100-150 \mathrm{ft})$ in length and $15.2 \mathrm{~m}(50 \mathrm{ft}$ ) in width (Sitterson 1953:137). During the earlier years of the industry horses powered the mills, by the eve of the Civil War, most sugar works in St. Mary Parish had converted to steam power. The mill pressed juice from the cane. The mill normally was housed within the sugar house, but some detached structures also existed on Louisiana plantations (Goodwin et. al. 1985:43). The most common method of cane juice clarification and evaporation was the open pan method. This method used a set of four kettles of decreasing size called, respectively, the grande, the flambeau, the syrup, and the battery. The kettles were set into a masonry structure usually about $9.1 \mathrm{~m}(30 \mathrm{ft})$

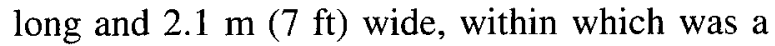
furnace and a flue for conveying heat to the kettles. The furnace was located under the battery, and an ash pit would have been located outside of the sugar house, adjacent to that structure. Both coal and wood were used to fuel the furnaces. The flue, positioned at the opposite end of the kettle set, would have turned at right angle to the set and passed to the outside of the sugar house, where it connected to the chimney (Sitterson 1953:141).

Furnishings on plantations often were simple, but usually a house contained a large number of chairs for entertaining large groups (De Grummond 1949:29-33). F. D. Richardson, the builder of Bayside Plantation, provided a description of an elaborate gathering at Nicolas Loisel's plantation (just a few miles below the proposed project area) ca. 1836. He wrote:

\begin{abstract}
The feast began in earnest with their farfamed Creole dish, not national, but state souvereign, gumbo, of African descent. I did not count the courses, they were "distinct as he bellows, yet one as the sea," and each bellow was enough to drown a common appetite (Richardson 1886).
\end{abstract}

The nascent sugar aristocracy was divided, however, into distinct Creole and American groups:

\footnotetext{
Very few of the Creoles of that day spoke English, or spoke it very imperfectly, which was no doubt the main cause of the little social intercourse there was between them and their American neighbors, planters of the same social position who settled among them (Richardson 1886).
}

The leading Creole planters along the Teche were Colonel Charles Olivier, M. DelaHoussaye, Mr. Malus, Nicholas Loisel, St. Marc Darby, Dr. Solange Sorrel (who later was murdered by his slaves), Frederic Pellerin, and Charles Pecot. American planters of similar social and economic standing included Thomas $\mathrm{H}$. Thompson, Colonel J. G. Richardson, Judge Moore, D. Bonin, J. W. Jeanerette and William 


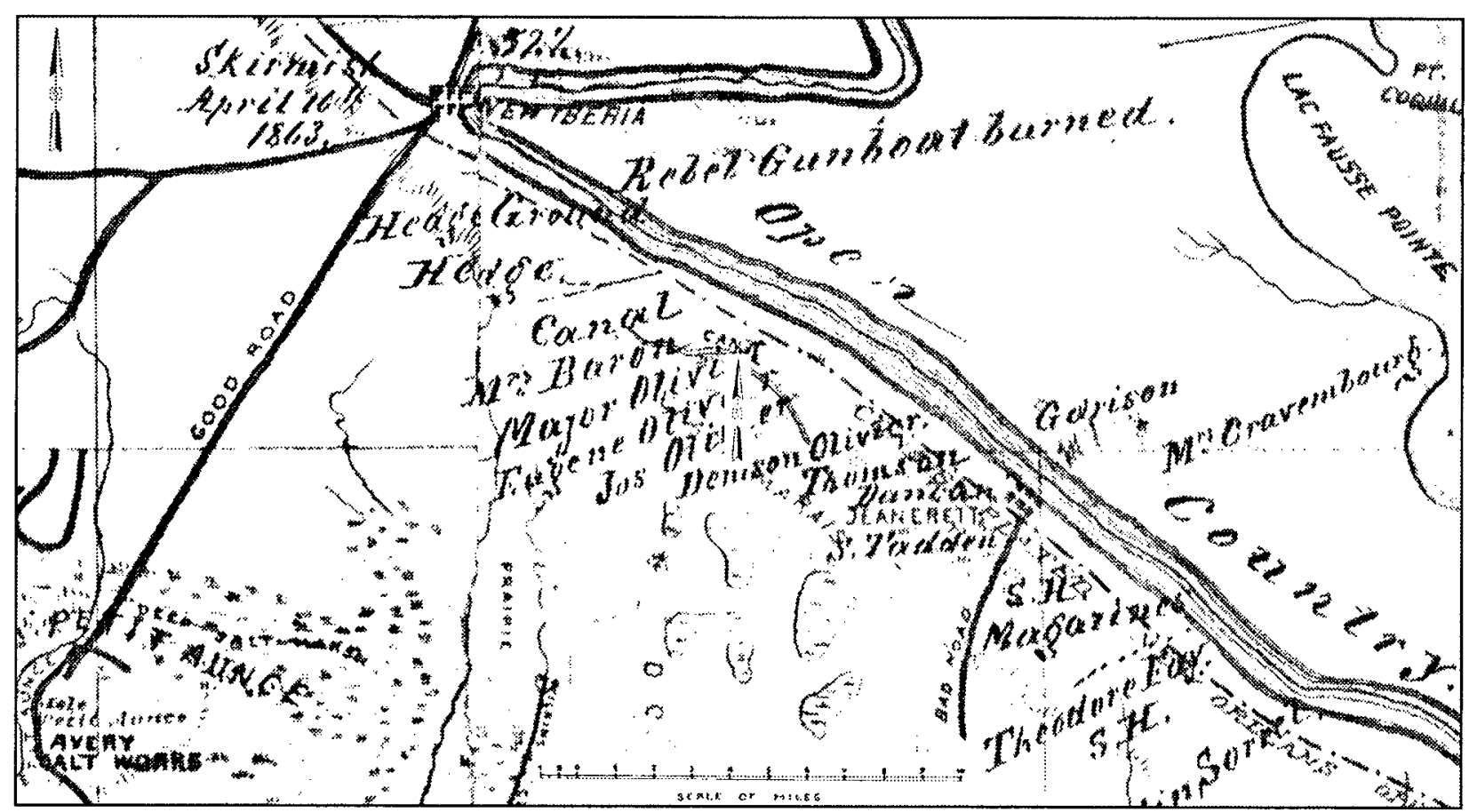

Figure 18.

[1863] Adaptation from Abbot's Department of the Gulf, Map No. 8, Atchafalaya Basin, prepared by Order of Maj. Gen. N. P. Banks. Excerpt depicts plantation owners downstream of New Iberia, as well as Petite Anse Island and Camp Bisland.

Weeks (Cayton 1881:85-87; Richardson 1886). Thus, by the late 1830 s, sugar agriculture had created a plantocracy along the banks of Bayou Teche that was similar to the society along the Mississippi River (Figure 18).

There were 613 ha $(1,515 \mathrm{ac})$ in cane cultivation in St. Mary Parish in 1824; during that year, the crop yielded 1,586 hogsheads of sugar, and it was worked by 644 slaves. One year later, 204 ha $(504 \mathrm{ac})$ were added to the total acreage planted, with a harvest of 2,254 hogsheads. By 1828 , there were 74 sugar producers in St. Mary Parish, harvesting a total crop of 4,528 hogsheads (Broussard and Broussard 1955:3; Degelos 1892:67).

Although not as prosperous as St. Mary Parish, adjacent St. Martin Parish also experienced growth in sugar agriculture during the antebellum years. In 1828, there were 19 sugar producers in St. Martin Parish, with a total sugar crop of 1,684 hogsheads. Just one year later, the parish counted 46 sugar producers; however, there was a drop in yield to 1,486 hogsheads. Although most of these St. Martin Parish planters held plantations along Bayou Teche, three men,
David Weeks, John C. Marsh, and John Hayes, began to develop Weeks and Avery Islands, two of the south Louisiana "salt islands," positioned just to the south of the proposed project area (Degelos 1892:67).

St. Mary Parish led the state in cane production during the $1850 \mathrm{~s}$. During that decade, however, two harvests (1853 and 1857) suffered from adverse weather conditions: in 1853, the parish crops were affected by the continuing consequences of a severe freeze and snowfall, and a few years later, an August 1856 hurricane disrupted parish sugar production for 1857 . St. Mary Parish rebounded the following season, though, when planters produced 44,634 hogsheads of sugar (Broussard and Broussard 1955:11; Champomier 1857:v-vii; De Grummond 1949:37, 43).

The slave population in St. Mary Parish was an indicator of the dominance of the plantation economy throughout the region. During the decade of the $1850 \mathrm{~s}$, the population of the parish grew from 13,697 inhabitants in 1850 , to 16,816 in 1860 , an increase of 3,119 people, only 85 of whom were white. The rest of the parish growth came from additional slaves; in 1850 , the slave 
population had numbered 9,850 . By 1860 , it had risen to 13,057 . The white population remained stable, numbering 3,423 in 1850 and 3,508 in 1860. Only the free black population declined during this period, from 424 in 1850 to 251 in 1860 (Broussard and Broussard 1955:4).

As a result of the increase in slave labor, and the shift in slave control under the American government, slave communities underwent dramatic changes during the antebellum period. As plantations grew in size, slave communities expanded. By early in the nineteenth century, the slave population held a significant majority in St. Mary Parish. Planters increased slave control, dispensing harsher punishments for smaller infractions. Louisiana, along with most other Southern states, passed laws prohibiting private manumissions and slave education. Fewer slaves were allowed to develop artisansal skills, and even fewer were permitted to travel freely, as deVaugine's charge "Big Louis" had done just a few years earlier.

On the eve of the Civil War, the majority of the planters in the region had converted their sugar houses from horse to steam power (De Grummond 1949:44), and harvests were measured in hogsheads. The contemporary chronicler of the sugar crop, Champomier, wrote in 1857 that "It is well known that our planters do not make hogsheads of the same size, and there is a wide margin in some of them"; nevertheless, he estimated the average hogshead contained 1,150 pounds of sugar (Champomier 1857:43).

Just before the war, the proposed project area was dedicated entirely to sugar planting. Included among the Bayou Teche properties along the upper portion of the study reach were Jonas Marsh's Marshfield Plantation owned and operated by Jonas Marsh; the Deblanc/Delacroix, Dubuclet, and François Darby sugar plantations, located just upstream from New Iberia (and collectively encompassing the Disposal Area 1, Staging Area 1, and Disposal Area 2 project items); and the St. Marc Darby Plantation, sometimes called St. Maur's Plantation (probably enclosing the Staging Area 2 project item). Below New Iberia were the Bayard property, which apparently became known as Mintmere; the Mestoyer [sic] Plantation (collectively containing the Staging Area 3 project item); and Hawthorn Plantation of S. O. Nelson (apparently located immediately below the
Staging Area 3 project item and probably containing the Disposal Area 3 project item). Toward Jeanerette were the Olivier family holdings, which included Orange Grove Plantation (apparently located just downstream of, or may have included, the Disposal Area 3 project item) (Bergerie 1962:24-47; Champomier 1844-1860; Glass 1898:18; La Tourrette 1845, 1853; unidentified surveyor ca. Civil War).

\section{Riverine Transportation}

Throughout the antebellum period, riverine transportation formed the primary means of travel throughout the Attakapas region, including the project area. The use of numerous lakes and bayous impeded development of overland routes between the district and the Mississippi River. While local traffic utilized a public road that followed the west bank of Bayou Teche (Conrad 1979), travel and commerce over long distances was dependent on the successful navigation of Bayou Teche.

During the early nineteenth century, commerce in the Attakapas region was focused on the production of beef, vegetable, and agricultural products, and on the distribution of these goods to New Orleans. Many of these products required rapid transportation to prevent spoilage during shipment. In response to this transportation need, commercial vessel routes between the district and New Orleans, via the Teche and the Mississippi River, were established beginning in the late 1810s. These routes initially extended from Bayou Teche, through the Atchafalaya Basin and Bayou Plaquemine, to the Mississippi River. Various steamers, including the 217-ton cattleboat, the Volcano, and the 48-ton Louisville, were used to transport agricultural commodities produced along the Teche. By the 1840 s and 1850 s, such steamboats as the St. Helena, the Kentucky, the St. Mary, the Judge, the McLean, and the Billow traveled frequently along the Teche (Goodwin et al. 1985). However, low water levels generally made them impassible during the summer and fall months. A few vessels, such as the Teche, transported goods to New Orleans via the Gulf of Mexico, although numerous snags along lower Bayou Teche hindered navigation to the Gulf, resulting in high operational costs (Brasseaux 1979).

Despite these problems, as early as the Cathcart and Landreth expedition in 1819, the 
schooner James Lawrence made regular trips from New Orleans, along Bayou Teche, as far upstream as New Iberia. By 1821, the Attakapas Steam Boat Company had constructed the 295ton steamer, the Teche, and monopolized steam navigation on the bayou. However, high operating expenses and frequent snags led to that firm's failure in 1825 (Goodwin et al. 1985; Conrad 1979:211). Increased agricultural production required improved transportation, however, and in 1825,40 planters donated $\$ 1,200.00$ each to clear Bayou Teche for steamboat navigation between St. Martinville and New Iberia, thereby extending the route further upstream, as well as to keep the lower Teche route navigable (Goodwin et. al 1985:41).

The completion of the New Orleans, Opelousas, and Great Western Railroad Company spurred riverine commerce and travel along Bayou Teche in 1857. The railroad ran between Algiers, situated across the Mississippi River from New Orleans, and Brashear City (modern-day Morgan City), located at the mouth of the Atchafalaya River. This $129 \mathrm{~km}$ (80 mi) long rail link with New Orleans permitted rapid, reliable transportation of passengers and cargo from the plantations along the Teche to New Orleans on a yearround basis. This resulted in a considerable increase in the volume of cargo carried by steamers along Bayou Teche to the railroad depot in Brashear City. The rail link proved so successful, that during the same year, 45 prominent St. Mary Parish planters and merchants petitioned the general assembly to erect a dam across Bayou Plaquemine to inhibit flooding of the new tracks (Brasseaux 1979; Millet 1983).

\section{Establishment of the Avery Island Salt Mine}

Ironically, other than sugar, the only major commodity in this region was salt. Avery Island is part of southern Louisiana's "Five Islands," a chain of coastal salt domes roughly paralleling the west bank of Bayou Teche, some 13 to 19 $\mathrm{km}$ ( 8 to $12 \mathrm{mi}$ ) below the waterway. In descending order, these land formations are known today as Jefferson Island, Avery Island, Weeks Island, Côte Blanche, and Belle Isle. The upper three "islands" are located in present-day Iberia Parish; the southeastern two can be found in St. Mary Parish. Avery Island was the only one of the five "islands" to commercially produce salt during the nineteenth century (Chisholm 1952; Hansen 1971:8-9). Salt was a crucial preservative used throughout the eighteenth and nineteenth centuries, to prepare meats and fish. With no means of refrigeration to extend the viability of these staple foods, curing meat with salt was the only option. As such, it was a very desirable and valuable commodity.

During the antebellum period, Avery Island was known as Petite Anse Island, and it probably was named for Bayou Petite Anse ("Little Creek"), which ran southwestward to Vermilion Bay. It should be noted that Petite Anse Island was called various names, including Thomas Island, Salt Island, and Marsh, or Marsh's, Island, until it finally became known commonly as Avery Island. Early settlers on the island included John Hayes, Jesse McCaul, and John Craig Marsh, all of whom arrived there during the Spanish colonial period. Not only was Marsh the man who made the first serious efforts at salt extraction, but he also was the progenitor of the family that remains associated with Avery Island to the present day (Chisholm 1952:175; Hansen 1971:428; Lonn 1933:32).

Brine springs had been discovered on Petite Anse Island during the previous century, ca. 1790 - 1791, by early settler John Hayes (Native American use of the springs apparently ended prior to historic discovery). Salt production first began at Petit Anse strictly as a household operation, i.e., buckets of briny water were boiled down for the salt residue. During the War of 1812, property holder John Marsh constructed a salt extraction plant near the springs (for U.S. military supply); however, it never was exploited fully and was shut down shortly thereafter. The outbreak of the Civil War motivated subsequent landowner Judge Daniel D. Avery (son-in-law of John Marsh) to revive the salt operation to help support the Confederate cause (Chisholm 1952:176-179; Lonn 1933:32-33; Meek and Gulledge 1986:4; Raphael 1976:54$55)$.

\section{The Civil War}

In late 1862, war descended on the Bayou Teche region, bringing disruption and death to families, turmoil to fields, and devastation to homes, crops, sugar houses, plantation outbuildings, bridges, and vessels. The Teche Campaign, 
undertaken during the spring of 1863, was planned as part of the Federal strategy to split the Confederacy by gaining control of the lower Mississippi River. Union command of the western tributaries of the Mississippi River was considered necessary to the success of this objective. In addition, Federal occupation of the Teche country would help terminate the southwestern Louisiana supply line connecting Texas and the Attakapas region to Confederate forces east of the Mississippi River. Due to its proximity to the Avery Salt Works on Petite Anse Island, New Iberia was important strategically to both Confederate and Union forces. The Confederate gunboat Stevens (formerly called the Hart) was burned and scuttled $3 \mathrm{~km}$ ( $2 \mathrm{mi}$ ) below New Iberia (just by Disposal Area 3 and Staging Area 3) in order to obstruct Union passage up Bayou Teche; however, both the town and the salt mine fell to Federal troops during April of 1863, cutting off an important supply of salt, and therefore meat, to the Confederacy (Davis 1971:256-257; Raphael 1976; Winters 1963).

\section{The Battle of Bisland or Bethel's Place}

The Confederates had established a position known as Camp Bisland on Bayou Teche, downstream of the proposed project area, just outside of Franklin, Louisiana. The camp was located on a plantation owned by Dr. Thomas Bisland and on Ricohoc Plantation, owned by William T. Palfrey. When a Federal force led by General Nathaniel Banks began an invasion up the Teche, the Confederates and Federals clashed primarily on the Bethel plantations.

According to a military historian, the Confederates had built:

between Pattersonville and Centreville ... a a line of simple breastworks across the narrow necks of dry land which extended on both sides of the Teche. Impenetrable cypress swamps and canebrakes flanked the short line on either extremity, and a strong redoubt served each side as an observation and command post. Along the Teche, which ran through the right center of the Confederate line, fields of knee-high sugar cane, laced with deep drainage ditches, stretched on either side back to the swamps (Winters 1963:223-224).
The battle, which took place on April 13, 1862, consisted of a powerful artillery duel combined with short forward infantry movements. When heavy fog lifted at 10 a.m., Federal infantry advanced on Confederate positions along both banks of the bayou.

On the right bank, the $75^{\text {th }}$ New York and the $114^{\text {th }}$ New York infantries moved to the far left in an attempt to flank the Confederate right. The New York troops twice tried to break through the Confederate lines but each time they were held in check. At 3 p.m., the Confederates positioned along the right bank began a counterattack. Startling the enemy with rebel yells, General H. H. Sibley and the Texas Brigade attempted a flanking movement through the canebrake. The Texans fought the New Yorkers in the soft swampland. Unable to see each other or strike directly, each side fired in the general direction of its enemy, without producing significant results. By nightfall, the Federals were preparing for a general assault along the entire Confederate works along the right bank. Nevertheless, for strategic reasons, the Confederates that evening withdrew quietly and effectively from all their positions before Camp Bisland, on both the right and left banks. The Federals realized, too late to pursue, that the enemy had abandoned the breastworks (Winters 1963:223-226).

\section{Military Engagements Along the Bayou Teche During the Civil War}

Because New Orleans was the south's largest city, and the controlling port of the Mississippi River, it, and regions that supplied it, became targets of Union assault. New Orleans was occupied by Federal troops in April, 1862.

In the Fall of 1862, Union forces attacked Confederate troop concentrations in western Louisiana. Brashear City (Morgan City) was occupied in early November, 1862, and it became the base of operations for Federal forces in the Bayou Teche region. Franklin was used as the staging area for the three Union offensives (April 1863, October 1863, and March 1984).

In early 1863 , Federal troops, under General Grover, were transported by steamers up Grand Lake to a landing near Irish Bend. They were instructed to march to Bayou Teche, seize the 
plantation bridges across the bayou and then advance to Franklin. One of Grover's vessel, the Arizona, ran aground at Cypress Pass (Raphael 1975:103). The Union drive at Irish Bend had been arrested, and Rebel troops withdrew toward Franklin while the Confederate gunboat Diana provided covering fire. The withdrawal of the Confederate Army from Irish Bend in April, 1863, resulted in the loss of the remaining Confederate vessels on Bayou Teche: the gunboat Diana was blown up along with eight other vessels that were burned or scuttled (Raphael 1975:117) (Figure 19).

Military engagements during the Civil War in the Bayou country, after the fall of New Orleans in May 1862, left the banks and channel of the Teche strewn with wrecks. The consequences of war left the

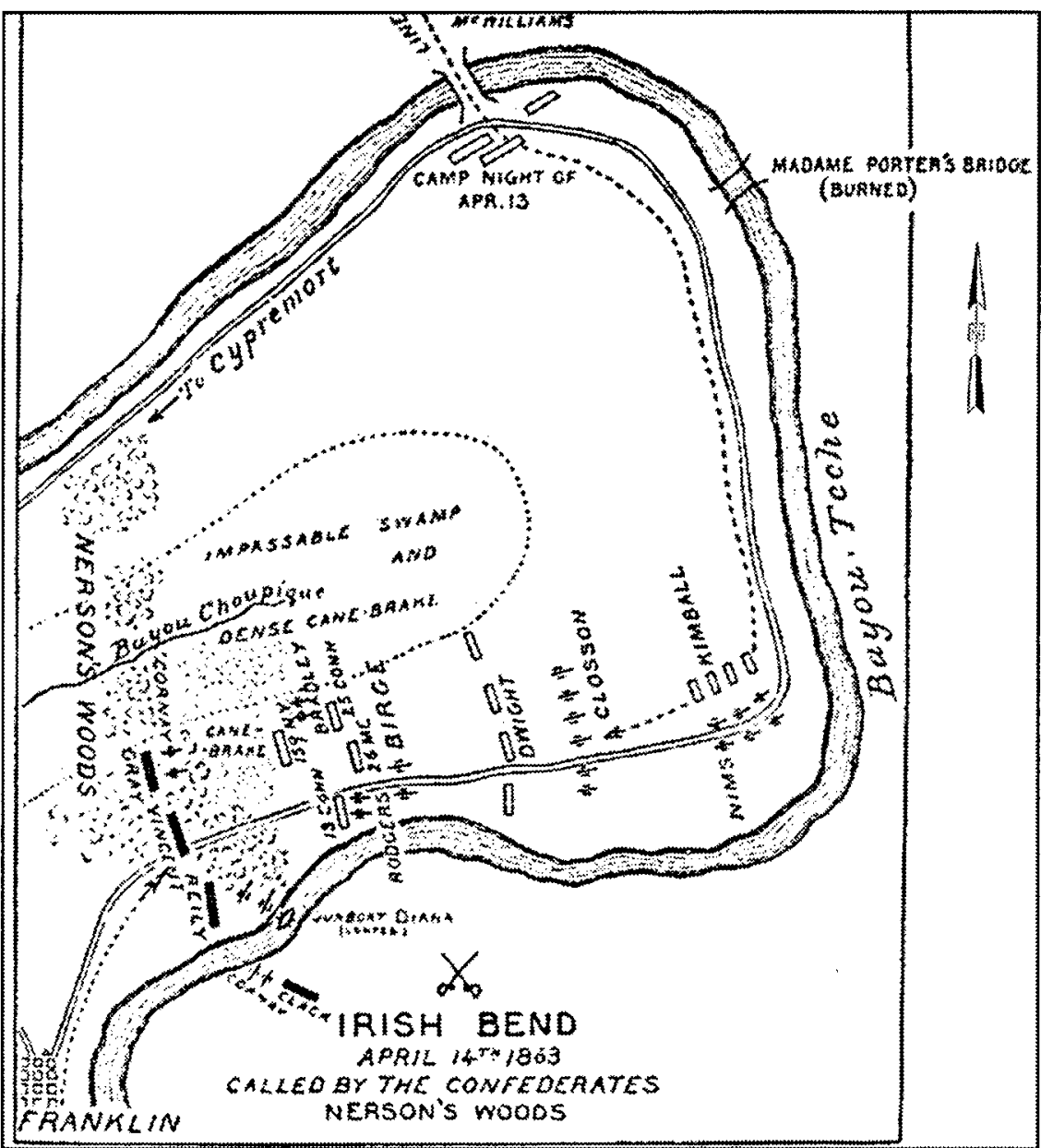

Figure 19. Excerpt from Irwin's 1893 map Irish Bend, in Raphael's The Battle in the Bayou Country. Teche hampered with obstructions that impeded trade,

transportation, and communication through the main water artery throughout the region. After the war, the U.S. Army Corps of Engineers was assigned the task of reopening Bayou Teche (Wilby 1991:1).

The Teche Campaign and the Federal Destruction of the Avery Salt Works

The Teche Campaign had a significant effect on the area around New Iberia. Several skirmishes took place just outside the town limits, as both sides scrambled for additional rations and provisions. The city housed a packing plant, which cured meat for the Confederate troops. In addition, Governor Thomas Moore opened a workshop where workers tanned leather, made harnesses and built cartridges and wagons. Confederate General Taylor established Camp Pratt in the town, and he immediately enforced the
Conscription Act, drafting all men from 18 to 35 . The stronghold did not last long. New Iberia fell to the Federals in early April, 1863. They placed over 150 residents under arrest, holding them in the Episcopal Church before moving them to Franklin (Figure 20). Supposedly, the scuff marks can still be seen on the old pews from the Union horse hooves. Union troops used the town as their headquarters for the campaign to destroy the Avery Salt Works (Bergerie 1962:20-21).

Salt was of primary importance to the Confederacy; although used as a seasoning and a chemical agent, it also was vital for preserving meat, maintaining healthy livestock, and tanning leather. With the fall of New Orleans and the coastal blockade of Louisiana, the South lost its chief port for salt shipped from its major supplier, England (Lonn 1933:13-18; Raphael 


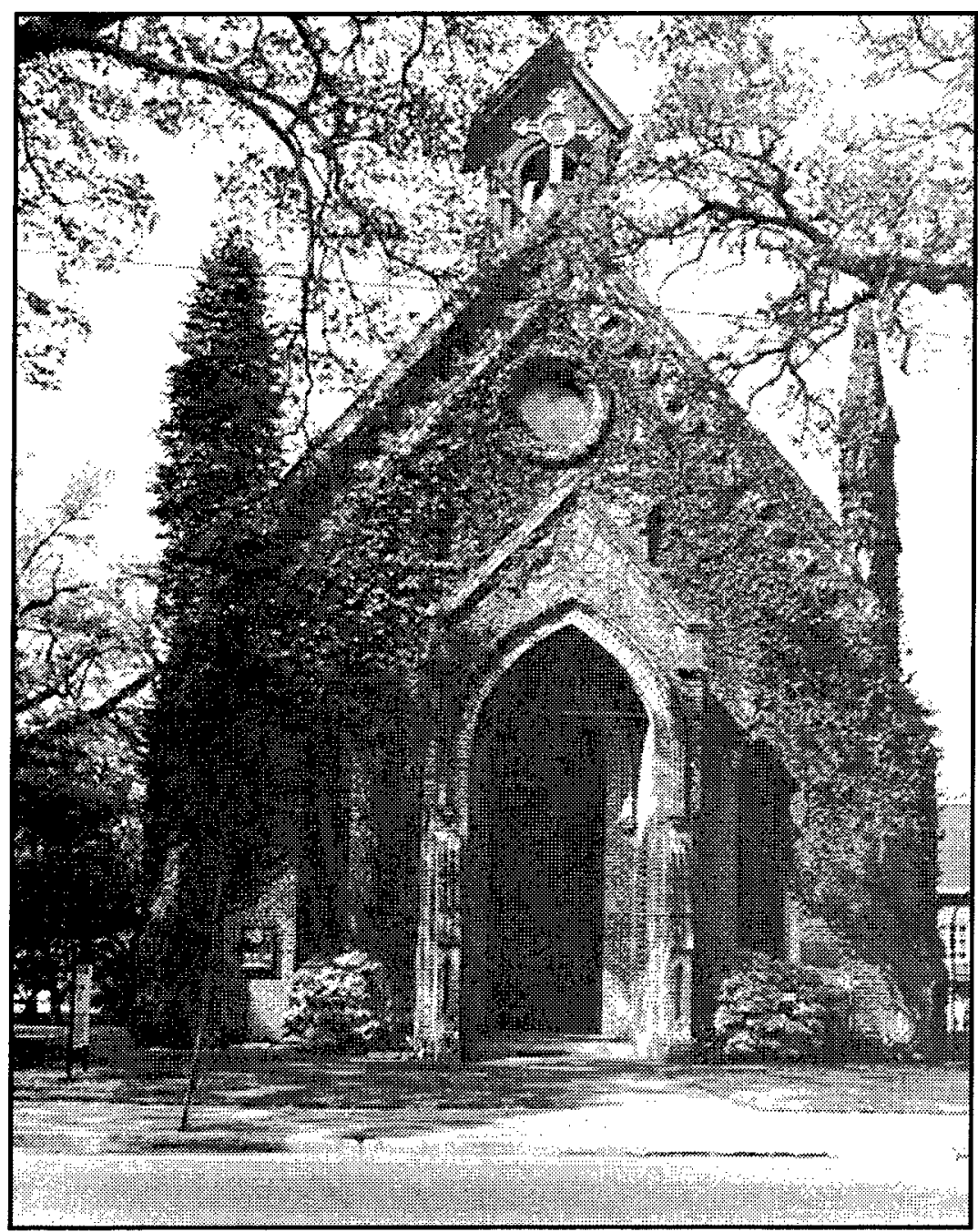

Figure 20. Modern picture of the Episcopal Church of the Epiphany, which Union troops used as a prison during the Federal occupation of New Iberia. From the Louisiana National Register of Historic Places, www.crt.state.la.us.

with various Southern states to provide them with salt. The Avery Salt Works produced an estimated 22,000,000 pounds of salt for the Confederacy between May of 1862 and mid-April of 1863 (Chisholm 1952:176-179; Lonn 1933:32-33; Meek and Gulledge 1986:4; Raphael 1976:54-55; Winters 1963:232).

A Confederate report dated November 9, 1862, noted that defensive measures should be taken regarding "the rich district bordering on the Teche, including the salt mines on Marsh Island, of incalculable value to the Confederacy" (U.S. Secretary of War [OR] 1886:15:175). The Federal command soon realized the importance of the Avery Salt Works to the Confederacy and it set about employing measures, first, to stop the salt shipments and, second, to end the salt-processing operations altogether. Although the Union blockade initially was a hindrance to salt transports from Petite Anse Island, Confederate forces quickly found a "back door" to their strongholds. From Bayou Teche, the salt shipments were conveyed to the Atchafalaya River, then over land to Alexandria and to the Red River, where they were loaded on steamboats

1976:54). Southerners became so desperate for a meat preservative that "They were collecting salt by going into smokehouses and taking the drippings from the sides of pig and beef, using the dirt that absorbed those drippings and mixing it with water to put on the meat" (Schweid 1980:60).

The outbreak of the Civil War motivated Petite Anse Island landowner Judge Daniel D. Avery to revive the salt operation to support the Confederates. On May 4, 1862, slaves on the Avery plantation discovered an enormous vein of rock salt, the first such discovery in the continental United States. Judge Avery accelerated the development of the mine, and he contracted for transport to the Mississippi River and on to Port Hudson, Vicksburg, and other Southernheld ports. In anticipation of a Union attack, two infantry companies and an artillery unit were placed both on Petite Anse Island and on Bayou Teche (Chisholm 1952:179; Hansen 1971:428; Lonn 1933:34; Raphael 1976:55-56).

In mid-November 1862, General Benjamin Butler, in charge of Federal troops in Louisiana, ordered the destruction of the Avery Salt Works. As a result, two Union gunboats and a transport steamer approached Petite Anse Island from the Gulf of Mexico, through Vermilion Bay, and up Bayou Petite Anse (Figure 21). As soon as news of the Federal naval movement was reported, 


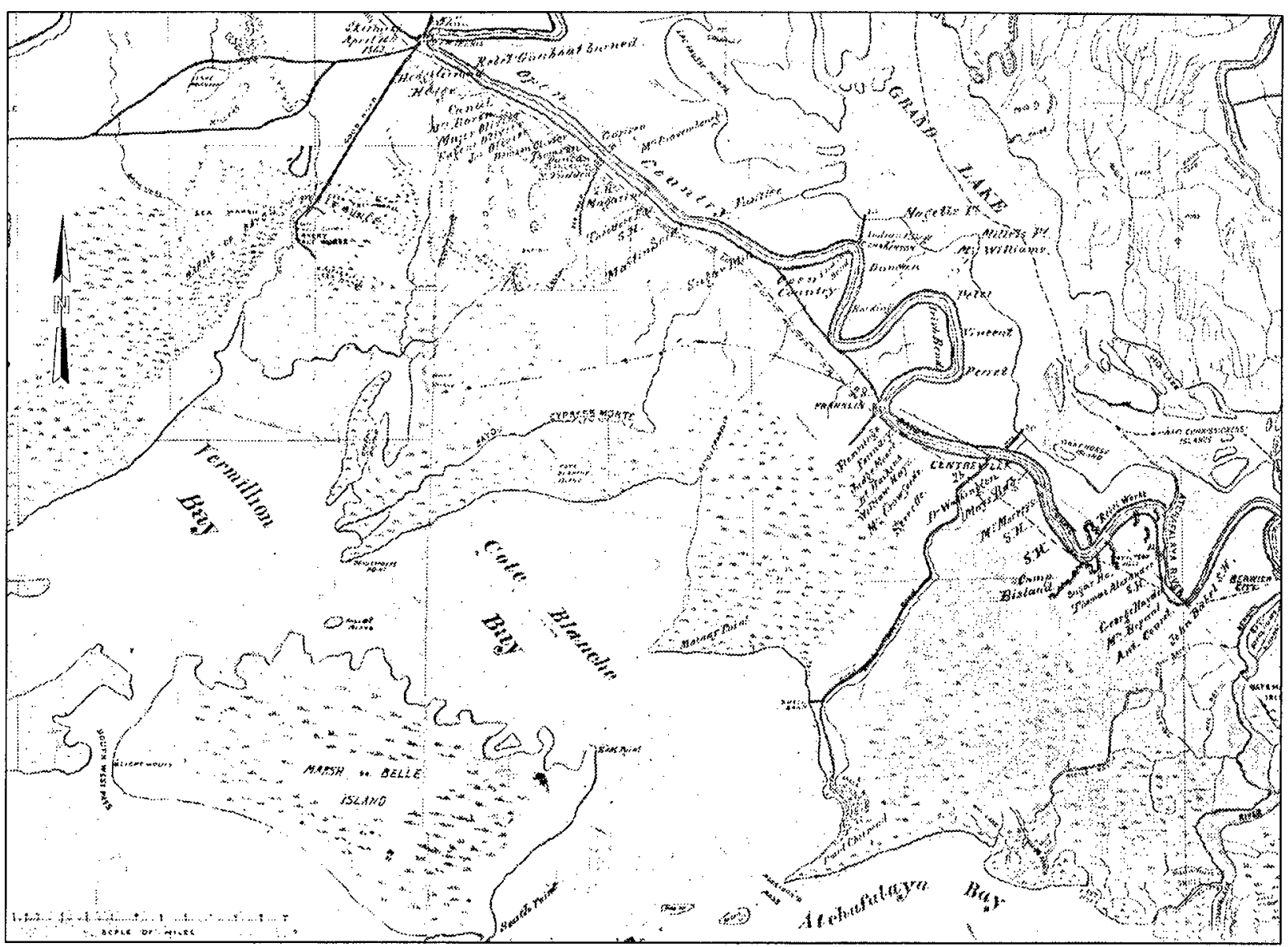

Figure 21. Adaptation from Abbot's Department of the Gulf, Map No. 8, Atchafalaya Basin, Prepared by order of Maj. Gen. N. P. Banks. Excerpt depicts location of Petite Anse Island and Camp Bisland.

Confederate forces were dispatched from Camp Bisland on Bayou Teche to intercept the Federals. On November 21, Captain T. A. Faries' and his Louisiana Artillery engaged the enemy at the lower end of Petite Anse Island, within sight (but out of howitzer range) of the gunboats positioned at the mouth of the bayou. The Federal forces retreated to their vessels and returned via their previous route. While the wind had aided their approach to Petite Anse Island, it worked against them during their retreat, creating a low tide that grounded the three boats for 15 to 20 days (Hansen 1971:428; OR 1886:15:1088; Raphael 1976:60-61).

Federal forces at last succeeded in destroying the Avery Salt Works on April 18, 1863. Colonel William K. Kimball arrived early that morning with his New England troops to discover that the Confederates had abandoned the facility (Raphael 1976:137; Winters 1963:232). In his report, Colonel Kimball described the scene as follows:

I . . . found the enemy had evacuated his works and removed his guns. I proceeded at once to destroy all the buildings, 18 in number, connected with the saltworks, steamengines, windlasses, boilers, mining implements, and machinery of all kinds; also 600 barrels of salt, ready for shipment. About one ton of powder and one ton of nails, found in the magazine, I caused to be transported to New Iberia . . . . The bomb-proof magazine connected with the fortification I caused to be blown up and the works destroyed, so far as they could be with the means at my command (OR 1886:15:382).

As the structures went up in flames, the Federals flooded the salt mine and ruined the Avery sugar plantation and grounds (Meek and Gulledge 
1986:4; Schweid 1980:60). Following the destruction of the Avery Salt Works, the vicinity of the current project area remained relatively quiet through the end of the Civil War.

\section{Commerce Along Bayou Teche}

The towns of New Iberia, Jeanerette, and Franklin were the principal merchant centers on Bayou Teche, which handled all commerce in the area, in part related to the plantations along the banks. In a discussion pertaining to the commercial value of the Teche, Major Stickney wrote:

\begin{abstract}
The commerce of the Teche is considerable, and is probably greater than that of any stream of the same length in Louisiana. The lands bordering the bayou are very rich and are all under cultivation, principally in sugar cane. It may be said to be the center of the sugar industry of the State. Cotton, cattle, hides, wool, moss, lumber, \&c., are also produced in quantities. The trade supports a line of steamers which make regular trips to New Orleans about three times in two weeks, besides steamers which make daily trips to Morgan City and other small steamers in local trade (ARCE 1884:1273)
\end{abstract}

In $1899,273,000$ tons of cargo were carried to and from market along the Teche. By 1909 shipments exported and received totaled 999,125 tons. The largest item of commerce were logs which made up three-quarters of the total shipments. By 1912, a boat and barge line, the Plaquemine route, already was established between New Iberia and New Orleans, which shipped cotton, cottonseed products, rice, sugar, sugar cane, cord wood, brick, machinery, shingles, potatoes, crossties, and molasses from points produced along the Teche. As stated previously, there were numerous sawmills operating along the Teche, as well as sugar plantations and sugar factories. Almost the entire tonnage of sugar being grown along the banks of the Teche was cultivated within $1.6 \mathrm{~km}(1.0 \mathrm{mi})$ of the bayou. Goods received from outside of the area included machinery, fertilizers, cooperage, coal, fuel oil, cane, logs, lime, cement, gravel, sand, corn, oats, ground feed, and brick (US Documents 1913:6-8,12).

At the turn of the century, the commerce of the Teche was transported principally along the
$87 \mathrm{~km}$ (54 mi) below New Iberia, primarily by stern-wheel steamboats and barges. In 1909, the number was 32 steamboats and 89 barges. Other vessels included gasoline boats that carried small cargoes of oysters, fish, and the like that made many short term jaunts (US Documents 1913:12).

Commercial activity along Bayou Teche before the Civil War was dominated by plantation agriculture and by bayou traffic and trade. Franklin, situated a few miles south of the proposed project corridor, became a major port of sugar export as shipping along Bayou Teche took on major economic importance. The town also served as a distribution center for goods entering the region. From 1847 to 1853 sugar shipments from Franklin increased three-fold and molasses five-fold. New York, Richmond, and Baltimore became the three top importers of goods originating from St. Mary Parish (De Grummond 1949:53-54).

Significant increases in trade, brought in by ship, occurred during the early 1850 s. A total of 71 domestic and 9 foreign vessels landed in Franklin in 1847. Approximately five years later, 24 foreign and 98 domestic ships imported goods into Franklin. Steamboat navigation between Franklin and New Orleans, however, frequently was troublesome and irregular, due to problems encountered by the vessels during low water, currents that were too swift, or floods (Thorpe 1853:766). Franklin continued to grow during the final decade before the Civil War, which was a boom time for the region.

\section{Surveying Bayou Teche}

The importance of Bayou Teche had been realized in 1811, when a Congressional document summarized the Teche as "understood to afford the greatest depth of water of any harbor near, and west of the western extremity of the swamp, or Delta, of the Mississippi" (U.S. Congress 1811). Since then, Bayou Teche has been the subject of numerous pieces of legislation providing for survey, assessment, clearing, and maintenance of the channel. The first piece of legislation, provided under the Rivers and Harbors Act of March 2, 1829, provided authorization for a study to examine the feasibility of improving and shortening navigation of the channel. Subsequent legislation in May 1870 approved a 
survey assessing the cost of removing obstructions to navigation within the Teche (Athens and Saltus 1991) (Figure 22).

This assessment was conducted under the direction of Major C. W. Howell of the United States Army Corps. In a letter by Captain C.W. Howell of the U.S. Army Corps, dated January 22, 1870, and addressed to his superior Brigadier General A.A. Humphreys, Howell mentions a printed sketch in existence in Louisiana (possibly the one produced in 1868 by Captain E.B. Trinidad) that showed the location of obstructions in Bayou Teche, with explanatory notes. The sketch was being used in order to argue for appropriations from the State of Louisiana, which was in session at that time, to be used for improvements to the Teche. Howell also quoted a couple of eye-witnesses to the condition of navigability of the Teche. Their testimonies were contradictory as to the severity of obstructions found there. Howell, therefore, decided that a survey was needed to ascertain the true condition of obstructions in the Bayou Teche (U.S. Army Corps of Engineers RG77, Entry H720, January 29, 1870).

Mr. W.D. Duke, a civil

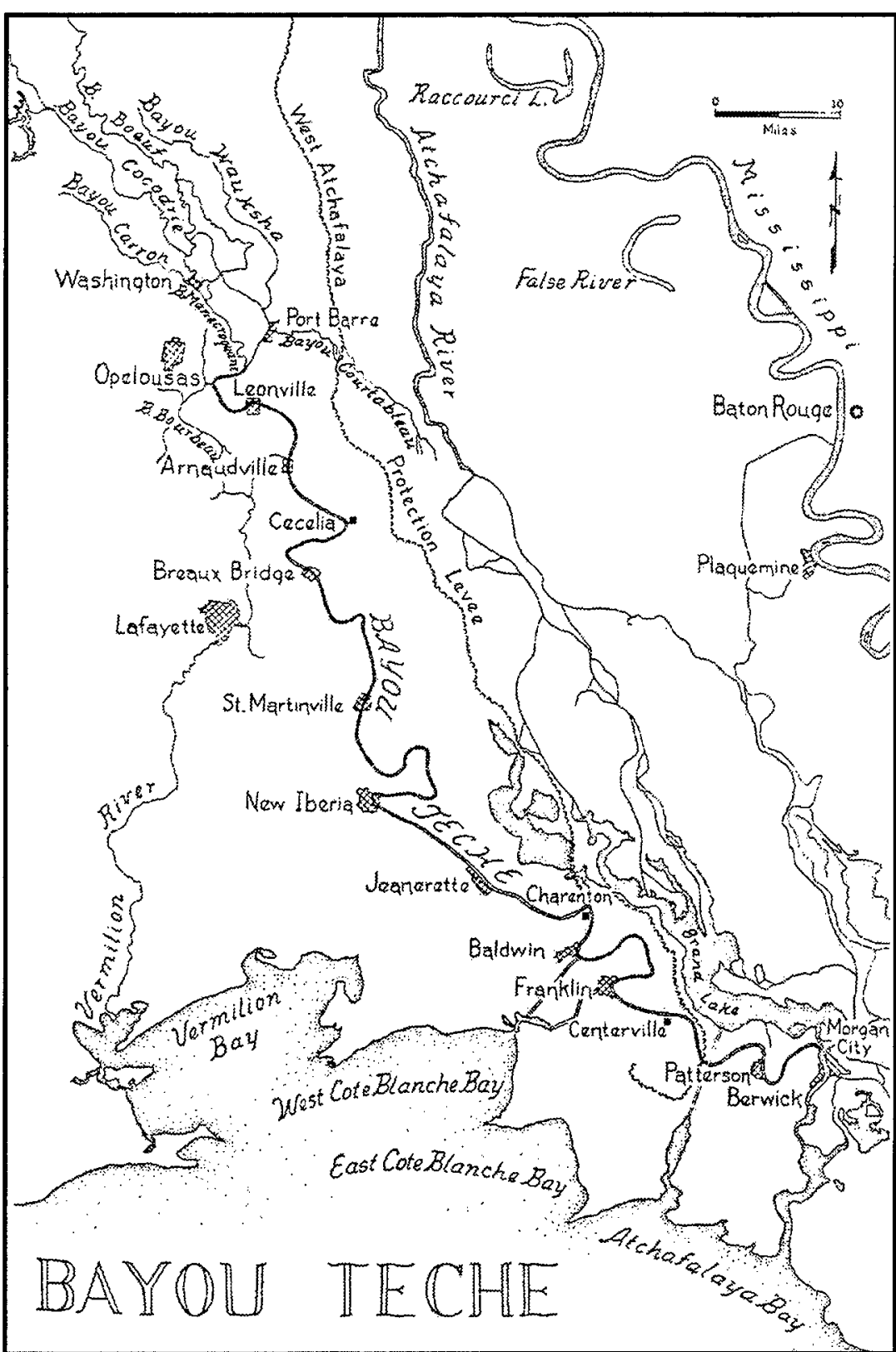

Figure 22.

$$
\text { Davis's The Rivers and Bayous of Louisiana. }
$$
engineer from St. Martinsville, and two assistants completed this assessment. During survey, the field party identified two classes of obstructions: (1) obstructions located in the bed of the bayou, including wrecks, snags, piles, and sunken logs and, (2) obstructions located on the banks of the bayou, including overhanging trees, projecting logs, and overhanging undergrowth (ARCE 1870:348).

Howell instructed his field parties to keep accurate records regarding the locations of ob-

structions. Obstructions were referenced by plantation boundaries; descriptions were provided for:

Wrecks: Dimensions, condition, how built, date of sinking, amount of machinery, (if any,) in what depth of water, how deep in mud or sand, how high above water, how much ought to be removed, what method of removal 
will probably be cheapest and most effective.

Snags and piles: Dimensions, stability, in or out of channel.

Bridges: How built, dimensions, width and arrangement of draw, position of draw with respect to channel and current.

Overhanging trees: Size, if can be felled on shore or into stream.

Torpedoes: If any, nature and location.

Bars: Length, depth, nature and location (ARCE 1870:351).

Duke's notes were used to produce a map of lower Bayou Teche documenting the distribution of the various obstructions from the mouth of Bayou Teche to approximately River Mile 75.5.

The 34 survey maps produced by Duke are remarkable for their detailed inclusion of natural and cultural features along $121 \mathrm{~km}(75 \mathrm{mi})$ of the Teche (Figure 23). The terrestrial portion depicts villages or towns along both sides of the bayou as well as the names of all buildings, piers, docks, bridges, including the locations of standing trees and underbrush. The maritime portion of the graphic includes every underwater vessel, pier, snag, tree, and $\log$ in relation to the terrestrial placenames. River widths and depths also were given, along with cross-sections of the river depicting the position, angle of orientation, depth, and distance from shoreline of each identified vessel (Wilby 1991:1) (Figure 24).

Howell designated numerous wrecks within the Bayou Teche for removal, and provided a general assessment of wrecks found throughout the Teche. Howell stated:

Some of the wrecks will be difficult of removal; but little besides the hull of each remains. All are visible at low water, most of them at high water. Nearly all are much decayed and partially broken up; the few that are comparatively sound can be shattered by several small charges of powder placed under them. All are but slightly imbedded in the mud. The bayou is narrow, and all the wrecks lie within from 10 to 75 feet of one bank or the other. The slope of the bed of the bayou and the banks is favorable for dragging out these wrecks either entire or piecemeal (ARCE 1870:348).

This detailed survey of Bayou Teche allowed the U.S. Army Corps of Engineers office in New Orleans to make an accurate estimate for the work needed to be done in removing the obstructions. On July 11, 1870, Congress approved $\$ 17,500.00$ for the clearing of obstructions in Bayou Teche. A newspaper announcement signed by Captain C.W. Howell of the United States Army Engineers, dated August 12, 1870, requested bids until September 13, 1870, from interested parties who were bonded and guaranteed to do the work. The bidders had to state the manner in which they proposed to do their work and the dates for commencing and completing the work (US Corps of Engineers RG77, Entry H906, September 26, 1870).

In December 1870 , construction began on a wrecking-flat derrick, or snag-boat, the Bayou Teche and a work crew was selected. The vessel was completed and delivered at Brashear City (now called Morgan City) in February 1871 (Chief of Engineers Report 1871:516; U.S. Documents 1871). Captain D. M. Kingsbury was chosen as the master of the vessel. Work was slated to begin on or about January 20 , 1871 , as soon as a reexamination of the bayou was carried through in order to ascertain what clearing was done by the authorities of the State of Louisiana (U.S. Documents 1871).

The contract for the Bayou Teche work stipulated that all snags and piles located within a distance of $30.5 \mathrm{~m}(100 \mathrm{ft})$ on either side of the line of deepest water were to be removed. It also stipulated that specifically the following wrecks were to be removed entirely:

Steamer Iberia, Steamboat Frank Keeling, Job boat Rob Roy, Gun-boat E.J. Hart, Gunboat Diana, flat boat near Hughes saw-mill, Schooner opposite Franklin, Steamboat Gossamer, Steamboat News Boy, Barge Abe Smith, Steamboat Plough Boy, Gun-boat Fly Catcher. Also to remove all that portion of the wreck of the Gunboat J.B. Cotton forward of her wheel shaft. Also to either entirely remove or to move to a distance of one hundred (100) feet from the navigable channel of the Bayou at the option of the said party of second part the following named wrecks viz; Three (3) Brick Barges 


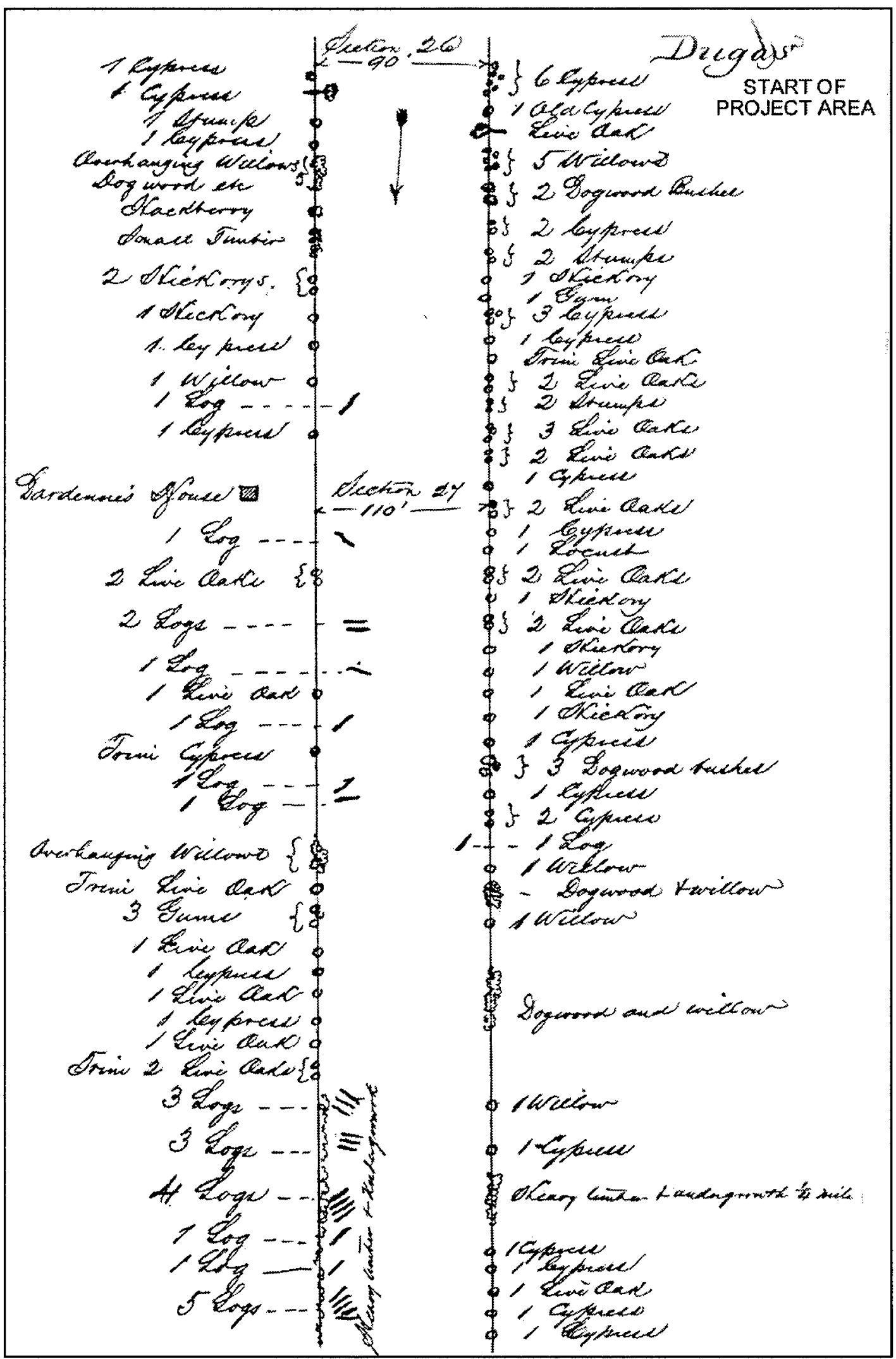

Figure 23. Excerpt from Duke's 1870 field maps Survey of the Bayou Teche, May Sheet $1 \quad 1870$, depicting the project area. 


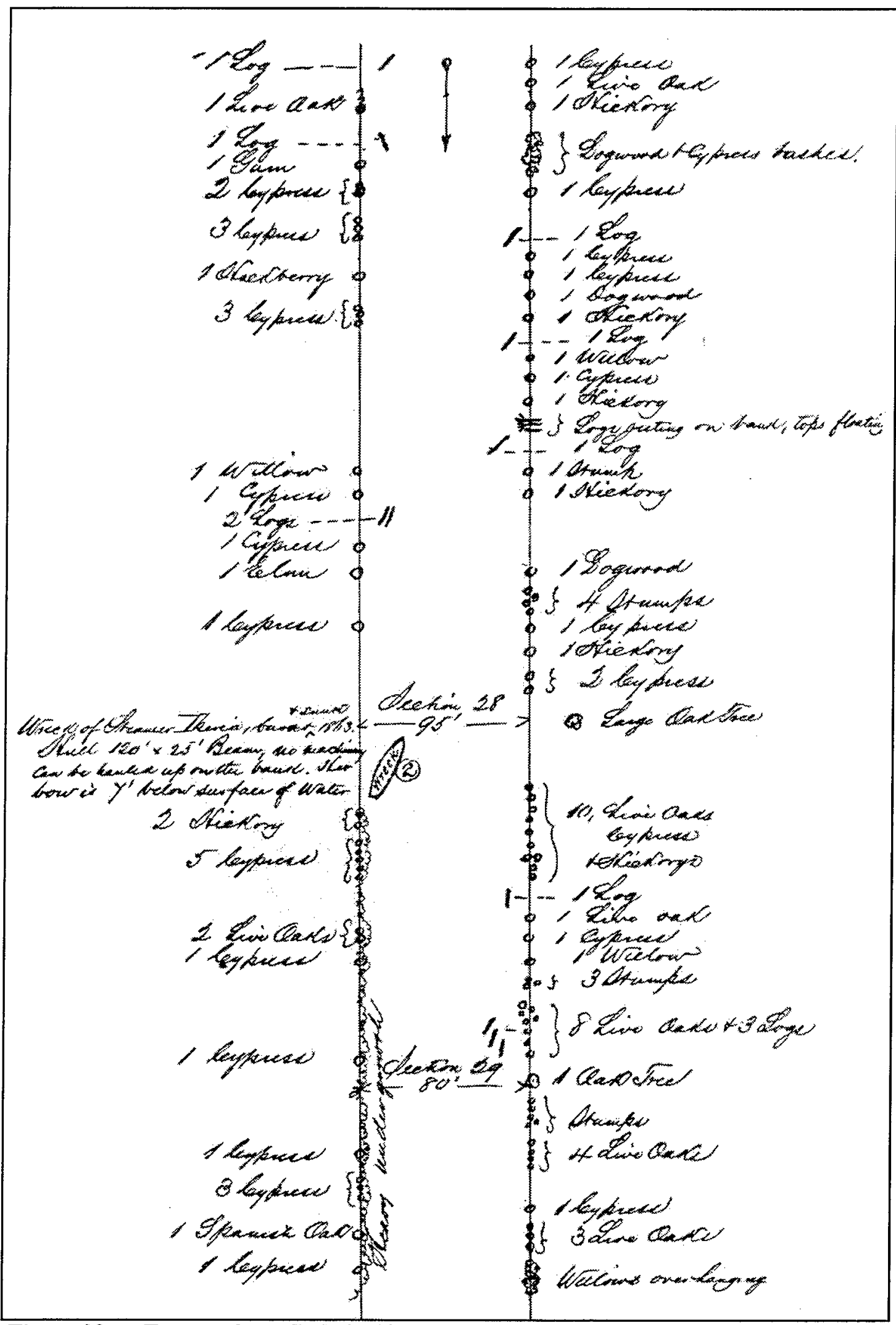

Figure 23. Excerpt from Duke's 1870 field maps Survey of the Bayou Teche, May Sheet $2 \quad 1870$, depicting the project area. 


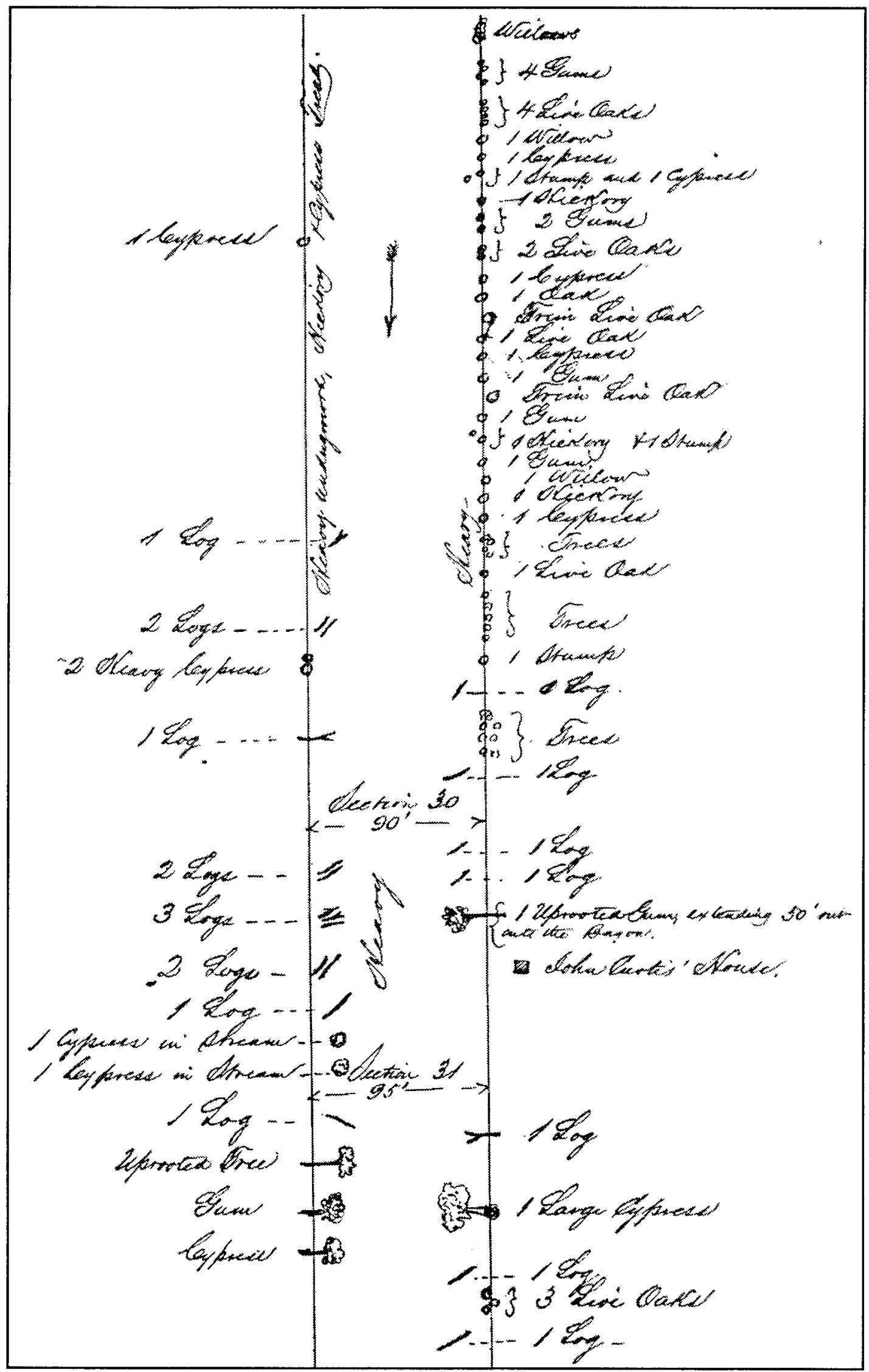

Figure 23. Excerpt from Duke's 1870 field maps Survey of the Bayou Teche, May Sheet 3 1870 , depicting the project area. 
Chapter IV: Historic Overview

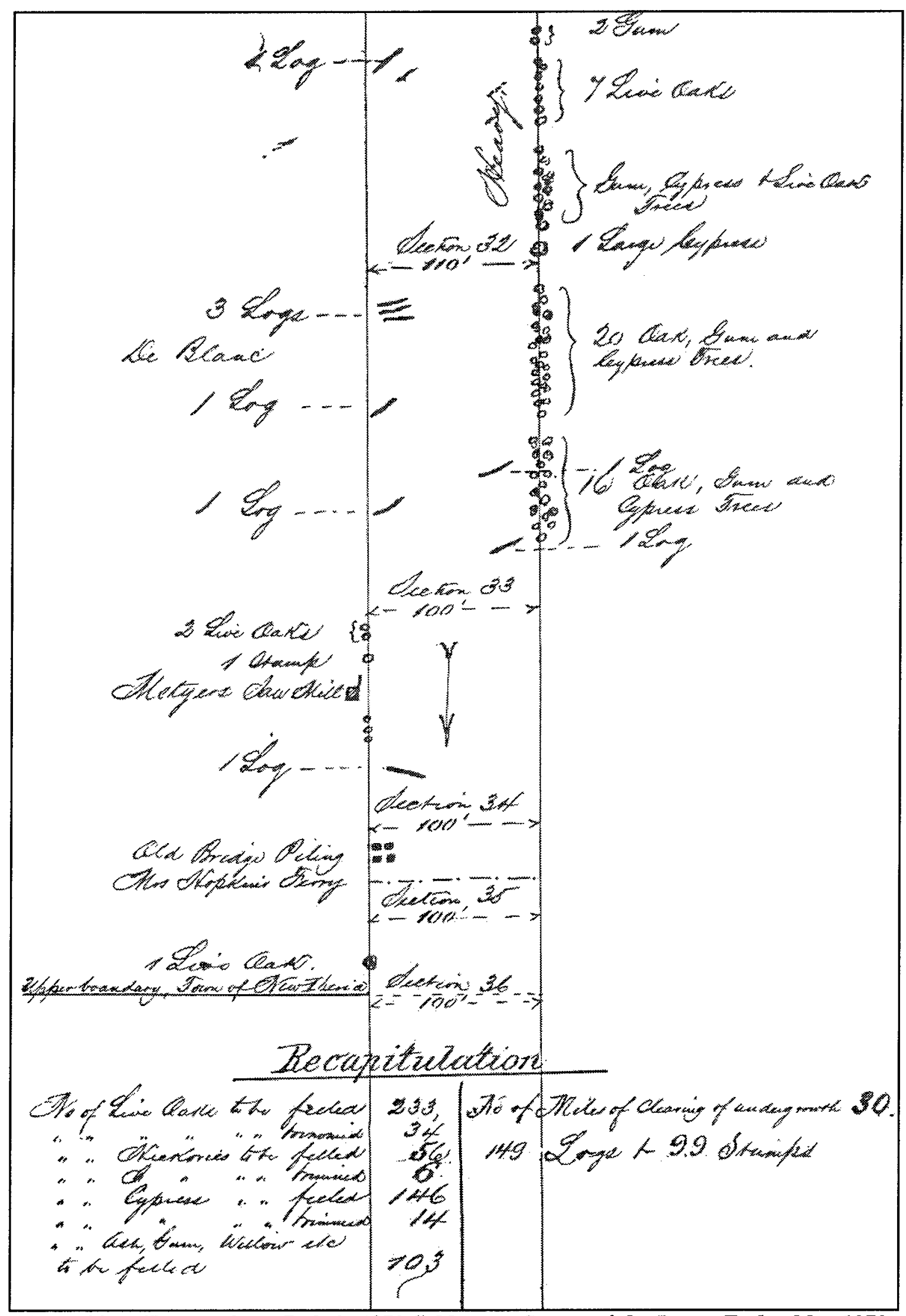

Figure 23. Excerpt from Duke's 1870 field maps Survey of the Bayou Tache, May 1870, Sheet 4 depicting the project area.

R. Christopher Goodwin \& Associates, Inc.

68 
Chapter IV: Historic Overview

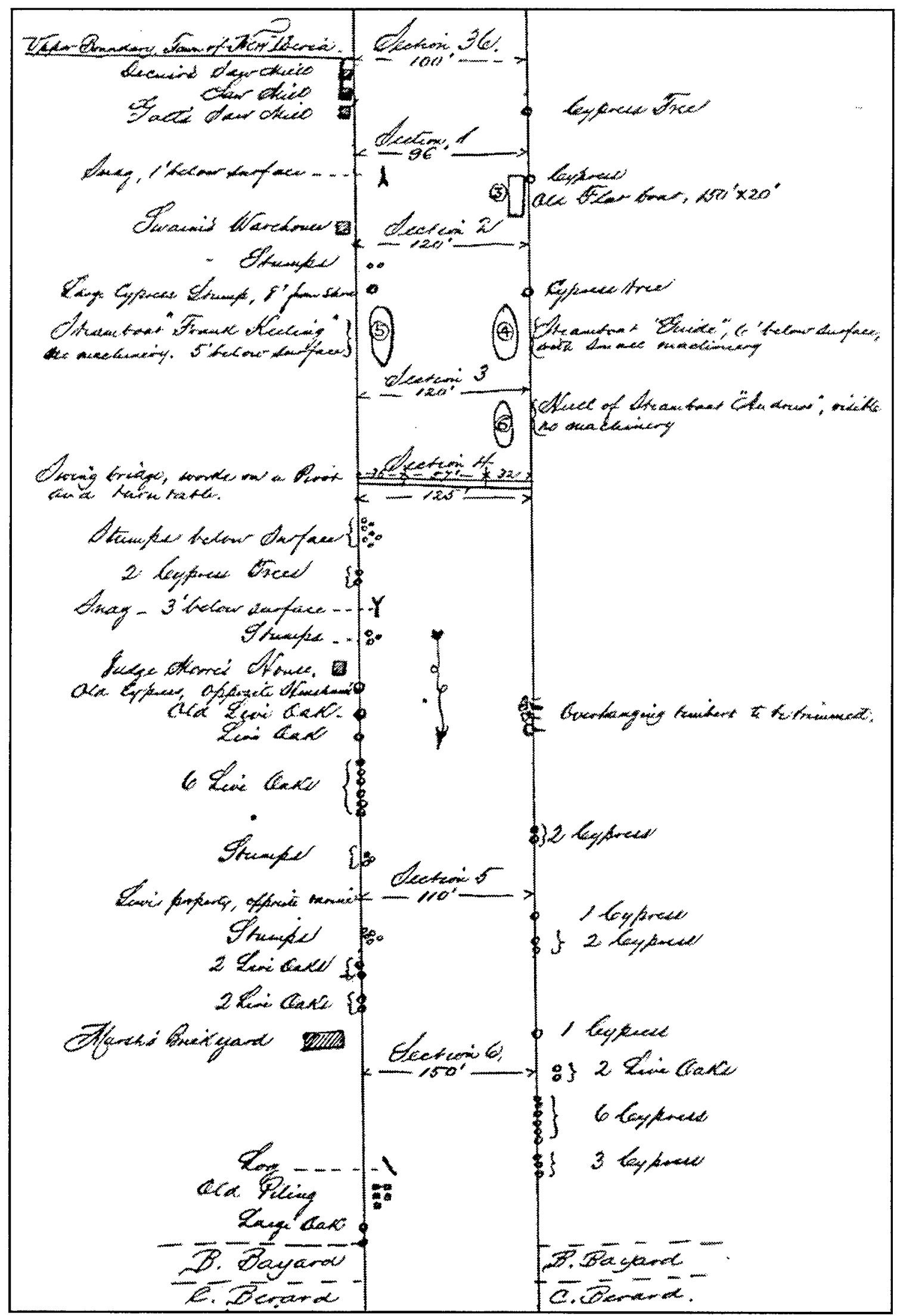

Figure 23. Excerpt from Duke's 1870 field maps Survey of the Bayou Teche, May 1870, Sheet 5 depicting the project area.

69

R. Christopher Goodwin \& Associates, Inc: 


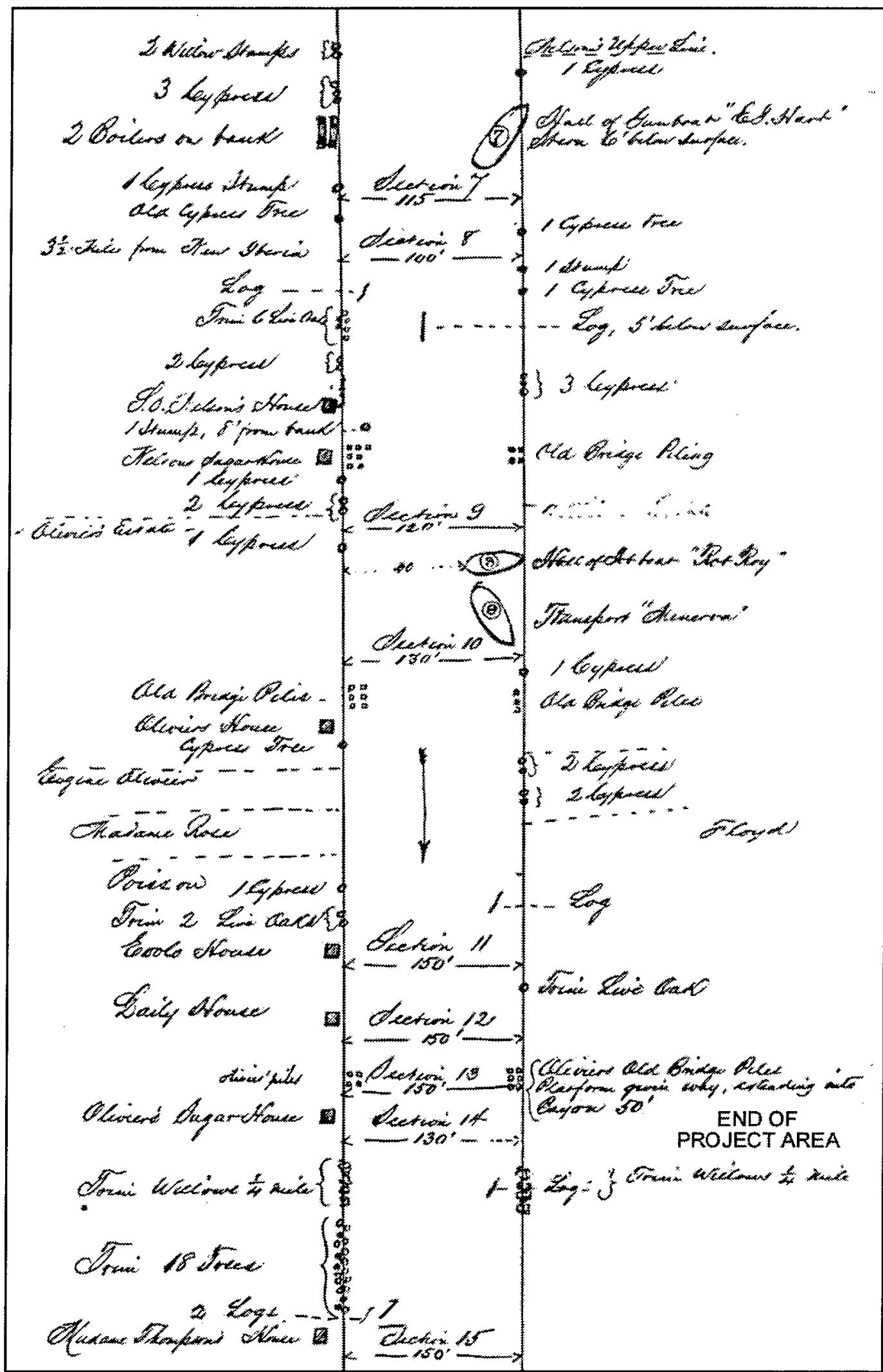

Figure 23. Excerpt from Duke's 1870 field maps Survey of the Bayou Teche, Sheet 6 May 1870, depicting the project area. 


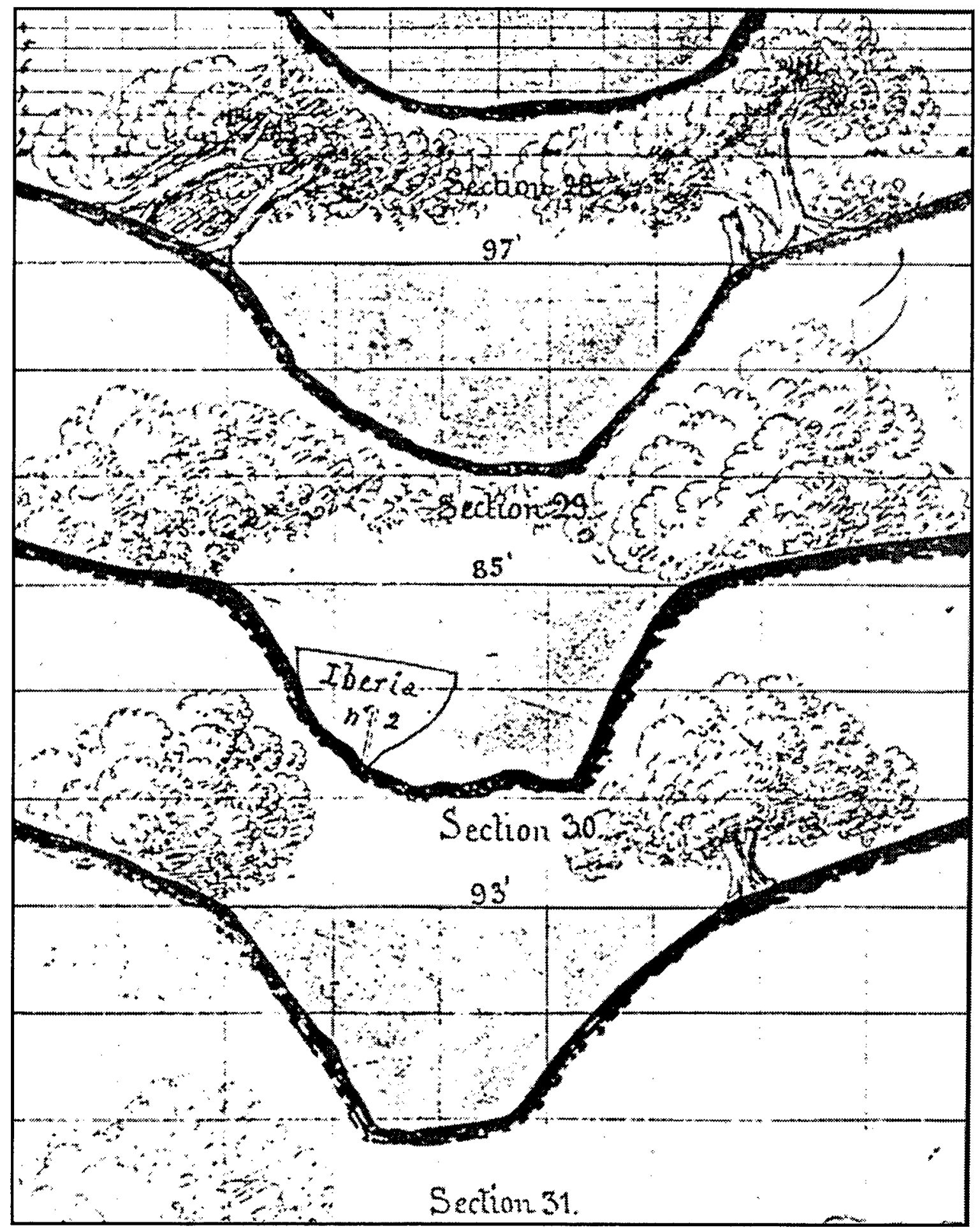

Figure 24. Excerpts from Duke's 1870 presentation maps Survey of the Bayou Teche, May 1870, Plate 1, depicting a cross section of Bayou Teche with the wreck Iberia. 
next above said Fly Catcher, one (1) sunken Schooner lying just above the wreck of the J.B. Cotton.

It also stipulated that all snags, piles, logs, wrecks, trees and trimmings were to be removed to points not subject to overflow from freshets (U.S. Army Corps of Engineers RG77, Entry H906, September 26, 1870). The work of the flat entailed removing piles, log rafts, disconnecting machinery from wrecks, and blasting wrecks with explosives (Wilby 1991:76).

Work on removing obstructions began on February 15, 1871. On June 30 the work plan was put on hold when the water level of the Teche became too high for the removal of the submerged wrecks. Work resumed again in November of that year (Chief of Engineers Report 1871:516).

After the first project, the clearing of the wreck Cotton, the Bayou Teche had to be repaired and altered. The derrick was increased to $6.4 \mathrm{~m}(21 \mathrm{ft})$ in height, the foredeck lengthened $1.2 \mathrm{~m}(4 \mathrm{ft})$, the afterdeck by $1.8 \mathrm{~m}(6 \mathrm{ft})$, and the plank shear increased $0.3 \mathrm{~m}(1.0 \mathrm{ft}$ ) (Wilby 1991:87).

The work resulted in obstructions being cleared from the mouth of the Bayou Teche to the town of New Iberia. A proposal was submitted for the fiscal year ending June 30, 1872, to continue the work of clearing obstructions all the way to St. Martinsville (Chief of Engineers Report 1871:516). The project was funded and work was resumed the following year commencing at the town of St. Martinsville. The previously cleared areas were revisited and a few new wrecks were removed. With the completion of the two projects from the mouth of the Bayou Teche to Martinsville, a $121 \mathrm{~km}(75 \mathrm{mi})$ stretch of open waterway clear of obstructions resulted (Chief of Engineers Report 1872:556).

Howell reported the results of the survey as follows:

Thirteen wrecks totally removed, viz, of steamers J. B. Cotton, Fly Catcher, News Boy, Gossamer, Diana, Minerva, E. J. Hart, Andrews, and Guide; 2 schooners and 2 barges.

Three wrecks partially removed, viz, 2 steamers, Rob Roy and Iberia; 1 lighter.
One sunken raft, of 194 large live-oak logs, totally removed; 82 bridge piles pulled out and removed; 24 dangerous snags removed; 38 over hanging trees cut and removed from banks; 4 live-oak roots, with dangerous stumps, removed; 106 large projecting limbs cut and removed; 39 projecting logs removed (ARCE 1872:556).

However, Howell contradicted a previous report, in which he discussed the complete removal of the Rob Roy. "I am informed by the engineer in charge of the work now being done by the State of Louisiana on the Teche, that this wreck [Rob Roy] was hauled ashore entire in three days, with only a steam capstan and drag ropes" (ARCE 1870:348).

With the exception of the Rob Roy, there is little information on how the thirteen wrecks were removed. In his 1870 report to Major General A. A. Humphreys, however, Howell proposed the following:

\begin{abstract}
Shore tack can be conveniently and economically used for loosening portions of each wreck, occasionally aided by a light derrick on a flat alongside the wreck. Oxen with drag ropes or chains can be used to haul the loosened pieces ashore and beyond the reach of floods (ARCE 1870:348).
\end{abstract}

Of the appropriated sum of $\$ 17,500.00$, $\$ 5,022.46$ was left unspent by Kingsbury (Chief of Engineers Report 1872:556).

\section{Wrecked Vessels Removed from Bayou Teche, 1870-1871}

At least four sources of data contained information on vessels lost in Bayou Teche and their removal: an 1868 map of wrecks recorded by E.B. Trinidad, Captain of the U.S. Mail steamer Warren Bell (route 8074) in Bayou Teche (Figure 25); a set of field survey maps (1870) recording all obstructions, including vessel wrecks, by civil engineer William D. Duke (Figure 23); a set of presentation maps (1870) by W.D. Duke based on the compiled survey maps (Figure 26); and letters describing clearing operations to Captain Howell, U.S. Army Corps of Engineers, by Daniel M. Kingsbury, master of Bayou Teche.

Survey maps compiled by Duke provide the main and largest body of information on post- 
Civil War obstructions in the Teche. The maps are divided into three divisions, with each division further subdivided into sections, and most of the recorded wrecks are numbered. Thus, Division I (from St. Martinsville to New Iberia) contains sections 1-36, Division II (from New Iberia to Franklin) contains sections 1-52, and Division III (from Franklin to the Atchafalaya River) contains sections 1-27. The project area spans Division I, sections 28-36 and Division II, sections 1-14. While the Trinidad map is not divided in any manner, the wrecks are numbered. At times, the Duke and Trinidad numbers coincide. Daniel M. Kingsbury, the master of the snagboat Bayou Teche, utilized the maps compiled by Duke while clearing obstructions from Bayou Teche. Table 9 lists all cultural sites that posed potential hazards as obstructions to navigation in the project area. It also summarizes information (1868 to 1870 ) on wrecked vessels encountered by Trinidad, Duke, and

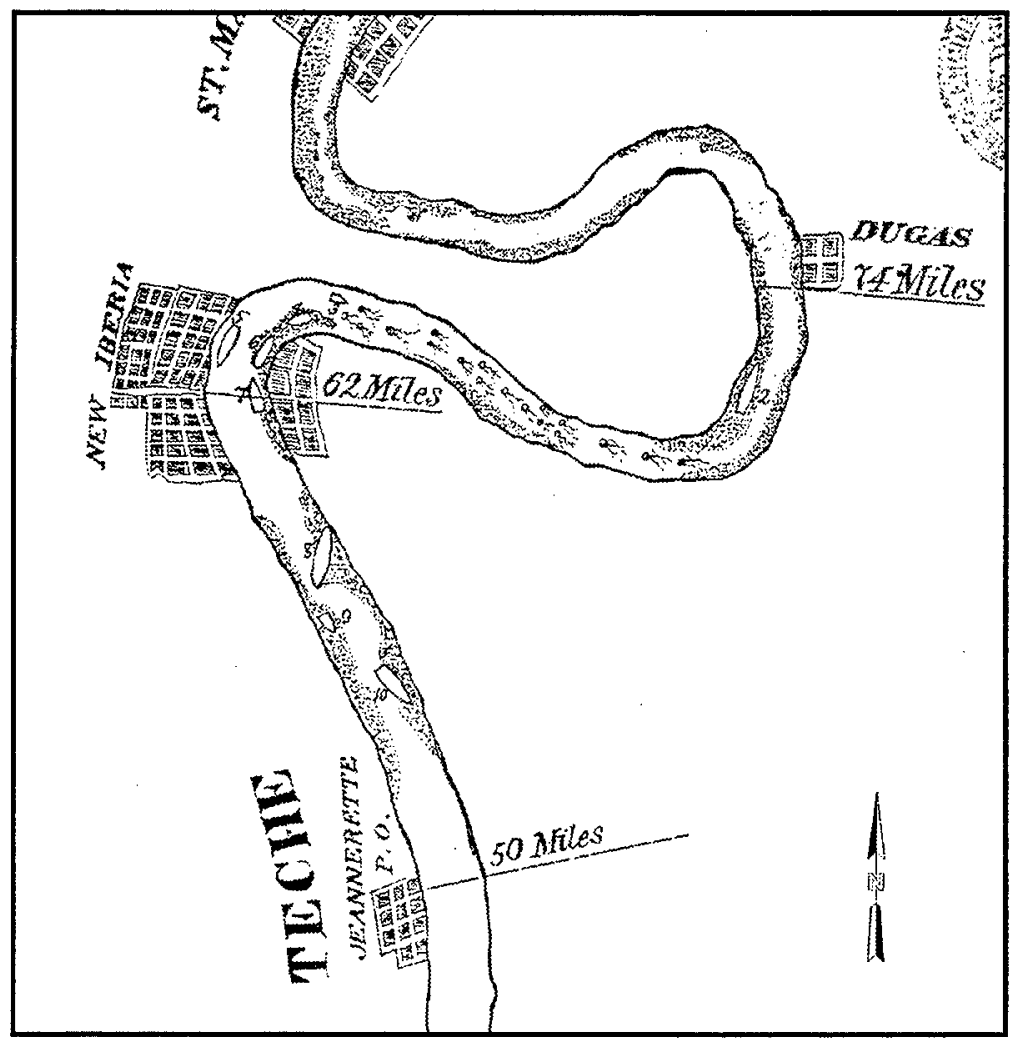

Figure 25. Excerpt from Trinidad's 1868 map Rough Sketch of Bayou Teche from St. Martinsville to the Atchafalaya River showing the project area.

Lawrence (vessel propeller) recorded by Trinidad in Div. II, Sec. 35-36, No. 3 . Mitchell (1975), Raphael (1994), and Way (1994).

\section{Wrecks Recorded within Proposed Project} Area of Division I (St. Martinsville to New Iberia) of Duke's Survey Maps

Only two obstructions were listed on the maps compiled by Duke for the pertinent areas of Division I -- 1 steamboat and 1 propeller. The wrecks were:

\section{Iberia (steamboat hull)} in Div. I, Sec. 28 (Sec. 29 on Duke presentation map), Duke No. 2 and Trinidad No. 2); and
Wrecks Recorded within Proposed Project Area of Division II (New Iberia to Franklin) of Duke's Survey Maps

Duke recorded a total of 12 wrecks in Division II. The types and amounts were 7 steamers; 3 flat boats; 1 job boat; and 1 transport. The wrecks were:

a flatboat, or an old barge in Div. II, Sec. 1, Duke No.3 and Trinidad No. 4;

Guide (stern-wheel steamboat) in Div. II, Sec. 2, Duke No.4 and Trinidad No. 6. She may be the 55 ton stern-wheel steamboat built in 1859 in Millersport, Ohio. She passed to Confederate control in 1861 (Mitchell 1975:90); 


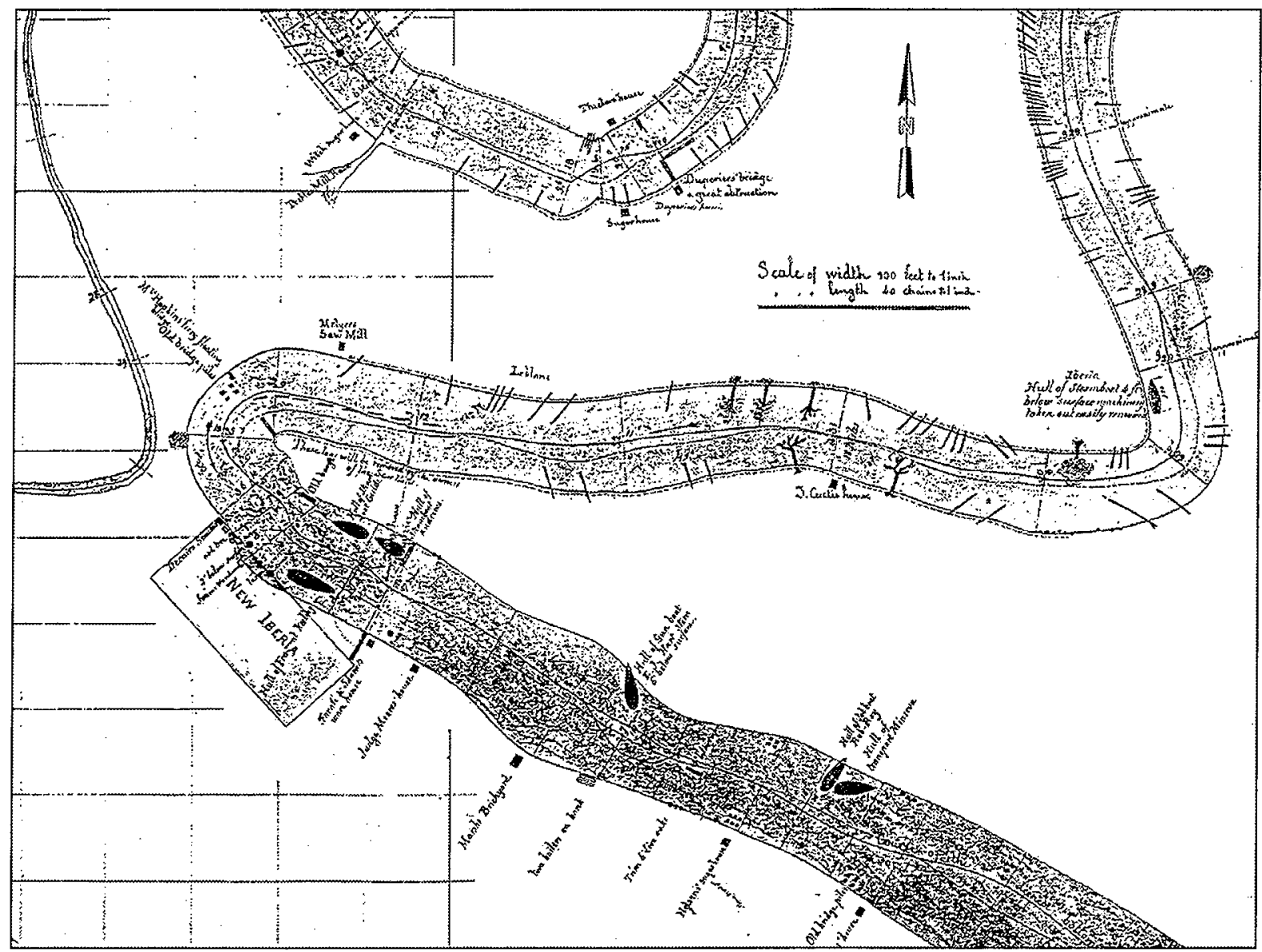

Figure 26. Excerpts from Duke's 1870 presentation map Survey of the Bayou Teche, May 1870, Plate 1, depicting the wrecks in the project area.

Frank Keeling (stern-wheel steamboat)

in Div. II, Sec. 2, both No. 5. The Keeling was built in 1852 in Monongahela, Pennsylvania, and it weighed 115 tons. Her first home port was Wheeling, Virginia. She was abandoned in 1860 (Mitchell 1975:76);

Andrews (steamboat hull)

in Div. II, Sec. 3, Duke No. 6 and Trinidad No. 7. The Andrews was removed on May 30 after 80 lbs of powder (two blasts) were used to break her apart (Wilby 1991:94);

\section{E.J. Hart (Confederate ironclad steam gunboat)} in Div. II, Sec. 6, Duke No. 7 and Trinidad Nos. 8 and 9. The wreck E.J. Hart was scuttled to deny Union forces. It consisted of a mass of iron and timber. An early attempt was made to clear the wreck on October 9, 1863, when explosives were placed underneath the boiler. (Raphael 1994;162). The Kingsbury crew arrived on the $24^{\text {th }}$ of May and by the $26^{\text {th }}$, and after three blasts, consuming 120 lbs of powder, had the gun boat E.J. Hart on the banks of the Bayou (Wilby 1991:93);

Rob Roy (job boat hull)

in Div. II, Sec. 9, Duke No. 8. It was decided by Kingsbury that a $12 \mathrm{~m}$ (40 ft) portion of the job boat Rob Roy would have to be removed because it represented a serious obstruction to navigation. The job was completed by the $22^{\text {nd }}$ of May, 1871 (Wilby 1991:93);

Minerva (Confederate transport)

in Div. II, Sec. 9, Duke No. 9 and Trinidad No. 10. Kingsbury arrived at the site of the wreck of the transport Minerva on the $15^{\text {th }}$ of May. By the $20^{\text {th }}$ he had her entire hull out of the water and on the banks of the Bayou. It took $165 \mathrm{lbs}$ of powder (four blasts) to remove her (Wilby 1991:92); 
Table 9. Summary of Shipwrecks and Other Cultural Obstructions along Bayou Teche, from St. Martinsville to the Atchafalaya River, Louisiana 1868-1887.

\begin{tabular}{|c|c|c|c|c|c|c|c|c|}
\hline 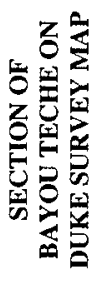 & 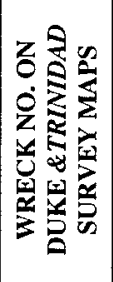 & 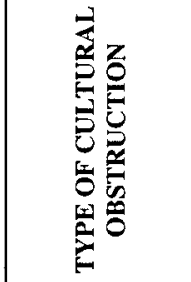 & 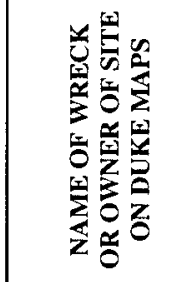 & 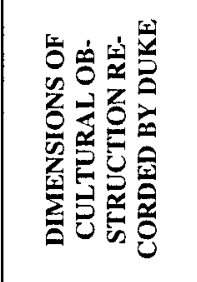 & 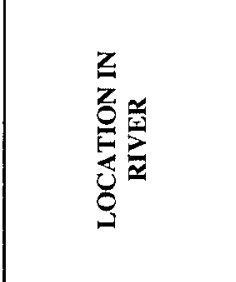 & 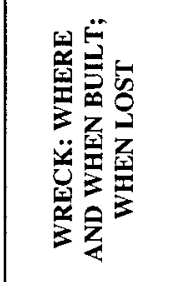 & 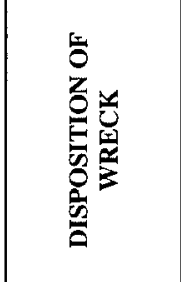 & 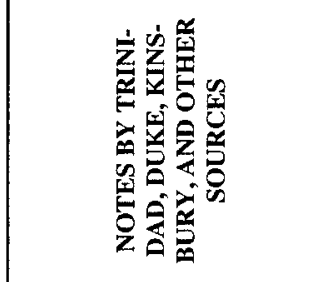 \\
\hline \multicolumn{9}{|c|}{ Duke Map Division I: St. Martinsville to New Iberia } \\
\hline $\mathrm{I}$ & \multicolumn{8}{|c|}{ Upper Boundary, Toun of St. Martinsville (along both banks) } \\
\hline 2 & & bridge (draw) & & $\begin{array}{l}44.6 \text { ' draw } \\
\text { opening }\end{array}$ & & & & $\begin{array}{l}\text { built in March } 1869, \text { in good } \\
\text { condition }\left(\mathrm{D}^{1}\right)\end{array}$ \\
\hline 3 & & wharf & Market & & & & & \\
\hline 4 & & wharf & Duchamps's & & & & & \\
\hline 9 & & landing & Borel's & & & & & \\
\hline 10 & & landing (stock) & $\begin{array}{l}\text { Voorhees' }\left(D^{1}\right) \\
\text { Workers' }\left(D^{2}\right)\end{array}$ & & & & & \\
\hline 14 & \multicolumn{8}{|c|}{ Kevstone Canal, leading to Spanish Lake Tasso (left bank) } \\
\hline 16 & 1 & flat boat (old) & Regina & $\begin{array}{l}\text { length: } 100^{\prime} \\
\text { width: } 20^{\prime}\end{array}$ & on edge of left bank & & \begin{tabular}{|l|} 
no information \\
available
\end{tabular} & $\begin{array}{l}\text { easily removed; not in chan- } \\
\text { nel: no machinery; no value } \\
\left(D^{1}\right): \text { not mentioned by name } \\
\text { on } \mathrm{D}^{2}\end{array}$ \\
\hline 21 & & bridge (draw) & Duperier's & $50^{\prime}$ draw opening & & & & $\begin{array}{l}\text { a great obstruction; to be } \\
\text { certainly removed }\left(D^{1}\right)\end{array}$ \\
\hline 26 & \multicolumn{8}{|c|}{ Town of Dugas, or Loreauville (right bank) } \\
\hline $\begin{array}{c}28 \\
\left(29-D^{2}\right)\end{array}$ & $\begin{array}{c}2 \\
\& 2\end{array}$ & steamboat (hull) & Iberia & $\begin{array}{l}\text { length: } 120^{\prime} \\
\text { width: } 25^{\prime}\end{array}$ & $\begin{array}{l}10^{\prime} \text { from right bank: } \\
\left.\text { bow } 7^{\prime}\left(4^{\prime}[D]\right)\right) \\
\text { below surface }\end{array}$ & & \begin{tabular}{|l|} 
burnt and sunk \\
$1863\left(D^{1}\right) ;$ \\
partially re- \\
moved $(\mathrm{Kn})$ \\
$(\mathrm{Hw})$
\end{tabular} & $\begin{array}{l}\text { can be hauled onto shore; } \\
\text { bow in channel; no machinery } \\
\text { (D) }\end{array}$ \\
\hline 34 & & $\begin{array}{l}4 \text { bridge piles } \\
\text { (old) }\end{array}$ & & & on right bank & & & \\
\hline 34 & & $\begin{array}{l}\text { ferry floating } \\
\text { bridge }\left(D^{2}\right)\end{array}$ & $\begin{array}{l}\text { Thomas Hop- } \\
\text { kins's }\end{array}$ & & & & & \\
\hline $35-36$ & 3 & propeller & \begin{tabular}{|l} 
Lawrence \\
$(\mathrm{Tr})$
\end{tabular} & & $\begin{array}{l}\text { between left bank } \\
\text { and channel }\end{array}$ & & & \\
\hline 36 & \multicolumn{8}{|c|}{ Upper Boundary, Town of New Iberia (along both banks) } \\
\hline \multicolumn{9}{|c|}{ Duke Map Division II: New Iberia to Franklin } \\
\hline 1 & $\begin{array}{c}3 \\
\& 4\end{array}$ & 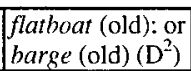 & unnamed & $\begin{array}{l}\text { length: } 150^{\prime} \\
\text { width: } 20^{\prime}\end{array}$ & \begin{tabular}{|l|} 
edge of left bank; \\
visible
\end{tabular} & & \begin{tabular}{|l|}
$\begin{array}{l}\text { no information } \\
\text { available }\end{array}$ \\
\end{tabular} & $\begin{array}{l}\text { not in channel; no machinery } \\
\text { (D') }\end{array}$ \\
\hline 2 & $\begin{array}{c}4 \\
\& 6\end{array}$ & $\begin{array}{l}\text { steamboat } \\
\text { (stern-wheel) }\end{array}$ & $\begin{array}{l}\text { Guide } \\
\text { (Confederate) }\end{array}$ & $\begin{array}{ll}\text { length: } & 120^{\prime} \\
\text { width: } & 25^{\prime} \\
\text { tons: } & 55(?)\end{array}$ & $\begin{array}{l}20^{\prime} \text { from left bank: } \\
6^{\prime} \text { below surface }\end{array}$ & $\begin{array}{l}\text { Millersport, } \\
\text { Ohio in } 1859 \\
\text { (?) (LH) }\end{array}$ & $\begin{array}{l}\text { fully removed } \\
(\mathrm{Kn}),(\mathrm{Hw})\end{array}$ & $\begin{array}{l}\text { to be certainly removed: in } \\
\text { the channel; with small ma- } \\
\text { chinery; all sunk; bought } \\
\text { before the war for } \$ 2,500 \\
\left(D^{1}\right) ; \text { deeply imbedded in } \\
\text { mud }(\mathrm{Kn}) \text {; passed to Confed- } \\
\text { erate control in } 1861(\mathrm{LH}) \\
\end{array}$ \\
\hline 2 & $\begin{array}{c}5 \\
\& 5\end{array}$ & \begin{tabular}{|l} 
steamboat \\
(stern-wheel)
\end{tabular} & Frank Keeling & $\begin{array}{ll}\text { length: } & 150^{\circ} \\
\text { width: } & 30^{\circ} \\
\text { tons: } & 115\end{array}$ & $\begin{array}{l}20^{\prime} \text { from right bank: } \\
5^{\prime} \text { below surface }\end{array}$ & $\begin{array}{l}\text { Monongahela, } \\
\text { Penn. in 1852; } \\
\text { abandoned in } \\
1860(\mathrm{LH})\end{array}$ & $\begin{array}{l}\text { abandoned } \\
1869(\mathrm{LH})\end{array}$ & $\begin{array}{l}\text { to be certainly removed: no } \\
\text { machinery }\left(\mathrm{D}^{1}\right) ; \text { deeply } \\
\text { imbedded in mud }(\mathrm{Kn}) \text {. }\end{array}$ \\
\hline 3 & $\begin{array}{l}6 \\
\& 7\end{array}$ & steamboat (hull) & $\begin{array}{l}\text { Andrews; } \\
\text { Andrew (Tr) }\end{array}$ & $\begin{array}{l}\text { length: } 150^{\circ} \\
\text { width: } 25^{\prime}\end{array}$ & $\begin{array}{l}\text { on edge of right } \\
\text { bank; visible }\end{array}$ & & $\begin{array}{l}\text { fully removed } \\
(\mathrm{Kn}),(\mathrm{Hw})\end{array}$ & $\begin{array}{l}\text { not in channel; no machinery } \\
\text { (D'); } 80 \text { lbs of explosives } \\
\text { used in two blasts (Kn) }\end{array}$ \\
\hline 4 & & bridge (swing) & & $\begin{array}{l}36^{\circ}+57^{\circ}(\mathrm{draw} \\
\text { opening })+32^{\prime}\end{array}$ & & & & $\begin{array}{l}\text { works on a pivot and turnta- } \\
\text { ble (D) }\end{array}$ \\
\hline 6 & & piles (old) & & & 5 along right bank & & & \\
\hline 6 & $\begin{array}{c}7 \\
\& 8,9\end{array}$ & $\begin{array}{l}\text { steam gunboat } \\
\text { (ironclad) }\end{array}$ & \begin{tabular}{|l} 
E.J. Hart \\
(Confederate)
\end{tabular} & $\begin{array}{l}\text { length: } 120^{\prime} \\
\text { width: } 20^{\circ}\end{array}$ & $\begin{array}{l}\text { on right bank; stern } \\
\text { 6' below surface }\end{array}$ & $\begin{array}{l}\text { sunk July } 28, \\
1863(\mathrm{Hh}) .\end{array}$ & \begin{tabular}{|l|} 
fully removed \\
(hull) and \\
placed on river \\
banks (Kn) \\
$(\mathrm{Hw})$
\end{tabular} & $\begin{array}{l}\text { to be certainly removed; in } \\
\text { channel; no machinery }\left(\mathrm{D}^{1}\right) ; \\
120 \mathrm{lbs} \text { of explosives used } \\
(\mathrm{Kn}) ; 2 \text { boilers on left bank } \\
\left(\mathrm{D}^{2}\right) ; 2 \text { sections of } \text { Hart de- } \\
\text { picted }(\mathrm{Tr}) ; \text { clearind at- } \\
\text { tempted October } 9,1863(\mathrm{Ra})\end{array}$ \\
\hline
\end{tabular}


Table 9 , continued

\begin{tabular}{|c|c|c|c|c|c|c|c|c|}
\hline 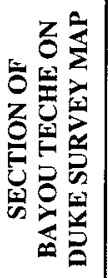 & 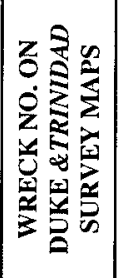 & 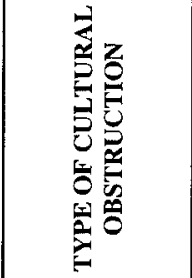 & 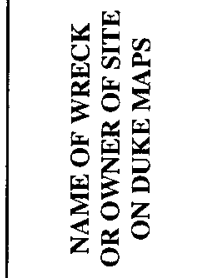 & 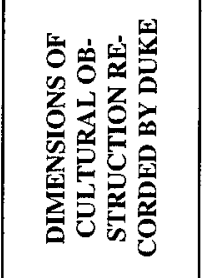 & 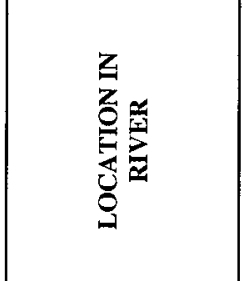 & 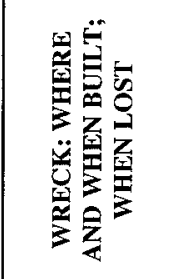 & 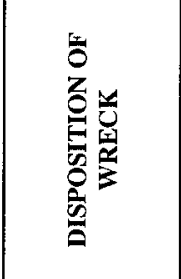 & 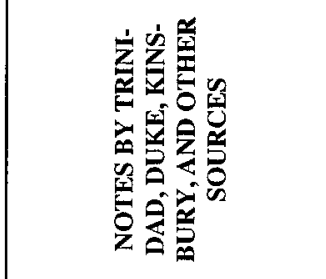 \\
\hline 8 & & $\begin{array}{l}\text { bridge piles } \\
\text { (old) }\end{array}$ & & & $\begin{array}{l}7 \text { on right bank; } 4 \text { on } \\
\text { left bank }\end{array}$ & & & \\
\hline 9 & 8 & job boat (hull) & Rob-Roy & $\begin{array}{l}\text { length: } 130^{\prime} \\
\text { width: } 25^{\prime}\end{array}$ & $\begin{array}{l}\text { on right bank; upper } \\
\text { works visible }\end{array}$ & & $\begin{array}{l}40 \mathrm{ft} \text { of wreck } \\
\text { removed may } \\
22,1871(\mathrm{Kn}) \\
(\mathrm{Hw})\end{array}$ & $\begin{array}{l}\text { to be certainly removed: in } \\
\text { channel; no machinery; since } \\
\text { survey, has been removed by } \\
\text { state }\left(\mathrm{D}^{1}\right) \text {; next to wreck } \\
\text { Minerva }\left(\mathrm{D}^{1 \& 2}\right)\end{array}$ \\
\hline 9 & $\begin{array}{c}9 \\
\& 10\end{array}$ & transport & $\begin{array}{l}\text { Minerva } \\
\text { (Confedrate) }\end{array}$ & $\begin{array}{l}\text { length: } 125^{\prime} \\
\text { width: } 20^{\prime}\end{array}$ & $\begin{array}{l}\text { parallel with right } \\
\text { bank; upper works } \\
\text { visible }\end{array}$ & & $\begin{array}{l}\text { fully removed } \\
\text { May 20,1871 } \\
(\text { Kn), (Hw) }\end{array}$ & $\begin{array}{l}\text { to be certainly removed; in } \\
\left.\text { channel; no machinery ( } \mathrm{D}^{1}\right) ; \\
\text { next to wreck Rob-Roy }\left(\mathrm{D}^{1 \mathrm{E}}\right. \\
\left.{ }^{2}\right) ; 165 \mathrm{lbs} \text { of explosives ( } 4 \\
\text { blasts) used (Kn) }\end{array}$ \\
\hline 10 & & bridge piles & & & $\begin{array}{l}6 \text { on right bank; } 3 \text { on } \\
\text { left bank }\end{array}$ & & & \\
\hline 13 & & $\begin{array}{l}\text { bridge piles and } \\
\text { platform (old) }\end{array}$ & Olivier's & & $\begin{array}{l}4 \text { on right bank; } 6 \text { on } \\
\text { left bank }\end{array}$ & & & $\begin{array}{l}\text { platform given way; extends } \\
\text { into bayou 50' }\left(D^{\top}\right)\end{array}$ \\
\hline 16 & & bridge (draw) & $\begin{array}{l}\text { Bronson and } \\
\text { Thompson's }\end{array}$ & $\begin{array}{l}90^{\prime} \text { draw open- } \\
\text { ing: } 28^{\prime} \text { W sec- } \\
\text { tion }\end{array}$ & & & & \\
\hline 17 & & bridge (draw) & Dr. Bussey's & 89' draw opening & & & & \\
\hline 18 & 10 & $\begin{array}{l}\text { steam job boat } \\
\text { (side-wheel) }\end{array}$ & Homer & $\begin{array}{ll}\text { length: } & 120^{\prime} \\
\text { width: } & 20^{\circ} \\
\text { tons: } & 194(?)\end{array}$ & $\begin{array}{l}30^{\prime} \text { from right bank; } \\
7^{\prime} \text { below surface }\end{array}$ & \begin{tabular}{|l|} 
Parkersburg, \\
Virginia in \\
$1859(?)(\mathrm{LH})$
\end{tabular} & \begin{tabular}{|l|} 
sunk in 1855 \\
$\left(D^{I}\right) ;$ no infor- \\
mation avail- \\
able
\end{tabular} & $\begin{array}{l}\text { to be removed: in channel; no } \\
\text { machinery }\left(D^{1}\right) ; \text { passed to } \\
\text { Confed. control in } 1861 \text { (LH) }\end{array}$ \\
\hline 19 & 11 & $\begin{array}{l}\begin{array}{l}\text { steamboat (hull, } \\
\text { old) }\end{array} \\
\end{array}$ & Ajax & $\begin{array}{l}\text { length: } 120^{\prime} \\
\text { width: } 25^{\prime}\end{array}$ & $\begin{array}{l}\text { close to left bank; } \\
\text { stern 7' below sur- } \\
\text { face }\end{array}$ & & $\begin{array}{l}\text { no information } \\
\text { available }\end{array}$ & $\begin{array}{l}\text { to be removed; easily re- } \\
\text { moved; falling to pieces; no } \\
\text { machinery }\left(\mathrm{D}^{\mathrm{T}}\right)\end{array}$ \\
\hline 20 & \multicolumn{8}{|c|}{\begin{tabular}{|l} 
Village of Jeannerette (left bank) \\
\end{tabular}} \\
\hline 21 & & bridge (draw) & Gravenberg's & $89^{\prime}$ draw opening & & & & $\begin{array}{l}\text { in fair condition }\left(D^{1}\right) ; \text { re- } \\
\text { quires reconstruction }\left(D^{2}\right)\end{array}$ \\
\hline 22 & & bridge (draw) & Fay's & 89' draw opening & & & & $\begin{array}{l}\text { built } 15 \text { years }\left(\mathrm{D}^{1}\right) \text {; requires } \\
\text { reconstruction }\left(\mathrm{D}^{2}\right)\end{array}$ \\
\hline 23 & \multicolumn{8}{|c|}{ Village of Cypremort } \\
\hline 23 & & bridge (draw) & Sorel's & $84^{\prime}$ draw opening & & & & in good condition $\left(\mathrm{D}^{1}\right)$ \\
\hline 25 & & bridge (draw) & G.L. Faselier's & $83^{\prime}$ draw opening & & & & $\begin{array}{l}\text { to be reconstructed in spring } \\
\text { of } 1871\left(\mathrm{D}^{1}\right)\end{array}$ \\
\hline 26 & & bridge (draw) & Sorel's & 89' draw opening & & & & in good condition $\left(\mathrm{D}^{1}\right)$ \\
\hline 28 & & bridge (draw) & $\begin{array}{l}\text { Austin and Whit- } \\
\text { house's }\end{array}$ & 87' draw opening & & & & \\
\hline 29 & 12 & flatboat & unnamed & & $\begin{array}{l}\text { mid-channel; } 8.5^{\prime} \\
\text { below surface }\end{array}$ & & $\begin{array}{l}\text { no information } \\
\text { available }\end{array}$ & $\begin{array}{l}\text { no obstruction; imbedded in } \\
\text { mud; no machinery }\left(\mathrm{D}^{1}\right)\end{array}$ \\
\hline 31 & \multicolumn{8}{|c|}{ Town of Charenton (along both banks); Indian Bend (right bank) } \\
\hline 31 & & ferry crossing & at Charenton & & & & & \\
\hline 33 & & ferry landing & Fuseliers's & & on left bank & & & \\
\hline
\end{tabular}

Abbreviations: $\quad$ Survey map $\left(\mathbf{D}^{1}\right)$ and presentation map $\left(\mathbf{D}^{2}\right)$ of Bayou Teche by William D. Duke, C.E., 1870; James E. Hemphill (Hh), Beneath the Waters, 1998; Captain Howell's (Hw) communications with Maj. Gen A.A. Humphreys and William D. Duke, 1870; Communications on Obstructions Cleared from Bayou Teche by Daniel M. Kinsbury (Kn), 1870-1871; C. Bradford Mitchell, "The LytleHoldcamper List," (LH) 1975; Morris Raphael (Ra), The Battle in the Bayou Country, 1994; Survey map by Captain E.B. Trinidad (Tr) in 1868; and Way's (Way) Packet Directory, 1994. 


\section{Postbellum Era}

The years following the end of the Civil War were difficult for southern Louisiana. The economy throughout the state had been destroyed; plantations and farms, railroads and levees, businesses and homes all had been affected by the war, both physically and financially. The emancipation of slaves, which accompanied Federal victory, not only destroyed the plantation labor system, but it also eliminated the millions of dollars planters in the region had invested in human bondage. According to one authority, abolition swept away one-third of Louisiana's wealth (Winters 1963:428). The postbellum period proved to be an era of recovery for the entire state.

The political boundaries of the proposed project area changed in 1868, when Iberia Parish was created from portions of southern St. Martin and western St. Mary Parishes. As early as 1848, legislative measures and surveys were taken to organize this new parish. The groundwork was not completed before the Civil War, which, of course, further delayed the process. Finally, on October 30, 1868, the Louisiana State Legislature approved the establishment of Iberia Parish (Bergerie 1962:22-23; Pourciaux 1985:6).

The period immediately after the close of the war was one of tremendous political and social unrest. Violence against freedmen erupted throughout the state. Even the pro-Union politicians, who had occupied Louisiana until the end of the war, were opposed to African American suffrage. Consequently, at the end of the War, freedmen still did not have the right to vote. When pro-Union politicians lost control of the state at the end of the Civil War, the extension of suffrage to African Americans became a Republican cause, partially as a means to regain power. A state constitutional convention for this purpose was called in July, 1866, in New Orleans. The session never opened, however, because of a lack of a quorum. During the delay, a riot broke out between freedmen and the police. As a result, 3 white Republicans and 34 African Americans were killed and 136 reconstructionists were wounded. This violence, one incident of many against African Americans, drew U.S. Congressional attention to the status of freedmen in the South. Congress acted to secure the civil and political rights for African Americans.

The first of the Military Reconstruction Acts passed Congress in early 1867. Louisiana and Texas were named the fifth military district, and they were placed under the command of General Philip Sheridan. The act permitted voter registration of only those adult males who could swear that they never had aided voluntarily and abetted the Confederacy. Because of the resultant disenfranchisement of most Confederate sympathizers, and consequently most Louisiana voters, Democratic victory in the 1868 presidential election depended on keeping African American voters from exercising the franchise. This was of particular concern in St. Mary Parish, where newly enfranchised blacks outnumbered whites three to one. The infamous Knights of the White Camelia, which was listed officially as a subversive organization by the United States government, was organized in 1867 in Franklin, Louisiana (just downstream of the project area), primarily to keep freedmen away from the polls. Judge Alcibiades de Blanc served as the chairman of the group, which claimed to be a "strictly peaceful, law abiding and loyal order; as much so as Freemasons or Odd Fellows" (Brown 1970).

Despite this claim, however, the intent of the organization was similar to that of the $\mathrm{Ku}$ Klux Klan. They sought to intimidate African Americans away from the polls, out of newlyelected office and solidify white dominance through fear. To this end, councils formed rapidly all over Louisiana. By the end of the decade, there were 10 councils and 800 Knights of the White Camelia in St. Mary Parish alone. Members of these councils were armed, reportedly, "for the protection of white people against lawlessness and violence, riots and blood shed" (Brown 1970).

The Knights of the White Camelia also threatened white, Northern "carpetbaggers." Republican rule in parish government, often by these Northern immigrants, spurred further violence in St. Mary Parish. Locals directed tremendous hostility toward the Northerners, who were widely blamed for all racial tensions: 
... the Negroes and white people of the parish would have been harmonious and friendly, had it not been for about a half a dozen carpetbaggers and scalawags who organized and stirred up hell in our midst (Brown 1970).

Daniel Dennet, a local journalist, suggested in 1869 that the "carpetbaggers" were responsible for all the problems of the area:

\begin{abstract}
The white people and conservative Colored people have every reason to take courage, and work for the over-throw of the carpetbagger, who, if elected, will overwhelm both planter and laborer in ruin. If we defeat them, we hope to see a good degree of peace, prosperity, and good feeling between the two races in this state. In no part of the world is the Colored race treated better or more kindly than in Louisiana. We want peace in this state, and we wish to give no encouragement to disturbers of the peace and mischief-makers of the carpet-bag persuasion (Brown 1970).
\end{abstract}

Notwithstanding this statement, and white popular belief, to the contrary, violence was frequent. Colonel Henry H. Pope, an African American from New York, settled in Franklin following the war, and he was elected sheriff in 1868. On October 18 of that very year, both Sheriff Pope and a newly-elected African American judge were murdered in the presence of Pope's family in O'Neill's Hotel in Franklin. The murderers were disguised, and the involvement of the Knights of the White Camelia could never be established.

Besides repairing the considerable physical damage to their holdings, sugar planters in the region who wished to resume operations had to deal for the first time with a labor supply that was not enslaved. Before labor could be hired, many obstacles had to be overcome, not the least of which was the complete lack of trust exhibited on both sides in the bargaining. Nevertheless, by 1869 , planters in the area were hiring workers at $\$ 15.00$ to $\$ 20.00$ a month for first class hands, which included a rudimentary cabin, scant rations, and fire wood (Sitterson 1953:244). As might be expected, the cabins, originally slave quarters, were insubstantial structures. Down the Teche from New Iberia, William T. Palfrey hired a carpenter to build some structures at Ricohoc in the 1850 s for $\$ 25.00$ each (Sitterson 1953:67).
The Civil War severely disrupted both the transportation system and the market for sugar. In 1869, when Bouchereau resumed the chronicle of the sugar crops that Champomier had written during the antebellum period, only a few plantations were operating along Bayou Teche. Several small planters in the Loreauville area switched from sugar to cotton cultivation. Not until the 1880s did the sugar growers of the Teche equal their output from the eve of the war. During these years, there was also a change in the old antebellum system whereby each plantation was designated a factory as well as a farm. The development of large processing plants made it uneconomical and unnecessary for each plantation to have its own sugar house. The Central Factory System evolved, virtually separating the cultivation of cane from the manufacturing of sugar. The renewed importance of the postbellum sugar industry to the region is reflected in the fact that a New Iberia newspaper of the period was called the Louisiana Sugar Bowl (Bergerie 1962:40-45; Bouchereau 1869-1876; Heitmann 1987).

Despite these changes to try to boost the productivity of the economically damaged plantations, the relationship between planters and slaves, now freedmen, had changed radically. Formerly successful planters had lost their cheap, abundant supply of labor and they were forced to pay workers in order to continue operations. In addition, despite their new status as freed persons, immediately following the war most former slaves remained in the agricultural fields of the South, both to stay near families and due to lack of industrial skills. Thus, the tenant farming land tenure system was born (Aiken 1978).

Under this tenure system, tenant farmers supplied their labor for the production of crops, which in the case of southern Louisiana included sugar, rice, and, in some areas, indigo. Planters, now functioning in their new roles as landlords, provided the land, seed crops, farm implements, and sometimes dwellings. They also extended a line of credit, either in the form of cash or commodities, from an inflated plantation commissary or store to the tenant farmers. As payment for their labor, the tenant farmers received a portion of the crops, usually 50 percent or less. In some few cases, the landlord paid the tenant farmer in cash for his portion of the crop. The 
proceeds, however, were never enough to allow the tenant farmer to pay off the debt he had accrued at the plantation store. This was a cyclical pattern between the landlord and the tenant farmer and it insured that the labor supply would remain on the plantation, and that, in the long term, the plantation would remain solvent. Only the planter profited as a result of this relationship.

\section{The 1890s and Beyond}

While the landlord/tenant system of production was fairly successful at the outset, some basic changes in agricultural techniques introduced during the early twentieth century led to its demise. These changes included the introduction of the tractor, the mechanization of the harvest, and improved weed control methods (Aiken 1978). The development of the tractor for use as an agricultural tool began during the nineteenth century; however, with the abundance of cheap labor, planters were at first reluctant to purchase expensive farm tractors. Over time, however, industrial employment in the North, combined with severe Jim Crow laws in the South, drew African Americans away from the fields and into the factories. As the labor supply dwindled, the use of tractors increased. The tractor provided a reliable source of power, and a larger scale of coverage (Aiken 1978).

In addition, several new methods mechanized the harvest of agricultural crops such as sugar, rice, and cotton. While at first they were not very reliable or widespread, new machines to cull cotton, cut cane and gather rice were quickly adapted for use with the new farm tractors. The coupling of these two technologies mitigated investments in labor and reduced harvest times dramatically. The net effect of this new technology was a dramatic reduction in the numbers of tenant farmers needed to sow, maintain, and harvest crops.

Significant advances in weed control were made during the early parts of the twentieth century. While weeding of crops previously had been done by hand, eventually new machines and herbicides became popular (Aiken 1978). Rotary hoes and weeders that could be attached to the tractor significantly reduced the time and labor needed to keep agricultural fields clear of weeds that so often choked crops and resulted in low productivity. In addition, major advances in chemistry aided in the development of several new herbicides that controlled weeds. Large scale weed control reduced planters' need for tenant labor and it also helped to boost crop productivity.

During the same period of centralization of the sugar factories, the lumber industry was beginning to develop along the Teche. Like the sugar industry, lumbering was assisted by an influx of northern capital:

.. you got people looking at government
surveys, and bam! It hits them right in the
middle of the eye, look at the cypress, look
at the timber, look at the lumber! And I'm
sure we must have had a hell of a lot of in-
flux of capital... like Williams and Patter-
son, or Hughes; Hughes is in Jeanerette.
Hughes is not a native of Louisiana, he's
some Yankee that saw a government survey.
That damn timber was there for $\$ 2.00$ an
acre, and he knew how to market It . .
(Goodwin et al. 1985).

Nineteenth century lumber mills, like the sugar factories, utilized steam engines for power, so the new lumber industry had need for individuals with knowledge of boilers, steam engines, and machinery maintenance. Larroque (Goodwin et al. 1985) believed that the skilled laborers who no longer could find employment in the sugar industry filled this need. This permitted rapid growth of the lumber industry, because the labor base in the region was pre-adapted to its technology.

The sugar and the lumber industries also prompted other industrial development in the region. Both encouraged the growth of local foundries to manufacture processing machinery. The sugar industry, in particular, needed local suppliers of machinery parts, since the mill rollers wore out and they had to be replaced on a regular basis. Antoine Moresi, a native of Switzerland, settled on Bayou Teche late in the antebellum period and he operated a small blacksmith and machine shop which repaired local sugar house equipment. By 1890, local demand for machinery and parts was so great that Moresi opened a foundry and machine shop that still is in operation today. Although the foundry initially was established to meet the 
needs of the sugar industry, similar machinery, and parts were utilized by sawmills. Like the lumber industry, the foundry was able to draw on a pool of skilled personnel who already had familiarity with sugar processing machinery, helping to insure the success of this industry.

The postbellum sugar and lumber industries also encouraged the expansion of regional transportation systems, since their continued growth was dependent on the efficient transport of processed goods. The New Orleans, Opelousas, and Great Western Railroad had been completed as far as Morgan City prior to the Civil War. Morgan's Louisiana and Texas Railroad resumed westward expansion of this line in the late 1870s. By 1879, tracks for this line had been laid through Franklin, Jeanerette, and New Iberia. Regular freight and passenger service began in November of that year.

The speed and reliability of rail service eventually resulted in a decline in the importance of river travel. Fewer steamboats operated on the Teche after the completion of Morgan's Line through the region. Steamboats increasingly were utilized on a charter basis, delivering supplies to and receiving outgoing products from local plantations. Thus, the bayou functioned primarily as a short-distance transportation corridor during the late nineteenth and early twentieth centuries. As such, it provided an alternative shipping route to the local roads, facilitating the transport of agricultural products and supplies between the plantations and factories of the centralized sugar industry.

All of these changes in farming methods and equipment led to a more streamlined plantation effort. Where once hundreds of workers were necessary for the successful operation of the plantation, now agricultural surpluses, and by extension profits, could be produced with fewer individuals. Consequently, the tenant farming land tenure system largely had collapsed by the end of the first half of the twentieth century.

By the turn of the century, further consolidation of farms and plantations had occurred in the project area, and the planting of cane had been separated from the manufacture of sugar (Figure 27). Shadyside, located at some distance downstream of the current study area along Bayou Teche, had emerged as a giant sugar processor. This firm controlled a series of plantations that in 1898 encompassed more than $2,023.5$ ha $(5,000 \mathrm{ac})$ of land, of which $1,214.1$ ha $(3,000 \mathrm{ac})$ were in cultivation. This acreage would increase during the twentieth century. A private tramway joined the different plantations; the railroad line used a locomotive and 60 cars to haul cane in the height of the harvesting season. At the Shadyside refinery, equipment included a Krajewski crusher, a six-roller mill, one $2.7 \mathrm{~m}(9 \mathrm{ft})$ and one $3.1 \mathrm{~m} \mathrm{(10} \mathrm{ft)} \mathrm{vacuum} \mathrm{pan,}$ ten centrifugals, a 150,000 pound double effect, the Deeming system of clarification, and numerous pumps and boilers (Glass 1898:71). In 1902, Shadyside manufactured more than $9,000,000$ pounds of sugar.

\section{The Twentieth Century}

The twentieth century was marked by major changes in the regional economy. Reliance on sugar cane agriculture decreased, while exploitation of mineral resources increased. Technological advances brought tremendous growth to the area salt mining operations, to the new petroleum industry, and even to sugar agriculture and refining. The Central Factory System now dominated the region, and it was quite successful; in 1893 Bouchereau remarked:

\footnotetext{
Gradually the cultivation of cane and the manufacture of sugar from it are becoming separate and distinct industries. Men of means invest their capital in equipping first class factories furnished with all the modern improvements that the genius of the inventor has produced; small planters pursue the cultivation on the general lines . . . . More sugar is now produced per acre than ever before (Bouchereau and Bouchereau 1874:xii-xiii).
}

A severe decline in sugar production occurred in the years after 1911, and in the 1920s, the sugar industry was confronted with extinction. Bad weather contributed to the troubles of the planter. In 1911, there were severe early frosts, and in 1912, floods damaged crops. Furthermore, plant disease, particularly mosaic, swept through the canefields with devastating effect. Another problem was the higher cost of labor, especially after the wartime economy offered better paying jobs to canefield workers. Prices for sugar were unusually low, and the new Democratic admini- 


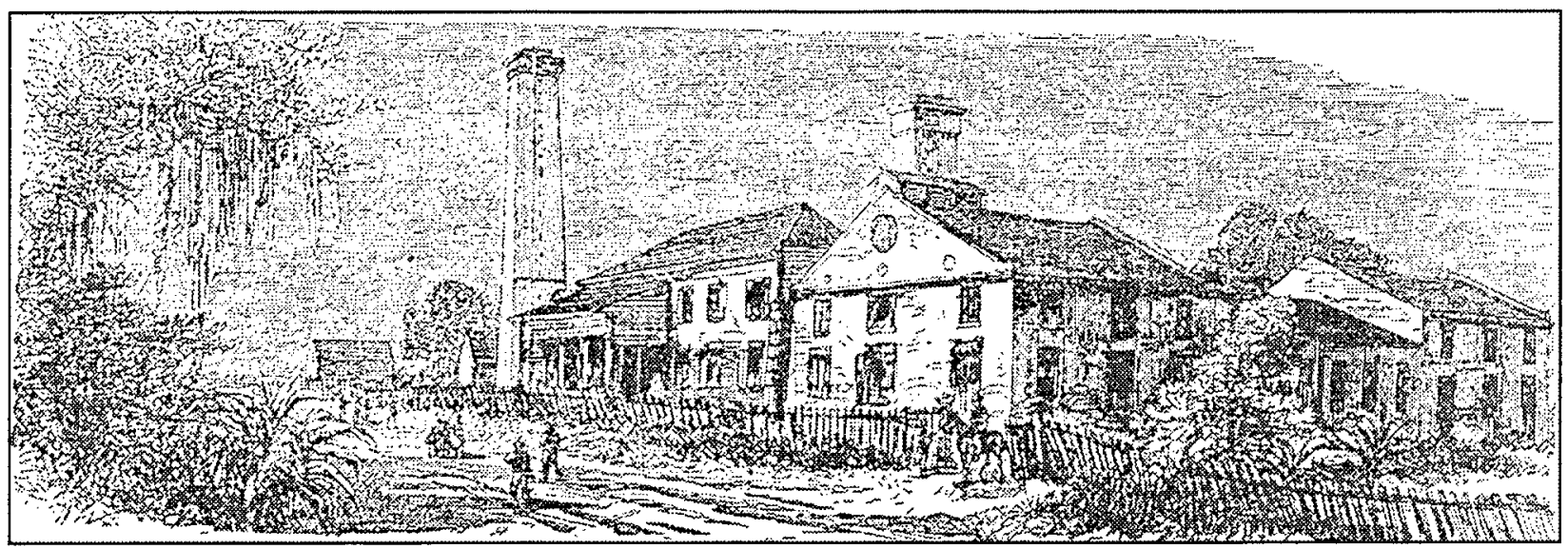

Figure 27. Harper's Weekly sketch of sugar houses along the Teche, ca. 1866. From Bergerie, They All Tasted Bayou Water.

stration of Woodrow Wilson in Washington, passed a bill that abolished the tariff on sugar.

World War I brightened the outlook of sugar planters temporarily. Congress repealed the free sugar bill, and an international shortage raised sugar prices to their highest levels since 1889 . Furthermore, in 1916, Louisiana planters produced a bountiful crop. Nevertheless, the federal government issued wartime controls that limited profits during the war.

After the removal of governmental controls, the sugar market entered a period of chaos. The expectation was that the price of sugar would rise on the world market. Instead, it collapsed and caught planters, manufacturers, and bankers by surprise. Louisiana sugar planters and manufacturers entered the 1920s in a severe depression from which many of them would not recover. This economic decline increased the movement toward consolidation of sugar factories, but at the same time it brought about a countermovement in the breakup of large cane plantations. Some plantations were abandoned, while others were subdivided into smaller holdings (Sitterson 1953:343-360).

Despite the problems of the early twentieth century, sugar cane cultivation has remained an important part of the area economy. Along the project reach, several sugar and syrup factories, or refineries, have been important influences on the Iberia Parish economy during the twentieth century. Among these Bayou Teche facilities, active and inactive, are the Vida Sugar Factory, Cajun Sugar, the Iberia Sugar Cooperative, and the Orange Grove Factory (Bergerie 1962:75;
Iberia Parish Development Board ca. 1948:18, 29-32, 132-147; Louisiana Planter \& Sugar Manufacturer Co. 1924:92, 1929:47).

New Iberia grew with manufacturing after the turn of the century. In 1903, the town housed several factories: the Trainor \& Sons sash and blind factory, the Bernard Wagon Factory, the Pharr lumber mill and planing factory, and the New Iberia Foundry and Machine Shop. Several sugar manufacturers, cotton gins, and rice mills flanked the Teche, and the first oil company opened an office along the Southern Pacific Railroad line. The growing commercial center even supported an opera house. The population had grown to 12,000 people, with enough residential diversity to warrant an African American Baptist church (Figure 28) (Sanborn Maps 1903:index).

Lumbering was an important industry in Iberia Parish during the latter half of the nineteenth century. The Timber Act of 1879 opened the cypress swamps of the Atchafalaya Basin, including the northeastern section of the parish, for sale (Norgress 1947). The Timber Act allowed the sale of the remaining unclaimed cypress stands for as little as 12.5 cents per acre (Norgress 1947). Innovations in the cypress lumber industry during the late 1800 s, such as the "overhead skidder," the "pull boat," the rotary saw, then the band saw, increased lumbering exploitation. The clearing of cypress stands in the basin between 1880 and 1920 progressed at a phenomenal rate (Gibson 1982). Lumber settlements, or mill towns, grew up near saw mill processing centers. "Portables" were communities established near harvest sites; they also 


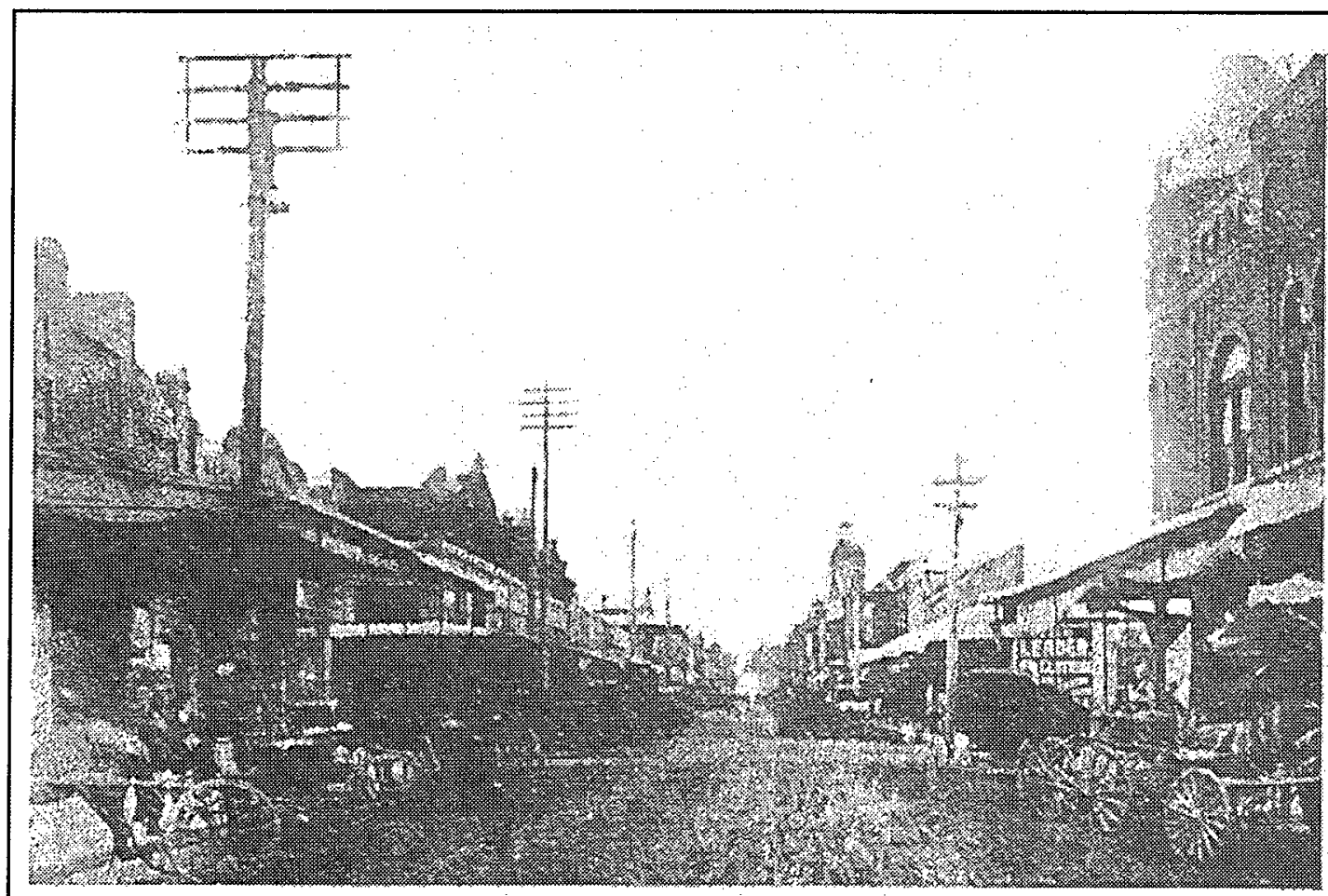

Main Street, New Iberia, 1910

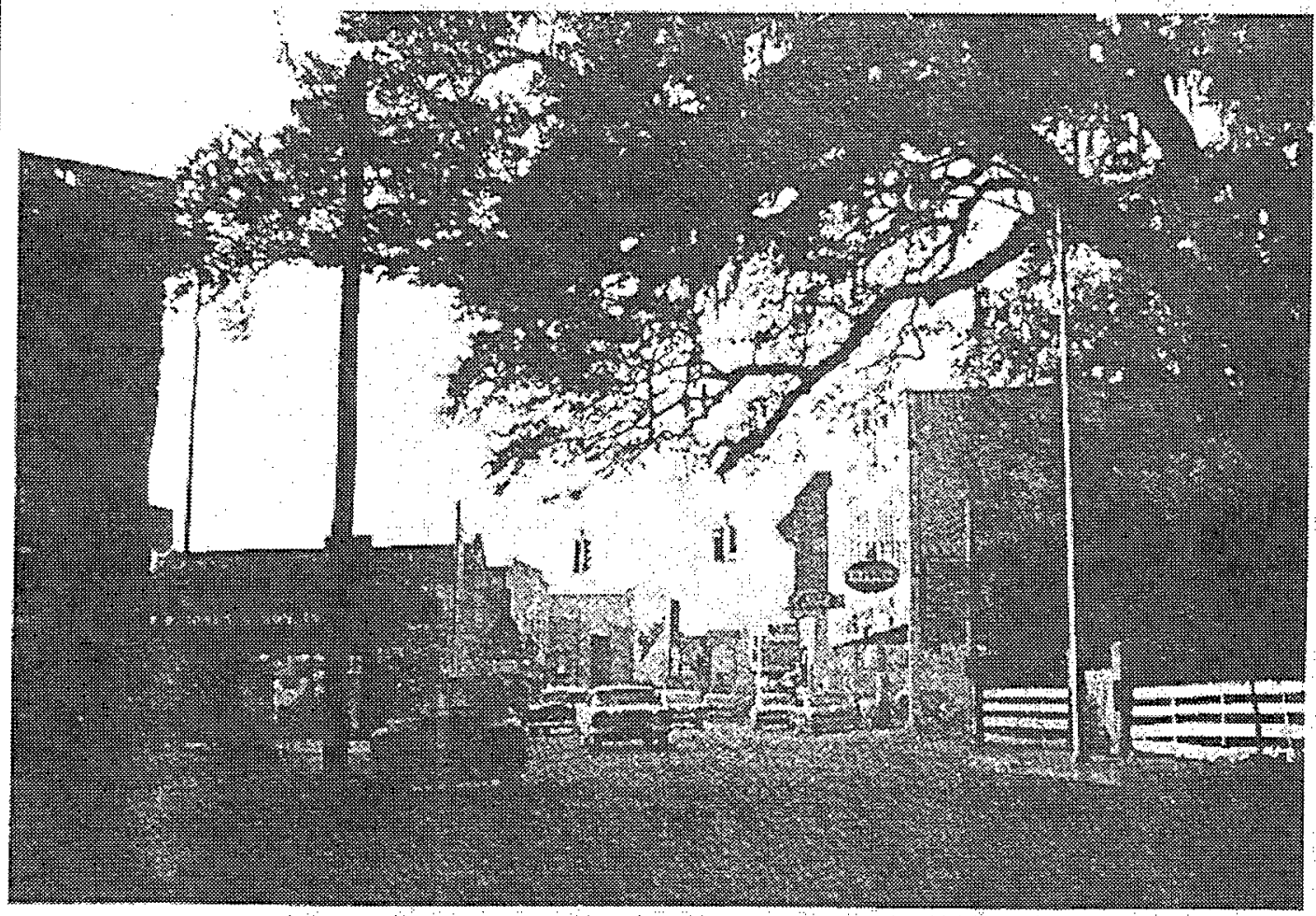

Main Streu, New Iberio, 1961

Figure 28. Main Street, New Iberia, 1910 and 1961, adapted from Bergerie, They All Tasted Bayou Water. 
were referred to as "skidder towns" (Roberts 1974). "Swampers" consisted of seasonal laborers who worked the temporary lumber camps of south Louisiana. The cypress industry, however, declined as rapidly as it developed. By the middle of the 1920s, the great cypress stands in the Atchafalaya Basin were being exhausted and the mills were forced to close (Roberts 1974). The cultural and ecological changes caused by the deforesting of the basin are still being felt. According to Comeaux (1978), the innovative swamper culture degenerated with the passage of the great lumbering era.

Another major twentieth century change occurred in the southern end of the parish. In 1911, Ned Mcllhenny secured purchase options to over 30,353 ha $(75,000 \mathrm{ac})$ of land on Marsh Island in order to establish a large wildlife refuge, primarily to protect wintering ducks and geese. Charles Ward helped McIlhenny with the property acquisitions, but the chief financial support came from New York philanthropist Mrs. Russell Sage. In 1916, Mrs. Sage transferred the title to most of Marsh Island to the Russell Sage Foundation. Following the death of Mrs. Sage in 1918, her executors transferred the remainder of Marsh Island to the Russell Sage Foundation in 1920. The latter donated the Marsh Island property to the State of Louisiana in November of 1920, with restrictions governing its management and use, along with the stipulation that failure to adhere to the transfer agreement would result in the return of the land title to the Foundation.

By 1933, the Marsh Island Wild Life Refuge totaled 32,093 ha $(79,300 \mathrm{ac})$, and it encompassed the entire island. Within the next decade, the acreage was renamed the Russell Sage Wildlife Preserve in honor of its chief benefactor. Today, the property contains approximately 33,185 ha $(82,000 \mathrm{ac})$, predominantly brackish marsh, and it is known as the Russell Sage Foundation State Wildlife Refuge, or more commonly as the Marsh Island Wildlife Refuge (Glenn et al. 1947:1:267270; Iberia Parish Library n.d.:20-21; Jones 1965:1, 5; LDC 1933:255, 257; 1943:93; LWLFC 1953:106). Since the early 1950s, oil and natural gas wells have harvested millions of gallons of energy from reserves found on Marsh and Avery Islands, currently employing as many workers as the Tabasco plant and salt works combined.
Modern petroleum exploration brought great changes to the physical landscape of Marsh Island, Avery Island, and Iberia Parish in general. By the early 1960s, flotation canals traversed the islands in order to facilitate the barge transport of oilfield equipment. In 1963, the Louisiana Wild Life and Fisheries Commission described this "most perplexing problem" presented by "the management of mineral operations . . . in a manner consistent with the wildlife preservation and development program" as follows:

\begin{abstract}
Although seismograph operations have been relatively simple to handle, the prevention of damage to valuable wild-life marshes is difficult during the period that the mineral lessee begins development. The general approach used by most mineral operators along the Louisiana Coast in reaching drilling sites has been to dredge out a flotation canal some eight feet in depth and sixty to eighty feet in width and barge in the drilling rig and other heavy equipment. Such operations as this not only cause direct losses of many acres of marsh in the excavation of the canals, but also creates water management problems involving drainage of the marshes, increased tidal flow, and some rapid changes in water levels and salinities. This generally tends to reduce the quality of the marsh for wildlife by bringing about changes in vegetative types, particularly in the brackish areas (LWLFC 1963:176).
\end{abstract}

This problem continues to plague Louisiana today, especially in the coastal regions where oil is, once again, king. While less-damaging roads have been constructed to drilling sites in some coastal areas, water-bound wells, such as Avery Island and rigs in the Gulf of Mexico, generally are too isolated for that method of entry. State officials hoped to lessen the potential damage by:

... requiring the lessees to confine their ac-
cess as much as possible to existing water-
ways. When it is necessary to cross a marsh
area with a drilling rig it will be specified that
the canal will be completely enclosed by
means of a levee constructed from material
dredged out of the access channel (LWLFC
1963:176-177).

Although sporadic mineral exploration began in neighboring St. Martin and St. Mary Parishes during the late nineteenth century, it wasn't until the 1920s that major exploitation of Iberia 
Parish petroleum resources began. By the early 1960 s, flotation canals traversed the marshlands to facilitate the barge transport of oilfield equipment, and New Iberia had become a center for petroleum industry suppliers. The oil boom brought a flood of new residents to the parish, and to New Iberia in particular. Along with the boom, came a shift in the economic focus of the parish. Oil dominated industrial concerns between the 1920s and the 1980s. In 1964, Iberia Parish produced over 11,500,000 barrels of oil. Today, several pipelines and petroleum facilities are located through or near the project area, above and below the town of New Iberia (Draughon et al. 1998:4; DTC Cartographic Services 1992; Hansen 1971:301-302). When the bottom fell out of the oil market in the late 1980 s, the wildcatters moved to new jobs, again changing the demographic base of the parish.

Several new factories opened in the parish during the last half of the twentieth century, including the Jeanrette underwear mill and a vibrant ship building industry, Universal Fabricators. Morton Salt Company now mines the Avery salt works, although the Tabasco Hot Sauce Factory employs almost as many workers. According to the 1996 Census Bureau reports, over 71,000 residents live in Iberia Parish, roughly half in New Iberia. Parish-wide about 25,000 are part of the labor force. Over 5,000 residents work in industrial jobs, the largest employment category.
Only 381 farms remain in the parish, most of them consist of very large cane cultivators, and only 985 Iberia Parish residents work on a farm (Agriculture Census, Iberia Parish 1997:1; Economic Census, Iberia Parish 1992-96:1; Regional Economic Information, Iberia Parish 1996-97:1).

\section{Summary}

There's a saying along the Teche, that once a person has "tasted bayou water," they must ever return to the area. New Iberia Parish natives, now working in fishing, tourism, support industries, as well as new manufacturing efforts, still live by the rhythm of the cane season. The largest event in the parish, which brings thousands of tourists, is the Sugar Cane Festival, still held in the fall when the cane is ready for harvest. While the area containing the proposed project items has remained part of an agricultural region from earliest tenure to the present, the reality of economic life in Iberia Parish no longer turns on the fate of the crops. Though many of the land tracts included within the study area were surveyed under colonial rule and farmed throughout the nineteenth and twentieth centuries, agriculture no longer determines the seasons. Now, New Iberia serves as the economic heart of the parish, where half the residents live, and employment opportunities are most plentiful. Sugar cane is but one commodity amongst many found along the banks of the Teche. 


\section{ChAPTER V}

\section{Previous Investigations}

I ntroduction

This chapter provides background information regarding previous archeological and architectural investigations completed within the vicinity of the proposed Bayou Teche project area. The collection and synthesis of this information ensures that any previously recorded cultural resources situated in or within the immediate vicinity of the proposed project reach are relocated during fieldwork. In addition, it provides data on the nature and distribution of those previously recorded cultural resources situated in or near the Areas of Potential Effect.

The chapter is divided into five sections. The first section contains a review of previous cultural resources surveys completed within $8 \mathrm{~km}(5 \mathrm{mi})$ of the proposed Bayou Teche project reach. The second section presents a review of previously recorded archeological sites located within 1.6 $\mathrm{km}(1 \mathrm{mi})$ of the proposed project area. A description of properties currently listed on the $\mathrm{Na}$ tional Register of Historic Places and situated within $1.6 \mathrm{~km}(1 \mathrm{mi})$ of the proposed project reach is presented next. This discussion is followed by a description of those previously recorded standing structures located within $1.6 \mathrm{~km}$ ( $1 \mathrm{mi})$ of the proposed Bayou Teche project corridor. Finally, the last section includes a brief review of A Database of Louisiana Shipwrecks (Clune and Wheeler 1991). The information contained in this chapter was based on a background search of data currently on file at the Louisiana Department of Culture, Recreation and Tourism, Office of Cultural Development, Divi- sions of Archaeology and Historic Preservation, in Baton Rouge.

The relatively broad $8 \mathrm{~km}(5 \mathrm{mi})$ and $1.6 \mathrm{~km}$ (1 mi) ranges for studying cultural resources surveys and archeological sites were chosen to maximize the understanding of the quantity and quality of data previously gathered on known cultural resources in the region encompassing the proposed project reach. A $1.6 \mathrm{~km}(1 \mathrm{mi})$ range was selected for National Register properties, previously recorded standing structures, and shipwrecks in order to limit this search to the area immediately surrounding the Areas of Potential Effect.

\section{Previously Conducted Cultural Resources Surveys Situated within $8 \mathrm{~km}(5 \mathrm{mi})$ of the Currently Proposed Bayou Teche Project Items}

As a result of this research, 10 previously completed cultural resources surveys and archeological inventories were identified within 8 $\mathrm{km}(5 \mathrm{mi})$ of the proposed Bayou Teche project reach (Table 10). These investigations resulted in the identification and recordation of 65 archeological sites. While two previously recorded sites (16IB101 and 16IB155) were identified within $1.6 \mathrm{~km}(1 \mathrm{mi})$ of the project reach, neither is positioned within the proposed Areas of Potential Effect. The 10 surveys examined are presented below in chronological order by parish; those surveys extending through more than one parish are discussed at the end of the section under the heading of Multiple Parishes. 
Table 10. Previously Completed Cultural Resources Surveys Conducted Within $8 \mathrm{~km}(5 \mathrm{mi})$ of the Currently Proposed Project Area

\begin{tabular}{|c|c|c|c|c|}
\hline \begin{tabular}{|l|} 
FIELD \\
DATE \\
\end{tabular} & $\begin{array}{l}\text { REPORT } \\
\text { NUMBER }\end{array}$ & TITLE/AUTHOR & $\begin{array}{l}\text { INVESTIGATION } \\
\text { METHODS }\end{array}$ & RESULTS AND RECOMMENDATIONS \\
\hline \multicolumn{5}{|c|}{ IBERIA PARISH } \\
\hline 1975 & $22-217$ & $\begin{array}{l}\text { Archaeological Assessment of the } \\
\text { Proposed Sewerage System, } \\
\text { Loreauville, Louisiana (Marshall } \\
\text { 1975) }\end{array}$ & $\begin{array}{l}\text { Records review, } \\
\text { windshield survey, and } \\
\text { pedestrian survey }\end{array}$ & $\begin{array}{l}\text { Relocated previously recorded Site } 16 \mathrm{IB} 40 \text {, as } \\
\text { well as identified a prehistoric mound (Mound } \\
\text { B) for which no site number was reported. } \\
\text { While no statement as to the significance of } \\
\text { Site } 16 \mathrm{IB} 40 \text { or Mound B was made, it was } \\
\text { reported that Mound B would be impacted by } \\
\text { proposed construction and additional testing } \\
\text { was recommended. Site } 16 \mathrm{IB} 40 \text { reportedly } \\
\text { would not be impacted and no additional } \\
\text { testing was recommended. } \\
\end{array}$ \\
\hline 1976 & $22-210$ & $\begin{array}{l}\text { Letter report. Subject: Cultural } \\
\text { Resources Survey of Nelson Canal } \\
\text { Bridge and Approaches, Route LA } \\
\text { 3195, Iberia Parish, Louisiana (Rivet } \\
\text { 1976) }\end{array}$ & $\begin{array}{l}\text { Records review and } \\
\text { pedestrian survey }\end{array}$ & $\begin{array}{l}\text { No cultural resources were identified; no } \\
\text { additional testing was recommended. }\end{array}$ \\
\hline 1977 & $22-489$ & $\begin{array}{l}\text { Letter report. Subject: Cultural } \\
\text { Resources Survey of Two Proposed } \\
\text { Project Areas Located Along Route } \\
\text { LA 14, Iberia Parish, Louisiana (Rivet } \\
\text { 1977) }\end{array}$ & $\begin{array}{l}\text { Records review and } \\
\text { pedestrian survey }\end{array}$ & $\begin{array}{l}\text { No cultural resources were identified; no } \\
\text { additional testing was recommended. }\end{array}$ \\
\hline 1978 & $22-364$ & \begin{tabular}{|l|} 
Facility Plan Environmental \\
Assessment for Proposed Wastewater \\
Treatment Works to Serve Sewerage \\
District No. 3 of Iberia Parish, \\
Louisiana (Simmons J. Barry \& \\
Associates 1978) \\
\end{tabular} & $\begin{array}{l}\text { Records review, } \\
\text { windshield survey, and } \\
\text { pedestrian survey }\end{array}$ & $\begin{array}{l}\text { No cultural resources were identified; no } \\
\text { additional testing was recommended. }\end{array}$ \\
\hline 1983 & $22-905$ & $\begin{array}{l}\text { Archaeological Excavations at } \\
\text { Shadows-on-the-Teche } 1983 \text { (Smith } \\
\text { 1983) }\end{array}$ & $\begin{array}{l}\text { Records review and unit } \\
\text { excavation }\end{array}$ & $\begin{array}{l}\text { Excavations of three areas resulted in the } \\
\text { collection of some } 3,600 \text { artifacts dating from } \\
\text { an undetermined prehistoric period through } \\
\text { the } 20^{\text {th }} \text { century. The Shadows-on-the-Teche } \\
\text { property (Site 16IB155) had previously been } \\
\text { listed on the National Register of Historic } \\
\text { Places in } 1974 \text {; however, additional testing of } \\
\text { the site was recommended. }\end{array}$ \\
\hline \multicolumn{5}{|c|}{ ST. MARTIN PARISH } \\
\hline $\begin{array}{l}\text { Not } \\
\text { reported }\end{array}$ & $22-2132$ & $\begin{array}{l}\text { National Register Evaluation of the } \\
\text { Keystone Lock and Dam, St. Martin } \\
\text { Parish, Louisiana (Bergstresser et al. } \\
\text { 1997) }\end{array}$ & $\begin{array}{l}\text { Records review and } \\
\text { pedestrian survey }\end{array}$ & $\begin{array}{l}\text { Following review, the Keystone Lock and } \\
\text { Dam was found to be potentially eligible for } \\
\text { listing to the national Register and } \\
\text { preservation of the lock was recommended. If } \\
\text { preservation was no possible, it was } \\
\text { recommended that a Level } 1 \text { Historic } \\
\text { American Engineering Record recording of } \\
\text { the lock and dam be completed. }\end{array}$ \\
\hline \multicolumn{5}{|c|}{ MULTIPLE PARISHES } \\
\hline 1975 & $22-105$ & $\begin{array}{l}\text { Archeological Survey of Bayou Teche, } \\
\text { Vermilion River, and Freshwater } \\
\text { Bayou, South Central Louisiana } \\
\text { (Gibson 1975) }\end{array}$ & $\begin{array}{l}\text { Records review and } \\
\text { boat survey augmented } \\
\text { by limited pedestrian } \\
\text { survey and subsurface } \\
\text { investigations with the } \\
\text { use of a trowel }\end{array}$ & $\begin{array}{l}\text { Identified } 37 \text { sites of which a total of } 16 \\
\text { (16IB2, 16LY5 - 16LY7, 16LY14, 16LY23, } \\
\text { 16LY61, 16SL2, 16SM13, 16SM15, 16SM17, } \\
\text { 16SM20,16SM24, 16VM7, 16VM11, and } \\
\text { 16VM127) were assessed as potentially } \\
\text { significant. Various recommendations, } \\
\text { ranging from no additional testing to } \\
\text { mitigation, were reported for each of the } 38 \\
\text { identified sites. }\end{array}$ \\
\hline 1979 & $22-1151$ & $\begin{array}{l}\text { A Cultural Resources Survey of the } \\
\text { Proposed Erath-Weeks Island } \\
\text { Pipeline Route (Swanson 1979) }\end{array}$ & $\begin{array}{l}\text { Records review, } \\
\text { helicopter survey, and } \\
\text { pedestrian survey }\end{array}$ & $\begin{array}{l}\text { Identified an historic period materials scatter } \\
\text { for which no site number was reported. While } \\
\text { this locus was not specifically assessed it was } \\
\text { recommended that the scatter be avoided } \\
\text { during proposed construction. If avoidance } \\
\text { was not possible, additional testing of the } \\
\text { locus was recommended. }\end{array}$ \\
\hline
\end{tabular}


Table 10 , continued

\begin{tabular}{|c|c|c|c|c|}
\hline $\begin{array}{l}\text { FIELD } \\
\text { DATE }\end{array}$ & $\begin{array}{l}\text { REPORT } \\
\text { NUMBER } \\
\end{array}$ & TITLE/AUTHOR & $\begin{array}{l}\text { INVESTIGATION } \\
\text { METHODS }\end{array}$ & RESULTS AND RECOMMENDATIONS \\
\hline ca. 1985 & $22-1053$ & $\begin{array}{l}\text { An Archeological and Historic Sites } \\
\text { lmventony of Bayou Teche between } \\
\text { Franklin and Jeanerette. Louisiana } \\
\text { (Goodwin et al. 1985) }\end{array}$ & $\begin{array}{l}\text { Records review, } \\
\text { informant interviews, } \\
\text { pedestrian survey, } \\
\text { shovel testing, and } \\
\text { remote testing }\end{array}$ & $\begin{array}{l}\text { Relocated Sites 16SMY2, 16SMY12, } \\
\text { 16SMY13, and 16IB49, as well as identifying } \\
\text { Sites 16SMYI71 - 16SMY177, 16IB56, and } \\
\text { 16IB57. Of these, Sites 16SMY12,16SMY13, } \\
\text { 16SMY171, 16SMY174, 16SMY176, 16IB49, } \\
\text { and 16IB57 were assessed as potentially } \\
\text { significant and additional testing was } \\
\text { recommended. Site 16SMY2 was not } \\
\text { assessed; however, additional testing was } \\
\text { recommended. The remaining five sites were } \\
\text { assessed as not significant and no additional } \\
\text { testing was recommended. }\end{array}$ \\
\hline 1990 & $22-1494$ & $\begin{array}{l}\text { Level II Archeological lnvestigation } \\
\text { of the Proposed Erath-South Section } \\
\text { 28 Pipeline Right-of-Way, Vermilion, } \\
\text { Iberia, and St. Martin Parishes, } \\
\text { Louisiana (Goodwin et al. 1990) }\end{array}$ & $\begin{array}{l}\text { Records review, } \\
\text { pedestrian survey, } \\
\text { shovel testing, auger } \\
\text { testing, probing, and } \\
\text { unit excavation }\end{array}$ & $\begin{array}{l}\text { Identified or relocated Sites 16VM141, } \\
\text { 16VM142,16IB63,16IB 114-16IB119, } \\
\text { 16SM7, 16SM9,16SM13, and 16SM28- } \\
\text { 16SM30. In addition, three loci for which no } \\
\text { site numbers were assigned also were noted. } \\
\text { Of these, only Site 16SM7 was assessed as } \\
\text { potentially significant; however, it was } \\
\text { reported that the proposed pipeline had been } \\
\text { rerouted around the site and no additional } \\
\text { testing was recommended. The remaining sites } \\
\text { and loci were assessed as not significant and } \\
\text { no additional testing was recommended. }\end{array}$ \\
\hline
\end{tabular}

\section{Iberia Parish}

On September 27, 1975, Richard Marshall conducted a Phase I cultural resources survey and archeological inventory of several areas located in the vicinity of the town of Loreauville, in Iberia Parish, Louisiana; this survey was conducted prior to construction of a proposed sewerage treatment system (Marshall 1975). The survey was conducted at the request of Sellers, Dubroc and Associates, Inc., of Lafayette, Louisiana, and it consisted of the inspection of the proposed treatment plant location, the proposed point of effluent discharge location, and the proposed area of minority concentration location. In addition, portions of the proposed sewer line right-of-way also were examined for cultural deposits. Marshall (1975) did not report the overall size of the examined project items.

Windshield survey augmented by limited pedestrian survey resulted in the relocation of previously recorded Site 16IB40, which had been described as a prehistoric period mound. In addition, Marshall (1975) identified a second prehistoric mound located an unspecified distance to the north of Site 16IB40. Marshall (1975) designated this as "Mound B;" however, no official site number was reported for the second mound. Site 16IB40 was described as con- taining a conical mound measuring 18.3 to 21.3 $\mathrm{m}(60$ to $70 \mathrm{ft}$ ) in diameter by 2.1 to $2.4 \mathrm{~m} \mathrm{(7} \mathrm{to}$ $8 \mathrm{ft}$ ) in height. No cultural material was recovered from the site. Marshall (1975) did not assess the significance of Site 16IB40; however, he reported that the proposed sewer line construction would not impact the site. No additional testing of the proposed project area was recommended.

Mound B was described as a flat-topped mound that measured approximately 13.7 to $15.2 \mathrm{~m}$ (45 to $50 \mathrm{ft}$ ) in diameter by approximately $0.9 \mathrm{~m}(3 \mathrm{ft})$ in height. Pedestrian survey of the mound and the surrounding area, failed to produce any cultural material. While Mound B was not assessed, Marshall (1975) reported that the proposed sewer line would impact the southern toe of the feature, and that avoidance of the mound was recommended. If avoidance was not possible, Marshall (1975) recommended additional testing within this portion of the Area of Potential Effect. Other than the two mounds, no additional cultural resources were identified. No additional testing of the proposed sewerage system project items was recommended. Neither Site 16IB40 nor Mound B is located within 1.6 $\mathrm{km}(1 \mathrm{mi})$ of the currently proposed project items. 
On October 26, 1976, the State of Louisiana, Department of Highways, conducted a Phase I cultural resources survey and archeological inventory of a section of Louisiana Highway 3195 within portions of Sections 22 and 38 of Township 12S, Range 7E. This survey was conducted prior to the proposed construction of the Nelson Canal Bridge over Bayou Teche (Rivet 1976). Pedestrian survey of the proposed Nelson Canal Bridge and its approaches failed to identify any cultural resources; no additional testing of the proposed project corridor was recommended.

On September 8, 1977, the State of Louisiana, Department of Highways, conducted a Phase I cultural resources survey and archeological inventory of the proposed Bayou Carlin Bridge project area and the proposed Delcambre - Junction Louisiana Highway 676 project area; both of project items were located within of Iberia Parish, Louisiana (Rivet 1977). While the nature of the proposed projects was not reported, Rivet (1977) stated that pedestrian survey of each area failed to identify any cultural material. No additional testing of the proposed Bayou Carlin bridge project item or the proposed Delcambre - Junction Louisiana Highway 676 project corridor was recommended.

During January, 1978, an unspecified party conducted a Phase I cultural resources survey and archeological inventory for Iberia Sewerage District No. 3, which included the west central portion of Iberia Parish (Simmons J. Barry \& Associates 1978). The overall size of the proposed project area was not reported, and windshield survey augmented by pedestrian survey of selected portions of the proposed project item failed to identify any cultural resources. No recommendations regarding additional testing of the proposed project area were reported (Simmons J. Barry \& Associates, Inc. 1978).

During June and July, 1983, the Center for Archaeology at Tulane University conducted archeological investigations at Shadows-on-theTeche (Site 16IB155), a historic period plantation located within irregular Section 50 of Township 12S, Range 6E, in Iberia Parish, Louisiana (Smith 1983). The Shadows-on-the Teche property had been listed previously on the $\mathrm{Na}$ tional Register of Historic Places in 1974 and it was described as a townhouse that was constructed for David Weeks between 1831 and 1834. Smith (1983) reported that the 1983 exca- vations were conducted in the vicinity of the former kitchen and slave quarters areas, as well as in an area believed to house a privy. The investigation was conducted at the request of the National Trust for Historic Preservation.

Smith (1983) reported that unit excavation within the former kitchen area failed to identify the kitchen wall foundation; however, subsurface features consisting of stained soil mixed with brick and mortar fragments were identified. It was suggested that the walls had been dismantled and that these features represented the refilled wall trenches of the west and east kitchen wall foundations. A single unit measuring $0.8 \times 2.3 \mathrm{ft}(2.5 \times 7.5 \mathrm{ft})$ in size was excavated in the vicinity of the former slave quarters in order to determine if a cultural midden was present. Smith (1983) noted that numerous artifacts were recovered from the single excavation unit indicating that a midden was present in the former slave quarters area. Finally, a single unit of unspecified size was excavated in the area believed to contain the privy. Smith (1983) stated that excavation failed to identify the privy; however, numerous artifacts dating from the late nineteenth to the early twentieth century were recovered. These artifacts apparently represented the remains of a dump.

Smith (1983) reported that the 1983 excavations resulted in the collection of 3,343 historic period artifacts, including ceramic sherds, glass shards, brick fragments, iron and various other metal fragments, coins, gun flint fragments, buttons, pipe fragments, jewelry, marbles, coal, shell, bone fragments, and plastic. In addition, 106 prehistoric period ceramic sherds, including the types Bell Plain, Mississippi Plain, Addis Plain, Maddox Engraved, Leland Incised, and Mazique Incised, also were recovered. Based on the excavations conducted at Site 16IB155, Smith (1983) was able to identify three separate occupations within the site. The first consisted of a prehistoric period occupation that dated from A.D. 1000 to European Contact. The second occupation dated from the historic period, i.e., from 1772 and ca. 1831 to 1834 . This date range was based on the recovery of French gun flints and a French coin dated 1772. The final occupation associated with Shadowson-the-Teche dated from ca. 1831 to the present. 
Since Site 16IB155 (Shadows-on-theTeche) had been listed on the National Register of Historic Places, Smith (1983) did not assess the significance of the site. He did, however, recommend additional testing of the archeological deposits within the site area. Site 16IB155 is located within $1.6 \mathrm{~km}(1 \mathrm{mi})$ of the currently proposed Bayou Teche project items and it is discussed in more detail below in the section on previously recorded sites, as well as in the section on structures currently listed on the National Register of Historic Places.

\section{St. Martin Parish}

Prentice Thomas and Associates, Inc., of Fort Walton Beach, Florida, conducted an evaluatory assessment of the Keystone Lock and Dam at an unspecified date prior to December, 1997 (Bergstresser et al. 1997). The Keystone Lock and Dam, constructed during the early twentieth century, was situated along Bayou Teche, between the towns of Martinville and New Iberia, Louisiana. Following both background research and pedestrian survey of the lock and dam area, Bergstresser et al. (1997), assessed the Keystone Lock and Dam as significant applying the National Register of Historic Places criteria for evaluation (36 CFR 60.4 [ad]). The authors recommended that the lock and dam be preserved; however, if preservation was not possible, it was recommended that a Level I Historic American Engineering Record be completed of the structure. The Keystone Lock and Dam is not located within $1.6 \mathrm{~km}(1 \mathrm{mi})$ of the current project items.

\section{Multiple Parishes}

During 1975, The University of Southwestern Louisiana, in Lafayette, conducted a Phase I cultural resources survey and archeological inventory of portions of Bayou Teche, the Vermilion River, and Freshwater Bayou, prior to implementing an unspecified amount of operation and maintenance work (Gibson 1975). The survey was conducted at the request of the U.S. Army Corps of Engineers, New Orleans District, and it extended through portions of Iberia, Lafayette, St. Landry, St. Martin, and Vermilion Parishes, Louisiana. Gibson examined a $100 \mathrm{~m}$ (328.1 ft) wide corridor that extended along both banks of Bayou Teche, the Vermilion River, and
Freshwater Bayou. Overall, the project area measured approximately $352 \mathrm{~km}(218.7 \mathrm{mi})$ in length and it included the entire lengths of the aforementioned waterways. A bankline survey augmented by limited pedestrian survey and minimal subsurface testing resulted in the identification of 37 sites (Sites 16IB2, 16LY5 16LY7, 16LY10, 16LY12 - 16LY14, 16LY22 16LY26, 16LY28, 16LY29, 16LY55, 16LY61 16LY63, 16SL2, 16SL31, 16SM6, 16SM13, 16SM15, 16SM17, 16SM18, 16SM21, 16SM24 - 16SM26, 16VM7, 16VM11, 16VM15, 16VM16, 16VM127, and the Indian Mound Road Site).

Gibson (1975) reported that 33 of the sites (Sites 16IB2, 16LY5, 16LY7, 16LY10, 16LY12 - 16LY14, 16LY22 - 16LY26, 16LY28, 16LY29, 16LY55, 16LY63, 16SL2, 16SL31, 16SM6, 16SM13, 16SM15, 16SM17, 16SM18, 16SM21, 16SM24 - 16SM26, 16VM7, 16VM11, 16VM15, 16VM16, 16VM127, and the Indian Mound Road Site) contained prehistoric period components, while Sites 16LY6, 16LY14, 16LY61, and 16LY62 provided evidence of both prehistoric and historic period occupations. A total of 16 sites (16IB2, 16LY5 16LY7, 16LY14, 16LY23, 16LY61, 16SL2, 16SM20, 16SM13, 16SM15, 16SM17, 16SM24, $16 \mathrm{VM} 7,16 \mathrm{VM} 11$, and $16 \mathrm{VM} 127$ ) were assessed as potentially significant and avoidance (or additional testing if avoidance was not possible) was recommended. The remaining sites were assessed as not significant; however, it was recommended that an archeologist monitor all construction activities conducted within the vicinity of these 21 sites. None of these sites were located within $1.6 \mathrm{~km}(1 \mathrm{mi})$ of the currently proposed project items.

During May of 1979, New World Research, Inc., conducted a Phase I cultural resources survey and archeological inventory of the proposed Erath-Weeks Island pipeline right-of-way located within portions of Vermilion and Iberia Parishes, Louisiana (Swanson 1979). The survey was conducted at the request of EMANCO, Inc., of Houston, Texas. While the proposed pipeline corridor measured approximately $34 \mathrm{~km}(21 \mathrm{mi})$ in length, the width of the proposed right-of-way was not reported. A helicopter survey of the proposed pipeline right-of-way augmented by limited pedestrian survey resulted in the identifi- 
cation of a single cultural resource (Site \#1) for which no official site number was assigned.

Site \#1 was described as a surface scatter of historic period artifacts located within a plowed field situated along the east bank of Jack's Coulee in Iberia Parish, Louisiana. Overall, the locus measured approximately $90 \times 165 \mathrm{~m}(295.3 \times$ $541.3 \mathrm{ft}$ ) in size. Pedestrian survey throughout the site area resulted in the collection of 31 historic period ceramic sherds, 9 glass shards, 2 nail fragments, and 1 piece of brick. Swanson (1979) suggests that Site \#1 represented the remains of a nineteenth century occupation. While the locus was not assessed, Swanson (1979) recommended that Site \#1 be avoided during the proposed pipeline construction. If avoidance of the site was not possible, then additional testing of Site \#1 was recommended. Site \#1 is not situated within $1.6 \mathrm{~km}(1 \mathrm{mi})$ of the currently proposed project items.

Prior to June, 1985, R. Christopher Goodwin \& Associates, Inc., conducted a Phase I cultural resources survey and archeological inventory along the right and left descending banks of Bayou Teche between River Mile 45.5, located $3.2 \mathrm{~km}(2 \mathrm{mi})$ north of the town of Jeanerette, in Iberia Parish, Louisiana, and River Mile 15.5, i.e., in the vicinity of the town of Franklin, in St. Mary Parish, Louisiana (Goodwin et al. 1985). The survey was conducted at the request of Louisiana Department of Culture, Recreation and Tourism, Office of Cultural Development, Division of Archaeology, Baton Rouge, Louisiana. The overall length of the Bayou Teche portion of the project corridor measured $48.9 \mathrm{~km}$ (30 mi); however, the width of the Bayou Teche study area was not reported specifically. Records review, informant interviews, pedestrian survey, shovel testing, and remote testing resulted in the identification of Sites 16IB56, 16IB57, and 16SMY171 16SMY177. In addition, previously recorded Sites 16IB49, 16SMY2, 16SMY12, and 16SMY13 were relocated.

Of the 13 sites reported, four (Sites 16SMY12, 16SMY13, 16SMY172, and 16SMY176) were described as prehistoric period occupations, while Sites 16IB49, 16IB56, 16IB57, 16SMY171, 16SMY173, 16SMY174, 16SMY175, and 16SMY177 dated from the historic period. The remaining site (16SMY2) was multi-component and it produced evidence of both prehistoric and historic period occupations. Additional testing was recommended for sites 16IB49, 16IB57, 16SMY12, 16SMY13, 17SMY171, 16SMY174, and 16SMY176. While Site 16SMY2 was not assessed, additional testing of the site was recommended. The remaining five sites (16IB56, 16SMY172, 16SMY173, 16SMY175, and 16SMY177) were assessed as not significant and no additional testing of these cultural resources was recommended. None of the aforementioned 13 sites are located within $1.6 \mathrm{~km}(1 \mathrm{mi})$ of the currently proposed project areas.

Between March and June, 1990, R. Christopher Goodwin \& Associates, Inc., conducted a Phase I cultural resources survey and archeological inventory of the proposed Southern Natural Gas Erath-South Section 28 Pipeline right-of-way located within portion of Vermilion, Iberia, and St. Martin Parishes, Louisiana (Goodwin et al. 1990). The survey was conducted at the request of Southern Natural Gas Company of Birmingham, Alabama, and it included testing of a right-of-way corridor that measured $45.1 \mathrm{~km}(28 \mathrm{mi})$ in length and $18.3 \mathrm{~m}$ $(60 \mathrm{ft})$ in width. Pedestrian survey augmented by shovel testing and limited auger testing, probing, and unit excavation resulted in the identification of Sites 16IB63, 16IB114 - 16IB119, 16SM7, 16SM9, 16SM13, 16SM28 - 16SM30, $16 \mathrm{VM} 141$, and 16VM142. In addition three nonsite cultural resource loci (Locus 3, Locus 4, and Locus 14), were identified.

A majority $(\mathrm{n}=11)$ of these sites (16IB114 - 16IB116, 16IB118, 16IB119, 16SM9, 16SM13, 16SM28 - 16SM30, and 16VM141) were described as historic period materials scatters that dated from the late nineteenth to early twentieth century. Site 16IB117, as well as Loci 3,4 , and 14 , all were described as abandoned railroad grades. Site $16 \mathrm{SM} 7$ was described as a prehistoric period artifact scatter, while the remaining two sites (16IB63 and 16VM142) produced evidence of both prehistoric and historic period components. Only one of these sites (16SM7) was assessed as potentially significant; however, Goodwin et al. (1990) reported that the proposed pipeline had been rerouted around the site and no additional testing of the site was recommended. The remaining sites and loci (Sites 
16IB63, 16IB114 - 16IB119, 16SM9, 16SM13, 16SM28 - 16SM30, 16VM141, Loci 4, 4, and 14) were assessed as not significant and no additional testing of these cultural resources was recommended. Sites 16IB63, 16IB114 16IB119, 16SM7, 16SM9, 16SM13, 16SM28 16SM30, 16VM141, 16VM142 and Loci 3, 4, and 14 are not situated within $1.6 \mathrm{~km}(1 \mathrm{mi})$ of the currently proposed Bayou Teche project items.

\section{Previously Recorded Archeological Sites Lo- cated within $1.6 \mathrm{~km}(1 \mathrm{mi})$ of the Currently Proposed Bayou Teche Project Areas}

Only two previously recorded archeological sites (16IB101 and 16IB155) were identified within $1.6 \mathrm{~km}(1 \mathrm{mi})$ of the currently proposed Bayou Teche project items (Table 11). Site 16IB101 was described as a prehistoric period mound, while Site 16IB155 includes a prehistoric period materials scatter and an historic period component associated with the Shadowson-the-Teche residential structure. This standing structure and the associated outbuildings were listed on the National Register of Historic Places in 1974. Each site is discussed in turn below.

Site 16IB101 was recorded in 1966 by Simmons (no first name reported). The site was described as the base of a small prehistoric period earthen mound situated within irregular Section 38 of Township 12S, Range 6E. While the size of Site 16IB101 was not reported, a pedestrian survey resulted in the collection of an unspecified quantity and type of prehistoric period artifacts. Site 16IB101 was characterized as a Poverty Point occupation. No recommenda- tions concerning additional testing of Site 16IB101 were reported.

Site 16IB155 (Shadows-on-the-Teche) was recorded officially by Ann Smith in 1983 (Smith 1983); however, the site area, which includes the Shadows-on-the-Teche residential structure and its associated outbuildings, was listed on the National Register of Historic Places in 1974. Shadows-on-the-Teche was constructed within irregular Section 50 of Township 12S, Range 6E. This two-and-one-half story brick structure, its two associated outbuildings, and the surrounding grounds, which contain the subsurface remains of several non-extant structures, including the former kitchen and slave quarters, dates from ca. 1831. While the overall size of Site 16IB155 was not reported, a parcel measuring 1 ha $(2.5 \mathrm{ac})$ in extent, which includes the Shadows-on-the-Teche site, was listed on the National Register of Historic Places. In addition, excavations conducted at Site 16IB155 by Smith (1983) resulted in the collection of a variety of historic period artifacts as well as 106 prehistoric period ceramic sherds. While the cultural affiliation of the prehistoric component of Site 16IB155 was undetermined, Smith (1983) suggested that at least two historic period occupations were contained within the site. The first dated from 1772 to ca. 1831 to 1834 and its age was based on the recovery of French gun flints and a French coin dated 1772. The second historic period occupation was associated with the Shadows-on-the-Teche and it dated from ca. 1831 to the present. As previously noted, Site 16IB155 (Shadows-on-the-Teche) had been listed on the National Register of Historic Places

Table 11. Previously Recorded Sites Located within $1.6 \mathrm{~km}(1 \mathrm{mi})$ of the Currently Proposed Project Area.

\begin{tabular}{|c|c|c|c|c|c|c|}
\hline $\begin{array}{c}\text { SITE } \\
\text { NUMBER }\end{array}$ & $\begin{array}{c}\text { USGS 7.5' } \\
\text { QUADRANGLE }\end{array}$ & $\begin{array}{c}\text { SITE } \\
\text { DESCRIPTION }\end{array}$ & $\begin{array}{l}\text { CULTURAL } \\
\text { AFFILIATION }\end{array}$ & $\begin{array}{c}\text { FIELD } \\
\text { METHODOLOGY }\end{array}$ & $\begin{array}{c}\text { NRHP } \\
\text { ELIGIBILITY }\end{array}$ & $\begin{array}{l}\text { RECORDED } \\
\text { BY }\end{array}$ \\
\hline 16 IB 101 & New Iberia South & $\begin{array}{l}\text { Remains of prehistoric } \\
\text { period mound }\end{array}$ & Poverty Point & Pedestrian survey & Not assessed & Simmons 1966 \\
\hline $\begin{array}{l}16 \text { IB } 155 \\
\text { (Shadows- } \\
\text { on-the } \\
\text { Teche) }\end{array}$ & New Iberia North & $\begin{array}{l}\text { Standing mansion and } \\
\text { associated outbuildings } \\
\text { as well as a prehistoric } \\
\text { and historic period } \\
\text { artifact scatter }\end{array}$ & $\begin{array}{l}\text { Undetermined } \\
\text { prehistoric period; } \\
19^{\text {th }} \text { century } \\
\text { historic period }\end{array}$ & $\begin{array}{l}\text { Pedestrian survey, } \\
\text { probing, auger } \\
\text { testing, and unit } \\
\text { excavation }\end{array}$ & Listed in 1974 & $\begin{array}{l}\text { Beauregard } \\
1972 ; \text { Smith } \\
1983\end{array}$ \\
\hline
\end{tabular}


and thus, Smith (1983) did not report on the significance of the site; however, she did recommend additional testing of the archeological deposits associated with Site 16IB155. Shadowson-the-Teche will be discussed below in the section on National Register standing structures located within the vicinity of the proposed project corridor.

\section{National Register of Historic Places Listed Properties which are Located within $1.6 \mathrm{~km}$ (1 mi) of the Currently Proposed Bayou Teche Project Areas}

A total of 17 National Register of Historic Places listed structures and a single National
Register district were identified within $1.6 \mathrm{~km}$ (1 mi) of the currently proposed Bayou Teche project reach (Table 12). These properties consisted of 6 residential structures, 6 commercial buildings, 2 churches, 2 industrial structures, and a school building. The single historic period district included 71 structures, a majority of which $(n=68)$ were described as residential in nature. All of these properties were situated within the town of New Iberia, Iberia Parish, Louisiana, and they are discussed chronologically below, i.e., as they were listed in the National Register of Historic Places. The discussions below are based on information contained in the National Register nomination forms.

Table 12. Historic Standing Structures Located within $1.6 \mathrm{~km}(1 \mathrm{mi})$ of the Currently Proposed Bayou Teche Study Area that Appear in the National Register of Historic Places.

\begin{tabular}{|c|c|c|c|c|c|c|}
\hline NAME & $\begin{array}{c}\text { NRHP } \\
\text { NUMBER } \\
\end{array}$ & $\begin{array}{c}\text { USGS 7.5' } \\
\text { QUADRANGLE } \\
\end{array}$ & ADDRESS & TYPE & \begin{tabular}{|c|} 
ARCHITECTURAL \\
STYLE \\
\end{tabular} & $\begin{array}{c}\text { YEAR } \\
\text { LISTED } \\
\end{array}$ \\
\hline \begin{tabular}{|l} 
Shadows-on-the \\
Teche (Site \\
16IB155) \\
\end{tabular} & 72000553 & New Iberia North & East Main St., New Iberia, LA & Residential & Creole/Greek Revival & 1974 \\
\hline $\begin{array}{l}\text { Episcopal Church } \\
\text { of the Epiphany } \\
\end{array}$ & 77000670 & New Iberia North & $\begin{array}{l}303 \text { West Main St., New Iberia, } \\
\text { LA }\end{array}$ & Religious & Gothic Revival & 1977 \\
\hline The Magnolias & 79001065 & New lberia North & 115 Jefferson St., New Iberia, LA & Residential & Creole & 1979 \\
\hline Steamboat House & 79001066 & New Iberia North & 623 East Main St., New Iberia, LA & Residential & None specified & 1979 \\
\hline Mintmere & 80001730 & New Iberia South & $\begin{array}{l}1400 \text { East Main St., New Iberia, } \\
\text { LA }\end{array}$ & Residential & Greek Revival & 1980 \\
\hline Conrad Rice Mill & 82000437 & New Iberia South & 307 Ann St., New Iberia, LA & \begin{tabular}{|l|} 
Industrial \\
\end{tabular} & None specified & 1982 \\
\hline $\begin{array}{l}\text { East Main Street } \\
\text { Historic District }\end{array}$ & 83000507 & $\begin{array}{l}\text { New Iberia North } \\
\text { and New tberia } \\
\text { South }\end{array}$ & $\begin{array}{l}\text { Portions of East Main, Lee, Ann, } \\
\text { and Philip Streets, New tberia, LA }\end{array}$ & $\begin{array}{l}\text { Residential, } \\
\text { Religious, } \\
\text { Commercial, } \\
\text { and } \\
\text { Governmental }\end{array}$ & $\begin{array}{l}\text { Creole, Greek Revival, } \\
\text { Georgian Revival, } \\
\text { Romanesque, Eastlake, } \\
\text { Queen Ann Revival, } \\
\text { Colonial Revival, and } \\
\text { Bungalow } \\
\end{array}$ & 1983 \\
\hline Pascal Building & 85003054 & New Iberia North & 223 East Main St., New Iberia, LA & Commercial & Italianate & 1985 \\
\hline \begin{tabular}{|l} 
Santiago \\
Lamperez House
\end{tabular} & 85003147 & New Iberia North & 203 Front St., New Iberia, LA & Residential & Creole & 1985 \\
\hline $\begin{array}{l}\text { Southern Pacific } \\
\text { Railroad Depot }\end{array}$ & 87002082 & New Iberia North & $\begin{array}{l}402 \text { West Washington St, New } \\
\text { Iberia, LA }\end{array}$ & Commercial & Romanesque Revival & 1987 \\
\hline $\begin{array}{l}\text { Andrew Romero } \\
\text { House }\end{array}$ & 89001855 & New Iberia North & 310 Marie St., New Iberia, LA & Residential & Moderne & 1989 \\
\hline \begin{tabular}{|l|} 
First United \\
Methodist Church
\end{tabular} & 89002002 & New Iberia North & 119 Jefferson St., New Iberia, LA & Religious & Italian Renaissance & 1989 \\
\hline $\begin{array}{l}\text { New Iberia High } \\
\text { School }\end{array}$ & 94000236 & New Iberia South & 415 Center St., New lberia, LA & Educational & Neo-Classical & 1994 \\
\hline $\begin{array}{l}\text { Auguste Erath } \\
\text { Building } \\
\end{array}$ & 95001156 & New lberia North & $\begin{array}{l}\text { 333-335 West St. Peter St., New } \\
\text { Iberia, LA }\end{array}$ & Commercial & $\begin{array}{l}\text { Greek } \\
\text { Revival/Italianate }\end{array}$ & 1995 \\
\hline $\begin{array}{l}\text { Wormser's } \\
\text { Department Store } \\
\end{array}$ & 95001158 & New Iberia North & 112 East Main St., New Iberia, LA & Commercial & Modernistic & 1995 \\
\hline $\begin{array}{l}\text { John R. Taylor } \\
\text { Drugstore }\end{array}$ & 95001563 & New Iberia North & $\begin{array}{l}145 \text { West Main St., New Iberia, } \\
\text { LA }\end{array}$ & Commercial & Romanesque Revival & 1996 \\
\hline $\begin{array}{l}\text { Lutzenberger } \\
\text { Foundry \& Pattern } \\
\text { Shop Building } \\
\end{array}$ & 98000228 & New Iberia North & 502/505 Jane St., New Iberia, LA & Industrial & None specified & 1998 \\
\hline $\begin{array}{l}\text { Evangeline } \\
\text { Theater }\end{array}$ & 99000234 & New Iberia North & 129 East Main St., New Iberia, LA & Commercial & Art Deco & 1999 \\
\hline
\end{tabular}


Shadows-on-the-Teche

Shadows-on-the-Teche is located at 317 East Main Street, within the town of New Iberia, Iberia Parish, Louisiana; the property was placed on the National Register of Historic Places on October 5, 1974. Data collected from the National Register nomination form suggests that, the Shadows-on-the-Teche structure was constructed between 1831 to 1834 as a townhouse for David Weeks. The building was described as a Creole/Greek Revival style structure constructed of locally fired, coral colored brick. It was reported that during the Civil War, Shadows-on-the-Teche was utilized as a headquarters by the Union Army.

Shadows-on-the-Teche was assessed as architecturally significant on a national level. The structure represented an excellent example of a Louisiana planters house. It also was noted that the Shadows-on-the-Teche represented a style of architecture of which many examples had been lost or poorly restored.

\section{The Episcopal Church of the Epiphany}

The Episcopal Church of the Epiphany is located at 303 West Main Street, within the town of New Iberia, Iberia Parish, Louisiana. The church, placed on the National Register of Historic Places on April 29, 1977, was constructed of locally manufactured brick between 1857 and 1858. In addition, the structure was renovated and a rear wing was added in 1959. Architecturally, the church structure was built in the Gothic Revival style.

The Episcopal Church of the Epiphany was assessed as significant on a local level; it is the oldest church building within Iberia Parish. In addition, information contained within the National Register nomination form suggests that the church building once was utilized by Union soldiers during 1863 as a barracks, a prison, a stable, and a hospital. The Episcopal Church of the Epiphany structure represents a good example of a mid-nineteenth century, brick Gothic Revival church.

\section{The Magnolias}

The Magnolias is a Creole style residence constructed at 115 Jefferson Street, within the town of New Iberia, Iberia Parish, Louisiana. The structure was listed in the National Register of Historic Places on December 6, 1979. Information contained on the National Register nomination form suggests that The Magnolias was constructed in 1852, and it represented an unusual adaptation of the Creole style. This twostory structure was four bays wide with two front doors constructed on each floor. In addition, the doors were straddled by a large, one bay wide portico. This structure represented an exemplary model of how the Creole plan could be combined with the Greek Revival style.

\section{The Steamboat House}

The Steamboat House was built at 623 East Main Street in the town of New Iberia, Iberia Parish, Louisiana. The residential structure was placed on the National Register of Historic Places on July 27, 1979 and it was considered significant on a state level. The National Register documents the construction of the building in 1896 , and it was described as a one-story, raised house based on a central hall plan; however, no particular architectural style was noted. The structure was extensively remodeled during the 1940s; however, it was undergoing restoration to its original state at the time of its nomination to the National Register.

The Steamboat House also was considered to be significant because of its association with two political figures. The builder of the house, John Emmer, was the mayor of New Iberia from 1889 to 1891 . In addition, the Steamboat House was reportedly owned by Dr. Paul Cyr from 1937 until his death in 1946. Dr. Cyr served as Louisiana's Lieutenant-Governor under Huey Long from 1928 to 1932 . Finally, the Steamboat House, once restoration was completed, would represent of one of the most elaborate late Victorian houses found in the town of New Iberia.

\section{Mintmere}

Mintmere was described as a Greek Revival style plantation house located at 1400 East Main Street, within the town of New Iberia, Iberia Parish, Louisiana. The residence was placed on the National Register of Historic Places on June 6, 1980. Mintmere was constructed ca. 1845 , and the floor plan utilized a central hall with double rooms positioned to either side. In addition, two wings at the rear of the structure formed a large, three-sided, galleried court. 
Mintmere was assessed as significant based on the presence of a rear galleried court, which was thought to be unique within the state of Louisiana. Finally, Mintmere represents a large and complex example of a Greek Revival style plantation house.

\section{Conrad Rice Mill}

The Conrad Rice Mill was placed on the National Register of Historic Places on November 10, 1982. The industrial structure was situated at 307 Ann Street, within the town of New Iberia, Iberia Parish, Louisiana. The Conrad Rice Mill apparently was constructed in three stages beginning in 1914 and concluding in 1930. The mill was constructed from a pair of two- to three-story, frame and metal structures. In addition, the rice mill still was in operation and utilizing much of its original equipment at the time of its nomination (1982).

The Conrad Rice Mill was considered to be significant at the local level for the role it played in the production of rice in Iberia Parish. According to the National Register nomination form, prior to the construction of the mill, locally grown rice had to be shipped to New Orleans for processing. In addition, the Conrad Rice Mill was the only rice mill still in existence within the parish. The mill also was significant at the state level because of the rotating shaft and belt drive system used to operate the milling machines. While this shaft and belt drive system (where a central rotating shaft powered many separate machines) was very common throughout the nineteenth and early twentieth century, less than one percent of all factories in the United States still operate by this system.

\section{East Main Street Historic District}

The East Main Street Historic District is located within the town of New Iberia, Iberia Parish, Louisiana, and it includes portions of East Main, Lee, Ann, and Philip Streets. The historic district was placed on the National Register of Historic Places on July 28, 1983. According to the National Register nomination form, 71 structures are included within the boundaries of the East Main Street Historic District; however, 14 of these buildings were described as non-contributing elements. A majority of the contributing structures $(n=54)$ were de- scribed as residential. The remaining three contributing elements included a synagogue, a post office, and a bank. Architectural styles represented within this historic district included Creole/Greek Revival, Georgian Revival, Romanesque, Eastlake, Queen Anne Revival, Colonial Revival, and bungalow.

The National Register nomination form notes that only 2 of the 57 buildings which contribute to the East Main Street Historic District predate the Civil War. Of these, one is Shadowson-the-Teche, which was previously listed on the National Register in 1974. At least four buildings dated from 1865 to 1889 , while 30 structures were constructed from 1890 to 1910 . The remaining 21 contributing elements were built sometime between 1911 and 1933. In addition to Shadows-on-the-Teche, one other building includsd within the East Main Street Historic District (Steamboat House) had been previously listed on the National Register of Historic Places. According to the National Register nomination form, the East Main Street Historic District was considered significant at the local level in the area of architecture.

\section{Pascal Building}

The Pascal Building was placed on the National Register of Historic Places on November 21,1985 . The structure was located at 223 East Main Street, within the town of New Iberia, Iberia Parish, Louisiana. The Pascal Building was a commercial structure constructed in 1898 in the Italianate style. This brick, two-story structure had been altered significantly from its original state; however, the National Register nomination form notes that the structure had been restored to portray its original appearance. The Pascal Building was considered to be architecturally significant on the local level as one of the best remaining examples of a late nineteenth to early twentieth century commercial building within the town of New Iberia.

\section{Santiago Lamperez House}

The Santiago Lamperez House was constructed at 203 Front Street and within the town of New Iberia, Iberia Parish, Louisiana. The structure was placed on the National Register of Historic Places on October 17, 1985. The Santiago Lamperez House was constructed ca. 1843, 
as a four room Creole style cottage with bousilage walls. In addition, the original siding, beams, ceiling boards, doors, door surrounds, and mantles all were beaded. The Santiago Lamperez House was considered to be significant at the local level and it represented an excellent example of a Creole cottage within the parish. This distinction reportedly was based upon the structures bousilage construction and the large amount of beading present associated with the original woodwork.

\section{Southern Pacific Railroad Depot}

The Southern Pacific Railroad Depot was placed on the National Register of Historic Places on November 30, 1987. The building was constructed at 402 West Washington Street and within the town of New Iberia, Iberia Parish, Louisiana. The Southern Pacific Railroad Depot, which dated from ca. 1900 , was described as a one-story brick structure with Romanesque Revival details. The depot contained two waiting rooms separated by a ticket office. The Southern Pacific Railroad Depot was considered to be significant at the state level in the area of transportation. This depot represented one of the few remaining resources associated with the peak of railroad development in Louisiana. Information contained on the National Register nomination form suggests that between 1880 to 1910 over $6,437.2 \mathrm{~km}(4,000 \mathrm{mi})$ of railroad track was constructed in Louisiana; before that point less than $804.7 \mathrm{~km}(500 \mathrm{mi})$ of track had been constructed within the state.

\section{Andrew Romero House}

The Andrew Romero House was described as a two-story plaster-over-concrete block residence constructed in the Moderne style; it was constructed in 1937. The structure, located at 310 Marie Street within the town of New Iberia, Iberia Parish, Louisiana, was placed on the $\mathrm{Na}-$ tional Register of Historic Places on October 30, 1989. The Andrew Romero House was considered to be locally significant in the area of architecture. The building, the only structure within the context of New Iberia originally designed to reflect the style of the Modern Movement, contains an Art Nouveau style staircase that was believed to be unique in this portion of the state.

\section{First United Methodist Church}

The First United Methodist Church was situated at 119 Jefferson Street, within the town of New Iberia, Iberia Parish, Louisiana. The church structure, placed on the National Register of Historic Places on November 16, 1989, originally was constructed in 1891 , but it was extensively remodeled following a fire in 1907 . The structure was described as a one-story stuccoover-masonry building representative of the Italian Renaissance style. In addition, the structure also contained a two-story bell tower constructed at one of its front corners. The First United Methodist Church was considered to be locally significant in the area of architecture; it represents the only Italian Renaissance style structure remaining within Iberia Parish.

\section{New Iberia High School}

The New Iberia High School was situated at 415 Center Street, within the town of New Iberia, Iberia Parish, Louisiana. The structure was placed on the National Register of Historic Places on March 17, 1994. The New Iberia High School consisted of a three-story, Neo-Classical style, masonry structure constructed in 1926, however, two-story additions were added to either side of the building in 1939. The New Iberia High School was considered to be locally significant in the area of architecture. The building was a landmark among the early twentieth century structures built in New Iberia. Finally, the New Iberia High School was the only remaining example of a Neo-Classical style building within Iberia Parish, Louisiana.

\section{Auguste Erath Building}

The Auguste Erath Building was situated within the town New Iberia, Iberia Parish, Louisiana, at 333 - 335 West St. Peter Street. The structure, described as a commercial/residential building, was placed on the National Register of Historic Places on October 5, 1995. The Auguste Erath Building was built in 1884, and it can be described as a two-story brick building constructed in the Greek Revival/Italianate style. The structure originally housed the hardware business and residence of Auguste Erath, who was described as a prominent citizen of New Iberia, serving as the town's mayor from 1888 to 1889. The Auguste Erath Building was consid- 
ered to be significant at the local level in the area of architecture. The structure retained a high degree of architectural integrity making it one of the most significant of the few remaining late nineteenth century structures located within downtown New Iberia.

\section{Wormser's Department Store}

The Wormser's Department Store building was constructed at 112 East Main Street, within the town of New Iberia, Iberia Parish, Louisiana. The structure was placed on the National Register of Historic Places on October 5, 1995. The structure originally was constructed as three separate buildings during the late nineteenth to early twentieth century; however, the parting wall of the two western most buildings was removed in 1932 to create a commercial space. At this time, the facade of the structure was rebuilt in the Modernistic style. An adjacent structure, located to the east of the first two was incorporated into the Wormser's Department Store design in 1966. Wormser's Department Store was considered to be significant on a state level in the area of architecture, because the structure represented an excellent example of the Modernistic style in Louisiana.

\section{John R. Taylor Drugstore}

The John R. Taylor Drugstore building was located at 145 West Main Street, within the town of New Iberia, Iberia Parish, Louisiana. The structure was placed on the National Register of Historic Places on January 22, 1996. The drugstore was constructed between 1906 to 1907 , and it was described as a two-story commercial building constructed in the Romanesque Revival style. The John R. Taylor Drugstore was considered to be locally significant in the area of architecture. It was reported that the structure retained a high degree of architectural integrity making it one of the most significant of the few remaining late nineteenth to early twentieth century structures located within downtown New Iberia.

\section{Lutzenberger Foundry and Pattern Shop}

The Lutzenberger Foundry and Pattern Shop Building consisted of two structures located at 502 and 505 Jane Street, within the town of New Iberia, Iberia Parish, Louisiana.
The structures were placed on the National Register of Historic Places on March 12, 1998. The Lutzenberger Foundry consisted of a onestory brick structure that was constructed in 1882, while the Pattern Shop was constructed of corrugated tin between 1892 and 1895. Due to the lack of styling details, no architectural style was specified. The Lutzenberger Foundry and Pattern Shop Building were considered to be significant on a state level in the area of industry. These structures represented a rare, surviving example of cast iron foundry, an industry that is now largely defunct within the state.

\section{Evangeline Theater}

The Evangeline Theater was placed on the National Register of Historic Places on February 18, 1999. It was located at 129 East Main Street, within the town of New Iberia, Iberia Parish, Louisiana. The theater was constructed during the late nineteenth century to early twentieth century and it originally was utilized as a grocery store. The structure was converted to a movie theater in 1929, and it was renovated between 1939 to 1940 at which time an Art Deco style facade and lobby were added. The Evangeline Theater was considered to be significant at the state level in the area of architecture; the structure reportedly represents an excellent example of the Modernistic style within Louisiana.

Previously Recorded Standing Structures Located within $1.6 \mathrm{~km}(1 \mathrm{mi})$ of the Currently Proposed Bayou Teche Project Items

A review of the standing structure files located at the Louisiana Department of Culture, Recreation and Tourism, Office of Cultural Development, Division of Historic Preservation, resulted in the identification of 20 previously recorded standing structures $(23-383,23-398$ 23-404, 23-407, 23-441 -23-447, 23-454 - 23456 , and 23-472) within $1.6 \mathrm{~km}(1 \mathrm{mi})$ of the currently proposed Bayou Teche project items (Table 13). All of these structures were located within Iberia Parish, Louisiana.

Structures 23-383, 23-398 - 23-404, and 23407 were recorded in 1979 by Dewailly and Fontenot, while Structures 23-441 - 23-447, 23454 - 23-456, and 23-472 were recorded by Fontenot in 1979. The examined standing struc- 
ture forms for these buildings only provided a limited amount of data for each building. A total of 18 structures $(23-398$ - 23-404, 23-407, 23$441-23-447$, and 23-454 - 23-456) were classified as residential, while the two remaining structures (23-383 and 23-398) were described as church buildings. Standing structures 23-398, 23 $399,23-402,23-403,23-442,23-447$, and 23-455 were described as Victorian style residences, while structure 23-404 consisted of a Bungalow style residence. Structure 23-407 was characterized as a Masion Acadienne style residence. Structure 23-445 was constructed in the Double Pen style, while Structure 23-454 was described as a Creole style residence. The architectural style associated with the remaining nine structures was not reported. Each of the buildings ranged in date of construction from ca. 1820 to ca. 1930.

Only one (Structure 23-442) of the 20 previously recorded structures identified within $1.6 \mathrm{~km}$ $(1 \mathrm{mi})$ of the proposed project items was assessed formally. Structure 23-442 (a Victorian style residence) was assessed as potentially significant; however, no recommendations concerning additional recordation of the structure were reported. None of the remaining 19 structures was assessed. In addition, none of these structures are listed on the National Register of Historic Places. No recommendations for additional architectural recordation were reported for the 20 identified standing structures.

Table 13. Previously Recorded Standing Structures Located within $1.6 \mathrm{~km}$ (1 mi) of the Currently Proposed Project Area.

\begin{tabular}{|c|c|c|c|c|c|c|}
\hline $\begin{array}{c}\text { STRUCTURE } \\
\text { NUMBER/NAME } \\
\end{array}$ & $\begin{array}{c}\text { USGS 7.5' } \\
\text { QUADRANGLE }\end{array}$ & $\begin{array}{c}\text { CONSTRUCTION } \\
\text { DATE }\end{array}$ & TYPE & STYLE & $\begin{array}{c}\text { NRHP } \\
\text { ELIGIBILITY }\end{array}$ & $\begin{array}{c}\text { RECORDED } \\
\text { BY } \\
\end{array}$ \\
\hline \multicolumn{7}{|c|}{ IBERIA PARISH } \\
\hline 23-383 & Jeanerette & ca. $1900-1920$ & Church & None reported & Not assessed & $\begin{array}{l}\text { Dewailly and } \\
\text { Fontenot } 1979\end{array}$ \\
\hline 23-398 & Jeanerette & ca. $1880-1910$ & Residential & $\begin{array}{l}\text { Victorian } \\
\text { cottage }\end{array}$ & Not assessed & $\begin{array}{l}\text { Dewailly and } \\
\text { Fontenot } 1979\end{array}$ \\
\hline $23-399$ & Jeanerette & ca. $1870-1900$ & Residential & Victorian & Not assessed & $\begin{array}{l}\text { Dewailly and } \\
\text { Fontenot } 1979\end{array}$ \\
\hline $23-400$ & Jeanerette & Not reported & Residential & None reported & Not assessed & $\begin{array}{l}\text { Dewailly and } \\
\text { Fontenot } 1979\end{array}$ \\
\hline $23-401$ & Jeanerette & 1900 & Residential & None reported & Not assessed & $\begin{array}{l}\text { Dewailly and } \\
\text { Fontenot } 1979\end{array}$ \\
\hline $23-402$ & New Iberia South & ca. $1870-1900$ & Residential & Victorian & Not assessed & $\begin{array}{l}\text { Dewailly and } \\
\text { Fontenot } 1979\end{array}$ \\
\hline $23-403$ & New Iberia South & ca. $1880-1910$ & Residential & Victorian & Not assessed & $\begin{array}{l}\text { Dewailly and } \\
\text { Fontenot } 1979\end{array}$ \\
\hline $23-404$ & New Iberia South & ca. $1910-1930$ & Residential & Bungalow & Not assessed & $\begin{array}{l}\text { Dewailly and } \\
\text { Fontenot } 1979\end{array}$ \\
\hline $23-407$ & New Iberia South & ca. $1890-1920$ & Residential & $\begin{array}{l}\text { Masion } \\
\text { Acadienne }\end{array}$ & Not assessed & $\begin{array}{l}\text { Dewailly and } \\
\text { Fontenot } 1979\end{array}$ \\
\hline $23-441$ & New Iberia North & ca. $1870-1900$ & Residential & None reported & Not assessed & Fontenot 1979 \\
\hline $23-442$ & New Iberia North & ca. $1820-1890$ & Residential & Victorian & $\begin{array}{l}\text { Potentially } \\
\text { significant }\end{array}$ & Fontenot 1979 \\
\hline $23-443$ & Loreauville & ca. $1890-1910$ & Residential & None reported & Not assessed & Fontenot 1979 \\
\hline $23-444$ & Loreauville & ca. $1870-1890$ & Residential & None reported & Not assessed & Fontenot 1979 \\
\hline $23-445$ & Loreauville & ca. $1890-1910$ & Residential & Double Pen & Not assessed & Fontenot 1979 \\
\hline $23-446$ & Loreauville & ca. $1900-1920$ & Residential & None reported & Not assessed & Fontenot 1979 \\
\hline $23-447$ & Loreauville & ca. $1870-1900$ & Residential & Victorian & Not assessed & Fontenot 1979 \\
\hline $23-454$ & Loreauville & ca. $1890-1920$ & Residential & Creole & Not assessed & Fontenot 1979 \\
\hline $23-455$ & Loreauville & ca. $1890-1910$ & Residential & Victorian & Not assessed & Fontenot 1979 \\
\hline $23-456$ & Loreauville & ca. $1840-1890$ & Residential & None reported & Not assessed & Fontenot 1979 \\
\hline $23-472$ & Loreauville & ca. $1890-1930$ & Church & None reported & Not assessed & Fontenot 1979 \\
\hline
\end{tabular}


Previously Recorded Shipwrecks Located within $1.6 \mathrm{~km}$ (1 mi) of the Currently Proposed Bayou Teche Project Areas

As a part of this review, a search of $A D a$ tabase of Louisiana Shipwrecks (Clune and Wheeler 1991) housed at the Louisiana Department of Culture, Recreation and Tourism, Office of Cultural Development, Division of Archaeology, was conducted. This examination identified seven vessels that may have sunk within 1.6 $\mathrm{km}(1 \mathrm{mi})$ of the currently proposed Bayou
Teche project reach. While the name of one of these boats was unknown, the remainder was listed as the Andrews, the Anna E., the E.J. Hart, the Frank Keeling, the Hart, and the Iberia. The Anna E., an unknown type of vessel, reportedly was lost in 1871 due to a snag; no information concerning the type of vessel, the date of loss or cause was reported for the remaining six vessels. No information regarding the possible significance of any of the vessels was noted the shipwreck database (Clune and Wheeler 1991). 


\section{ChaPTER VI}

METHODS

$\mathbf{O}$ bjective

The objective of this investigation was to evaluate the potential impacts that the proposed U.S. Army Corps of Engineers, New Orleans District undertaking will have on cultural resources located throughout the proposed project reach. The proposed study area included the $19.3 \mathrm{~km}(12 \mathrm{mi})$ stretch of Bayou Teche situated between River Mile 48.7 and River Mile 61.0, six terrestrial project items, and two access roads. The $19.3 \mathrm{~km}(12 \mathrm{mi})$ stretch of Bayou Teche will be subjected to maintenance dredging by the U.S Army Corps of Engineers, New Orleans District. The six terrestrial project items consisted of three staging areas that will be used to coordinate the planned dredging operations and three disposal sites that will receive the material dredged from the bottom of Bayou Teche (Figure 3, Sheets 1-2 and Attachment 1).

Both underwater and terrestrial components are associated with the current undertaking. This chapter presents a discussion of the methods utilized to survey the underwater portion of Bayou Teche, as well as terrestrial portions of the Areas of Potential Effect.

\section{Research Methods Utilized during the Un- derwater Portion of the Survey}

The methods utilized to complete the underwater portion of the currert investigation were two-fold. Prior to initiating fieldwork, archival research pertaining to the $19.3 \mathrm{~km}(12 \mathrm{mi})$ stretch of Bayou Teche was completed. After completing this aspect of the investigation, field survey was initiated. The methods used in com- pleting the underwater portion of this research are presented below.

\section{Archival Investigations}

Archival research pertaining to the Bayou Teche component of the proposed undertaking focused primarily on assessing historic period use of the waterway and the development of waterborne transportation throughout this section of the Louisiana coastal zone. In addition, this research focused on the identification of specific vessels reported lost near or within the proposed project corridor. To accomplish this task, the archives of a number of institutions were consulted. For example, the shipwreck data were obtained from the State of Louisiana Shipwreck Database (Department of Culture, Recreation, and Tourism, Division of Archeology), the U.S. Army Corps of Engineers, New Orleans District shipwreck data base, and the Automated Wreck and Obstruction Information System (AWOIS) maintained by the National Oceanic and Atmospheric Administration (NOAA). Additional shipwreck data were obtained from published secondary sources, specifically Berman's Encyclopedia of American Shipwrecks, Way's Packet Directory, and Lytle and Holdcamper's Merchant Steam Vessels of the United States, 1790-1868.

\section{Archeological Investigations}

The marine remote sensing component of this investigation was conducted from the $7.3 \mathrm{~m}$ (24 ft) long research vessel Coli. The Coli, leased from the Louisiana Universities Marine 
Consortium (LUMCON), was captained by Mr. Samuel LeBouef. The proposed project reach was divided into six survey blocks. Each block was examined along two survey track lines spaced $15 \mathrm{~m}(50 \mathrm{ft})$ apart. The entire survey encompassed an area measuring approximately $19,312 \times 23 \mathrm{~m}(63,360 \times 75 \mathrm{ft})$ in size, or roughly 38.6 linear $\mathrm{km}$ (24 linear mi) of transect survey.

The remote sensing investigation was designed to identify specific magnetic or acoustic anomalies and/or clusters of anomalies that might represent potentially significant submerged cultural resources, e.g., historic period shipwrecks. The natural and anthropogenic forces that form such sites typically scatter ferrous objects like fasteners, anchors, engine parts, ballast, weaponry, cargo, tools, and miscellaneous debris across the bayou bottom. These objects normally can be detected utilizing a marine magnetometer, side scan sonar system, and digital fathometer. Together, these instruments record anomalous magnetic or acoustic underwater signatures that stand out against the ambient magnetic or visual field. During the interpretation of raw data, two critical elements were examined. These were patterning among the identified anomalies, and in the case of the magnetic anomalies, their amplitude and duration. Because of the importance anomaly patterning plays in the identification of cultural anomalies, accurate recording and positioning of each anomaly location is essential.

The equipment array used to complete the Bayou Teche remote sensing survey included a DGPS, a proton precession marine magnetometer, a side scan sonar, and a digital fathometer (Figure 29). Data were collected and correlated via a laptop computer using hydrographic survey software.

\section{Positioning}

A Differential Global Positioning System (DGPS) was used to direct navigation and to accurately record the locations of all magnetic and acoustic anomalies identified during survey. The DGPS system consisted of a Northstar 941XD with internal DGPS. The Northstar 941XD transmitted positioning data in NMEA 0183 code to the computerized navigation system (Hypack version 7.0). Hypack translated the
NMEA message and it displayed the position of the survey vessel on a computer screen relative to the position of the two pre-plotted track lines. During post-processing, the Hypack positioning files were utilized to produce track plot maps and to derive the $X, Y$, and $Z$ values used to produce the magnetic and bathymetric contour maps of the project corridor. Throughout the course of this investigation, positioning control points were obtained at one-second intervals, and strong differential signals were acquired with a minimum noise to signal ratio.

\section{Magnetometry}

The recording proton precession marine magnetometer is an electronic instrument used to record the strength of a magnetic field, and it displays the data in increments of nano-Teslas or gammas. Magnetometers have proven useful in marine research as detectors of anomalous distortions in the ambient magnetic field of the earth; they are particularly useful in the identification of distortions caused by concentrations of naturally occurring and manmade, ferrous materials. Distortions or changes as small as 0.5 gammas are detectable when operating the magnetometer at a sampling rate of one second. Magnetic distortions associated with shipwrecks may range in intensity from several gammas to several thousand gammas, depending upon such factors as the mass of ferrous materials present, the distance of the ferrous mass from the sensor, and the orientation of the mass relative to the position of the sensor. The use of magnetometers in marine archeology and the theoretical aspects of the physical principals behind their operation are summarized and discussed in detail in Aitken (1961), Breiner (1973), Green (1990), Hall (1966), and Tite (1972).

Individual anomalies produce distinctive magnetic "signatures." These individual signatures may be categorized as 1) positive monopole; 2) negative monopole; 3) dipolar or 4)multi component (Figure 30). Positive and negative anomalies refer to monopolar deflections of the magnetic field and usually indicate a single source. They produce either a positive or negative deflection from the ambient magnetic field, depending on how the object is oriented relative to the magnetometer sensor and whether its positive or negative pole is positioned closest 
Chapter VI: Methods

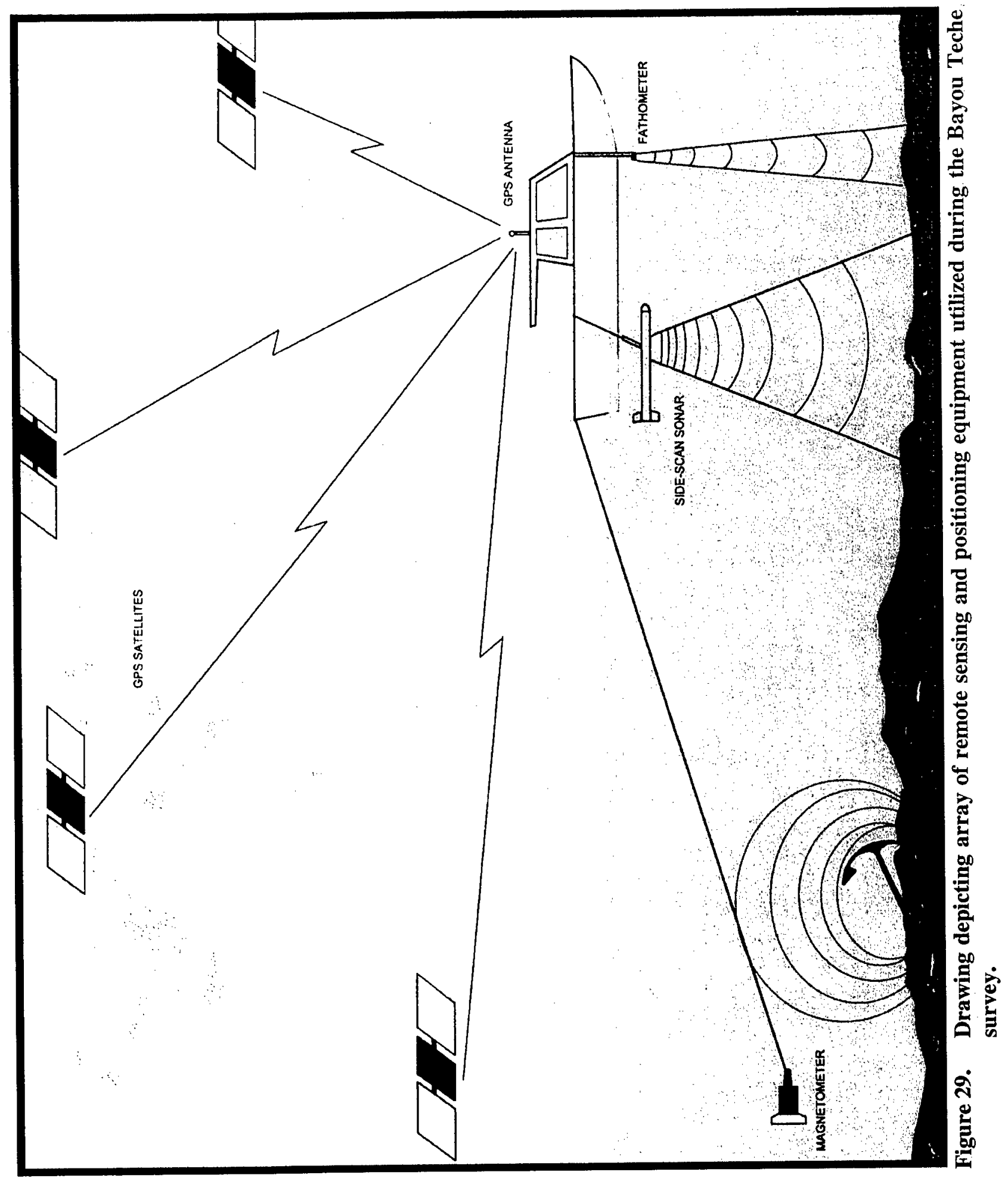




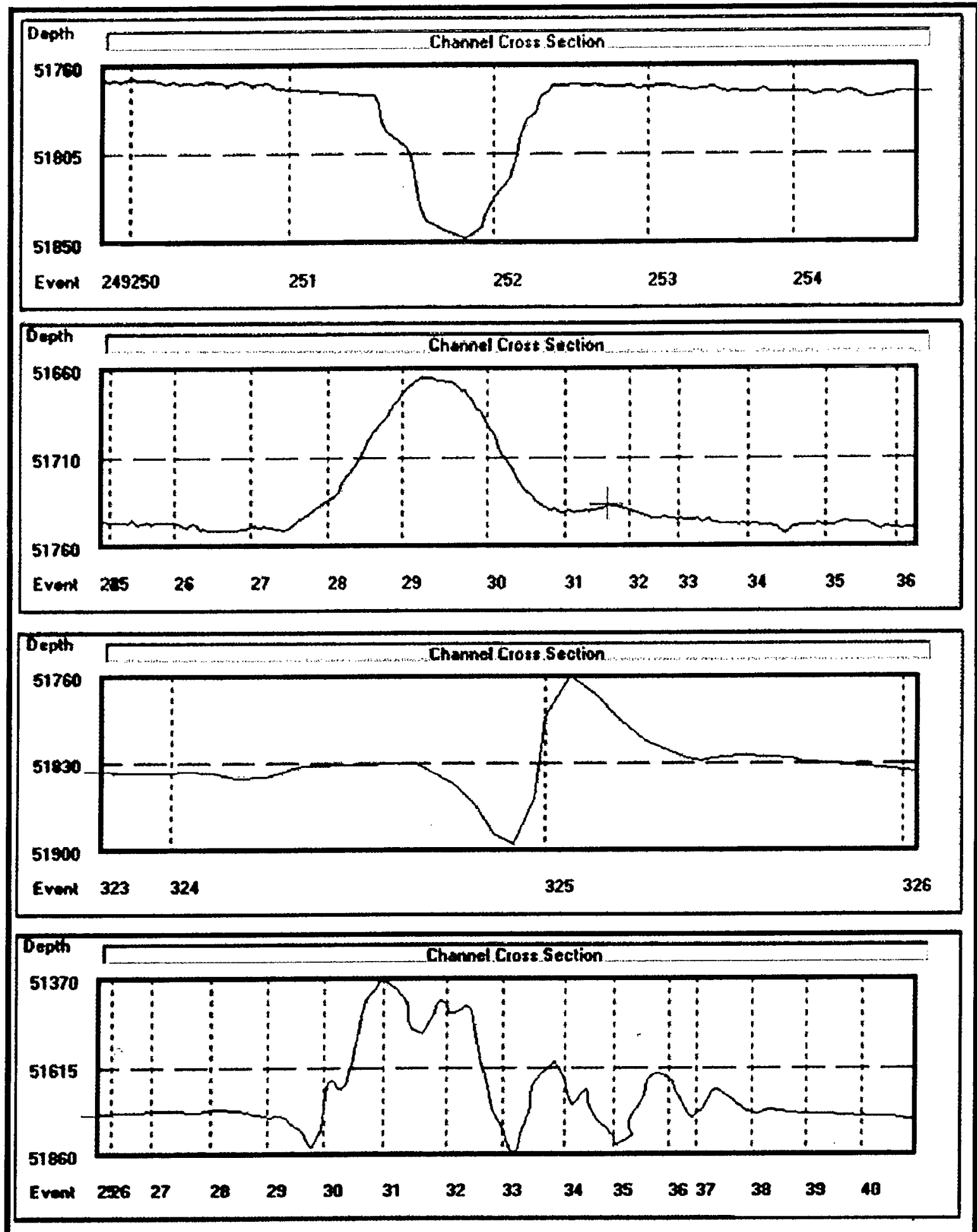

Figure 30. Hypack "Edit" screen images illustrating magnetic anomalies with positive monopolar, negative monopolar, dipolar, and multi-component signatures. 
to the sensor. Dipolar signatures display both a rise and a fall above and below, vice-versa the ambient field; they often are associated with single source anomalies, with the dipole usually aligned along the axis of the magnetic field and the negative peak of the anomaly falling nearest the North Pole.

Especially important for archeological surveys are multi-component anomalies. Multicomponent or complex signature anomalies consist of both dipolar and monopolar magnetic perturbations associated with large overall deflections that can be indicative of the multiple types of ferrous materials comprising the debris patterns typically associated with shipwrecks. The complexity of the signature is affected partially by the distance of the sensor from the debris and the by quantity of the debris. If the sensor is positioned close to the wreck, the signature will be multi component; if it lies far away, the anomaly may appear as a single source signature.

A Geometrics G866 proton precession marine magnetometer was used to complete the magnetic survey of the Bayou Teche project corridor. The G866 is a 0.1 gamma sensitivity magnetometer that downloads magnetic data in digital format; the information subsequently is stored as numeric data files using the previously discussed Hypack software. As the magnetic data are being collected, Hypack attaches the precise real-time DGPS coordinates to each magnetic reading, thus ensuring precise positioning control. The magnetometer was towed far enough behind the survey vessel to minimize the associated noise, which generally measured less than two gammas. A float was attached to the magnetometer sensor, so that a consistent depth below water surface could be maintained.

\section{Acoustic Imaging}

Over the past 25 years, the combined use of acoustic (sonar) and magnetic remote sensing equipment has proven to be the most effective method of identifying submerged cultural resources and assessing their potential for further research (Green 1990; Hall 1966). When combined with magnetic data, the near photographicquality, acoustic records produced by side scan sonar systems have left little doubt regarding the identifications of some targets as intact ship- wrecks during other projects(Figure 31). For targets lacking structural integrity or those partially buried beneath bottom sediments, identification can be extremely difficult. Because intact and exposed wrecks are less common than broken and buried wrecks, remote sensing surveys generally produce acoustic targets that require groundtruthing by divers to determine their identification and historic significance.

An Imagenex color imaging digital side scan sonar was utilized continuously during survey to produce sonograms of the bayou bottom along each survey transect. The Imagenex system consisted of a Model 858 processor coupled with a Model 855 dual transducer tow fish operating at a frequency of $330 \mathrm{KHz}$. The sonar was set at a range of $27.4 \mathrm{~m}(90 \mathrm{ft})$ per channel, which resulted in overlapping coverage of the proposed Bayou Teche project corridor. Sonar data were recorded and stored in a digital format on a Iomega 1GB Jazz Drive. A stream of timetags was attached to the sonar data to assist in post-processing, and in correlating both the acoustic and magnetic data sets. Latitude and longitude taken from the DGPS also were recorded onto the acoustic record. Acoustic images were displayed on a VGA monitor as they were recorded during the survey, and an observation log was maintained by the sonar technician to record the description of the various anomalies and the times and locations associated with each target. Potential targets were inventoried both during survey and in post-processing.

The methodology employed during survey produced favorable results, with reliable DGPS signals, low noise levels on the magnetometer, and clear acoustic images. All positioning and remote sensing equipment performed reliably, and regular and evenly spaced coverage was maintained throughout the project corridor.

\section{Survey Control and Correlation of Data Sets}

The Hypack survey software provided the primary method of control during survey. Survey track lanes were planned in Hypack, geodetic parameters were established, and the instruments were interfaced and the data recorded through the computer software. During the investigation of the proposed project corridor, the planned survey lines were displayed on a computer monitor, and position of the survey vessel 


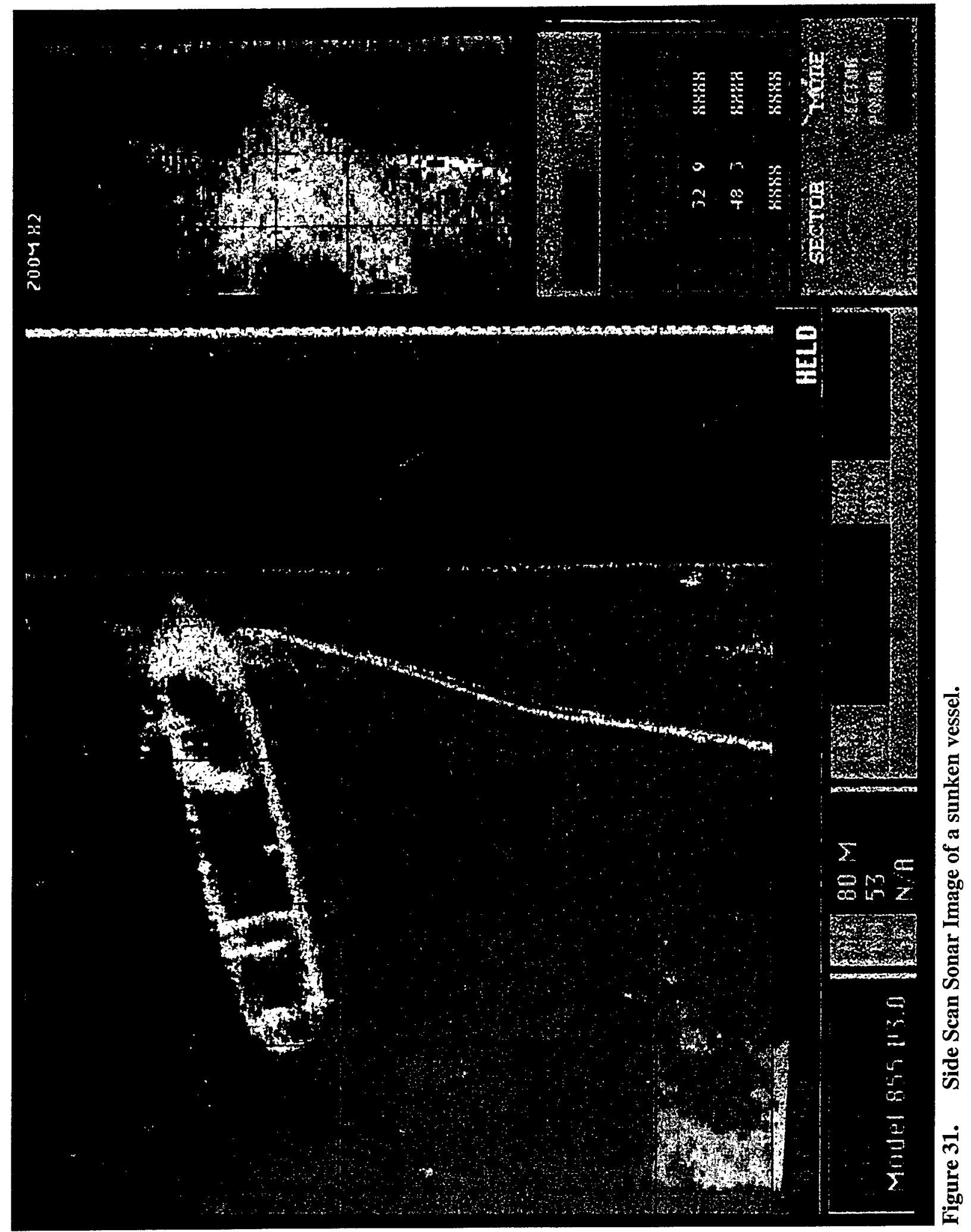


was monitored constantly. In addition to providing steering direction for the helmsman, $\mathrm{Hy}$ pack allowed the surveyors to monitor instruments and incoming data through additional windows on the survey screen.

All remote sensing data were correlated with DGPS positioning data and time through Hypack. Positions for all data then were corrected through the software for instrument layback and offsets. Positioning was recorded using Louisiana South State Plane grid coordinates, referencing the North American Datum of 1983 (NAD-83). The GRS-1980 ellipsoid and a Lambert projection were utilized in processing the data.

\section{Remote Sensing Data Analysis}

Magnetic and acoustic data were analyzed in the field at the time they were generated, and post-processed using Hypack and Auto$C A D$ (Autodesk Version 14) computer software applications. These computer programs were used to assess the signature, intensity, and duration of each magnetic disturbance, and to plot its position within the proposed underwater project area.

Each individual anomaly was identified and carefully examined. First, its profile was characterized in terms of pattern, amplitude, and duration. Magnetic data then were correlated with the field notes, so that deflections from modern sources, such as channel markers, could be identified. Although all anomalies with an amplitude of greater than 10 gammas were assigned a unique number for reference purposes and then the results tabulated (Appendix II), anomalies of larger amplitude (more than 50 gammas) and of longer duration (more than 20 seconds) generally are considered to have a higher likelihood of representing the remains of shipwrecks, especially when such anomalies cluster together.

Side scan sonar data were examined for anomalous acoustic targets and shadows that might represent potentially significant submerged cultural resources (Appendix III). Correlations also examined between magnetic or bathymetric anomalies and corresponding targets were identified (Appendix IV).

\section{Stratification of the Proposed Terrestrial Pro- ject Items into Areas of Low, Moderate, and High Archeological Potential}

As part of the terrestrial component of this investigation, the six project items were stratified into areas deemed to possess a low, moderate, or high probability for containing intact cultural deposits (Attachment 1). These determinations were made on the basis of previously completed archeological, geomorphological, and historical background research.

High probability areas were located on natural levees, as well as in the proximity of a project item to known historic period standing structures and/or cultural features depicted on historic period maps of the area, National Register of Historic Places properties, and/or the modern and historic period banklines of Bayou Teche. Historic period standing structures and/or cultural features identified as a result of this research included residences, stores, barns, gins, landings, etc. This background investigation resulted in the identification of 20 historic period standing structures and 17 National Register of Historic Places properties located within the general vicinity of the six terrestrial project items.

In addition, the designation of each high probability area also took into account the distribution of all previously recorded archeological sites situated within the immediate vicinity of the Areas of Potential Effect. Only two previously recorded archeological sites were identified within $1.6 \mathrm{~km}(1 \mathrm{mi})$ of the entire project reach. These sites included Site 16IB101 and 16IB155. Site 16IB101 was characterized as the remains of a Poverty Point period mound. According to the State of Louisiana Site Record Form, this site has not been assessed applying the National Register of Historic Places criteria of evaluation (36 CFR 60.4). The other site, Site 16IB155, consisted of the mansion and associated outbuildings of the Shadows-on-the-Teche Plantation. This site was listed on the National Register of Historic Places in 1974.

Detailed historic period map analysis also was utilized to delineate areas with a high probability for containing intact cultural deposits. Maps used during the background review and subsequent stratification of the overall project 
area included Department of the Gulf, Map No. 8 (Abbot 1863); Survey of the Bayou Teche, May 1870 (Howell 1870); Reference Map of the State of Louisiana from the Original Survey of the United States (La Tourrette 1845, 1853); the Louisiana Department of Highway, Traffic and Planning Section (1950 and 1974) maps of Iberia Parish; maps of the Approved Survey of Township 12S, Range 7W, Southwestern District, Louisiana (Louisiana Surveyor General 1846, 1849); maps of the Approved resurvey of Portions of Township 12S, Range 7W (Louisiana Surveyor General 1893 and 1897); Insurance Maps of New Iberia, Iberia Parish, Louisiana (Sanborn Map Company 1885, 1892, 1895, 1899, 1904, 1909, 1925, and 1931); Land Grants on the Teche (Taylor 1980); a Civil War period map produced by an unidentified surveyor and designated as Unidentified Maps of St. Martin and St. Mary Parishes; the Mississippi River Commission (1963) map of the Jeanerette Quadrangle, Louisiana; the U.S. Army Corps of Engineers (1965) map of the Jeanerette Quadrangle, Louisiana; and the U.S. Army Corps of Engineers (1973) map of the St. Martinville Quadrangle, Louisiana.

In addition to the above documents, the positions of Bayou Teche bankline at various times during the historic and modern periods were considered when designating areas with a high probability for containing intact cultural deposits. Historic period banklines were digitized from historic period maps that dated from 1846,1849 , the Civil War period, and 1870. In addition, modern bankline positions also were included those from the 1996 digital USGS 7.5' series topographic quadrangles that encompass the project reach. The comparisons of the positions of both modern and historic period banklines resulted in the identification of several areas that may have not been impacted by the lateral migration of the Bayou Teche channel. Those areas deemed to be little altered by channel migration were classified as having a high potential for containing intact cultural deposits.

Finally, all areas exhibiting substantial subsurface disturbance were eliminated from consideration as areas with moderate or high probabilities for containing intact cultural deposits. These included areas impacted by prior pipeline and powerline construction that crossed through the Areas of Potential Effect. In addition, those locales that have been subjected to substantial impacts as a result of previous construction activities, e.g., the construction of sewage disposal ponds and other disposal areas, were eliminated from consideration as areas with a moderate or high potential for possessing intact cultural deposits. All of these disturbances were included on Attachment 1; this map was utilized by field personnel to guide both the auger and backhoe testing throughout the Areas of Potential Effect. Use of Attachment 1 as a supplementary field map insured avoidance of those areas that contained buried electrical, oil, and/or natural gas transmission lines.

The original Scope of Work provided by the U.S. Army Corps of Engineers, New Orleans District required sampling of only the high probability areas. The results of the stratification process, however, indicated that the six terrestrial project items possessed varying probabilities for containing intact cultural deposits. Those project items situated in close proximity to Bayou Teche, on the natural levee, or within 500 $\mathrm{m}(1,640 \mathrm{ft})$ of a known or suspected historic period structure, were assessed as having a high probability for containing intact cultural deposits. Those items situated further back from the Bayou Teche bankline and not within the vicinity of any known or suspected historic period structures were assessed as having a moderate probability for containing intact cultural deposits. Finally, those areas that have been subjected to substantial disturbance, e.g., the construction of the extant sewage disposal ponds and/or modern buildings and parking lots, or that have been impacted by the lateral migration of the Bayou Teche channel, were designated as low probability areas. Low probability areas were not tested during survey; instead they were subjected to pedestrian survey and they were photodocumented. Subsurface testing methods utilized within the moderate and high probability areas consisted of both auger testing and backhoe trenching. Each sampling procedure is discussed in detail below.

\section{Field Methods Utilized during the Terrestrial Survey}

An examination of the results of the digitization process, i.e., Attachment 1, indicated that 
no historic period structures or other cultural features were identified within the terrestrial portions of the Areas of Potential Effect; however, historic period structures were noted within $500 \mathrm{~m}(1,640 \mathrm{ft})$ of four of the proposed project items (see Attachment 1). These included Staging Area 1, Staging Area 2, Disposal Area 2, and Disposal Area 3.

\section{Auger Testing}

Auger tests were excavated within both the moderate and high probability areas to determine if intact cultural deposits were located within the terrestrial portions of the Areas of Potential Effect. All auger tests were excavated by hand with $6.4 \mathrm{~cm}$ ( 2.5 in) diameter "Dutch" augers, and each extended to an approximate depth of $2 \mathrm{~m}(6.6 \mathrm{ft})$ below surface. Each auger test was excavated in $20 \mathrm{~cm}$ (7.9 in) levels within natural strata, and the fill associated with each level was screened separately through 0.64 $\mathrm{cm}(0.25 \mathrm{in})$ hardware cloth. Extremely wet soils and clay were hand-sifted, troweled, and examined visually for cultural material. Munsell Soil Color Charts were used to record soil color; texture and other identifiable characteristics also were recorded using standard soils nomenclature. Each of the auger tests was backfilled immediately upon completion of the archeological recordation process.

In high probability areas, auger tests were excavated at 10.0, 15.0, and $30.0 \mathrm{~m}(32.8,49.2$, and $98.4 \mathrm{ft}$ ) intervals, depending upon the size of the proposed project item being examined. The auger tests were excavated along survey transects spaced 10.0 to $30.0 \mathrm{~m}(32.8$ to $98.4 \mathrm{ft})$ apart; again, spacing depended upon the size of the proposed project item being investigated. Where possible, auger tests excavated along adjacent transects were offset to maximize coverage throughout each project item. In moderate probability areas, auger tests were excavated at $50 \mathrm{~m}(164 \mathrm{ft})$ intervals along survey transects spaced $50 \mathrm{~m}(164 \mathrm{ft})$ apart.

A total of 134 auger tests were excavated successfully as a result of this Phase I cultural resources survey and archeological inventory (Table 14). The auger tests were distributed as follows. During survey, 7 of 8,13 of 13 , and 10 of 12 planned auger tests were excavated successfully within the boundaries of Staging Area 1, Staging Area 2, and Staging Area 3, respectively. In addition, 25 of 25,1 of 1 , and 71 of 71 planned auger tests were excavated successfully within the boundaries of Disposal Area 1, Disposal Area 2, and Disposal Area 3, respectively. Finally, 3 of 3 and 4 of 4 planned auger tests were excavated successfully along Access Road 1 and Access Road 2, respectively.

\section{Backhoe Trenching}

In addition to auger testing, backhoe trenching was utilized to test for the presence of intact cultural deposits within the terrestrial portions of the proposed project area. Backhoe trenches measuring approximately $1.0 \times 2.0 \mathrm{~m}$ $(3.3 \times 6.6 \mathrm{ft})$ were excavated to a depth of $2.0 \mathrm{~m}$ $(6.6 \mathrm{ft})$ below surface. These trenches were excavated in $20.0 \mathrm{~cm}$ (7.9 in) levels within natural strata. Screening of backhoe trench fill was not attempted; rather monitoring of the test trench excavation and the visual examination of the resultant spoil piles was undertaken. Once excavated, all artifact-producing backhoe trenches

Table 14. Breakdown of the Terrestrial Areas of Potential Effect by Testable Area, Testing Intervals, and Number of Auger Tests and Backhoe Trenches Excavated.

\begin{tabular}{|c|c|c|c|c|c|}
\hline $\begin{array}{l}\text { PROJECT } \\
\text { ITEM } \\
\end{array}$ & $\begin{array}{c}\text { TESTABLE } \\
\text { AREA } \\
\end{array}$ & $\begin{array}{c}\text { ACCESS ROAD } \\
\text { LENGTH } \\
\end{array}$ & $\begin{array}{l}\text { TESTING } \\
\text { INTERVAL } \\
\end{array}$ & $\begin{array}{l}\text { NUMBER OF AUGER } \\
\text { TESTS EXCAVATED } \\
\end{array}$ & $\begin{array}{c}\text { NUMBER OF BACKHOE } \\
\text { TRENCHES EXCAVATED }\end{array}$ \\
\hline Staging Area 1 & 0.4 ha $(1.1 \mathrm{ac})$ & - & $\begin{array}{c}15 \text { to } 30 \mathrm{~m} \\
(49.2 \text { to } 98.4 \mathrm{ft})\end{array}$ & $7 / 8$ & $4 / 4$ \\
\hline Staging Area 2 & 0.9 ha $(2.2 \mathrm{ac})$ & - & $30 \mathrm{~m}(98.4 \mathrm{ft})$ & $13 / 13$ & $21 / 21$ \\
\hline Staging Area 3 & 0.2 ha $(0.5 \mathrm{ac})$ & - & $10 \mathrm{~m}(32.8 \mathrm{ft})$ & $10 / 12$ & $0 / 0$ \\
\hline Disposal Area 1 & 10.6 ha $(26.1 \mathrm{ac})$ & - & $50 \mathrm{~m}(164 \mathrm{ft})$ & $25 / 25$ & $28 / 28$ \\
\hline Disposal Area 2 & $0.8 \mathrm{ha}(1.9 \mathrm{ac})$ & - & $30 \mathrm{~m}(98.4 \mathrm{ft})$ & $1 / 1$ & $13 / 13$ \\
\hline Disposal Area 3 & 14.0 ha $(34.4 \mathrm{ac})$ & - & $50 \mathrm{~m}(164 \mathrm{ft})$ & $71 / 71$ & $0 / 0$ \\
\hline Access Road 1 & - & $437 \mathrm{~m}(1,433 \mathrm{ft})$ & $30 \mathrm{~m}(98.4 \mathrm{ft})$ & $4 / 4$ & $0 / 0$ \\
\hline Access Road 2 & - & $790 \mathrm{~m}(2,591 \mathrm{ft})$ & $50 \mathrm{~m}(164 \mathrm{ft})$ & $3 / 3$ & $0 / 0$ \\
\hline Totals & 26.9 ha $(66.2 \mathrm{ac})$ & $1,227 \mathrm{~m}(4,025 \mathrm{ft})$ & $-\cdots$ & 134 & 66 \\
\hline
\end{tabular}


and a sample of the non-artifact producing backhoe trenches were profiled, with vertical locations of all strata breaks and cultural materials plotted accordingly. Profiling proceeded from the surface of each backhoe trench; for safety reasons, personnel from $\mathrm{R}$. Christopher Goodwin \& Associates, Inc., did not enter any of the excavated backhoe trenches. In addition, all artifact-producing trenches and a sample of the nonartifact producing trenches were photographed in both plan and profile view. All backhoe trenches were backfilled immediately upon completion of the archeological recordation process.

Where more than a single transect of backhoe trenches was excavated, they were offset toallow maximum coverage of the area under examination. A total of 132 linear $\mathrm{m}$ (216.5 linear $\mathrm{ft}$ ) of backhoe trenching was completed as a part of this cultural resources investigation. Because each backhoe trench measured approximately $1 \times 2 \mathrm{~m}(3.3 \times 6.6 \mathrm{ft})$ in size, 66 trenches were excavated. These trenches were distributed among the six proposed project items as follows. During this investigation, 4 of 4 and 21 of 21 planned backhoe trenches were excavated successfully within Staging Area 1 and Staging Area 2, respectively (Table 14). Due to the presence of buried cables, low overhead wires, and a request by the landowner (LaBiche Engineering) not to excavate trenches on his property, no backhoe trenches were excavated within Staging Area 3. Staging Area 3 also contained a paved parking lot and a large cement office building used by LaBiche Engineering.

In addition, 28 of 28 and 13 of 13 planned backhoe trenches were excavated successfully within Disposal Area 1 and Disposal Area 2, respectively. Backhoe trenching was not attempted within Disposal Area 3, since the testable portion of this area consisted of a narrow strip of land situated between two large extant sewage drainage ponds. The excavation of backhoe trenches was omitted in this area because the restricted space of the test area did not permit easy and safe maneuvering of the heavy equipment.

\section{Application of the Criteria for Evaluation (36 CFR 60.4 [a-d])}

All archeological loci identified during fieldwork were examined to ascertain, if possible, the nature, size, depth, integrity, age, and affiliation of the cultural deposits. Delineation also was used to assess the stratigraphic placement, density, and research potential of each identified locus. This information was gathered to assist in the subsequent assessment of whether a locus was significant, potentially significant, or not significant applying the National Register of Historic Places criteria for evaluation (36 CFR 60.4 [a-d]).

Delineation of each cultural resources locus consisted of a combination of the following: (1) establishment of a datum labeled N1000 E1000; (2) intensive surface reconnaissance throughout the immediate area; (3) excavation of tightly spaced auger tests and/or backhoe trenches to delineate both locus size and configuration; and (4) mapping and photographing of the locus under investigation. Both black and white and color photographs were taken of each locus identified during fieldwork. Unit excavation was not undertaken as part of the locus delineation process.

\section{Laboratory Analyses}

Laboratory analyses consisted of a detailed study of all of the data collected as a result of this investigation. It included the analysis of all materials recovered during survey and the compilation of locus descriptions for all cultural resources loci identified as a result of this survey effort.

The laboratory analysis provided information on locus type and chronology. All of the material recovered during survey was washed and sorted by material category, and it was encoded into computerized catalogs that allowed for further manipulation of the data. The nature and structure of the analyses was guided by the goals of the project.

The first requirement of the research was to determine whether or not a cultural resources locus had the potential to meet the legal definition of an historic property. Therefore, particular care 
was taken to observe and record chronologically sensitive attributes of historic artifacts, and to evaluate, for example, whether or not the material is more than 50 years in age.

Beyond the determination of minimum age, the artifact analysis consisted of making and recording a series of observations for each recovered specimen. The observations were chosen to provide the most significant and diagnostic information about each specimen. A total of two separate databases were required to store, organize, and manipulate the data generated by the analytical process. Separate databases were used to analyze the historic/modern period artifacts and faunal materials recovered during survey. The use of these different databases reflected the differences in the analytical protocols required to study thoroughly the different types of materials.

During the data analysis phase, locus descriptions were compiled for all loci identified during survey. Minimally, these descriptions included data on locus type, size, and cultural/temporal affiliation. In addition, data pertaining to landform, elevation, distance to water, and soil type were recorded. These descriptions also included an assessment of archeological integrity and significance applying the National Register of Historic Places criteria for evaluation (36 CFR 60.4 [a-d]).

\section{Historic/Modern Period Material Analysis}

The analysis of the historic/modern period cultural material was organized by class, functional group, type, and subtype. The first level, class, represented the material category, e.g., ceramic, glass, or metal. The second level, functional group, e.g., architecture, kitchen, or personal, was based on classifications established by South (1977). The third and fourth levels, type and subtype, described the temporal or culturally diagnostic attributes of an artifact. The identification of artifacts was aided by consulting standard reference works, including Coates and Thomas (1990), Fike (1987), Florence (1990), Kovel and Kovel (1986), Miller (1980, 1991), Nelson (1968), South (1977), Speer (1979), Switzer (1974), Toulouse (1969, 1971) and Wilson (1981).

\section{Faunal Analysis}

The faunal database was organized by type and subtype. The biological class according to conventional systematics, e.g., mammal and bird, was listed under "type." The subtype column included the family, genus, or species when identifiable. When generic or specific identification were not possible, each skeletal element was placed into a general descriptive category, e.g., large mammal, large to medium mammal, medium to small mammal, small mammal, bird, reptile, fish, etc. The orientation of recovered skeletal element also was identified when possible. In addition, for the purposes of recordation, thermal modification to each recovered bone was noted as burned, charred, or ashed. The presence of cut marks, butchering, and/or sawing also was identified when possible, as was fragmentation.

Vertebrate remains recovered from the cultural resources loci located during fieldwork were examined using standard zooarcheological methods. Identifications were made using the comparative reference skeletal collections of R. Christopher Goodwin \& Associates, Inc.; these collections are housed at our New Orleans laboratory. In addition to the aforementioned type collections, guidelines and manuals were used to aid identification procedures. These guidelines and manuals included those compiled by Gilbert (1980), Hillson (1986), and Olsen $(1964,1979)$.

\section{Summary}

The field and laboratory methods described above were designed to meet all requirements specified in the Scope of Work drafted by the U.S. Army Corps of Engineers, New Orleans District. To achieve this goal, the proposed terrestrial project items were stratified into areas of low, moderate, or high probability for containing intact archeological deposits; only areas designated with a moderate or high probability for containing intact cultural deposits were tested; low probability areas were not examined during survey of the proposed project reach. In addition, magnetometer survey was used to examine the bottom of Bayou Teche. 


\section{Chapter VII}

\section{RESULTS OF THE INVESTIGATION}

I ntroduction

This chapter presents the results of Phase I cultural resources survey and archeological inventory of both the underwater and terrestrial portions of the proposed Bayou Teche project reach. The underwater project item measured $19.3 \mathrm{~km}(12 \mathrm{mi})$ in length and it extended from River Mile 48.7 to River Mile 61.0. The terrestrial portion of the project reach encompassed six proposed project items, the testable portions of which totaled approximately 26.8 ha $(66.2 \mathrm{ac})$ in extent. The project area also included two proposed access roads; they measured approximately $437 \mathrm{~m}(1,433 \mathrm{ft})$ and $790 \mathrm{~m}(2,591 \mathrm{ft})$ in length, respectively (Figure 3, Sheets 1-2 and Attachment 1).

The underwater portion of this investigation included a magnetic and acoustic remote sensing survey using a proton precession marine magnetometer, a side scan sonar, and a digital fathometer. Fieldwork conducted in association with the terrestrial portion of this survey included pedestrian survey augmented by the systematic excavation of both auger tests and backhoe trenches throughout the limits of the six proposed project items. Each of the proposed access roads was examined visually for evidence of cultural material and/or intact cultural deposits; auger tests were excavated in the undisturbed portions of these roads.

The remote sensing survey resulted in the identification of 48 acoustic and 614 magnetic anomalies within the channel of Bayou Teche. In addition, two non-site cultural resources loci (SA2-01 and DA2-01) were identified during survey of the terrestrial components associated with this undertaking. The results of both the underwater and terrestrial portions of the survey are discussed in detail below.

\section{Results of Survey of the Underwater Project Item}

The following discussion presents the results of the remote sensing investigation of the bayou portion of the proposed project corridor. A general overview is provided, followed by a description of the targets identified within the Area of Potential Effect. Figure 32, Sheets 1 - 13 depict the spatial distribution of the magnetic anomalies and targets identified during survey. The survey corridor was subdivided into six blocks to facilitate control during the survey process (Figure 32, Sheets 1 - 13). As noted in the previous chapter (Chapter VI), the underwater anomalies were identified during the analysis of the data collected during survey of each individual trackline. Once identified, the anomalies were clustered into groups and magnetic contour maps were produced and analyzed to identify targets that may be impacted by the proposed Bayou Teche Dredging Project.

Bayou Teche is a slow, turbid river; water depths along the banks are shallow and the central navigation channel seldom measures deeper

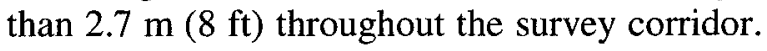
The majority of the bankline within the survey area is paved with concrete rubble and/or sheet iron bulkheads that property owners have used to stabilize their holdings. Some of this material has migrated into the bayou and it now covers the channel bottom throughout the survey area. The extent of the bankline not stabilized and/or cut back probably comprised less than two percent of the total project corridor. 
Chapter VII: Results of the Investigation

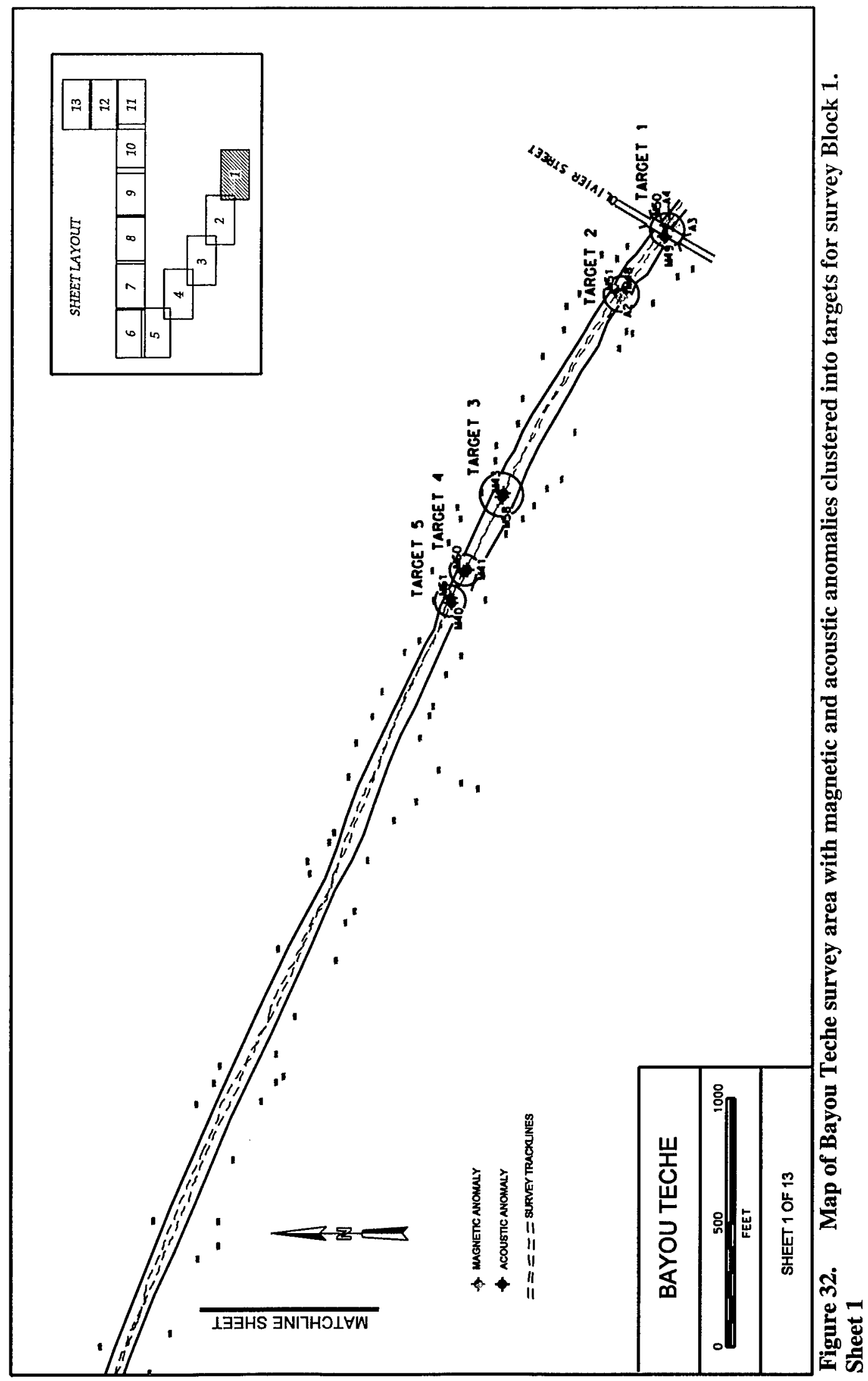




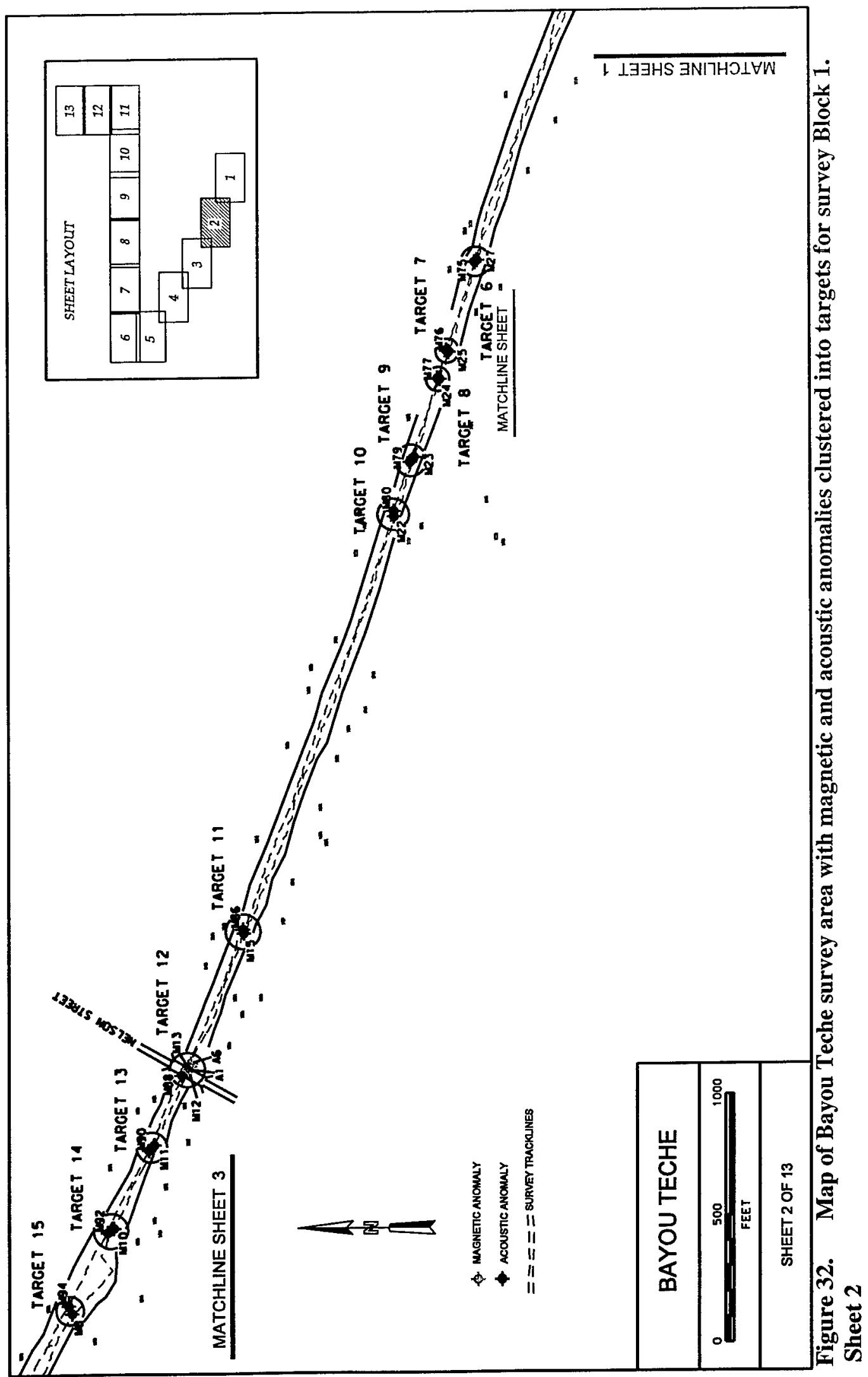


Chapter VII: Results of the Investigation

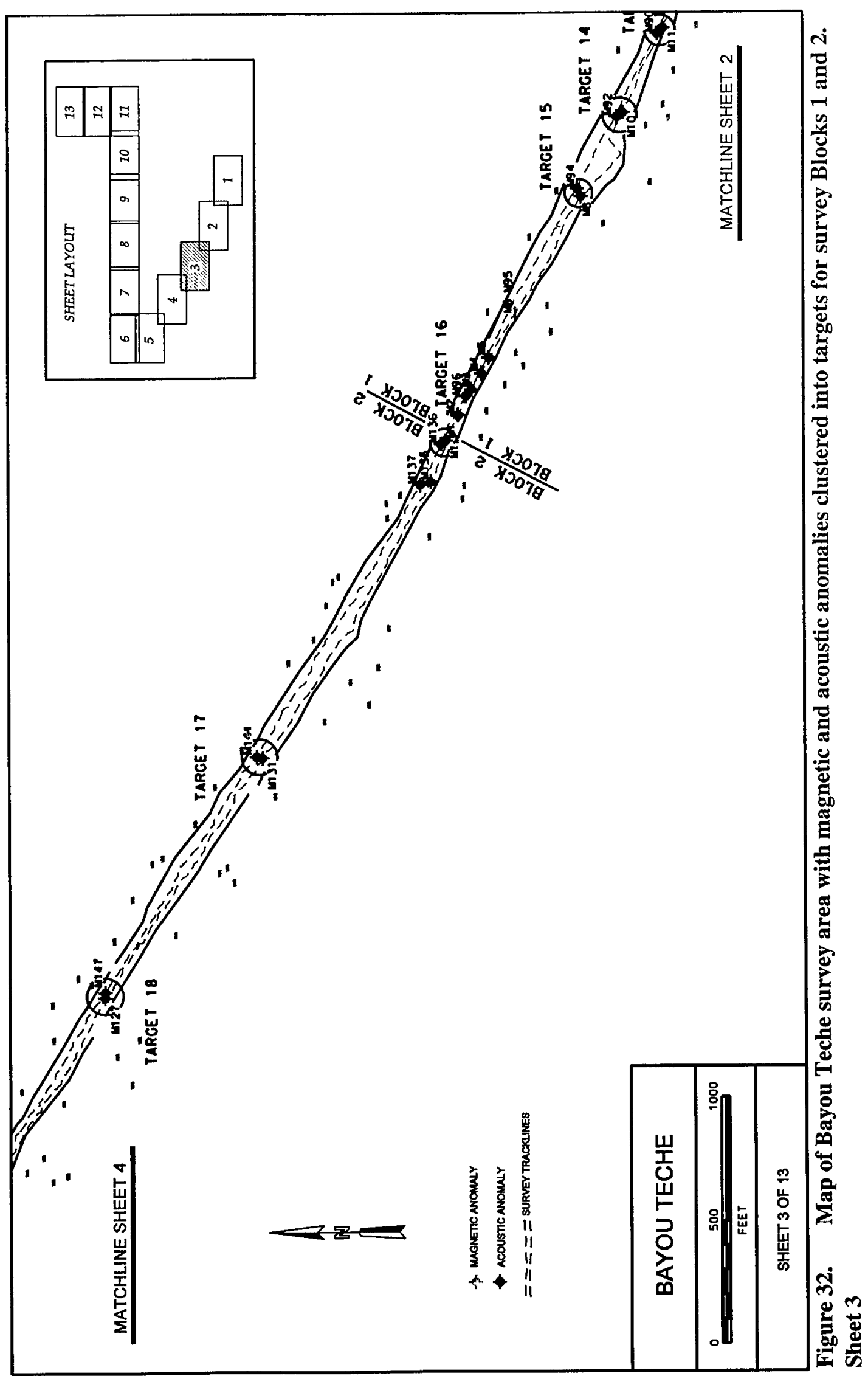


Chapter VII: Results of the Investigation

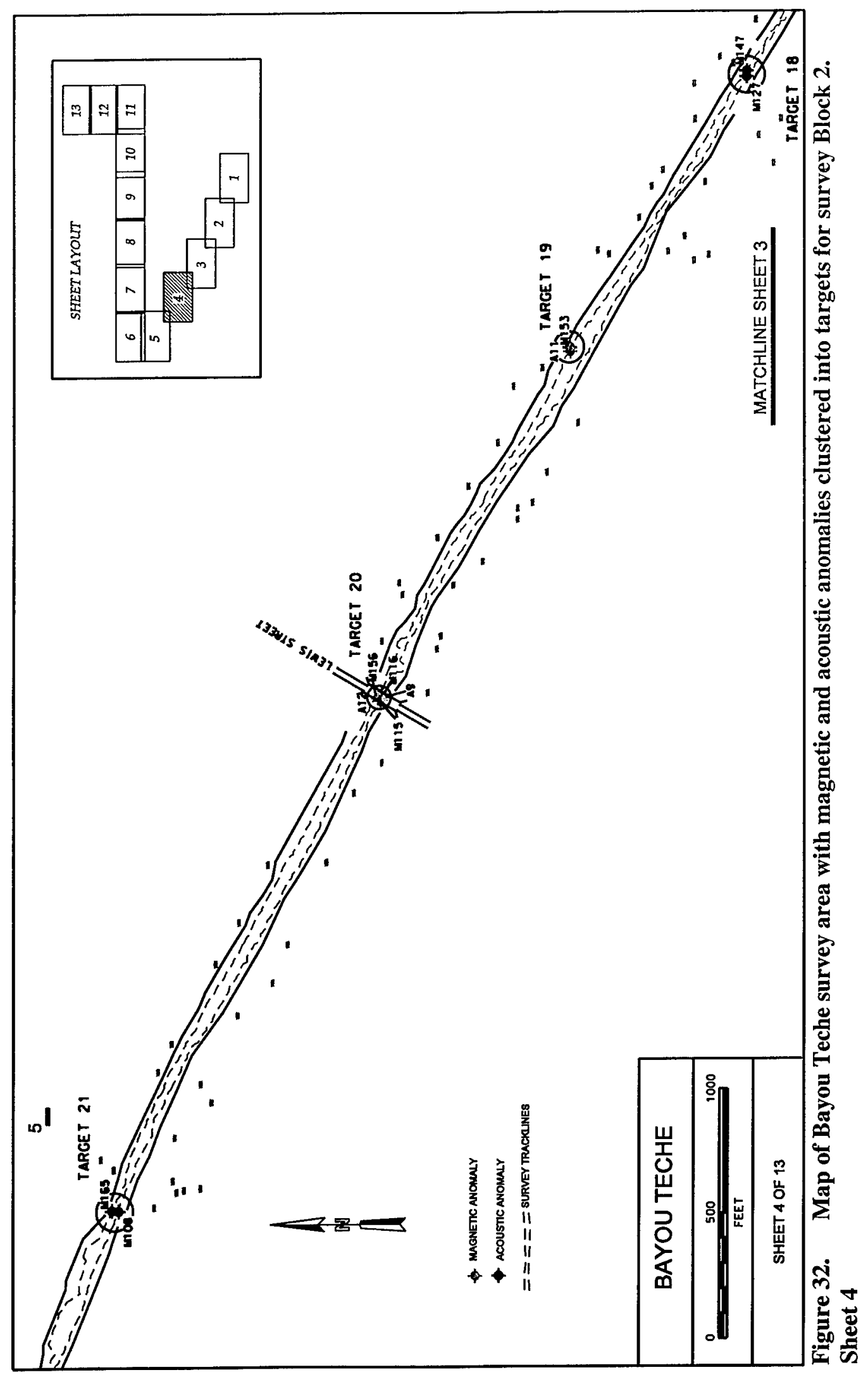


Chapter VII: Results of the Investigation

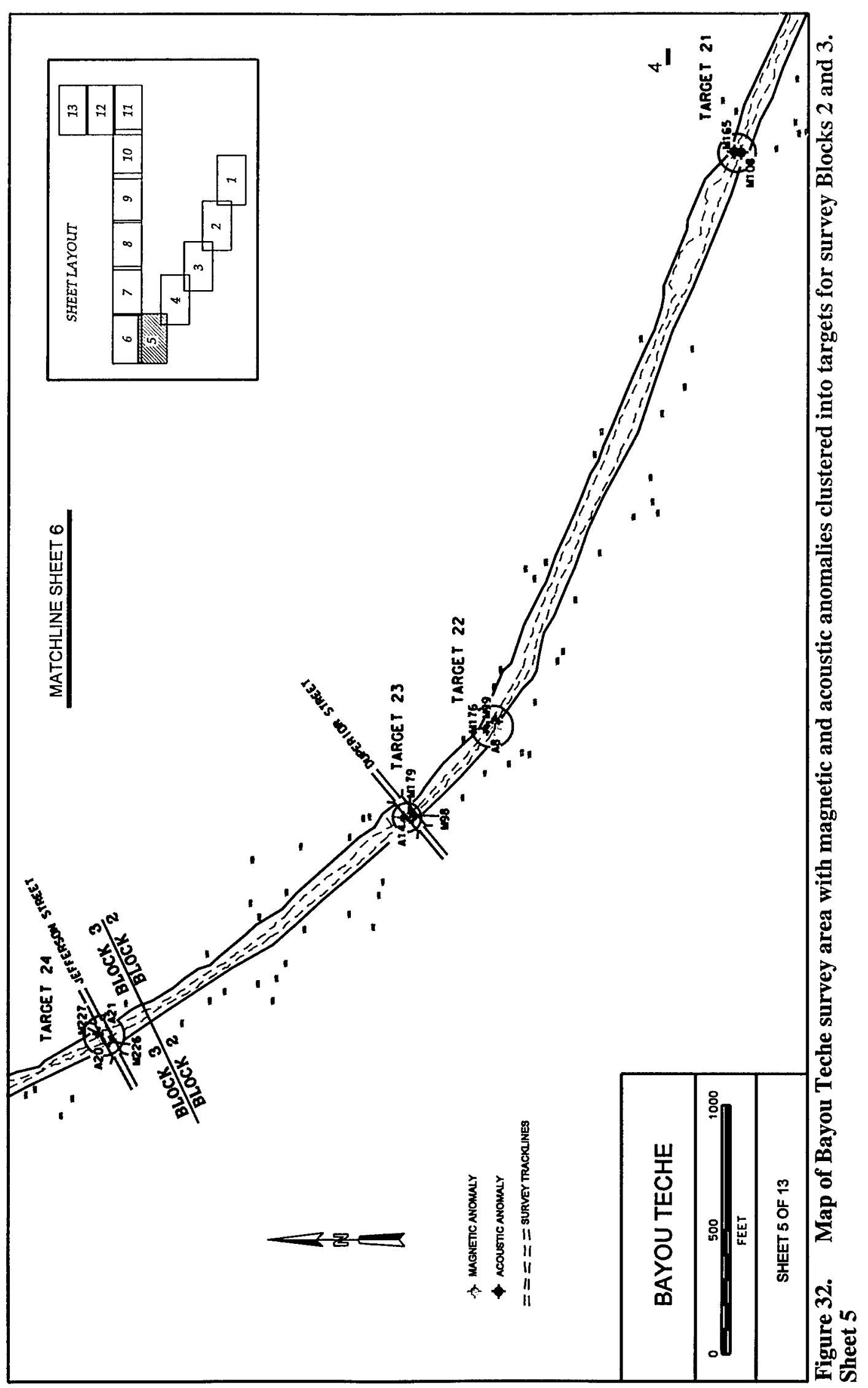




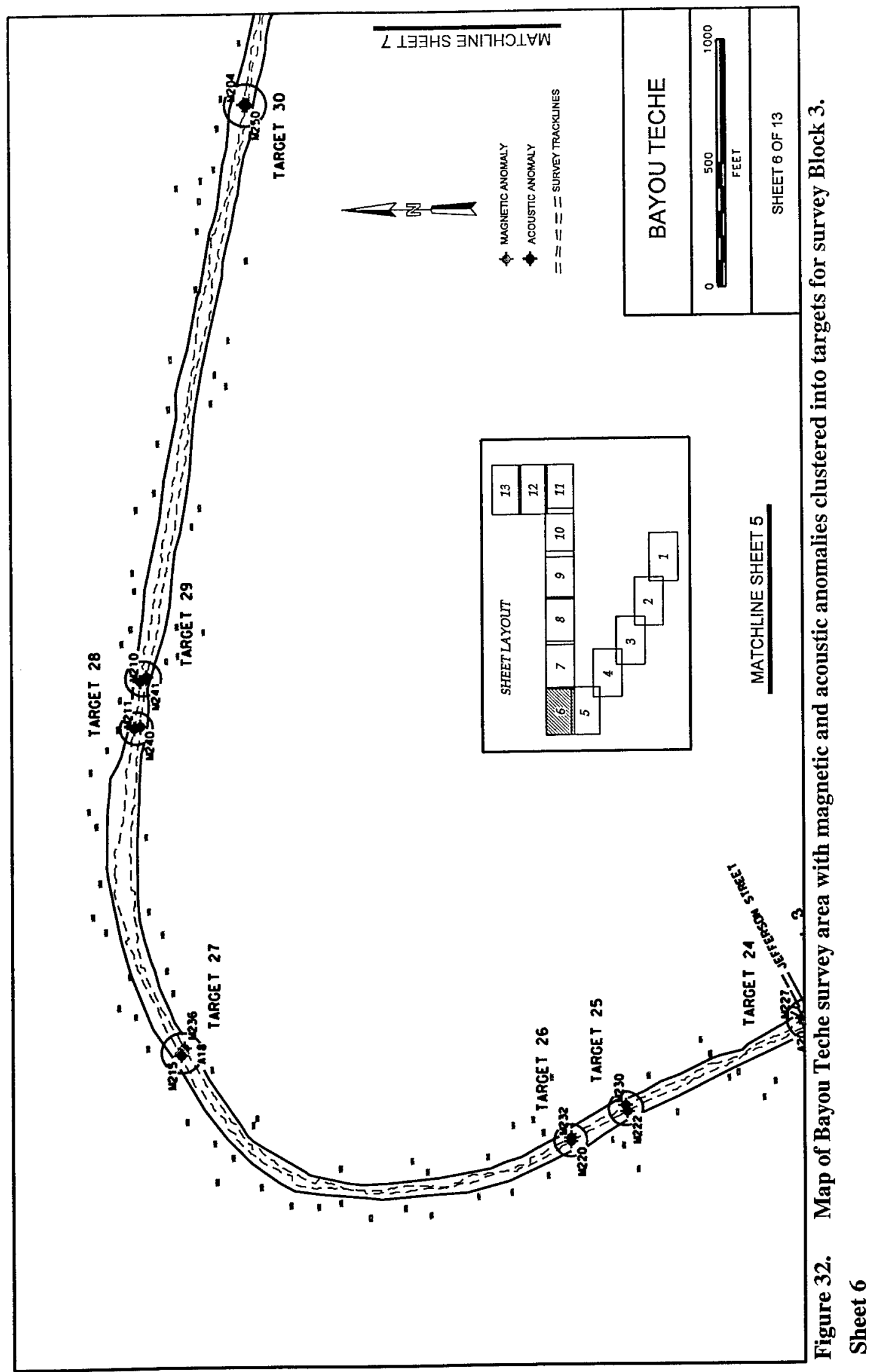


Chapter VII: Results of the Investigation

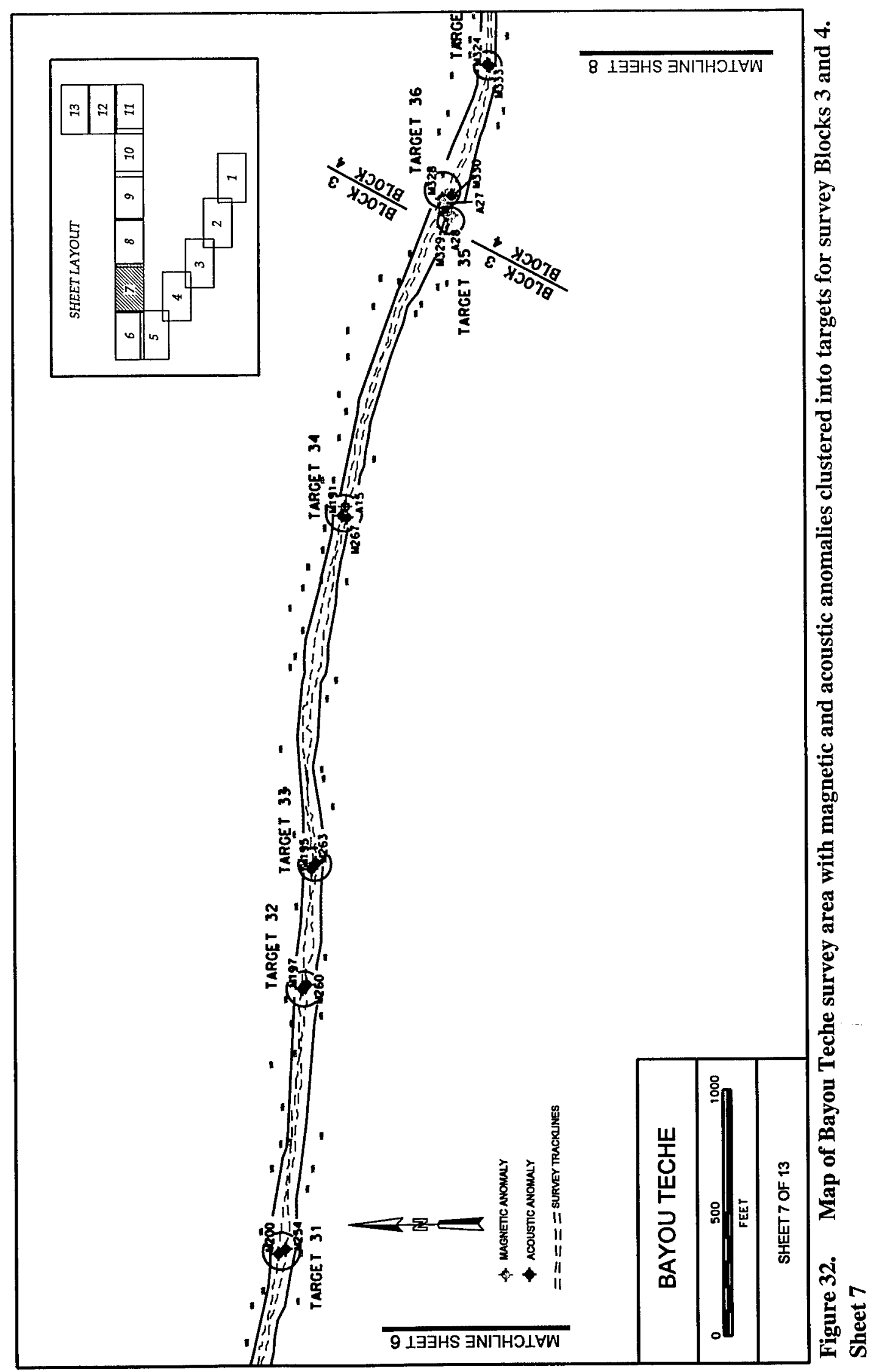




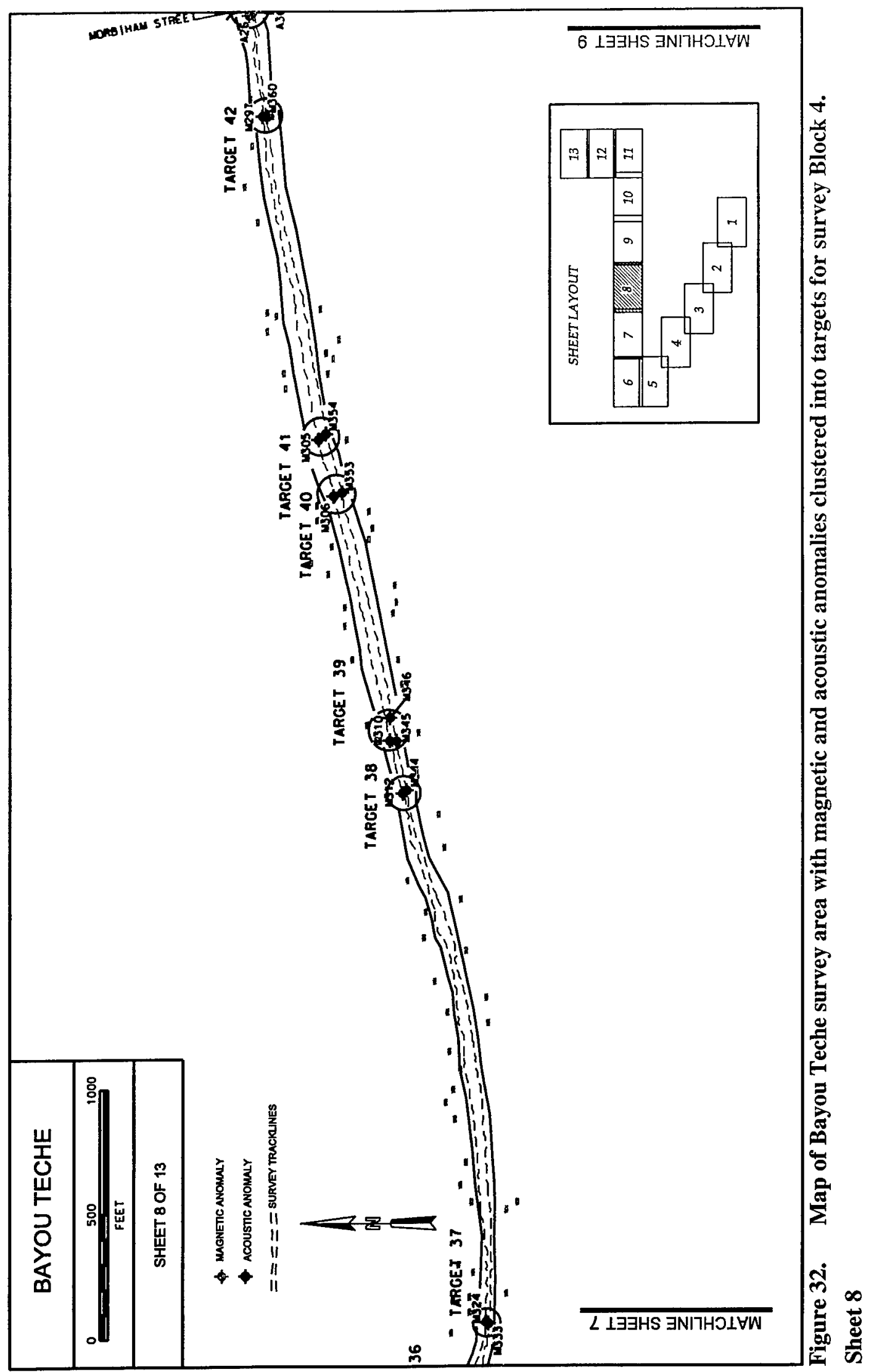


Chapter VII: Results of the Investigation

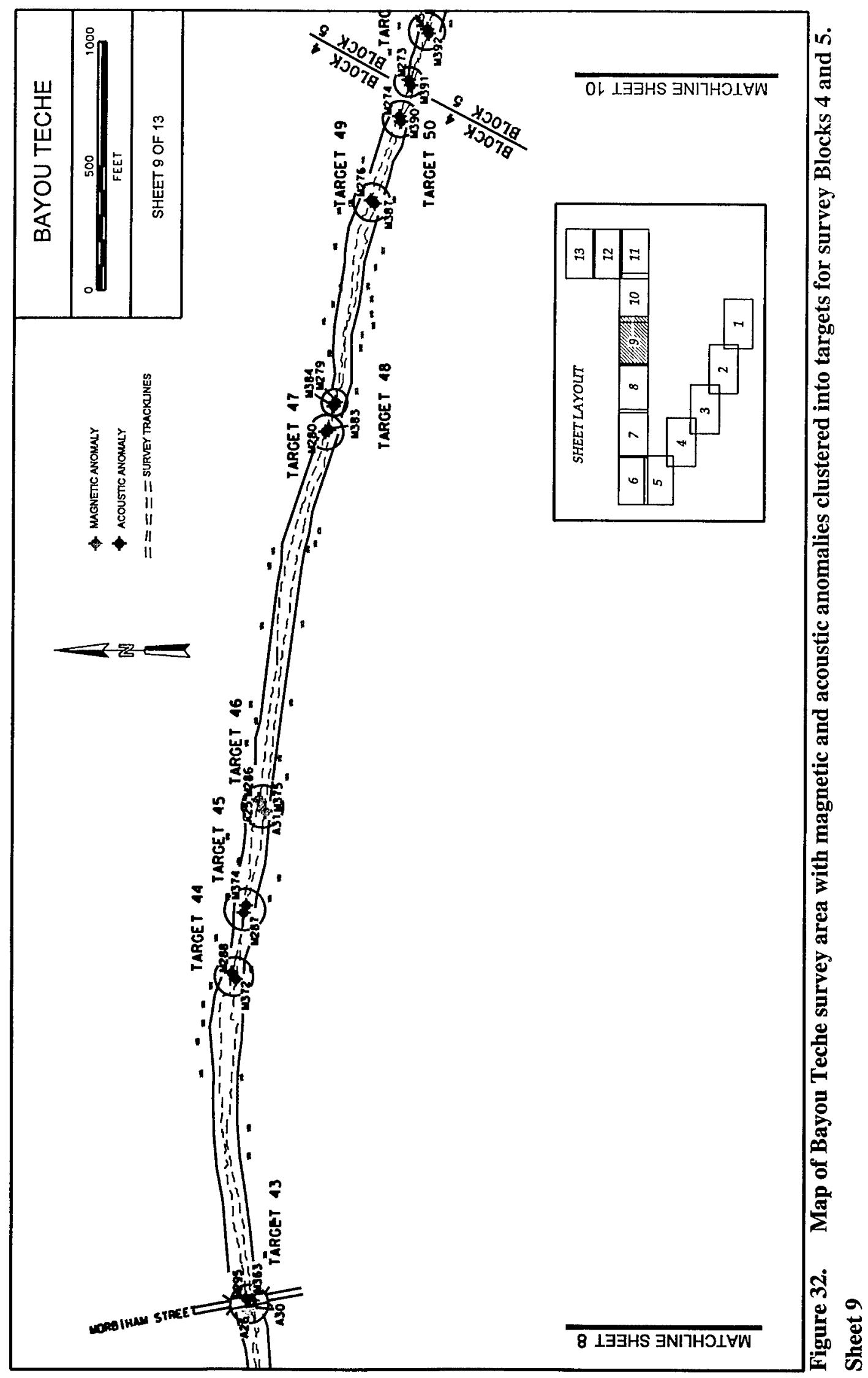




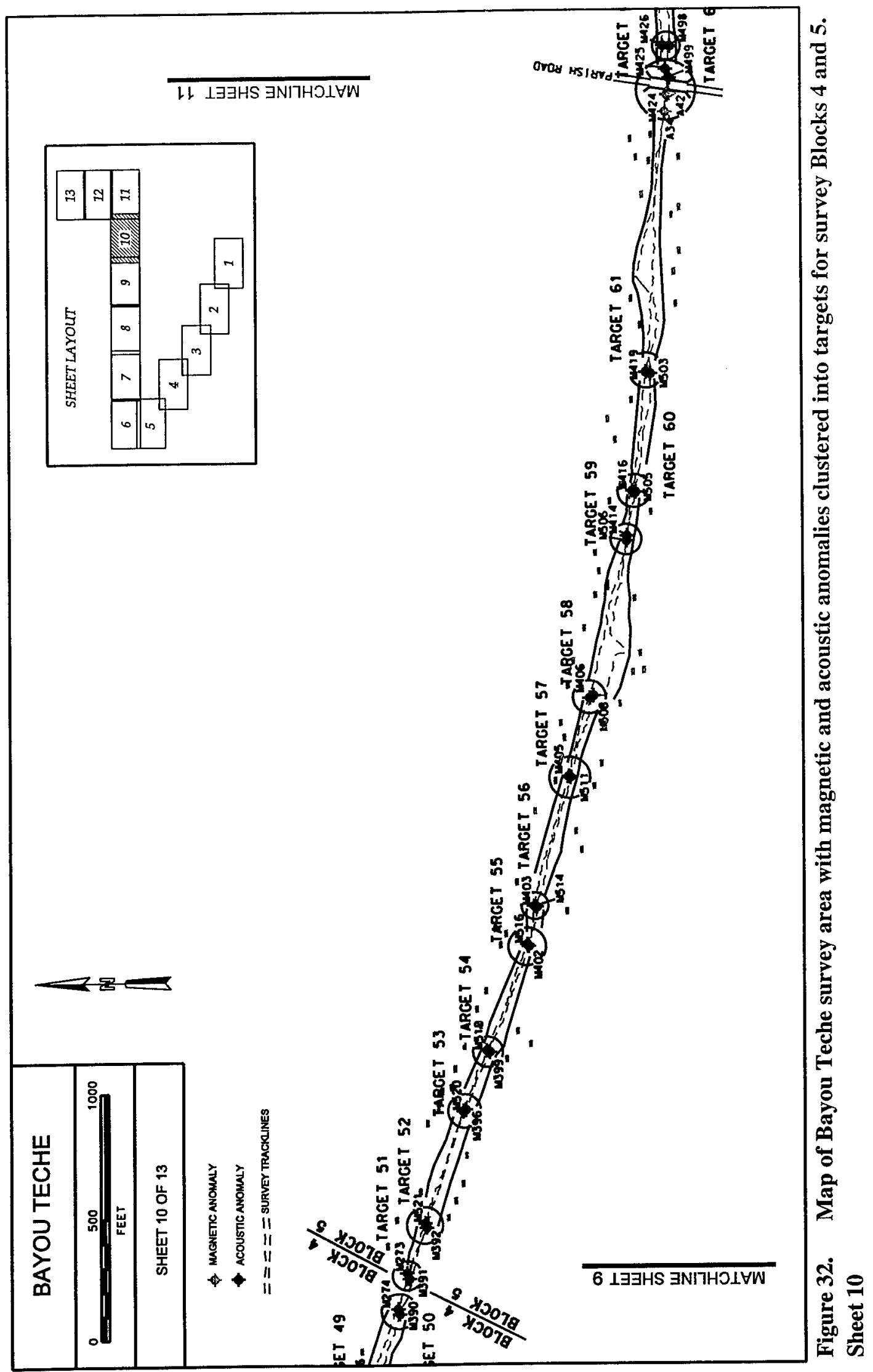




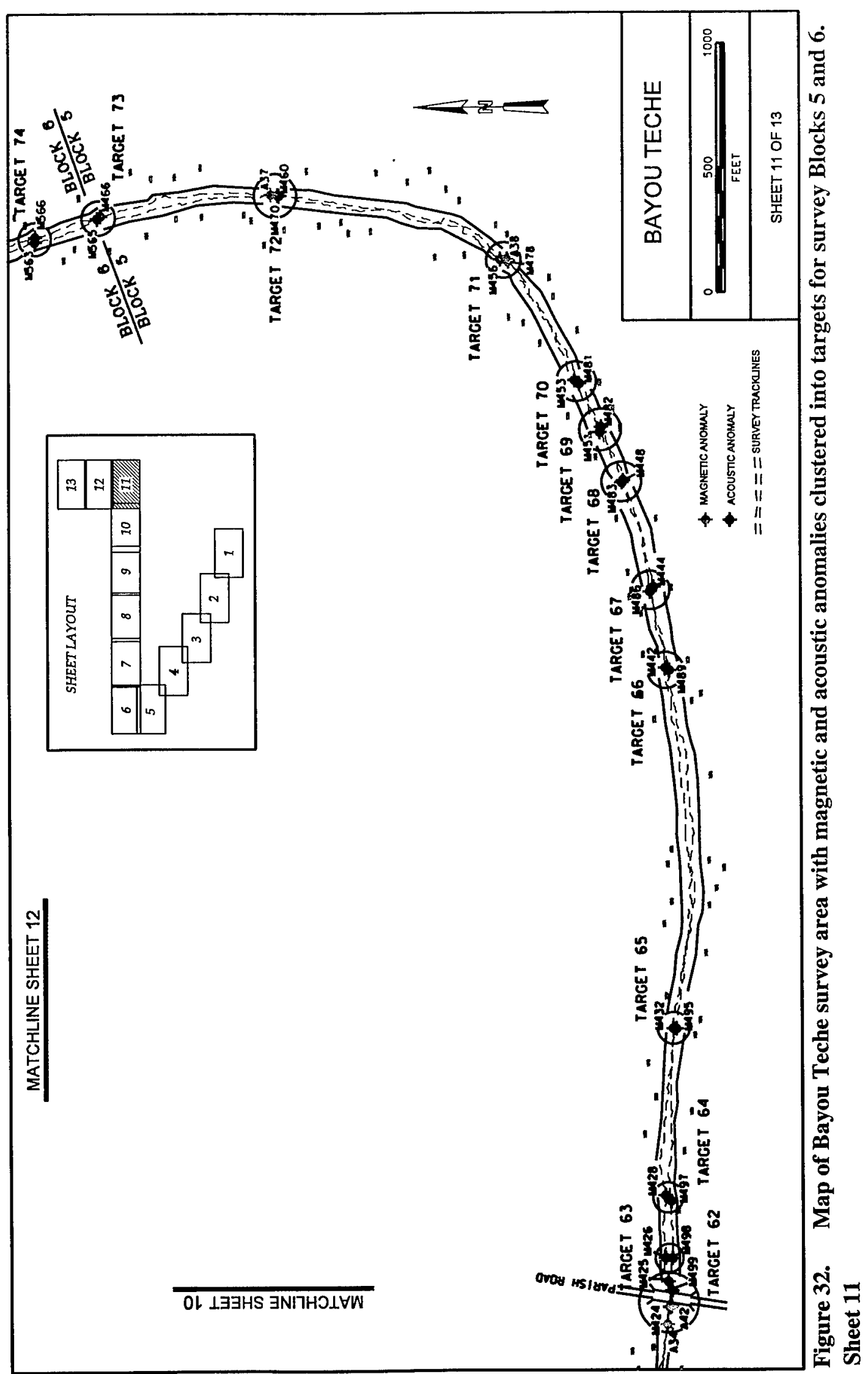


Chapter VII: Results of the Investigation

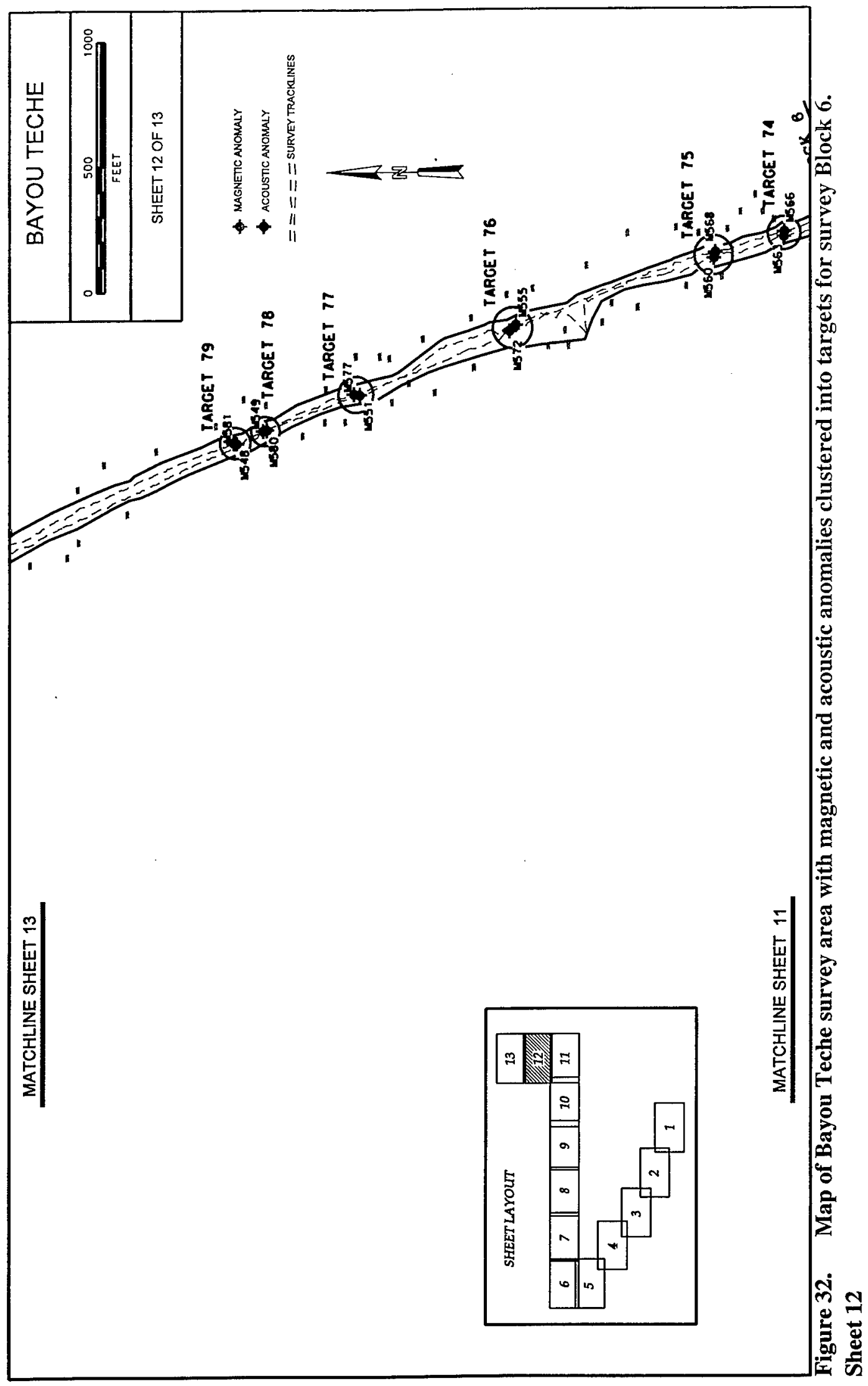


Chapter VII: Results of the Investigation

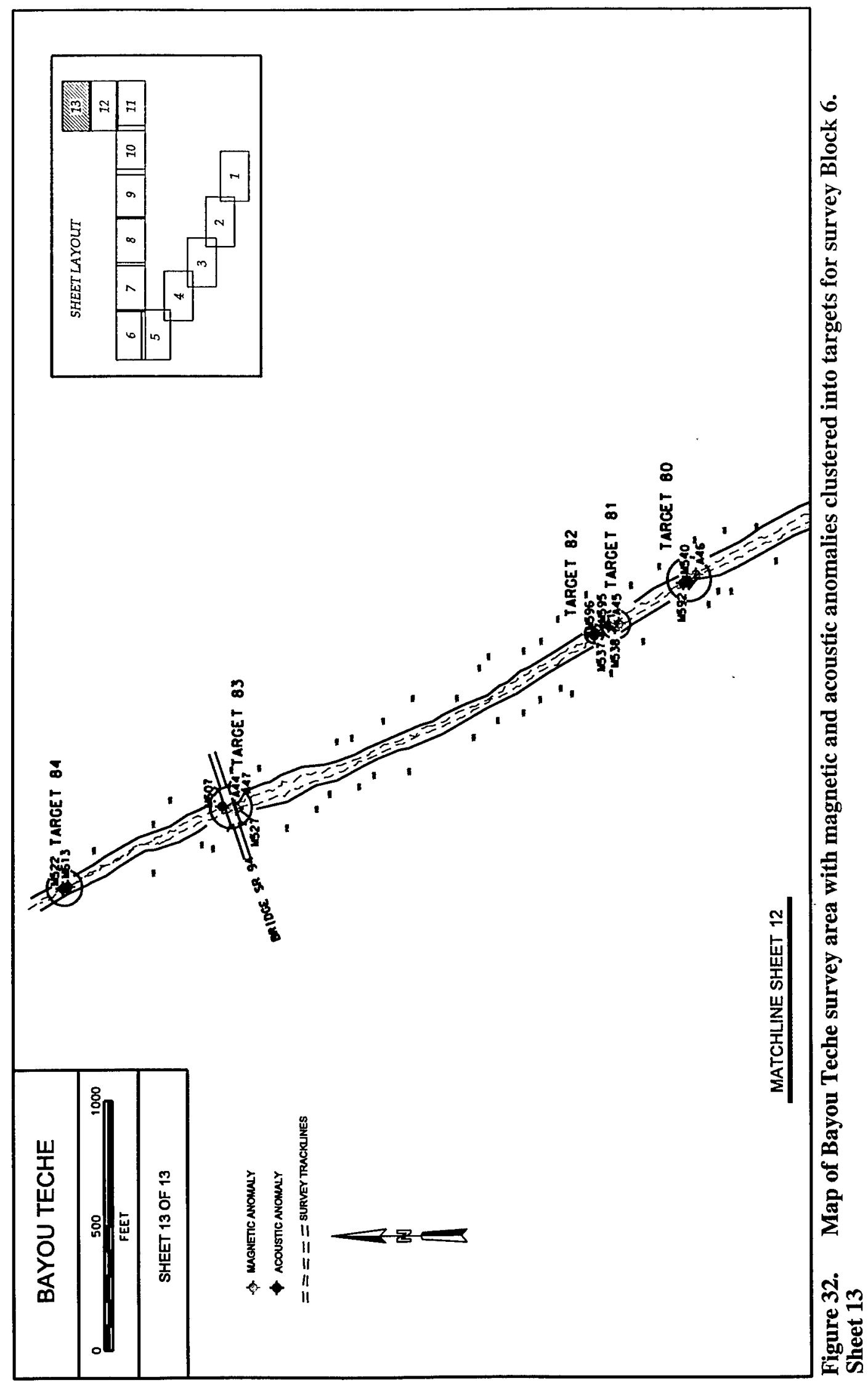


General Overview of the Survey Results

A total of 614 magnetic anomalies were detected during the remote sensing investigation of Bayou Teche. The characteristics of each individual magnetic anomaly was quantified and that data appears in Table 14. Of the 614 magnetic anomalies identified during survey, 445 represented modern scatters of ferrous debris. The remaining 169 magnetic anomalies were combined to form 84 target groups. In addition, 48 acoustic anomalies were recorded during survey; of these anomalies, 20 corresponded to the previously identified magnetic anomalies (Table 15). Many of the magnetic targets corresponded to bridges that spanned the survey corridor, the bulkheads constructed adjacent to the survey corridor, or other related debris. Most of the acoustic data correlated with recorded bridge pilings, pipeline or cable crossings, or modern debris.

In the following section, the 84 targets identified during survey of the Bayou Teche corridor are described (Table 16). Each of these targets appears to be associated with modern manmade structures, such as bridges, pipeline or cable crossings, or bulkheads; or debris that has washed into the river, fallen off of vessels, or that has been discarded. Finally, a small portion of the debris is natural in origin, e.g., submerged trees and logs. An assessment of the potential for each target to represent a significant submerged cultural resource is presented and management recommendations for these anomalies are provided below. In assessing the significance and origin of each anomaly, water depth, lane spacing, magnetic deflection, duration of deflection, and proximity to observed manmade structures all were taken into account.

\section{Bridge Structures}

A total of eight bridge structures spanned the Bayou Teche project corridor. The magnetic and acoustic signatures associated with these bridges were detected during survey and they are reflected in the data. A total of eight targets were identified. These included Target Nos. 1, 12, 20, 23, 24, 43, 62, and 83; each of these targets is discussed below. The figures provided for Target No. 62 are representative of bridge structure and includes both magnetic and acoustic signatures (Figures 33 and 34).

\section{Target No. 1}

Target No. 1 was identified during the remote sensing investigation of Survey Block 1 (Figure 32, Sheet 1). It consisted of two magnetic anomalies (M49 and M50), and two acoustic anomalies (A3 and A4). Magnetic Anomaly 49 possessed a short duration signature of 6.5 seconds with an amplitude of 1,652.5 gammas, and a negative monopolar signal. Magnetic Anomaly 50 retained a long duration signature of 49.9 seconds and an amplitude of 5,853.5 gammas, and a negative monopolar signal. Acoustic Anomalies 3 and 4 were associated with Target No. 1, and they exhibited elements that were representative of a bridge structure. This target was identified visually as the Olivier St. Bridge.

\section{Target No. 12}

Target No. 12 consisted of three magnetic anomalies (M12, M13, and M88), and two acoustic anomalies (A1 and A6); it too was identified within Survey Block 1 (Figure 32, Sheet 2). Magnetic Anomaly 12 registered a duration of 45.9 seconds and an amplitude of 8,086 gammas, and a negative monopolar signal. Magnetic Anomaly 13 was of a short duration, measuring only 3.3 seconds, a high amplitude of 15,642.5 gammas, and a negative, monopolar signal. Magnetic Anomaly 88 had a duration signature of 45.0 seconds, and an high amplitude of 5,346.5 gammas, and a negative monopolar signal. In addition, two acoustic anomalies were associated with Target No. 12: $\mathrm{Al}$ and A6. Acoustic Anomalies 1 and 6 represented elements of a bridge structure and related pipeline. This target was identified visually as the Nelson St. Bridge and a pipeline that extends parallel to the bridge.

\section{Target No. 20}

Target No. 20 was identified within Survey Block 2 and it consisted of three magnetic anomalies (M115, M116, and M156) and two acoustic anomalies (A9 and A12) (Figure 32, Sheet 4). Magnetic Anomaly 115 produced a medium duration signature of 26.3 seconds, a 


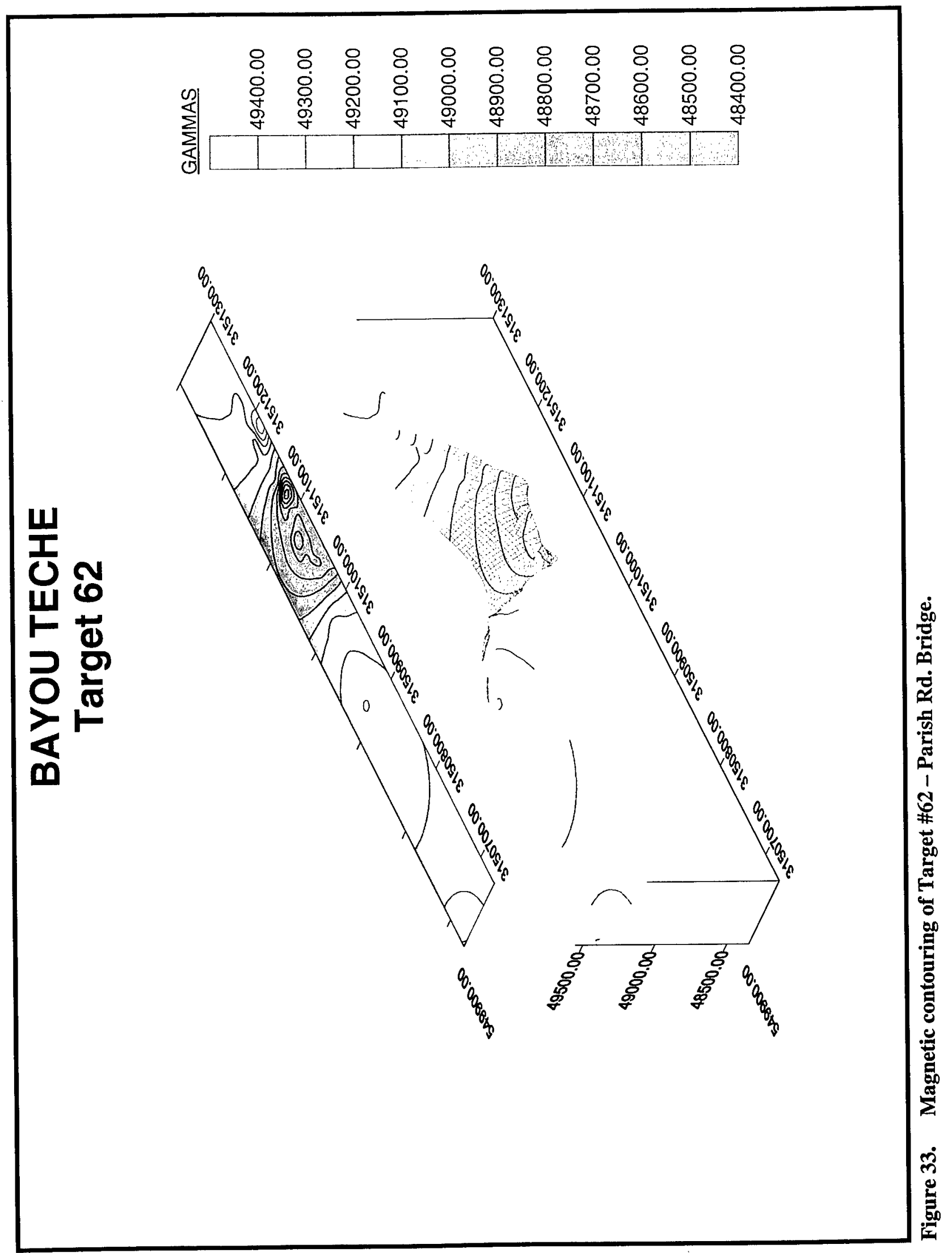




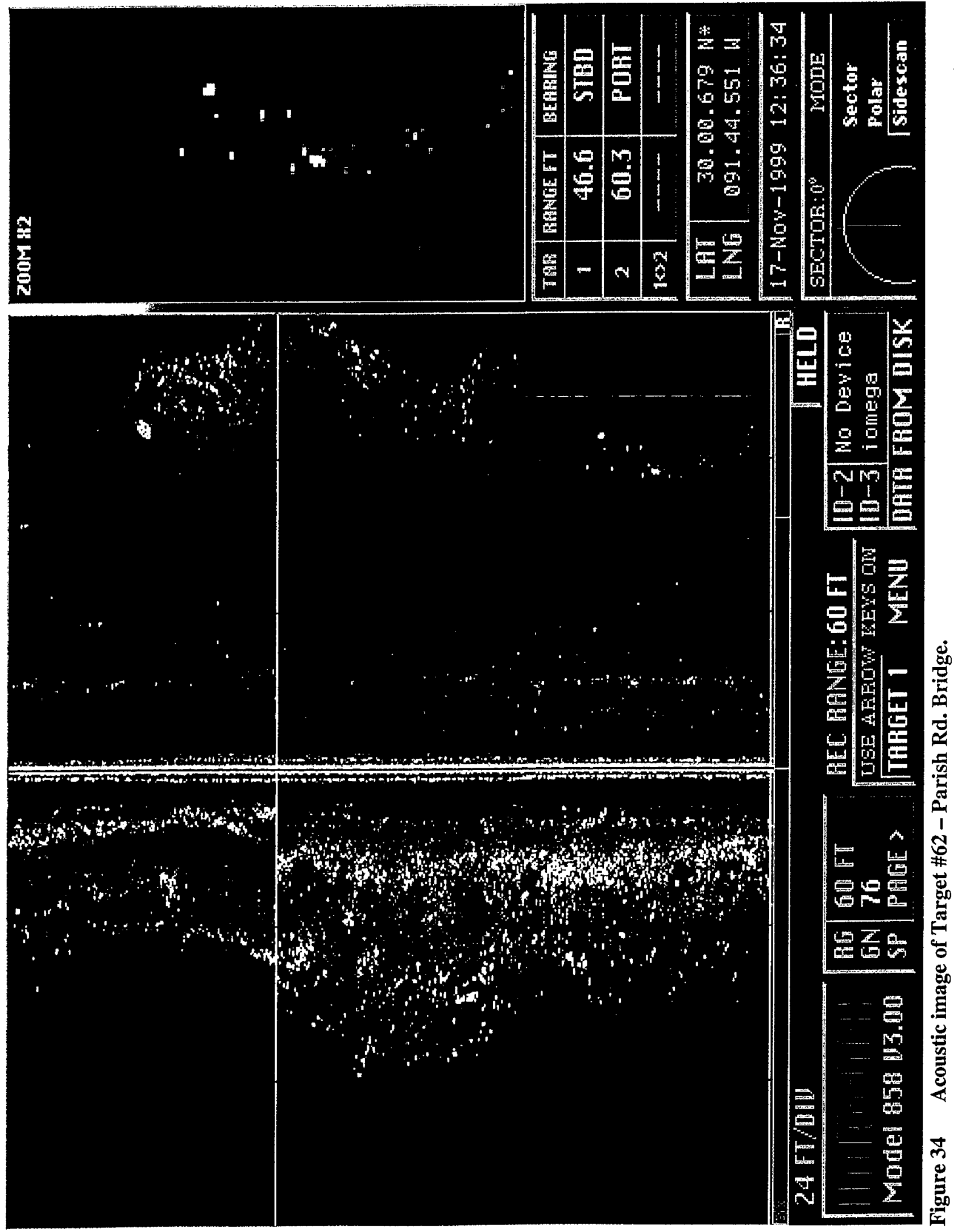


high amplitude of 1,776.5 gammas, and a negative monopolar signal. Magnetic Anomaly 116 possessed a medium duration signature of 22.0 seconds, a high amplitude of 26,655 gammas, and a negative monopolar signal. Finally, Magnetic Anomaly 156 had a long duration signature of 1 minute, 29.9 seconds, a high amplitude of 39,278 gammas, and a multi-component signal. Acoustic Anomalies 9 and 12 were identified as elements of bridge structure and a related linear anomaly associated with an extant pipeline. This target was identified visually as the Lewis St. Bridge and a pipeline that extends parallel to the bridge.

\section{Target No. 23}

Target No. 23 was recorded within Survey Block 2 (Figure 32, Sheet 5). It consisted of two magnetic anomalies (M98 and M179), and one acoustic anomaly (A14). Magnetic Anomaly 98 consisted of a long duration signature of 43.8 seconds, a high amplitude of 6,746 gammas, and a negative, monopolar signal. Magnetic Anomaly 179 retained similar characteristics, including a long duration signature of 42.7 seconds and a high amplitude of 5,305.5 gammas; it, however, possessed a multi-component signal.

\section{Target No. 24}

Target No. 24 consisted of two magnetic anomalies (M226 and M227), and two acoustic anomalies (A20 and A21); it was identified within Survey Block 3 (Figure 32, Sheet 7). Magnetic Anomaly 226 was of a short duration signature ( 7.1 seconds), had a high amplitude of 43,211.5 gammas, and a negative, monopolar signal, while Magnetic Anomaly 227 was characterized by a medium duration signature of 19.7 seconds, a high amplitude of 8,145 gammas, and a dipolar signal. Acoustic Anomalies 20 and 21 depicted elements of bridge structure. This target was identified visually as the Jefferson St. Bridge; a cable crossing and bulkhead also were noted in association with this target.

\section{Target No. 43}

Target No. 43 was recorded within Survey Block 4 (Figure 32, Sheet 9) and it encompassed Magnetic Anomalies M295 and
M363, as well as Acoustic Anomalies A26 and A30. Magnetic Anomaly 295 retained a long duration signature of 53.2 seconds, a high amplitude of 1,083 gammas, and a negative monopolar signal. Magnetic Anomaly 363 has a long duration signature of 37.2 seconds, a high amplitude of 1,938 gammas, and a negative monopolar signal. The two acoustic anomalies, A26 and $\mathrm{A} 30$, were representative of structural elements of a bridge. During survey, Target No. 43 was identified visually as the Moriham St. Bridge.

\section{Target No. 62}

Target No. 62 consisted of three magnetic anomalies (M424, M425, and M499), and a single acoustic anomaly (A42); these anomalies were recorded within Survey Block 5 (Figures 32, Sheet 10, 33 and 34). Magnetic Anomaly 424 was characterized by a long duration signature of 56.9 seconds, a high amplitude of 1,447 gammas, and a multi-component signal. Magnetic Anomaly 425 possessed a short duration signature of 6.0 seconds, a high amplitude of 102 gammas, and a negative monopolar signal. Finally, Magnetic Anomaly 499 retained a medium duration signature of 12.0 seconds, a high amplitude of 621.5 gammas, and a dipolar signal. Acoustic Anomaly 42, the only such anomaly associated with Target No. 62, exhibited elements characteristic of a bridge structure. This target was identified visually as the Parish $\mathrm{Rd}$. Bridge. Figure 33 depicts an example of a magnetic contour plot of a bridge signature and Figure 34 shows the acoustic image of the bridge pilings that are characteristic of the survey area.

\section{Target No. 83}

Target No. 83 was identified within Survey Block 6 (Figure 32, Sheet 13). It consisted of two magnetic anomalies (M527 and M607), and two acoustic anomalies (A44 and A47). Magnetic Anomaly 527 retained a medium duration signature of 21.9 seconds, a high amplitude of 5,109.5 gammas, and a dipolar signal, while Magnetic Anomaly 607 possessed a medium duration signature of 25.7 seconds, a high amplitude of 35,854 gammas, and a dipolar signal. The two acoustic anomalies, A47 and A44, were characteristic of a bridge structure. In fact, this 
target corresponded to the location of the SR 94 Bridge, which spans Bayou Teche.

None of the underwater targets discussed above possess the qualities of significance as defined by the National Register of Historic Places criteria for evaluation (36 CFR 60.4 [ad]). No further study of these targets is recommended; however, if dredging is initiated within the vicinity of any of these targets, then caution is recommended.

\section{Pipeline or Cable Crossings}

In addition to the aforementioned bridge structures, 10 possible underwater cables and/or pipelines were identified within the Area of Potential Effect during survey. These were represented by Target Nos. 2, 12, 19, 20, $22,24,35,36,46$, and 70 . All of these targets had correlating magnetic and acoustic signatures. In addition, three of the targets discussed above in the section on bridges, also were associated with cables or pipelines; these included Target Nos. 12, 20, and 24. The figures provided for Target Nos. 22, 36, and 46 are representative of pipeline or cable crossings (Figures $35-38$ ).

\section{Target No. 2}

Target No. 2 consisted of two magnetic disturbances (M48 and M51), and one acoustic anomaly (A2); they were recorded within Survey Block 1 (Figure 32, Sheet 1). Magnetic Anomaly 48 retained a medium duration signature of 28.0 seconds, and a high amplitude of 265 gammas, a positive monopolar signal. Magnetic Anomaly 51 possessed similar characteristics. It had a medium duration signature of 15.8 seconds, and a high amplitude of 798.5 gammas, a positive monopolar signal. The single acoustic anomaly, A2, identified in association with Magnetic Anomalies 48 and 51, was representative of a possible underwater cable. This target was identified tentatively as a cable crossing that extended parallel to the Olivier St. Bridge.

Target No. 19

Target No. 19 was identified within Survey Block 2 and it consisted of a single mag- netic anomaly (M153), and one acoustic anomaly (A11) (Figure 32, Sheet 4). The single magnetic anomaly, M153, retained a medium duration signature of 20.9 seconds, a medium amplitude of 67 gammas, and a multi-component signal. The single associated acoustic anomaly, A11, was linear in nature. Target No. 19 consisted of an underwater cable that crossed Bayou Teche.

\section{Target No. 22}

Target No. 22 consisted of two magnetic anomalies (M99 and M175), and one acoustic anomaly (A8); it was identified within Survey Block 2 of the project corridor (Figure 32, Sheet 5). Magnetic Anomaly 99 possessed a long duration signature of 44.9 seconds, a high amplitude of 384 gammas, and a multi-component signal. In contrast, Magnetic Anomaly 175 retained a short duration signature of 7.7 seconds, a high amplitude of 137 gammas, and a dipolar signal. The single acoustic anomaly, A8, was linear in nature. Target No. 22 was identified visually as a cable crossing or pipeline and associated bank debris. Figure 35 depicts the magnetic contour plot of this cable or pipeline signature, while Figure 36 shows the acoustic image of this underwater target.

\section{Target No. 35}

Target No. 35 consisted of a single magnetic anomaly (M329), and one acoustic anomaly (A28); it was recorded within Survey Block 4 (Figure 32, Sheet 7). The single magnetic anomaly associated with this underwater target, M329, had a short duration signature of $6.6 \mathrm{sec}-$ onds, a high amplitude of 211.5 gammas, and a positive monopolar signal. In addition, Acoustic Anomaly 28 consisted of a linear anomaly with upright features. Target No. 35 was identified visually during survey as water and natural gas pipelines.

\section{Target No. 36}

Target No. 36 was identified within Survey Block 4 (Figure 32, Sheet 7) and it contained two magnetic anomalies (M328 and M330) and one acoustic anomaly (A27). Magnetic Anomaly 328 had a short duration signature of 9.9 

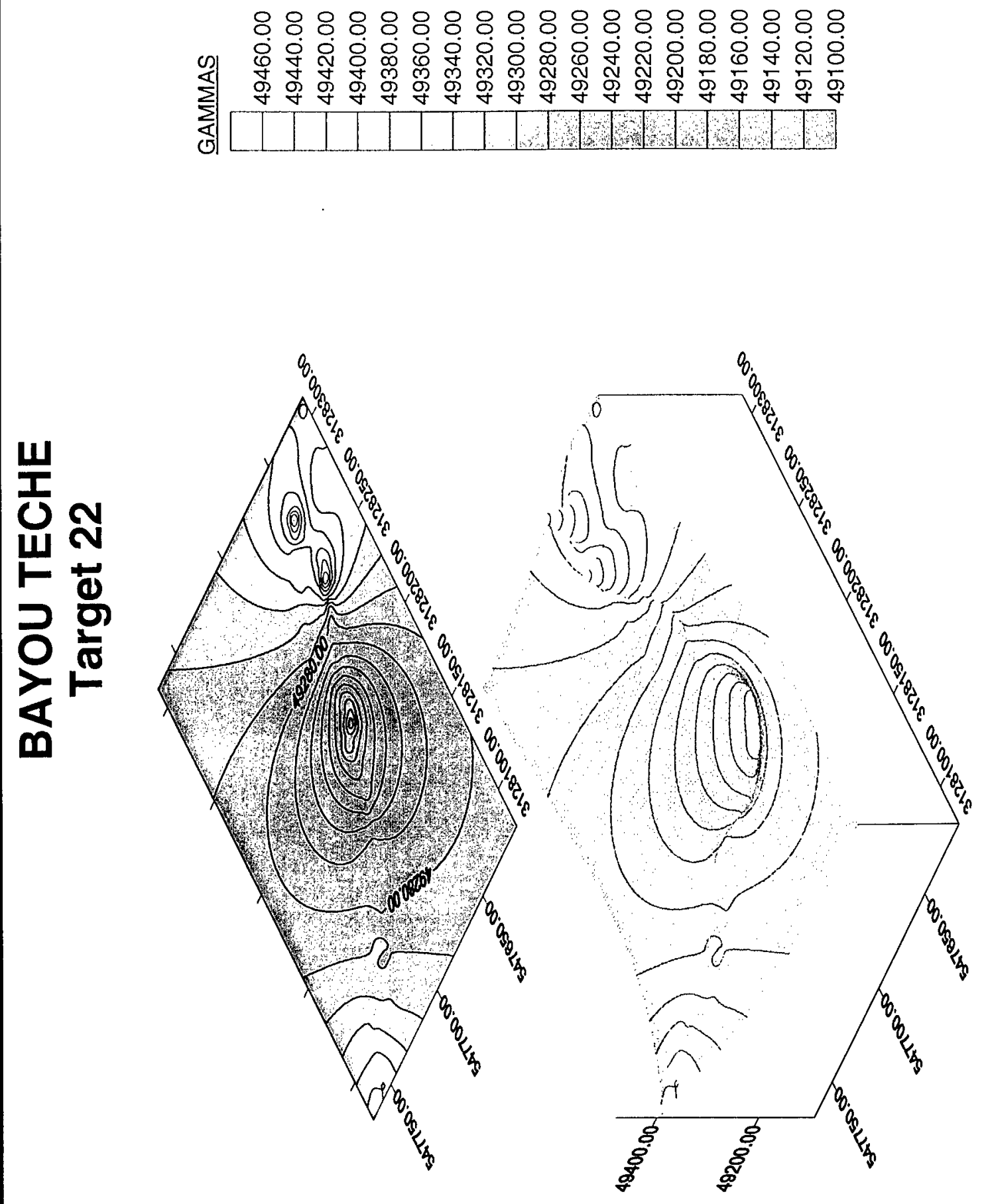


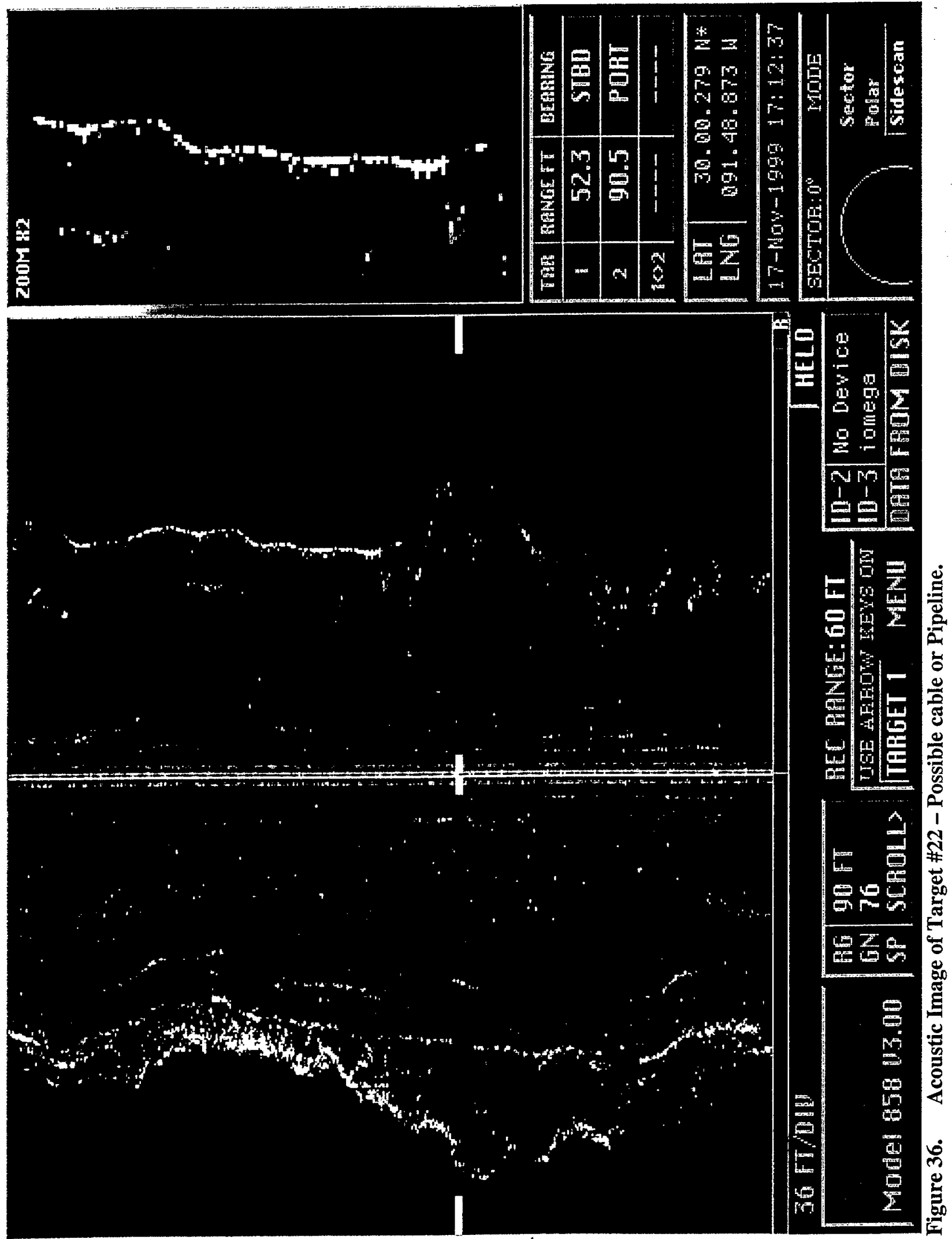




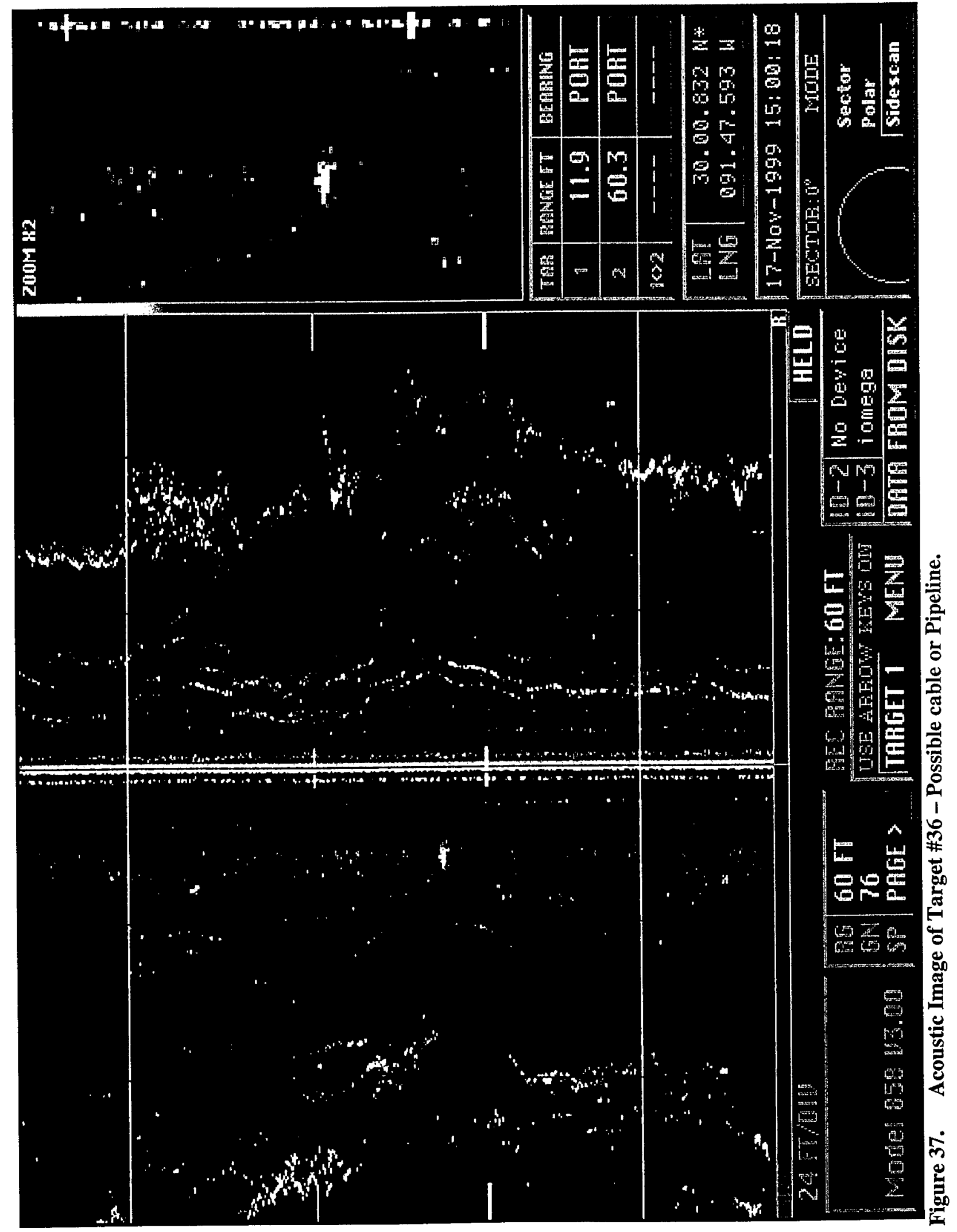




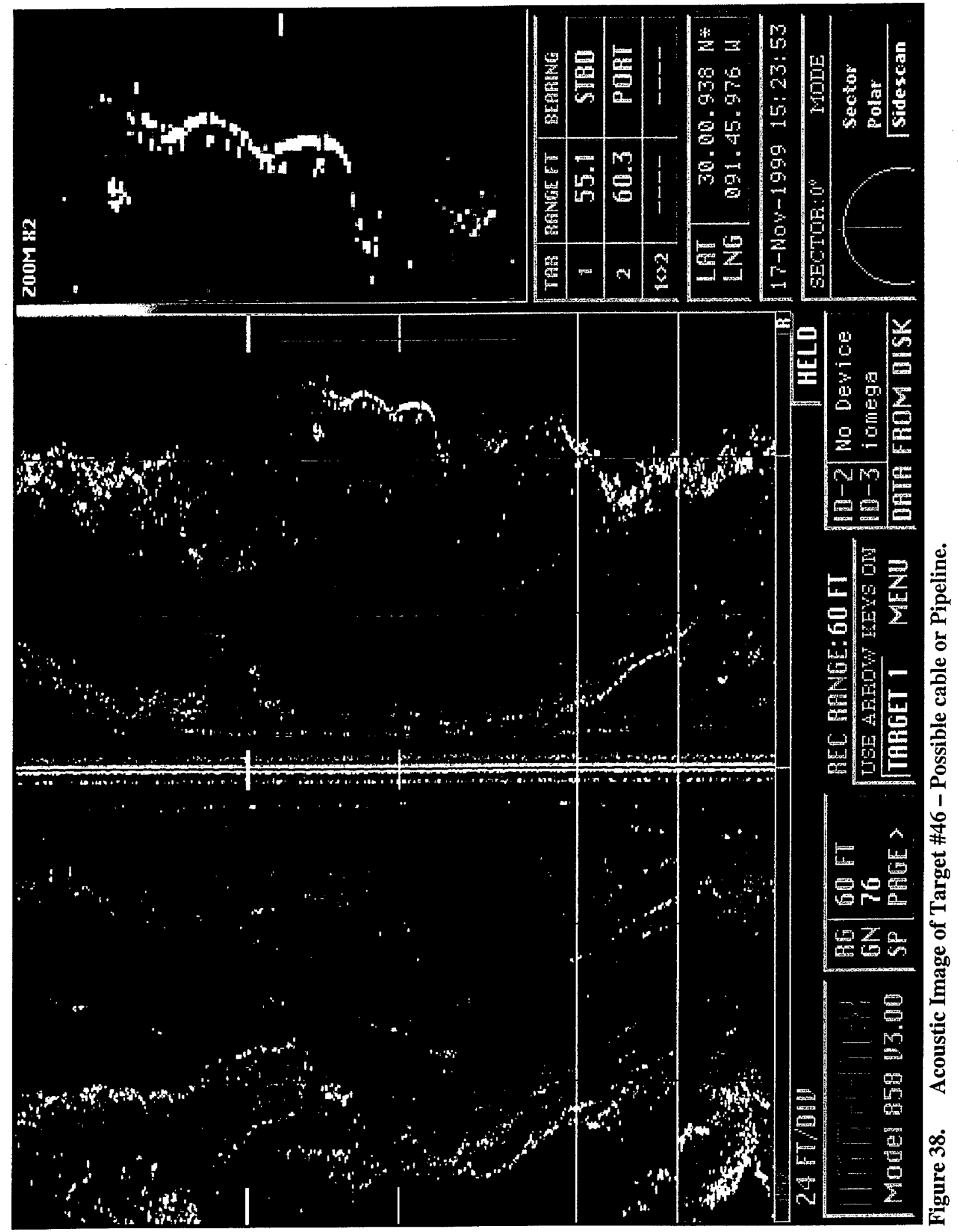


seconds, a high amplitude of 918.5 gammas, and a negative monopolar signal, whereas Magnetic Anomaly 330 possessed a medium duration signature of 14.8 seconds, a high amplitude of 601.5 gammas, and a negative monopolar signal. The single acoustic anomaly, A27, was representative of a linear feature that was visible at the mid-channel point. The magnetic element of Target No. 6 was identified as a drainage outfall and the sonar image depicted an unrelated water and gas pipeline crossing as indicated by banking signs. Figure 37 depicts the acoustic image of Target No. 36.

\section{Target No. 46}

Target No. 46 consisted of two magnetic anomalies (M286 and M375), and two acoustic anomalies (A25 and A31) that were recorded within Survey Block 4 (Figure 32, Sheet 9). Magnetic Anomaly 286 had a long duration signature of 36.7 seconds, a high amplitude of 1,245 gammas, and a multi-component signal. Magnetic Anomaly 375 possessed a medium duration signature of 24.1 seconds, a high amplitude of 779.5 gammas, and a dipolar signal. The acoustic anomalies, A25 and 31, were linear in nature. This target was identified visually as a pipeline crossing. Figure 38 depicts the acoustic image of the pipeline.

\section{Target No. 70}

Target No. 70, located in Survey Block 5, encompassed two magnetic anomalies (M453 and M481) (Figure 32, Sheet 11). Magnetic Anomaly 453 retained a medium duration signature of 11.0 seconds, a high amplitude of 518 gammas, and a dipolar signal, while Magnetic Anomaly 481 possessed a medium duration signature of 24.2 seconds, a medium amplitude of 55 gammas, and a dipolar signal. No acoustic anomalies were associated with Target No. 70. This target was identified visually as an underwater pipeline and unrelated bank debris.

None of the underwater targets identified as possible cables and/or pipelines possessed the qualities of significance as defined by the National Register of Historic Places criteria for evaluation (36 CFR 60.4 [a-d]). No additional investigation of these targets is recommended; however, for safety reasons, avoidance of these areas during dredging may be warranted.

Bulkheads

In addition to the previously described bridge structures, pipelines, and cable crossings, eight bulkheads were noted along the banks of Bayou Teche. These bulkheads were identified through both visual examination and by correlating them with the magnetic signatures the produced. These bulkheads were represented by Target Nos. 3, 4, 6, 16, 28, 29, 34, and 84. One of these bulkheads, Target No. 34, also was identified acousticly with the side scan sonar. The contour plot generated for Target No. 84 is representative of such targets (Figure 39).

\section{Target No. 3}

Target No. 3 was identified within Survey Block 3; it consisted of two magnetic anomalies (M43 and M58) (Figure 32, Sheet 1). Magnetic Anomaly 43 produced a medium duration signature of 14.8 seconds, a high amplitude of 279 gammas, and a dipolar signal. Magnetic Anomaly 58 exhibited similar characteristics; it produced a medium duration signature of $12.5 \mathrm{sec}$ onds, a high amplitude of 954.5 gammas, and a dipolar signal. No acoustic anomalies were identified in association with Target No. 3. This target was identified visually as a bulkhead and related boat ramp.

\section{Target No. 4}

Target No. 4 was recorded within Survey Block 1 (Figure 32, Sheet 1). This target consisted of two magnetic anomalies (M41 and M60). Magnetic Anomaly 41 produced a medium duration signature of 12.6 seconds, a high amplitude of 112.5 gammas, and a dipolar signal. Magnetic Anomaly 60 possessed a short duration signature of 9.9 seconds, a high amplitude of 244 gammas, and a dipolar signal. No acoustic anomalies were identified in association with Target No. 4 . This target also consisted of a bulkhead.

\section{Target No. 6}

Target No. 6 was identified within Survey Block 2; it encompassed two magnetic anomalies (M27 and M75) (Figure 32, Sheet 2). The 


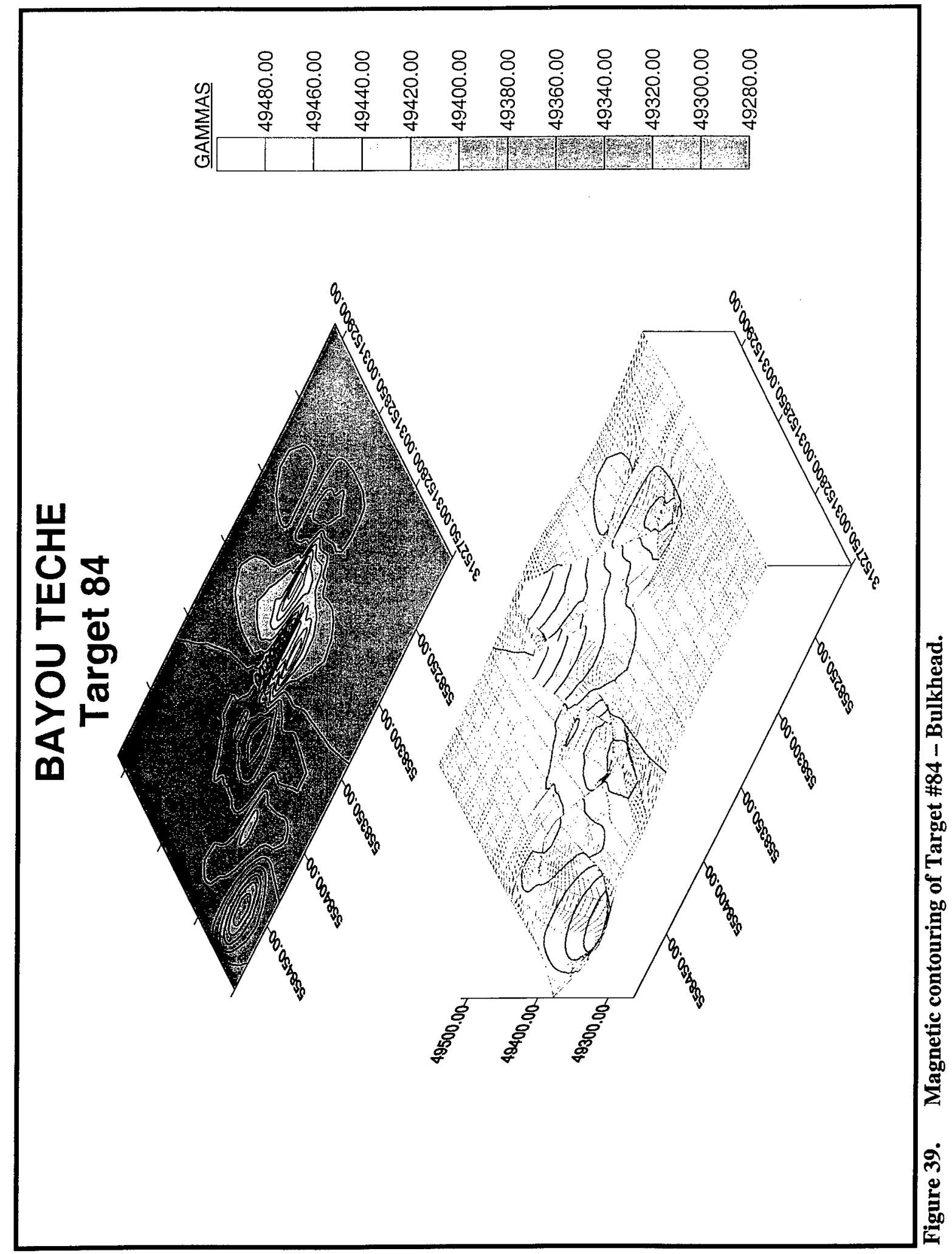


first magnetic anomaly, M27, exhibited a short duration signature of 6.6 seconds, a low amplitude of 45 gammas, and a dipolar signal. Magnetic Anomaly 75 produced a very long duration signature of 2 minutes, 6.2 seconds, a high amplitude of 141 gammas, and a multicomponent signal. No acoustic anomalies were associated with this underwater target. Target No. 6 also was identified visually as a bulkhead.

\section{Target No. 16}

This target was located within Survey Block 2 (Figure 32, Sheet 3). It consisted of two magnetic anomalies (M1 and M136). Magnetic Anomaly 1 produced a medium duration signature of 11.5 seconds, a low amplitude of 16 gammas, and a multi-component signal, while magnetic anomaly 136 produced a medium duration signature of 19.8 seconds, a high amplitude of 105 gammas, and a multicomponent signal. No acoustic anomalies were associated with Target No. 16. This target also was identified visually as part of a bulkhead.

\section{Target No. 28}

Target No. 28 consisted of two magnetic anomalies (M211 and M240); they were recorded within Survey Block 3 (Figure 32, Sheet 6). The first magnetic anomaly, M211, possessed a long duration signature of 49.3 seconds, a high amplitude of 395 gammas, and a negative monopolar signal. The second magnetic anomaly, M240, exhibited similar characteristics; it produced a long duration signature of 54.9 seconds, a high amplitude of 1,297 gammas, and a negative monopolar signal. This target also was identified visually as a bulkhead. No acoustic signatures were identified in association with this magnetic anomaly.

\section{Target No. 29}

Target No. 29 was identified within Survey Block 3 and it consisted of two magnetic anomalies (M210 and M241) (Figure 32, Sheet 6). Magnetic Anomaly 210 had a short duration signature of 8.2 seconds, a high amplitude of 213.5 gammas, and a dipolar signal. Magnetic Anomaly 241 produced a short duration signature of 7.2 seconds, a low amplitude of 28 gammas, and a negative monopolar signal.
Target No. 29 produced no associated acoustic anomaly. This target also was identified during survey as a bulkhead.

\section{Target No. 34}

Target No. 34 was identified in Survey Block 3; it consisted of two magnetic anomalies (M191 and M267), and one acoustic anomaly (A15) (Figure 32, Sheet 7). Magnetic Anomaly 191 retained a long duration signature of 37.9 seconds, a high amplitude of 135 gammas, and a multi-component signal. Magnetic Anomaly 267 exhibited similar characteristics, a long duration signature of 35.0 seconds, a medium amplitude of 50 gammas, and a multi-component signal. The single acoustic anomaly associated with Target No. 34, A15, displayed the physical characteristics of a bulkhead. This target also was identified visually as a bulkhead.

\section{Target No. 84}

This underwater target was recorded within Survey Block 6 (Figure 32, Sheet 13) Target No. 84 was composed of two magnetic anomalies (M522 and M613). The first anomaly, M522, had a long duration signature of 47.0 seconds, a high amplitude of 994 gammas, and a multicomponent signal. The second anomaly, M613, possessed a medium duration signature of 14.8 seconds, a high amplitude of 598 gammas, and a multi-component signal. No acoustic anomalies were associated with this anomaly. Target No. 84 also was identified visually as a bulkhead. An example of a magnetic contour plot of a typical bulkhead signature appears below (Figure 39).

None of the bulkheads discussed above possess the qualities of significance as defined by the National Register of Historic Places criteria for evaluation (36 CFR 60.4 [a-d]). No additional investigation of these targets is recommended. It should be noted, however, that numerous bulkheads were identified along the survey corridor; however, they were not recorded magnetically, nor did they represent potentially significant cultural resources applying the same National Register criteria identified above.

\section{Bank Debris}

Much of the debris located along the banks of Bayou Teche was detected as a result of the magnetic signature it produced. A total of 13 
targets were considered to be bank debris and they were verified visually and correlated with the magnetic signatures detected during survey. These included Target Nos. 9, 11, 15, 18, $25,26,37,49,50,60,67,77$, and 78. Target No. 9 is representative of the contour plots associated with this debris (Figure 40).

\section{Target No. 9}

Target No. 9 was identified within Survey Block 1 (Figure 32, Sheet 2). It consisted of two magnetic anomalies (M23 and M79). Magnetic Anomaly 23 produced a long duration signature of 36.8 seconds, a high amplitude of 236 gammas, and a multi-component signal. The second magnetic anomaly, M79, exhibited similar magnetic characteristics. It had a long duration signature of 30.2 seconds, a high amplitude of 274.5 gammas, and a multi-component signal. No acoustic anomalies were identified in association with Target No. 9. This target was identified visually as bank debris.

\section{Target No. 11 \\ Identified within Survey Block 1, Target No. 11 encompassed two magnetic anomalies (M15 and M86) (Figure 32, Sheet 2). The first anomaly, M15, produced a short duration sig- nature of 7.1 seconds, a medium amplitude of 66.5 gammas, and a positive, monopolar sig- nal. Magnetic Anomaly 86 possessed a me- dium duration signature of 26.9 seconds, a low amplitude of 44.5 gammas, and a multi- component signal. No acoustic anomalies were detected in association with Target No. 11. This target also was identified visually as bank debris.}

\section{Target No. 15}

This underwater target was recorded within Survey Block 2 (Figure 32, Sheet 2). It consisted of two magnetic anomalies (M8 and M94) only; no acoustic signatures were associated with Target No. 15. Magnetic Anomaly 8 retained a short duration signature of $8.7 \mathrm{sec}$ onds, a low amplitude of 18.5 gammas, and a dipolar signal. Magnetic Anomaly 94, on the other hand, produced a medium duration signature of 10.9 seconds, a medium amplitude of 57.5 gammas, and a positive, monopolar sig- nal. This target was identified visually as bank debris.

\section{Target No. 18}

Target No. 18 included two magnetic anomalies (M127 and M147) and it was recorded within Survey Block 2 (Figure 32, Sheet 3). Magnetic Anomaly 127 produced a medium duration signature of 22.4 seconds, a high amplitude of 210 gammas, and a positive, monopolar signal. Magnetic Anomaly 147 yielded a long duration signature of 31.7 seconds, a low amplitude of 46.5 gammas, and a multicomponent signal. No acoustic anomalies were associated with Target No. 18. This target was identified visually as bank debris.

\section{Target No. 25}

Recorded within Survey Block 3, Target No. 25 consisted of two magnetic anomalies (M222 and M230); it failed to produce any evidence of an acoustic signature (Figure 32, Sheet 6). The first anomaly, M222, had a long duration signature of 32.9 seconds, a high amplitude of 522.5 gammas, and a positive monopolar signal. Magnetic Anomaly 230 possessed similar characteristics, a long duration signature of $47.0 \mathrm{sec}-$ onds, a high amplitude of 474.5 gammas, and a positive monopolar signal. This target also was identified visually as bank debris.

\section{Target No. 26}

Target No. 26 was recorded within Survey Block 3 and it encompassed two magnetic anomalies (M220 and M232) (Figure 32, Sheet 6 ). The first anomaly, M220, retained a short duration signature of 6.0 seconds, a high amplitude of 107 gammas, and a dipolar signal. The second anomaly, M232, produced a medium duration signature of 11.5 seconds, a high amplitude of 106.5 gammas, and a positive monopolar signal. No acoustic anomalies were associated with Target No. 26. This underwater target was identified visually as bank debris.

\section{Target No. 37}

Target No. 37 consisted of two magnetic anomalies (M324 and M333); it was identified within Survey Block 4 (Figure 32, Sheet 8). Magnetic Anomaly 324 produced a short duration signature of 8.7 seconds, a low amplitude of 

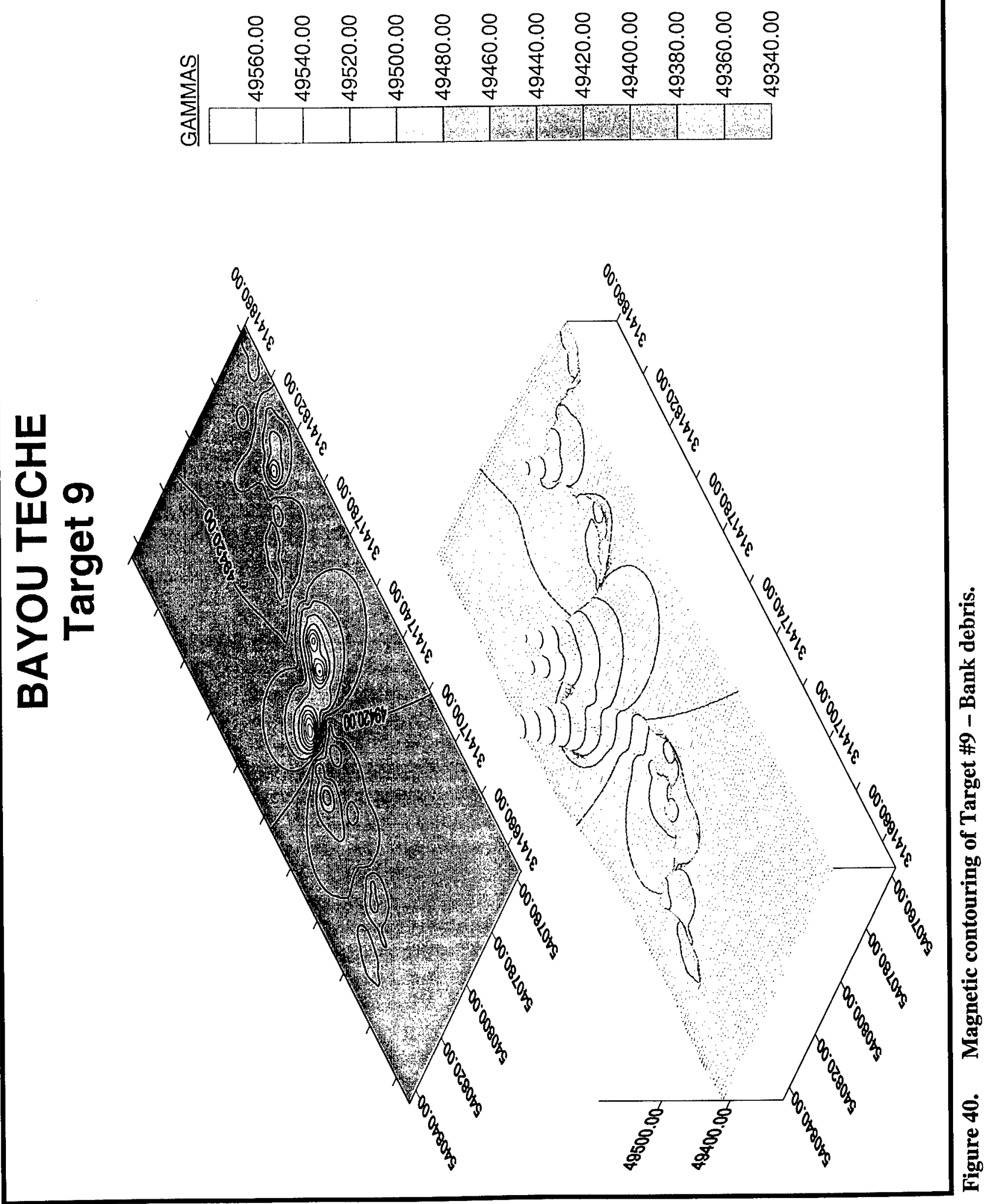
24 gammas, and a positive monopolar signal. Magnetic Anomaly 333 yielded a medium duration signature of 12.1 seconds, a high amplitude of 134 gammas, and a multi-component signal. No acoustic anomaly was detected in association with Target No. 37. This target also was identified in the field as bank debris.

\section{Target No. 49}

Target No. 49 was identified within Survey Block 4 and it encompassed two magnetic anomalies (M276 and M387) (Figure 32, Sheet 9). The first anomaly, M276, retained a short duration signature of 4.4 seconds, a medium amplitude of 93 gammas, and a negative monopolar signal. The second anomaly, M387, had a short duration signature of 9.3 seconds, a high amplitude of 105.5 gammas, and a negative monopolar signal. No acoustic anomalies were associated with Target No. 49. This target was identified visually as bank debris and fencing that extended into Bayou Teche.

\section{Target No. 50}

Target No. 50 also was located within Survey Block 4 (Figure 32, Sheet 9). This underwater target consisted of two magnetic anomalies (M274 and M390). Magnetic Anomaly 274 possessed a medium duration signature of 15.3 seconds, a high amplitude of 503.5 gammas, and a multi-component signal. Magnetic Anomaly 390 retained a short duration signature of 7.7 seconds, a high amplitude of 227 gammas, and a negative monopolar signal. Target No. 50 produced no detectable acoustic signature. This target was identified visually as bank debris.

\section{Target No. 60}

Target No. 60 was identified in Survey Block 5, it consisted of two magnetic anomalies (M416 and M505) (Figure 32, Sheet 10). The first anomaly, M416, produced a medium duration signature of 20.3 seconds, a high amplitude of 3,591 gammas, and a positive monopolar signal. The second anomaly, M505, yielded a long duration signature of $36.6 \mathrm{sec}-$ onds, a high amplitude of $\mathbf{4 9 0 . 5}$ gammas, and a dipolar signal. Although it produced no recognizable acoustic signature, Target No. 60 was identified visually in the field as bank debris.

\section{Target No. 67}

Target No. 67 was identified within Survey Block 5 (Figure 32, Sheet 11). It consisted of two magnetic anomalies (M444 and M486). Magnetic Anomaly 444 possessed a short duration signature of 7.2 seconds, a high amplitude of 235 gammas, and a dipolar signal. Magnetic Anomaly 486 also retained a short duration signature of 6.6 seconds, a medium amplitude of 99 gammas, and a positive monopolar signal. No acoustic anomalies were detected in association with Target No. 67; it was identified visually as bank debris.

\section{Target No. 77}

Target No. 77 was identified within Survey Block 6 (Figure 32, Sheet 12). It consisted of two magnetic anomalies (M551 and M577). The first anomaly, M551, retained a long duration signature of 35.7 seconds, a high amplitude of 179.5 gammas, and a multi-component signal. Magnetic Anomaly M577 produced a short duration signature of 6.0 seconds, a low amplitude of 40 gammas, and a negative monopolar signal. No acoustic anomalies were identified in association with this target. Target No. 77 was identified visually as bank debris.

\section{Target No. 78}

Recorded within Survey Block 6, Target No. 78 consisted of two magnetic anomalies (M549 and M580) (Figure 32, Sheet 12). Magnetic Anomaly 549 produced a medium duration signature of 28.5 seconds, a medium amplitude of 92.5 gammas, and a negative monopolar signal. Magnetic Anomaly 580 produced a medium duration signature of 19.7 seconds, a medium amplitude of 72 gammas, and a multicomponent signal. Target No. 78 was identified visually during survey as bank debris. No acoustic signatures were identified in association with this anomaly.

The underwater targets discussed above all were characterized as bank debris. None of these anomalies possess the qualities of significance as defined by the National Register of Historic Places criteria for evaluation (36 CFR 60.4 [ad]). No additional investigation of these targets is recommended. 


\section{Other Debris}

The remainder of the underwater targets recorded during the survey of the Bayou Teche channel consisted of probable scatters of ferrous material. Only five of these magnetic targets produced associated acoustic data. These included Target Nos. 27, 71, 72, 80, and 81 . Target 27 represented an abandoned sugar dock, while the other targets represented ferrous objects intermixed with natural debris, such as submerged trees. The figures provided for the targets identified in this section are representative of most of the magnetic plots and acoustic images associated with this debris. None of the targets discussed below possess the qualities of significance as defined by the National Register of Historic Places criteria for evaluation (36 CFR 60.4 [a-d]). No additional investigation of these underwater targets is recommended.

\section{Target No. 5}

Target No. 5 was recorded within Survey Block 1; it encompassed two magnetic anomalies (M40 and M61) (Figure 32, Sheet 1). The first magnetic anomaly, M40, produced a short duration signature of 6.0 seconds, a medium amplitude of 94 gammas, and a negative, monopolar signal. The second anomaly, M61, produced a medium duration signature of 26.3 seconds, a low amplitude of 36.5 seconds, and a multi-component signal. No acoustic signature was associated with this target. Target No. 5 represented a scatter of ferrous debris identified along the channel bottom.

\section{Target No. 7}

Target No. 7 also was identified within Survey Block 1 (Figure 32, Sheet 2). It consisted of two magnetic anomalies (M25 and M76). Magnetic Anomaly 25 had a medium duration signature of 12.0 seconds, a high amplitude of 164 gammas, and a dipolar signal. Magnetic Anomaly 76 produced a short duration signature of 3.8 seconds, a medium amplitude of 57 gammas, and a dipolar signal. This scatter of ferrous debris failed to yield a detectable acoustic signature.
Target No. 8

Situated within Survey Block 1, Target No. 8 was composed of two magnetic anomalies (M24 and M77) (Figure 32, Sheet 2). The first magnetic anomaly, M24, possessed a short duration signature of 8.8 seconds, a medium amplitude of 51 gammas, and a dipolar signal. The second magnetic anomaly, M77, retained a short duration signature of 7.2 seconds, a low amplitude of 46.5 gammas, and a positive, monopolar signal. No acoustic signature was associated with Target No. 8. It too was characterized as ferrous debris scattered along the channel bottom.

\section{Target No. 10}

Target No. 10 was identified within Survey Block 1 (Figure 32, Sheet 2). This target was composed of two magnetic anomalies (M22 and M80). Magnetic Anomaly 22 had a medium duration signature of 19.2 seconds, a medium amplitude of 67.5 gammas, and a multi-component signal. Magnetic Anomaly 80 exhibited similar characteristics, a medium duration signature of 21.9 seconds, a medium amplitude of 74 gammas, and a multi-component signal. No detectable acoustic signature was identified in association with Target No. 10 (Figure 41).

\section{Target No. 13}

Target No. 13 consisted of two magnetic anomalies (M11 and M90); it was recorded within Survey Block 1 (Figure 32, Sheet 2). The first anomaly, M11, produced a medium duration signature of 12.1 seconds, a high amplitude of 179 gammas, and a dipolar signal. The second anomaly, M90, exhibited characteristics similar to those of Magnetic Anomaly 11. It produced a medium duration signature of 11.5 seconds, a high amplitude of 187 gammas, and a dipolar signal. Target No. 13 was classified as a scatter of ferrous material lying within the channel bottom. No acoustic anomalies were identified in the Target No. 13 area.

\section{Target No. 14}

Identified within Survey Block 1, Target No. 14 encompassed two magnetic anomalies 

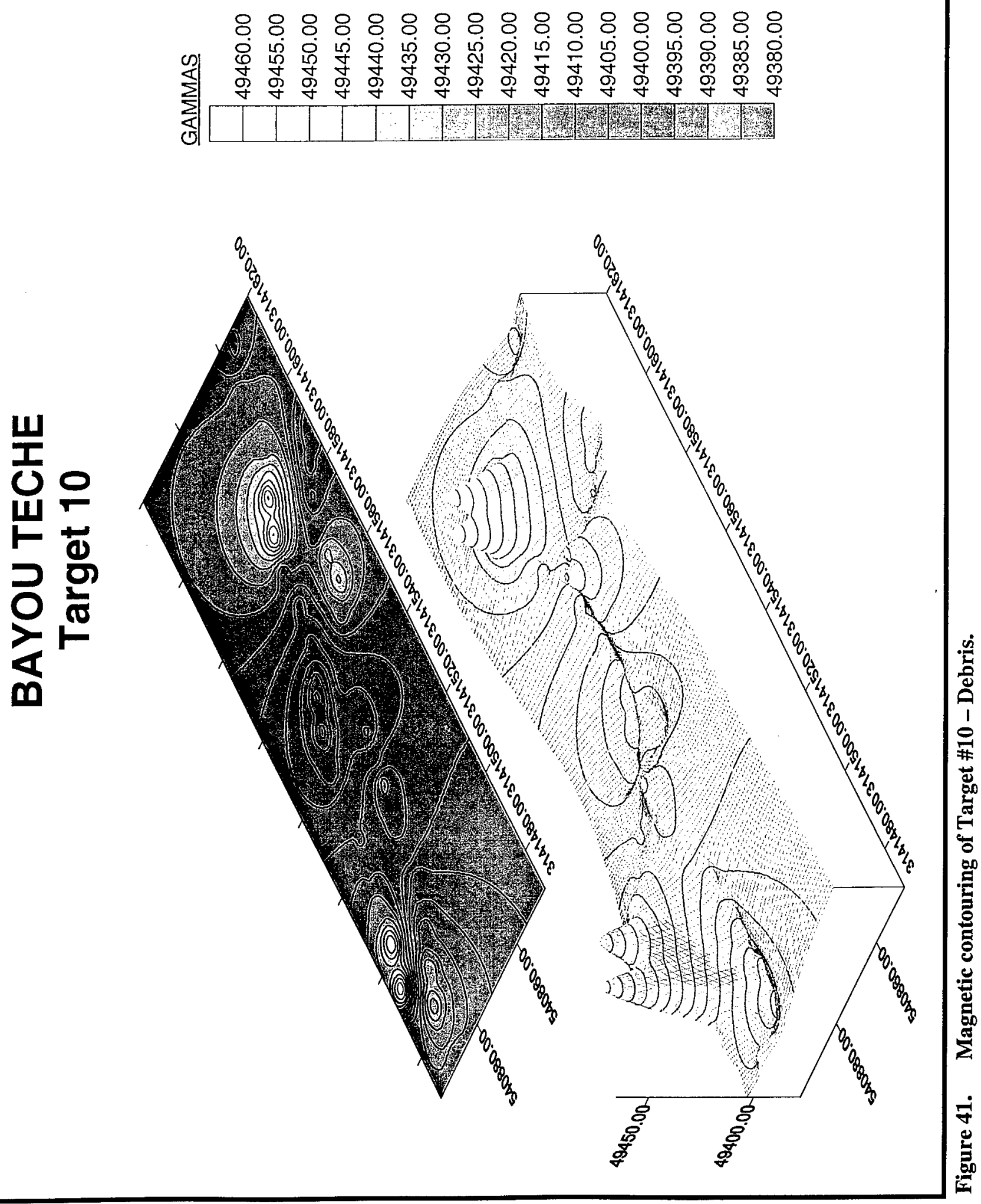
(M10 and M92) (Figure 32, Sheet 2). Magnetic Anomaly 10 retained a medium duration signature of 24.7 seconds, a high amplitude of 144.5 gammas, and a multi-component signal, while Magnetic Anomaly 92 possessed a medium duration signature of 12.0 seconds, a medium amplitude of 65 gammas, and a multicomponent signal. This scatter of ferrous debris produced no acoustic signature.

\section{Target No. 17}

Target No. 17 was recorded within Survey Block 2 (Figure 32, Sheet 3). It consisted of two magnetic anomalies (M131 and M141). The first anomaly, M131, produced a short duration signature of 9.8 seconds, a medium amplitude of 69.5 gammas, and a dipolar signal. The second anomaly, M141, produced a short duration signature of 7.1 seconds, a low amplitude of 23.5 gammas, and a positive, monopolar signal. This target also was classified as a scatter of ferrous debris; it produced no detectable acoustic signature.

\section{Target No. 21}

Target No. 21 was recorded within Survey Block 2 (Figure 32, Sheet 4). It encompassed two magnetic anomalies (M108 and M165). Magnetic Anomaly 108 possessed a short duration signature of 8.2 seconds, a medium amplitude of 89 gammas, and a positive monopolar signal. Magnetic Anomaly 165 retained a medium duration signature of 24.1 seconds, a high amplitude of 117 gammas, and a dipolar signal. This scatter of underwater ferrous debris produced no associated acoustic signature.

\section{Target No. 27}

Target No. 27 was recorded within Survey Block 3; it consisted of two magnetic anomalies (M215 and M236), and a single acoustic anomaly (A18) (Figure 32, Sheet 6). Magnetic Anomaly 215 produced a long duration signature of 47.0 seconds, a high amplitude of 875.5 gammas, and a multi-component signal. The second magnetic anomaly, M236, produced a long duration signature of 49.9 seconds, a high amplitude of 233 gammas, and a negative monopolar signal. The single acoustic signature, A18, may represent the structural elements of a dock; however, this target had suffered extensive damage historically (Figures 42 and 43).

Target No. 30

Target No. 30 was identified within Survey Block 3 (Figure 32, Sheet 6). This underwater target was composed of two magnetic anomalies (M204 and M250). The first anomaly, M204, had a short duration signature of 4.9 seconds, a medium amplitude of 68 gammas, and a positive monopolar signal. The second anomaly, M250, retained a medium duration signature of 25.1 seconds, a medium amplitude of 74 gammas, and a dipolar signal. This underwater target, characterized as a scatter of ferrous debris within the channel bottom, failed to produce an associated acoustic signature.

\section{Target No. 31}

Recorded within Survey Block 3, Target No. 31 consisted of two magnetic anomalies (M200 and M254) (Figure 32, Sheet 7). Magnetic Anomaly 200 produced a long duration signature of 59.3 seconds, a medium amplitude of 75.5 gammas, and a multi-component signal. Magnetic Anomaly 254 produced a long duration signature of 37.7 seconds, a medium amplitude of 69 gammas, and a positive monopolar signal. This scatter of ferrous debris is depicted in Figure 44. No acoustic signatures were identified in association with this anomaly.

\section{Target No. 32}

Target No. 32 was identified within Survey Block 3 (Figure 32, Sheet 7). It was composed of two magnetic anomalies (M197 and M260); no acoustic signature was detected in association with this survey. Magnetic Anomaly 197 produced a short duration signature of 8.7 seconds, a medium amplitude of 77.5 gammas, and a dipolar signal. Magnetic Anomaly 260 possessed a medium duration signature of 14.8 seconds, a low amplitude of 14 gammas, and a dipolar signal. This target also was described as a scatter of ferrous debris resting on the channel bottom.

Target No. 33

Target No. 33 was identified within Survey Block 3, and it consisted of two magnetic anomalies (M195 and M263) (Figure 32, Sheet 


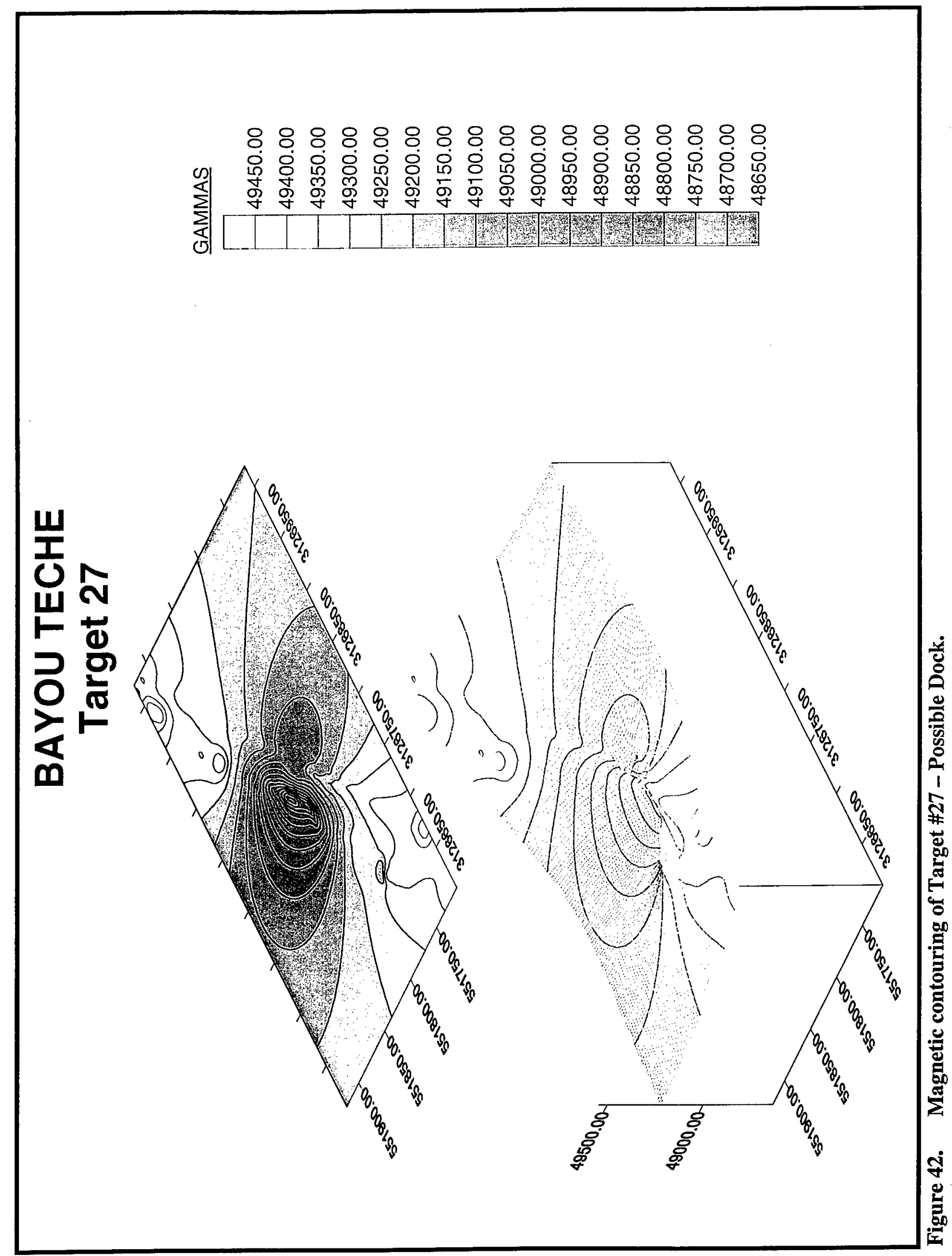




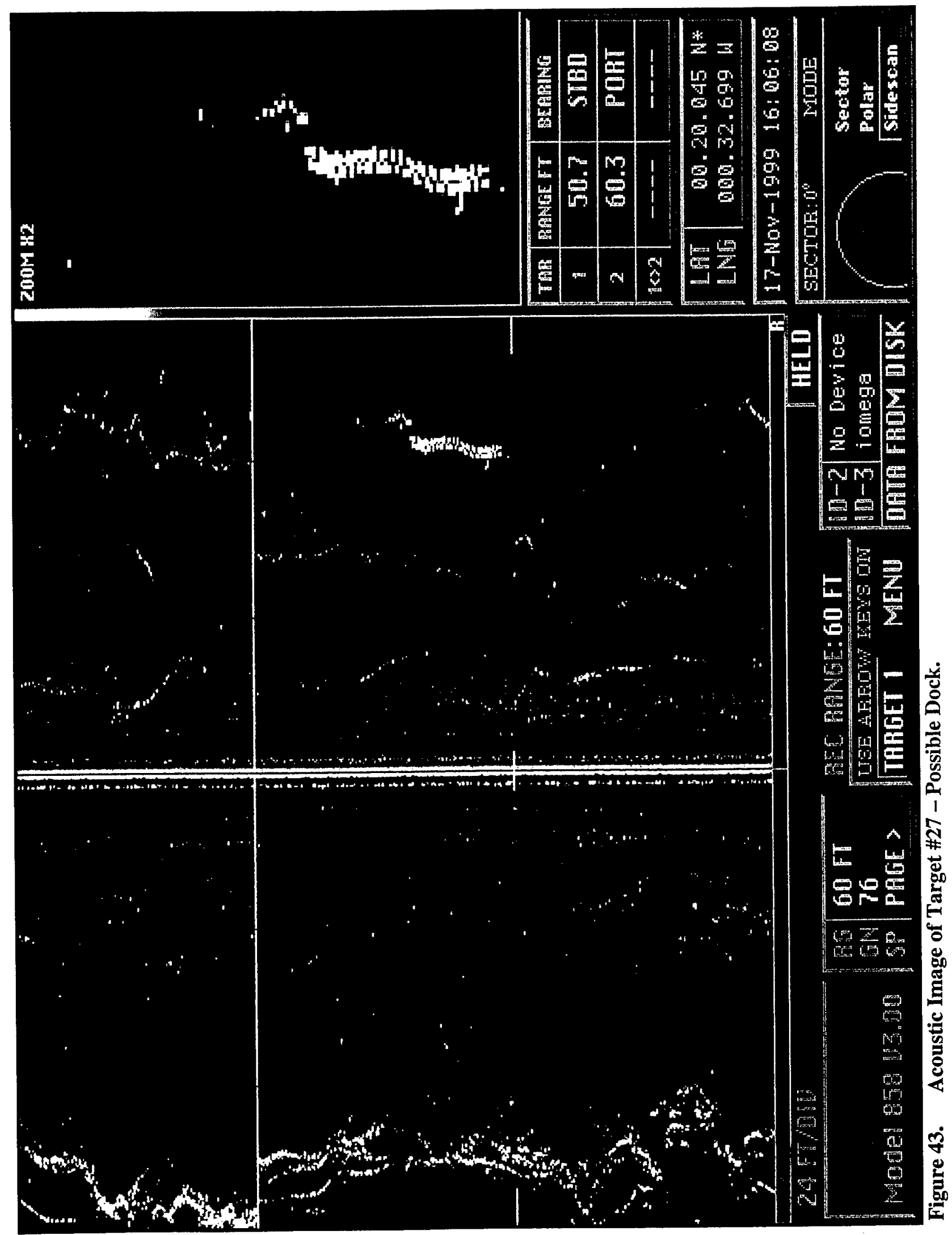



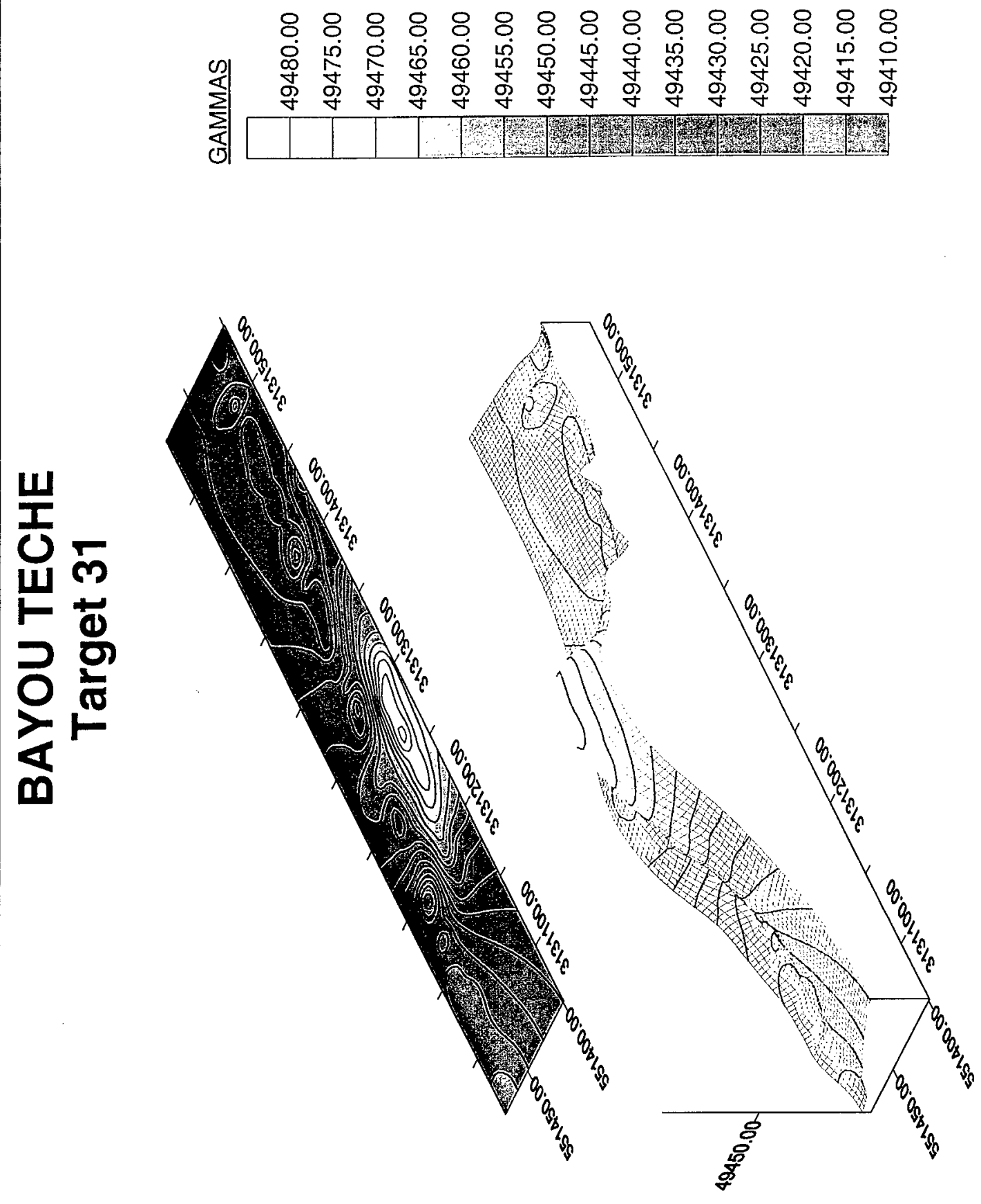
7). Magnetic Anomaly 195 possessed a medium duration signature of 11.5 seconds, a high amplitude of 229 gammas, and a dipolar signal. Magnetic Anomaly 263 produced a medium duration signature of 14.7 seconds, a high amplitude of 115 gammas, and a multicomponent signal. No acoustic signature was detected as part of Target No. 33.

Target No. 38

Target No. 38 was recorded within Survey Block 4; it consisted of two magnetic anomalies (M312 and M344) (Figure 32, Sheet 8). Magnetic Anomaly 312 had a short duration signature of 6.7 seconds, a low amplitude of 18 gammas, and a dipolar signal. Magnetic Anomaly 344 produced a long duration signature of 39.0 seconds, a low amplitude of 30.5 gammas, and a multi-component signal. The magnetic contour plot of this underwater target is depicted in Figure 45. Target No. 38 also consisted of a scatter of ferrous debris; it produced no detectable acoustic signature.

\section{Target No. 39}

Target No. 39 was located within Survey Block 4 (Figure 32, Sheet 8). It encompassed two magnetic anomalies (M310 and M345). The first anomaly, M310, produced a medium duration signature of 12.7 seconds, a low amplitude of 30 gammas, and a dipolar signal. The second magnetic anomaly, M90, produced a medium duration signature of 11.5 seconds, a high amplitude of 187 gammas, and a dipolar signal. This underwater scatter of ferrous debris, like Target No. 38, failed to produce an associated acoustic signature.

\section{Target No. 40}

Target No. 40 also was identified within Survey Block 4; it consisted of two magnetic anomalies (M306 and M353) (Figure 32, Sheet 8). Magnetic Anomaly 306 possessed a long duration signature of 35.5 seconds, a medium amplitude of 62.5 gammas, and a multicomponent signal. Magnetic Anomaly 353 exhibited similar characteristics; it produced a medium duration signature of 26.9 seconds, a high amplitude of 102 gammas, and a multicomponent signal. No acoustic signature was associated with Target No. 40; it was described as a scatter of ferrous debris identified along the channel bottom.

\section{Target No. 41}

Situated within Survey Block 4, Target No. 41 produced two magnetic anomalies (M305 and M354) (Figure 32, Sheet 8). Magnetic Anomaly 305 produced a medium duration signature of 12.0 seconds, a medium amplitude of 78.5 gammas, and a negative, monopolar signal. Magnetic Anomaly 354 exhibited a long duration signature of 36.2 seconds, a medium amplitude of 64.5 gammas, and a multi-component signal. This scatter of underwater ferrous debris failed to produce a detectable acoustic signature.

\section{Target No. 42}

Target No. 42 consisted of two magnetic anomalies (M297 and M360) that were identified within Survey Block 4 (Figure 32, Sheet 8). Magnetic Anomaly 297 retained a medium duration signature of 15.3 seconds, a medium amplitude of 53.5 gammas, and a multi-component signal. Magnetic Anomaly 360 had a short duration signature of 3.9 seconds, a low amplitude of 27.5 gammas, and a negative monopolar signal. No acoustic signature was associated with this scatter of ferrous debris.

\section{Target No. 44}

Target No. 44 was situated within Survey Block 4 and it encompassed two magnetic anomalies (M288 and M372) (Figure 32, Sheet 9). Magnetic Anomaly 288 retained a long duration signature of 54.2 seconds, a high amplitude of 103 gammas, and a multi-component signal. Magnetic Anomaly 372 produced a long duration signature of 35.1 seconds, a low amplitude of 21.5 gammas, and a multi-component signal. This underwater target, interpreted as a scatter of ferrous debris, failed to produce a detectable acoustic signature.

\section{Target No. 45}

Target No. 45 consisted of two magnetic anomalies (M287 and M374) that were identified within Survey Block 4 (Figure 32, Sheet 9). The first magnetic anomaly, M287, possessed a medium duration signature of 13.7 seconds, a low amplitude of 36.5 gammas, and a multicomponent signal. The second magnetic anom- 

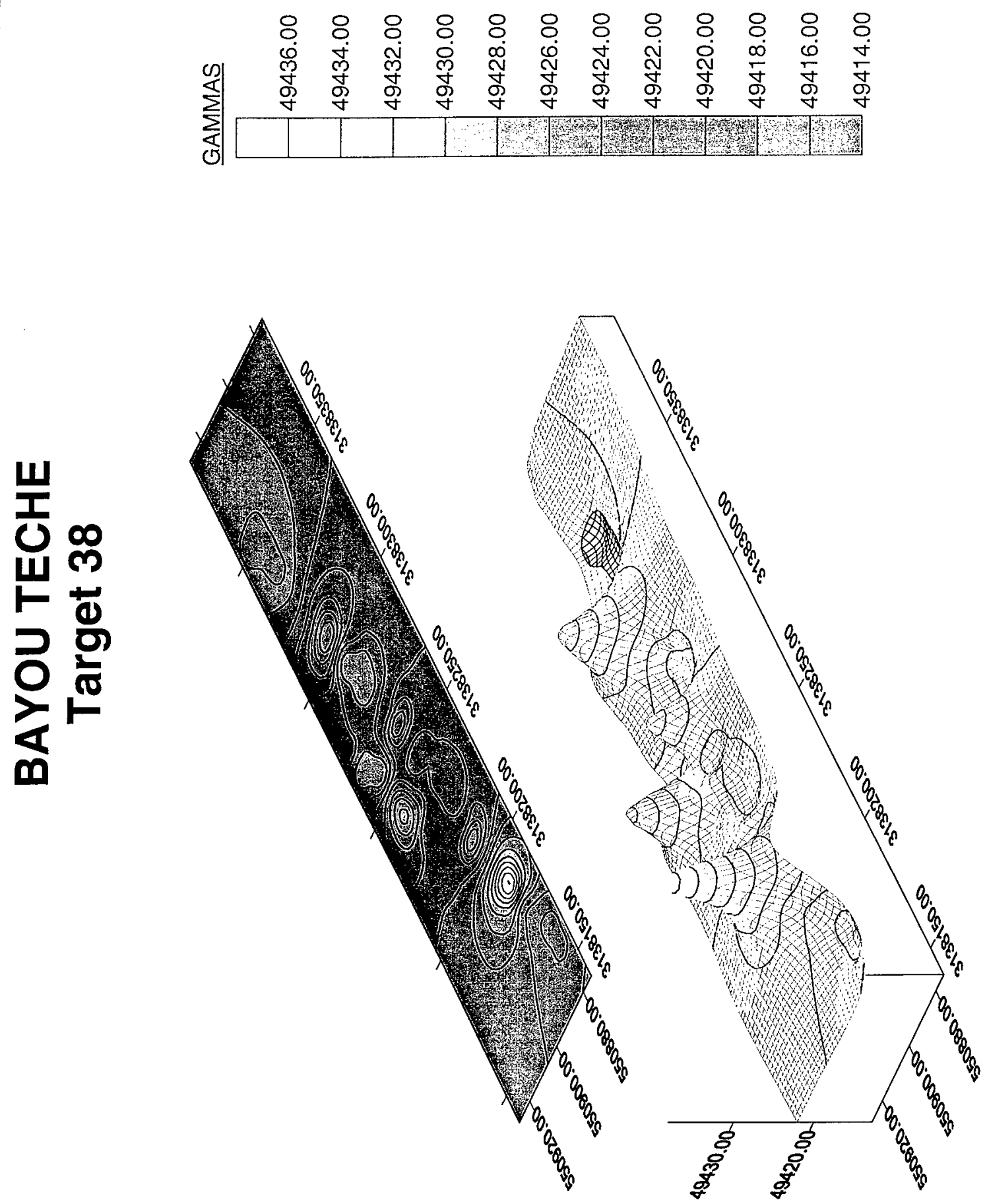

年 
aly, M374, produced a medium duration signature of 15.9 seconds, a high amplitude of 127.5 gammas, and a multi-component signal. The magnetic contour plot of this scatter of ferrous debris is depicted in Figure 46; no associated acoustic signature was associated with this magnetic target.

\section{Target No. 47}

Target No. 47 encompassed two magnetic anomalies (M280 and M383); they were identified within Survey Block 4 (Figure 32, Sheet 9; Figure 47). The first of these anomalies, M280, retained a medium duration signature of 14.8 seconds, a high amplitude of 108 gammas, and a multi-component signal. The second magnetic anomaly, M383, displayed a medium duration signature of 13.2 seconds, a high amplitude of 256.5 gammas, and a dipolar signal. No associated acoustic signature was detected during survey.

\section{Target No. 48}

Target No. 48 also was recorded within Survey Block 4; it was composed of two magnetic anomalies (M279 and M384) (Figure 32, Sheet 9). Magnetic Anomaly 279 retained a medium duration signature of 15.9 seconds, a low amplitude of 39.5 gammas, and a multi-component signal. Magnetic Anomaly 384 possessed a short duration signature of 5.0 seconds, a medium amplitude of 56 gammas, and a negative monopolar signal. This scatter of ferrous debris did not produce an associated acoustic signature.

\section{Target No. 51}

Target No. 51 consisted of two magnetic anomalies (M273 and M391) that were identified within Survey Block 5 (Figure 32, Sheet $10)$. The first magnetic anomaly, M273, produced a medium duration signature of 10.5 seconds, a medium amplitude of 65 gammas, and a dipolar signal. The second magnetic anomaly, M391, produced a medium duration signature of 28.0 seconds, a medium amplitude of 60.5 gammas, and a multi-component signal. No associated acoustic signature was detected from this scatter of ferrous debris.
Target No. 52

Target No. 52 also was recorded within Survey Block 5; it consisted of two magnetic anomalies (M392 and M521); no acoustic anomalies were detected in association with this underwater target (Figure 32, Sheet 10). Magnetic Anomaly 392 possessed a short duration signature of 6.5 seconds, a low amplitude of 18 gammas, and a multi-component signal. Magnetic Anomaly 521 produced a long duration signature of 52.0 seconds, a medium amplitude of 89 gammas, and a multi-component signal. Target No. 52 represents a scatter of ferrous debris.

\section{Target No. 53}

Target No. 53 consisted of two magnetic anomalies (M396 and M520) identified within Survey Block 5 (Figure 32, Sheet 10). The first magnetic anomaly, M396, retained a medium duration signature of 12.7 seconds, a low amplitude of 39.5 gammas, and a negative monopolar signal. The second anomaly, M520, exhibited a medium duration signature of 24.1 seconds, a medium amplitude of 77 gammas, and a multicomponent signal. No acoustic signature was detected in association with Target No. 53; it too was classified as a scatter of ferrous debris.

\section{Target No. 54}

Recorded within Survey Block 5, Target No. 54 encompassed two magnetic anomalies (M399 and M519) (Figure 32, Sheet 10). Magnetic Anomaly 399 was characterized by a short duration signature of 6.6 seconds, a low amplitude of 43 gammas, and a dipolar signal. Magnetic Anomaly 519 produced a medium duration signature of 11.6 seconds, a low amplitude of 19 gammas, and a multi-component signal. This scatter of ferrous debris did not produce an associated acoustic signature.

\section{Target No. 55}

Target No. 55 consisted of two magnetic anomalies (M402 and M516); they also were recorded within Survey Block 5 (Figure 32, Sheet 10; Figure 48). The first magnetic anomaly, M402, was characterized by a short duration signature of 9.8 seconds, a medium amplitude of 74.5 gammas, and a dipolar signal. In contrast, 


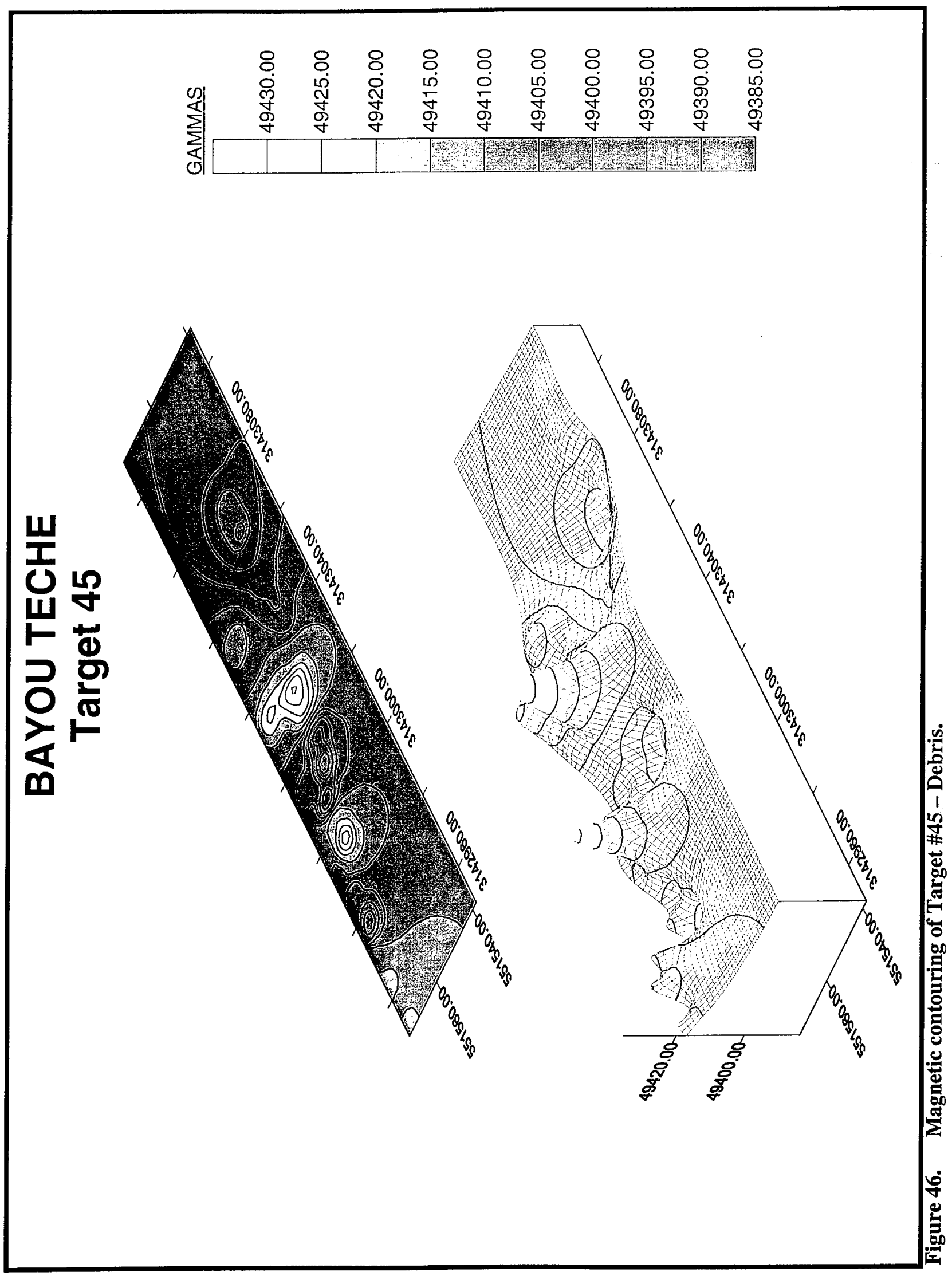




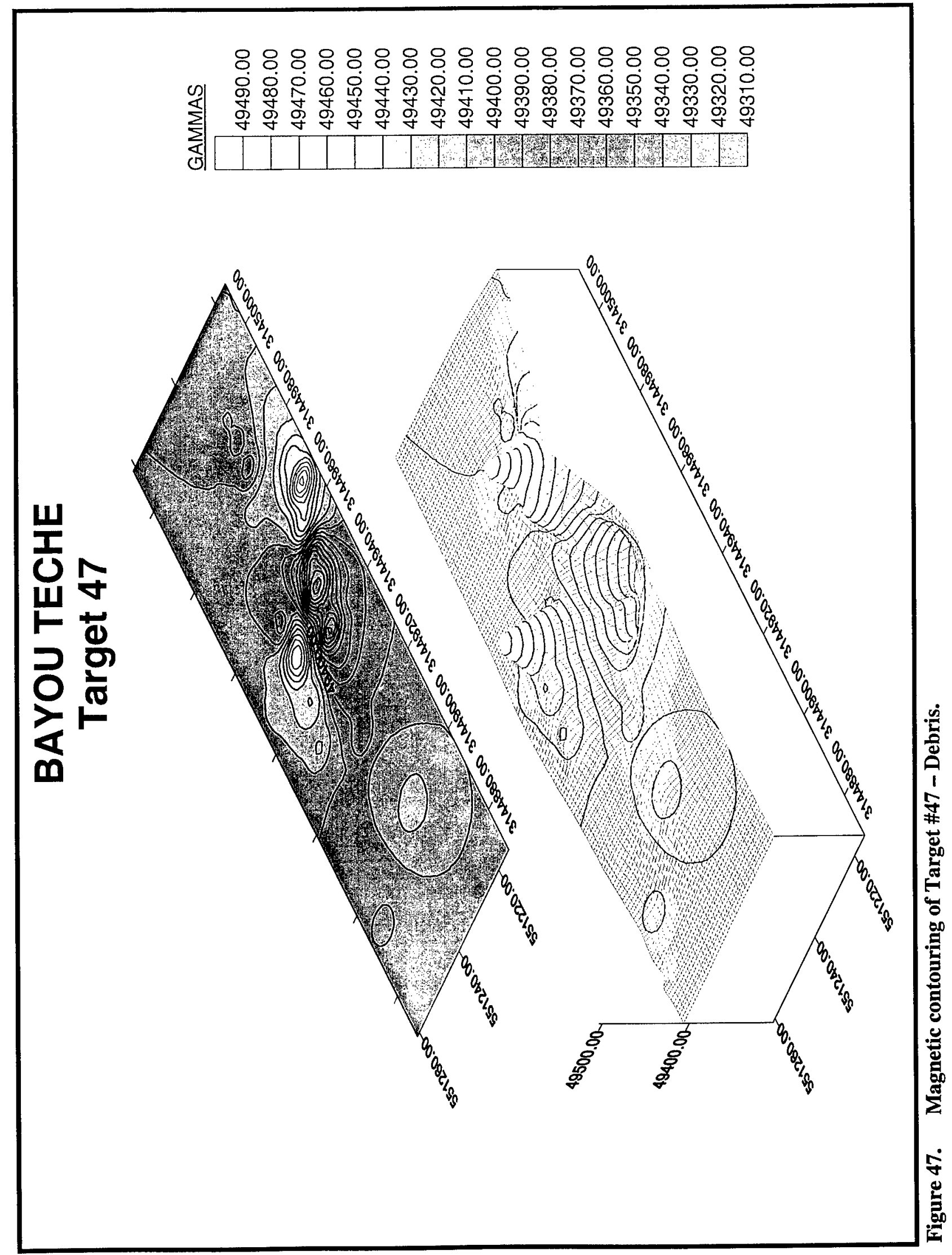




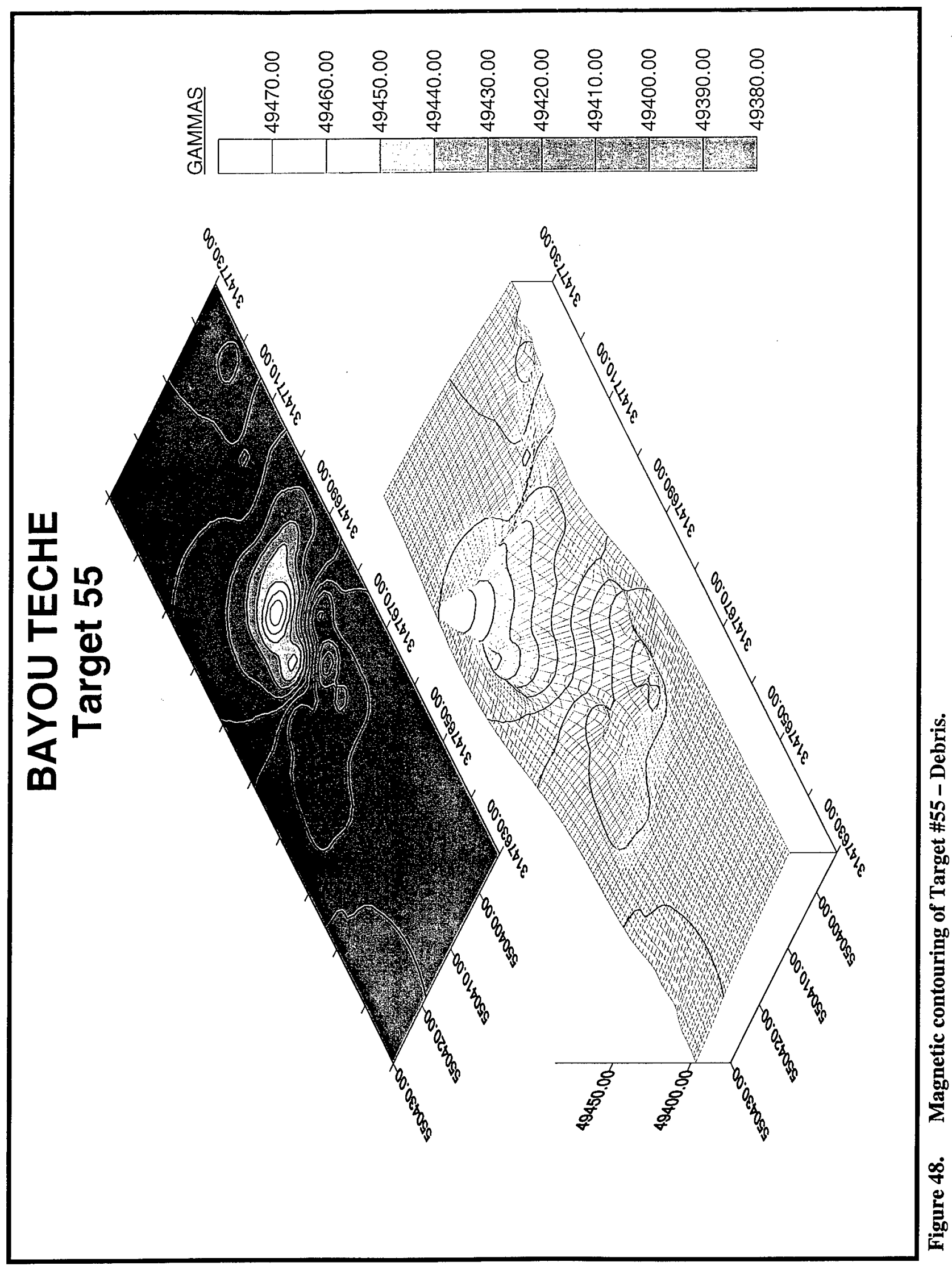


Magnetic Anomaly 516 exhibited a medium duration signature of 13.2 seconds, a high amplitude of 138 gammas, and a positive monopolar signal. Target No. 55 failed to produce an acoustic signature.

\section{Target No. 56}

Target No. 56 was identified within Survey Block 5; it was composed of two magnetic anomalies (M403 and M514) (Figure 32, Sheet 10). Magnetic Anomaly 403 had a very long duration signature of 1 minute and $12.9 \mathrm{sec}-$ onds, a high amplitude of 138.5 gammas, and a multi-component signal. Magnetic Anomaly 514 , in contrast, exhibited a short duration signature of 8.3 seconds, a medium amplitude of 65.5 gammas, and a positive monopolar signal. This underwater target, classified as a scatter of ferrous debris, did not produce an associated acoustic signature.

\section{Target No. 57}

Target No. 57 encompassed two magnetic anomalies (M405 and M511) that were recorded within Survey Block 5 (Figure 32, Sheet 10). The first magnetic anomaly, M405, possessed a long duration signature of 41.1 seconds, a medium amplitude of 76 gammas, and a multi-component signal. The second magnetic anomaly, M511, also retained a long duration signature of 49.9 seconds, a high amplitude of 107.5 gammas, and a multicomponent signal. No acoustic signature was associated with this scatter of ferrous debris.

\section{Target No. 58}

Target No. 58 produced two magnetic anomalies (M406 and M508); it also was situated within Survey Block 5 (Figure 32, Sheet 10). Magnetic Anomaly 406 had a medium duration signature of 19.3 seconds, a low amplitude of 46 gammas, and a multicomponent signal. Magnetic Anomaly 508 produced a medium duration signature of 11.0 seconds, a low amplitude of 47 gammas, and a negative monopolar signal. No acoustic signature was associated with this catter of ferrous debris.
Target No. 59

Target No. 59 consisted of two magnetic anomalies (M414 and M506) that were identified within Survey Block 5 (Figure 32, Sheet 10); no acoustic signature was associated with this target. The first magnetic anomaly, M414, yielded a medium duration signature of 12.0 seconds, a high amplitude of 104 gammas, and a multi-component signal. The second magnetic anomaly, M506, was characterized by a medium duration signature of 19.2 seconds, a low amplitude of 44.5 gammas, and a multi-component signal. This scatter of underwater ferrous debris is depicted in Figure 49.

\section{Target No. 61}

Recorded within Survey Block 5 of the survey area, Target No. 61 was composed of two magnetic anomalies (M419 and M503) (Figure 32, Sheet 10). Magnetic Anomaly 419 retained a medium duration signature of 19.7 seconds, a low amplitude of 32.5 gammas, and a multicomponent signal. Magnetic Anomaly 503 exhibited a medium duration signature of 13.1 seconds, a low amplitude of $\mathbf{3 9 . 5}$ gammas, and a dipolar signal. No acoustic signature was associated with this scatter of ferrous debris.

\section{Target No. 63}

Target No. 63 consisted of two magnetic anomalies (M426 and M498) that were identified within Survey Block 5 (Figure 32, Sheet 11). This underwater target failed to produce an associated acoustic signature. Magnetic Anomaly 426 produced a short duration signature that measured 6.0 seconds, a high amplitude of 242 gammas, and a negative monopolar signal. Magnetic Anomaly $498 \mathrm{had}$ a medium duration signature of $10.9 \mathrm{sec}-$ onds, a high amplitude of 342 gammas, and a dipolar signal. This underwater target was characterized as a scatter of ferrous debris.

\section{Target No. 64}

Target No. 64 also was recorded within Survey Block 5; it consisted of two magnetic anomalies (M428 and M497) (Figure 32, Sheet 11). The first of the magnetic anomalies, M428, yielded a medium duration signature of 11.5 seconds, a low amplitude of 30.5 gammas, and a multi- 

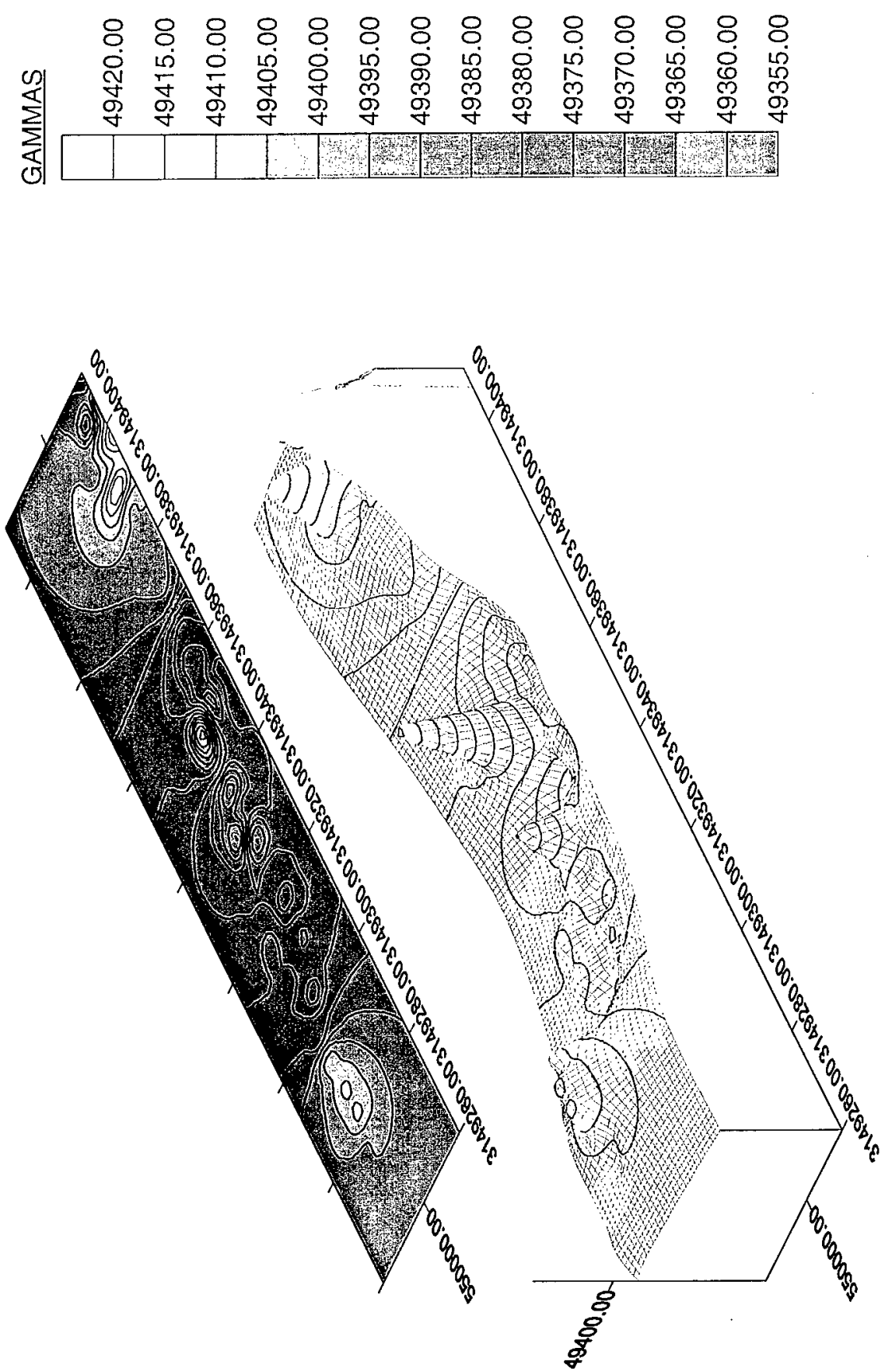
component signal. Magnetic Anomaly 497 also produced a medium duration signature of 15.3 seconds, a medium amplitude of 65.5 gammas, and a multi-component signal. No detectable acoustic signature was associated with this scatter of ferrous debris spread across the channel bottom.

\section{Target No. 65}

Recorded within Survey Block 5 of the survey area, Target No. 65 encompassed two magnetic anomalies (M432 and M495) (Figure 32, Sheet 11). The first, Magnetic Anomaly 432 , possessed a short duration signature of 3.3 seconds, a low amplitude of 27 gammas, and a positive monopolar signal. Magnetic Anomaly 495 retained a medium duration signature of 17.5 seconds, a medium amplitude of 57.5 gammas, and a multi-component signal. This target, a scatter of ferrous debris, failed to produce an associated acoustic signature.

\section{Target No. 66}

Target No. 66 consisted of two magnetic anomalies (M442 and M489) that were identified within Survey Block 5 (Figure 32, Sheet 11); no acoustic signature was associated with this magnetic target. Magnetic Anomaly 442 was characterized by a short duration signature of 6.1 seconds, a low amplitude of 16.5 gammas, and a negative monopolar signal. Magnetic Anomaly 489 produced a medium duration signature of 11.0 seconds, a high amplitude of 115.5 gammas, and a positive monopolar signal. Target No. 66 was described as a scatter of ferrous debris scattered across the bayou bottom.

\section{Target No. 68}

Target No. 68 also was identified within Survey Block 5 (Figure 32, Sheet 11). This target consisted of two magnetic anomalies (M448 and M483). The first magnetic anomaly, M448, produced a short duration signature of 7.7 seconds, a low amplitude of 21.5 gammas, and a dipolar signal. The second magnetic anomaly, M483, produced a medium duration signature of 10.4 seconds, a medium amplitude of 70.5 gammas, and a positive monopolar signal. This scatter of ferrous debris did not produce an associated acoustic signature.
Target No. 69

Target No. 69 was composed of two magnetic anomalies (M451 and M482) that were identified within Survey Block 5 (Figure 32, Sheet 11). Magnetic Anomaly 451 possessed a short duration signature of 3.8 seconds, a medium amplitude of 54.5 gammas, and a dipolar signal. Magnetic Anomaly 482 yielded a long duration signature of 1 minute and 11.8 seconds, a medium amplitude of 59.5 gammas, and a multicomponent signal. This scatter of ferrous debris failed to produce an associated acoustic signature (Figure 50).

\section{Target No. 71}

Target No. 71 also was identified within Survey Block 5 (Figure 32, Sheet 11). It consisted of two magnetic anomalies (M456 and M478), and one acoustic anomaly (A38) (Figure 51). Magnetic Anomaly 456 was characterized by a medium duration signature of 14.8 seconds, a medium amplitude of 62.5 gammas, and a multicomponent signal. Magnetic Anomaly 478 yielded a medium duration signature of 10.9 seconds, a high amplitude of 268.5 gammas, and a multicomponent signal. The single acoustic anomaly, A38, was indicative of barge scar along the bayou bottom and associated ferrous debris.

\section{Target No. 72}

Target No. 72 encompassed two magnetic anomalies (M460 and M470) and one acoustic anomaly (A37) that were recorded within Survey Block 5 (Figure 32, Sheet 11). The first magnetic anomaly, M460, yielded a medium duration signature of 20.7 seconds, a low amplitude of 47.5 gammas, and a multi-component signal. The second magnetic anomaly, M470, exhibited similar characteristics. It produced a medium duration signature of 15.8 seconds, a low amplitude of 36.5 gammas, and a multi-component signal. This scatter of ferrous debris is depicted in Figures 52 and 53.

\section{Target No. 73}

Identified within Survey Block 5, Target No. 73 consisted of two magnetic anomalies (M466 and M565) (Figure 32, Sheet 11). Magnetic Anomaly 466 exhibited a medium duration signature of 24.6 seconds, a high amplitude of 128.5 gammas, and a multi-component signal. Mag- 


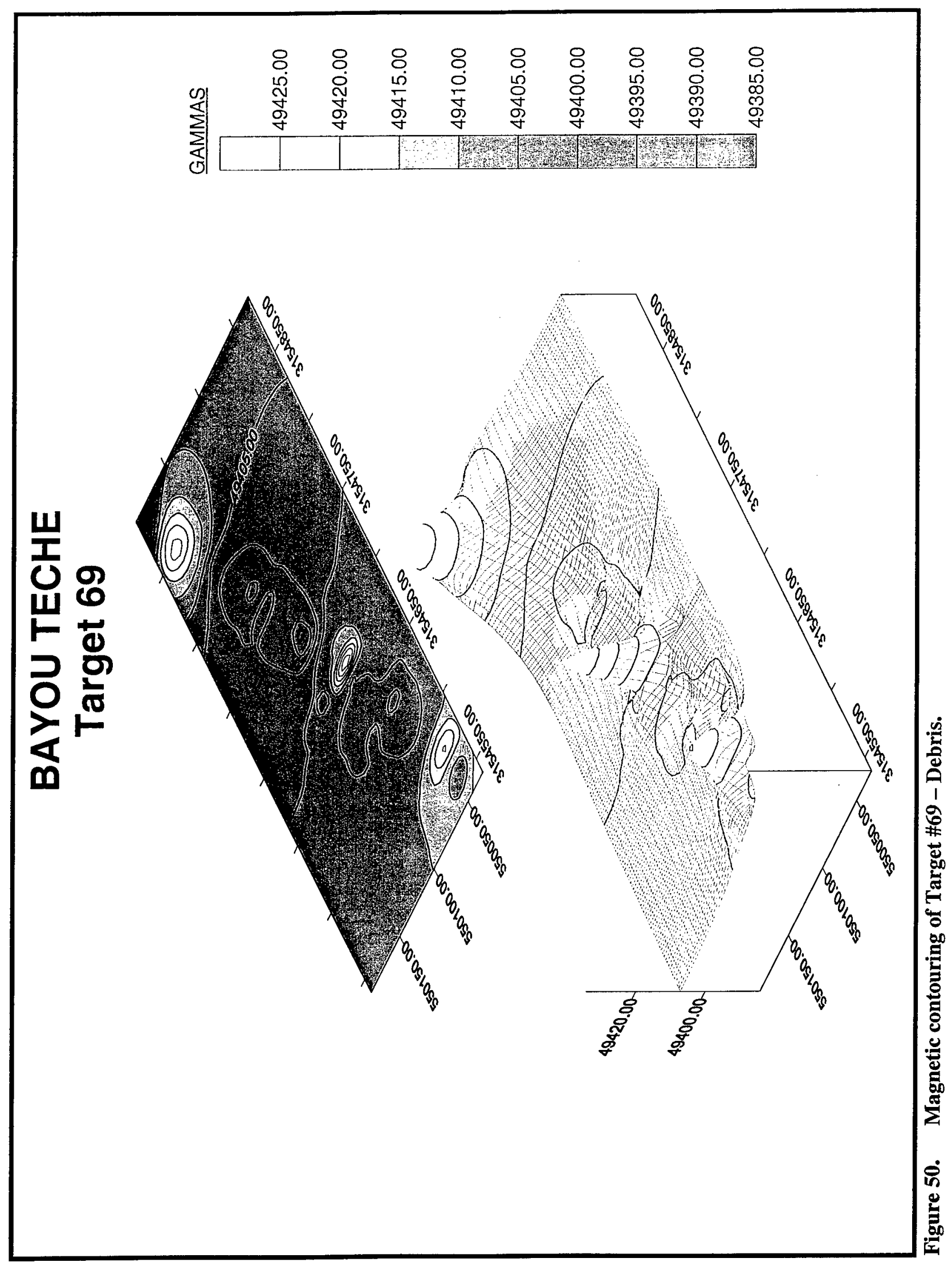



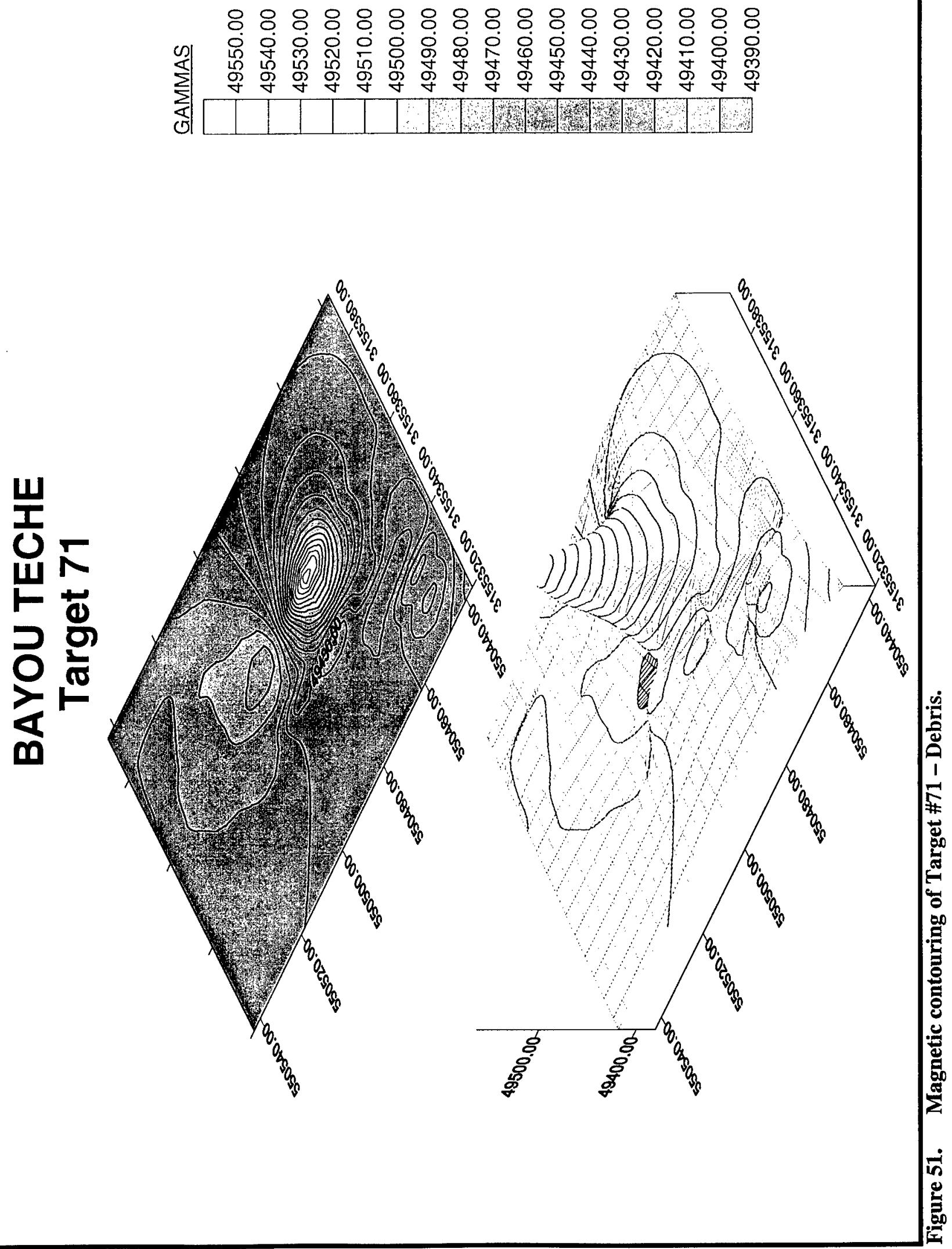


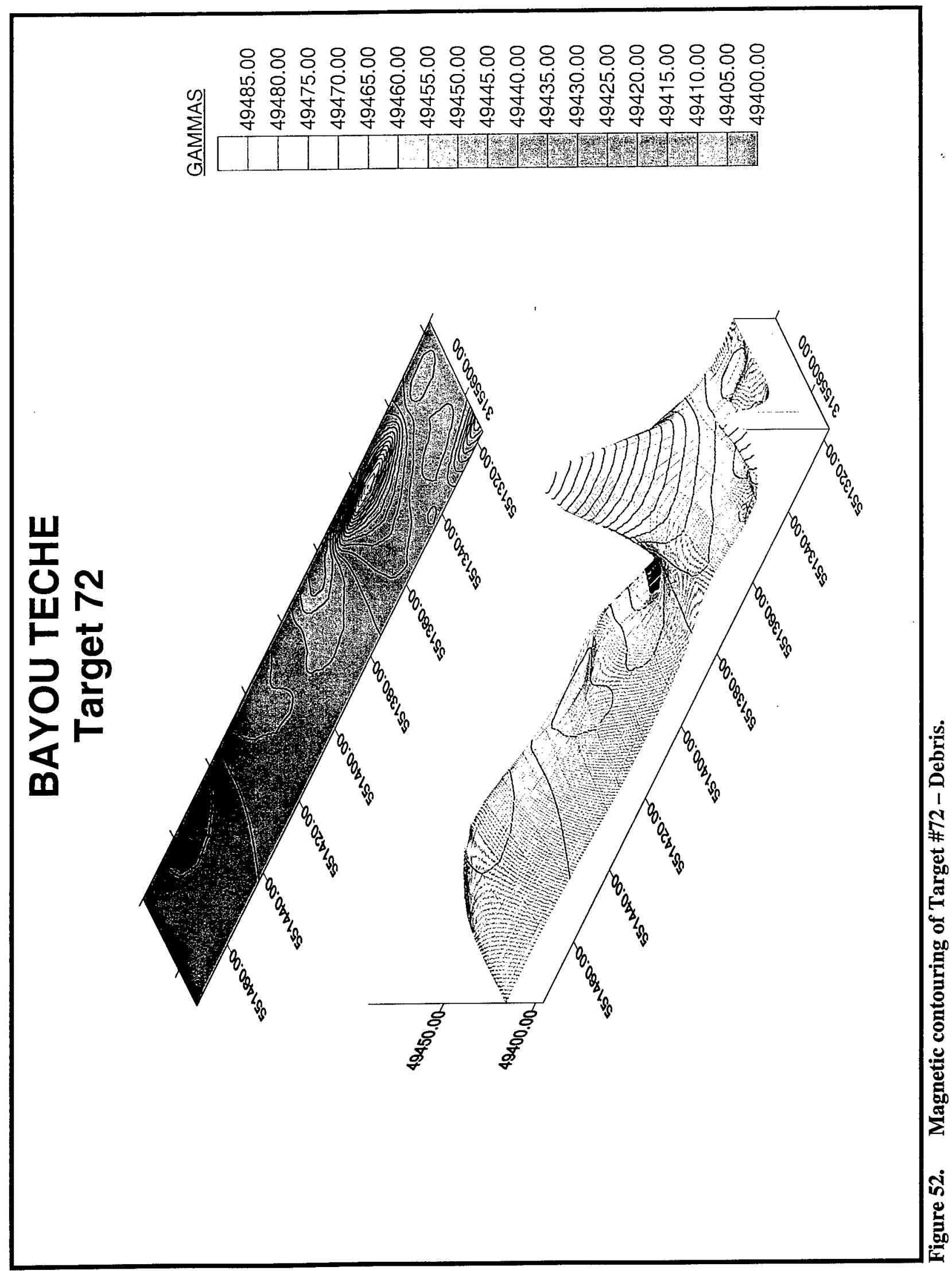




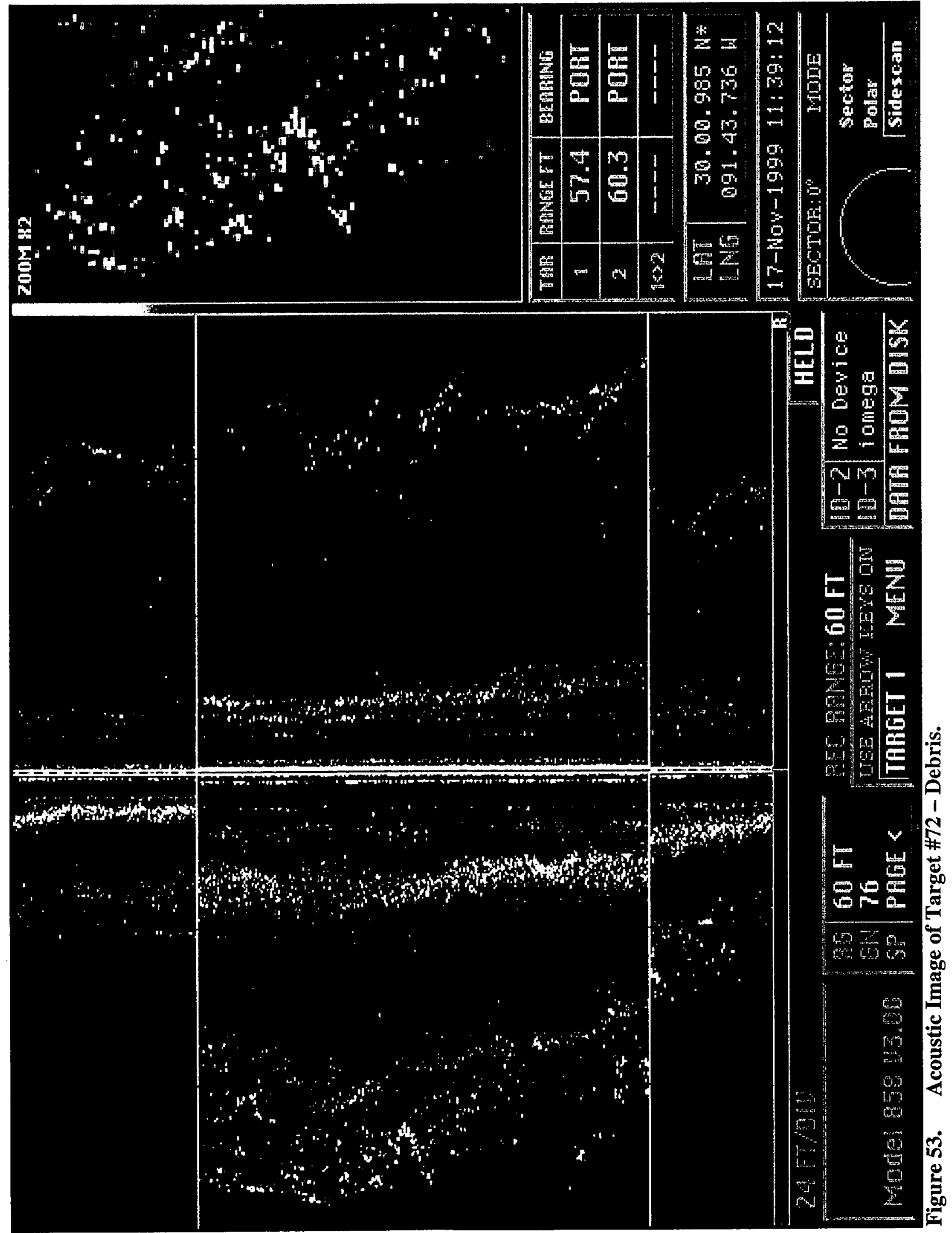


netic Anomaly 565 displayed a short duration signature of 7.1 seconds, a medium amplitude of 80 gammas, and a positive monopolar signal. Target No. 73 was classified as a scatter of ferrous debris; it did not produce an associated acoustic signature.

\section{Target No. 74}

Target No. 74 was composed of two magnetic anomalies (M563 and M566) that were identified within Survey Block 6 (Figure 32, Sheet 11). The first magnetic anomaly, M563, produced a medium duration signature of 14.9 seconds, a medium amplitude of 73 gammas, and a dipolar signal. The second magnetic anomaly, M566, yielded a medium duration signature of 12.1 seconds, a medium amplitude of 77 gammas, and a multi-component signal. No associated acoustic signature of this scatter of ferrous debris (Figure 54).

\section{Target No. 75}

Target No. 75 also was identified within Survey Block 6 (Figure 32, Sheet 12). This target consisted of two magnetic anomalies (M560 and M568). Magnetic Anomaly 560 had a short duration signature of 6.0 seconds, a low amplitude of 24.5 gammas, and a negative monopolar signal. Magnetic Anomaly 568 also retained a short duration signature of $49.9 \mathrm{sec}-$ onds, a high amplitude of 248 gammas, and a dipolar signal. This underwater target consisted of a scatter of ferrous debris; it failed to produce a detectable acoustic signature.

\section{Target No. 76}

Target No. 76 was identified within Survey Block 6; it encompassed two magnetic anomalies (M555 and M572) (Figure 32, Sheet 12). The first, Magnetic Anomaly 555, retained a short duration signature of 7.6 seconds, a high amplitude of 128.5 gammas, and a positive monopolar signal. The second magnetic anomaly, M572, possessed a short duration signature of 8.3 seconds, a high amplitude of 436 gammas, and a negative monopolar signal. No acoustic signature was associated with this scatter of ferrous.

\section{Target No. 79}

Target No. 79 was recorded within Survey Block 6 and it consisted of two magnetic anomalies (M548 and M581) (Figure 32, Sheet 12). Magnetic Anomaly 548 produced a short duration signature of 8.2 seconds, a low amplitude of 45.5 gammas, and a dipolar signal. Magnetic Anomaly 581 produced a medium duration signature of 23.0 seconds, a low amplitude of 23.5 gammas, and a multi-component signal. This underwater target, interpreted as a scatter of ferrous debris resting on the channel bottom, did not produce an associated acoustic signature.

\section{Target No. 80}

Recorded within Survey Block 6, Target No. 80 encompassed two magnetic anomalies (M540 and M592) and a single acoustic anomaly (A46) (Figure 32, Sheet 13). Magnetic Anomaly 540 produced a short duration signature of 7.7 seconds, a medium amplitude of 51.5 gammas, and a dipolar signal. Magnetic Anomaly 592 possessed a medium duration signature of 10.9 seconds, a high amplitude of 145.5 gammas, and a dipolar signal. The single acoustic anomaly, A46, depicted ferrous debris resting along the channel bottom. The magnetic plot of this underwater target is depicted in Figure 55 .

\section{Target No. 81}

Target No. 81 also was identified within Survey Block 6; it was composed of two magnetic anomalies (M538 and M595), and a single acoustic anomaly (A45) (Figure 32, Sheet 13; Figure 56). The first magnetic anomaly, M538, yielded a medium duration signature of 20.3 seconds, a high amplitude of 946.5 gammas, and a positive monopolar signal. The second magnetic anomaly, M595, produced a medium duration signature of 19.8 seconds, a high amplitude of 39,277.5 gammas, and a dipolar signal. The single acoustic anomaly, A45, represented a large submerged tree and bottom debris.

\section{Target No. 82}

Finally, Target No. 82 was recorded within Survey Block 6 of the survey area and it consisted 

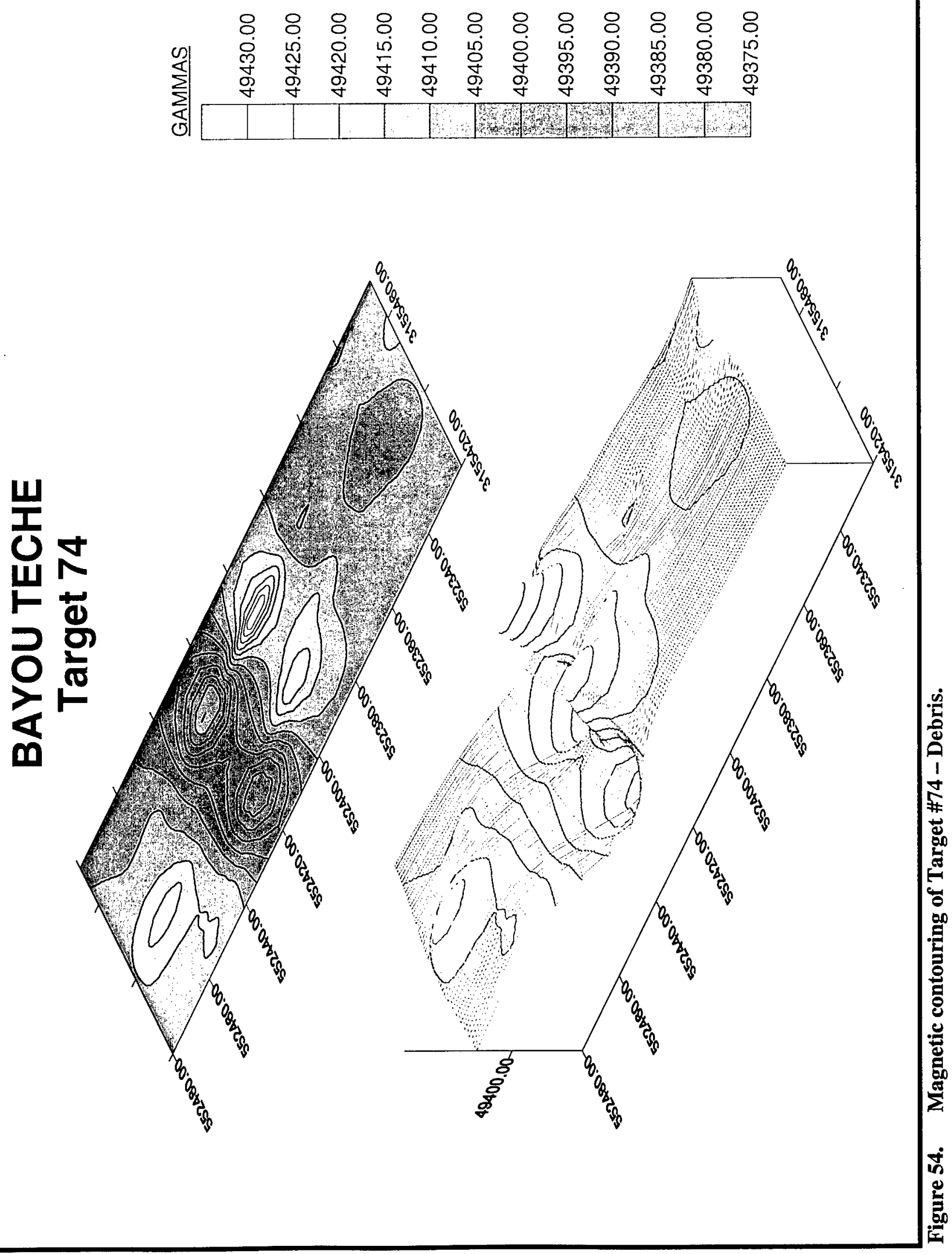


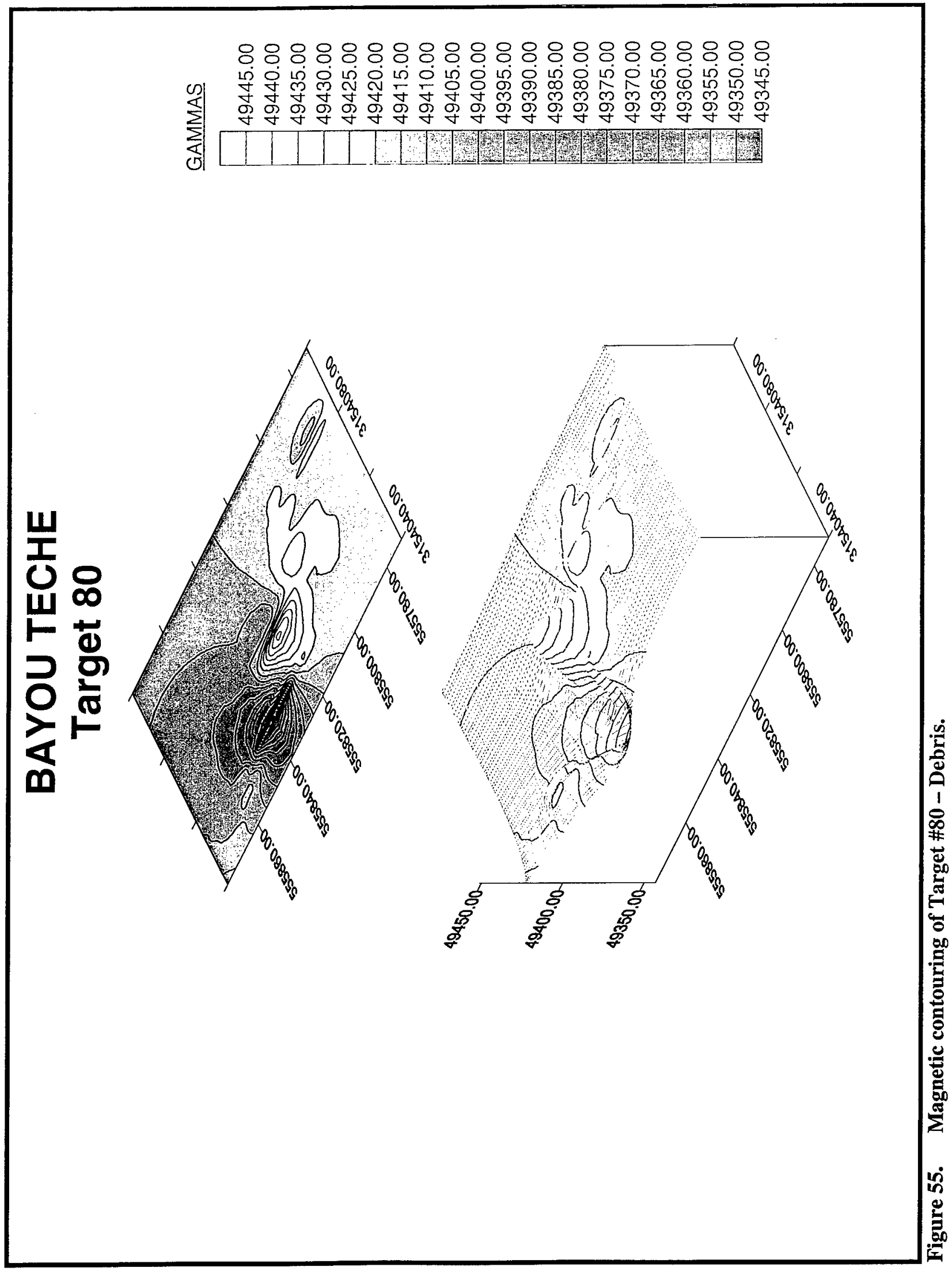



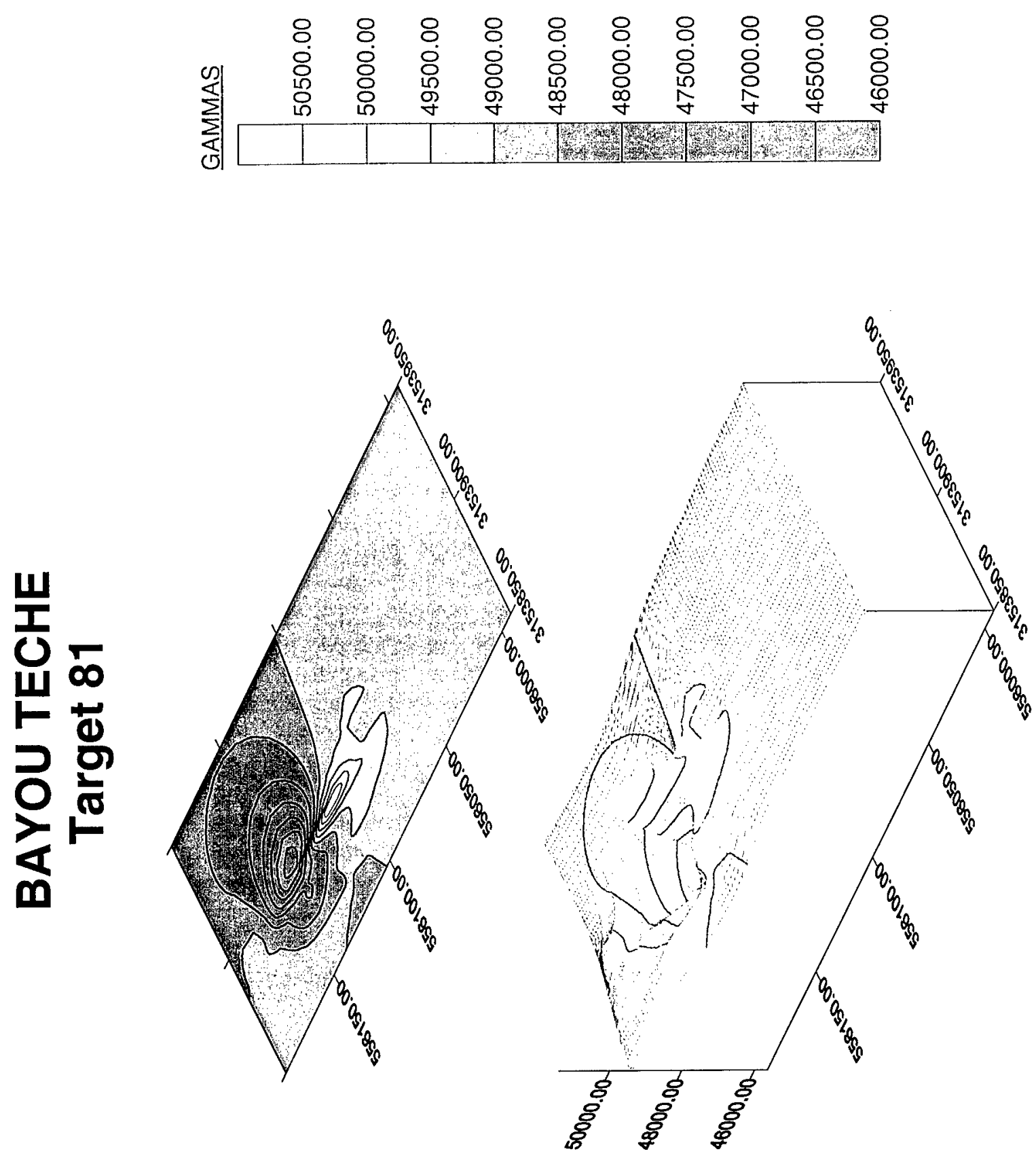
of two magnetic anomalies (M537, M596) (Figure 32, Sheet 13). Magnetic anomaly 537 had a short duration signature of 7.7 seconds, a medium amplitude of 76.5 gammas, and a dipole signal, while magnetic anomaly 596 retained a short duration signature of $7.1 \mathrm{sec}-$ onds, a low amplitude of 27.5 gammas, and a positive monopolar signal. This underwater target, which was interpreted as a scatter of ferrous debris, failed to produce a detectable acoustic signature.

\section{Results of Survey of the Terrestrial Project Items}

This section presents the results of Phase I cultural resources survey and archeological inventory of the six terrestrial project items and the two proposed access roads. It describes the location, physical characteristics, and the number of backhoe trenches and auger tests excavated throughout each project item and along each access road. In addition, typical backhoe trench and auger test profiles are provided for various portions of the Areas of Potential Effect. An overview of the number of testable hectares/acres associated with each proposed project item, the length of each proposed access road, the testing interval used to assess each project item and access road, and the number of auger tests and backhoe trenches excavated successfully throughout each project item is presented in Table 14. west by Disposal Area 2 (Figure 58). This area was overgrown and it contained a thick layer of underbrush and several large pecan trees were noted at the time of survey. Examination of the ground surface within the Area of Potential Effect indicated that prior activities had impacted much of the proposed project item. For example, numerous bulldozer push piles and a series of large ditches crisscrossed the proposed project item. Despite these impacts, Staging Area 1 was treated as though it possessed a high probability for containing intact cultural deposits, in part because of its proximity to Bayou Teche and its position on a natural levee landform. As a result, auger testing and backhoe trenching throughout the Area of Potential Effect was conducted at $30 \mathrm{~m}(98.4 \mathrm{ft})$ intervals, along survey transects spaced approximately $15 \mathrm{~m} \mathrm{(49.2}$ m) apart.

During survey, four of four planned backhoe trenches (100 percent) and 7 of 8 planned auger tests (86 percent) were excavated successfully throughout Staging Area 1. These sampling units were spaced along three parallel survey transects. The placement of the auger tests and backhoe trenches were offset to maximize coverage throughout the proposed project item (Figure 58).

A typical backhoe trench excavated within with the proposed Staging Area 1 project item extended to a depth of $200 \mathrm{cmbs}$ (78.7 inbs) and it exhibited four strata in profile (Figures 59 and 60). Stratum I extended from 0 to $42 \mathrm{cmbs}$ (16.5 inbs) and it was described as a layer of dark brown

\section{Staging Area 1}

Staging Area 1 was located on property owned by the Cajun Sugar Company within Irregular Section 9 of Township 12S, Range 7E (Figure 57; Attachment 1). The proposed project item was situated immediately adjacent to the west bank of Bayou Teche. The testable portion of this proposed project item measured approximately 0.4 ha $(1.1 \mathrm{ac})$ in size, and it was bounded to the north by a treeline, to the east by a deep drainage ditch, and to the

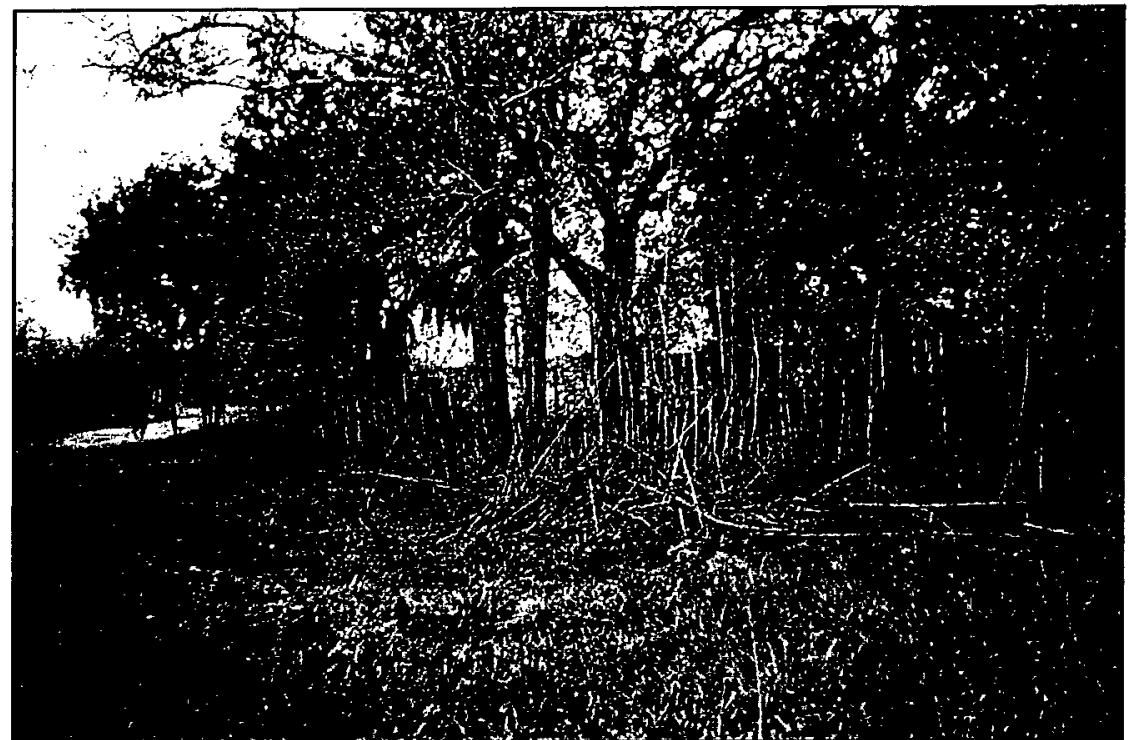

Figure 57. Overview photo of Staging Area 1 facing west. 


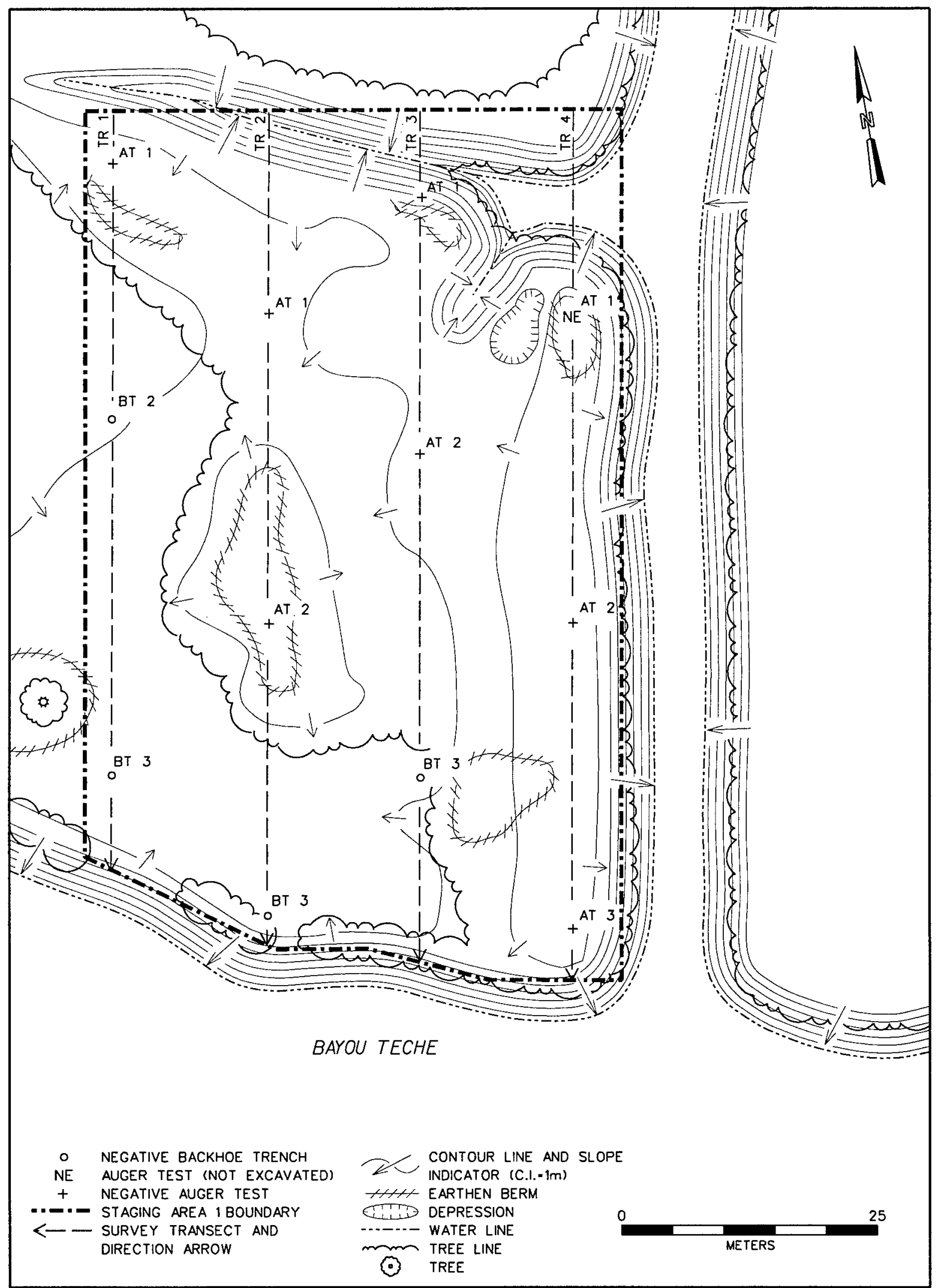

Figure 58. Plan view of Staging Area 1 depicting the locations of auger tests and backhoe trenches. 


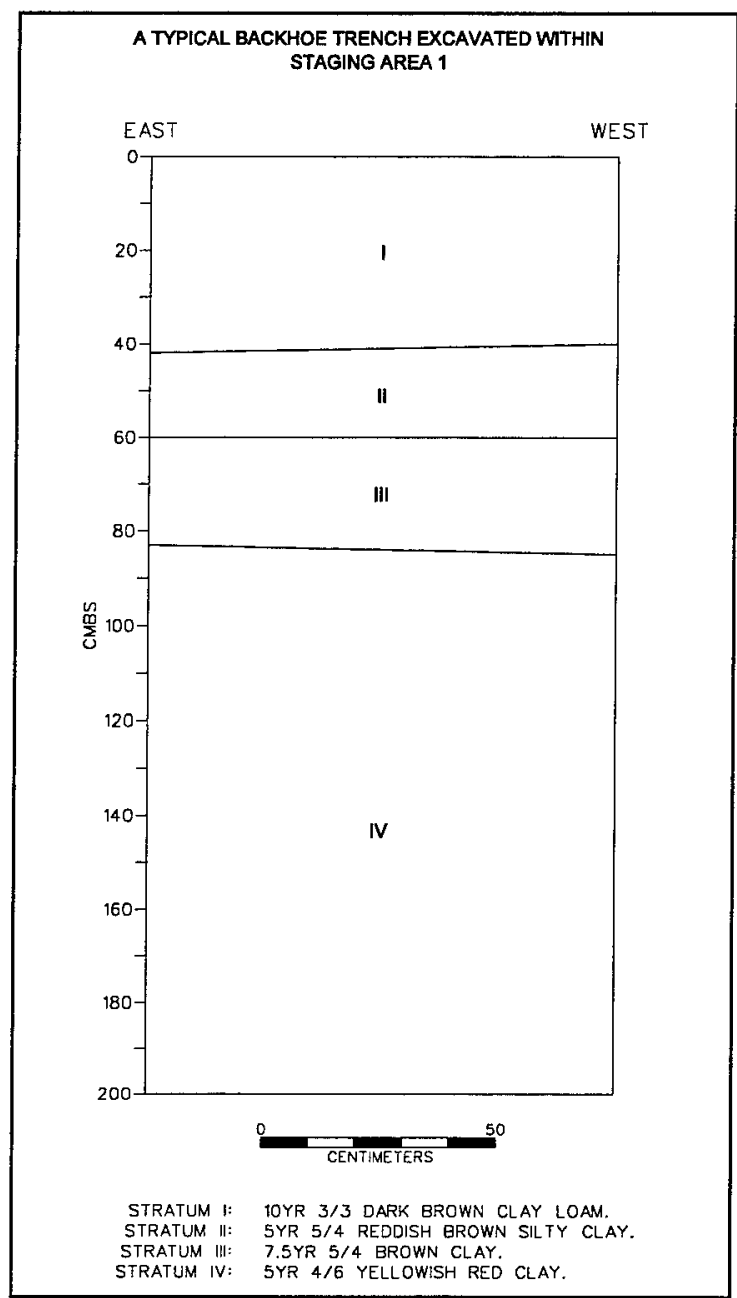

Figure 59. Profile of a typical backhoe trench excavated within Staging Area 1.

(10YR 3/3) clayey loam. Stratum II ranged in depth from 42 to $68 \mathrm{cmbs}$ ( 16.5 to $27.2 \mathrm{inbs}$ ); it was characterized as a deposit of reddish brown (5YR 5/4) silty clay. Stratum II was underlain by Stratum III, a layer of brown (7.5YR 5/4) clay that extended from 68 to 83 (27.2 to 32.7 inbs). Finally, Stratum IV reached from 83 to $200 \mathrm{cmbs}$ (32.7 to 78.7 inbs); it consisted of a layer of yellowish red (5YR 4/6) clay.

A typical auger test excavated within Staging Area 1 extended to a depth of 200 cmbs (78.7 inbs) and it exhibited three strata in profile (Figure 61). The auger tests were excavated within the vicinity of areas disturbed by bulldozing; thus, the original top strata in these areas had been removed prior to survey of the proposed project item. Stratum I consisted of a

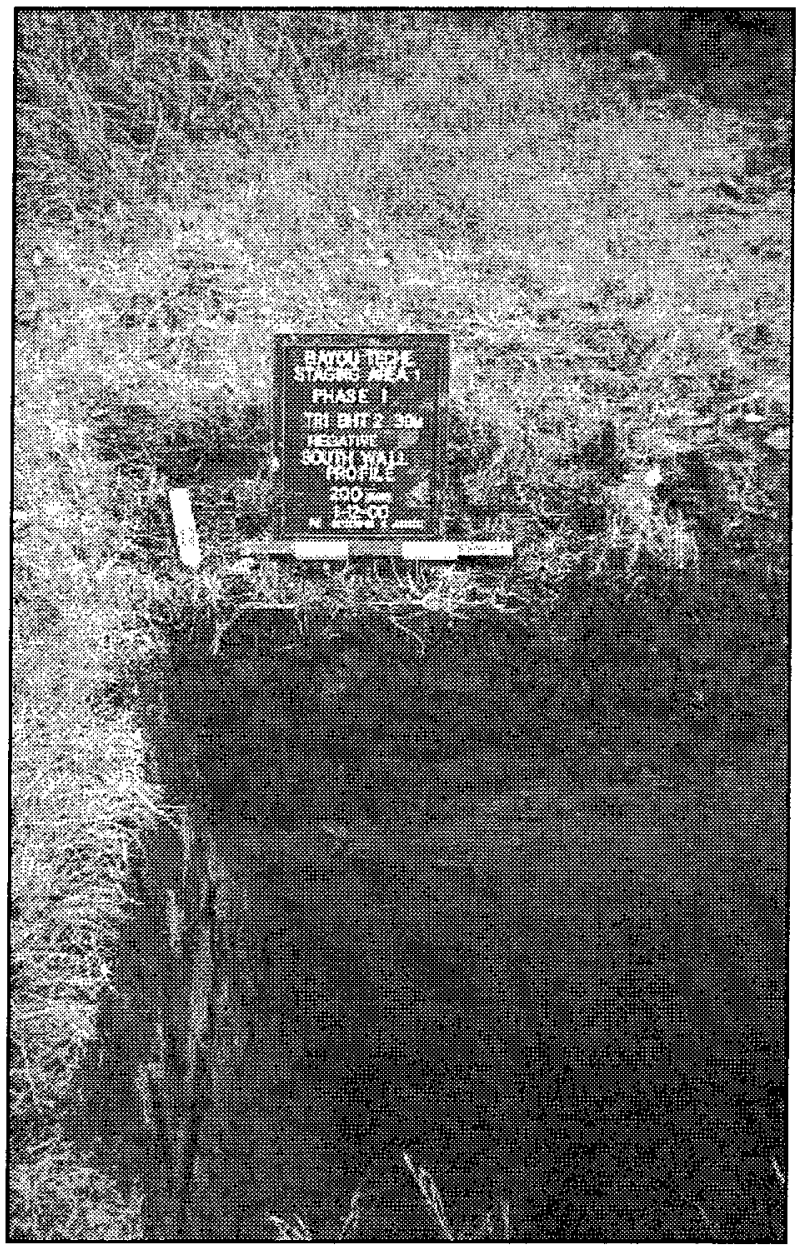

Figure 60. Overview photo of the profile of a typical backhoe trench excavated within Staging Area 1.

layer of brownish gray (10YR $3 / 3$ ) silty clay that extended from 0 to $38 \mathrm{cmbs}$ ( 0 to 14.9 inbs). It was underlain by Stratum II. Stratum II ranged in depth from 38 to $180 \mathrm{cmbs}$ ( 14.9 to $70.8 \mathrm{inbs}$ ) and it was described as a layer of dark gray (10YR4/1) clay. Finally, Stratum III, a layer of brown (7.5YR $5 / 4$ ) silty clay, extended from 180 to $200 \mathrm{cmbs}$ (70.8 to 78.7 inbs).

One of the auger tests, Auger Test 4 on Transect 4, was not excavated because it fell within an area impacted by prior activity. Despite the successful excavation of seven auger tests and four backhoe trenches throughout the Area of Potential Effect, no cultural resources were identified during the cultural resources survey of Staging Area 1. No additional testing of this proposed project item is recommended. 


\section{A TYPICAL AUGER TEST EXCAVATED WITHIN STAGING AREA 1}

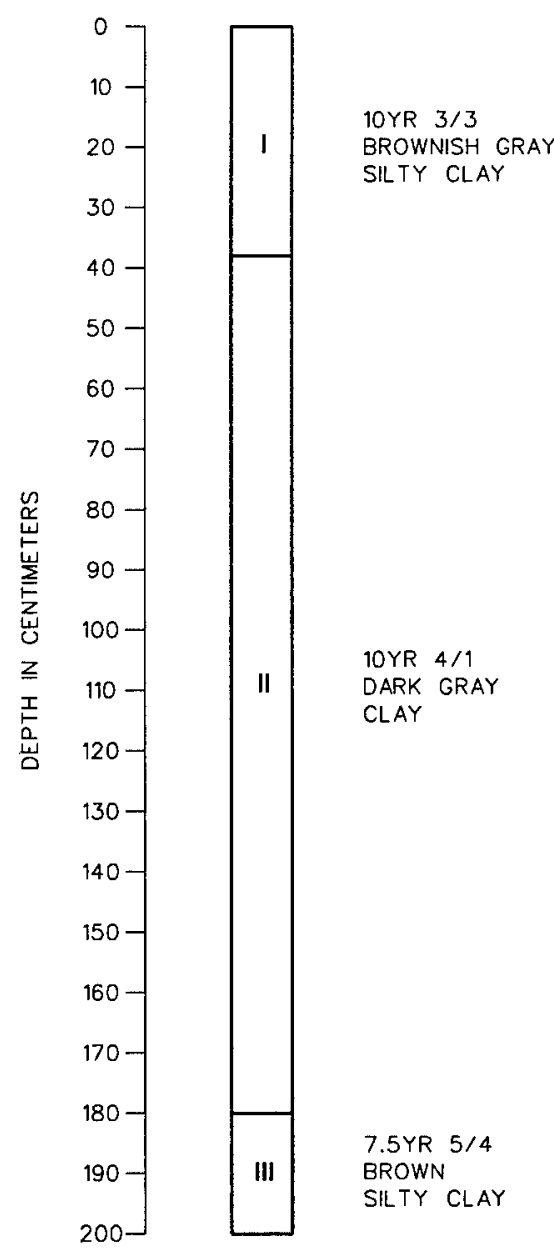

Figure 61.

Profile of a typical auger test excavated within Staging Area 1.

\section{Staging Area 2}

Staging Area 2 was located within Section 13 of Township 12S, Range 6E, on property owned by the Iberia Sugar Company (Figure 62 ). The testable portion of this proposed project item measured approximately 0.9 ha $(2.2$ ac) in extent and it was bounded to the south by Bayou Teche, to the east by a treeline, to the west by a two track road, and to the north by a drainage ditch (Figure 63). This area consisted of roughly equal proportions of mixed deciduous trees, open grasses, and wetlands. Visual examination of the ground surface prior to testing suggested that the area had witnessed only limited disturbance consisting of a two- track road and the excavation of a drainage ditch. Staging Area 2, because of its position on the natural levee and its close proximity to Bayou Teche, was assumed to retain a high probability for containing intact cultural deposits. Auger testing and backhoe trenching was conducted at $30 \mathrm{~m}(98.4 \mathrm{ft})$ intervals throughout the Area of Potential Effect.

During survey, 21 of 21 planned backhoe trenches (100 percent) and 13 of 13 planned auger tests (100 percent) were excavated successfully throughout the Staging Area 2 project item (Figure 63). These sampling units were excavated along three parallel survey transects that trended in a north-south direction. Auger tests and backhoe trenches along adjacent transects were offset to maximize coverage throughout the proposed project item.

A typical backhoe trench excavated within the Staging Area 2 project item exhibited four strata in profile and it extended to a depth of 200 cmbs (78.7 inbs) (Figures 64 and 65). Stratum I extended from 0 to $78 \mathrm{cmbs}$ ( 0 to $31.1 \mathrm{inbs}$ ) and it consisted of a layer of black (5YR 2.5/1) silty loam. Stratum II ranged in depth from 78 to 104 cmbs (31.1 to 40.9 inbs); it was characterized as a layer of light brown (7.5YR 6/4) silty clay. Stratum II was underlain by Stratum III, a layer of reddish brown (5YR 4/4) clay that ranged in depth from 104 to 175 (40.9 to 68.9 inbs). Finally, Stratum IV reached from 175 to $200 \mathrm{cmbs}$ (68.9 to $78.7 \mathrm{inbs})$; it was described as a layer of yellowish red (5YR 5/6) clay.

A typical auger test excavated within the proposed Staging Area 2 project item also extended to a depth of $200 \mathrm{cmbs}$ (78.7 inbs); it exhibited four strata in profile (Figure 66). Stratum I extended from 0 to $21 \mathrm{cmbs}$ ( 0 to $8.3 \mathrm{inbs}$ ) and it was described as a layer of black (5YR 2.5/1) silty loam. It was underlain by Stratum II, a layer of reddish brown (5YR 5/4) clay that ranged in depth from 21 to $94 \mathrm{cmbs}$ (8.3 to $37.0 \mathrm{inbs}$ ). Stratum III was characterized as a layer of brown (7.5YR 5/4) silty clay that extended from 94 to $185 \mathrm{cmbs}$ (37.0 to 72.8 inbs). Finally, Stratum IV, ranged in depth from 185 to $200 \mathrm{cmbs}$ (72.8 to $78.7 \mathrm{inbs}$ ); it consisted of a layer of bluish gray (5B 6/1) gley.

The successful excavation of 13 auger tests and 21 backhoe trenches throughout the Staging Area 2 Area of Potential Effect resulted in the 


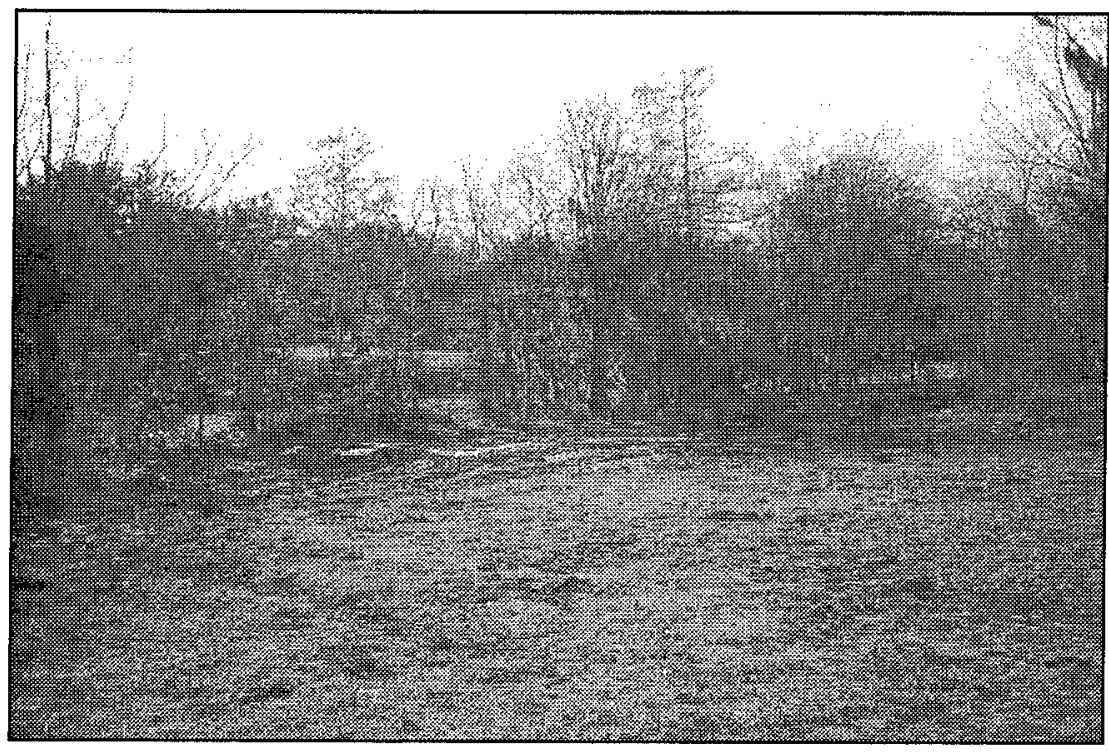

Figure 62. Overview photo of Staging Area 2 facing south.

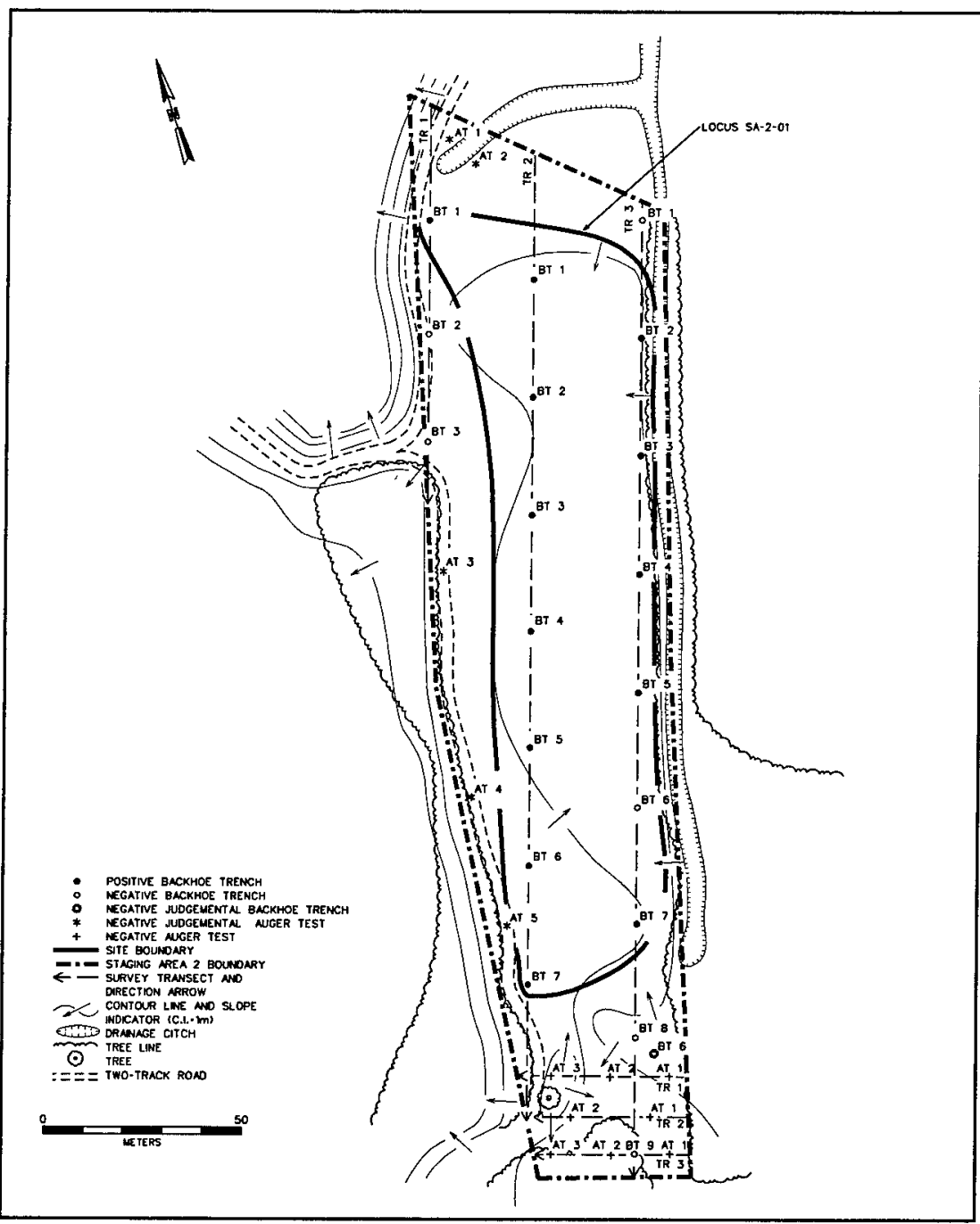

Figure 63. Plan view of Staging Area 2 depicting the locations of auger tests and backhoe trenches. 


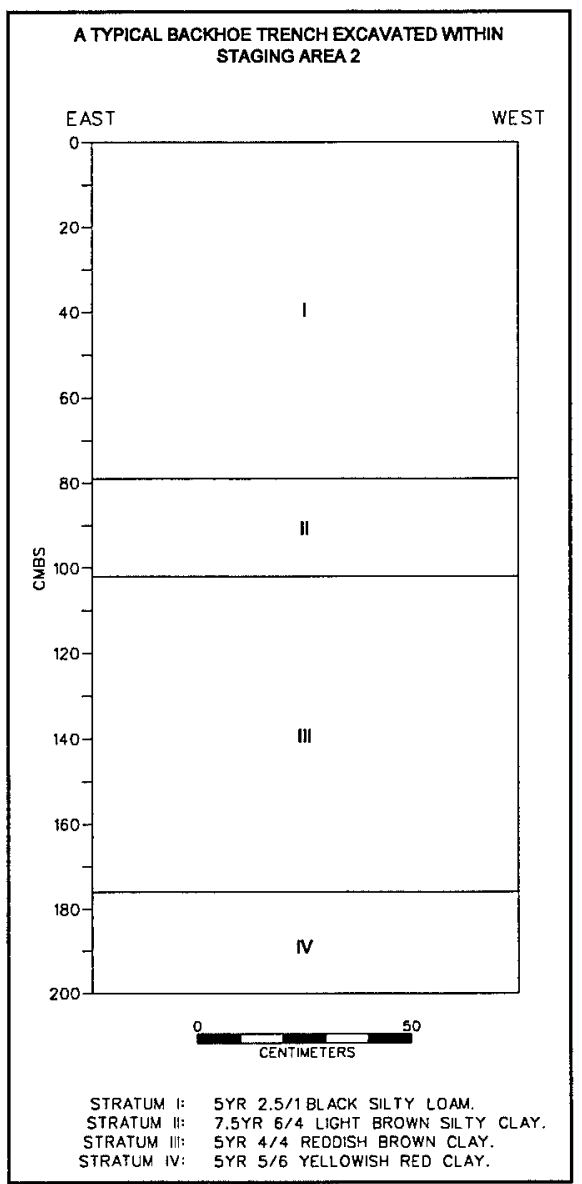

Figure 64. Profile of a typical backhoe trench excavated within Staging Area 2.

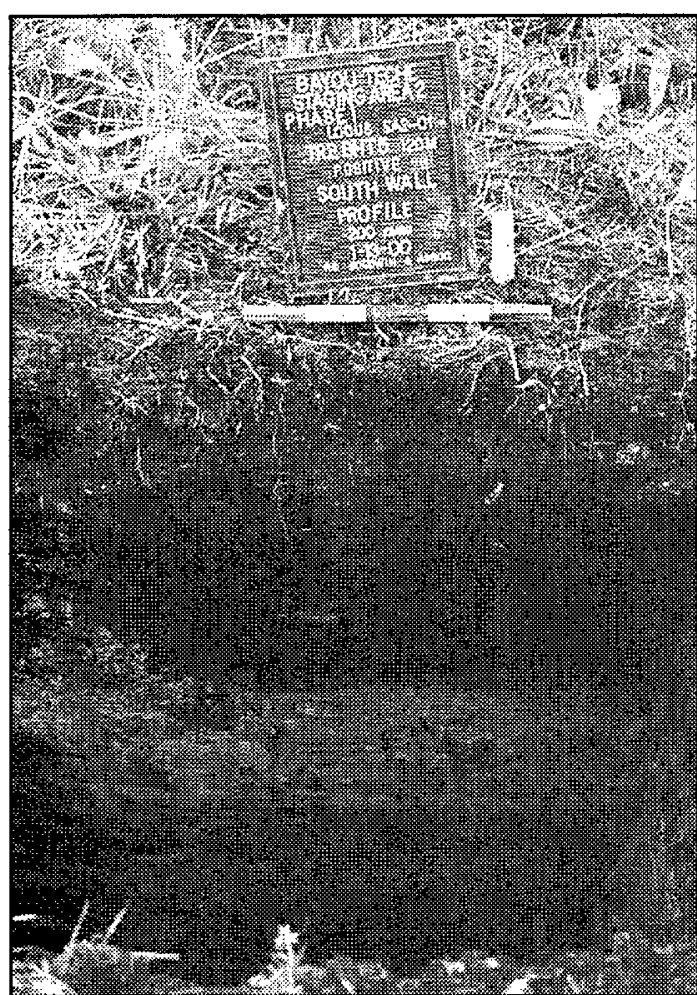

Figure 65. Overview photo of the profile of a typical backhoe trench excavated within Staging Area 2.

A TYPICAL AUGER TEST EXCAVATED WTHIN STAGING AREA 2

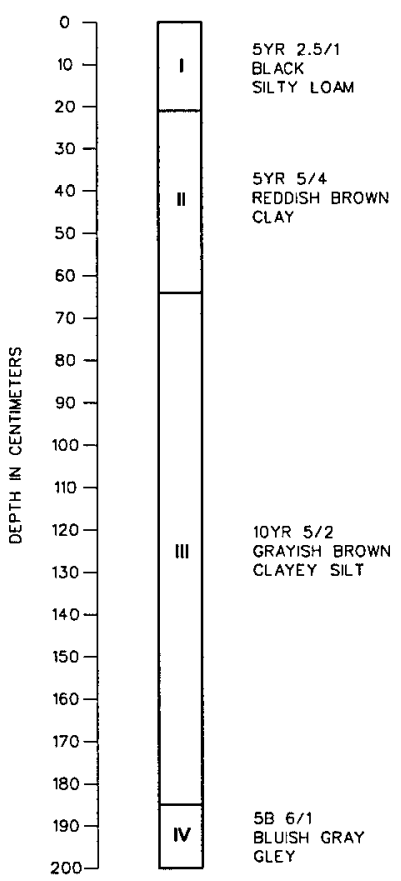

Figure 66. Profile of a typical auger test excavated within Staging Area 2. 


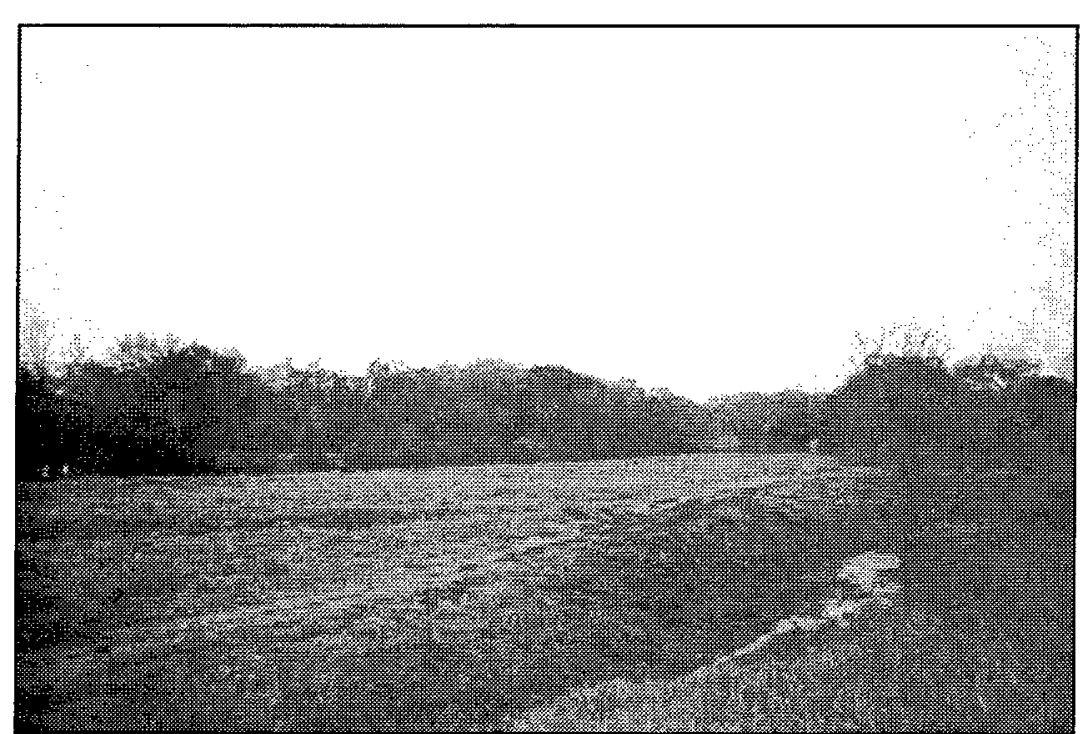

Figure 67. Overview photo of Locus SA2-01 facing south.

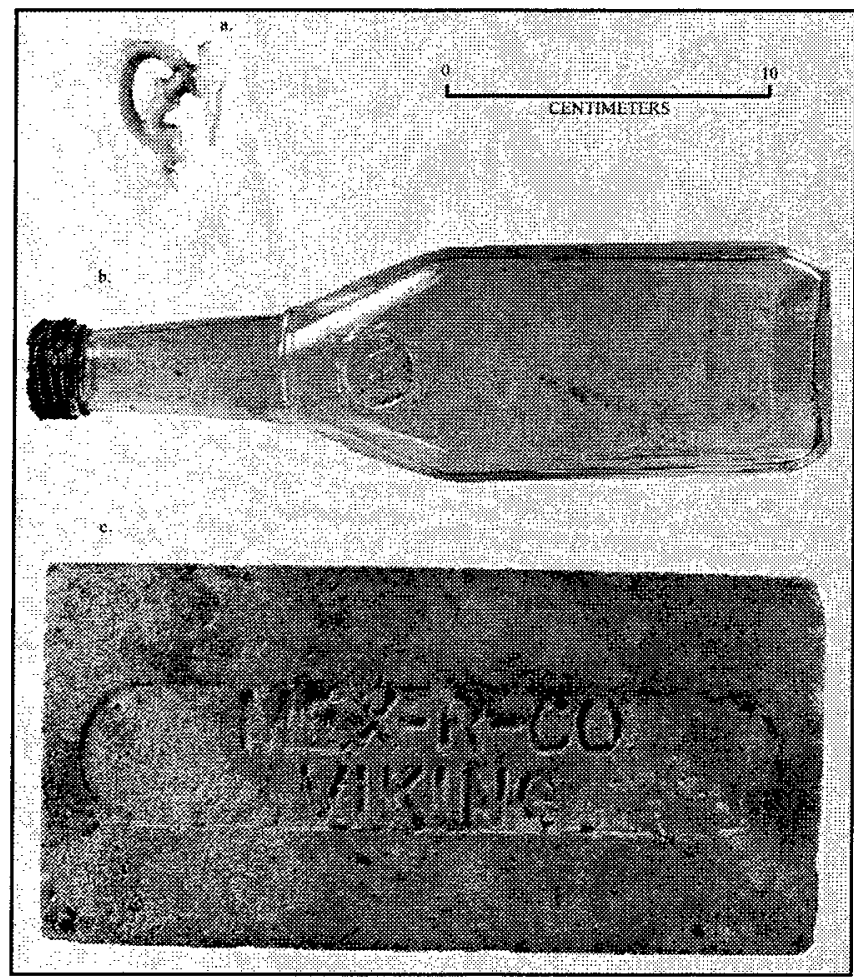

Figure 68. Selected historic period artifacts recovered from Locus SA2-01: (a) hard paste porcelain tea cup sherd with iridescent luster body, gold gilded lip and intricate handle (FS \#3); (b) colorless machine made square form bottle with a continuous thread lip (FS \#4) embossed with a "M" seal on each shoulder, "25.4 FL.OZ" on front and back heels, "750 ML" on both side heels, and "3935 A/ 5 (Brockway Glass Co. mark)/ 11" on base; and (c) a complete brick (FS \#5) embossed with "MEX-R-CO/ VIKING (Mexico Refractories Co., Missouri). identification of a single cultural resources locus (SA2-01) (Figure 67). This locus is described below.

\section{Locus SA2-01}

Locus SA2-01 was confined to Stratum I and Stratum II of the Staging Area 2 project item. Inspection revealed that the deposit consisted of a layer of redeposited topsoil covering a layer of fill that had been spread across the majority of the proposed staging area sometime in the recent past. The cultural material associated with Locus SA2-01 was confined to the open, grass-covered portion of the proposed staging area; no cultural material was recovered from those auger tests excavated within the center of the existing two-track road or those excavated near the bankline of Bayou Teche.

The vast majority of the cultural material noted within Locus SA2-01 clearly was modern in origin. It consisted of styrofoam, plastic soda bottles, strips of metal, plastic utensils, wire fragments, pieces of rubber, plastic wrappers, cement fragments, pieces of wood, fragments of modern clothing, and a flour bag; none of these items were collected. Only three historic period artifacts identified during survey were retained for further analysis. These artifacts consisted of 1 hard paste porcelain sherd with gold gilt, 1 whole fired brick containing the words "MEX-R-CO/ VIKING" (Mexico Refractories Co., Missouri), and 1 complete colorless machinemade bottle (Table 15 and Figure 68). These artifacts date from post ca. 1870 , post ca. 1925 , and ca. 1935 to 1942 , respectively. No other historic period artifacts were recovered during survey.

Locus SA2-01 does not merit archeological site status and it does not possess the qualities of significance as defined by the National Register of Historic Places criteria for evaluation (36 CFR 60.4 [a-d]). No additional testing of Locus SA2-01 or the proposed Staging Area 2 project item is recommended. 
Table 15. Historic Period Artifacts Recovered from Locus SA2-01.

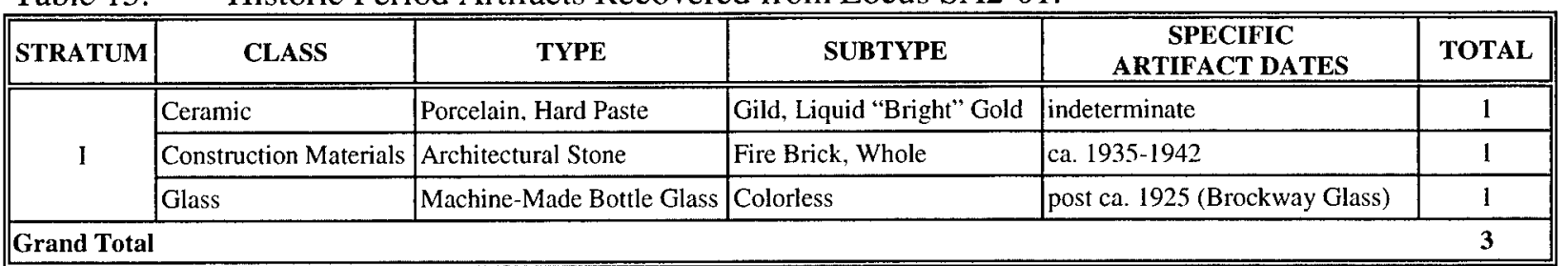

\section{Staging Area 3}

The proposed Staging Area 3 project item was situated within Irregular Section 38 of Township 12S, Range 7E on property owned by the LaBiche Engineering Company (Figure 69). The testable portion of the proposed project item measured approximately 0.2 ha $(0.5 \mathrm{ac})$ in extent and it was bounded to the north by Bayou Teche, to the east by Louisiana Highway 3195 , to the west by a treeline, and to the south by an office building and paved parking lot owned and operated by the LaBiche Engineering Company (Figure 70). Groundcover within the testable portion of the proposed project item consisted of manicured grass. Visual examination of the ground surface prior to testing suggested that the area has been disturbed by the construction of the nearby office building and parking lot, as well as by the installation of buried power lines and a drainage ditch that was oriented parallel to Louisiana Highway 3195.

In addition, conversations with Mr. LaBiche revealed that the proposed staging area once was owned by Mr. Francis Romero, who operated a shell processing facility on the site. Mr. Romero transported shell to the site and crushed it to produce marketable lime and other shellrelated products. Mr. Romero operated the shell-crushing business on that spot from ca. 1950 to 1970 ; the area apparently laid fallow for the next 15 years. The current office building and parking lot were constructed in 1985.

Despite the presence of previous ground-disturbing activities, Staging Area 3, because of its location on the natural levee and in close proximity to Bayou Teche, was considered to have a high potential for containing deeply-buried intact cultural deposits. In addition, the testable portion of this proposed project item was very small and auger testing was conducted at $10 \mathrm{~m}$ (32.8 ft) intervals throughout the Area of Potential Effect. Backhoe trenching was not conducted because of the limited size of the Area of Potential Effect, the presence of buried power lines, and because the landowner requested that backhoe trenches not be excavated in the area.

During survey, 10 of 12 planned auger tests (83 percent) were excavated successfully throughout this portion of the Area of Potential Effect. Auger tests were excavated at $10 \mathrm{~m} \mathrm{(32.8}$ $\mathrm{ft}$ ) intervals along two parallel transects spaced approximately $10 \mathrm{~m}(32.8 \mathrm{ft}$ ) apart (Figure 70$)$. A typical auger test extended to a depth of $200 \mathrm{cmbs}$ (78.7 inbs) and it exhibited three strata in profile (Figure 71). Stratum I ranged in depth from 0 to $50 \mathrm{cmbs}$ ( 0 to 19.7 inbs) and it was described as a layer of dark grayish brown (10YR 4/2) clayey loam mixed with minor amounts of shell. Stratum I was underlain by Stratum II, a layer of dark gray

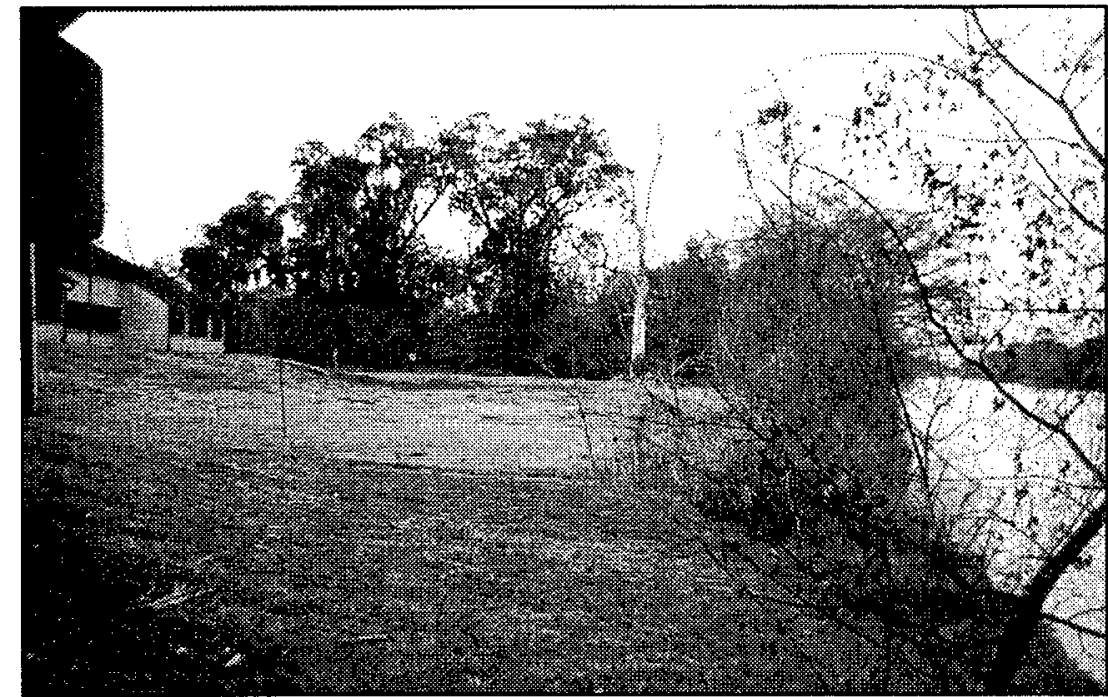

Figure 69. Overview photo of Staging Area 3 facing west. 


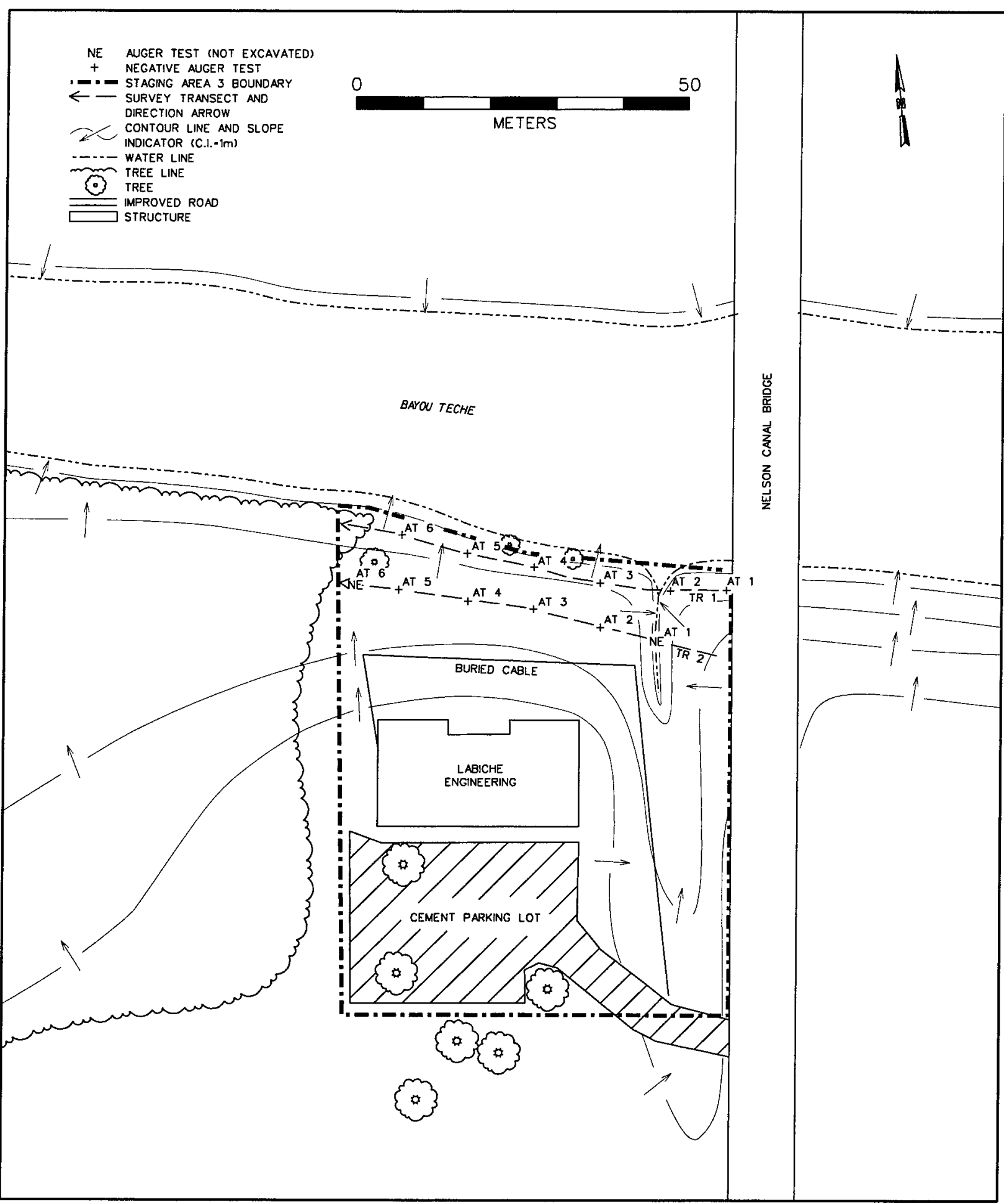

Figure 70. Plan view of Staging Area 3 depicting the locations of auger tests and backhoe trenches. 


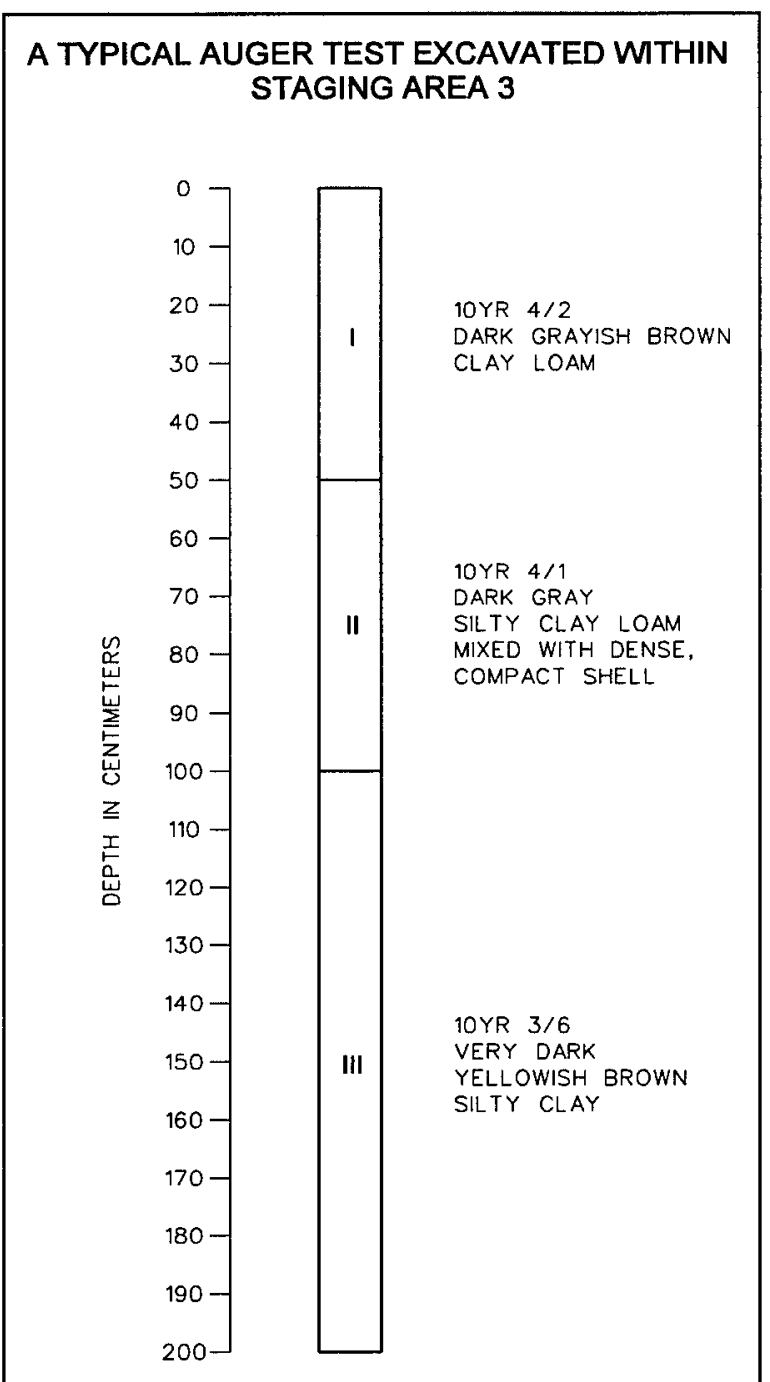

Figure 71. Profile of a typical auger test excavated within Staging Area 3.

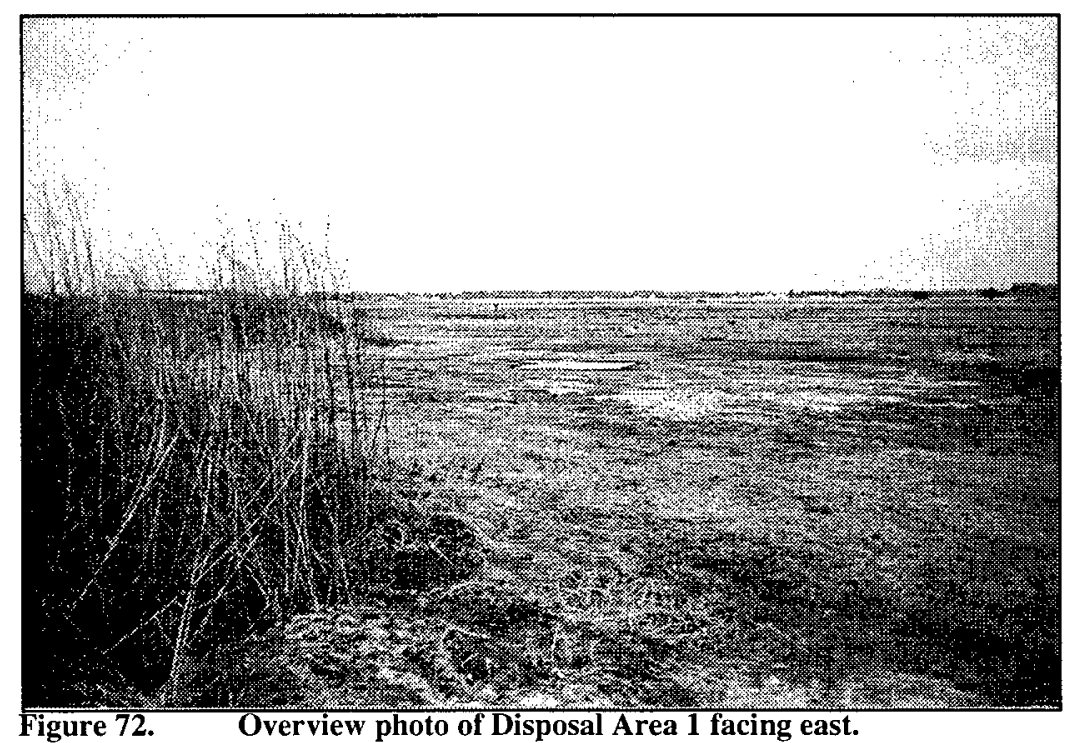

Figure 72.
(10YR 4/1) silty clay mixed with dense deposits of compact shell related to the former shell processing facility that was located in the proposed project item; it extended from 50 to $100 \mathrm{cmbs}$ (19.7 to 39.4 inbs). Finally, Stratum III was characterized as a layer of very dark yellowish brown (10YR 3/6) silty clay that was encountered from 100 to a maximum excavated depth of $200 \mathrm{cmbs}$ (39.4 to 78.7 inbs).

Despite the excavation of 10 of 12 planned auger tests throughout the Area of Potential Effect, no cultural resources were identified during survey of the proposed Staging Area 3 project item. No additional testing of the proposed Staging Area 3 project item is recommended.

\section{Disposal Area 1}

The proposed Disposal Area 1 project item was situated on land owned by the Cajun Sugar Company and within Irregular Sections 9 and 77 of Township 12S, Range 7E (Figure 72). The testable portion of the proposed project item measured approximately 10.6 ha $(26.1 \mathrm{ac})$ in extent. It was bounded to the east by a large sugar cane field, to the south by a drainage ditch, and to the west and north by a levee that separated the proposed disposal area from a series of large sewage treatment ponds (Figure 73). While the proposed Disposal Area 1 project item was situated within a sugar cane field, there was no groundcover at the time of survey.

Due to its location away from Bayou Teche and off of the natural levee, Disposal Area 1 was assessed as having a moderate potential for containing intact cultural deposits. Thus, auger testing and backhoe trenching throughout the Area of Potential Effect proceeded at $50 \mathrm{~m}(164 \mathrm{ft})$ intervals. In addition, all survey transects were separated by $50 \mathrm{~m}(164 \mathrm{ft})$, and auger tests and backhoe trenches along adjacent transects were offset to provide maximum coverage of the proposed project item.

During survey, 25 of 25 planned auger tests (100 percent) and 28 of 28 planned backhoe trenches (100 percent) were excavated successfully throughout this 


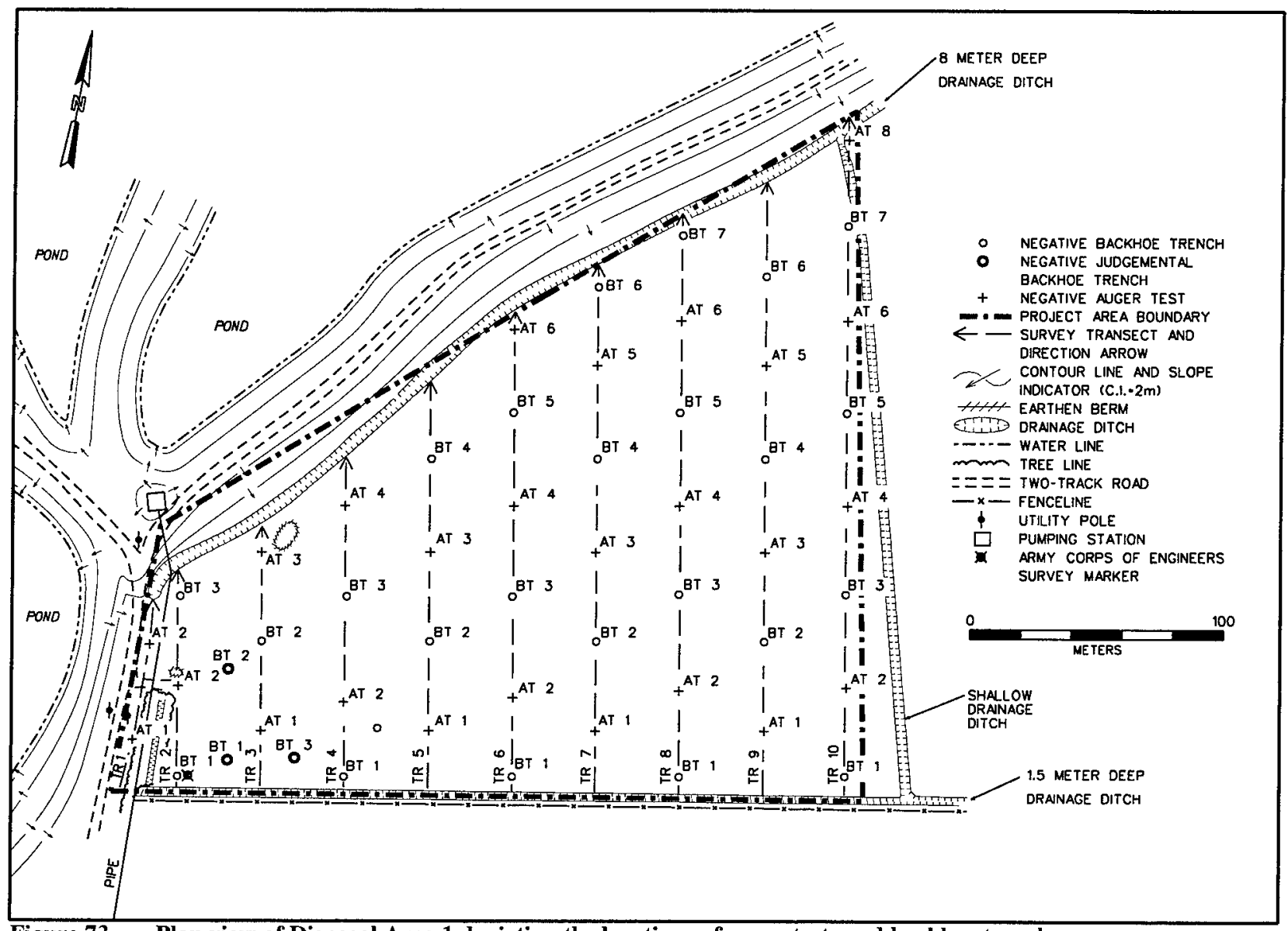

Figure 73. Plan view of Disposal Area 1 depicting the locations of auger tests and backhoe trenches.

portion of the Area of Potential Effect. The auger tests and backhoe trenches were excavated along 10 parallel survey transects spaced approximately $50 \mathrm{~m}(164 \mathrm{ft})$ apart.

A typical backhoe trench excavated within the proposed Disposal Area 1 project item exhibited four strata in profile (Figures 74 and 75). Stratum I extended from 0 to $35 \mathrm{cmbs}$ (0 to 13.8 inbs) and it was characterized as a layer of very dark gray (10YR 3/1) clay. Stratum II ranged in depth from 35 to $77 \mathrm{cmbs}$ (13.8 to 30.3 inbs); it was classified as a layer of grayish brown (2.5YR 5/2) clay. Stratum II was underlain by Stratum III, a layer of grayish brown $(2.5$ YR $5 / 2)$ silty clay mottled with dark yellowish brown (10YR 4/6) silty clay; it extended from 77 to $126 \mathrm{cmbs}$ (30.3 to 49.6 inbs). Finally, Stratum IV reached from 126 to $200 \mathrm{cmbs}$ (49.6 to 78.7 inbs) and it was described as a layer of gray (10YR 5/1) clay.
A typical auger test excavated within the proposed Disposal Area 1 project item extended to a depth of $200 \mathrm{cmbs}$ (78.7 inbs) and it exhibited three strata in profile (Figure 76). Stratum I extended from 0 to $21 \mathrm{cmbs}$ ( 0 to $8.3 \mathrm{inbs}$ ); it was classified as a layer of dark grayish brown (10YR 4/2) clay. Stratum I was characterized as the plowzone. It was underlain by Stratum II, a layer of gray (10YR 5/1) clay mottled with reddish brown (5YR 5/4) clay; it ranged in depth from 21 to $83 \mathrm{cmbs}$ ( 8.3 to 32.7 inbs). Finally, Stratum III was described as a layer of reddish brown (5YR $5 / 4$ ) clay mottled with gray (10YR 5/1) clay; it extended from 83 to $200 \mathrm{cmbs}$ ( 32.7 to $78.7 \mathrm{inbs}$ ).

Despite the excavation of 25 of 25 planned auger tests and 28 of 28 planned backhoe trenches throughout the Area of Potential Effect, no cultural resources were identified during survey of Disposal Area 1. No additional testing of this proposed disposal area is recommended. 


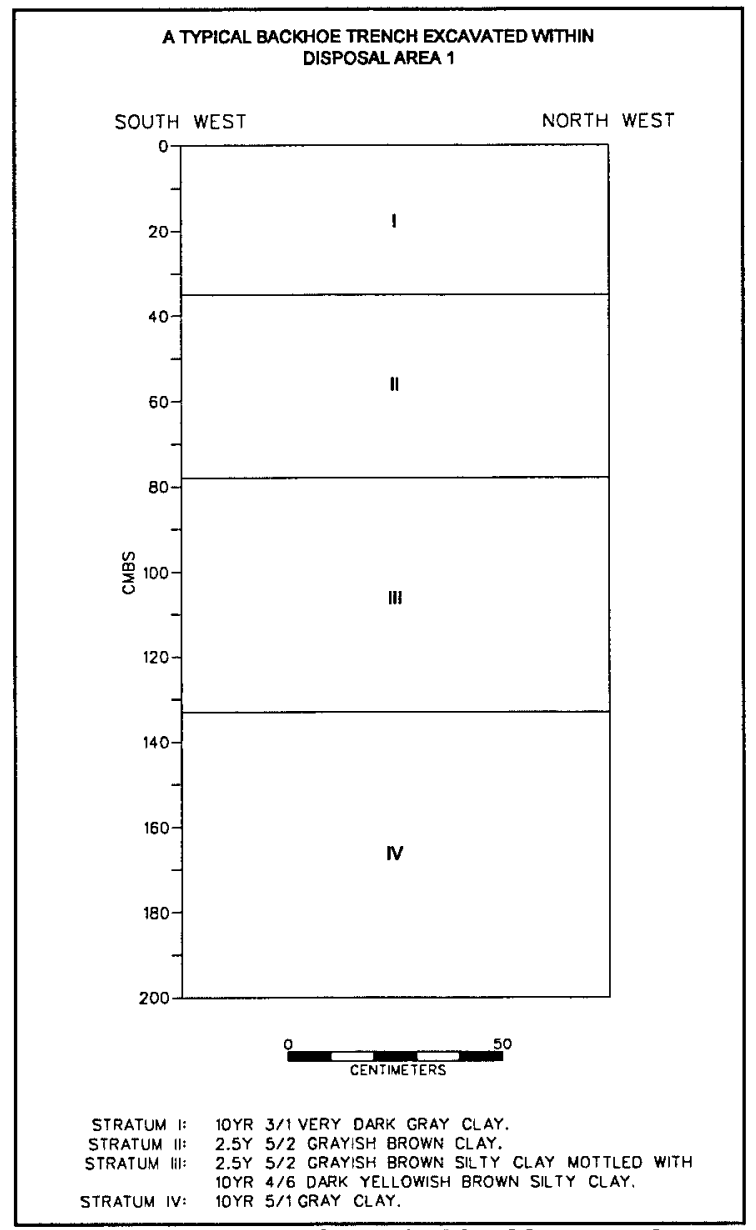

Figure 74. Profile of a typical backhoe trench excavated within Disposal Area 1.

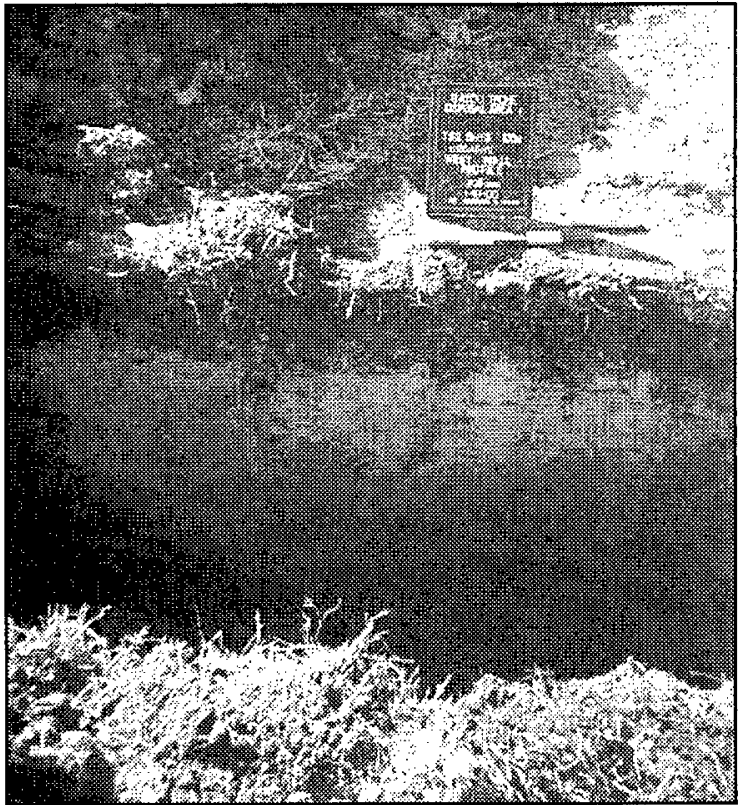

Figure 75. Overview photo of the profile of a typical backhoe trench excavated within Disposal Area 1.

A TYPICAL AUGER TEST EXCAVATED WITHIN DISPOSAL AREA 1

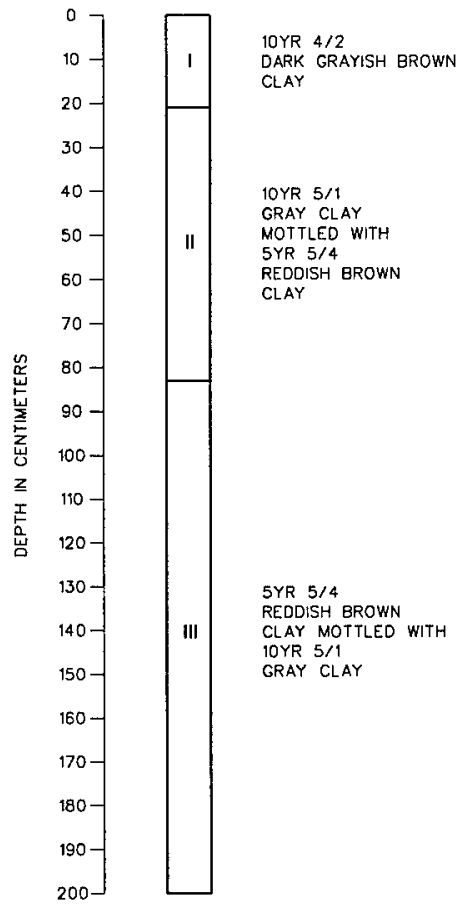

Figure 76.
Profile of a typical auger test excavated within Disposal Area 1. 


\section{Disposal Area 2}

Disposal Area 2 was located within Section 9 of Township 12S, Range 7E on property owned by the Iberia Sugar Company (Figure 77). This proposed project item encompassed approximately 0.75 ha $(1.86 \mathrm{ac})$ and it was bounded by Bayou Teche to the south, by the proposed Staging Area 1 project item to the east, by a large water intake pipe to the west, and by a cooling pond used by the Cajun Sugar Company to the north (Figure 78). Vegetation recorded within the boundaries of this project item included grass, oaks, and brush. Visual examination of the ground surface prior to testing suggested that the area had witnessed only limited disturbance associated with the construction of the water pipe and the cooling pond. Because of its position on the natural levee and proximity to Bayou Teche, Disposal Area 2 was assumed to have a high potential for containing intact cultural deposits; therefore, auger testing and backhoe trenching was conducted at $30 \mathrm{~m}(98.4 \mathrm{ft})$ intervals throughout the Area of Potential Effect.

During survey, 13 of 13 planned backhoe trenches (100 percent) and one planned auger test was excavated successfully throughout the Area of Potential Effect. These sampling units were excavated along three survey transects (Figure 78). Transects 1 and 2 were spaced approximately $30 \mathrm{~m}(98.4 \mathrm{ft})$ apart, while Transects 2 and 3 were spaced approximately 10 m (32.8 ft) apart. Transect 3 was added to the testing regime because coverage throughout this portion of the project item was judged to be inadequate. In addition, the placement of the auger test and the backhoe trenches were offset to maximize coverage throughout the Area of Potential Effect.

A typical backhoe trench excavated within the Disposal Area 2 project item extended to a depth of $200 \mathrm{cmbs}$ (78.7 inbs) and it also exhibited three strata in profile (Figures 79 and 80 ). Stratum I extended from 0 to $35 \mathrm{cmbs}$ ( 0 to $13.8 \mathrm{inbs}$ ) and it was described as a layer of dark brown (10YR $3 / 2$ ) clayey loam mottled with dark red (2.5YR 4/6) clayey loam. Stratum II ranged in depth from 35 to $75 \mathrm{cmbs}$ (13.8 to 29.5 inbs); it was characterized as a layer of very dark brown (10YR 2/2) silty loam. Finally, Stratum III consisted of a layer of dark red (2.5YR 4/6) clay that extended from 75 to 200 ( 29.5 to 78.7 inbs).

The single auger test excavated within the proposed Disposal Area 2 project item extended to a depth of $200 \mathrm{cmbs}$ ( $78.7 \mathrm{inbs}$ ) and it exhibited three strata in profile (Figure 81). Stratum I extended from 0 to $10 \mathrm{cmbs}$ ( 0 to 3.9 inbs) and it was described as a layer of very dark gray (10YR 3/1) clayey loam. Stratum I was underlain by Stratum II, a layer of brown (7.5YR 5/3) clay that extended from 10 to $125 \mathrm{cmbs}$ (3.9 to $49.2 \mathrm{inbs}$ ). Finally, Stratum III was classified as a layer of very dark brown (10YR 3/2) clay mottled with dark red (2.5YR 4/6) clay it was encountered at depths ranging from 125 to $200 \mathrm{cmbs}$ (49.2 to 78.7 inbs).

The successful excavation of 1 planned auger test and 13 planned backhoe trenches throughout the Area of Potential Effect resulted in the identification of a single cultural resources locus (DA201) (Figure 82). Locus DA2-01 is described below.

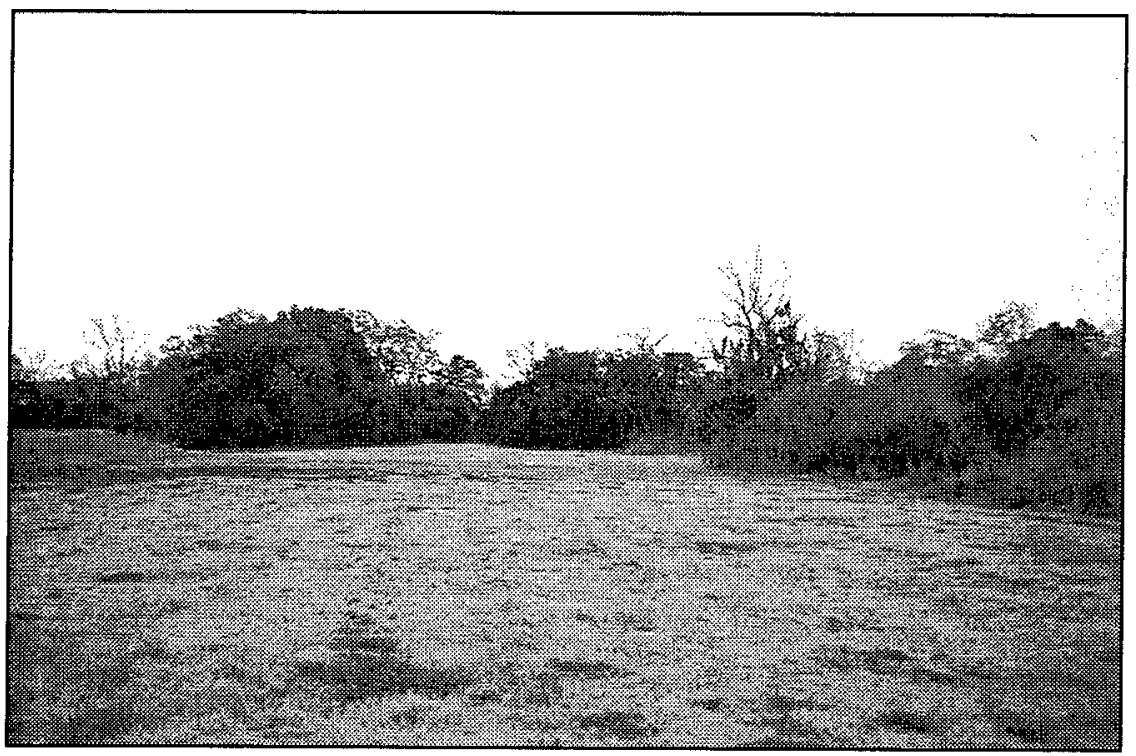

Figure 77. Overview photo of Disposal Area 2 facing east. 


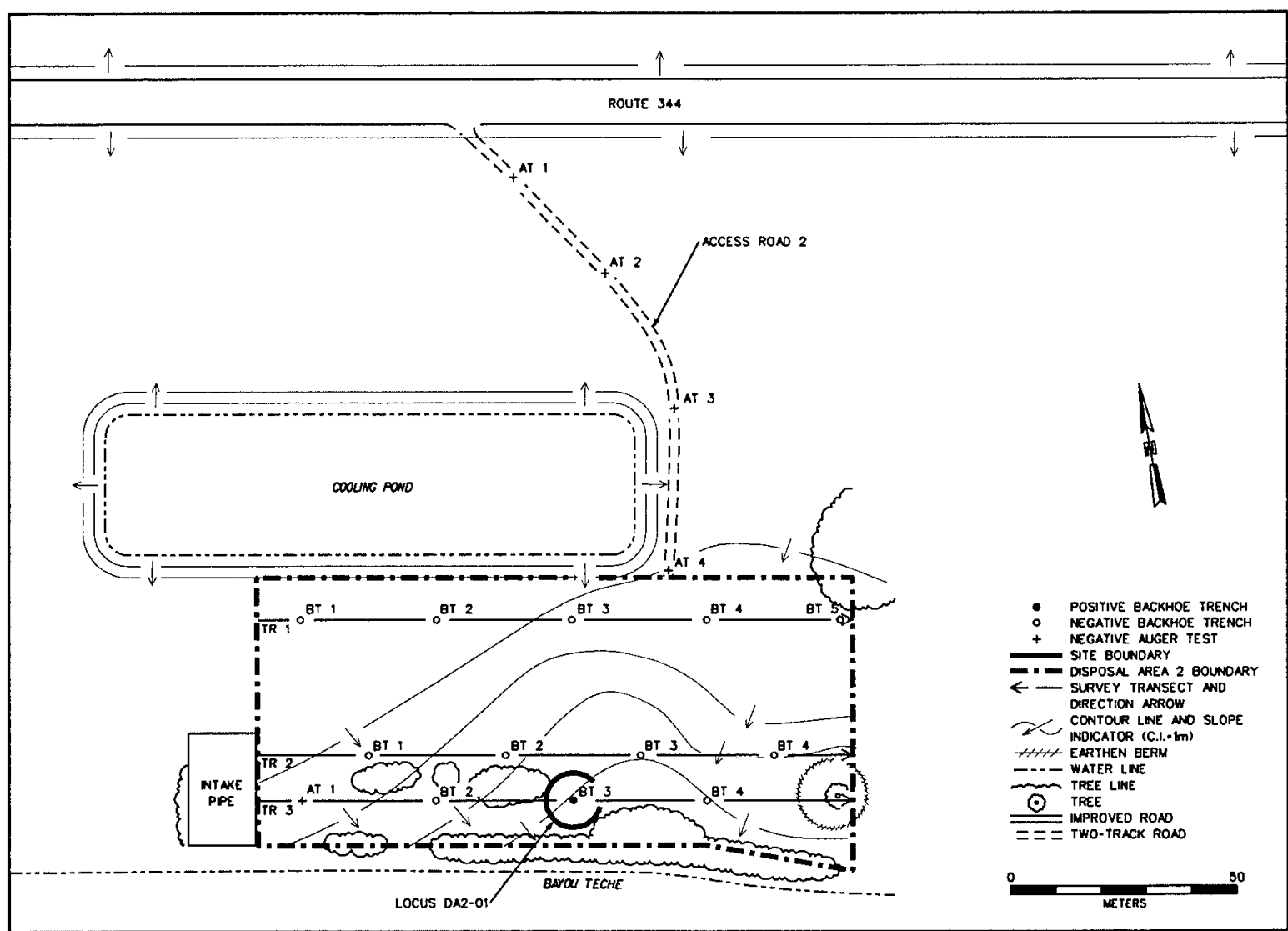

Figure 78. Plan view of Disposal Area 2 depicting the locations of auger tests and backhoe trenches.
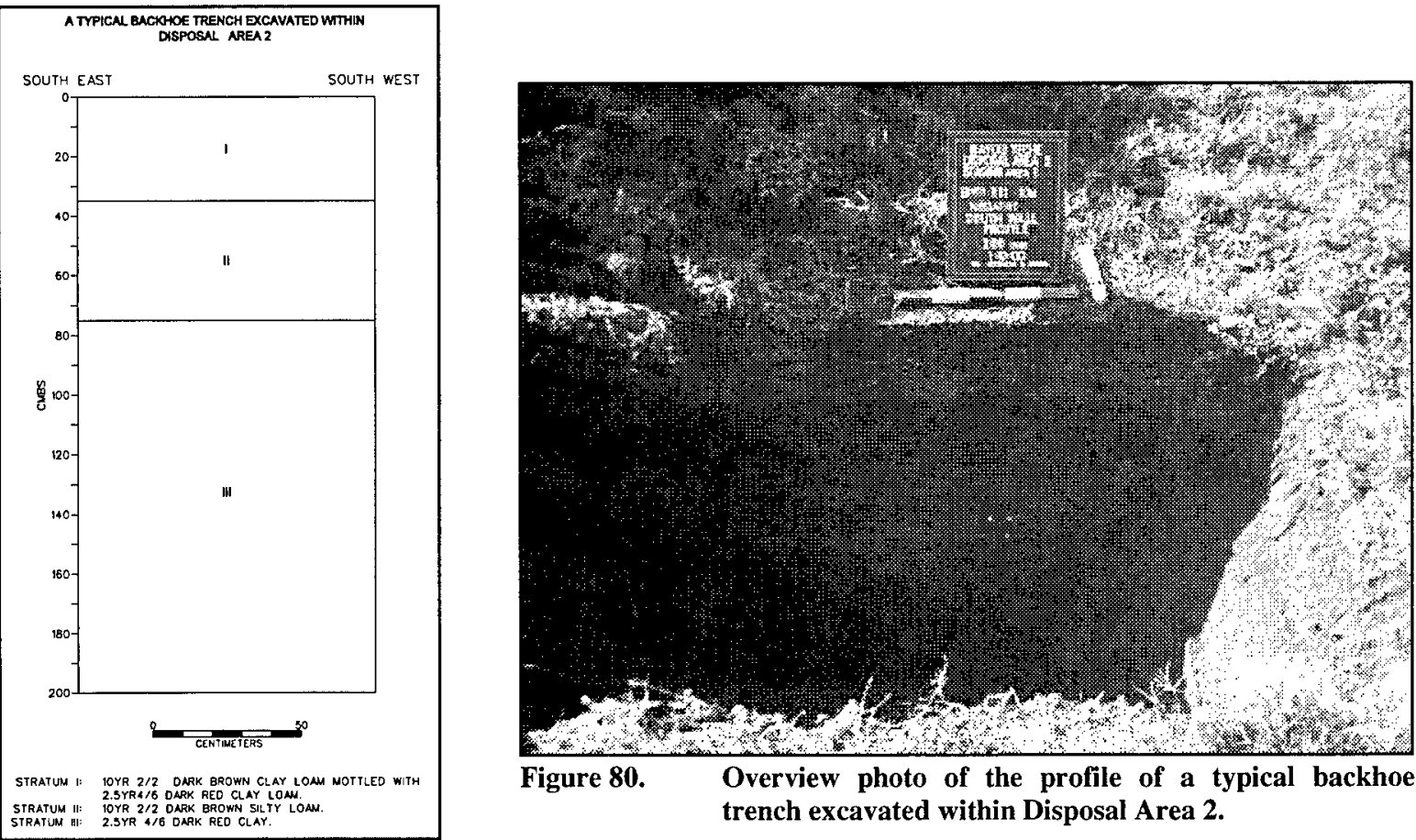

Figure 80.

Overview photo of the profile of a typical backhoe trench excavated within Disposal Area 2.

Figure 79. Profile of a typical backhoe trench excavated within Disposal Area 2. 


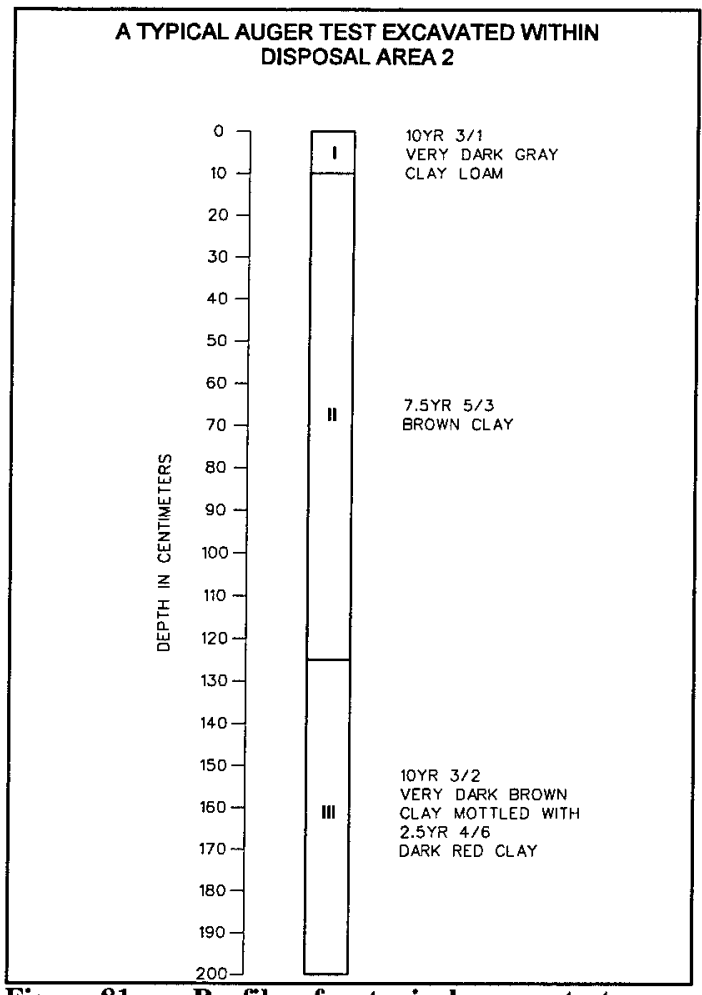

Figure 81. Profile of a typical auger test excavated within Disposal Area 2.

\section{Locus DA2-01}

Locus DA2-01 consisted of the buried remains of a cow that exhibited a set of large horns (Figure 83) and one glass shard. The animal was identified within Backhoe Trench 3 on Transect 3. A single colorless machine-made glass shard also was recovered from this backhoe trench; it was recovered from the backdirt pile created during the excavation of the trench. The glass shard was recovered from deposits situated above the animal remains. The cow/bull remains were exposed, drawn in plan view, and photographed using both black and white and color film. Finally, several skeletal elements, including 1 atlas vertebrae, 1 cranial fragment, 1 right mandible, 1 left mandible, and 1 long bone shaft fragment (Table 16), were collected and the backhoe trench was filled upon completion of the archeological recordation process; the remainder of the skeleton was left in situ. Despite the excavation of additional backhoe trenches in the area, no additional cultural material was identified.

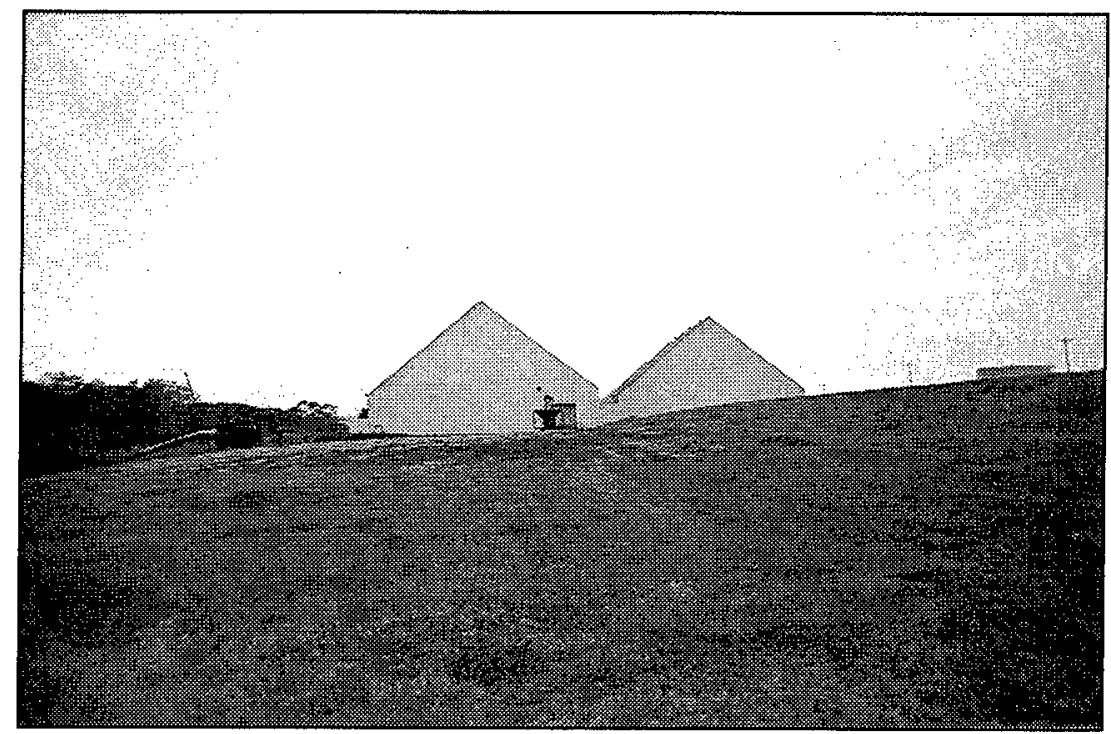

Figure 82. Overview photo of Locus DA2-01 facing west.

Table 16. Artifacts and Faunal Specimens Recovered from Locus DA2-01.

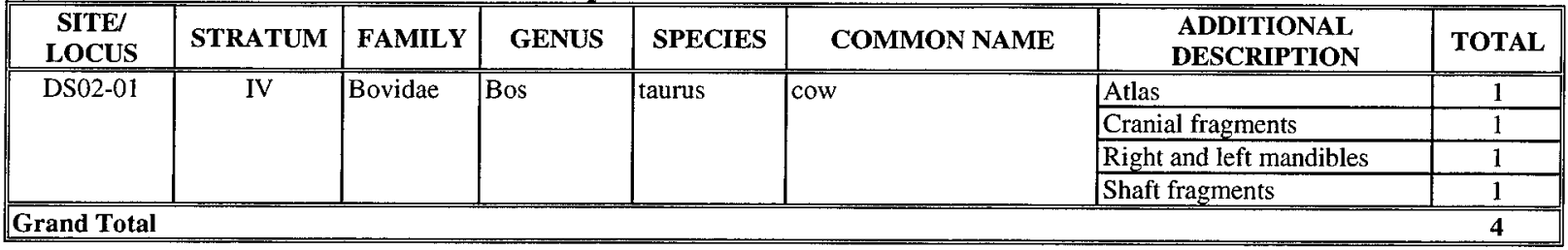




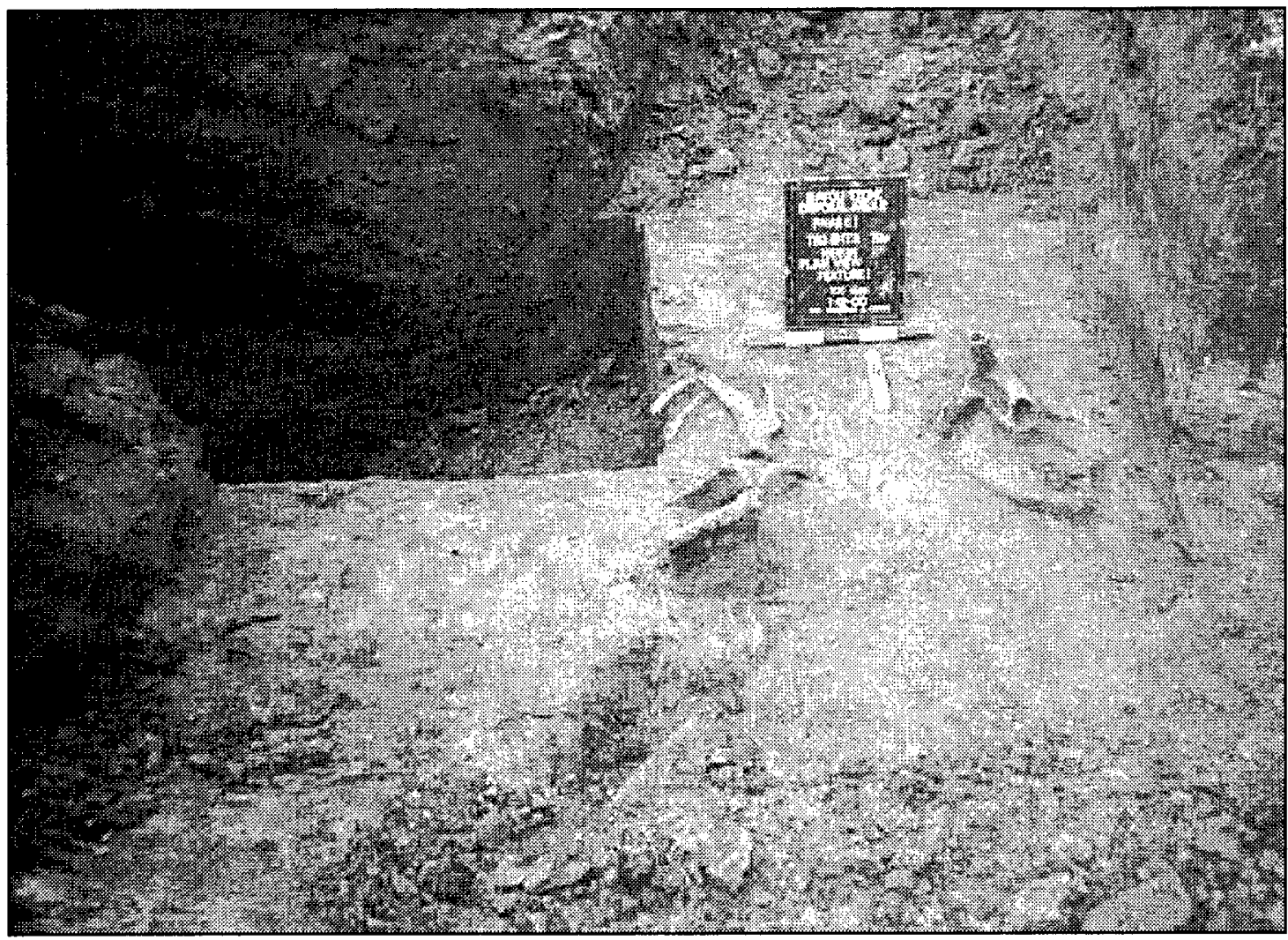

Figure 83. Photo of cow burial identified within Locus DA2-01.

The cultural material and faunal remains noted within Locus DA2-01 were modern in origin. Locus DA2-01 did not merit archeological site status and it did not possess the qualities of significance defined by the $\mathrm{Na}$ tional Register of Historic Places criteria for evaluation (36 CFR 60.4 [a-d]). No additional testing of Locus DA2-01 or the Disposal Area 2 project item is recommended.

\section{Disposal Area 3}

Disposal Area 3 was located on property owned by Ms. Mildred Estis within Section 39 of Township 12S, Range 7E (Figure 84). The proposed project item was located approximately $600 \mathrm{~m}(1,968 \mathrm{ft})$ south of the west bank of Bayou Teche and it encompassed a testable area that measured approximately 14.0 ha $(34.4 \mathrm{ac})$ in size. This area was characterized by small hardwood trees, scrub brush, and three linear sewage disposal ponds that measured from 600 to $700 \mathrm{~m}(1,968$ to $2,296 \mathrm{ft})$ in length by 75 to $100 \mathrm{~m}$ ( 246 to $328 \mathrm{ft}$ ) in width (Figure 85). Examination of the ground surface

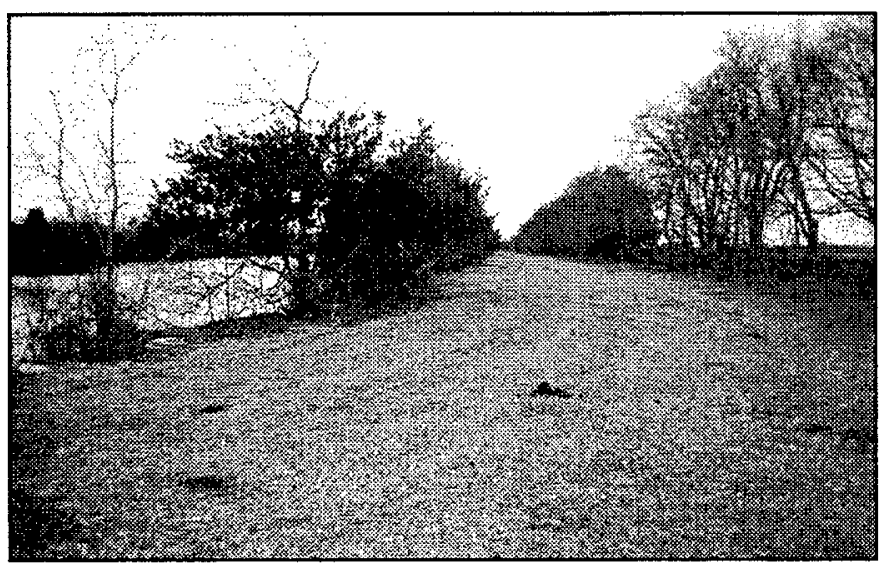

Figure 84. Overview photo of Disposal Area 3 facing south. 
Chapter VII: Results of the Investigation

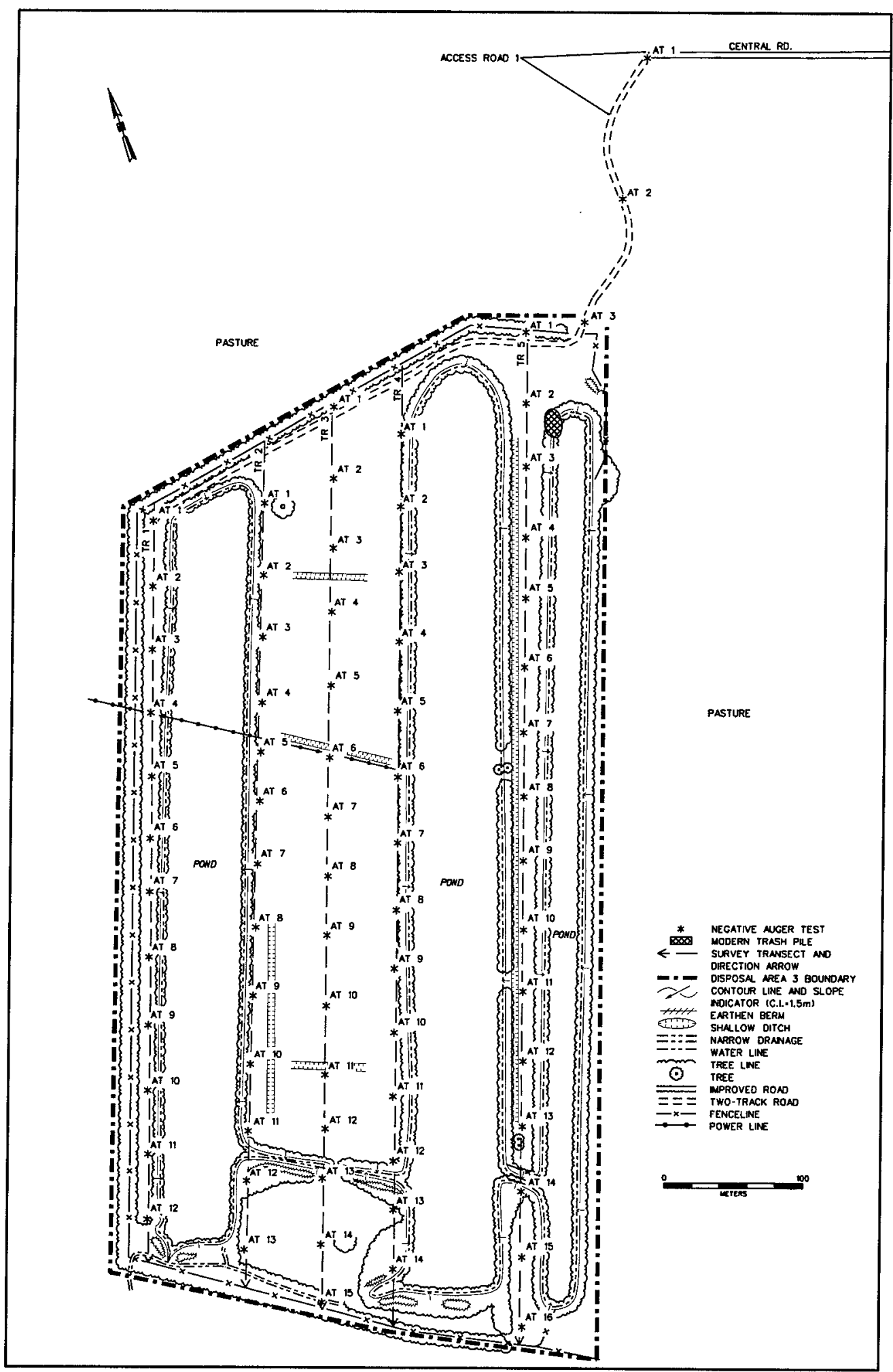

Figure 85. Plan view of Disposal Area 3 depicting the locations of auger tests and backhoe trenches. 
within the proposed project item indicated that the area had been subjected to previous disturbances, such as the construction of drainage ditches, berms, and power lines.

Due to its distance from Bayou Teche, its location off of the natural levee, and the impacts associated with the aforementioned ground disturbances, Disposal Area 3 was assessed as having only a moderate potential for containing intact cultural deposits. In addition, no backhoe trenching was conducted within Disposal Area 3 due to the limited space for maneuvering heavy equipment; only auger testing was conducted within the Area of Potential Effect. Auger testing within the testable portion of the Area of Potential Effect was conducted at $50 \mathrm{~m}(164 \mathrm{ft})$ intervals. Survey transects were spaced approximately $50 \mathrm{~m}$ $(164 \mathrm{~m})$ apart, and adjacent transects were staggered to maximize coverage of the proposed project item (Figure 85).

During survey, 71 of 71 planned auger tests (100 percent) were excavated successfully throughout the Area of Potential Effect. These auger tests were excavated along five survey transects spaced $50 \mathrm{~m}(164 \mathrm{ft})$ apart. A typical auger test excavated within the proposed Disposal Area 3 project item extended to a depth of $200 \mathrm{cmbs}$ ( 78.7 inbs) and it exhibited three strata in profile (Figure 86 ). Stratum I ranged in depth from 0 to $10 \mathrm{cmbs}$ ( 0 to $3.9 \mathrm{inbs}$ ) and it was classified as a layer of very dark gray (10YR 3/1) clay mottled with strong brown (7.5YR 5/6) clay. Stratum I was underlain by Stratum II, a layer of very dark gray (10YR $3 / 1$ ) clay; it ranged in depth from 10 to 37 cmbs (3.9 to 14.6 inbs). Finally, Stratum III was described as a layer of light olive brown (2.5YR 5/3) clay that extended from 37 to 200 cmbs (14.6 to 78.7 inbs).

Despite the successful excavation of 71 of 71 (100 percent) planned auger tests within the Area of Potential Effect, no cultural resources were identified during survey of Disposal Area 3. No additional testing of this proposed project item is recommended.

\section{Access Road 1}

Access Road 1 was located within Sections 39 and 40 of Township 12S, Range 7E and it measured approximately $437 \mathrm{~m}(1,433$

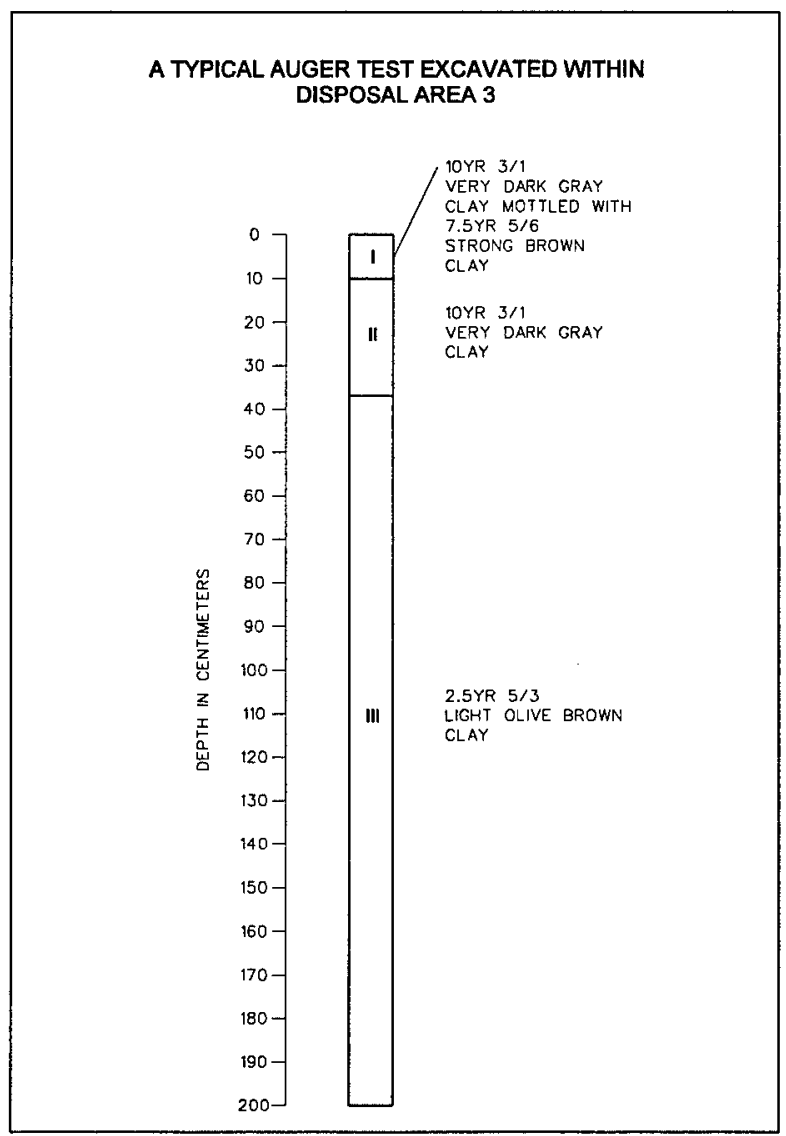

Figure 86. Profile of a typical auger test excavated within Disposal Area 3.

$\mathrm{ft}$ ) in length. The initial $350 \mathrm{~m}(1,148 \mathrm{ft})$ of this road was paved with asphalt and it was named Central Road (Figures 85 and 87). The remainder of the access road was a packed dirt two-track that connected Disposal Area 3 with Central Road. During survey, three of three planned auger tests (100 percent) were excavated successfully within the packed dirt two-track portion of Access Road 1 ; the paved portion of the access road (Central Road) was subjected to pedestrian survey and photodocumentation only.

A typical auger test auger test excavated along Access Road 1 extended to a depth of 200 cmbs (78.7 inbs) and it exhibited two strata in profile (Figure 88). Stratum I extended from 0 to 100 cmbs (0 to 39.4 inbs) and it was described as a layer of very dark gray (2.5YR 3/1) silty loam. Stratum I was underlain by Stratum II, a layer of brown (7.5YR 4/4) clay that extended from 101 to a maximum excavated depth of $200 \mathrm{cmbs}$ (39.4 to 78.7 inbs). 


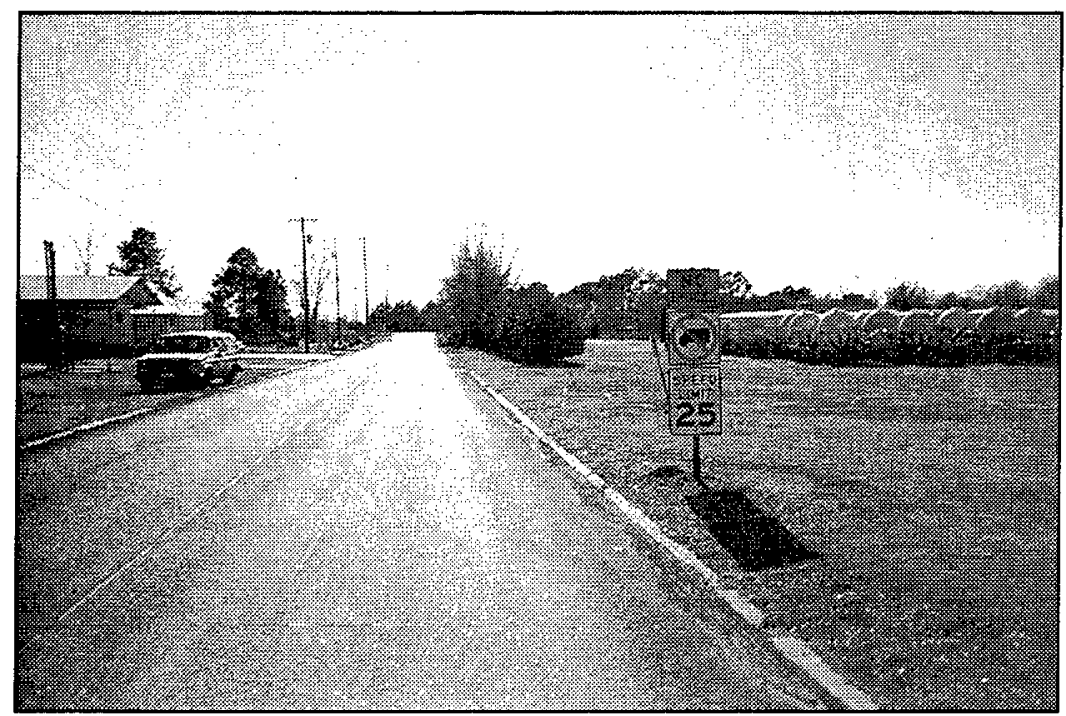

Figure 87. Overview photo of Access Road 1 facing south.

Despite the excavation of the three auger tests along the length of Access Road 1 and the completion of pedestrian survey, no cultural resources were identified. No additional testing of Access Road 1 is recommended.

\section{Access Road 2}

Access Road 2 was located within Sections 9 and 77 of Township 12S, Range 7E. Access Road 2 connects Disposal Area 2 with Disposal Area 1 (Figure 1, Sheet 1). It extended for approximately $790 \mathrm{~m}(2,591 \mathrm{ft})$ from the west bank of Bayou Teche across Louisiana Highway 334 and into property owned by the Cajun Sugar Company, where it connects with Disposal Area 1. This planned access road consisted of a mixture of

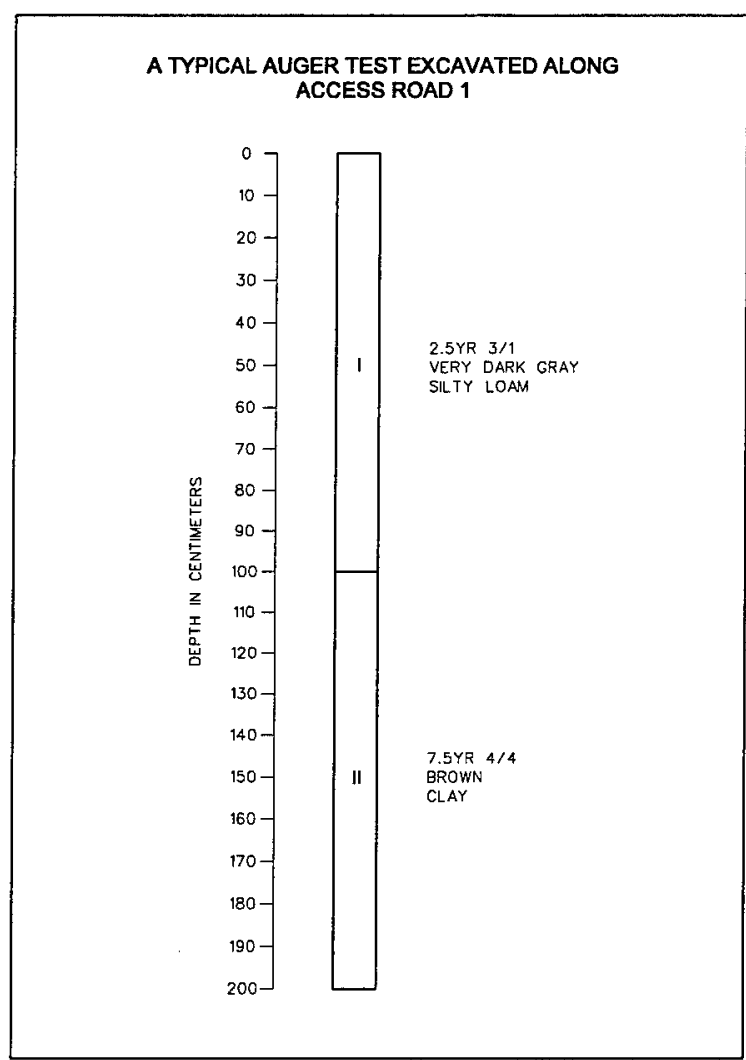

Figure 88. Profile of a typical auger test excavated within Access Road 1. open grass, paved highway, and packed dirt twotrack road (Figure 89). These areas totaled approximately 15,20 , and 75 percent of the proposed access road area, respectively. The entire access road was subjected to pedestrian survey. The packed dirt two-track portions of the road had been impacted previously by construction of the nearby parking lot and sewage disposal ponds and they were subjected to photodocumentation only. The portion of the road extending from the northern border of Disposal Area 2 to Louisiana Highway 334 was subjected to auger testing.

A total of four of four planned auger tests (100 percent) were excavated successfully with the unpaved portion of Access Road 2 that extended from the northern border of Disposal Area 2 to Louisiana Highway 334. A typical auger test excavated along Access Road 2 extended to a depth of $200 \mathrm{cmbs}$ (78.7 inbs) and it exhibited two strata in profile (Figure 90). Stratum I ranged in depth from 0 to $45 \mathrm{cmbs}$ ( 0 to 17.7 inbs) and it consisted of a layer of dark gray (10YR 5/1) clay. Stratum I was underlain by Stratum II, a layer of yellowish brown (10YR 5/6) clay mottled with gray (10YR 5/1) clay; it extended from 45 to 200 cmbs (17.7 to $78.7 \mathrm{inbs}$ ). 


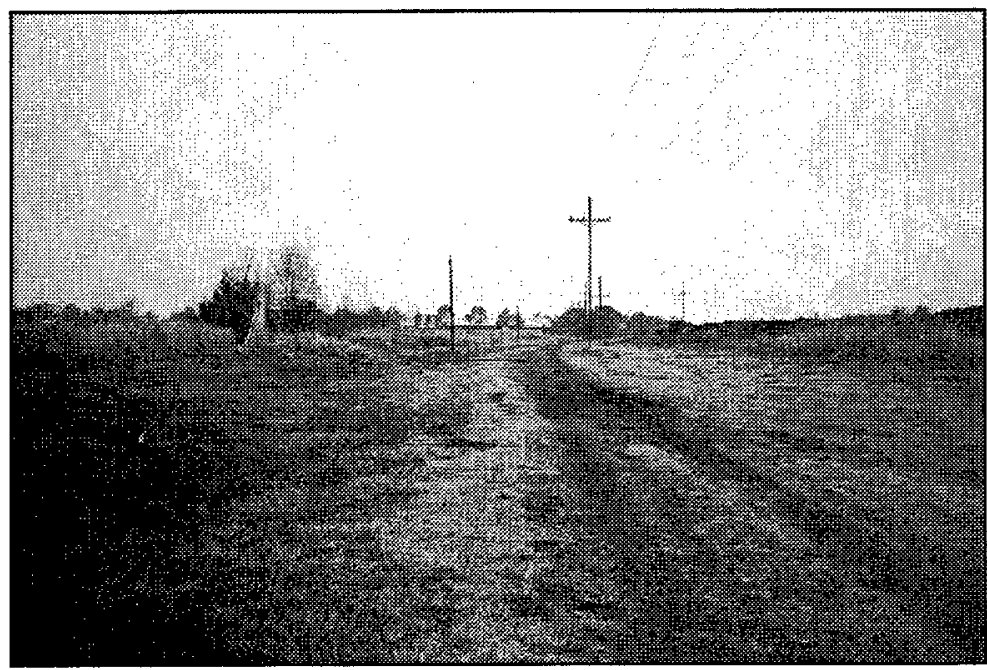

Figure 89. Overview photo of Access Road 2 facing south.

Pedestrian survey and the excavation of four auger tests along the length of Access Road 2 failed to produce any cultural material. In addition, pedestrian survey of the remainder of the access road also failed to yield any cultural material. No additional testing of Access Road 2 is recommended.

\section{Summary}

During the Phase I cultural resources survey and archeological inventory of the $19.3 \mathrm{~km}(12 \mathrm{mi})$ stretch of Bayou Teche, the six proposed terrestrial project items, and the two proposed access roads, 614 underwater magnetic anomalies, 48 underwater acoustic anomalies, and two non-site terrestrial cultural resources loci (SA2-01 and DA201) were identified. The 614 magnetic and 48 acoustic anomalies were identi-

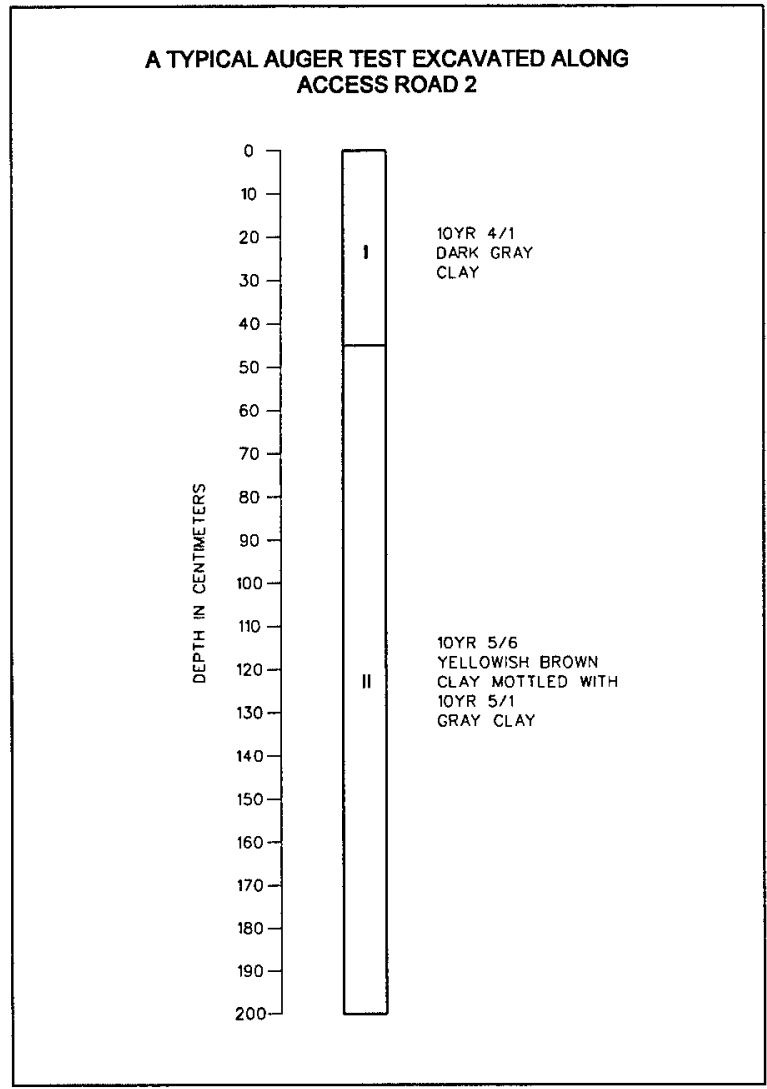

Figure 90. Profile of a typical auger test excavated within Access Road 2. fied within the examined portions of the Bayou Teche channel. A total of 445 of the magnetic anomalies were classified as scatters of ferrous debris. The remaining 169 anomalies were clustered into 84 underwater targets, which consisted of bridge structures, underwater cables, pipeline crossings, and bulkheads. None of the magnetic or acoustic anomalies identified as a result of the underwater portion of this investigation possesses the qualities of significance as define by the National Register of Historic Places criteria for evaluation (36 CFR 60.4 [a-d]). No additional investigation of these anomalies is recommended.

In addition, the terrestrial portion of the Phase I cultural resources survey and archeological inventory resulted in the identification and recordation of two non-site cultural resources loci: SA2-01 and DA2-01. Locus SA2-01 was identified within the proposed Staging Area 2 project item and it consisted of a scatter of modern and historic period debris. Locus DA2-01 was recorded within the confines of the Disposal Area 2 project item. It produced the remains of a cow and a single unassociated glass shard. Neither locus possesses the qualities of significance as defined by the National Register of Historic Places criteria for evaluation (36 CFR 60.4 [a-d]). No additional testing of the Loci SA2-01 or DA2-01, or the six proposed project items, or the two access roads is recommended. 


\section{Chapter VIII}

\section{SUMMARY AND RECOMMENDATIONS}

A Phase I cultural resources survey and archeological inventory was completed of a $19.3 \mathrm{~km}(12 \mathrm{mi})$ stretch of the Bayou Teche channel. In addition, six proposed terrestrial project items, consisting of three staging areas and three disposal areas, and two proposed access roads were examined for cultural resources. The entire project corridor extended through portions of Iberia Parish, Louisiana. This investigation was undertaken in December of 1999 and January of 2000 on behalf of the U.S. Army Corps of Engineers, New Orleans District.

The underwater investigations consisted of an examination of the river bottom, along two parallel $19.3 \mathrm{~km}$ (12 mi) long track lines or survey transects spaced $15 \mathrm{~m}(50 \mathrm{ft})$ apart. The equipment array utilized included a DGPS, a proton precession marine magnetometer, a side scan sonar, and a digital fathometer. The underwater survey was conducted from the $7.3 \mathrm{~m} \mathrm{(24}$ ft) long research vessel Coli, which was leased from the Louisiana Universities Marine Consortium (LUMCON). Survey data were inventoried and analyzed using hydrographic survey software, and a number of specific targets were identified within the limits of the proposed project corridor.

The terrestrial fieldwork component of the investigation included pedestrian survey augmented by auger testing and backhoe trenching throughout the Areas of Potential Effect. The six project items were classified as areas with either moderate or high probability for containing intact cultural deposits. Auger testing and backhoe trenching was conducted at $30 \mathrm{~m}(98.4 \mathrm{ft})$ intervals in high probability areas and at $50 \mathrm{~m} \mathrm{(164}$ $\mathrm{ft}$ ) intervals in moderate probability areas. Those portions of the project items described as low probability areas, i.e., areas that had been disturbed previously by drainage canals or bulldozer spoil piles, were not tested. In addition, delineation auger tests and backhoe trenches were excavated at each identified cultural resource locus in order to determine the extent of the cultural resource.

Examination of the $19.3 \mathrm{~km}(12 \mathrm{mi})$ long stretch of Bayou Teche channel resulted in the identification and recordation of 614 magnetic anomalies and 48 acoustic anomalies. Of the 614 magnetic anomalies, 445 were assessed as isolated scatters of ferrous debris. The remaining 169 magnetic anomalies were clustered into 84 underwater targets. Careful scrutiny of the underwater targets, the ferrous debris scatters, and the acoustic anomalies demonstrated that none of the identified anomalies possessed the qualities of significance as defined by the National Register of Historic Places criteria for evaluation (36 CFR 60.4 [a-d]). No additional testing of the identified anomalies is recommended.

In addition, these investigations resulted in the identification of two terrestrial non-site cultural resources (SA2-01 and DA2-01). Locus SA2-01 consisted of a scatter of modern trash; it produced three historic period artifacts. This locus was confined to a layer of fill and redeposited topsoil within the Staging Area 2 project item. The second locus (DA2-01) consisted of the remains of a cow identified within Disposal Area 2. A single glass shard also was recovered from the backhoe trench in which the cow was found; however, it was not associated with the animal remains. The two non-site cultural resources loci 
do not possess the qualities of significance as defined by the National Register of Historic Places criteria for evaluation (36 CFR 60.4 [a-d]). No additional testing of either Locus SA2-01 or Locus DA2-01 is recommended. In addition, no additional testing of the six proposed terrestrial project items and the two proposed access roads is recommended.
In summary, no significant or potentially significant cultural resources were identified within the proposed underwater or terrestrial portions of the Areas of Potential Effect. No additional testing of the underwater portion of the proposed project reach, the six terrestrial project items, or the two proposed access roads is recommended. 


\section{$\underline{\text { References Cited }}$}

Aiken, Charles S.

1978 The Decline of Sharecropping in the Lower Mississippi River Valley. Geoscience and Man, Volume XIX: Man and Environment in the Lower Mississippi River Valley. School of Geoscience, Louisiana State University, Baton Rouge.

Aitken. M. J.

1961 Physics and Archeology. Interscience, New York.

Allain, Mathe

1979a Bouligny's Account of the Founding of New Iberia. Attakapas Gazette 14(2):79-84.

1979b Bouligny's Account of the Founding of New Iberia. Attakapas Gazette 14(3):124-131.

Annual Reports, War Department, U.S. Army Corps of Engineers (ACRE)

1870 - Report of the Chief of Engineers. Office of the Chief of Engineers, U.S. Army Corps of

1884 Engineers, Washington, D. C.

Athens, William P. and Allen R. Saltus, Jr.

1991 Evaluation of Magnetic Anomalies Located in Lower Bayou Teche, St. Mary Parish, Louisiana. Submitted by R. Christopher Goodwin \& Associates, Inc. to the U.S. Army Corps of Engineers, New Orleans, Louisiana.

Autin, W. J., S. F. Burns, B. J. Miller, R. T. Saucier, and J. I. Snead

1991 Quaternary Geology of the Lower Mississippi Valley. In Quaternary Nonglacial Geology, Conterminous U. S., edited by R. B. Morrison, pp. 547-582, The Geology of North America, v. K-2, Geological Society of America, Boulder.

Beavers, R.C., T.R. Lamb, and J.R. Greene

1984 Archaeological Survey of the Upper Lafourche Delta, Lafourche, Terrebonne Parishes, Louisiana. Research Report No. 8. Archaeological and Cultural Research Program, University of New Orleans, New Orleans.

Bergerie, Maurine

1962 They Tasted Bayou Water, A Brief History of Iberia Parish. Pelican Publishing Company, New Orleans.

Bergstresser, Jack R. Sr., Carl Brasseaux, James R. Morehead, and Prentice M. Thomas, Jr.

1997 National Register Evaluation of the Keystone Lock and Dam, St. Martin Parish, Louisiana. Prentice Thomas and Associates, Inc., Fort Walton Beach, Florida. Submitted to the U.S. Army Corps of Engineers, New Orleans District, New Orleans, Louisiana. 
Bouchereau, Alcee

1881- $\quad$ Statement of the Sugar and Rice Crops Made in Louisiana (1877-1917). Pelican Steam 1892 and Job Printing, New Orleans.

Bouchereau, Louis

1869- $\quad$ Statement of the Sugar and Rice Crops Made in Louisiana (1868-1877). Pelican Steam 1876 Book and Job Printing, New Orleans.

Bouchereau, Louis and Alcee Bouchereau

1868 - Statement on the Sugar and Rice Crops Made in Louisiana. Pelican Steam Book and

1917 Job Printing, New Orleans.

Boyd, R., J. Suter, and S. Penland

1988 Implications of Modern Sedimentary Environments for Sequence Stratigraphy. In Sequences, Stratigraphy, Sedimentology: Surface and Subsurface, edited by D. P. James and D. A. Leckie, pp. 33-36, Canadian Society of Petroleum Geologists, Brasseaux, Carl A. Calgary, Canada.

1979 New Iberia's Steamboat Days. In New Iberia - Essays on the Town and Its People. Center for Louisiana Studies, University of Southwestern Louisiana, Lafayette.

1987 The Founding of New Acadia: The Beginnings of Acadian Life in Louisiana, 1765-1803. Louisiana State University Press, Baton Rouge.

Breiner, Sheldon

1973 Applications Manual for Portable Magnetometers. Geometrics, Sunnyvale, California.

Broussard, Beverly Bernard, and Raymond L. Broussard

1955 A History of St. Mary Parish. No publisher listed, Franklin, Louisiana.

Brown, C. A.

1965 Louisiana Trees and Shrubs. Clairot's Publishing Division, Baton Rouge.

1972 Wildflowers of Louisiana. Louisiana State University Press, Baton Rouge.

Brown, Fay G.

1970 Reconstruction Sweeps Away Way of Life. St. Mary and Franklin Banner-Tribune, April 23, 1970, Sesqui-Centennial Edition.

Brown, Ian W., and Nancy Lambert-Brown

1978 Archaeological Investigations at the Banana Bayou Mound (33-I-5). Lower Mississippi Survey, Petite Anse Project Research Notes 5. Peabody Museum, Harvard University, Cambridge.

Brown, Ian

1981 The Role of Salt in Eastern North American Prehistory. Department of Culture, Recreation and Tourism, Louisiana Archaeological Survey and Antiquities Commission, Anthropological Study No. 3. 
Byrd, K.M.

1994 Tchefuncte Subsistence Practices at the Morton Shell Mound, Iberia Parish, Louisiana. Louisiana Archaeology 16:1-128. (For 1989).

Campbell, J. L., J. R. Morehead, and A. F. Servello

1990 Data Recovery at 16VN791: A Multi-Component Prehistoric Site in the Birds Creek Drainage, Fort Polk Military Reservation, Fort Polk, Louisiana. Report of Investigations No. 188, New World Research, Inc.

Cayton, Frank M.

1881 Landings on all the Western and Southerm Rivers and Bayous Showing Location Post Office Distances. Woodward, Tifany, and Hale Printers and Binders, St. Louis.

Chabreck, R.H. and R.E. Condrey

1979 Common Vascular Plants of the Louisiana Marsh. Sea Grant Publication No. LSU-T79-003. Louisiana State University Center for Wetland Resources, Baton Rouge.

Chambers, Henry E.

1898 West Florida and Its Relation to the Historical Cartography of the United States. In Anglo-American Relations and Southern History, pp. 2-59. Johns Hopkins University Studies in Historical and Political Science, vol. XVI, No. 5. The Johns Hopkins Press, Baltimore.

Champomier, P. A.

1844- $\quad$ A Statement of the Sugar Crop Made in Louisiana (1844-1862). Cook, Young, and 1860 Company, New Orleans.

Chapman, J. and A.B. Shea

1981 The Archaeobotanical Record: Early Archaic Period to Contact in the Lower Little Tennessee River Valley. Tennessee Anthropologist 6(1):61-84.

Chisholm, John Wright

1952 Economics of the Salt Industry in Louisiana. Unpublished Ph.D. dissertation. Department of Economics, Louisiana State University and Agricultural and Mechanical College, Baton Rouge.

Clark, Henry L. and Almond G. White

1978 Soil Survey of Iberia Parish. United States Department of Agriculture, Soil Conservation Service, in Cooperation with the Louisiana Agricultural Experiment Station.

Clune, John and Karla W. Wheeler

1991 A Database of Louisiana Shipwrecks. Database on file at the Louisiana Department of Culture, Recreation and Tourism, Office of Cultural Development, Division of Archaeology, Baton Rouge, Louisiana.

Coates, Earl J. and Dean S. Thomas

1990 An Introduction to Civil War Small Arms. Thomas Publications, Gettysburg. 
Coleman, J. M.

1982 Deltas Processes of Deposition and Models for Exploration. International Human Resources Development Corporation, Boston.

Coleman, J. M., and H. H. Roberts

1988 Sedimentary Development of the Louisiana Continental Shelf Related to Sea Level

Cycles: Part I - Sedimentary Sequence: Geo-Marine Letters 8:63-108.

Coleman, J. M., and S. M. Gagliano

1964 Cyclic Sedimentation in the Mississippi River Deltaic Plains. Transactions of the Gulf Coast Association of Geological Societies 14:67-40.

Comeaux, Malcolm L.

1978 The Acadians: Myths and Realities. The Cajuns: Essays on the History and Culture, Ed.

Glenn R. Close, pp. 142-160. University of Southwestern Louisiana, Lafayette.

Conrad, Glenn R.

1979

A Road for Attakapas. Attakapas Gazette 14:30-36.

Craft, B. R.

1984 Wildlife Habitat. In Soil Survey of Lafourche Parish, Louisiana, complied by S.D. Matthew, pp. 39-42. United States Department of Agriculture, Soil Conservation Service, Washington, D.C.

Darby, William

1816 A Geographical Description of the State of Louisiana. John Melish, Philadelphia.

Dart, Henry P.

1926 A Louisiana Indigo Plantation on Bayou Teche, 1773. The Louisiana Historical Quarterly 9(4):565-589.

Davis, Dave D.

1984 Comparative Aspects of Late Prehistoric Faunal Ecology at the Sims Site. Louisiana Archaeology 11:111-138. (Published 1987, dated 1984).

Davis, Edwin A.

1968 The Rivers and Bayous of Louisiana. Louisiana Education Research Association, Baton Rouge, Louisiana.

1971 Louisiana, A Narrative History. 3rd ed. Claitor's Publishing Division, Baton Rouge.

Davis, John (translator)

1806 Travels in Louisiana and the Floridas in the Year 1802, Giving a Correct Picture of Those Countries. I. Riley \& Co., New York.

De Grummond, Jewel Lynn Delaune

1949 A Social History of St. Mary Parish, 1845-1860. Louisiana Historical Quarterly 32:17-102. 
De Ville, Winston

1973 Opelousas, The History of a French and Spanish Military Post in America, 1716 1803. Polyanthos, Cottonport, Louisiana.

1986 Opelousas Post: The Census of 1771. Published by the author, Ville Platte, Louisiana.

Degelos, Pierre A. 1892

Statement of Sugar Made in Louisiana in 1828 and 1829. The Louisiana Planter and Sugar Manufacturer IX(4):65-68.

Draughon, Ralph, Jr., Susan Barrett Smith, Jeremy Horowitz, Michael Godzinski, Denise Matherne, Christopher Matthews, and R. Christopher Goodwin

1998 Further Real Estate Acquisitions in the Atchafalaya Basin: Land Use Studies in St. Martin, St. Mary, Iberia, and Iberville Parishes, Louisiana. Submitted by R. Christopher Goodwin \& Associates, Inc., to the U.S. Army Corps of Engineers, New Orleans District.

Fike, Richard E.

1987 The Bottle Book: A Comprehensive Guide to Embossed Medicine Bottles. Gibbs M. Smith, Peregrine Smith Books, Salt Lake City.

Fisk, H. N.

1944 Geological Investigation of the Alluvial Valley of the Lower Mississippi River. Mississippi River Commission, Vicksburg, Mississippi.

1955 Sand Facies of the Recent Mississippi Delta Deposits. In Proceedings of the Fourth World Petroleum Congress, 3:378-398.

1960 Recent Mississippi River Sedimentation and Peat Accumulation. In Congres Pour L'advancement des Etudes de Stratigraphie et de Geologie du Carbonifere, 4th Heerlen, edited by Van Aelst, pp. 189-199, Compte rendu, Maastrict, Netherlands.

Florence, Gene

1990 The Collector's Encyclopedia of Depression Glass. Collector Books, Paducah, Kentucky.

Fontenot, Mary Alice, and Rev. Paul B. Freeland

1976 Acadia Parish, Louisiana: A History to 1900. Claitor's Publishing Division, Baton Rouge.

Frazier, D. E.

1967 Recent Deltaic Deposits of the Mississippi River, Their Development and Chronology. Transactions of the Gulf Coast Association of Geological Societies 7:287-315.

1974 Depositional - Episodes: Their Relationship to the Quaternary Stratigraphic Framework of the Northwestern Portion of the Gulf Basin. Texas Bureau of Economic Geology Geological Circular 74-1, Austin. 
French, B. F. (editor and translator)

1875 Historical Collections of Louisiana and Florida, Including Translations of Original Manuscripts Relating to Their Discovery and Settlement, with Numerous Historical and Biographical Notes. Albert Mason, New York.

Gagliano, Sherwood M.

1967 Occupation Sequence at Avery Island. Coastal Studies Series No. 22. LSU Press, Baton Rouge.

1979 Cultural Resources Studies in the Pearl River Mouth Area, Louisiana-Mississippi: Chef Menteur and Rigolets Passes Hurricane control Structures Orleans and St. Tammany Parishes, Louisiana. Prepared for the U.S. Army Corps of Engineers, New Orleans District.

Gibson, Dennis (editor)

1979 The Journal of John Landreth. Attakapas Gazette 14(3):103-109.

1980 The Journal of John Landreth. Attakapas Gazette 15(1):37-40.

Gibson, Jon L.

1975 Archaeological Survey of Bayou Teche, Vermilion River, and Freshwater Bayou, South Central Louisiana. The University of Southwestern Louisiana, Lafayette, Louisiana. Submitted to the U.S. Army Corps of Engineers, New Orleans District, New Orleans, Louisiana.

1976a Archaeological Survey of Bayou Teche, Vermillion River, and Freshwater Bayou, South Central Louisiana. University of Southwestern Louisiana Center for Archaeological Studies Report No. 2. Lafayette.

1976b Archaeological Survey of Mermentau River and Bayous Nezpique and Des Cannes. Center for Archaeological Studies Report 1, Department of Anthropology and Sociology, University of Southwestern Louisiana, Lafayette.

1979 Poverty Point Trade in South Central Louisiana: An Illustration from Beau Rivage. Louisiana Archaeology, Vol. 4:91-116 (for 1977).

1984 The Troyville-Baytown Issue. The Troyville-Baytown Period in Lower Mississippi Valley Prehistory: A Memorial to Robert Stuart Neitzel. Louisiana Archaeology Vol. 9:31-64 (for 1982).

1994 Over the Mountain and Across the Sea: Regional Poverty Point Exchange. In Exchange in the Lower Mississippi Valley and Contiguous Areas in 1100 B.C., Louisiana Archaeology Vol. 17:251-299 (for 1990).

Gibson, Jon L., Robert B. Grambling, Steven J. Brazda, Stephen Traux, Michael J. Nault, and Kathleen M. Bird

1978 Archaeological Survey of the Lower Atchafalaya Region, South Central Louisiana. University of Southwestern Louisiana Center for Archaeological Studies, Report No. 5. 
Gibson, Jon L., and J. Richard Shenkel

1988 Louisiana Earthworks: Middle Woodland and Predecessors. In Middle Woodland Ceremonialism in the Mid-South and Lower Mississippi Valley. Proceedings of the 1984 Mid-South Archaeological Conference, pp. 7-18. Mississippi Department of Archives and History, Jackson.

Gilbert, B. Miles

1980 Mammalian Osteology. Missouri Archaeological Society, Columbia, Missouri.

Glass, J. S.

1898 St. Mary Parish. J. S. Glass, Franklin, Louisiana.

Glenn, John M., Lilian Brandt, and F. Emerson Andrews

1947 Russell Sage Foundation, 1907-1946. 2 vols. Russell Sage Foundation, New York.

Goins, Charles R., and John M. Caldwell

1995 Historical Atlas of Louisiana. University of Oklahoma Press, Norman.

Goodwin, R. C., S. Hinks, W. P. Athens, R. Draughon, Jr., J. A. Cohen, W. A. Morgan, A. R. Saltus, Jr., and P. V. Heinrich

1990 Historical and Archeological Investigations of Fort Bisland and Lower Bayou Teche, St. Mary Parish, Louisiana. Report submitted by R. Christopher Goodwin \& Associates, Inc., to the U.S. Army Corps of Engineers, New Orleans District.

Goodwin, R. Christopher, James M. Wojtala, William A. Morgan, William P. Athens, Jennifer A. Cohen, Julie H. McClay, and Susan Barrett Smith

1990 Level II Archeological Investigation of the Proposed Erath-South Section 28 Pipeline Right-of-Way, Vermilion, Iberia, and St. Martin Parishes, Louisiana. R. Christopher Goodwin \& Associates, Inc., New Orleans, Louisiana. Submitted to Southern Natural Gas Company, Birmingham, Alabama.

Goodwin, R. Christopher, Jill-Karen Yakubik, Galloway W. Selby, Kenneth R. Jones, Debra Stayner, and Janice Cooper

1985 An Archeological and Historic Sites Inventory of Bayou Teche Between Franklin and Jeanerette, Louisiana. R. Christopher Goodwin \& Associates, Inc., New Orleans, Louisiana. Submitted to the Louisiana Department of Culture, Recreation and Tourism, Office of Cultural Development, Division of Archaeology, Baton Rouge, Louisiana.

Gosselink, J. G.

1984 The Ecology of Delta Marshes of Coastal Louisiana. Performed by Center for Wetland Resources, Louisiana State University, Baton Rouge. Performed for Nation Coastal Ecosystems Team, Division of Biological Service, Research, and Development, Fish and Wildlife Service, U.S. Department of the Interior, Washington, D.C.

Gould, H. R.

1960 The Mississippi Delta Complex. In Deltaic Sedimentation: Modern and Ancient, edited by J. P. Morgan and R. S. Shaver, p. 3-30, SEPM Special Publication No. 15, The Sedimentary Society, Tulsa. 
Green, James A., Jr.

1991 Calcasieu Point: A Formal Description. Central States Archaeological Journal. Central States Archaeological Societies, Inc., Kirkwood, Missouri.

Green, Jeremy

1990

Maritime Archaeology: A Technical Handbook. Academic Press, New York.

Griffin, J. B.

1990 Comments on the Late Prehistoric Societies in the Southeast. In Towns and Temples Along the Mississippi, p. 5-15, D. H. Dye and C. A. Cox editors, University of Alabama Press, Tuscaloosa.

Hall, E. T.

1966 The Use of a Proton Magnetometer in Underwater Archeology. Archaeometry 9:3244.

Hall, Gwendolyn Midlo

1992 Africans in Colonial Louisiana: The Development of Afro-Creole Culture in the Eighteenth Century. Louisiana State University Press, Baton Rouge.

Hansen, Harry (editor)

1971 Louisiana, A Guide to the State. Revised ed. Hastings House, New York. Originally published 1941, Louisiana Library Commission at Baton Rouge.

Harrar, E. S. and J. G. Harrar

1946 Guide to Southern Trees. Dover Publications, New York.

Haynes, C. V., Jr.

1991 Geoarchaeological and Paleohydrological Evidence for a Clovis Age Drought in North

America and its Bearing on Extinction. Quaternary Research 35:438-450.

Heitmann, John Alfred

1987 The Modernization of the Louisiana Sugar Industry, 1830-1910. Louisiana State University Press, Baton Rouge.

Hemphill, James E.

1998 Beneath the waters: guide to Civil War shipwrecks. Burd Street Press, Shippensburg, Pennsylvania.

Hillson, Simon

1986 Teeth. Cambridge Manuals in Archaeology, Cambridge University Press, Cambridge.

Holmes, Jack D.

1967 Indigo in Colonial Louisiana and the Floridas. Louisiana History 8:329-349.

Hudson, Charles

1978 The Southeastern Indians. The University of Tennessee Press.

Iberia Parish Census Figures

1992 - Agricultural and Economic Census. Plaquemines, Louisiana.

1996 
Iberia Parish Development Board

ca. Iberia Parish Resources and Facilities. State of Louisiana, Department of Public 1948 Works, Planning Division, Baton Rouge.

Iberia Parish Library

n.d. Unidentified excerpt from text on Louisiana wildlife refuges. Excerpt on file,

LA-Marsh Island Vertical File, Iberia Parish Library, New Iberia, Louisiana.

Jackson, H.E.

1991 Bottomland Resources and Exploitation Strategies During the Poverty Point Period. The Poverty Point Culture. Edited by K.M. Byrd, pp. 131-157. Geoscience and Man, Vol. 29. Louisiana State University, Baton Rouge.

Jenkins, Ned J.

1979 Miller Hopewell of the Tombigbee Drainage. In Hopewell Archaeology: The Chillicothe Conference, edited by David S. Brose and N'omi Greber, pp. 171-180. Kent State University Press, Kent, Ohio.

Jeter, Marvin D., Jerome C. Rose, G. Ishmael Williams, Jr., and Anna M. Harmon

1989 Archeology and Bioarcheology of the Lower Mississippi Valley and Trans-Mississippi South in Arkansas and Louisiana. Arkansas Archeological Survey Research Series No. 37. Final Report Submitted to the U.S. Army Corps of Engineers, Southwestern Division Study Unit 6 of the Southwestern Division Archeological Overview. Contract No. DACW63-84-C-0149.

Jones, Finas

1965 Haven in the Bayous. Petroleum Today, Winter 1965:1-5.

Kidder, T. R.

1988 Protohistoric and Early Historic Cultural Dynamics in Southeast Arkansas and Northeast Louisiana, A.D. 1542-1730. Print in 1995 by U.M.I. Dissertation Information Service, Ann Arbor, Michigan.

Kniffen, Fred B., Hiram F. Gregory, and George A. Stokes

1987 The Historic Indian Tribes of Louisiana: From 1542 to the Present. Louisiana State University Press, Baton Rouge.

Knight, Vernon J., Jr.

1984 Late Prehistoric Adaptation in the Mobile Bay Region. In Perspectives on Gulf Coast Prehistory, University Presses of Florida, Gainesville.

Kolb, C. R., and J. R. Van Lopik

1958 Geology of the Mississippi River Deltaic Plain. Southeastern Louisiana. U. S. Army Engineer Waterways Experimental Station Technical Report 3-483, Vicksburg, Mississippi.

1966 Depositional Environments of the Mississippi River Deltaic Plain. In Deltas in Their Geologic Framework, edited by M. L. Shirley and J. R. Ragsdale, pp. 17-62, Houston Geological Society, Houston. 
Kosters, E. C.

1989 Organic-Clastic Facies Relationships and Chronostratigraphy of the Barataria Interlobe Basin, Mississippi Delta Plain. Journal of Sedimentary Petrology 59:98-113.

Kovel, Ralph and Terry Kovel

1986 Kovels' New Dictionary of Marks. Crown Publishers, Inc., New York.

Largent, F. B., M. R. Waters, and D. L. Carlson

1991 The Spatiotemporal Distribution and Characteristics of Folsom Projectile Points in Texas. Plains Anthropologist 36(137):323-341, Plains Anthropological Society.

Larson, Lewis H., Jr.

1980 Aboriginal Subsistence Technology on the Southeastern Coastal Plain during the Late Prehistoric Period. The University Presses of Florida, Gainesville.

Lentz, David L.

1986 Archaeobotanical Remains from the Hester Site: The Late Paleo-Indian and Early Archaic Horizons. Midcontinental Journal of Archaeology 11(2):269-279.

Lonn, Ella

1933 Salt as a Factor in the Confederacy. Walter Neale, New York.

Louisiana Department of Conservation [LDC]

1933 Eleventh Biennial Report of the Department of Conservation of the State of Louisiana, 1932-1933. Department of Conservation, New Orleans.

Louisiana Planter and Sugar Manufacturer Co., Inc.

1924 - The Reference Book of the Sugar Industry of the World. Louisiana Planter and Sugar 1929- Manufacturer Co., New Orleans.

Louisiana Wild Life and Fisheries Commission

$196310^{\text {th }}$ Biennial Report, 1962-1963. Louisiana Wild Life and Fisheries Commission, New Orleans.

Lowery, G. H.

1974 The Mammals of Louisiana and Its Adjacent Waters. Louisiana State University Press, Baton Rouge.

Marshall, Richard A.

1975 Archaeological Assessment of the Proposed Sewerage System, Lareauville, Louisiana. Submitted to Sellers, Dubroc and Associates, Inc., Lafayette, Louisiana.

Martin, Paulette Guilbert (translator)

1976 The Kelly Nugent Report on the Inhabitants and Livestock in the Attakapas, Natchitoches Opelousas and Rapide Posts, 1770. Attakapas Gazette 11(4):187-192.

McClane, A. J. (editor)

1974 McClaine's Standard Fishing Encyclopedia. Holt, Rinehart, and Winston, New York.

Meek, A. J., and Jo Gulledge

1986 Red Pepper Paradise, Avery Island, Louisiana. Audubon Park Press, New Orleans. 
Miller, George L.

1980

1991

Millet, Donald J.

1983
Classification and Economic Scaling of $19^{\text {th }}$ Century Ceramics. Historical Archaeology 14:1-40. Society for Historical Archaeology.

A Revised Set of CC Index Values for Classification and Economic Scaling of English Ceramics from 1787-1880. Historical Archaeology 25:1-25.

Southwest Louisiana Enters the Railroad Age. Louisiana Historical Quarterly 2:165183.

Mitchell, C. Bradford with Kenneth R. Hall, editors

1975 Merchant steam vessels of the United States, 1790-1868: "The Lytle-Holdcamper list, "initially compiled from official merchant marine documents of the United States and other sources by William M. Lytle and Forrest R. Holdcamper'." Steamship Historical Society of America, Staten Island, New York.

Muller, Jon

1983

The Southeast. In Ancient North Americans, edited by Jesse D. Jennings, pp. 373-420. W. H. Freeman and Company, New York.

National Register of Historic Places

2000

Statement of Significance. Darby Plantation, Darby Lane, New Iberia, Iberia Parish, Louisiana. www.crt.la.us/nh12

Nelson, Lee $\mathrm{H}$. 1968

Nail Chronology as an Aid to Dating Old Buildings. American Association for State and Local History, Technical Leaflet 15, History News 24(11).

Neuman, R.W.

1984

An Introduction to Louisiana Archaeology. Louisiana State University Press. Baton Rouge.

Norgress, Rachel Edna

1947 The History of the Cypress Lumber Industry in Louisiana. The Louisiana Historical Quarterly 30(3):979-1059.

Olsen, Stanley J.

1964 Mammal Remains from Archaeological Sites: Part I, Southeastern and Southwestern united States. Papers of the Peabody Museum of Archaeology and Ethnology Vol. 56, No. 1. Harvard University, Cambridge.

1979 Osteology for the Archaeologist. Papers of the Peabody Museum of Archaeology and Ethnology Vol. 56, Nos. 3-5. Harvard University, Cambridge.

Parmalee, P. W. 1962

Faunal Remains from the Stanfield-Worley Bluff Shelter. Journal of Alabama Archaeology 8:112-114. 
Parmalee, P. W., R. B. McMillian, and F. B. King

1976 Changing Subsistence Patterns at the Rogers Shelter. In Prehistoric Man and His Environments: A Case Study in the Ozark Highlands, edited by W. R. Wood and R. B. McMillian, pp. 141-62, Academic Press, New York.

Pearson, Charles E.

1986 Dating the Course of the Lower Red River in Louisiana: the Archaeological Evidence. Geoarchaeology 1:39-43.

Penland, S.

1990 Geomorphic Evolution of the Mississippi Delta and Chenier Plains, Louisiana. Unpublished Ph.D. thesis, Department of Geography and Anthropology, Louisiana State University, Baton Rouge.

Penland, S., J. R. Suter, and R. Boyd

1985 Barrier Islands Arcs Along Abandoned Mississippi River Deltas. In Marine Geology 63:197-233.

Penland, S., J. R. Suter, and R. A. McBride

1987 Delta Plain Development and Sea Level History in the Terrebonne Parish Region, Louisiana. In Coastal Sediments, pp. 1689-1705, American Society of Civil Engineers.

Perino, Gregory

1985

Selected Preforms, Points and Knives of the North American Indians. Volume 1. Points and Barbs Press, Idabel, Oklahoma.

Perrault, S. L., and R. A. Weinstein

1994 National Register Eligibility Testing at the Sarah Peralta Site, East Baton Rouge Parish, Louisiana. Prepared for the Division of Archaeology, Office of Cultural Development, Louisiana Department of Culture, Recreation and Tourism, Coastal Environments, Inc., Baton Rouge.

Phillips, Phillip

1970 Archeological Survey in the Lower Yazoo Basin, Mississippi, 1949-1955. Papers of the Peabody Museum, Vol. 60, Harvard University, Cambridge.

Pittman, Philip

1973 The Present State of the European Settlements on the Mississippi. Facsimile reproduction, University of Florida Press, Gainesville, originally published 1770, J. Nourse, London.

Pourciaux, Betty (editor and compiler)

1985 St. Martin Parish History. Comite des Archives de la Louisiane, Baton Rouge.

Prichard, Walter, Fred B. Kniffen, and Clair A. Brown (editors)

1945 Southern Louisiana and Southern Alabama in 1819: The Journal of James Leander Cathcart. Louisiana Historical Quarterly 23(3):735-921.

Raphael, Morris

1976

The Battle in the Bayou Country. Harlo Press, Detroit. 
Rees, Grover 1965

A Narrative History of Breaux Bridge, Once Called "La Pointe". Attakapas Historical Association, St. Martinville, Louisiana.

Reese, W. D. 1992

Acadiana Flora. Center for Louisiana Studies, Lafayette, Louisiana.

Richardson, F. D.

1886 The Teche country Fifty Years Ago. Southern Bivouac 4:593-599.

Rivet, Philip G.

1975

Letter report on file at the Louisiana Department of Culture, Recreation and Tourism, Office of Cultural Development, Division of Archaeology, Baton Rouge, Louisiana.

Roberts, Omer Lounie, Jr.

1974 Cypress Land and Floodway: Environmental Change and the Development of the Land Utilization in the Atchafalaya Basin, Louisiana. Unpublished Ph.D. dissertation, Department of Geography, University of Tennessee, Knoxville.

Robertson, James Alexander

1911 Louisiana Under the Rule of Spain, France and the United States 1785-1807. Arthur H. Clark Company, Cleveland.

Roland, Charles P.

1957

Louisiana Sugar Plantations during the Civil War. E. J. Brill, Leiden, The Netherlands.

Saucier, R. T. 1963

Recent Geomorphic History of the Pontchartrain Basin. Louisiana State University Press, Baton Rouge.

1974 Quaternary Geology of the Lower Mississippi Valley. Arkansas Archaeological Survey Research Series No. 6, Fayetteville.

1981 Current Thinking on Riverine Processes and Geologic History as Related to Human Settlement in the Southeast. Geoscience and Man 22:7-18.

1994 Geomorphology and Quaternary Geologic History of the Lower Mississippi Valley. U.S. Army Engineer Waterways Experiment Station, Vicksburg, Mississippi.

Schmitz, Mark

1977

Economic Analysis of Antebellum Sugar Plantations in Louisiana. Arno Press, New York.

Schweid, Richard

1980

Hot Peppers, Cajuns and Capsicum in New Iberia, Louisiana. Madrona Publishers, Seattle.

Shenkel, J. R.

1981 Pontchartrain Tchefuncte Site Differentiation. Louisiana Archaeology 8:21-35. 
Sibley, John

1806 An Account of Louisiana at the Time of Its Transfer to the United States. In Message from the President of the United States, Communicating Discoveries Made in Exploring the Mississippi River, Red River, and Washita, by Captains Lewis and Clark, Doctor Sibley, and Mr. Dunbar..., pp. 67-97. Hopkins and Seymour, New York.

Simmons J. Barry \& Associates

1975 Facility Plan Environmental Assessment for Proposed Wastewater Treatment Works to Serve Sewerage District No. 3 of Iberia Parish, Louisiana. Simmons J. Barry \& Associates, Baton Rouge, Louisiana. Report on file at the Louisiana Department of Culture, Recreation and Tourism, Office of Cultural Development, Division of Archaeology, Baton Rouge, Louisiana.

Sitterson, J. Carlyle

1953 Sugar Country: The Cane Sugar Industry in the South. The University of Kentucky Press, Lexington.

Smith, Ann E.

1983 Archaeological Excavations at Shadows-on-the-Teche 1983. Tulane University, Center for Archaeology, New Orleans, Louisiana. Submitted to The U.S. National Trust for Historic Preservation.

Smith, Bruce D.

1987 The Independent Domestication of Indigenous Seed-bearing Plants in Eastern North America. In Emergent Horticultural Economies of the Eastern Woodlands, edited by W. F. Keegan. Center for Archaeological Investigations, Occasional Paper 7. Southern Illinois University, Carbondale.

Smith, L., J. Dunbar, and L. Britsch

1986 Geomorphological Investigation of the Atchafalaya Basin, Area West, Atchafalaya Delta, and Terrebonne Marsh. U. S. Army Engineer Waterways Experimental Station Technical Report GL-86-3, Vicksburg, Mississippi.

Smith, Steven D., Philip G. Rivet, Kathleen M. Byrd, and Nancy C. Hawkins

1983 Louisiana's Comprehensive Archaeological Plan. State of Louisiana, Department of Culture, Recreation and Tourism, Office of Cultural Development, Division of Archaeology, Baton Rouge.

South, Stanley

1977

Method and Theory in Historical Archaeology. Academic Press, New York.

Speaker, John Stuart, Joanna Chase, Carol Poplin, Herschel A. Franks, and R. Christopher Goodwin 1986 Archeological Assessment of the Barataria Unit, Jean Lafitte National Historical Park. Professional Paper No. 10, Southwest Cultural Resources Center, National Park Service, Santa Fe.

Speer

1979 Reloading Manual Number Ten for Rifle and Pistol. Developed and edited by the research staff of Speer, Omark Industries, Inc., Lewiston, Idaho. 
St. Martin Parish Development Board

ca. St. Martin Parish Resources and Facilities. State of Louisiana, Department of Public 1950 Works, Planning Division, Baton Rouge.

Steponaitis, Vincas P.

1983 Ceramics, Chronology, and Community Patterns, an Archaeological Study at Moundville. Studies in Archaeology, Stuart Struever, consulting editor, Academic Press, New York.

1986 Prehistoric Archaeology in the Southeastern United States, 1970 - 1985. Annual Review of Anthropology 15:363-404.

Story, D. A., J. A. Guy, B. A. Burnett, M. D. Freeman, J. C. Rose, D. G. Steele, B. W. Olive, and K. J. Reinhard

1990 The Archeology and Bioarcheology of the Gulf Coastal Plain: Volume 1. Arkansas Archeological Survey Research Series No. 38.

Suter, John R., Henry L. Berryhill, Shea Penland

1987 Late Quaternary Sea-Level Fluctuations and Depositional Sequences, Southwest Louisiana Continental Shelf. In Sea-Level Fluctuations and Coastal Evolution, edited by D. Nummedal, O. H. Pikley, and J. D. Howard, p. 199-222, SEPM Special Publication No. 41, The Society for Sedimentary Geology, Tulsa.

Swanson, Mark T.

1975 A Cultural Resources Survey of the Proposed Erath-Weeks Island Pipeline Route. New World Research, Inc., submitted to EMANCO, Inc., Houston, Texas.

Swanton, John R.

1946 The Indians of the Southeastern United States. Smithsonian Institution, Bureau of American Ethnology Bulletin 137.

1953 Indian Tribes of North America. Smithsonian Institute, Bureau of American Ethnology, Bulletin 145.

Switzer, Ronald, R.

1974 The Bertrand Bottles: A Study of $19^{\text {th }}$ Century Glass and Ceramic Containers. National Park Service, Washington, D.C.

Taylor, Gertrude C. 1980

Land Grants along the Teche. Part 2: St. Martinville to Sorrel. Attakapas Historical Association in cooperation with the Center for Louisiana Studies, University of Southwestern Louisiana, Lafayette.

Taylor, Joe Gray 1976

Louisiana. W. W. Norton and Company, Inc., New York.

Tite, M.S.

1972 Methods of Physical Examination in Archeology. Seminar Press, New York.

Tolle, Charles 1975

Jean Darby and Descendants. Attakapas Gazette 10(3):165-168. 
Toth, Edwin Alan

1988

Early Marksville Phases in the Lower Mississippi Valley: A Study of Culture Contact Dynamics. Archaeological Report No. 21. Mississippi Department of Archives and History, Jackson, Mississippi in cooperation with The Lower Mississippi Survey, Harvard University.

Toulouse, Julian Harrison

1969 Fruit Jars. Thomas Nelson, Inc. Publishers, Nashville, Tennessee.

1971 Bottle Makers and Their Marks. Thomas Nelson, Inc. Publishers, Camden, New Jersey.

Trammell, Camilla Davis

1987 Seven Pines: Its Occupants and Their Letters, 1825-1872. Rev. ed. Southern Methodist University Press, Dallas.

Tye, R. S., and E. C. Kosters

1986 Styles of Interdistributary Basin Sedimentation: Mississippi Delta Plain, Louisiana. Transactions Gulf Coast Association of Geological Societies 36:575-588.

U.S. Army Corps of Engineers

1870 Records of the Corps of Engineers. National Archives, Record Group 77, Washington, D.C.

1870 Captain Howell's correspondence concerning the survey and clearing of Bayou Teche. Record Group 77, entries H720 (January 29, 1870), H805 (June 14, 1870), and H906 (September 26, 1870), National Archives, Washington, D.C.

U.S. Congress

1913 Bayou Teche, La. House of Representatives. $62^{\text {nd }}$ Congress, $3^{\text {rd }}$ Session, Document No. 1329, Government Printing Office, Washington, D.C.

U.S. Secretary of War [OR]

1886 The War of the Rebellion: A Compilation of the Official Records of the Union and Confederate.

Vermilion Historical Society

1983 History of Vermilion Parish, Louisiana. Vermilion Historical Society, Abbeville, Louisiana.

Voorhies, Jacqueline K.

1973 Some Late Eighteenth-Century Louisianians: Census Records 1758-1796. The USL History Series, University of Southwestern Louisiana, Lafayette.

Wall, Bennett H., Charles Edwards O'Neill, Joe Grey Taylor, William Ivy Hair, Mark T. Carleton, and Michael L. Kurtz

1984 Louisiana: A History. Forum Press, Arlington Heights, Illinois.

Walthall, John A.

1980 Prehistoric Indians of the Southeast, Archaeology of Alabama and the Middle South. The University of Alabama Press, University, Alabama. 
Way, Frederick, editor

1994 Way's packet directory, 1848-1994: passenger steamboats of the Mississippi River system since the advent of photography in mid-continent America. Ohio University Press, Athens, Ohio.

Webb, Clarence $\mathrm{H}$.

1982 The Poverty Point Culture. Geoscience and Man Vol. XVII, Revised second printing, School of Geoscience, Louisiana State University, Baton Rouge.

Weinstein, R. A., and S. M. Gagliano

1985 The Shifting Deltaic Coast of the Lafourche Country and its Prehistoric Settlement. In

The Lafourche Country: The People and the Land, edited by Philip D. Uzee, pp. 122-

148, Center for Louisiana Studies, University of Southwestern Louisiana, Lafayette.

Weinstein, Richard A., and David B. Kelley

1989 Cultural Resource Investigations Related to the Terrebonne Marsh Backwater Complex, Terrebonne, St. Mary, and Assumption Parishes, Louisiana. 2 vols. Submitted by Coastal Environments, Inc., to the U.S. Army Corps of Engineers, New Orleans District, Contract No. DACW 29-86-D-0092.

1992 Cultural Resources Investigations in the Terrebonne Marsh, South-Central Louisiana. Submitted by Coastal Environments, Inc., Baton Rouge, to the U.S. Army Corps of Engineers, New Orleans District.

Wilby, Routh Trowbridge

1991 Clearing Bayou Teche After the Civil War, The Kingsbury Project, 1870-1871. Center for Louisiana Studies, University of Southwest Louisiana, Lafayette, Louisiana.

Willey, Gordon R., and Phillip Phillips

1958 Method and Theory in American Archaeology. The University of Chicago Press, Chicago.

Williams, Stephen, and Jeffrey P. Brain

1983 Excavations at the Lake George Site, Yazoo County, Mississippi, 1958-1960. Papers of the Peabody Museum of Archaeology and Ethnology Vol. 74, Harvard University, Cambridge.

Wilson, Rex L.

1981 Bottles on the Western Frontier. University of Arizona Press, Tucson.

Winters, John D.

1963 The Civil War in Louisiana. Louisiana State University Press, Baton Rouge. 


\section{Maps Cited}

Abbot, Henry L.

1863 Department of the Gulf, Map No. 8, Atchafalaya Basin, Prepared by Order of Maj. Gen. N. P. Banks. Map on file, Civil Works Map File, National Archives.

Banks, Maj. Gen. N. P.

1863 Abbot's Department Of The Gulf, Map No. 8, Atchafalaya Basin, Prepared By Order Of Maj. Gen. N. P. Banks. Cartographic division, National Archives, Record Group 77, Map 448, Washington, D.C.

Design Technics Corporation

1992 Louisiana Parish Pipeline \& Industrial Atlas. DTC, Houston.

Howell, Major C. W.

1870 Survey of the Bayou Teche, May 1870. Cartographic Division, National Archives, Record Group 77, Civil Works Map File, Map 137-1.

La Tourrette, John

1845 Reference Map of the State of Louisiana from the Original Survey of the United States. Map on file, Cartographics Branch, Library of Congress, Washington.

1853 Reference Map of the State of Louisiana from the Original Survey of the United States. Map on file, Special Collections, Howard-Tilton Memorial Library, Tulane University, New Orleans.

Louisiana Department of Highways, Traffic and Planning Section

1950 Iberia Parish, Louisiana. Map on file, Special Collections, Howard-Tilton Memorial Library, Tulane University, New Orleans.

1974 Iberia Parish, Louisiana. Map on file, Williams Research Center, Historic New Orleans Collection, New Orleans.

Louisiana Surveyor General

1846 Approved survey of Township 12S, Range 7W, South Western District, Louisiana. Map on file, State Land Office, Baton Rouge.

1849 Approved Survey of Township Range 12S, Range 6W, South Western District, Louisiana. Map on file, Louisiana State Land Office, Department of Natural Resources, Baton Rouge.

1893 Approved resurvey of portion of Township 12S, Range 7W, South Western District, Louisiana. Map on file, State Land Office, Baton Rouge.

1897 Approved resurvey of portion of Township 12S, Range 7W, South Western District, Louisiana. Map on file, State Land Office, Baton Rouge.

Mississippi River Commission

1963 Jeanerette Quadrangle, Louisiana. 15 Minute Series (Topographic). U.S. Geological Survey, Department of the Interior, Washington, D.C. 
Sanborn Map and Publishing Co., Ltd.

var. Insurance Maps of New Iberia, Iberia Parish, Louisiana. Maps series covers the years $1885,1892,1895,1899,1903,1904,1909,1925,1931$ and 1931 revised to 1948. Microfilm copies on file, Williams Research Center, Historic New Orleans Collection, New Orleans.

Taylor, Gertrude C.

1980 Land Grants along the Teche. Part 2: St. Martinville to Sorrel. Attakapas Historical Association in cooperation with the Center for Louisiana Studies, University of Southwestern Louisiana, Lafayette.

Unidentified surveyor

1760 Untitled map of Louisiana. Map on file, Geography and Map Division, Library of Congress, Washington, D.C.

ca. Unidentified maps of St. Martin and St. Mary Parishes. Map copies on file, Cammie Civil G. Henry Research Center, Watson Memorial Library, Northwestern State UniverWar sity, Natchitoches, Louisiana.

U.S. Army Corps of Engineers

1870 Survey of the Bayou Teche, May 1870. Survey maps by William D. Duke of Bayou Teche obstructions; in three sections, Record Group 77, Entry H805 (June 20, 1870). National Archives, Washington, D.C.

1965 Jeanerette Quadrangle, Louisiana. 15 Minute Series (Topographic). U.S. Army Engineer District, New Orleans, Corps of Engineers.

1973 St. Martinville Quadrangle, Louisiana. 15 Minute Series (Topographic). U.S. Army Engineer District, New Orleans, Corps of Engineers.

\section{$\underline{\text { Web Sites Cited }}$}

Louisiana National Register of Historic Places

$2000 \quad$ www.crt.state.la.us 


\section{APPENDIX I}

\section{MATERIALS RECOVERED DURING SURVEY}


Table 1. Historic Artifacts Recovered During Survey.

\begin{tabular}{|c|c|c|c|c|c|c|c|c|c|}
\hline $\begin{array}{l}\text { SITE/ } \\
\text { LOCUS }\end{array}$ & TRANSECT & STRATUM & $\begin{array}{l}\text { DEPTH } \\
\text { (CMBS) }\end{array}$ & COUNT & CLASS & TYPE & SUBTYPE & $\begin{array}{l}\text { ADDITIONAL } \\
\text { DESCRIPTION }\end{array}$ & $\begin{array}{l}\text { SPECIFIC } \\
\text { DATES }\end{array}$ \\
\hline DSO2-01 & 3 & & $0-100$ & 1 & Glass & $\begin{array}{l}\text { Machine-Made } \\
\text { Bottle Glass }\end{array}$ & Colorless & $\begin{array}{l}\text { Stipple-textured upper } \\
\text { shoulder and neck; “”... } \\
\text { NO RETU[RN] .... . . } \\
\text { NO DE[POSIT] ..." }\end{array}$ & Indeterminate \\
\hline $\mathrm{SA02-01}$ & 3 & I & $0-38$ & 1 & Ceramic & $\begin{array}{l}\text { Porcelain, Hard } \\
\text { Paste }\end{array}$ & $\begin{array}{l}\text { Gild, Liquid } \\
\text { "Bright" } \\
\text { Gold } \\
\end{array}$ & $\begin{array}{l}\text { Iridescent luster body } \\
\text { with gold gilded lip and } \\
\text { intricate handle }\end{array}$ & Indeterminate \\
\hline SA02-01 & 3 & I & $0-90$ & 1 & Glass & $\begin{array}{l}\text { Machine-Made } \\
\text { Bottle Glass }\end{array}$ & Colorless & $\begin{array}{l}\text { Square form; continuous } \\
\text { thread lip; "M" in } \\
\text { embossed seal on each } \\
\text { shoulder; " } 25.4 \text { Fl.OZ" on } \\
\text { front and back heels; "750 } \\
\text { ML" on both side heels; } \\
\text { "3935 A } 5 \text { (Brockway } \\
\text { Glass Co. mark)/ 11" on } \\
\text { base } \\
\end{array}$ & post ca. 1925 \\
\hline $\mathrm{SA} 02-01$ & 2 & I & $0-113$ & 1 & $\begin{array}{l}\text { Construction } \\
\text { Materials }\end{array}$ & $\begin{array}{l}\text { Architectural } \\
\text { Stone }\end{array}$ & $\begin{array}{l}\text { Fire Brick, } \\
\text { Whole }\end{array}$ & $\begin{array}{l}\text { "MEX-R-CO/ VIKING" } \\
\text { (Mexico Refractories Co., } \\
\text { Missouri) }\end{array}$ & ca. $1935-1942$ \\
\hline
\end{tabular}

Table 2. Faunal Specimens Recovered During Survey.

\begin{tabular}{|c|c|c|c|c|c|c|c|c|c|c|}
\hline $\begin{array}{c}\text { SITE/ } \\
\text { LOCUS } \\
\end{array}$ & TRANSECT & METER & $\begin{array}{c}\text { ADDITIONAL } \\
\text { PROVENIENCE } \\
\end{array}$ & COUNT & CLASS & FAMILY & GENUS & SPECIES & $\begin{array}{c}\text { COMMON } \\
\text { NAME }\end{array}$ & $\begin{array}{l}\text { ADDITIONAL } \\
\text { DESCRIPTION } \\
\end{array}$ \\
\hline DS02-01 & 3 & 70 & $\begin{array}{l}\text { Backhoe Trech 3@ } \\
100 \mathrm{cmbs}\end{array}$ & 1 & Mammalia & Bovidae & Bos & taurus & Cow & Atlas \\
\hline $\mathrm{DS} 02-01$ & 3 & 70 & $\begin{array}{l}\text { Backhoe Trech } 3 @ \\
100 \mathrm{cmbs}\end{array}$ & 2 & Mammalia & Bovidae & Bos & taurus & Cow & Shaft fragments \\
\hline $\mathrm{DS} 02-01$ & 3 & 70 & $\begin{array}{l}\text { Backhoe Trech 3@ } \\
100 \mathrm{cmbs}\end{array}$ & 2 & Mammalia & Bovidae & Bos & taurus & Cow & $\begin{array}{l}\text { Right and left } \\
\text { mandibles }\end{array}$ \\
\hline $\mathrm{DS} 02-01$ & 3 & 70 & $\begin{array}{l}\text { Backhoe Trech 3@ } \\
100 \mathrm{cmbs}\end{array}$ & 7 & Mammalia & Bovidae & Bos & taurus & Cow & Cranial fragments \\
\hline
\end{tabular}




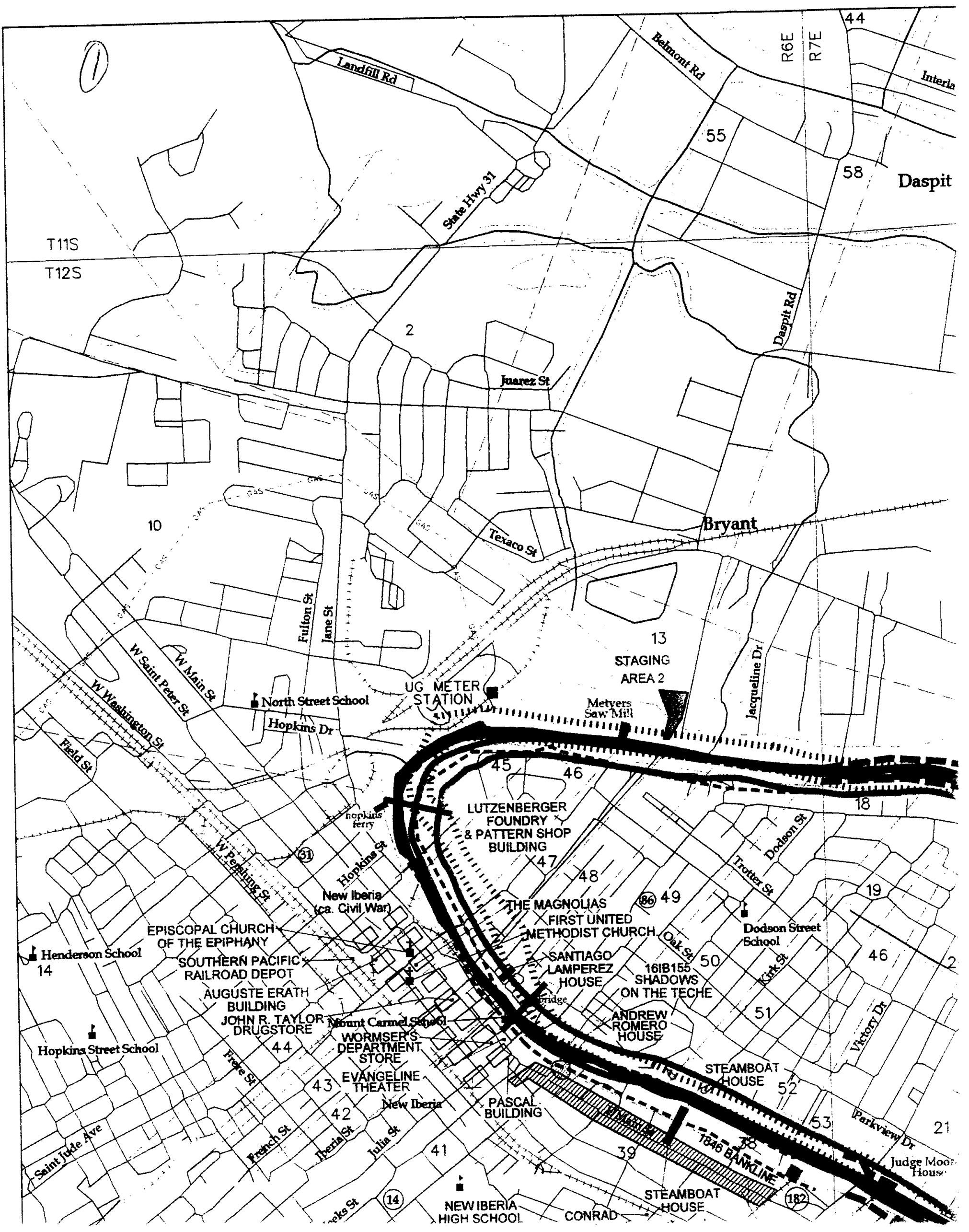




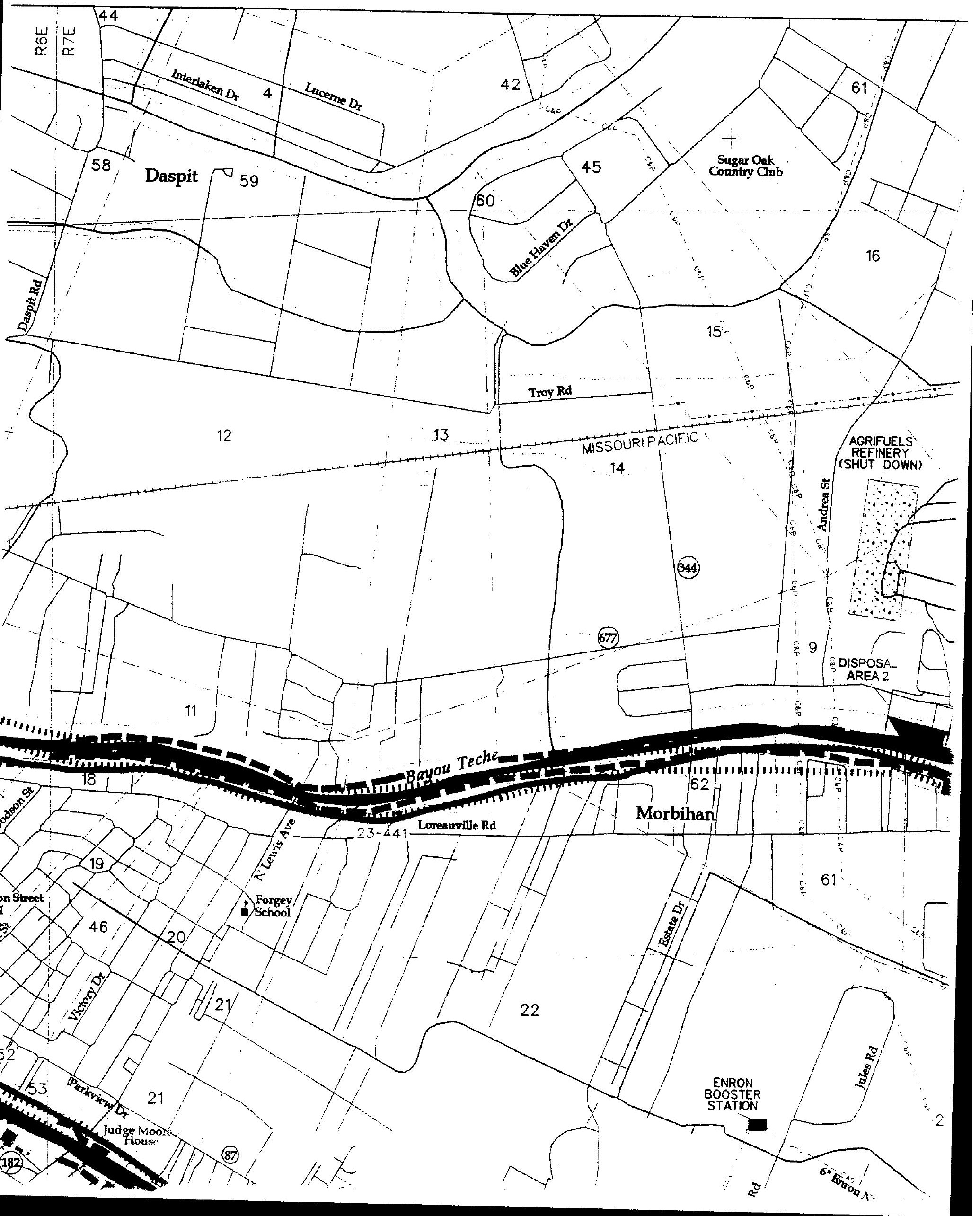




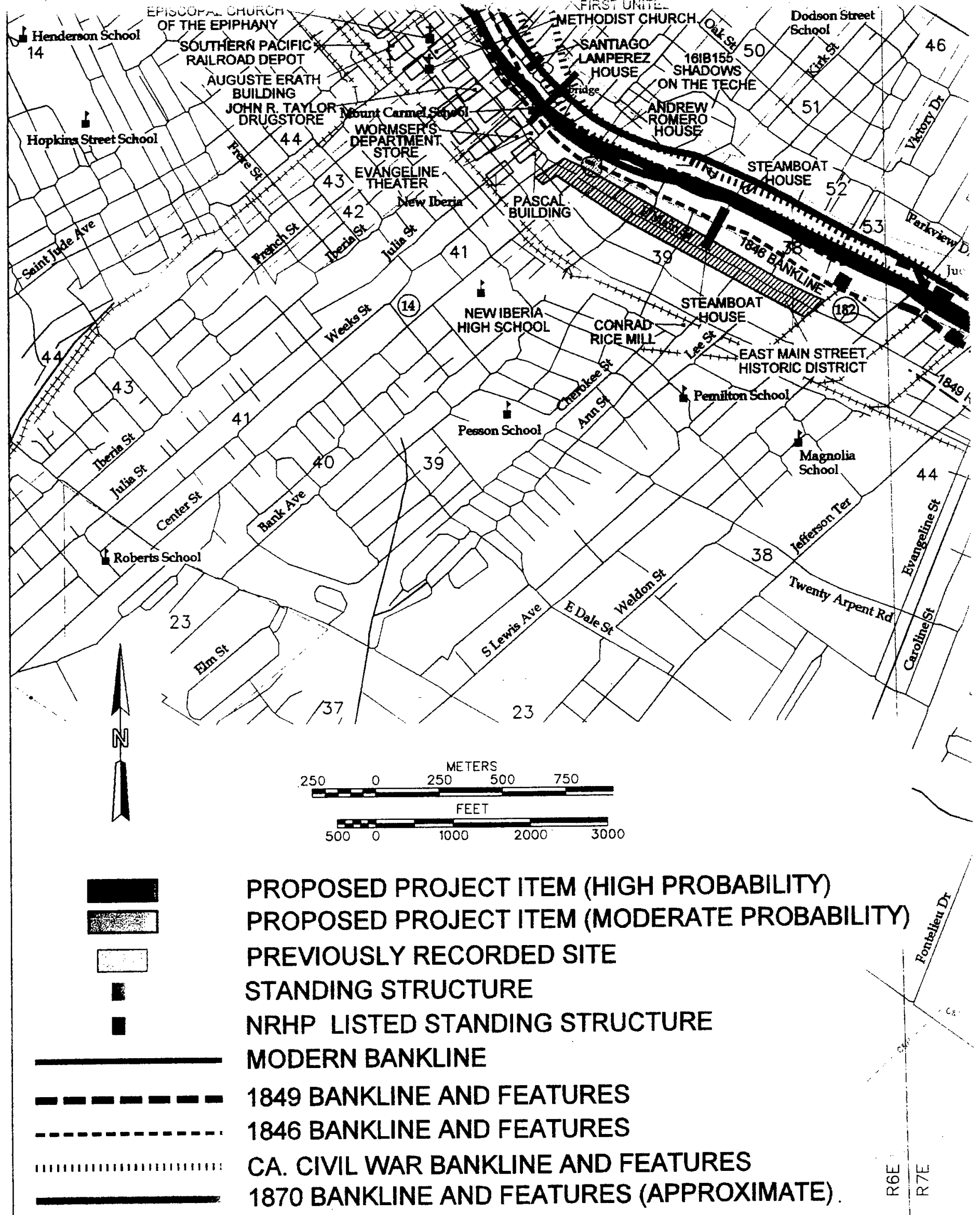




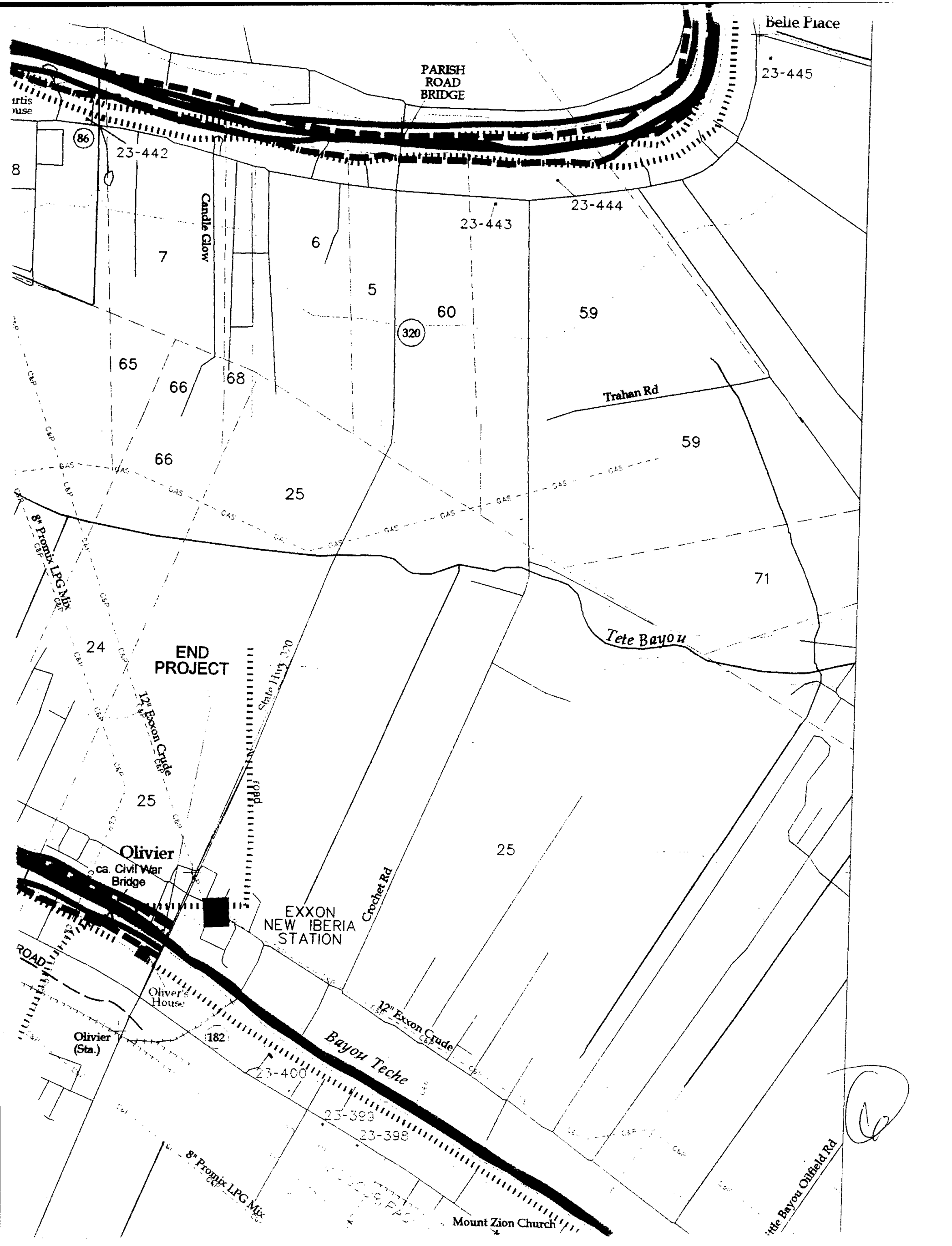

